Anna Barańska-Szmitko

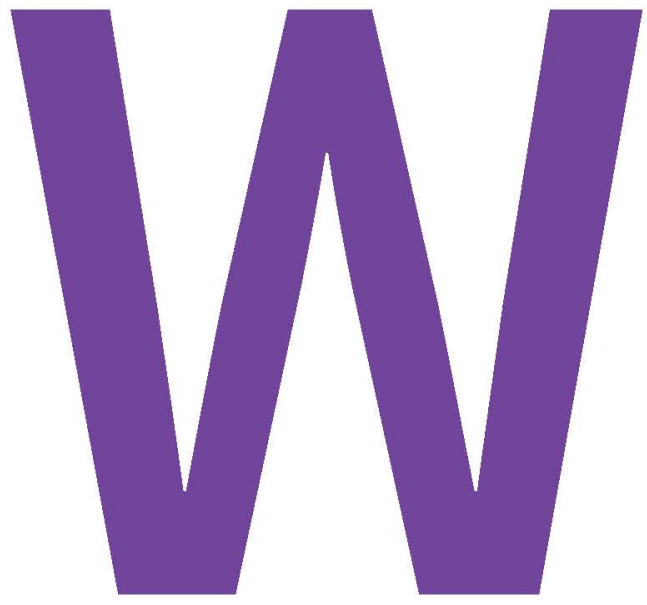

\title{
Wpływ stowa i obrazu na wizerunek osoby publicznej
}

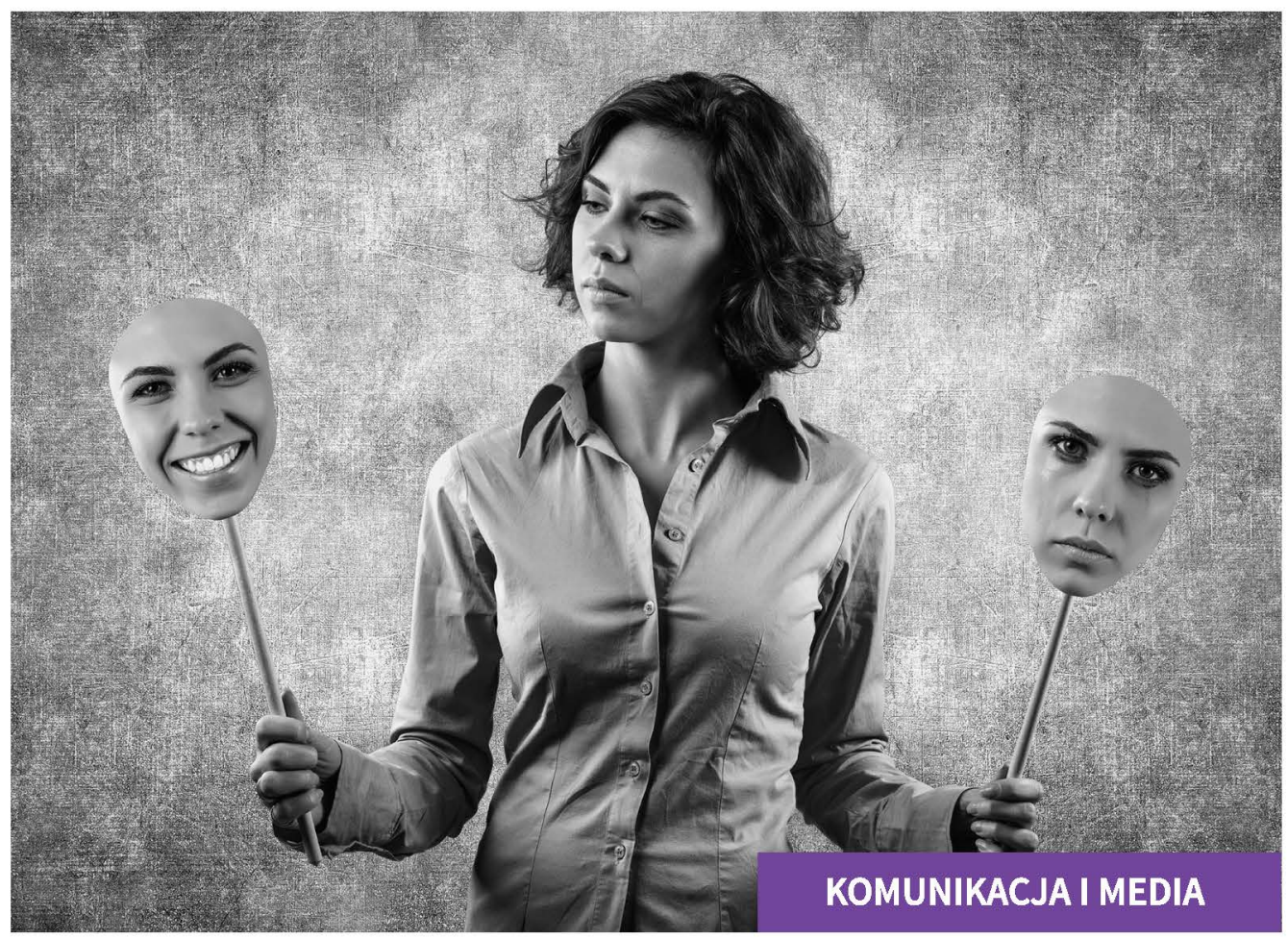




\section{Wpływ stowa i obrazu na wizerunek osoby publicznej}


蓄 
Anna Barańska-Szmitko

\section{Wpływ stowa i obrazu na wizerunek osoby publicznej}


Anna Barańska-Szmitko - Uniwersytet Łódzki, Wydział Filologiczny

Katedra Dziennikarstwa i Komunikacji Społecznej, Zakład Teorii i Praktyki Komunikacji

90-236 Łódź, ul. Pomorska 171/173

\author{
RECENZENT \\ Michael Fleischer \\ REDAKTOR INICJUJĄCY \\ Urszula Dzieciątkowska \\ OPRACOWANIE REDAKCYJNE \\ Anna Obrębska \\ SKŁAD I ŁAMANIE \\ Sylwia Moszczyńska \\ KOREKTA TECHNICZNA \\ Leonora Gralka \\ PROJEKT OKŁADKI \\ Katarzyna Turkowska
}

Zdjęcie wykorzystane na okładce: (C) Depositphotos.com/Foto_vika

Wydrukowano z gotowych materiałów dostarczonych do Wydawnictwa UŁ

Publikacja dofinansowana z dotacji celowej na rozwój młodych naukowców oraz uczestników studiów doktoranckich. Kod projektu: B1811300001984.02

Publikacja dofinansowana przez Wydział Filologiczny UŁ

(C) Copyright by Anna Barańska-Szmitko, Łódź 2018

(C) Copyright for this edition by Uniwersytet Łódzki, Łódź 2018

Wydane przez Wydawnictwo Uniwersytetu Łódzkiego

Wydanie I. W.08906.18.0.M

Ark. druk. 17,25

ISBN 978-83-8142-393-9

e-ISBN 978-83-8142-394-6

Wydawnictwo Uniwersytetu Łódzkiego

90-131 Łódź, ul. Lindleya 8

www.wydawnictwo.uni.lodz.pl

e-mail: ksiegarnia@uni.lodz.pl

tel. (42) 6655863

https://www.doi.org/10.18778/8142-393-9 


\section{Spis treści}

$\begin{array}{ll}\text { WPROWADZENIE } & 9\end{array}$

\section{ROZDZIAŁ I}

BADANIA NAD WIZERUNKIEM 13

1.1. Stan badań 13

1.2. Przyjęta perspektywa badawcza 17

$\begin{array}{ll}\text { 1.2.1. Teoretyczna perspektywa badawcza } & 17\end{array}$

$\begin{array}{ll}\text { 1.2.1.1. Konstruktywizm } & 18\end{array}$

1.2.1.2. Kreowanie wizerunku przez odbiorcę wypowiedzi 23

1.2.1.3. Komunikowanie wizerunku przez autora wypowiedzi 23

1.2.1.4. Wizerunek a tożsamość $\quad 24$

1.3. Metodologiczne rozwiązania 25

1.3.1. Szczegółowe cele badania 26

1.3.2. Dobór metodologii do celów badania 28

1.3.2.1. Układ poleceń w grupach i brzmienie pytań 32

1.3.2.2. Sposób przedstawienia materiałów i kart odpowiedzi 41

1.3.2.3. Czas i miejsce realizacji badania 44

1.3.2.4. Uczestnicy badania 46

1.3.2.5. Dlaczego felieton? $\quad 49$

1.3.2.6. Kryteria doboru autorów i wykorzystane felietony 51

1.3.2.7. Trafność wewnętrzna eksperymentu i jej realizacja 52

1.3.2.8. Wyniki - rozwiązania analityczne $\quad 54$

1.3.2.9. Ustalenia terminologiczne 56

1.4. Stan badań i metodologia - podsumowanie 57 


\section{ROZDZIAŁ II}

WIZERUNKI FELIETONISTÓW

2.1. Sposób przedstawienia wyników $\quad 61$

2.2. Krzysztof Varga 63

2.2.1. Krzysztof Varga - wizerunek na podstawie anonimowego tekstu 63

2.2.2. Krzysztof Varga - wizerunek publiczny 70

2.2.3. Krzysztof Varga - wizerunek wizualny 75

2.2.4. Krzysztof Varga - wizerunek na podstawie tekstu ze zdjęciem i informacją o tożsamości autora 80

2.2.5. Zależności między poszczególnymi typami wizerunków Krzysztofa $\begin{array}{ll}\text { Vargi } & 87\end{array}$

2.3. Piotr Zaremba 90

2.3.1. Piotr Zaremba - wizerunek na podstawie anonimowego tekstu 90

2.3.2. Piotr Zaremba - wizerunek publiczny 97

2.3.3. Piotr Zaremba - wizerunek wizualny 101

2.3.4. Piotr Zaremba - wizerunek na podstawie tekstu ze zdjęciem i informacją o tożsamości autora 108

2.3.5. Zależności między poszczególnymi typami wizerunków Piotra Zaremby 117

2.4. Magdalena Środa $\quad 120$

2.4.1. Magdalena Środa - wizerunek na podstawie anonimowego tekstu 120

2.4.2. Magdalena Środa - wizerunek publiczny 128

2.4.3. Magdalena Środa - wizerunek wizualny 133

2.4.4. Magdalena Środa - wizerunek na podstawie tekstu ze zdjęciem i informacją o tożsamości autora $\quad 145$

2.4.5. Zależności między poszczególnymi typami wizerunków Magdaleny Środy

2.5. Szymon Hołownia 159

2.5.1. Szymon Hołownia - wizerunek na podstawie anonimowego tekstu 159

2.5.2. Szymon Hołownia - wizerunek publiczny 167

2.5.3. Szymon Hołownia - wizerunek wizualny 175

2.5.4. Szymon Hołownia - wizerunek na podstawie tekstu ze zdjęciem i informacją o tożsamości autora 183

2.5.5. Zależności między poszczególnymi typami wizerunków Szymona Hołowni 


\section{ROZDZIAt III}

WNIOSKI

3.1. Możliwy do komunikowania wizerunek na podstawie wyników dotyczących wszystkich autorów

3.1.1. Wizerunek werbalny anonimowego autora tekstu i felietonisty

o znanej tożsamości

3.1.2. Wizerunek publiczny

205

3.1.3. Wizerunek wizualny

210

3.2. Wizerunek werbalny, wizualny, publiczny - wzajemne wpływy

ZAKOŃCZENIE

LITERATURA 225

SPIS TABEL

ANEKS 1

ANEKS 2

ANEKS 3

ANEKS 4 



\section{Wprowadzenie}

Badanie, które stało się inspiracją niniejszego opracowania, dotyczyło wizerunku, komunikowanego werbalnie, a konstruowanego przez czytelników tekstu. Pojawiały się jednak dodatkowe wątpliwości: A może znajomość nazwiska wpływa na przypisywany autorowi wypowiedzi image? Czy i jak zdjęcie autora obok tekstu wpływa na jego wizerunek? Jaka jest różnica między wizerunkiem „Z tekstu” a wizerunkiem „ze zdjęcia”? I na jakich zasadach funkcjonuje wizerunek, który tworzymy i zapamiętujemy po jakimś czasie? Te pytania stały się podstawą opracowania, które Czytelnik trzyma w ręku. Dokładniej zaś rzecz ujmując, dąży się tu do określenia, jaki wizerunek możliwy jest do komunikowania za pomocą słowa, a jaki za pomocą obrazu, oraz jak pozatekstowa wiedza o autorze wypowiedzi wpływa na jego wizerunek werbalny (konstruowany na podstawie tekstu).

Co ważne: weryfikacji podlega wizerunek komunikowany przez autora słów, a zatem nie chodzi o to, co inni powiedzieli o publicyście, ale jakie jego słowa mają wpływ na konstruowanie przez interpretatora jego image’u. Respondentom w jednej grupie podawano do przeczytania felieton anonimowego autora, w drugiej grupie tekst publicysty o znanej tożsamości (Krzysztof Varga, Piotr Zaremba, Magdalena Środa, Szymon Hołownia), zaś w trzeciej zdjęcie felietonisty. Następnie, po zapoznaniu się z tekstem/zdjęciem, ankietowani byli proszeni o podanie cech autora wypowiedzi (wizerunek werbalny) bądź osoby ze zdjęcia (wizerunek wizualny). W jeszcze innej grupie należało podać skojarzenia $\mathrm{z}$ nazwiskiem (wizerunek publiczny). Porównanie wyników pozwoliło zauważyć pewne tendencje w sposobie konstruowania wizerunku osoby publicznej przez czytelnika, widza czy po prostu odbiorcy mediów.

Tło naukowe, w jakim sytuuje się niniejsza praca, określone zostało w rozdziale I Badania nad wizerunkiem, gdzie zreferowano stan badań dotyczących 
image’u osób (publicznych), a także przedstawiono przyjętą perspektywę teoretyczną i wynikające z niej oraz z celów badania rozwiązania metodologiczne. W rozdziale II Wizerunki felietonistów znajduje się analiza poszczególnych imageów każdego z felietonistów, którego teksty wykorzystano w badaniu. Wnioski dotyczące możliwości słowa i obrazu oraz wypowiedzi wielokodowych $\mathrm{w}$ zakresie komunikowania wizerunku zawiera rozdział III Wnioski. Najważniejsze rezultaty i interpretacje wypunktowano w Zakończeniu.

W tym miejscu pragnę złożyć podziękowania osobom, bez których nie miałaby szans powstać ta praca. Profesor Grażyna Habrajska stanowiła bezpośrednią inspirację, a potem zaufała i pozwoliła na nieograniczoną swobodę naukową, za co jestem Jej ogromnie wdzięczna. Bez wahania w przeprowadzeniu badania pomogli znajomi wykładowcy z Uniwersytetu Wrocławskiego: dr Michał Grech, dr Mariusz Wszołek, dr Dominik Lewiński, prof. Michael Fleischer, oraz z Uniwersytetu Kazimierza Wielkiego w Bydgoszczy: dr Wiesław Czechowski. Rozdanie teczek z ankietami umożliwiły mi również osoby, dla których byłam zupełnie anonimowa. Nie sposób ich tu wszystkich wymienić, jednak wspomnę chociaż, że mieli swój udział w niniejszej pracy też inni wykładowcy z dziennikarstwa i polonistyki uniwersytetów: Łódzkiego, Warszawskiego, Wrocławskiego, Adama Mickiewicza w Poznaniu, Kazimierza Wielkiego w Bydgoszczy i Uniwersytetu w Białymstoku. Za możliwość zaproszenia studentów do badania bardzo im dziękuję.

Ta książka nie miałaby szans powstać także bez mojego Męża, który wspierał mnie od początku prac nad tymi badaniami po ostatnią kropkę. I za to dziękuję najmocniej, jak potrafię. Równie szczególne podziękowania należą się mojej Mamie - w dużej mierze z jej inspiracji i w wyniku jej poświęcenia oraz uwagi danej wnuczce ta książka mogła powstać w czasie, w jakim powstała. Dziękuję także mojej Teściowej, która zwłaszcza starszej wnuczce nie szczędziła czasu, kiedy mama musiała pracować. Tacie i Teściowi należą się podziękowania za cierpliwość. I na końcu córkom, za to, że - paradoksalnie - stanowiły silną motywację. 
ROZDZIAŁ I 



\section{Badania nad wizerunkiem}

\subsection{Stan badań}

Idea, jaka przyświecała referowanej tu próbie określenia wpływu słowa i obrazu na wizerunek publiczny, to zrealizowanie badania sprawdzającego wizerunek osoby publicznej, a nie instytucji/marki, który wynikałby na poziomie werbalnym z jej - tej osoby - słów (a nie słów „o niej”), przy czym za równie ważne przyjęto posłużenie się metodą zakładającą intersubiektywizm badaw$\mathrm{czy}^{1}$ (zminimalizowany wpływ badacza na zbieranie danych i analizę), a ponadto istotna też musiała być próba izolacji wpływu słowa i obrazu na wizerunek, mający za podstawę więcej niż jeden system znaków.

Literatura przedmiotu reprezentuje wiele opracowań realizujących przynajmniej jedno z powyższych założeń, choć trudno wskazać analizy spełniające wszystkie wyznaczone wyżej kryteria. Istnieją liczne badania sondażowe, które weryfikują wizerunek osób publicznych - pojawiają się w mediach, zwłaszcza w okresie przedwyborczym. Nie mają one jednak charakteru naukowych opracowań. W samej literaturze naukowej wizerunkowi osób poświęca się niewiele uwagi, podobnie jak rzadko bada się wyłącznie werbalny poziom komunikowania image'u. Wizerunek stał się przy tym przedmiotem badań głównie public relations oraz nauki o komunikacji w jej konstruktywistycznym paradygmacie, jeśli mówić o jego komunikowaniu za pomocą wielu systemów znakowych. Image w jego wymiarze językowym (system języka naturalnego) stał się domeną badań głównie medioznawstwa

1 Realizowanie „obiektywizmu” uważa się w tej pracy za przedsięwzięcie utopijne. 
i językoznawstwa. Zobaczmy, co i w jakim zakresie podlega naukowej weryfikacji w obrębie wizerunku.

Opracowania badawcze, powstałe zarówno w obszarze public relations, jak i konstruktywistycznej nauki o komunikacji, charakteryzują się dość dużą różnorodnością, jeśli chodzi o zakres uwzględnianych obiektów, choć niewiele dotyczy image’u osób. Poświęcone są wizerunkowi np.: kierunku studiów (Pietrzak 2012) albo pracowników uniwersytetów (zob. Grech 2014), uniwersytetu jako takiego (Grech 2011, 2013) lub konkretnego (Zemanek 2017), szkoły wyższej (Szymańska 2003; Kurek 2010; Waszkiewicz 2010, 2011), studentów (Leszczyńska, Mikołajczyk, Miszczak 2011), terytorium, np. kraju i jego mieszkańców (zob. np. Obraz Polski i Polaków w Europie 2003), jednostek samorządu terytorialnego (Chachołek 2011). Określano także image np. „inteligentnego domu” (Burska 2013), designu i wzornictwa (Romańczukiewicz 2012), Facebooka i Naszej Klasy (Sierakowska 2012), marek herbat (Piasny 2013), aut (Jeżewska 2013), Galerii Wnętrz (Wszołek 2013), Państwowego Muzeum Auschwitz-Birkenau (Turek 2013), buddyzmu (Chycki 2013) czy wegetarianizmu (Trzciałkowska 2016). Niewielką tylko część stanowią prace poświęcone wizerunkowi osób. Można tu wspomnieć o image’u „człowieka instytucji” Steve’a Jobsa (Szymański 2013) czy opiniach o prezydencie Wrocławia, Rafale Dudkiewiczu (Adamczyk 2016). Bez względu na to, jaki obiekt badano, zwracano uwagę na wizerunek jako efekt wszelkiego rodzaju działań komunikacyjnych, nie tylko werbalnych, a w zakresie stosowanej metody posługiwano się ankietami i kwestionariuszem różnego rodzaju pytań, w tym dyferencjałem semantycznym.

Uwzględnienie wszelkich systemów znakowych jeszcze bardziej jest widoczne, gdy badaniu za pomocą case study podlega cały proces kreowania wizerunku - wówczas image to jedna ze zmiennych branych pod uwagę. W takim typowym i najczęstszym dla public relations przypadku badaniom związanym ściśle z wizerunkiem towarzyszy analiza np.: rynku (np. Tworzydło, Rymarz, Górska 2004; Stasiuk-Krajewska 2011), warunków ekonomicznych (np. miasta - Młynarczyk 2010), historii firmy (np. Tworzydło, Rymarz, Górska 2004, Szafraniec 2007; również w kontekście politycznym: Skawińska 2007), sprzedaży (Szafraniec 2007), dokumentów (Borkowski 2011), relacji działań PR-owych do ich efektów (Smyczyńska 2007; Szafraniec 2007; Tworzydło, Rymarz, Górska 2004). Również tutaj badacze częściej skupiają się na instytucjach/markach niż na osobach.

Nieco inaczej są projektowane badania wizerunku osadzone w konstruktywistycznej nauce o komunikacji, gdzie oprócz badania wizerunku poszczególnych obiektów (patrz: wyżej), zwraca się uwagę na znaczenie samej grupy interpretatorów, na kształt image’u, ale przede wszystkim na zmienne wpływające na wizerunek. 
Różnice w konstrukcji wizerunku w zależności od grupy interpretatorów ukazano $\mathrm{w}$ zakresie image'u wewnętrznego i zewnętrznego policjanta (zob. Cychański 2014, por. Cychański 2013), ale też brano pod uwagę większą liczbę badanych grup (np. Fleischer 2004 - image „O” wśród przyjaciól, studentów, image konstruowany przez żonę „O”, oraz przez samego „O”; podobnie Choma 2012 - wizerunek wśród członków rodziny, znajomych ze szkoły, studiów, pracy i pozostałych znajomych). Tego typu prace również uwzględniają efekt komunikacyjny, wynikający z przyswojenia ofert komunikacyjnych wielu systemów znakowych. Stosuje się wówczas dyferencjał semantyczny, by móc porównać wyniki między poszczególnymi grupami.

Drugi z typów badań wizerunku konstruktywistycznej nauki o komunikacji wiąże się już z izolowaniem poszczególnych czynników i weryfikowaniem ich wpływu na image, przy czym do tej pory z użyciem eksperymentu sprawdzano znaczenie dla image'u osoby takich obiektów komunikacji, jak np. wybrane marki samochodów (Łopuch 2012), obuwie (Grobelna 2012), papieros (Wielgus, Żukowska 2012), marka portalu społecznościowego (Smółka-Dolecka 2012), rodzaj oprawek okularów (Grobelna 2013). Weryfikowano również konsekwencje image'owe dla marki, wynikające $\mathrm{z}$ formy jej opakowania (zob. Janicka 2012; Gliniecka 2017) czy różnej wysokości ceny (zob. Łysoń 2012). Sprawdzano wpływ kolorów w komunikacji wizualnej banków na ich wizerunek (Rabenda-Derman 2017), czy znaczenie barwy i etykiety opakowań na postrzeganie produktu (Wszołek, Moszczyński, Mackiewicz 2017). $\mathrm{W}$ tego typu opracowaniach dominuje metoda eksperymentu i nie uwzględniano w nich image'u konkretnych osób.

Jak widać, badania weryfikujące wynik działania ofert komunikacyjnych kilku systemów znakowych dotyczą głownie obiektów innych niż człowiek i skupiają się na konkretnym efekcie komunikacyjnym (image’u) lub na zmiennych na niego wpływających (ale są to poszczególne obiekty, a nie zmienne w rodzaju systemów znaków), w mniejszym stopniu na zależności od grupy interpretatorów. Prowadzone są w sposób zakładający intersubiektywizm badawczy.

Tam, gdzie uwzględnia się wyłącznie werbalny poziom komunikowania wizerunku, do czynienia mamy przede wszystkim z badaniami dotyczącymi wszelakiego rodzaju doniesień medialnych, a opartymi na lingwistyce korpusowej, analizie treści bądź zawartości, jak również różnie rozumianej analizie dyskursu ${ }^{2}$. W tej grupie prace badawcze często skupiają się na aktualnych zjawiskach, takich jak komunikacja partii politycznych w zakresie np. wizerunku imigrantów (Pielużek 2018, na materiale publikacji partii) albo

2 Celowo pomija się tu analizę zawartości przekazów medialnych ze względu na niewielką jej reprezentację wśród opracowań naukowych (zob. Metody badania wizerunku w mediach 2009, por. też Pisarek 1983, 1997; Lisowska-Magdziarz 2004), a silną wśród badań komercyjnych. 
image’u uchodźców (Olender 2017) czy obrazu Polski (Olender 2018), (re)konstruowanych z wpisów na oficjalnych profilach w mediach społecznościowych. Niekiedy analizie podlegają dawniejsze publikacje, jak np. (od)twarzające obraz Polski i Polaków w chicagowskim „Dzienniku Związkowym” (Dembowska-Wosik 2017). Zdarzają się w tym przypadku analizy image’u osób, jak choćby przedstawienie ks. Józefa Tischnera jako osobowości medialnej (Secer 2013) czy (od)tworzenie wizerunku Leonida Kuczmy na łamach tygodnika „Wprost” (Mazurkiewicz 2008).

Cechą charakterystyczną tego typu opracowań jest wykorzystywanie materiałów językowych na temat badanego obiektu oraz analiza dokonywana przez jednego badacza. Innymi słowy, badaniu podlegają wypowiedzi o kimś/czymś i na tej podstawie (od)twarza się wizerunek tego kogoś/czegoś, a nie są brane pod uwagę wypowiedzi danej osoby i to nie one właśnie stają się podstawą analizy. Inaczej też niż w przypadku badania wizerunku jako wyniku działania wielu systemów znaków, gdy badaniu podlega wyłącznie poziom werbalny, odchodzi się od zasady intersubiektywności ${ }^{3}-\mathrm{z}($ re)konstruowany image to wypadkowa refleksji jednego badacza, a nie zapatrywania wielu interpretatorów.

Podsumowując, należy zauważyć, że wśród dotychczasowych badań wiele uwagi poświęcono wizerunkowi marki/instytucji, a trudno o takie, które nie mają charakteru sondażowego i skupione są na weryfikowaniu wizerunku osoby publicznej. Opracowania poświęcone image’owi osób są nakierowane na weryfikację i specyfikację wpływu poszczególnych obiektów (np. obuwie, okulary), a nie ofert komunikacyjnych reprezentujących pojedynczy rodzaj systemu znakowego (wizualny, werbalny). Warto też podkreślić, że jeśli pojawiają się opracowania dotyczące wizerunku osób, to najczęściej mają charakter sondażowy $\mathrm{i}$ - tak samo jak w przypadku prac opartych na materiale językowym - nie jest to wizerunek na podstawie wyłącznie słów danej osoby. Opracowania czerpiące metody z badań społecznych charakteryzują się intersubiektywizmem badawczym, co w niewielkim tylko stopniu realizowane zostaje w pracach bazujących na wypowiedziach w systemie języka naturalnego.

Nieliczne tylko opracowania łączą wspomniane wyżej podejścia. Wykorzystano np. formułę eksperymentu, by określić wizerunek tekstu i jego autora, kiedy zmienną uczyniono imię i nazwisko sugerujące konkretną narodowość wypowiadającego się (Hałafin 2016). Respondenci czytali więc tekst, a następnie określali wizerunek autora felietonu.

Ta sama formuła przyświecała badaniom pilotażowym i wstępnym do referowanego niżej badania. Po przeczytaniu felietonu respondenci określali

3 Może z wyjątkiem zastosowania list frekwencyjnych, kiedy najistotniejsza jest liczba wystąpień danego leksemu (jak np. w Pielużek 2018). 
np. wizerunek autora w sytuacji, gdy wypowiedzi towarzyszyło zdjęcie felietonisty i wówczas, gdy go nie było (Barańska 2011 - wizerunek Aleksego Awdiejewa, Barańska-Szmitko 2013 - Image Krzysztofa Vargi); gdy fotografia przedstawiała osobę rozbawioną lub zamyśloną (Barańska-Szmitko 2012); gdy sprawdzano, jaki wpływ ma zdjęcie oraz wiedza pozatekstowa o Szymonie Hołowni na przypisywany mu wizerunek (Barańska-Szmitko 2014d); lub kiedy poddawano analizie image Magdaleny Środy, konstruowany wyłącznie na podstawie jej anonimowych słów (Barańska-Szmitko 2017c). Pojawiły się też pierwsze próby określenia możliwości komunikowania wizerunku na poziomie werbalnym w warunkach braku znajomości tożsamości autora, na podstawie wyników dotyczących Szymona Hołowni i Magdaleny Środy (Barańska-Szmitko 2014a). Podstawę metodologiczną stanowił więc eksperyment, a materiał badawczy - odpowiedzi respondentów na pytania dotyczące wizerunku felietonisty, kiedy bazą odpowiedzi był anonimowy tekst, wypowiedź autora o znanej tożsamości, przywołanie samego imienia i nazwiska lub wyłącznie zdjęcie publicysty. W ten sposób wykorzystano intersubiektywne podejście, pozwalające izolować (na ile to możliwe) wyznaczone zmienne, dotyczące wizerunku konkretnych osób. Pełna charakterystyka już całego badania, wraz z zapleczem teoretycznym, opisem metodologii i analizą wyników zostanie przedstawiona w kolejnych rozdziałach.

\subsection{Przyjęta perspektywa badawcza ${ }^{4}$}

Opisywane badania prowadzono w oparciu o teoretyczne założenia racjonalnego konstruktywizmu Michaela Fleischera, dlatego niżej przybliżona zostanie ta perspektywa badawcza, ze szczególnym uwzględnieniem aspektów kluczowych dla tematu badawczego, takich jak kreowanie wizerunku przez odbiorcę wypowiedzi i komunikowanie image'u przez autora wypowiedzi. Precyzji wywodu posłuży ustalenie sposobu rozumienia wizerunku w opozycji do tożsamości.

\subsubsection{Teoretyczna perspektywa badawcza}

W badaniu przyjęto postawę konstruktywistyczną jako podstawę determinującą sposób ujęcia tematu badawczego, dlatego też poniżej przedstawiono kluczowe zagadnienia teoretyczne, rzutujące na metodologiczne rozwiązania.

4 Zob. też Barańska-Szmitko 2018: 24-41. 


\subsubsection{Konstruktywizm}

Określenie wpływu słowa i obrazu na wizerunek felietonisty zrealizowano w paradygmacie rozsądnego konstruktywizmu Michela Fleischera, w ramach ogólnej teorii komunikacji, mającej swoje korzenie w teorii systemów społecznych Niklasa Luhmanna. Najistotniejsze aspekty tej ostatniej zostaną poniżej zaprezentowane dla lepszego wyobrażenia o samym konstruktywizmie.

\section{Radykalny konstruktywizm - Niklas Luhmann}

Luhmann znany jest jako twórca teorii, w której centralne miejsce zajmują tzw. systemy autopojetyczne, czyli samoodnoszące/samoreferencyjne/ autoreferencyjne (w zależności od tłumaczenia powstają różne wersje leksykalne tego określenia, por. Fleischer 2002, 2007; Szacki 2012: 935-342; Luhmann 1994 [1981], 2007 [1984], 2012; Skąpska 2007), samoobserwujące, wyłaniające się ze środowiska (Luhmann 1994 [1981]: 58-64; 2007 [1984]: 42, 166-196). Cechą charakterystyczną systemów autopojetycznych jest to, że same siebie tworzą przez mechanizm samoreferencji, odnoszenia się do samego siebie (Luhmann 2007 [1984]: 407-443; Luhmann 1994 [1981]: 43-50; Szacki 2012: 938; Skąpska 2007: XIV). Samoobserwację rozumie się przy tym jako „operację posługującą się rozróżnieniami” (Luhmann 1990: $39^{5}$ za: Fleischer 2002: 163), „wprowadzeniem rozróżnienia między systemem a środowiskiem do systemu, który konstytuuje się za pomocą tego rozróżnienia" (Luhmann 2007 [1984]: 42). Bazuje zatem na wyłonieniu różnicy/dyferencji (Luhmann 2007 [1984]: 42 i n.; Szacki 2012: 938; Skąpska 2007: XIII; Fleischer 2002: 161) między systemem a środowiskiem. Środowisko pojmuje się natomiast jako wszystko to, czym system nie jest. Przy tym autoreferencyjność systemu ma pewną istotną konsekwencję czy też cechę. Wszystko, co decyduje o istnieniu systemu, dzieje się wewnątrz niego, a także odnosi się do wcześniej nagromadzonych obserwacji, co ogranicza jego elastyczność. Innymi słowy, system - mimo poznawczego otwarcia - jest operacjonalnie i strukturalnie zamknięty (Luhmann 2007 [1984]: 42-46 i n.; Fleischer 2007: 49-58; Szacki 2012: 938; Skąpska 2007: XV).

Ważne, że system różnicuje się ze środowiska poprzez redukcję kompleksowości/złożoności (terminy stosowane zamiennie w zależności od preferencji tłumacza: zob. np. Fleischer 2002, 2007; Luhmann 2007 [1984]). Wynika to z faktu, że w Luhmannowskiej teorii środowisko systemu jest bardziej

5 Por. Luhmann 1990: 31-58. 
złożone niż sam system, który ma też pewną granicę własnej kompleksowości (Fleischer 2002: 160). Pewne więc nasycenie relacyjności staje się przyczyną jej ograniczenia $w$ celu powstania systemu i tym samym zapobieżenia nadmiernemu obciążeniu i entropii oraz wpłynięciu na jego spójność (zob. Skąpska 2007: XIV).

Kierunek, kształt czy zasięg rozwoju systemu pozostaje domeną przypadku. Luhmann używał określenia „kontyngencja”, które oznacza, iż wiele różnych rozwiązań, co do przyszłości systemu, jest możliwych, ale żadne nie jest przez cokolwiek zdeterminowane (Luhmann 2007 [1984]: 101-165; Fleischer 2002: 160-161). Rozwój systemu pozostaje zatem przypadkowy i nieprzewidywalny.

Tak więc systemem jest procesualny i dynamiczny efekt wytwarzania różnic przez ten system, a jego oddzielenie się od środowiska ustanawiane jest przez obserwatora, którym także jest dany system. Wypowiadanie się więc o systemie nie decyduje o jego statusie ontologicznym. Istnienie systemu zależne jest od obserwatora i to ten ostatni dokonuje konstrukcji systemu (Skąpska 2007: XI). Stąd też charakter epistemologiczny tej teorii, nazywanej radykalnym konstruktywizmem.

Ważne też jest to, że system społeczny dla Luhmanna nie miał charakteru ludzkiego w tym sensie, że: „społeczeństwo nie składa się z ludzi, lecz z międzyludzkich układów komunikacyjnych" (Luhmann 1994 [1981]). W tym układzie jednostki ludzkie z ich życiem psychicznym stanowią część środowiska (Szacki 2012: 938-939; Fleischer 2002: 162-163). W tym kontekście istotne dla rozumienia komunikacji jest stwierdzenie, że system stale się tworzy „na nowo" poprzez samoreferencję, tak więc akt komunikacji postrzegać należy procesualnie, jako niekończący się ciąg wydarzeń (Luhmann 2007 [1984]: 154-165; Skąpska 2007: XII). System społeczny może przy tym być rozumiany globalnie, jako ogólny system społeczny, lub lokalnie - jako mniejsze systemy społeczne i podsystemy funkcyjne (np. gospodarka, rodzina, polityka, nauka, sztuka) (zob. Luhmann 1994 [1981]; Szacki 2012: 938-941). W istocie bez komunikacji nie ma takich podsystemów, jak: gospodarka, rodzina, polityka, nauka, sztuka itd. Komunikacja konstytuuje system społeczny.

\section{Rozsądny konstruktywizm - Michael Fleischer}

Luhmannowska teoria systemów stała się podstawą ogólnej teorii komunikacji Michaela Fleischera, reprezentującej - jak sam to jej twórca ujmuje - rozsądny konstruktywizm (Fleischer 2007).

Istotne dla tej perspektywy jest podkreślenie rozróżnienia na system i jego mechanizm. W rozsądnym konstruktywizmie komunikacja stanowi 
mechanizm systemu społecznego. Oba te zjawiska znajdują się w układzie relacyjnym, a dokładniej - funkcjonują na zasadzie mechanizmu zwrotnego. Innymi słowy, komunikacja tworzy system społeczny i odwrotnie: bez systemu społecznego nie ma szans powstać komunikacja. Wzajemnie się konstytuują. Z punktu widzenia funkcjonowania systemu „zawartość”, treści komunikacji pozostają bez znaczenia, ważne, by komunikacja trwała i zapewniała tym samym egzystencję systemu. To istotne, ponieważ oznacza rezygnację z dość powszechnego $\mathrm{w}$ humanistyce postrzegania komunikacji jako narzędzia porozumienia, zrozumienia, informowania itd.

W ujęciu Fleischerowskim relację między systemem społecznym a środowiskiem obrazuje koncepcja trzech rzeczywistości: fizycznej, biologicznej i społecznej. Pewną inspiracją była tu koncepcja trzech kategorii Charlesa Peirce’a (zob. Fleischer 2007: 306-309 i n.), dlatego pierwsza rzeczywistość stanowi bazę, niezbędną dla istnienia drugiej, a te dwie są podstawą potrzebną do powstania trzeciej.

Pierwsza rzeczywistość rozumiana jest w kategoriach praw fizyki. Tworzą ją wzory, czy też lepiej: współoddziaływania wzorów, czyli jednostek systemu fizycznego (Fleischer 2007: 311). „Wzory nie powstają jednak w pustej przestrzeni, lecz zostają z czegoś wyfiltrowane" (Fleischer 2007: 92) - z kontinuum, które „składa się, na podstawie tego, co dzisiaj wiemy, z różnie rozłożonych strun". Materiałem realności są fale, drgania, struny.

Druga rzeczywistość - biologiczna - oparta jest na postrzeganiu i konstruowaniu obiektów. Wzór/materia staje się obiektem, kiedy zostanie spostrzeżona jako obiekt przez organizm. Postrzeganie jest tu koniecznym warunkiem. Wzór bowiem "może” stać się obiektem dopiero wówczas, gdy zostanie wyłoniony z realności w wyniku postrzegania. W tym ujęciu obiekt nie istnieje, dopóki uczestnik systemu biologicznego go nie spostrzeże i nie dokona jego konstrukcji. W przeciwieństwie do wzorów organizmy mają możliwość postrzegać i różnicować, dzięki czemu porządkują realność: „Obiekty są konstruowane, by za ich pomocą obserwować środowisko systemu i je segmentować” (Fleischer 2007: 14).

W rzeczywistości biologicznej duże znaczenie ma zależność od organów postrzegania (Fleischer 2007: 306). Zarówno człowiek, jak i lis czy mucha mogą dzięki dostępnym zmysłom skonstruować obiekt „kwiat”. Prawdopodobnie nie będą to jednak te same konstrukty. W tym więc ujęciu nie mamy szans poznać rzeczywistości „taką, jaka jest”, ponieważ nasze poznanie jest zawsze zapośredniczone. Realność „jaka jest, dowiedzieć możemy się jedynie za pomocą naszej kognicji i naszych emocji, a zatem w rezultacie dowiedzieć się tylko tego, co ta kognicja i te emocje nam dowiedzieć się pozwalają" (Fleischer 2007: 172). Podkreślić jednocześnie należy asemantyczność 
konstruowanych w rzeczywistości biologicznej obiektów. Semantykę „dodają" dopiero znaki, czyli podstawa trzeciej rzeczywistości.

To w trzeciej rzeczywistości - społecznej, odbywa się przypisanie znaczeń obiektom. Znaczenia i system społeczny są nierozerwalne, ponieważ semantyka stanowi immanentną część komunikacji, a ta stanowi mechanizm systemu społecznego. Interpretator (uczestnik systemu społecznego, ten, kto bierze udział w procesach komunikacji) „komunikuje z innymi interpretatorami o konstruktywnych obiektach semantycznych, a więc o operatywnych fikcjach, konstruktach lub konceptach. Żeby to było możliwe, wymagane są znaczenia, a więc znaki” (Fleischer 2008: 30). Kiedy obiekt postrzegania zyskuje semantykę, staję się obiektem komunikacyjnym.

Schematycznie zależności między trzema rzeczywistościami można przedstawić za pomocą następującego algorytmu:

$\{[($ współoddziaływania + organizm $)=$ postrzeganie $]+$ znaki $\}=$ komunikacja (Fleischer 2007: 172)

lub rozpisać na triadyczne szeregi (tabela 1):

Tabela 1. Triadyczne szeregi w koncepcji trzech rzeczywistości

\begin{tabular}{|l|l|l|l|}
\hline \multicolumn{1}{|c|}{ rzeczywistość } & \multicolumn{1}{c|}{ 1. rzeczywistość } & \multicolumn{1}{c|}{ 2. rzeczywistość } & \multicolumn{1}{c|}{ 3. rzeczywistość } \\
\hline systemy & system fizyczny & system biologiczny & system społeczny \\
\hline kategorie & pierwszość & drugość & trzeciość \\
\hline modus & współoddziaływanie & postrzeganie & komunikacja \\
\hline produkt & wzory & obiekty & znaczenia \\
\hline produkt z & wzory z kontinuum & obiekty ze wzorów & znaczenia z obiektów \\
\hline materiał & materia/fale/energia & organizmy & kognicja/emocje \\
\hline obserwator & pierwszego & drugiego & trzeciego stopnia \\
\hline uczestnik & wzór & aktant & interpretator \\
\hline operacje & wzór & rozróżnienie & obserwacja \\
\hline
\end{tabular}

Źródło: Fleischer 2007: 172

Systemy rozsądnego konstruktywizmu podlegają kontyngencji, rozumianej jako dokonanie nieodwracalnego wyboru z danego pola alternatyw, co oznacza, ,że kiedy wybrały jedną z możliwych alternatyw, wybór ten ustala rozwój w tym właśnie kierunku i jest nieodwracalny" (Fleischer 2007: 124). Kontyngencja więc nie oznacza chaosu, ale dokonanie możliwego wyboru, który jednocześnie wiąże się z eliminacją innych. 
Michael Fleischer rozróżnia też skomplikowanie i kompleksowość. To pierwsze ma charakter przestrzenny i dotyczy liczby elementów. Drugie jest zjawiskiem czasowym i wiąże się ze wzajemnie funkcjonalnie usieciowionymi składnikami systemu. Przy czym postrzegane może być tylko skomplikowanie (Fleischer 2007: 141).

Przy charakterystyce systemu społecznego podkreślić należy, że jako trzeciość jest najbardziej kompleksowym systemem, który „bazuje oczywiście na obydwu pozostałych (mniej kompleksowych) systemach, nie jest jednak do nich sprowadzalny" (Fleischer 2007: 167). Wykorzystuje więc elementy pierwszej i drugiej rzeczywistości, ale różni się nadawaniem charakteru znakowego: „Zarówno współoddziaływania, jak i postrzegania uzyskać mogą (dla obserwatora) charakter znakowy, a tym samym znaczenie, jednak wyłącznie w bardziej kompleksowym systemie, w systemie społecznym (Fleischer 2007: 167).

W takim razie „system społeczny nie składa się z jednostek (indywiduów - ludzi lub innych zwierząt), nie składa się także z populacji, lecz z komunikacji, które tworzone są przez mechanizm komunikacji" (Fleischer 2007: 166). Z komunikacji, czyli „wielkości produkujących znaczenia i będących wyprodukowanymi przez znaczenia, które muszą być pojmowane jako mechanizm produkujący znaki, nieróżniący się jednak generalnie z uwagi na swoje funkcje i swój stan od pozostałych mechanizmów (Fleischer 2007: 167). Ujmując rzecz metaforycznie, komunikacja jest producentem rzeczywistości otwartego systemu społecznego (Fleischer 2007: 167).

Jak widać, komunikacja nie jest rozpatrywana w kategoriach nadawcy i odbiorcy, ale jako mechanizm systemu i jako taki wpływa na jego powstanie i utrzymanie poprzez ciągłe posługiwanie się znakami przez systemy świadomości i tym samym umożliwienie tym ostatnim orientowania się $\mathrm{w}$ tak komunikacyjnie utworzonej rzeczywistości.

Komunikacja determinuje powstanie programów komunikacji, rozumianych jako specyficzne obszary zastosowań komunikacji i jako producentów systemów funkcyjnych systemu społecznego, takich jak: gospodarka, religia, medycyna, prawo, wojsko, polityka, administracja, edukacja, nauka, nauki humanistyczne, sport, rozrywka, technika, prywatność (Fleischer 2007: 174-225).

Te z aspektów rozsądnego konstruktywizmu, które bezpośrednio łączą się z problemem badawczym niniejszego opracowania, zostaną szczegółowo omówione w kolejnych rozdziałach. 


\subsubsection{Kreowanie wizerunku przez odbiorcę wypowiedzi}

W koncepcji trzech rzeczywistości ta rzeczywistość, którą znamy, jest wynikiem konstrukcji, będących rezultatem postrzegania realności przez pryzmat zmysłów (kiedy powstają obiekty postrzegania) i ostatecznie używania znaków w procesie komunikacji (kiedy powstają obiekty komunikacji). Konstrukcja ta dokonuje się w interpretatorze - uczestniku systemu społecznego i tym samym odbiorcy obiektów znakowych. Wizerunek autora wypowiedzi (zbudowanej ze znaków) jest więc także efektem konstrukcji dokonywanej przez odbiorcę tej wypowiedzi.

$\mathrm{Na}$ poziomie drugiej rzeczywistości niemożliwe jest postrzeganie bez konstruowania obiektów. Jak zaznacza Fleischer, „nieprzerwanie postrzegamy obiekty, konstruując je; a ponadto - nie możemy nie postrzegać bez konstrukcji i konstruowania obiektów” (Fleischer 2007: 12). W kontekście języka naturalnego „obiekty obecne są więc zarówno przed komunikacją (w podwójnym względzie - jako obiekty postrzegania i jako obiekty językowe), jak i w komunikacji. Równocześnie obiekty konstruowane są także podczas komunikacji i przez komunikację" (Fleischer 2007: 12). Ostatecznie poznajemy to tyle co konstruujemy rzeczywistość ze znaków w komunikacjach.

W ten sposób nasza rzeczywistość tworzona jest w procesie komunikacji za pośrednictwem znaków, który to proces wzmacnia socjalizacja. Trzecia, społeczna i komunikacyjna rzeczywistość ,jest tak samo realna jak realność, a realność tak samo realna jak rzeczywistość" (Fleischer 2007: 140). Nie ma innej możliwości poznania rzeczywistości niż za pośrednictwem komunikacji, ponieważ, już postrzegając obiekty, je konstruujemy, a mówiąc o nich, wykorzystujemy znaki, które produkują obiekty komunikacyjne. Tym samym granice naszego poznania sięgają tak daleko jak granice naszych możliwości komunikacyjnych.

Tak samo wizerunek osoby, który powstaje na podstawie jej wypowiedzi (o charakterze znakowym), nie może być inny niż ten kreowany przez odbiorcę.

\subsubsection{Komunikowanie wizerunku przez autora wypowiedzi}

Omawiany w niniejszym opracowaniu problem badawczy dotyczy komunikatu, tego, co zakomunikowano (wizerunek), na podstawie tego, co powiedziano (wypowiedź). Tym samym stosuje się tutaj konstruktywistyczny podział na mówienie i komunikowanie. Może bowiem ktoś powiedzieć, że ma szeroką wiedzę na temat literatury greckiego średniowiecza i najwyżej ceni jego głównego przedstawiciela Alberta Einsteina, w szczególności zaś jego czołowe dzieło Makbeta za zastosowanie nowatorskich rozwiązań narracyjnych. Wówczas 
autor wypowiedzi powiedział nie więcej niż powyższe słowa, ale zakomunikowat co najmniej głęboką ignorancję w zakresie historii literatury.

Mówienie dotyczy treści, stanowienia wypowiedzi, które realizowane mogą być $\mathrm{w}$ jakimkolwiek systemie znakowym, w tym również za pomocą znaków języka naturalnego. „W tym sensie 'mówienie' to wszelkie akty produkujące szeroko rozumiane wypowiedzi” (Fleischer 2011: 13-14, zob. też tenże 2012: 28). Podsumowując, „o ile zatem mówienie sprowadza się do tego, co się mówi, o tyle komunikowanie odnosi się do tego, jak się to mówi i co się przez to, co i w jaki sposób się mówi, jeszcze komunikuje" (Fleischer 2011: 14 i tenże 2012: 29).

Rozróżnienie na „mówienie” i „komunikowanie” stanowiło punkt wyjścia dla weryfikowanego problemu badawczego i definiowało w szczegółach przebieg całego badania. Celem badania, była bowiem m.in. eksploracja, jaki wizerunek może być komunikowany („komunikowanie”) werbalnie z udziałem informacji o tożsamości autora bądź bez tych danych i na podstawie pozatekstowej wiedzy o nim lub mając do dyspozycji wyłącznie zdjęcie felietonisty. $\mathrm{W}$ ten sposób w różnych systemach znaków i w różnych warunkach respondenci otrzymywali gotowe wypowiedzi, to, co powiedziane, a z kolei odpowiedzi uczestników badania pozwoliły określić, to, co zakomunikowane ${ }^{6}$.

Szczegółowo o wpływie celów badania na dobór rozwiązań metodologicznych traktuje rozdział 1.3.2.

\subsubsection{Wizerunek a tożsamość}

Parafrazując formułowane przy okazji opisu corporate identity słowa Michaela Fleischera, że „wizerunek jest zatem tym, co funkcjonuje na temat organizacji zewnętrznie na rynku, jest tym, co my o danej organizacji społecznie mniemamy (...) co ludzie o organizacji na zewnątrz sądzą (kimkolwiek owi 'ludzie' by byli)" (2010: 215), przyjmuje się w niniejszym opracowaniu, iż wizerunek jest tym, co odbiorcy wypowiedzi, dokonanej w jakimkolwiek systemie znakowym, konstruują na temat obiektu.

Tak ogólna definicja mieści jednak w sobie ustalenia innych badaczy, którzy zgadzają się co do tego, że wizerunek może dotyczyć firmy, marki, produktu instytucji, osoby itd. (zob. Figiel 2013: 13; Stasiuk-Krajewska 2011: 267; Tarczydło 2007: 326; Wojcik 2009: 41; Leksykon public relations 2009: 174;

6 Referowane w tym opracowaniu badanie miało też swoją drugą część (tam, gdzie czytano tekst), kiedy po określeniu cech wizerunkowych, respondentów proszono o wskazanie fragmentów tekstu, które stały się podstawą do przypisania wskazanych cech felietonisty. W ten sposób można było szczegółowo zbadać, co należy mówić, by komunikować konkretną cechę wizerunkową. O tej - drugiej - części badania traktuje publikacja Wizerunek felietonisty i sposoby jego werbalnego komunikowania (Barańska-Szmitko 2018). 
Tworzydło 2008: 14), zatem dowolnego obiektu komunikacji. Panuje zgoda co do tego, że image stanowi wyobrażenie niejednorodne, zróżnicowane, wieloelementowe (np. Altkorn 2004: 7-8; Wojcik 2009: 41; Budzyński 2008: 11; Tworzydło 2008: 14). Wielu zwraca też uwagę na subiektywny i aktywny charakter tworzenia wizerunku w świadomości/umysłach odbiorców ofert komunikacyjnych (Kolbus 2011: 154; Altkorn 2004: 7-8; Rzemieniak 2011: 86; Budzyński 2008: 11). Dodać też należy, iż część badaczy zauważa i podkreśla brak możliwości niekomunikowania image’u, i chociaż „nie znaczy to oczywiście, że wszyscy aktorzy grający na tej scenie podejmują świadome działania wizerunkowe (realizują strategie budowania wizerunku), z pewnością jednak wszyscy oni ów wizerunek mają" (Borkowski, Stasiuk-Krajewska 2011: 12) 7 .

Ważne przy tym, by nie mylić wizerunku z tożsamością. Ta ostatnia rozumiana jest w literaturze przedmiotu w dwojaki sposób, ale żaden $\mathrm{z}$ nich nie wykazuje cech wspólnych z image’em. Po pierwsze, tożsamością nazywa się elementy wizualne identyfikujące firmę, instytucję, produkt itd., często wystandaryzowane w tzw. księdze tożsamości wizualnej (zob. Cenker 2000: 47-67; Rozwadowska 2002: 193-214; Figiel 20013: 29; Kwiecień 2010: 21). W szerszym ujęciu tożsamość „dotyczy wewnętrznego sposobu widzenia, rozumienia, pojmowania się organizacji, funkcjonującej na rynku, czyli tego jak organizacja sama siebie widzi” (Fleischer 2010: 215), przy czym - w zależności od szczegółowych rozwiązań - różnie się rozumie ów zakres wewnętrznego sposobu widzenia (zob. Wojcik 2009: 156-157; Cenker 2000: 47-67; Rozwadowska 2002: 193-214; Fleischer 2010; Tworzydło 2008: 13-14; Nikodemska-Wołowik 2008: 59; Altkorn 2004: 17-18).

$\mathrm{O}$ ile więc wizerunek wiąże się $\mathrm{z}$ tym, jak obiekt jest widziany przez interpretatorów, o tyle tożsamość wyraża sposób widzenia firmy, instytucji itd. przez samą siebie. Warto też zaznaczyć, iż tożsamość człowieka stanowi domenę psychologii osobowości, dlatego - kiedy mówimy o tożsamości funkcjonującej w komunikacji społecznej - to badacze uwzględniają wyłącznie tożsamość firm, instytucji, organizacji itp., ale nie tożsamość konkretnych osób.

\subsection{Metodologiczne rozwiązania ${ }^{8}$}

Zaplecze teoretyczne oraz sam problem badawczy zdeterminowały selekcję metodologicznych rozwiązań. Poniżej określono cele szczegółowe i opisano procedurę badawczą im podporządkowaną, w której uwzględniono układ i brzmienie pytań, sposób przedstawienia materiałów respondentom, dobór uczestników, miejsca

7 O wizerunku „nieświadomym”, komunikowanym niecelowo, zob. np. Skawińska 2007; Borkowski 2011. 8 Opis narzędzi metodologicznych i przebiegu badania w kontekście innych niż tu referowane celów badawczych zob. i por. Barańska-Szmitko 2018: 44-86. 
badania oraz wykorzystanych tekstów, uzasadniono wybór poszczególnych felietonistów, by na końcu określić trafność wewnętrzną przeprowadzonego eksperymentu, zastosowane rozwiązania analityczne i w końcu ustalenia terminologiczne w zakresie definicji o charakterze operacyjnym.

\subsubsection{Szczegółowe cele badania}

Temat niniejszego opracowania, czyli określenie wizerunku możliwego do komunikowania werbalnie, przy jednoczesnej próbie scharakteryzowania wpływów zdjęcia i wiedzy pozatekstowej na image felietonisty, konstruowany przez czytelnika na podstawie lektury tekstu, to część zadań stawianych przed większym projektem, w jakim istotne też było określenie wykładników komunikacyjnych poszczególnych cech wizerunkowych i ocena zastosowanej metody. Poniżej przedstawione zostaną wszystkie szczegółowe cele całego badania z uwagi na fakt,żerealizowanojepraktyczniejednocześnieitrudnojeizolować(odpowiedzi na stawiane pytania uzyskiwano w tych samych grupach badawczych w trakcie tego samego badania), a także w celu przedstawienia pełniejszego obrazu. To jednak, co nie stanowi problematyki niniejszego opracowania, traktowane będzie skrótowo lub wręcz zdawkowo i w odpowiednich miejscach Czytelnik znajdzie stosowne odwołania do opracowania szczerzej traktującego poszczególne zagadnienia - Wizerunek felietonisty i sposoby jego werbalnego komunikowania (Barańska-Szmitko 2018).

Szczegółowe cele prowadzonych w paradygmacie empirycznym badań zdefiniowano jako odpowiedzi na sformułowane niżej pytania, którym jednocześnie towarzyszą hipotezy badawcze, powstałe głównie na podstawie dotychczasowych badań i obserwacji. Wszystkie te pytania można podzielić na cztery grupy: I. Opis wizerunków; II. Wzajemne wpływy (analiza i interpretacja danych zawarta w niniejszym opracowaniu dotyczyć będzie właśnie tych dwóch grup); III. Metoda; IV. Wykładniki komunikacyjne.

\section{Opis wizerunków}

Pytanie nr 1: Jaki wizerunek autora tekstu może być przez niego komunikowany, gdy pisze na temat inny niż własna osoba i w sytuacji, gdy taki autor słów pozostaje anonimowy dla odbiorcy wypowiedzi?

Pytanie nr 2: Jaki wizerunek autora tekstu może być przez niego komunikowany, gdy mówi na temat inny niż własna osoba i w sytuacji, gdy tożsamość takiego autora słów jest znana odbiorcy wypowiedzi? 
Hipoteza do pyt. 1 i 2: Wizerunek werbalny anonimowego i jawnego twórcy może komunikować cechy charakteru (np. „zabawny”, „inteligentny”, „indywidualista”, „szczery”, „empatyczny”), postawę (np. „racjonalista”, „otwarty”, „obserwator”, „doradzający”) i poglądy/wartości (np. „patriota”), wiedzę (np. filozof) (Barańska 2011, 2012).

Pytanie nr 3: Jaki wizerunek osoby jest możliwy do komunikowania przez fotografię z jej podobizną?

Hipoteza: Wygląd i cechy charakteru będą elementami najbardziej podkreślanymi w image’u wizualnym. Zauważony powinien też być wiek.

Pytanie nr 4: Jaki wizerunek osoby jest możliwy do komunikowania przez całość działań komunikacyjnych (jakie cechy przypisuje się danej osobie, gdy przywoła się jej tożsamość - imię i nazwisko)?

Hipoteza: Ze względu na wielość możliwych źródeł wypowiedzi i podstaw konstrukcji wizerunku image publiczny powinien wykazywać się największą absorbcją cech i kategorii z innych typów wizerunków (werbalnego i wizualnego).

\section{Wzajemne wpływy}

Pytanie nr 5: Czy/jaki wpływ na kreowany przez interpretatora wizerunek autora wypowiedzi werbalnej ma informacja o tożsamości mówiącego oraz jego zdjęcie, które towarzyszy wypowiedzi werbalnej? = jaka jest różnica między wizerunkiem anonimowego autora tekstu a wizerunkiem autora tekstu o znanej tożsamości i wyglądzie?

Hipoteza: Wizerunki będą podobne, przy czym image anonimowego felietonisty będzie bardziej rozproszony (mając więcej cech) (Barańska 2011).

Pytanie nr 6: Czy/jaki jest wpływ wizerunku komunikowanego w systemie wizualnym na wizerunek komunikowany werbalnie? = jaka jest różnica między wizerunkami komunikowanymi za pomocą warstwy wizualnej i werbalnej?

Hipoteza: Wizerunek wizualny będzie aktualizował wizerunek publiczny i ten ostatni wpłynie na image werbalny.

Pytanie nr 7: Na ile wizerunek autora wypowiedzi determinowany jest przez samą jego wypowiedź, a na ile przez wygląd (towarzyszący tekstowi obraz z podobizną autora) i przypisywany mu przez odbiorcę wizerunek, powstały jeszcze przed przeczytaniem tekstu? Innymi słowy: który z wpływających na konstrukcję wizerunku systemów znakowych jest dominujący?

Hipoteza: Fotografia aktualizuje wizerunek publiczny, dlatego jej wpływ jest niewielki. W konstrukcji wizerunku werbalnego dominuje wizerunek publiczny, który wpływa na to, co tworzy czytelnik danej wypowiedzi werbalnej i jakie cechy przypisuje osobie $\mathrm{z}$ fotografii. 
Pytanie nr 8: Czy/jaki jest wpływ tematu wypowiedzi na wizerunek jej autora?

Hipoteza: Wizerunek kreowany przez odbiorców zależy od poruszanej przez wypowiadających się tematyki (Barańska-Szmitko 2011, 2012). Na jakich zasadach - pozostaje pytaniem otwartym.

Pytanie nr 9: Czy/jaki jest wpływ postawy ideowej/światopoglądu na wizerunek jego przedstawiciela?

Hipoteza: Reprezentowany światopogląd ma wpływ na wizerunek. Tematyka społeczno-polityczna służyć będzie bardziej komunikowaniu cech wyrażających poglądy ideowe.

Ponadto, poza interesującymi nas zagadnieniami, starano się określić wykładniki komunikacyjne cech wizerunkowych (pytanie nr 10: Jakie są językowe wykładniki cech przypisywanych autorom słów, czyli - jakie mechanizmy komunikacji na poziomie werbalnym odpowiadają za przypisanie określonej cechy wizerunku?) oraz ocenić stosowaną metodę („Jakie są możliwości i ograniczenia badania wizerunku za pomocą triangulacji metod, polegającej na połączniu eksperymentu z analizą dyskursu?”) (więcej w: Wizerunek felietonisty...).

\subsubsection{Dobór metodologii do celów badania}

By osiągnąć wymienione cele z perspektywy racjonalnego konstruktywizmu jako teorii wiodącej, wykorzystano narzędzia paradygmatu empirycznego w ramach interdyscyplinarnego podejścia, posłużono się więc triangulacją metodologiczną. Cechy wizerunku w każdym wariancie badania pozwoliły wyłonić metody badań społecznych, stosowane przez konstruktywistyczną naukę o komunikacji (eksperyment $\mathrm{z}$ wykorzystaniem ankiet - patrz: niżej). Metodę wyłonienia wykładników językowych podanych przez respondentów cech wizerunku narzucił sam językowy charakter materiału badawczego - wypisane fragmenty tekstów poddano konstruktywistycznej analizie dyskursu - zob. Wizerunek felietonisty...). Zawarty poniżej opis badania skupia się głównie na części poświęconej poszczególnym wizerunkom i wpływom na nie (patrz niżej o formule eksperymentu), a nawiązuje do drugiego etapu badania tylko tam, gdzie to konieczne (relacja cele badawcze - wariant badania).

Posłużono się formułą eksperymentu, czyli metodą testującą hipotezy, ustalającą i wyjaśniającą związki przyczynowe (zob. np. Fleischer 2008a: 107; Babbie 2004: 246; Creswell 2013: 38; Lipski 2012: 96; Wójcik 2007: 135), ponieważ celem interesującej nas tu części badania dotyczącej wizerunku (a nie wykładników językowych poszczególnych cech) było ustalenie wpływu 
danego zjawiska komunikacyjnego (zdjęcie i znajomość nazwiska) na kształt wizerunku komunikowanego werbalnie.

Klasyczny schemat eksperymentalny zakłada utworzenie dwóch grup: eksperymentalnej i kontrolnej, z czego w obu przeprowadza się pomiar początkowy (pretest) i pomiar końcowy (posttest), ale tylko grupa eksperymentalna poddawana jest działaniu bodźca. By znieść jednak wpływ pretestu na wyniki, proponuje się także np. wyłącznie pomiar końcowy po zastosowaniu bodźca w grupie eksperymentalnej i pomiar początkowy w grupie kontrolnej (Wójcik 2007: 143; Babbie 2004: 258-259).

Ten ostatni schemat został zastosowany $\mathrm{w}$ opisywanym tu badaniu (zob. rysunek 1).

Wariant 1 badania (sam anonimowy tekst) - z jednej strony - stwarzał możliwość określenia, jaki wizerunek jest możliwy do komunikowania na poziomie werbalnym, $\mathrm{z}$ drugiej strony - jego realizacja stanowiła pretest $\mathrm{w}$ grupie kontrolnej. By sprawdzić, na ile odtworzony w grupie kontrolnej wizerunek jest wynikiem działania samego sytemu języka naturalnego, a na ile innych czynników, przedstawione respondentom w grupie eksperymentalnej (wariant 2) teksty miały postać kserokopii strony z tygodnika, zawierały więc informację o tożsamości autora oraz jego fotografię.

Rysunek 1. Schemat eksperymentalny: pomiar końcowy w grupie eksperymentalnej i początkowy w grupie kontrolnej dla badania: „Kreowanie wizerunku autora felietonu przez odbiorcę tekstu”

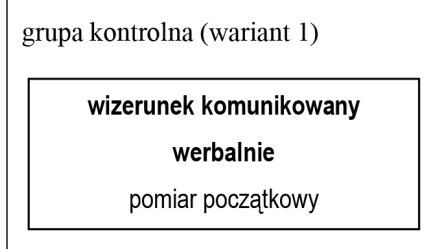

grupa eksperymentalna (wariant 2)

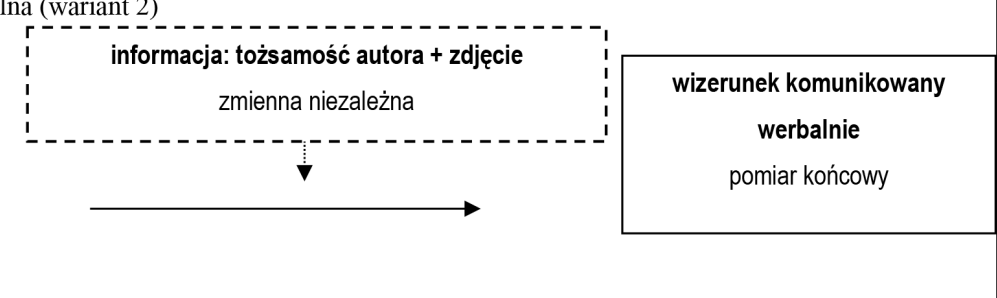

Źródło: opracowanie własne 
Poza tą główną częścią badania w wariancie 3 (samo zdjęcie) i wariancie 4 (skojarzenia $\mathrm{z}$ nazwiskiem) weryfikowano możliwości komunikowania wizerunku odpowiednio przez fotografię oraz przez całokształt działań komunikacyjnych, przywoływany za pomocą nazwiska felietonisty. Innymi słowy, wprowadzono w tych przypadkach tylko jeden pomiar. Teoretycznie można było stworzyć kolejne grupy eksperymentalne z bodźcami w postaci zdjęcia i osobno nazwiska autora z pomiarem końcowym w ten sposób, że w jednej $\mathrm{z}$ takich grup uczestnicy czytaliby teksty opatrzone zdjęciem felietonisty (bez informacji o nazwisku), a w drugiej teksty z informacją o nazwisku (bez zdjęcia). Nie miało to jednak uzasadnienia ani merytorycznego, ani w zakresie możliwości fizycznego wykonania. Zarówno samo nazwisko przywołuje wygląd osoby, jak i wygląd osoby łączy się z jej tożsamością, w związku z czym niemożliwe jest izolowanie tych dwóch zmiennych, wyniki więc w dużej mierze nakładałyby się, jeśli nie byłyby niemal identyczne. Ponadto, przy konieczności zachowania homogeniczności grup i zapewnienia losowego do nich doboru (patrz niżej), przy potrzebie dużej liczebności każdej z grup (252 osoby na grupę) i mając na uwadze, że eksperyment powinien odbywać się w tym samym czasie (a przynajmniej jedna $\mathrm{z}$ jego tur czasowych), to przeprowadzenie eksperymentu $\mathrm{z}$ udziałem czterech grup, każda w liczbie 252 osób (więc razem 1008), było fizycznie niewykonalne.

Dlatego też zrezygnowano z potraktowania nazwiska felietonisty i jego wyglądu jako dwóch izolowanych zmiennych i weryfikowania wizerunku na podstawie wypowiedzi werbalnej osobno dla każdej z nich, ale za zasadne uznano sprawdzenie, jaki image jest możliwy do komunikowania na podstawie fotografii osoby (wariant 3) oraz, osobno, na podstawie jej nazwiska (wariant 4) (nie na podstawie tekstu $\mathrm{z}$ fotografią $\mathrm{i}$ tekstu $\mathrm{z}$ nazwiskiem). Po pierwsze, uzupełniało to główny cel badawczy (czyli ustalenie, jaki wizerunek na podstawie tekstu jest możliwy do komunikowania) o aspekt wizualny i ogólnokomunikacyjny ${ }^{9}$. Po drugie, porównanie rezultatów z tych dwóch wariantów znacząco uzupełniało wyniki z wariantów 1 (sam tekst) i 2 (tekst + zdjęcie + nazwisko), tj. umożliwiało lepsze ustalenie zależności wizerunku „tekstowego” od innych. Ponadto, możliwe było zadanie pytań dotyczących image’u na podstawie fotografii i nazwiska w trakcie realizacji głównych zadań (wariant 1 i 2), bez konieczności tworzenia kolejnych grup i bez szkody dla rzetelności wyników (zadbano o odpowiedni układ poleceń w poszczególnych wariantach - patrz: rozdziały: 1.3.2.1, 1.3.2.2 oraz 1.3.2.7), powstały więc dwie grupy, liczące łącznie 504 osoby, których zgromadzenie na potrzeby badania okazało się możliwe.

$9 \mathrm{~W}$ tym ostatnim przypadku założono, że image wywołany przez nazwisko będzie wizerunkiem, którego podstawę tworzą wypowiedzi - z udziałem bądź na temat danej osoby - wszystkich systemów znakowych dostępnych respondentowi, stąd mówienie o aspekcie ogólnokomunikacyjnym. 
Jak już wspomniano, całość badania prowadzono w czterech jego wariantach:

Wariant 1. Sam tekst. Respondenci otrzymywali sam tekst do przeczytania bez informacji o tożsamości autora oraz bez jego fotografii. Po przeczytaniu tekstu przypisywali autorowi wypowiedzi cechy (a następnie wskazywali słowa/zdania/fragmenty, które stały się podstawą przypisania wskazanych cech, o czym - jak wyżej wspomniano - traktuje komplementarna publikacja Wizerunek felietonisty i sposoby jego werbalnego komunikowania).

Wariant 2. Tekst + zdjęcie + nazwisko. Respondenci otrzymywali tekst do przeczytania $\mathrm{z}$ informacją o tożsamości autora oraz jego fotografią towarzyszącą tekstowi i tak samo jak w wariancie 1, po przeczytaniu, przypisywali autorowi wypowiedzi cechy (a następnie wskazywali słowa/zdania/fragmenty, które stały się podstawą przypisania wskazanych cech).

Wariant 3. Samo zdjęcie. Respondenci przypisywali cechy osobie widocznej na zdjęciu.

Wariant 4. Nazwisko. Respondenci przypisywali cechy osoby o podanym imieniu i nazwisku.

Poniższe zestawienie (tabela 2) ilustruje realizację każdego z pytań badawczych przez poszczególne warianty i części badania. Na szaro zaznaczono te części, których dotyczy niniejsze opracowanie.

Tabela 2. Realizacja pytań badawczych w poszczególnych wariantach lub częściach badania

\begin{tabular}{|c|c|c|}
\hline $\begin{array}{l}\text { Wariant/część } \\
\text { badania }\end{array}$ & \multicolumn{2}{|c|}{$\begin{array}{c}\text { Pytania badawcze } \\
\text { (numery pytań - zob. rozdz. 1.3.1. Szczegółowe cele badania) }\end{array}$} \\
\hline $\begin{array}{l}\text { Wariant } 1 . \\
\text { Respondenci otrzy- } \\
\text { mują sam tekst BEZ } \\
\text { nazwiska autora }\end{array}$ & $\begin{array}{l}\text { Pyt. 1. Jaki wizerunek anonimo- } \\
\text { wego autora jest możliwy do ko- } \\
\text { munikowania za pomocą samej } \\
\text { wypowiedzi werbalnej? }\end{array}$ & \multirow{2}{*}{$\begin{array}{l}\text { Zestawienie tych dwóch wariantów } \\
\text { i różnice między nimi pozwolą sformu- } \\
\text { łować odp. na pyt. 5. (Jaka jest różnica } \\
\text { między wizerunkiem powstającym wy- } \\
\text { łącznie na podstawie tekstu a wizerun- } \\
\text { kiem powstałym przy udziale zdjęcia } \\
\text { i sprecyzowanej tożsamości autora?). }\end{array}$} \\
\hline $\begin{array}{l}\text { Wariant } 2 \text {. } \\
\text { Tekst + zdjęcie } \\
\text { + nazwisko autora }\end{array}$ & $\begin{array}{l}\text { Pyt. 2. Jaki wizerunek autora } \\
\text { o podanym imieniu i nazwisku } \\
\text { jest możliwy do komunikowania } \\
\text { werbalnie? }\end{array}$ & \\
\hline $\begin{array}{l}\text { Wariant } 3 . \\
\text { Samo zdjęcie }\end{array}$ & $\begin{array}{l}\text { Pyt. 3. Jaki wizerunek jest możli- } \\
\text { wy do komunikowania za pomo- } \\
\text { cą samego zdjęcia osoby? }\end{array}$ & $\begin{array}{l}\text { Zestawienie z wariantem } 1 \text { i } 2 \text { może po- } \\
\text { zwolić wyizolować oraz sprawdzić, czy } \\
\text { i jaki wpływ ma warstwa wizualna na } \\
\text { tekstową w zakresie komunikowania } \\
\text { wizerunku (pyt. 6). }\end{array}$ \\
\hline $\begin{array}{l}\text { Wariant } 4 . \\
\text { Pytanie } \\
\text { o skojarzenia } \\
\text { z samym } \\
\text { nazwiskiem }\end{array}$ & $\begin{array}{l}\text { Pyt. 4. Jaki wizerunek ma dana } \\
\text { osoba na podstawie całokształtu } \\
\text { (dostępnych dla respondenta) } \\
\text { działań komunikacyjnych? }\end{array}$ & $\begin{array}{l}\text { Zestawienie z pozostałymi wariantami } \\
\text { może pozwolić odpowiedzieć na pyt. } 8 \text {. } \\
\text { (Czy i który system znakowy dominuje } \\
\text { w procesie konstruowania wizerunku } \\
\text { na podstawie kilku takich systemów?). }\end{array}$ \\
\hline
\end{tabular}


Tabela 2 (cd.)

\begin{tabular}{|l|l|}
\hline \multicolumn{1}{|c|}{$\begin{array}{c}\text { Wariant/część } \\
\text { badania }\end{array}$} & \multicolumn{1}{c|}{\begin{tabular}{c}
\multicolumn{1}{c|}{ Pytania badawcze } \\
(numery pytań - zob. rozdz. 1.3.1. Szczegółowe cele badania)
\end{tabular}} \\
\hline $\begin{array}{l}\text { Wypisanie z tekstu } \\
\text { słów/zdań/ } \\
\text { fragmentów } \\
\text { będących pod- } \\
\text { stawą wyłonienia } \\
\text { danej cechy autora } \\
\text { tekstu } \\
\text { (w wariantach 1 i 2) }\end{array}$ & $\begin{array}{l}\text { Pyt. 7. Jakie wykładniki językowe odpowiadają za komunikowanie okre- } \\
\text { ślonej cechy wizerunku? }\end{array}$ \\
\hline $\begin{array}{l}\text { Całość badania } \\
\text { Porównanie }\end{array}$ & $\begin{array}{l}\text { Pyt. 9. Czy i jak połączenie eksperymentu z analizą dyskursu sprawdza się } \\
\text { w celu określenia wizerunku i jego językowych wykładników? }\end{array}$ \\
\hline $\begin{array}{l}\text { Pynt. 10. Czy/jaki jest wpływ tematu wypowiedzi na wizerunek jej autora? } \\
\text { dotyczących } \\
\text { poszczególnych } \\
\text { autorów }\end{array}$ & $\begin{array}{l}\text { Pyt. 11. Czy/jaki jest wpływ postawy ideowej/światopoglądu na wizerunek } \\
\text { jego przedstawiciela? }\end{array}$ \\
\hline
\end{tabular}

Źródło: opracowanie własne

\subsubsection{Układ poleceń w grupach i brzmienie pytań}

Dwa czynniki wpłynęły na liczbę grup w badaniu i układ poleceń. Po pierwsze, należało zadbać o porównywalność rezultatów między wynikami dla poszczególnych osób publicznych i dla każdego z wariantów. Po drugie, do choćby wstępnej generalizacji wniosków potrzebna była relatywnie duża próba badawcza.

Osiągniecie relatywnie dużej liczby uczestników i tym samym ankiet spotkało się z dwiema głównymi przeszkodami. Pierwszą było ograniczenie dotyczące kierunku studiów respondentów (głównie dziennikarstwo i dodatkowo polonistyka) i ich rocznika (tylko I i II rok - patrz: rozdz. 1.3.2.4. Uczestnicy badania). Drugie utrudnienie to podejście wykładowców, bowiem niektórzy nie pozwalali na pojawienie się na zajęciach ze względu na niezgodność tematyczną ankiet $\mathrm{z}$ prowadzonym przez nich przedmiotem. Przeprowadzenie badania na zajęciach wprowadzono jako warunek obligatoryjny, ponieważ zapewniało to kontrolę nad osobami biorącymi udział w badaniu, tj. proponowano realizację zadań tylko tym, którzy mogli wziąć w badaniu udział. Te ograniczenia spowodowały, że powstały nie cztery (co byłoby idealnym rozwiązaniem), ale dwie grupy badanych, w których przeprowadzono cztery warianty badania, dbając o odpowiedni układ poleceń, wykluczający bądź minimalizujący wpływ jednych odpowiedzi na drugie. Warunek porównywalności wyników mógł być 
osiągnięty poprzez bezwzględne zachowanie proporcji w obrębie wariantów, analogiczne brzmienie pytań i sugestię podania określonej liczby cech felietonisty. Łącznie udało się zebrać 1260 ankiet dla 4 wariantów badania, przeprowadzonych wśród 504 respondentów.

Układ wariantów w każdej z grup oraz proporcje dla każdego z autorów przedstawia tabela 3. Sekwencję wariantów wraz z dosłownym brzmieniem pytań w każdej grupie na przykładzie wizerunku werbalnego Krzysztofa Vargi, wizualnego Piotra Zaremby oraz publicznego Piotra Zaremby i Magdaleny Środy ilustruje tabela 4. Te dwa zestawienia posłużą jako punkt wyjścia dla opisu kolejności wariantów i kształtu poleceń oraz dla uzasadnienia podjętych wyborów.

Tabela 3. Układ i kolejność felietonistów, których dotyczyły pytania w poszczególnych grupach i wariantach badania

\begin{tabular}{|c|c|c|c|c|c|c|}
\hline grupa & $\begin{array}{c}\text { zmienna } \\
\text { niezależna }\end{array}$ & \multicolumn{4}{|c|}{$\begin{array}{l}\text { felietonista, którego dotyczyły pytania } \\
\qquad \times \text { liczba ankiet }\end{array}$} & razem \\
\hline \multirow{2}{*}{$\begin{array}{l}\text { grupa } 1 \\
\text { (wariant } \\
2+3)\end{array}$} & $\begin{array}{l}\text { wariant 2: } \\
\text { tekst } \\
\text { + zdjęcie } \\
\text { + nazwisko }\end{array}$ & $\begin{array}{l}\text { Krzysztof } \\
\text { Varga } \\
\times 63\end{array}$ & $\begin{array}{l}\text { Piotr } \\
\text { Zaremba } \\
\times 63\end{array}$ & $\begin{array}{l}\text { Magdalena } \\
\text { Środa } \\
\times 63\end{array}$ & $\begin{array}{l}\text { Szymon } \\
\text { Hołownia } \\
\times 63\end{array}$ & $\begin{array}{l}252 \text { (po } 63 \text { an- } \\
\text { kiety na każde- } \\
\text { go felietonistę) }\end{array}$ \\
\hline & $\begin{array}{l}\text { wariant 3: } \\
\text { zdjęcie }\end{array}$ & $\begin{array}{l}\text { Piotr } \\
\text { Zaremba } \\
\times 63\end{array}$ & $\begin{array}{l}\text { Krzysztof } \\
\text { Varga } \\
\times 63\end{array}$ & $\begin{array}{l}\text { Szymon } \\
\text { Hołownia } \\
\times 63\end{array}$ & $\begin{array}{l}\text { Magdalena } \\
\text { Środa } \\
\times 63\end{array}$ & $\begin{array}{l}252 \text { (po } 63 \text { an- } \\
\text { kiety na każde- } \\
\text { go felietonistę) }\end{array}$ \\
\hline \multirow[t]{3}{*}{ grupa 2} & $\begin{array}{l}\text { wariant } 4 \text { : } \\
\text { nazwisko } 1\end{array}$ & $\begin{array}{l}\text { Piotr } \\
\text { Zaremba } \\
\times 63\end{array}$ & $\begin{array}{l}\text { Krzysztof } \\
\text { Varga } \\
\times 63\end{array}$ & $\begin{array}{l}\text { Szymon } \\
\text { Hołownia } \\
\times 63\end{array}$ & $\begin{array}{l}\text { Magdalena } \\
\text { Środa } \\
\times 63\end{array}$ & \multirow{2}{*}{$\begin{array}{l}504 \\
\text { (po } 126 \text { ankiet } \\
\text { na każdego } \\
\text { felietonistę) }\end{array}$} \\
\hline & $\begin{array}{l}\text { wariant 4: } \\
\text { nazwisko } 2\end{array}$ & $\begin{array}{l}\text { Magdalena } \\
\text { Środa } \\
\times 63\end{array}$ & $\begin{array}{l}\text { Szymon } \\
\text { Hołownia } \\
\times 63\end{array}$ & $\begin{array}{l}\text { Krzysztof } \\
\text { Varga } \\
\times 63\end{array}$ & $\begin{array}{l}\text { Piotr } \\
\text { Zaremba } \\
\times 63\end{array}$ & \\
\hline & $\begin{array}{l}\text { wariant } 1 \text { : } \\
\text { sam tekst }\end{array}$ & $\begin{array}{l}\text { Krzysztof } \\
\text { Varga } \\
\times 63\end{array}$ & $\begin{array}{l}\text { Piotr } \\
\text { Zaremba } \\
\times 63\end{array}$ & $\begin{array}{l}\text { Magdalena } \\
\text { Sroda } \\
\times 63\end{array}$ & $\begin{array}{l}\text { Szymon } \\
\text { Hołownia } \\
\times 63\end{array}$ & $\begin{array}{l}252 \text { (po } 63 \text { an- } \\
\text { kiety na każde- } \\
\text { go felietonistę) }\end{array}$ \\
\hline
\end{tabular}

Źródło: opracowanie własne. Zob. Barańska-Szmitko 2018: 62 
Tabela 4. Układ wariantów i brzmienie pytań w każdej grupie na przykładzie badania wizerunku werbalnego Krzysztofa Vargi, wizualnego Piotra Zaremby oraz publicznego Piotra Zaremby i Magdaleny Środy

\begin{tabular}{|c|c|c|}
\hline grupa & $\begin{array}{c}\text { zmienna } \\
\text { niezależna }\end{array}$ & brzmienie poleceń \\
\hline \multirow[t]{2}{*}{$\begin{array}{l}\text { grupa } 1 \\
\text { (wariant } \\
2+3)\end{array}$} & $\begin{array}{l}\text { wariant 2: } \\
\text { tekst + zdjęcie } \\
\text { + nazwisko }\end{array}$ & $\begin{array}{l}\text { 1. Proszę przeczytać tekst. } \\
\text { 2. Mając za podstawę tekst przeczytanego felietonu, jakimi sło- } \\
\text { wami opisałby Pan/opisałaby Pani autora Krzysztofa Vargę? } \\
\text { 3. Proszę do każdej wskazanej przez Pana/Panią cechy Krzyszto- } \\
\text { fa Vargi wypisać z tekstu słowa/zdania/fragmenty, które stały } \\
\text { się podstawą do wyłonienia danej cechy. }\end{array}$ \\
\hline & $\begin{array}{l}\text { wariant 3: } \\
\text { zdjęcie }\end{array}$ & $\begin{array}{l}\text { Mając za podstawę przedstawione zdjęcie, jakimi słowami opisałby } \\
\text { Pan / opisałaby Pani przedstawioną na tej fotografii osobę? (na zdjęciu } \\
\text { Piotr Zaremba - przyp. ABS) } \\
\text { Czy wie Pan/Pani, kogo przedstawia zdjęcie? } \\
\square \text { TAK } \square \text { kogo?................. } \\
\square \text { Nie jestem pewny/pewna, ale wydaje mi się, że może to być } \\
\quad(\text { kto?) ..................................... } \\
\text { NIE } \square\end{array}$ \\
\hline \multirow[t]{3}{*}{$\begin{array}{l}\text { grupa } 2 \\
\text { (wariant } \\
4+1)\end{array}$} & $\begin{array}{l}\text { wariant 4: } \\
\text { nazwisko } 1\end{array}$ & $\begin{array}{l}\text { 1. Czy zna Pan/Pani nazwisko: Piotr Zaremba? Proszę zakreślić } \\
\text { swoją odwiedź krzyżykiem ( } X \text { ). } \\
\square \text { TAK. Jeśli tak, proszę przejść do pytania nr } 2 \text {. } \\
\square \text { NIE. Jeśli nie, proszę schować kartkę do teczki. } \\
\text { 2. Jakimi słowami scharakteryzował(a)by Pan/Pani osobę pu- } \\
\text { bliczną Piotra Zarembę? }\end{array}$ \\
\hline & $\begin{array}{l}\text { wariant 4: } \\
\text { nazwisko } 2\end{array}$ & $\begin{array}{l}\text { 1. Czy zna Pan/Pani nazwisko: Magdalena Środa? Proszę zakre- } \\
\text { ślić swoją odwiedź krzyżykiem (X). } \\
\square \text { TAK. Jeśli tak, proszę przejść do pytania nr } 2 \text {. } \\
\square \text { NIE. Jeśli nie, proszę schować kartkę do teczki. } \\
\text { 2. Jakimi słowami scharakteryzował(a)by Pan/Pani osobę pu- } \\
\text { bliczną Magdalenę Środę? }\end{array}$ \\
\hline & $\begin{array}{l}\text { wariant } 1 \text { : } \\
\text { sam tekst }\end{array}$ & $\begin{array}{l}\text { 1. Proszę przeczytać tekst. [Krzysztofa Vargi - tożsamości re- } \\
\text { spondentom w tym przypadku nie podawano - przyp. ABS] } \\
\text { 2. Mając za podstawę tekst przeczytanego felietonu, jakimi sło- } \\
\text { wami opisałby Pan / opisałaby Pani autora tego tekstu? } \\
\text { 3. Proszę do każdej wskazanej przez Pana/Panią cechy autora } \\
\text { felietonu wypisać z tekstu słowa/zdania/fragmenty, które stały } \\
\text { się podstawą do wyłonienia danej cechy. } \\
\text { 4. Czy wiesz, kto jest autorem tekstu? } \\
\square \text { TAK, wiem (kto?) ............................................ } \\
\square \text { Nie jestem pewny/pewna - wydaje mi się, że autorem może } \\
\text { być (kto?) .................................. } \\
\square \text { NIE, nie wiem. }\end{array}$ \\
\hline
\end{tabular}

Źródło: opracowanie własne. Zob. Barańska-Szmitko 2018: 62-63 
Jak pokazuje tabela 3, uzyskano następujące rezultaty liczbowe:

- wariant $1-63$ ankiety dotyczące każdego z felietonistów, razem: 252,

- wariant 2 - 63 ankiety dotyczące każdego z felietonistów, razem: 252, łącznie dla wariantów z tekstem do przeczytania: 504 ankiety;

- wariant 3 (samo zdęcie) - 63 ankiety dotyczące każdego z felietonistów, razem: 252 ,

- wariant 4 (wizerunek publiczny) - 126 ankiet dotyczących każdego z felietonistów, razem: 504 (zob. Barańska-Szmitko 2018: 63).

Taka liczebność ankiet pozwala na wstępne generalizacje wyników i zauważenie pewnych tendencji czy mechanizmów obserwowanych zjawisk. Warianty 1 i 2 dostarczyły łącznie 504 kwestionariusze z cytatami, manifestującymi określone przez respondentów cechy felietonistów. Dało to niespełna 2500 wskazań przymiotów twórców (w każdej ankiecie sugerowano podanie pięciu cech wizerunkowych autora: $504 \times 5=2516)^{10}$ i tyle samo cytatów. Uznano taki rezultat za satysfakcjonujący i wystarczający.

Dbałość o eliminację, a przynajmniej minimalizację wpływu odpowiedzi na kolejne zadania determinowała układ wariantów w grupach i tym samym istotnie wpływała na kolejność pytań.

Tak więc w grupie pierwszej (zob. tabela 4) proszono o przeczytanie tekstu jednego $\mathrm{z}$ autorów, następnie o podanie cech budujących jego wizerunek i w końcu o wykładniki językowe wskazanych przymiotów twórcy. Dalej zapytano o image, możliwy do (od)tworzenia na podstawie zdjęcia innego felietonisty. Wariant 2 (tekst + zdjęcie + nazwisko) poprzedzał więc wariant 3 (tylko zdjęcie).

Oczywiście, by zachować rzetelność badania, posłużono się takim kształtem poleceń (zob. tabela 5), który nie traktował dosłownie celu badawczego (wizerunek i wykładniki cech wizerunkowych). Nazwisko w każdym z poleceń zmieniało się odpowiednio na: Piotra Zarembę / Magdalenę Środę / Szymona Holownię / Krzysztofa Vargę - w zależności od tego, czyj felieton czytał dany respondent. Zarówno w przypadku pierwszego z pytań, jak i drugiego na karcie odpowiedzi widniało pięć ponumerowanych punktorów, sugerujących podanie pięciu cech felietonisty w przypadku pierwszego pytania i pięciu cytatów w przypadku pytania drugiego. Zastosowano pytania otwarte z uwagi na eksploracyjny charakter badania (Babbie 2004: 111). Sformułowany problem badawczy zakłada bowiem dopiero sprawdzenie, jaki wizerunek jest możliwy do komunikowania na poziomie werbalnym. Zastosowanie pytań zamkniętych narzucałoby odpowiedzi i tym samym uniemożliwiło osiągniecie wyznaczonych zamierzeń (zob. m.in. Grech 2012: 14).

10 Nie wszyscy uczestnicy badania podali równo 5 epitetów określających wypowiadającego się. Stąd sformułowanie „niespełna”. 
W kwestii samego brzmienia pytanie służące (od)tworzeniu wizerunku komunikowanego na poziomie zdjęcia (wariant 3) dotyczyło innego publicysty i miało analogiczne brzmienie językowe do polecenia $\mathrm{z}$ wariantu 2 (zob. tabela 4): „Mając za podstawę przedstawione zdjęcie, jakimi słowami opisałby Pan / opisałaby Pani przedstawioną na tej fotografii osobę?". W tym przypadku także pod pytaniem widniało pięć punktorów, sugerujących wypisanie pięciu cech. W wariancie 3 sprawdzano też znajomość osoby ze zdjęcia i ewentualny wpływ tej wiedzy na konstruowany wizerunek. Służyło temu pytanie(tabela 4): „Czy wie Pan/Pani, kogo przedstawia zdjęcie?”. By uzyskać lepszą orientację, obok odpowiedzi „Tak, kogo?” oraz „Nie”, zaproponowano też „Nie jestem pewny/pewna, ale wydaje mi się, że może to być (kto?)".

W sytuacji, kiedy uczestnik badania najpierw pracował na tekście felietonisty o podanej tożsamości (wariant 2), można było bez szkody dla wyników w następnym etapie badania realizować wariant 3, a zatem zapytać o image konstruowany na podstawie fotografii. Ponieważ imię i nazwisko, a także zdjęcie autora tekstu zostały respondentowi podane, a w wariancie 3 przedstawiano fotografię innego felietonisty, to zniesiona została obawa, że wizerunek autora tekstu będzie wpływał na image osoby ze zdjęcia (co mogłoby mieć miejsce, gdyby najpierw podano respondentowi anonimowy tekst, a potem zaprezentowano fotografię - wówczas uczestnik mógłby uznać, że na zdjęciu znajduje się podobizna autora felietonu).

W grupie drugiej (zob. tabela 3) najpierw zapytano o wizerunek publiczny dwóch felietonistów (wariant 4: nazwisko), a następnie przedstawiono tekst anonimowego twórcy (wariant 1), innego niż wymienione we wcześniejszym wariancie osoby publiczne.

Zadanie dotyczące wizerunku publicznego rozpoczynały pytania filtrujące (zob. tabela 4). Mianowicie na wstępie sprawdzono, czy respondent w ogóle zna osobę, której dotyczy pytanie, np.: „Czy zna Pan/Pani nazwisko: Piotr Zaremba? Proszę zakreślić swoją odwiedź krzyżykiem”. Zaproponowano dwie odpowiedzi: „TAK. Jeśli tak, proszę przejść do pytania nr 2” oraz „NIE. Jeśli nie, proszę schować kartkę do teczki"11. W przypadku negatywnej odpowiedzi nie proszono o podanie cech wizerunkowych. Bezzasadne było bowiem pytanie o kogoś, kogo uczestnik badania nie kojarzył. Odpowiedź twierdząca odsyłała do pytania nr 2, które miało analogiczny kształt do innych pytań wizerunkowych i brzmiało: „Jakimi słowami scharakteryzował(a)by Pan/ Pani osobę publiczną Piotra Zarembę?”. Pojawiające się w poleceniu nazwisko

11 Polecenia znajdowały się co do zasady na odrębnych kartkach, umieszczonych w tekturowych teczkach. Więcej na ten temat zob. w rozdziale: 1.3.2.2. Sposób przedstawienia materiałów $i$ kart odpowiedzi. 
zmieniało się w zależności od tego, czyj wizerunek publiczny miał być odtwarzany, a więc na: Krzysztofa Vargę, Magdalenę Środę, Szymona Hołownię czy wspomnianego Piotra Zarembę. Na karcie odpowiedzi również w przypadku tego pytania pozostawiano pięć punktorów, by uzyskać od respondenta odpowiedź $\mathrm{w}$ postaci pięciu cech.

W drugiej grupie badanych wprowadzono zasadę rządzącą realizacją wariantu 4 (nazwisko), że nazwiska, z którymi skojarzenia mieli podać respondenci, są inne niż nazwisko osoby, której tekst potem będą czytać (wariant 1) (zob. tabela 3). Ponieważ w tej grupie czytany felieton nie był opatrzony nazwiskiem autora, istniało niebezpieczeństwo, że wcześniejsze pytanie o wizerunek publiczny jednego felietonisty może mieć wpływ na (od)twarzany później image twórcy czytanej wypowiedzi. Tak więc, na przykład, pytanie o image publiczny Piotra Zaremby może spowodować, że respondent będzie się spodziewał, iż przedstawiony mu tekst to felieton właśnie Piotra Zaremby. Aby ten wpływ zminimalizować, zapytano o wizerunek publiczny dwóch różnych felietonistów, a następnie zaprezentowano tekst jeszcze innego twórcy. Uczestnik badania tym samym został w pewien sposób zdezorientowany. Jeśli znał obydwa nazwiska autorów, których dotyczyły dwa pierwsze polecenia, to mógł zauważyć, że przedstawiony mu felieton jest jeszcze innego autorstwa. Nie sugerował się zatem skojarzeniami podanymi w dwóch pierwszych zadaniach. Jeśli podane w realizacjach wariantu 4 nazwiska nie były w ogóle znane respondentowi, to tym bardziej skojarzenia z nimi (tj. brak takich skojarzeń) nie mógł wpływać na wizerunek, który - zdaniem badanego - manifestował felietonista w swoim tekście.

$\mathrm{W}$ grupie drugiej, dalej, po realizacji zadań $\mathrm{z}$ wariantu 4 (nazwisko), respondent otrzymywał do przeczytania felieton anonimowego twórcy, tj. sam tekst bez informacji o tożsamości jego autora (wariant 1) (zob. tabela 3), co umożliwiło ustalenie, jaki wizerunek jest możliwy do komunikowania werbalnie w warunkach, gdy twórca pozostaje nieznany. Polecenie po przeczytaniu wypowiedzi miało analogiczne brzmienie do innych pytań dotyczących wizerunku: „Mając za podstawę tekst przeczytanego felietonu, jakimi słowami opisałby Pan / opisałaby Pani autora tego tekstu?" (zob. tabela 4). Forma męska słowa „autor” pojawiała się tam, gdzie zaznajamiano się z felietonem Krzysztofa Vargi, Piotra Zaremby lub Szymona Hołowni. Tam, gdzie zadanie dotyczyło Magdaleny Środy, posługiwano się żeńską formą, stąd polecenie miało wówczas postać: „Mając za podstawę tekst przeczytanego felietonu, jakimi słowami opisałby Pan / opisałaby Pani autorkę tego tekstu?"12. Ta sama zasada, dotycząca uzależnionej od płci felietonisty odmiany leksemu „autor”,

12 Podkreślenie ABS. Nie występowało w oryginalnym pytaniu. 
dotyczyła następnego zadania: „Proszę do każdej wskazanej przez Pana/Panią cechy autora felietonu wypisać $\mathrm{z}$ tekstu słowa/zdania/fragmenty, które stały się podstawą do wyłonienia danej cechy". Po obu poleceniach pojawiało się pięć punktorów, by zasugerować podanie pięciu cech twórcy wypowiedzi i pięciu cytatów. W ten sposób uzyskiwano materiał do analizy pozwalającej wyłonić mechanizmy rządzące wykładnikami poszczególnych cech wizerunkowych. Aby sprawdzić, czy założenie anonimowości tekstu zostało spełnione, na koniec pytano: „Czy wiesz, kto jest autorem tekstu?”, dając trzy możliwości odpowiedzi: „TAK, wiem (kto?)”, następnie „Nie jestem pewny/pewna - wydaje mi się, że autorem może być (kto?)” oraz „NIE, nie wiem”.

Porównywalność wyników zapewniało kilka procedur: zachowanie proporcji w każdym z wariantów, analogiczne pytania, pięciopunktowe miejsce na karcie odpowiedzi.

Tak więc zadbano o proporcje ilościowe. W każdej turze badania (zob. rozdział 1.3.2.3. Czas i miejsce realizacji badania) (3 tury czasowe) każdy z siedmiu ostatnich felietonów danego autora $(3 \times 7)$ czytany był przez trzech respondentów $(3 \times 7 \times 3)$, a zatem udało się uzyskać wyniki 63 ankiet $(3 \times 7 \times 3=63)$ dla każdego z czterech twórców $(63 \times 4=252)$. Ta proporcja dotyczyła wariantu 1 (sam tekst) oraz wariantu 2 (tekst + zdjęcie + nazwisko). Wszystko pozostawało identyczne pod względem ilościowym, jak również pod względem jakościowym - czytano dokładnie te same teksty. Uzyskano więc materiał do analizy wykładników językowych z 504 kwestionariuszy $(252 \times 2$ warianty $=504)$. W przypadku wariantu 3 (zdjęcie) $\mathrm{w}$ każdej $\mathrm{z}$ trzech tur czasowych odpowiedzi do zdjęcia każdego $\mathrm{z}$ twórców podawało 21 uczestników badania ( 3 tury $\times 4$ twórców $\times 21$ uczestników $\times 1$ wariant), co łącznie pozwoliło uzyskać rezultat 252 kwestionariuszy w skali całości ${ }^{13}$. W wariancie 4 (nazwisko) 42 respondentów określało wizerunek publiczny każdego z czterech publicystów $(42 \times 4)$ w każdej z trzech tur czasowych $(42 \times 4 \times 3=504)$, dzięki czemu zebrano łącznie 504 ankiety, z czego po 126 przypadało na każdego $\mathrm{z}$ felietonistów.

Zachowaniu proporcji służył także analogiczny kształt pytań (zob. tabela 5) dotyczących wizerunku i poleceń związanych z wykładnikami językowymi wskazywanych cech. Wówczas w wariancie (2), gdzie należało przeczytać tekst twórcy o podanej tożsamości, zmieniano wyłącznie nazwisko konkretnego felietonisty. Tam, gdzie wypowiadający się pozostawał anonimowy (wariant 1) nazwisko zamieniano na słowo „autor” lub ,autorka” - w zależności od jego/ jej płci. Wszystko inne pozostawało identyczne. Analogicznie w wariancie 3, gdzie zaprezentowano fotografię, sformułowanie „tekst przeczytanego felietonu”

13 Analizowano wyniki oddzielnie dla każdego z autorów. 
zastąpiono wyrazami „przedstawione zdjęcie”, a zamiast danego nazwiska czy słowa „autor” pojawił się odpowiednio odmieniony ciąg słów „przedstawiona na tej fotografii osoba". Co do zasady, pytanie więc pozostawało takie samo, zmieniono wyłącznie te elementy, które tego wymagały z racji innej bazy do (re)konstruowania wizerunku (tekst/zdjęcie). W wariancie 4 (nazwisko) pytanie pozbawiono części odwołującej się do materiału, na podstawie którego respondent miał (od)twarzać wizerunek. Zrezygnowano z tego członu, ponieważ uczestnik badania miał posłużyć się wynikiem operacji, które dotyczyły danego felietonisty, na wszystkich dostępnych mu systemach znakowych. Zamieniono „opisałby Pan / opisałaby Pani” na „scharakteryzował(a)by Pan/ Pani”, zakładając, że takie sformułowanie będzie bardziej syntetyzowało odpowiedzi. Nie zrobiono tego w innych wariantach, gdyż obawiano się, że sugestia syntetyzacji może zbytnio utrudnić realizację zadania. By podkreślić, że nie chodzi o cechy wyłącznie osobowe, charakterologiczne, do leksemu „osoba” dodano epitet „publiczna”. Wprowadzone zmiany służyły więc dostosowaniu do warunków polecenia i jak największej możliwej paralelności w brzmieniu i wyrazie z innymi zadaniami. W poleceniach dotyczących wykładników językowych zamieniano wyłącznie odpowiednio odmieniony leksem „autor” $\mathrm{w}$ wariancie 1 na imię i nazwisko felietonisty, którego tekst respondenci czytali $\mathrm{w}$ wariancie 2 . Wszystko inne pozostawało identyczne. Jak zatem widać, zadbano w największym możliwym stopniu o analogiczne brzmienie pytań i wprowadzano tylko niezbędne zmiany, dostosowujące kształt polecenia do stawianego mu celu.

Tabela 5. Analogiczne brzmienie pytań dotyczących wizerunku oraz wykładników cech przypisanych felietonistom

\begin{tabular}{|l|l|}
\hline \multicolumn{1}{|c|}{ wariant } & \multicolumn{1}{c|}{ brzmienie pytania dotyczącego wizerunku } \\
\hline $\begin{array}{l}\text { wariant 1: } \\
\text { sam tekst }\end{array}$ & $\begin{array}{l}\text { Mając za podstawę tekst przeczytanego felietonu, jakimi słowami opisałby Pan / } \\
\text { opisałaby Pani autora tego tekstu? }\end{array}$ \\
\hline $\begin{array}{l}\text { wariant 2: } \\
\text { tekst + zdjęcie } \\
\text { + nazwisko }\end{array}$ & $\begin{array}{l}\text { Mając za podstawę tekst przeczytanego felietonu, jakimi słowami opisałby } \\
\text { Pan / opisałaby Pani autora [tu imię i nazwisko odpowiedniego felietonisty/ } \\
\text { felietonistki]? }\end{array}$ \\
\hline $\begin{array}{l}\text { wariant 3: } \\
\text { zdjęcie }\end{array}$ & $\begin{array}{l}\text { Mając za podstawę przedstawione zdjęcie, jakimi słowami opisałby Pan / opisa- } \\
\text { łaby Pani przedstawioną na tej fotografii osobę? }\end{array}$ \\
\hline $\begin{array}{l}\text { wariant 4: } \\
\text { nazwisko }\end{array}$ & $\begin{array}{l}\text { Jakimi słowami scharakteryzował(a)by Pan/Pani osobę publiczną [tu imię i na- } \\
\text { zwisko odpowiedniego felietonisty/felietonistki]? }\end{array}$ \\
\hline \multicolumn{1}{|c|}{ wariant } & \multicolumn{1}{|c|}{ brzmienie pytania dotyczącego wykładników } \\
\hline $\begin{array}{l}\text { wariant 1: } \\
\text { sam tekst }\end{array}$ & $\begin{array}{l}\text { Proszę do każdej wskazanej przez Pana/Panią cechy autora [lub: autorki, je- } \\
\text { śli podano felieton Magdaleny Środy] felietonu wypisać z tekstu słowa/zdania/ } \\
\text { fragmenty, które stały się podstawą do wyłonienia danej cechy. }\end{array}$ \\
\hline
\end{tabular}


Tabela 5 (cd.)

\begin{tabular}{|l|l|}
\hline \multicolumn{1}{|c|}{ wariant } & \multicolumn{1}{|c|}{ brzmienie pytania dotyczącego wykładników } \\
\hline $\begin{array}{l}\text { wariant 2: } \\
\text { tekst + zdjęcie } \\
\text { + nazwisko }\end{array}$ & $\begin{array}{l}\text { Proszę do każdej wskazanej przez Pana/Panią cechy [tu imię i nazwisko odpo- } \\
\text { wiedniego felietonisty/felietonistki] wypisać z tekstu słowa/zdania/fragmenty, }\end{array}$ \\
które stały się podstawą do wyłonienia danej cechy. \\
\hline
\end{tabular}

Źródło: opracowanie własne

Dodać jeszcze należy, że brzmienie pytań weryfikowano w badaniach pilotażowych (zob. Barańska-Szmitko 2011: 4, Barańska 2012), na podstawie których zrezygnowano $\mathrm{z}$ trzech innych sposobów artykułowania poleceń związanych $\mathrm{z}$ wizerunkiem ${ }^{14}$. Ostateczny kształt pytań uznano za optymalny, realizujący cel badawczy, a pozwalający w największym stopniu ominąć streszczenia felietonów i podawanie wyłącznie cech charakteru.

Założono, że dzięki wskazaniu na kartach odpowiedzi pięciu punktorów, sugerujących podanie pięciu cech felietonisty, uzyska się wystarczającą do badań liczbę wskazanych przymiotów twórców. Ta metoda pomogła również unikać sytuacji, w której jeden respondent podaje dwa epitety, a kolejny siedem, co utrudnia zliczanie i porównywanie wyników. Przy czym wcześniejsze badania (Barańska 2011) wykazały, że liczba pięć jest w tym przypadku najbardziej optymalna, tj. najczęściej tyle wypisywano określeń autora, gdy pozostawiano respondentom dowolność co do liczby wypisywanych określeń (por. Barańska 2011). Pamiętać też należy, że punktory stanowiły sugestię, a nie obligatoryjną część badania i niektórzy z uczestników korzystali z możliwości podania mniejszej liczby przymiotów twórcy. Ustandaryzowanie liczby odpowiedzi w zakresie podawanych cech autora tekstu / osoby na zdjęciu / osoby publicznej pozwalało generować wnioski w obrębie wizerunku każdego z felietonistów osobno, a także stanowiło - obok zasady proporcjonalności i analogiczności pytań wizerunkowych - narzędzie umożliwiające porównywanie wyników dotyczących poszczególnych twórców.

Wykonywaniem poleceń rządziła reguła, że należy skończyć bieżące zadanie, by przejść do realizacji kolejnego. Wprowadzono tę zasadę, aby uniknąć takiego formułowania odpowiedzi, które pozwalałoby łatwiej wykonać poszczególne polecenia. Np. respondent mógł podać w pierwszej kolejności dogodny fragment felietonu, by potem dopiero przypisać mu cechę, co skutkowałoby prymatem wyrazistości tekstu nad wyrazistością

14 „Jaki jest autor felietonu? Proszę podać cechy”, „Jaką osobą jest autor felietonu? Proszę podać cechy”, „Jaką osobą jawi się autor felietonu? Proszę podać cechy” (zob. Barańska 2011: 4; 2012). 
wizerunku i trudniej uchwytne cechy publicysty byłby marginalizowane w odpowiedziach.

Przebieg badania, a w tym dokładny wygląd i układ wykorzystanych materiałów i kart ankietowych oraz wypowiedzi osoby prowadzącej badanie, został opisany w kolejnym rozdziale.

\subsubsection{Sposób przedstawienia materiałów i kart odpowiedzi}

Materiały (tekst, zdjęcie) i następujące po sobie polecenia przedstawiono respondentom na osobnych kartkach w teczkach, co uznano za optymalne rozwiązanie w warunkach sekwencyjności zadań, nieznajomości kolejności poleceń i realizacji badania w kilku wariantach w dwóch grupach.

Badanie zawsze przeprowadzała autorka niniejszego opracowania, dzięki czemu zachowano kontrolę nad warunkami badania, w tym nad doborem uczestników (patrz rozdział 1.3.2.4. Uczestnicy badania) i ścisłym przestrzeganiem procedury.

Badanie przeprowadzano najczęściej na początku zajęć konwersatoryjnych, jak również na początku wykładu lub (dwa razy) po egzaminie. Wybierano na poszczególnych uniwersytetach te grupy, które spełniały kryteria (studenci dziennikarstwa lub filologii polskiej oraz I lub II rok studiów) i proszono wykładowców o możliwość przeprowadzenia badania, informując skrótowo o stawianych celach i formie realizacji. W przypadku uzyskania zgody autorka niniejszego opracowania pojawiała się na zajęciach i była anonsowana studentom jako gość, który przeprowadza badania ankietowe związane z felietonami i który poprosi o udział w nich. Po tej zapowiedzi grupa otrzymywała komunikat już od gościa o treści: „Badanie polega przede wszystkim na przeczytaniu tekstu felietonu i odpowiedzi na kilka pytań. Udział jest dobrowolny i w pełni anonimowy. Całość trwa około 15 minut. Czy zgadzacie się Państwo wziąć udział?”. Następnie tym osobom, które wyraziły zgodę, przekazywano informację o następującym brzmieniu: „Zostaną Państwu za chwilę rozdane teczki z pytaniami. Bardzo proszę, byście Państwo nie zaglądali do środka, dopóki wszyscy, którzy wyrazili zgodę, ich nie otrzymają. Chodzi o to, że rozpoczęcie ankiety musi poprzedzić krótka instrukcja z mojej strony".

Teczki w każdej z grup wyglądały doładnie tak samo. Nie wyróżniały się. Były to szare, tekturowe teczki. Ułatwiało to także losowy dobór osób do każdej z grup (patrz: rozdział 1.3.2.4. Uczestnicy badania). Pierwsza kartka w teczce odwrócona była zadrukowaną stroną do czytelnika, każda kolejna druk miała od strony dna teczki. 
Kiedy rozdano teczki, informowano respondentów: „Po otworzeniu teczki zobaczycie Państwo kartę z tekstem do przeczytania lub kartkę z pytaniem. Tekst należy przeczytać. Na pytanie oczywiście odpowiedzieć. Każda kolejna kartka w tekście jest odwrócona zadrukowaną stroną do dna teczki. Chodzi o to, byście Państwo najpierw wykonali jedno zadanie i dopiero po jego ukończeniu przeszli do kolejnego, czyli odwrócili kartkę i zrealizowali polecenie na niej się znajdujące. W razie potrzeby możecie Państwo wrócić do poprzednich kartek, ale nie zaglądać, co znajduje się na następnych, dopóki nie skończycie bieżącego zadnia. Niektórzy z Państwa mogą trafić na kartkę tylko ze zdjęciem, wówczas należy obejrzeć zdjęcie i odwrócić następną kartkę. Jesteście Państwo proszeni o szczere i spontaniczne odpowiedzi. Nie ma błędnych odpowiedzi. Odpowiadacie Państwo anonimowo. Każda odpowiedź jest prawidłowa i cenna dla badania. W razie ewentualnych Państwa pytań, jestem do Państwa dyspozycji. Można otworzyć teczki". W tym momencie uczestnicy badania rozpoczynali realizację poleceń.

Kartki z tekstami i kartki ze zdjęciami miały format A4, by tekst mógł pozostać czytelny i by w przybliżeniu oddać wielkość oryginalnych stron tygodników, z których pochodziły felietony. Wszystkie kartki z pytaniami reprezentowały już mniejszy format A5, który ograniczał ilość odpowiedzi i nie wydłużał niepotrzebnie badania, a tym samym nie nadwyrężał zbytnio koncentracji uczestników.

W grupie czytającej tekst autora o podanej tożsamości (wariant 2) przedstawiono uczestnikom kserokopię strony z tygodnika. Tekst funkcjonował w oryginalnym layoucie. Natomiast w drugiej grupie, w której respondenci dysponowali felietonem anonima, tekst wydrukowano na białej kartce i starano się, na ile to możliwe, by dla każdego felietonisty ten wydruk był podobny (ta sama czcionka, ten sam rozmiar wydruku tytułu i tekstu głównego, te same marginesy) ${ }^{15}$.

O ile trudno mówić o wpływie kroju pisma na wizerunek felietonisty, to istnieje zależność między charakterem zdjęcia towarzyszącego tekstowi a image’em jego autora - innymi słowy, zmiana wyrazu twarzy może determinować

15 Nie odwzorowywano czcionki z tygodnika publikującego tekst, gdyż wątpliwe wydaje się znaczenie kształtu samego zapisu dla image’u felietonisty. Wykazano co prawda, że krój pisma może mieć wpływ na wizerunek firmy, ale dotyczyło to nazwy i równie istotnym determinantem okazywała się semantyka leksemu budującego tę nazwę. Stąd nie tylko rodzaj czcionki i forma zapisu miały znaczenie dla image'u firmy Sougart, ale brzmienie nazwy semantyczne ukierunkowywało na skojarzenia z cukrem, ogrodem i sztuką (zob. Fleischer 2003b: 28-36). Pozwala to wnioskować, iż przy dłuższych tekstach dla czytelników źródłem konstruowanego komunikatu będzie treść wypowiedzi, przy marginalnym (jeśli w ogóle) znaczeniu kształtu wizualnego. 
odmienny odbiór twórcy (zob. Barańska 2012), dlatego też na każdej kserokopii strony z pisma, która została przedstawiona uczestnikom, widniała zawsze ta sama fotografia danego felietonisty. Wspomnieć o tym należy, ponieważ redakcje, w czasie badania, posługiwały się różnymi podobiznami twórców, tj. felietonom wykorzystanym w poszczególnych turach badania (wiosna 2012, wiosna 2013, jesień 2013) niejednokrotnie oryginalnie towarzyszyły inne zdjęcia autorów (zob. tabela 6). W przypadku Krzysztofa Vargi nie tyle nawet zmieniono fotografię, co zastąpiono ją portretem, sprawiającym wrażenie ołówkowego szkicu. Podążanie za modyfikacjami redakcji i posłużenie się ściśle wiernymi kopiami stron mogło zniekształcić wyniki i wpłynąć negatywnie na ich rzetelność. Podczas badań w każdej turze czasowej respondenci otrzymywali więc kopię tekstu, ale ze zdjęciem, które pierwotnie towarzyszyło tekstowi w felietonach wykorzystanych w pierwszej turze badania (wiosna 2012). W ten sposób każdy z felietonów w grupie czytających wypowiedź autora o podanej tożsamości opatrzony był identycznym zdjęciem danego twórcy.

Tabela 6. Zdjęcia dołączane przez redakcje do felietonów w tekstach, które pojawiły się w badaniu

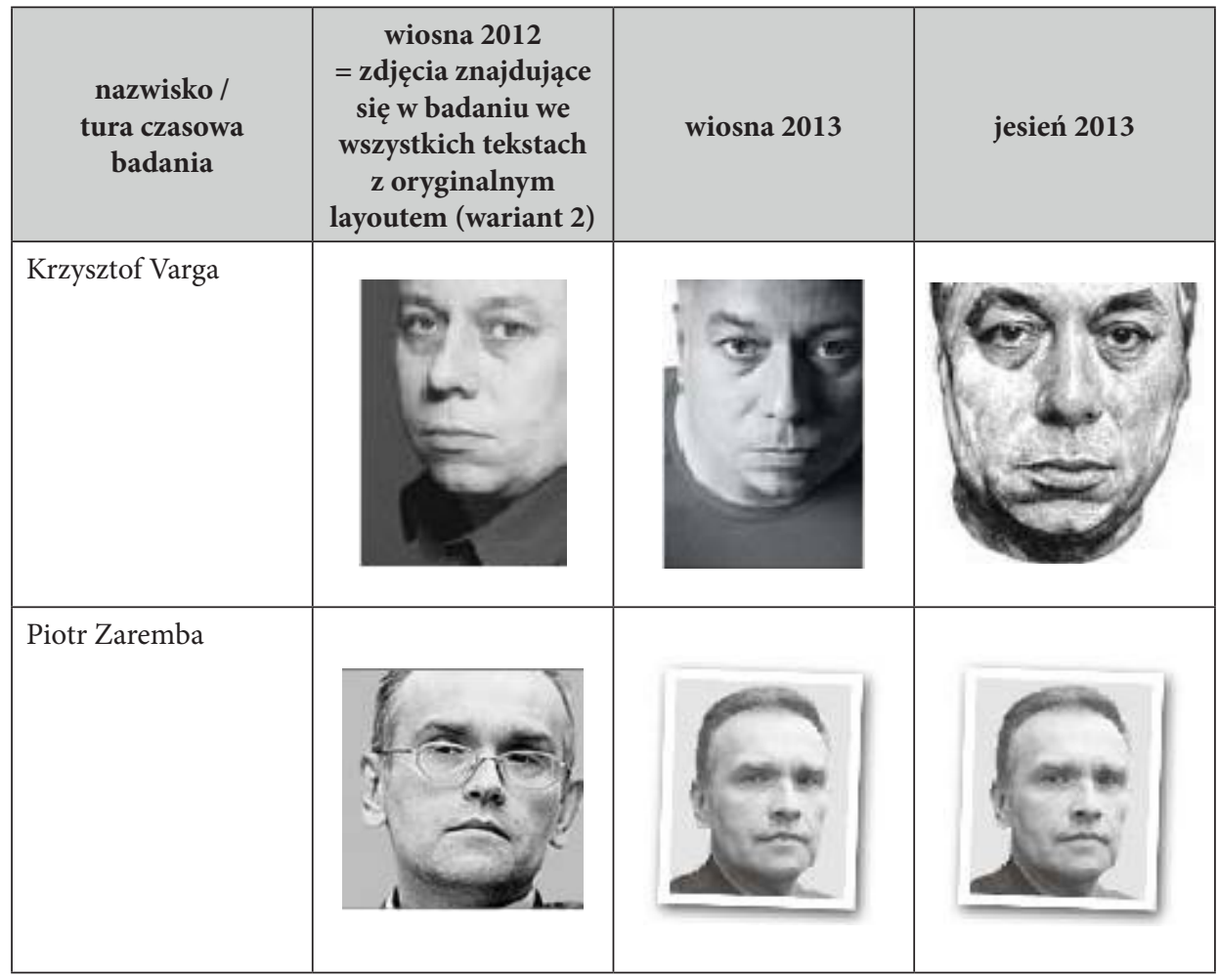


Tabela 6 (cd.)

\begin{tabular}{|c|c|c|c|}
\hline $\begin{array}{l}\text { nazwisko / } \\
\text { tura czasowa } \\
\text { badania }\end{array}$ & $\begin{array}{c}\text { wiosna } 2012 \\
=\text { zdjęcia znajdu- } \\
\text { jące się w badaniu } \\
\text { we wszystkich } \\
\text { tekstach z orygi- } \\
\text { nalnym layoutem } \\
\text { (wariant 2) }\end{array}$ & wiosna 2013 & jesień 2013 \\
\hline Magdalena Środa & & & \\
\hline Szymon Hołownia & & & \\
\hline
\end{tabular}

* Na siedem tytułów felietonów Magdaleny Środy, zebranych do przedstawienia respondentom w turze badania „wiosna 2013”, dwukrotnie tekstowi towarzyszyło inne, mniejsze zdjęcie Magdaleny Środy, które w wersji dla respondentów zmieniono - jak w każdym przypadku - na fotografię z tury „wiosna 2012”

Źródło: opracowanie własne na podstawie zawartości czasopism. Zob. Barańska-Szmitko 2018: 69

Wracając do przebiegu badania, studenci, którzy zakończyli realizację wszystkich zadań, najczęściej podnosili rękę, by to zasygnalizować, i prowadząca odbierała od takiej osoby teczkę. Gdy zebrane zostały wszystkie teczki, podziękowano za udział $\mathrm{w}$ badaniu i pożegnano się $\mathrm{z}$ respondentami.

\subsubsection{Czas i miejsce realizacji badania}

Badanie realizowano na kilku polskich uczelniach w ciągu jednego roku kalendarzowego, w trzech turach czasowych. Tabela 7 ukazuje ilościowy udział studentów poszczególnych kierunków, a także miejsce przeprowadzania badania. 
Tabela 7. Miejsce realizacji badania w każdej z trzech tur czasowych oraz ilościowy udział studentów poszczególnych kierunków

\begin{tabular}{|c|c|c|c|c|c|}
\hline $\begin{array}{c}\text { tura } \\
\text { badania }\end{array}$ & $\begin{array}{l}\text { termin realizacji } \\
\text { badania }\end{array}$ & miejsce $^{\star}$ & $\begin{array}{l}\text { kierunek } \\
\text { studiów }^{* *}\end{array}$ & $\begin{array}{c}\text { rok } \\
\text { studiów }\end{array}$ & $\begin{array}{c}\text { liczba } \\
\text { respondentów }\end{array}$ \\
\hline \multirow{5}{*}{ jesień 2013} & 7 października & UŁ & diks & I & 55 \\
\hline & 9 października & \multirow{2}{*}{ UW } & diks & I & 61 \\
\hline & 16 października & & diks & II & 22 \\
\hline & 21 i 28 października & UKW & diks & I & 30 \\
\hline & & \multicolumn{3}{|c|}{ suma } & 168 \\
\hline \multirow{7}{*}{ wiosna 2013} & 4 i 6 czerwca & UŁ & $\mathrm{fp}$ & I & 36 \\
\hline & 10 czerwca & UWr & diks & I & 39 \\
\hline & \multirow{2}{*}{11 czerwca } & \multirow{2}{*}{ UAM } & diks & I & 12 \\
\hline & & & diks & II & 31 \\
\hline & 12 czerwca & UKW & diks & I & 39 \\
\hline & 13 czerwca & UB & $\mathrm{fp}$ & II & 11 \\
\hline & & \multicolumn{3}{|c|}{ suma } & 168 \\
\hline \multirow{6}{*}{ wiosna 2012} & \multirow{2}{*}{21 maja } & \multirow{2}{*}{ UWr } & diks & I & 28 \\
\hline & & & diks & II & 14 \\
\hline & 22 maja & SWPS & diks & I & 16 \\
\hline & 29 i 31 maja & UŁ & $\mathrm{fp}$ & I & 61 \\
\hline & 6 czerwca & UKW & diks & I & 49 \\
\hline & & & & suma & 168 \\
\hline \multicolumn{5}{|c|}{ razem w całym badaniu } & 504 \\
\hline
\end{tabular}

* Skróty: UŁ - Uniwersytet Łódzki, UW - Uniwersytet Warszawski, UKW - Uniwersytet Kazimierza Wielkiego w Bydgoszczy, UWr - Uniwersytet Wrocławski, SWPS - Szkoła Wyższa Psychologii Społecznej we Wrocławiu, UB - Uniwersytet Białostocki, UAM - Uniwersytet Adama Mickiewicza w Poznaniu.

** Skróty: diks - dziennikarstwo i komunikacja społeczna, fp - filologia polska.

Źródło: opracowanie własne

Na czas i miejsce realizacji badania wpłynęły następujące czynniki: wybór studentów dziennikarstwa i komunikacji społecznej oraz pomocniczo filologii polskiej jako optymalnych respondentów (zob. rozdz. 1.3.2.4. Uczestnicy badania), cel uzyskania dużej liczby ankiet, pozwalającej umocnić wnioski, oraz wykorzystanie takiej liczby tekstów, która wykaże się dużą dywersyfikacją tematyczną (by uniknąć determinacji wyników tematem wypowiedzi - zob. Aneks), posłużenie się gatunkiem felietonu, którego jedną z zasadniczych cech jest wypowiedź na aktualne tematy. 
Studentów dziennikarstwa i pomocniczo filologii polskiej I i II roku uznano za optymalną grupę badawczą (zob. rozdz.1.3.2.4. Uczestnicy badania), przez co ich liczba na macierzystej uczelni stała się niewystarczająca i należało poszerzyć badania o inne uczelnie, na których prowadzono wspomniane kierunki, tj.: Uniwersytet Wrocławski (UWr), Szkoła Wyższa Psychologii Społecznej we Wrocławiu (SWPS), Uniwersytet Warszawski (UW), Uniwersytet Kazimierza Wielkiego w Bydgoszczy (UKW), Uniwersytet Białostocki (UB), Uniwersytet Adama Mickiewicza w Poznaniu (UAM).

Założono też cel uzyskania dużej liczby ankiet, pozwalającej umocnić wnioski, oraz wykorzystanie takiej liczby tekstów, która wykaże się dużą dywersyfikacją tematyczną. Uniemożliwiało to jednak przeprowadzenie eksperymentu w krótkim czasie. Ponadto, wykorzystany gatunek - felieton - zakładał odwoływanie się do aktualnych wydarzeń, więc ulokowanie badania w trzech turach czasowych pozwalało na realizację tego wymogu - w każdej turze badania wykorzystano 7 ostatnich tekstów, traktujących o ostatnich wydarzeniach, jednego $\mathrm{z}$ czterech felietonistów, przy czym każdy z felietonów czytały trzy osoby w każdym $\mathrm{z}$ dwóch wariantów ( 3 tury $\times 7$ tekstów $\times 4$ felietonistów $\times 3$ czytania $\times 2$ warianty badania $=504$ ankiety). Realizowano badanie na początku lub na końcu roku akademickiego, ponieważ najwięcej wykładowców zgadzało się akurat wtedy na wejście na zajęcia, a także były to okresy z relatywnie dużą frekwencją studentów. Zobowiązania dydaktyczne autorki niniejszego opracowania nie pozwoliły natomiast prowadzić jednej $\mathrm{z}$ tur badania na początku semestru letniego. Prowadzono badania w październiku 2012, ale nie udało się zebrać wystarczającej liczby kwestionariuszy, dlatego nie uwzględniono ich w analizie wyników, a brane są pod uwagę rezultaty uzyskane z tur: wiosna 2012, wiosna 2013, jesień 2013.

\subsubsection{Uczestnicy badania}

O wyborze odpowiedniej grupy respondentów decydować musiały kryteria merytoryczne i organizacyjne. Podczas realizacji badania uwzględnić należało losowy przydział do każdej z grup. Na oddzielną uwagę zasługuje także tzw. reprezentatywność próby.

Przy badaniu wizerunku jednego felietonisty, również z uwzględnieniem znajomości jego tożsamości lub nie, można kierować się wyborem takich uczestników, którzy są lub mogą stanowić czytelników pisma, w jakim publikowane są teksty danego twórcy (zob. o badaniu image’u Aloszy Awdiejewa w „Charakterach” - Barańska 2011). Sytuacja się komplikuje, jeśli z założenia chcemy zbadać kilku autorów, piszących na różne tematy i reprezentujących odmienne postawy 
ideowe, a jednym z warunków koniecznych jest możliwość porównania wyników. Nawet nie mając wybranych takich felietonistów, łatwo sobie wyobrazić, iż będą pisać dla różnych tytułów, a więc i zupełnie inne osoby stanowią ich czytelników. Przy założeniu zestawienia rezultatów niedopuszczalne jest więc posłużenie się kryterium doboru respondentów według klucza profilu czytelnika danego tygodnika. W przypadku każdego autora powstałaby wówczas odrębna grupa badanych i efektów nie można by już było porównać.

Posłużono się więc kryterium homogeniczności próby, zatem zadbano o dobór uczestników, którzy są porównywalni i w miarę jednolici pod ustalonymi względami (Babbie 2004: 252). Takie rozwiązanie pozwoliło na porównanie wyników w sposób zgodny z celem badań oraz wymogami eksperymentu (zob. Babbie 2004: 131).

Cechą wspólną wszystkich uczestników badania uczyniono warunek relatywnie wysokiej świadomości językowej oraz elokwencji - ich umiejętności komunikatywnego wypowiadania się. Za istotne uznano, by w jak największym stopniu potrafili „odpowiednie dać rzeczy słowo”, mieli umiejętność relatywnie (lepszej niż inni potencjalni respondenci) trafnej artykulacji własnych myśli i wyobrażeń. Założono, że studenci dziennikarstwa i komunikacji społecznej realizują ten warunek. Ponieważ nie zawsze było możliwe zebranie odpowiedniej liczby osób z tego kierunku, to uznano, że podobne kompetencje posiadać będą również studenci filologii polskiej ${ }^{16}$. Jednocześnie zdecydowano się na udział wyłącznie osób z I i II roku ze względu na przewidywaną zbyt dużą świadomość języka, gatunków dziennikarskich, zabiegów stylistycznych i retorycznych u reprezentantów wyższych roczników, co mogłoby zakłócić zakładany naturalny odbiór tekstów i procesu konstrukcji wizerunku autora.

Wszystkie teczki wyglądały identycznie, choć zawartość realizować mogła inne warianty badania, nie było więc możliwe kontrolowanie przydziału poszczególnych osób do danych grup i przypadek decydował o tym, kto trafi do konkretnej grupy, co pozwoliło na realizację warunku losowego przydziału do grup (zob. Babbie 2004: 251; Creswell 2013: 171; Lipski 2012: 97).

16 Zaznaczyć przy tym należy, iż celowo nie stosuje się tutaj kryterium kompetencji komunikacyjnych, gdyż najczęściej o kompetencji mówi się w kontekście poprawności (Fleischer 2008a: 99-100; Habrajska 2012: 111), a w rozumieniu konstruktywizmu nie można mówić o lepszej lub gorszej komunikacji, bardziej lub mniej poprawnej komunikacji, albo o wiedzy dotyczącej takiej poprawności komunikacji. Jeśli komunikacja jest mechanizmem systemu społecznego, to niemożliwe jest posiadanie kompetencji w obrębie całego mechanizmu całego systemu (Fleischer 2008a: 99-100). 


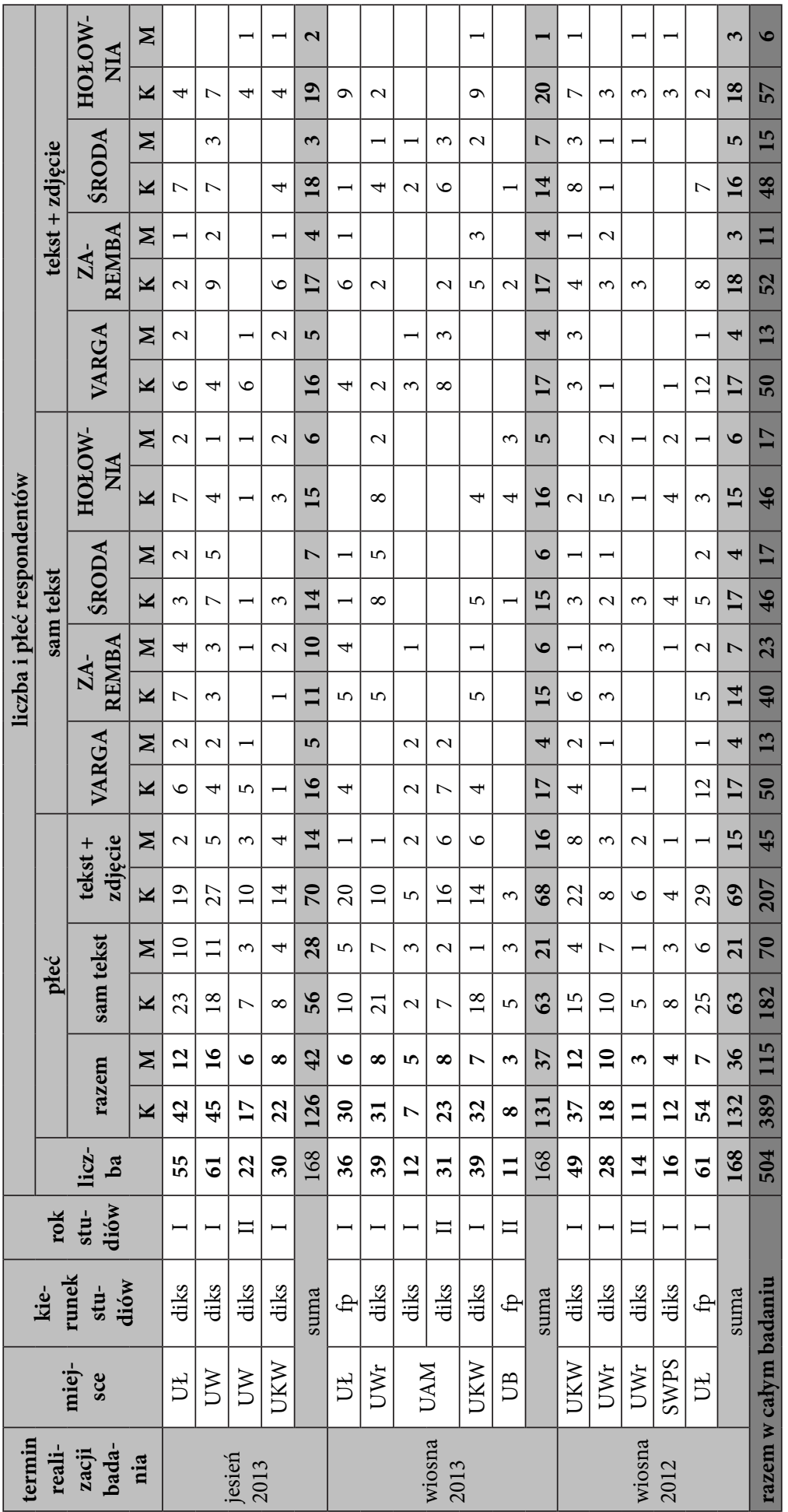


Na uwagę zasługuje także kwestia reprezentatywności próby. Z punktu widzenia ogólnej teorii komunikacji jest trudna czy też wręcz niemożliwa do uchwycenia ${ }^{17}$. Z perspektywy typowych nauk społecznych nie jest konieczna do zapewnienia w badaniach opartych na eksperymencie ${ }^{18}$.

Szczegółowe dane na temat miejsca, gdzie przeprowadzano badanie, liczby, kierunku i roku studiów oraz płci uczestników, a także czasu realizacji ilustruje tabela 8.

\subsubsection{Dlaczego felieton? ${ }^{19}$}

Należało znaleźć taki rodzaj tekstu, który pozwoli zrealizować główny cel badawczy, czyli zweryfikować możliwości komunikowania wizerunku autora wypowiedzi werbalnej. Potrzebna zatem była wypowiedź, która umożliwiała swobodę i ekspresję wizerunku wypowiadającego się. Najlepiej przy tym, by było kilku autorów, podejmujących różne tematy i reprezentujących odmienne poglądy (by uniknąć determinacji wyników przez te zmienne), ale piszących w ramach jednego gatunku tekstowego, funkcjonującego wedle tych samych reguł (wówczas gatunek tekstu nie wpływa na wizerunek), w końcu forma cykliczna pozwalała wykorzystać wiele tekstów jednego autora (ominięcie determinacji wyników przed temat wypowiedzi).

W szystkie te warunki spełniał gatunek felietonu, który - choć nie posiada kanoniczego wzorca - to charakteryzuje się kilkoma typowymi cechami, co do których panuje zgoda wśród badaczy. Tak np. do tzw. zewnętrznych wyznaczników felietonu zalicza się: cykliczność wypowiedzi i tytuł cyklu, graficzne wyróżnianie tekstu i/lub jego fragmentów, niewielkie rozmiary (zob. np. Wojtak 2004: 204; Fras 1999: 85; Niczyperowicz 1996: 48; Sławkowa 2000: $308-$ 309; Maziarski 1976; Wolny-Zmorzyński, Kaliszewski, Furman 2006: 89; Chudziński 2008: 354; Klein: 1983: 261). Badacze nie mają też wątpliwości co do takich cech gatunku, jak:

- usytuowanie na pograniczu publicystyki i literatury (Chudziński 2008: 345, 355; Niczyperowicz 1996: 82-83, 89-92; Jedliński 1984: 36,

17 Po pierwsze, dlatego że rezultaty badań są zawsze zapośredniczone. Po drugie, dlatego że nie da się ustalić reprezentatywności, skoro wyznaczenie populacji i jej próby staje się niewykonalne. Zob. na ten temat Fleischer 2008a: 62.

18 Istotą eksperymentu jest związek przyczynowo-skutkowy, który pozwala wyjaśniać pewne procesy, bardziej niż je opisywać i w tym względzie ścisła reprezentatywność nie jest wymagana. Zakłada się, że jeśli występuje (lub nie) wpływ między zmiennymi, to - generalizując - będzie funkcjonował niemal w każdej grupie osób, bez względu na jej skład i wielkość (zob. Babbie 2004: 250).

19 Rozdział ten jest w dużej mierze powtórzeniem treści (z niewielkimi tylko zmianami) zawartych w: Barańska-Szmitko 2014c: 212-217. 
42-45; Stasiński 1982: 7; Maziarski 1976: 80; Wolny-Zmorzyński, Kaliszewski, Furman 2006: 88; Wojtak 2004: 202, 205),

- aktualność poruszanej problematyki (Jedliński 1984: 36; Maziarski 1976: 80; Klein 1983: 262; Chudziński 2008: 354; Wolny-Zmorzyński, Kaliszewski, Furman 2006: 88; Wojtak 2004: 205; Wojtak 2008: 109), (Stasiński 1982: 9; Jedliński 1984: 47; Chudziński 2008: 355),

- tematyczna dowolność (Stasiński 1982: 9; Jedliński 1984: 47; Chudziński 2008: 355),

- pełna swoboda stylistyczna (Stasiński 1982: 9; Maziarski 1976: 80; Klein 1983: 262-263; Niczyperowicz 1996: 51-52; Jedliński 1984: 45-47; Wolny-Zmorzyński, Kaliszewski, Furman 2006: 88; Wojtak 2004: 205; Wojtak: 2008: 110),

- subiektywność, a nawet stronniczość wypowiedzi (Maziarski 1976: 80; Stasiński 1982: 10-12; Klein 1983: 265; Jedliński 1984: 47; Niczyperowicz 1996: 48, 52; Chudziński 2008: 254-355; Wojtak 2004: 205; Wojtak: 2008: 110; Wolny-Zmorzyński, Kaliszewski, Furman 2006: 88, Piątek 2011: 96; Marczyk 2005: 185),

- skłonność publicystów do silnego wartościowania w sposób prześmiewczy (Stasiński 1982: 9-10; Maziarski 1976: 80; Klein 1983: 262; Niczyperowicz 1996: 48, 52; Jedliński 1984: 36, 47; Chudziński 2008: 356; Wolny-Zmorzyński, Kaliszewski, Furman 2006: 88; Wojtak 2004: 206; Wojtak 2008: 110).

Właściwości felietonu, co do których zgadza się większość badaczy, z jednej strony dają dość ogólne wytyczne, $\mathrm{z}$ drugiej: czynią z felietonu miejsce właściwie niczym nieskrępowanej manifestacji własnej osoby z jej postawą, światopoglądem, cechami personalnymi.

Słuszność wyboru felietonu jako narzędzia tekstowego w referowanym badaniu potwierdziły wstępne badania, weryfikujące możliwości i ograniczenia tego gatunku w zakresie komunikowania wizerunku na poziomie werbalnym (Barańska-Szmitko 2014c). Udało się w nich ustalić, że chociaż cechy gatunkowe felietonu mają wpływ na przypisywane autorom cechy, to ich elastyczność nie tyle ogranicza, co daje bardzo dużą swobodę ekspresji, czasami skrajnie różnych, postaw, poglądów, stanowisk czy charakterów (zob. Barańska-Szmitko 2014c: 220-224).

Wyeliminowano wpływ tematu (pomijając rzecz jasna ogólny profil tematyczny, specyficzny dla każdego z autorów) na konstruowany przez interpretatora wizerunek, posługując się w badaniu 21 felietonami każdego z publicystów. Niewielkie rozmiary felietonu wpływały na pozytywną decyzję o udziale w badaniu, nie zniechęcając i nie wpływając na ewentualną rezygnację z udziału. 


\subsubsection{Kryteria doboru autorów i wykorzystane felietony}

Różnorodność tematyczna oraz światopoglądowa/ideowa felietonistów, a także szacowana tzw. komunikatywność/zrozumiałość tekstów stanowiły prymarne kryteria doboru autorów i ich felietonów. Ponadto, w celu porównywania wyników, uwzględniono tę samą periodyzację publikacji i podobieństwa struktury organizacyjnej tekstu, a także mniej więcej tę samą długość, obecność zdjęcia autora oraz zakładaną powszechną, lub nie, znajomość felietonistów.

Różnorodność tematyczna i ideowa pozwalały sprawdzić wpływ (bądź nie) tych czynników na wizerunek, a zrozumiałość ujęto jako bliskość kontekstu komunikacyjnego ${ }^{20}$. Ostatecznie wykorzystano teksty: Krzysztofa Vargi, Piotra Zaremby, Magdaleny Środy i Szymona Hołowni. Uznano je za najbardziej optymalne w kontekście kształtu polskiego rynku prasowego w czasie, gdy planowano badanie. Krzysztof Varga skupia się głównie na nowościach wydawniczych, rzadziej na filmach, eventach, przedsięwzięciach artystycznych, czy tych z zakresu popkultury. Piotr Zaremba traktuje o filmach i serialach, obecnych w telewizji, chociaż niektóre teksty dotyczyły książek, programów telewizyjnych lub wydarzeń ze świata artystycznego. Magdalena Środa i Szymon Hołownia reprezentują tematykę społeczno-polityczną, przy czym autorka pisze przede wszystkim o polskiej scenie politycznej lub wydarzeniach medialnych, niekiedy o ostatniej lekturze. Dziennikarz, chociaż ma podobną motywację tematyczną, to opisuje też np. doświadczenia z podróży, które zwykle stara się odnieść do realiów życia w Polsce.

W kwestii stałości postawy ideowej trzeba zaznaczyć, że dwójka z felietonistów (Piotr Zaremba i Szymon Hołownia) zmieniała redakcję i tytuł periodyku, w którym ukazywały się felietony, jednak nie było to wynikiem zmiany poglądów - jak pokazują wypowiedzi dziennikarzy i same felietony - co właśnie wyrazem trwania przy własnych wartościach ${ }^{21}$.

Jednym z kolejnych kryteriów była różna znajomość felietonistów. Założono, iż najbardziej rozpoznawalny powinien być Szymon Hołownia, ze względu na prowadzone programy telewizyjne. Wypowiedzi nie tylko felietonowe Piotra

20 Zrezygnowano np. z uwzględnienia w badaniu tekstów z „Twojego Stylu”, których problematyka jest zdecydowanie bliższa starszym odbiorcom. Podobnie z felietonów Waldemara Łysiaka, przywołującego odległe zazwyczaj dla studentów konteksty historyczne. Ostatecznie w wypełnionych ankietach, na etapie pilotażu, a potem we właściwej części badania, nie pojawiły się żadne przesłanki sugerujące nieadekwatny dobór felietonów, co potwierdza zasadność dokonanych wyborów.

21 Krzysztof Varga w trakcie trwania badania niezmiennie pisał dla „Dużego Formatu” "Gazety Wyborczej”, a Magdalena Środa nieprzerwanie do tygodnika „Wprost”. 
Zaremby i Magdaleny Środy również pojawiały się w przestrzeni publicznej, więc uznano, że te nazwiska nie pozostaną respondentom obce. Wstępnie uznano, że najmniej wiedzy posiadać będą uczestnicy o Krzysztofie Vardze, który przede wszystkim jest pisarzem, a teksty dziennikarskie stanowią raczej dodatek do jego głównej pracy.

Ta sama periodyzacja gwarantowała brak „przedawnienia” tematów. Brano pod uwagę wyłącznie tygodniki. Podobna struktura organizacyjna (brak np. stałej stylizacji na list lub serwis informacyjny) i zbliżona niezbyt duża długość tekstów pozwalały na porównanie wyników.

\section{Zestawienie tytułów wykorzystanych felietonów zawiera Aneks nr 1.}

\subsubsection{Trafność wewnętrzna eksperymentu i jej realizacja}

Trafność wewnętrzna, a więc odwzorowanie w wynikach wpływów bodźca, polega $\mathrm{w}$ istocie na tym, by wyeliminować nietrafność, a „zagrożenie nietrafnością wewnętrzną zachodzi zawsze, gdy cokolwiek innego niż bodziec mogło wpłynąć na zmienną zależną" (Babbie 2004: 255). Należy zatem nie dopuścić do pojawienia się źródeł nietrafności wewnętrznej, takich jak: historia, dojrzewanie, pomiar, narzędzia, regresja statystyczna, obciążenia doboru, przyczynowy porządek czasowy; oraz w eksperymentach przeprowadzanych w rzeczywistych sytuacjach ${ }^{22}$ : rozpowszechnianie lub naśladowanie, rekompensata, rywalizacja o rekompensatę, zniechęcenie (Babbie 2004: 255-257).

Część z powyższych czynników (te niedotyczące rzeczywistych sytuacji) uwzględniono w trakcie pracy nad opisywanym badaniem. Szczegółowe dane związane z eliminacją większości ze źródeł nietrafności wewnętrznej znajdują się w poszczególnych wcześniejszych podrozdziałach. By nie powtarzać niepotrzebnie treści przy omawianiu każdego ze źródeł nietrafności wewnętrznej, podane są odsyłacze do poszczególnych podrozdziałów, przywołujące realizację każdego z zagadnień w detalach.

Starano się znieść działanie tzw. „historii”, czyli zakłóceń spowodowanych nieprzewidywanymi zdarzeniami (np. zamach na afroamerykańskiego polityka w trakcie trwania badania dotyczącego uprzedzeń rasowych). W przypadku opisywanego tutaj badania mówić można o dwóch takich czynnikach. Jednym z nich była jednostkowa sytuacja, kiedy goszczący badaczkę wykładowca poinformował studentów, że udział w badaniu jest obowiązkowy i będzie miał wpływ na ocenę z egzaminu, po którym badanie

22 Eksperymenty $\mathrm{w}$ rzeczywistych sytuacjach to np. sprawdzanie działania danego programu edukacyjnego w szkole, wprowadzenie programu opieki nad pacjentami w szpitalu itp. (Babbie 2004: 256-257). 
się odbywało. Przeprowadzająca badanie po tym obwieszczeniu weszła na salę, poprosiła studentów o udział w badaniu, zaznaczając, że jest to udział dobrowolny i anonimowy, a następnie rozdała teczki z zadaniami, dowiadując się post factum o informacji wcześniej przekazanej studentom. Wprowadzono respondentów w błąd, otrzymali sprzeczne informacje. Wyniki tych ankiet nie zostały uwzględnione w badaniu. Podobnie w sytuacji, kiedy wykładowca poinformował studentów, iż ich zadaniem będzie wypełnienie 5-10-minutowej ankiety (a nie 15-minutowej), o czym badaczka dowiedziała się po przeprowadzeniu badania. Odpowiedzi nie zostały uwzględnione w wynikach, ponieważ wprowadzono studentów w błąd, a także w związku z tym karty ankietowe respondenci wypełniali wyrywkowo.

Zadbano o zniesienie efektu „dojrzewania”, czyli zmiany nastawienia uczestników do badania (Babbie 2004: 255; Wójcik 2007: 139), w dłuższych eksperymentach mogącego zachodzić wraz z wiekiem, w krótszych jako wynik znużenia, znudzenia lub np. uczucia głodu, co może mieć wpływ na jakość wyników. W niniejszym badaniu wysiłek włożony w realizację zadań i pytań odpowiadał poziomowi poznawczemu respondentów. Uczestnicy byli też informowani, na czym polega zadnie i jak długo będzie trwało, i dopiero wtedy decydowali o udziale w badaniu (większość godziła się wziąć udział, były też jednak osoby, które skorzystały z możliwości odmowy). Sam układ poleceń (zob. rozdział 1.3.2.1. Układ poleceń $w$ grupach i brzmienie pytań) miał także minimalizować wysiłek tam, gdzie to możliwe. Staranne wypełnianie ankiet i zastosowanie się do wszystkich poleceń sugeruje, że udało się osiągnąć trafność wewnętrzną w tym względzie.

Zminimalizowano też wpływ pomiaru początkowego (Babbie 2004: 255; Wójcik 2007: 139 - „pomiar początkowy”), czyli sytuacji, kiedy respondenci, np. chcąc uchodzić za konsekwentnych, nie wykazują zmiany postawy mimo wprowadzenia bodźca (zob. Wójcik 2007: 139; Babbie 2004: 255). Zastosowano schemat eksperymentalny, w którym nie przeprowadza się w jednej grupie pretestu i posttestu. Niniejsze badanie uwzględnia pomiar początkowy w grupie kontrolnej i pomiar końcowy w grupie eksperymentalnej (zob. rozdział 1.3.2. Dobór metodologii do celów badania).

Zwrócono szczególną uwagę na brak zmian w stosowanym narzędziu (Babbie 2004: 255-256; Wójcik 2007: 139-140). Przeprowadzenie pomiaru początkowego uprzedzeń rasowych za pomocą jednego kwestionariusza, a w pomiarze końcowym za pomocą innego jest w stanie podać w wątpliwość wyniki całego eksperymentu (Babbie 2004: 255-256). Jak podano w poprzednich rozdziałach, w omawianym badaniu wszystkie pytania kwestionariuszowe oparte były na identycznym schemacie. Zmianie ulegała wyłącznie część dotycząca badanej zmiennej. Zamiast np. słów „autora/autorkę” w zdaniu: 
„Mając za podstawę tekst przeczytanego felietonu, jakimi słowami opisałby Pan / opisałaby Pani autora/autorkę tego tekstu?” wstawiano imię i nazwisko felietonisty. O szczegółach dotyczących brzmienia poleceń i ich układu (zob. rozdz. 1.3.2.1. Układ poleceń w grupach i brzmienie pytań).

Uwzględniono także tzw. obciążenie doboru. By można wnioskować na podstawie przeprowadzonego eksperymentu, grupy powinny być porównywalne, co ma zapewnić kontrolowanie składu i losowy do nich przydział (Babbie 2004: 256; Wójcik 2007: 140). W przypadku omawianych badań homogeniczność próby zapewniał udział studentów dwóch tylko kierunków, teczki nie były w żaden sposób oznaczone i rozdawane bez wiedzy o ich zawartości (zarówno badaczki, jak i respondentów), zatem przydział do grup odbywał się losowo (zob. na ten temat rozdz. 1.3.2.4. Uczestnicy badania).

Ponieważ realizacja wszystkich zadań zajmowała kilkanaście minut i wymagała skupienia, a zazwyczaj każdy z respondentów czytał inny tekst, eksperymentu nie obciążał problem "rozpowszechniania i naśladowania” (Babbie 2004: 256), czyli kontaktowania i komunikowania się członków grup między sobą.

Zachowano także przyczynowy porządek czasowy (Babbie 2004: 256; Wójcik 2007: 137), tj. działanie bodźca (np. tekstu) poprzedzało na niego reakcję (odtworzenie wizerunku komunikowanego werbalnie). Jeśli pojawiło się w obrębie grupy więcej zadań dla respondentów, zadbano o odmienny ich układ dla każdej z grup i o wyeliminowanie inferencji między reakcjami na poszczególne bodźce (zob. rodział 1.3.2.1. Układ poleceń w grupach i brzmienie pytań). Sama możliwość porównania wyników pozwalała także na określenie ewentualnych wzajemnych wpływów.

Jak zatem widać, zaprojektowano badanie w taki sposób, by wyeliminować lub zneutralizować działanie potencjalnych źródeł nietrafności wewnętrznej.

\subsubsection{Wyniki - rozwiązania analityczne}

Głównym przedmiotem analizy były treści ankiet zawierające albo wyłącznie przypisane felietonistom określenia (w wariantach dotyczących wizerunku na podstawie zdjęcia i na podstawie wiedzy pozatekstowej), albo wypisane przez respondentów-czytelników cechy autorów testów wraz z fragmentami tekstu, będącymi podstawą przypisania danej cechy. By wyłonić spójne cechy wizerunkowe poszczególnych publicystów, w każdym z powyższych przypadków posłużono się kodowaniem otwartym. Tak uzyskane dane następnie poddano prostej analizie częstości z uwzględnieniem wzajemnych zależności. W toku analizy przydatne okazało się również tworzenie tzw. bloków 
semantycznych w obrębie cech pojedynczego autora, co ułatwiało lepsze określenie wizerunku każdego z nich.

Wykorzystano kodowanie otwarte, rozumiane jako klasyfikacja i nazywanie pojęć „na podstawie bezpośredniego wglądu w dane oraz ich dokładnej analizy" (Babbie 2004: 626-627; zob. też: Gibbs 2011: 91), ponieważ narzucił to eksploracyjny charakter badania, jak również typ zastosowanych pytań. Zrezygnowano z czysto opisowego kodowania, by lepiej widzieć zasady rządzące tworzeniem wizerunku. Nie uwzględniano w procesie kodowania literatury przedmiotu czy wcześniejszych badań z braku stosownych opracowań, ale przede wszystkim dlatego, iż takie kodowanie teoretyczne kłóciło się z eksploracyjnym podejściem i celem niniejszych badań.

Kodowanie w zależności od wariantów nieznacznie się różniło. Wówczas, gdy odpowiedzi dotyczyły wizerunku powstałego na podstawie obrazu i z wykorzystaniem pozatekstowej wiedzy o felietoniście, kategoryzowano przypisane publicystom epitety $\mathrm{w}$ spójne cechy wizerunkowe. $\mathrm{W}$ tych natomiast wariantach, gdzie czytano tekst (sam tekst lub tekst ze zdjęciem i informacją o tożsamości autora), do dyspozycji pozostały również cytaty $\mathrm{z}$ felietonów, które respondenci wskazali jako podstawę do łączenia z konkretnym epitetem. Relacja takiego cytatu do wypisanego określenia stanowiła też element uwzględniany w kategoryzowaniu poszczególnych epitetów w spójne cechy wizerunkowe. Stworzono klucz kodowy, dla którego podstawową zasadą, oprócz przywiązania do leksemów wypisanych przez respondentów i ich semantycznych synonimów, było również zwracanie uwagi na spójność i powtarzalność wykładników komunikacyjnych (reguł widocznych w cytatach realizujących daną cechę) zawsze, kiedy to tylko było możliwe.

Rzetelność badań, określaną jako spójność ujęcia między innymi badaniami własnymi i innych autorów (Gibbs 2011: 174; zob. też Creswell 2013: 206), zapewniało ciągłe sprawdzanie i porównywanie spójności kodowania, prowadzone stale od pierwszego kroku kodowania do ostatniego, realizowane na sukcesywnie zwiększającym się porównywanym materiale.

Analizowano częstość wystąpień cech wizerunkowych dla poszczególnych typów wizerunków (zob. wizerunek werbalny, publiczny, wizualny w rozdziale 1.3.2.9. Ustalenia terminologiczne), kolejnych autorów, weryfikując wzajemne relacje zarówno między typami wizerunków, jak i między samymi autorami. Uwzględniano przy tym dane z pytań dodatkowych, weryfikujących znajomość felietonistów i ich tekstów. Globalne porównanie pozwoliło zdefiniować i określić wzajemne zależności.

$\mathrm{W}$ trakcie analizy zaistniała potrzeba połączenia cech wizerunkowych w bloki semantyczne - grupy cech wizerunkowych, podkreślających zbliżone 
przymioty felietonisty, co pozwalało uwypuklić najważniejsze wyróżniki każdego z publicystów.

Zastosowano zatem kodowanie otwarte, by następnie dokonać analizy częstości z uwzględnieniem relacji między typami wizerunków i między felietonistami, co pozwoliło określić wzajemne wpływy między wizerunkami.

\subsubsection{Ustalenia terminologiczne}

Część z poniższych „terminów” pojawiła się już wcześniej w toku wywodu, ale tutaj dla większej przejrzystości wszystkie przedstawione są zbiorczo. Zaznaczyć należy, że przytoczone niżej definicje mają charakter wyłącznie operacyjny (zob. Babbie 2004: 146-148), to znaczy zostały stworzone tylko na potrzeby opisu przebiegu i wyników prezentowanego badania, nie mają więc charakteru uniwersalnego.

Część badania głównego - etap badania wydzielony ze względu na jego cel; całość podzielona na dwie części: pierwszą z pytaniem o cechy autora wypowiedzi, by określić komunikowany wizerunek, drugą - pytanie o cytaty manifestujące dane cechy, by wyłonić wykładniki komunikacyjne poszczególnych cech wizerunkowych.

Określenie/przymiot/epitet - cecha przypisana przez respondenta autorowi tekstu po przeczytaniu felietonu w pierwszej części badania.

Cecha (wizerunkowa) - cecha skodowana jako element wizerunku felietonisty, zbierająca różne warianty leksykalne ją wyrażające.

Wariant badania - część badania, w której weryfikowano wpływ określonej zmiennej na wizerunek. W opisywanym badaniu zrealizowano cztery warianty, których nazwy odzwierciedlają bodziec, który stanowił podstawę do konstruowania wizerunku: 1) tekst, 2) tekst + nazwisko + zdjęcie, 3) samo zdjęcie, 4) samo nazwisko.

Wizerunek - to, co odbiorcy jakiejkolwiek wypowiedzi, dokonanej w jakimkolwiek systemie znakowym konstruują na temat obiektu ${ }^{23}$ :

- wizerunek werbalny - konstruowany przez odbiorcę wypowiedzi na podstawie wypowiedzi werbalnej (felietonu),

- wizerunek publiczny - konstruowany przez interpretatora na podstawie wszystkich dostępnych mu systemów znakowych (w kontekście badania - przed udziałem w badaniu),

- wizerunek wizualny - konstruowany przez odbiorcę wypowiedzi na podstawie systemów znaków wizualnych (zdjęcia). 


\subsection{Stan badań i metodologia - podsumowanie}

Podsumujmy, jaki obraz problemu badawczego wyłania się z dostępnej literatury, a także jak przyjęta perspektywa teoretyczna oraz cel badań determinują wybór środków metodologicznych.

$\mathrm{W}$ powziętych do tej pory badaniach dominuje zainteresowanie wizerunkiem firm/instytucji, natomiast weryfikacja wizerunku osób publicznych podejmowana jest znacznie rzadziej i ma charakter sondażowy lub eksperymentalny. W drugim z tych przypadków badacze sprawdzają wpływ poszczególnych obiektów na image, trudno natomiast wskazać opracowania skupione na możliwościach wpływania ofert komunikacyjnych pojedynczego systemu znakowego. Tam, gdzie badania czerpią z metod badań społecznych, realizowane jest założenie intersubiektywizmu badawczego (wykorzystuje się kwestionariusze ankiet), nieimplikowanego w badaniach bazujących na materiale języka naturalnego. Nieliczne opracowania dotyczą wpływu wypowiedzi danej osoby na jej wizerunek, a raczej badacze koncentrują się na wypowiedziach „o" danej osobie i z takich wypowiedzi odtwarzają jej image.

Ponieważ zauważyć można brak badań w sposób intersubiektywny badających wpływ wypowiedzi w poszczególnych systemach znakowych na wizerunek osoby publicznej, to zasadne wydaje się zweryfikowanie udziału słowa w komunikowaniu wizerunku osoby wypowiadającej się na dowolny temat, inny niż własna osoba, a ponadto sprawdzenie, jaki wpływ ma zdjęcie autora tekstu umieszczone przy jego wypowiedzi oraz jaki wizerunek powstaje, gdy interpretatorzy mają do dyspozycji wiele różnych wypowiedzi realizowanych $\mathrm{w}$ różnych systemach znakowych.

Bazę teoretyczną stanowi racjonalny konstruktywizm Michaela Fleischera, jako teoria zakładająca istnienie trzech rzeczywistości, w tym rzeczywistości komunikacyjnej, konstruowanej przez interpretatorów, tworzących za pomocą komunikacji system społeczny. W tym ujęciu również wizerunek stanowi efekt konstrukcji interpretatorów, dokonujących owej(-ych) konstrukcji na podstawie dostępnych ofert komunikacyjnych.

By osiągnąć założone cele badawcze, wykorzystano formułę eksperymentu, przedstawiając respondentom teksty felietonów (gatunek zakładający dużą ekspresję osobowości autora wypowiedzi) czterech różnych polskich publicystów (Krzysztof Varga, Piotr Zaremba, Magdalena Środa, Szymon Hołownia), raz bez informacji o tożsamości autora, a raz ze zdjęciem i widniejącym imieniem i nazwiskiem felietonisty. Pytano następnie o cechy danego felietonisty (tzw. wizerunek werbalny anonima i znanego autora). Analogiczne pytanie zadano badanym po zapoznaniu się przez nich ze zdjęciem (wizerunek wizualny) i pytając o skojarzenia z nazwiskiem (image publiczny). Sprawdzano 
przy tym przedeksperymentalną znajomość publicystów przez respondentów. Dobór próby badanych, miejsca badania, wybór felietonistów i tekstów dostosowano do stawianych celów badawczych i/lub możliwości organizacyjnych, dbając o zapewnienie trafności i rzetelności, zarówno na etapie realizacji eksperymentu, jak i analizy materiału.

Wyniki wraz z analizą i interpretacją prezentują kolejne rozdziały. 
ROZDZIAŁ II 



\section{Wizerunki felietonistów}

Zaprezentowano niżej wszystkie ujęte w badaniu wizerunki każdego z felietonistów, by finalne zestawienie rezultatów pozwoliło określić, co jest możliwe do komunikowania w zakresie wizerunku na poziomie słowa (wizerunek werbalny anonimowego felietonisty oraz autora o podanej tożsamości), większej liczby systemów znakowych (image publiczny) i obrazu (wizualny). W analizie uwzględniono wzajemne wpływy między wizerunkami.

\subsection{Sposób przedstawienia wyników}

W podrozdziałach poniżej przedstawiono osobno wizerunki każdego z czterech felietonistów, kolejno: Krzysztofa Vargi, Piotra Zaremby, Magdaleny Środy, Szymona Hołowni. W obrębie jednej osoby uwzględniono cztery typy jej image’u. Po pierwsze, wizerunek powstały wyłącznie na podstawie słów twórcy anonimowego dla czytelnika, a więc to, co można komunikować werbalnie na temat własnej osoby. Następnie image publiczny - by móc określić, jakie cechy zależą tylko od języka, a jakie od dostępnego odbiorcy zbioru wypowiedzi w różnych systemach znaków. Na te dwa ujęcia - jako trzeci - nałożony został „filtr” wizerunku wizualnego - (od)twarzanego z fotografii autora tekstu, aby podjąć próbę ustalenia, co zależne jest w przypadku image’u od słów, a co od elementów wizualnych. Całości dopełnią wyniki dotyczące wizerunku twórcy felietonu w sytuacji, w której odbiorcy tekstu mają podaną tożsamość autora $\mathrm{i}$ jego zdjęcie - te rezultaty w zestawieniu z poprzednimi pomogą precyzyjniej określić wzajemne wpływy.

Przedstawiane dane zestawiono w tabelach, informujących o cesze wizerunkowej i jej wariantach leksykalnych w ujęciu ilościowym. Perspektywa 
liczbowa pozwala zauważyć, ile razy wskazano daną cechę wizerunkową (n) oraz jaki jest to procent wszystkich wskazań (\%). W analizie uwzględnia się także liczbę osób (n osób), która wskazała daną cechę wizerunkową oraz jej odpowiednik w wartości procentowej na tle wszystkich uczestników (\% osób).

W poszczególnych tabelach pozostawiono oryginalny zapis określeń z kart odpowiedzi. Zasady tej przestrzegano ściśle, stosując ją nawet w przypadku błędów ortograficznych uczestników badania.

Poszczególne epitety oddzielone są od siebie średnikami. Przecinek oznacza przecinek w wypowiedzi respondenta, tak więc np. „inteligentna osoba, posiada wiedzę na różne tematy" to określenie, które zostało przez uczestnika badania wypisane $\mathrm{w}$ jednym punkcie.

W nawiasie przy konkretnym słowie znajduje się liczba wskazań dosłownego brzmienia danego atrybutu, tak więc zapis „zdystansowany (5)” informuje, iż tego konkretnego leksemu użyto pięć razy na określenie danego felietonisty w omawianym wariancie badania. Brak nawiasu oznacza, że wymienionym wyrazem posłużono się tylko raz. Zero w nawiasie „(0)” sygnalizuje arbitralnie nadane brzmienie w celu zsumowania znaczenia różnorodnie wyrażanego przez respondentów.

Omawianie wyników ma charakter linearny, tzn. to co, bierze się pod uwagę $\mathrm{w}$ analizie $\mathrm{i}$ wnioskach $\mathrm{w}$ jednym rozdziale, uwzględnia właśnie referowane dane, a ponadto rezultaty i ustalenia $\mathrm{z}$ rozdziałów poprzednich, ale nie wyprzedza kolejnych. Uwagi analityczne i interpretacyjne narastają więc wraz z każdym kolejnym rozdziałem. Ma to tę konsekwencję, że niekiedy wnioski przedstawiane na podstawie analizy danych pierwszego wizerunku są nieaktualne przy którymś $\mathrm{z}$ wizerunków, np. trzeciego $\mathrm{z}$ felietonistów (po prostu szerszy zakres danych prowadzi do interpretacji uwzględniających więcej zmiennych, a kolejne zmienne czasami modyfikują wcześniejsze ustalenia). Wybrano takie rozwiązanie jako niepozbawione wad, ale lepsze od innego - można bowiem było wprowadzić holistyczne potraktowanie wyników, czyli przedstawić ostateczne wnioski i następnie za pomocą konkretnych rezultatów je uzasadniać. Wielość danych jest jednak zbyt duża i powiązania między nimi nie byłyby wtedy tak widoczne, a i sama autorka miała obawy co do własnych możliwości poznawczych i zdolności udźwignięcia poprowadzenia tego typu wywodu.

Zakończenie analizy każdego z poszczególnych wizerunków stanowi próba usystematyzowania cech, jakie można komunikować w każdym z czterech omawianych tu wariantów. Zebrane cechy wizerunkowe dzielono na kilka kategorii, których zawartość i kształt zostały zdeterminowane przez wyniki. Same nazwy kategorii możliwego do komunikowania image’u są arbitralne (np. „zawód”, 
„wygląd”, „wiedza”, a zwłaszcza „postawy” czy „cechy charakteru”). Chodziło wyłącznie o wprowadzenie pewnego porządku, ułatwiającego analizę różnic między poszczególnymi typami wizerunków.

\subsection{Krzysztof Varga}

\subsubsection{Krzysztof Varga - wizerunek na podstawie anonimowego tekstu $^{1}$}

Po przeczytaniu felietonów anonimowego dla czytelników autora - Krzysztofa Vargi - 63 uczestników badania odpowiedziało na pytanie: „Mając za podstawę tekst przeczytanego felietonu, jakimi słowami opisałby Pan / opisałaby Pani autora tego tekstu?", z czego jedna osoba wskazała dwie cechy, trójka respondentów podała po trzy epitety, czternastu uczestników badania wypisało po cztery określenia, a reszta, czyli 46 studentów, przypisało po pięć przymiotów felietoniście. Odpowiedzi te łącznie dały 297 epitetów, z których trzy zakodowano podwójnie ${ }^{2}$, w efekcie więc poddano kodowaniu 300 określeń, budujących 16 spójnych cech wizerunkowych.

Po wykonaniu zadań (wypisanie cech oraz fragmentów je manifestujących) respondenci odpowiadali jeszcze na pytanie: „Czy wiesz, kto jest autorem tekstu?” i zaznaczali jedną z trzech odpowiedzi: 1) „TAK, wiem (kto?)...”; 2) Nie jestem pewny/pewna - wydaje mi się, że autorem może być (kto?)...” oraz „NIE, nie wiem”, przy czym 56 osób odpowiedziało „NIE, nie wiem”, jedna osoba potwierdziła prawidłowo tożsamość felietonisty, a pozostałych sześciu uczestników badania, zaznaczając brak pewności, wynotowało: „Hawryszczuk”, „Nie jestem pewny - Pani, która prosiła mnie o udział w badaniu”, „Zaremba Piotr”, „Pani?”, „W. Cejrowski”, „Kuba Wojewódzki / Wojciech Cejrowski”. Odpowiedzi „niezdecydowanych” da się wyjaśnić dwojako. Po pierwsze, respondenci niejako „na siłę” szukali odpowiedzi i znaleźli ją w osobie przeprowadzającej badanie albo wśród nazwisk pojawiających się wcześniej w badaniu. Stąd też w odpowiedziach jeden z bohaterów felietonu („Hawryszczuk”) albo „Piotr Zaremba”, o którego wizerunek publiczny (oraz o wizerunek publiczny Magdaleny Środy) pytani byli respondenci, zanim dotarli do tekstu

1 Zob. w Barańska 2013 cząstkowe wyniki, z uwzględnieniem danych pilotażowych na temat wizerunku werbalnego K. Vargi.

2 Określenie „mający własne zdanie - niekompromisowy - krytyczny” przypisano do cech wizerunkowych „dosadnie wyrażający swoje odważne sądy” oraz „krytyczny”; epitet „inteligentny i oczytany człowiek” zakodowano do „inteligentny” oraz „oczytany”, a „krytyczny i uszczypliwy” skategoryzowano jako „krytyczny” oraz „ironiczny”. 
felietonu Krzysztofa Vargi (zob. tabela 3). Wspomnienie natomiast Wojciecha Cejrowskiego i Kuby Wojewódzkiego może być związane $\mathrm{z}$ wizerunkowym podobieństwem. Uczestnicy, nie znając autora, szukali skojarzeń z osobami znanymi z ironii, przykuwania uwagi, inteligencji, a przede wszystkim wyrazistego sposobu przekazywania swoich sądów, co doprowadziło ich do tych właśnie postaci medialnych.

Tabela 9. Zestawienie odpowiedzi respondentów czytających tekst anonimowego autora (Krzysztofa Vargi) na pytanie: „Mając za podstawę tekst przeczytanego felietonu, jakimi słowami opisałby Pan / opisałaby Pani autora tego tekstu?"

\begin{tabular}{|c|c|c|c|c|c|c|}
\hline \multirow{2}{*}{ lp. } & \multirow{2}{*}{$\begin{array}{c}\text { cecha } \\
\text { wizerunkowa }\end{array}$} & \multirow{2}{*}{ warianty leksykalne } & \multicolumn{2}{|c|}{ wskazania } & \multicolumn{2}{|c|}{ osoby } \\
\hline & & & $\mathbf{n}$ & $\%$ & $\mathbf{n}$ & $\%$ \\
\hline 1. & $\begin{array}{l}\text { inteligentny } \\
\text { (22) }\end{array}$ & $\begin{array}{l}\text { to niezwykle inteligentna osoba; } \\
\text { inteligentny i oczytany człowiek; } \\
\text { inteligentny (o czym świadczy styl } \\
\text { pisania); inteligentna osoba, posia- } \\
\text { da wiedzę na różne tematy; bły- } \\
\text { skotliwy (8); bystry; refleksyjny; } \\
\text { myślący; rozsądny; intelektualista; } \\
\text { mądry, wykształcony człowiek }\end{array}$ & 40 & 13,33 & 33 & 52,38 \\
\hline 2. & $\begin{array}{l}\text { ironiczny } \\
(14)\end{array}$ & $\begin{array}{l}\text { autoironiczny; odrobinę ironicz- } \\
\text { ny; ironiczny/sarkastyczny; iro- } \\
\text { nista; ironiczny charakter tekstu; } \\
\text { autor jest ironiczny; ironiczny } \\
\text { (nieco); wyraża się sarkastycznie } \\
\text { i z odrobiną ironii, wyraża swoje } \\
\text { opinie; sarkastyczny (3); prze- } \\
\text { śmiewczy (2); tematyka religijna, } \\
\text { z której lekko kpi; satyryk }\end{array}$ & 29 & 9,67 & 26 & 41,27 \\
\hline 3. & $\begin{array}{l}\text { ciekawie } \\
\text { piszący }(0)\end{array}$ & $\begin{array}{l}\text { opowiada w sposób przyjemny } \\
\text { i klarowny o trudnych rzeczach; pi- } \\
\text { szący prosto, ale w sposób ciekawy; } \\
\text { budzący zainteresowanie; zajmują- } \\
\text { cy; ciekawie piszący; przekonujący; } \\
\text { ciekawy styl pisania i ujęcie tematu; } \\
\text { mający lekką rękę (dobry styl); ma } \\
\text { lekkie pióro; elokwentny; posiada } \\
\text { „lekkie pióro”, potrafi zaintereso- } \\
\text { wać odbiorcę; posiadający lekkość } \\
\text { w pisaniu; potrafi przedstawić } \\
\text { rzeczywistość za pomocą obra- } \\
\text { zowych przenośni, przykładów; } \\
\text { posługujący się potocznymi, wręcz } \\
\text { wulgarnymi wyrażeniami; }\end{array}$ & 24 & 8,00 & 18 & 28,57 \\
\hline
\end{tabular}




\begin{tabular}{|c|c|c|c|c|c|c|}
\hline \multirow{2}{*}{ lp. } & \multirow{2}{*}{$\begin{array}{c}\text { cecha } \\
\text { wizerunkowa }\end{array}$} & \multirow{2}{*}{ warianty leksykalne } & \multicolumn{2}{|c|}{ wskazania } & \multicolumn{2}{|c|}{ osoby } \\
\hline & & & $\mathbf{n}$ & $\%$ & $\mathrm{n}$ & $\%$ \\
\hline 4. & $\begin{array}{l}\text { dosadnie } \\
\text { przekazujący } \\
\text { swoje } \\
\text { odważne } \\
\text { sądy }\end{array}$ & $\begin{array}{l}\text { odważny, nie boi się wyrażać swo- } \\
\text { jego zdania; odważny, bez strachu; } \\
\text { posiadający dość odwagi, aby obna- } \\
\text { żyć naturę showbiznesu wykorzy- } \\
\text { stującego prowokację; odważny (3); } \\
\text { bezpośredni (2); w sposób bezpo- } \\
\text { średni wyraża swoje zdanie; kontro- } \\
\text { wersyjny (2); mający nietuzinkowe } \\
\text { poglądy; ma swoja opinię na temat } \\
\text { katolicyzmu; ma swoje poglądy na } \\
\text { świat; ma własne zdanie i potrafi je } \\
\text { uargumentować; nonkonformista; } \\
\text { mający własne zdanie - niekompro- } \\
\text { misowy - krytyczny; pewny siebie } \\
\text { (2); nietuzinkowy; nieograniczony } \\
\text { przez konwenans; zacietrzewiony; } \\
\text { konkretny; mający własne zdanie - } \\
\text { niekompromisowy - krytyczny }\end{array}$ & 24 & 8,00 & 15 & 23,81 \\
\hline 5. & zabawny (5) & $\begin{array}{l}\text { zabawny w swój oryginalny spo- } \\
\text { sób; z poczuciem humoru (4); } \\
\text { potrafi z humorem wyjaśnić } \\
\text { dręczące go problemy; dowcipny; } \\
\text { zdystansowany; patrzy z pewnym } \\
\text { dystansem na wydarzenia histo- } \\
\text { ryczne opisane przez autora tek- } \\
\text { stu; zachowuje dystans do świata } \\
\text { tzw. showbiznesu; zdystansowany } \\
\text { wobec sytuacji w Polsce }\end{array}$ & 16 & 5,33 & 14 & 22,22 \\
\hline 6. & krytyczny & $\begin{array}{l}\text { krytyczny (3); krytykujący; lubi kry- } \\
\text { tykować; krytyczny i uszczypliwy; } \\
\text { podejmuje się krytyki otaczającej go } \\
\text { rzeczywistości; krytycznie nastawio- } \\
\text { ny do świata filmowego; krytyczny } \\
\text { w stosunku do polityków; niezado- } \\
\text { wolony z działań dzisiejszych poli- } \\
\text { tyków; niezadowolony; negatywny } \\
\text { stosunek do futbolu polskiego i wę- } \\
\text { gierskiego; zirytowany ignorancją } \\
\text { dla pisarzy; zbuntowany człowiek, } \\
\text { którego irytuje otaczająca go rzeczy- } \\
\text { wistość; mający własne zdanie - nie- } \\
\text { kompromisowy - krytyczny }\end{array}$ & 15 & 5,00 & 13 & 20,63 \\
\hline 7. & oczytany (9) & $\begin{array}{l}\text { człowiek oczytany; inteligentny } \\
\text { i oczytany człowiek; erudyta ( } 4 \text { ) }\end{array}$ & 15 & 5,00 & 15 & 23,81 \\
\hline 8. & $\begin{array}{l}\text { spostrzegaw- } \\
\text { czy (3) }\end{array}$ & $\begin{array}{l}\text { spostrzegawczy, dobry obserwa- } \\
\text { tor; spostrzegawczy i wnikliwy; } \\
\text { dociekliwy obserwator; }\end{array}$ & 14 & 4,67 & 12 & 19,05 \\
\hline
\end{tabular}


Tabela 9 (cd.)

\begin{tabular}{|c|c|c|c|c|c|c|}
\hline \multirow{2}{*}{ lp. } & \multirow{2}{*}{$\begin{array}{c}\text { cecha } \\
\text { wizerunkowa }\end{array}$} & \multirow{2}{*}{ warianty leksykalne } & \multicolumn{2}{|c|}{ wskazania } & \multicolumn{2}{|c|}{ osoby } \\
\hline & & & $\mathbf{n}$ & $\%$ & $\mathbf{n}$ & $\%$ \\
\hline 8. & $\begin{array}{l}\text { spostrzegaw- } \\
\text { czy (3) }\end{array}$ & $\begin{array}{l}\text { dobry obserwator świata; obser- } \\
\text { wator społeczeństwa; człowiek, który } \\
\text { obserwuje tendencje w kulturze; } \\
\text { uważny; dostrzega ogromny problem } \\
\text { Polaków - ciągłe życie przeszłością; } \\
\text { przenikliwy, dociekający; przenikli- } \\
\text { wy; socjolog }\end{array}$ & 14 & 4,67 & 12 & 19,05 \\
\hline 9. & $\begin{array}{l}\text { interesujący } \\
\text { się }(0)\end{array}$ & $\begin{array}{l}\text { interesuje się tematyką powojenną } \\
\text { i wojenną; zainteresowany polityką; } \\
\text { kierujący swoje zainteresowania na } \\
\text { zachowania społeczne; zaintereso- } \\
\text { wany pomnikami religijnymi; inte- } \\
\text { resuje się historią; zainteresowany } \\
\text { i zorientowany w nowościach; inte- } \\
\text { resujący się aktualnymi wydarzenia- } \\
\text { mi i polityką; interesuje się filmem } \\
\text { i kinem; lubiący dobrą literaturę; } \\
\text { miłośnik teatru w jego klasyczniej } \\
\text { formie; pasjonat }\end{array}$ & 11 & 3,67 & 10 & 15,87 \\
\hline 10. & $\begin{array}{l}\text { znawca } \\
\text { tematu }(0)\end{array}$ & $\begin{array}{l}\text { ma świadomość tego, co dzieje się } \\
\text { aktualnie w społeczeństwie; obyty ze } \\
\text { sztuką; posiadający dużo informacji } \\
\text { o życiu na Węgrzech; osoba inte- } \\
\text { ligentna, posiada wiedzę na różne } \\
\text { tematy; dobrze poinformowany } \\
\text { w opisywanym temacie; świadomy } \\
\text { historycznie i politycznie; znający } \\
\text { się na kulturze i historii; znający hi- } \\
\text { storię i nawiązujący do niej; znawca; } \\
\text { inteligentny - znawca swego tema- } \\
\text { tu; zainteresowany i zorientowany } \\
\text { w nowościach }\end{array}$ & 11 & 3,67 & 11 & 17,46 \\
\hline 11. & szczery (7) & & 7 & 2,33 & 7 & 11,11 \\
\hline 12. & $\begin{array}{l}\text { wykształcony } \\
\text { (4) }\end{array}$ & $\begin{array}{l}\text { osoba wykształcona; mądry, wy- } \\
\text { kształcony człowiek; człowiek } \\
\text { wykształcony }\end{array}$ & 7 & 2,33 & 7 & 11,11 \\
\hline 13. & złośliwy (3) & $\begin{array}{l}\text { złośliwy, kąśliwy; uszczypliwy; } \\
\text { krytyczny i uszczypliwy }\end{array}$ & 6 & 2,00 & 6 & 9,52 \\
\hline 14. & sceptyczny (3) & $\begin{array}{l}\text { zgorzkniały; sceptycznie nastawiony } \\
\text { do przyszłości literatury i kultury }\end{array}$ & 5 & 1,67 & 5 & 7,94 \\
\hline 15. & młody (2) & $\begin{array}{l}\text { młody z wieku; idący z duchem } \\
\text { czasu; nowoczesny }\end{array}$ & 5 & 1,67 & 5 & 7,94 \\
\hline 16. & realista & $\begin{array}{l}\text { trzeźwo patrzący na rzeczywi- } \\
\text { stość; racjonalista czy może } \\
\text { bardziej realista; racjonalny }\end{array}$ & 4 & 1,33 & 4 & 6,35 \\
\hline
\end{tabular}




\begin{tabular}{|c|c|c|c|c|c|c|}
\hline \multirow{2}{*}{ lp. } & \multirow{2}{*}{$\begin{array}{c}\text { cecha } \\
\text { wizerunkowa }\end{array}$} & \multirow{2}{*}{ warianty leksykalne } & \multicolumn{2}{|c|}{ wskazania } & \multicolumn{2}{|c|}{ osoby } \\
\hline & & & $\mathbf{n}$ & $\%$ & $\mathbf{n}$ & $\%$ \\
\hline 17. & inne & $\begin{array}{l}\text { nienowoczesny; o dość konser- } \\
\text { watywnych poglądach; konser- } \\
\text { watywny; drobiazgowy, używa } \\
\text { drobiazgowych i szczegółowych } \\
\text { opisów; skrupulatny; obiektywny; } \\
\text { sprawiedliwy; rozważający; otwar- } \\
\text { ty; ciekawy świata (2); sentymen- } \\
\text { talny; pamiętliwy; szanuje innych } \\
\text { felietonistów (Pilcha); szanujący } \\
\text { Pilcha; dociekliwy; dociekliwy } \\
\text { (znał przeszłość J. Brzechwy, mimo } \\
\text { że jeszcze go na świecie nie było); } \\
\text { cynik; cyniczny; zaangażowany; } \\
\text { osoba chcąca wnieść zamiany } \\
\text { w dzisiejszych mediach; wrażliwy; } \\
\text { zakompleksiony; niezadowolony } \\
\text { ze swoich osiągnięć lub ich braku; } \\
\text { niedoceniany; subiektywny; autor } \\
\text { wydaje bardzo subiektywne opinie; } \\
\text { subiektywny; przeciwny pokazywa- } \\
\text { niu swojej prywatności na porta- } \\
\text { lach społecznościowych; taki sam, } \\
\text { jak kultura, którą opisuje; powtarza } \\
\text { się; pochodzi z Polski, ale obecnie } \\
\text { przebywa na Węgrzech; zaprzecza } \\
\text { sobie; nie lubi PiS-u; doświad- } \\
\text { czony; pesymistyczny; człowiek } \\
\text { o wielu talentach; nietolerancyjny; } \\
\text { despotyczny; człowiek, który chce } \\
\text { „odciąć się” od przeszłości; nie jest } \\
\text { typowym Polakiem; osoba wierzą- } \\
\text { ca (?); zachowuje dystans do świata } \\
\text { tzw. showbiznesu; nie jest ślepo } \\
\text { zapatrzony na religię; osoba, która } \\
\text { wyolbrzymia pewne fakty; nie } \\
\text { narzuca swojego zdania; nie ocenia; } \\
\text { ugodowy; snobistyczny; operatyw- } \\
\text { ny; nieskromny; patriota; przewi- } \\
\text { dujący; niepoddający się wpływom } \\
\text { popkultury; nudny; konsekwentny; } \\
\text { NIE patriota; profesjonalista; roz- } \\
\text { kojarzony; niewierzący; romantyk; } \\
\text { odporny na wpływ otaczającej nas } \\
\text { głupoty; ambitny; rozszerzający } \\
\text { temat; emocjonalny; zawiedziony }\end{array}$ & 67 & 22,33 & 52 & 82,54 \\
\hline & & razem & 300 & 100,00 & & \\
\hline
\end{tabular}

Źródło: opracowanie własne 
Jak ilustruje tabela 9, Krzysztof Varga czytelnikom nieznającym jego tożsamości jawi się na podstawie swoich felietonów jako osoba przede wszystkim „inteligentna”. Na tę jego cechę wizerunkową zwróciła uwagę ponad połowa respondentów (33 osoby, 52,38\%) 40 razy (13,33\% wskazań). Niewiele mniej (26 uczestników, 41,27\%) uznało pisarza za „ironicznego” (29 wskazań, 9,67\%). Dla nieomal $1 / 3$ biorących udział w badaniu $(18 ; 28,57 \%)$ felietonista jest autorem „ciekawie piszącym” (24 wskazania, 8,00\%). Chociaż już mniej osób $(15 ; 23,81 \%)$ widzi twórcę „dosadnie przekazującego swoje odważne sądy”, to najwyraźniej dla tych, którzy to zauważyli, ta cecha imageowa była silnie eksponowana, ponieważ aż 24 razy zwrócono na nią uwagę (8\% wskazań), czyli liczba wskazań jest o połowę większa niż liczba osób tę cechę wizerunkową zauważających. Wynikać to może ze złożonego charakteru tej cechy wizerunkowej, mającej konsekwencje w dużej różnorodności leksykalnej użytej do jej zdefiniowania. Nie mogąc dobrać odpowiedniego słowa, czytelnicy podawali po dwa lub nawet trzy określenia synonimiczne. Za to taka sama liczba respondentów i taka sama liczba wskazań (15) dotoczy „oczytania” (5\% wskazań i $23,81 \%$ osób). Dość istotnymi cechami wizerunkowymi wydają się również atrybuty: „zabawny” (16 wskazań, 5,33\%), „krytyczny” (15; 5,00\%), „,spostrzegawczy" (14; 4,67\%), dostrzeżone przez ok. 1/5 respondentów (odpowiednio: 16 osób - 22,22\%; 15 - 20,63\%; 14 - 19,05\%). Nieco mniejszym znaczeniem charakteryzują się wypisane 11 razy (3,67\% wskazań) przymioty „interesujący się" oraz „znawca tematu” przez odpowiednio 10 i 11 osób (15,87\% i 17,46\%). Siedmiokrotnie uznano Vargę za „,szczerego" i „wykształconego" (2,33\% wskazań, 7 osób - 11,11\%). Marginalne ilościowo wydają się cechy wizerunkowe wskazane sześciokrotnie lub rzadziej: „złośliwy”, „sceptyczny”, „młody”, „realista" (odpowiednio: 2\%, 1,67\%, 1,67\%, 1,33\% wskazań). Jak zatem widać, podstawą wizerunku werbalnego Krzysztofa Vargi jest jego inteligencja (,inteligentny”) oraz przedstawianie swojego wyrazistego zdania („dosadnie przekazujący swoje odważne sądy”) w sposób ciekawy („ciekawie piszący”) i ironiczny (,ironiczny”).

Zdaje się, że z pierwszą z wymienionych cech koresponduje również jedna ze słabiej reprezentowanych: „spostrzegawczy”. Pewność swoich sądów („dosadnie przekazujący swoje odważne sądy”) może łączyć się z cechą image’ową „krytyczny”. Możliwe, że ironiczność felietonisty wspiera jego złośliwość („złośliwy”) i sceptycyzm („sceptyczny”). Podobnie poczucie humoru („zabawny”) towarzyszy interesującemu sposobowi pisania („,ciekawie piszący”) i/lub „ironiczności” ${ }^{3}$, a wyrazem kompetencji mogą być takie cechy image’owe,

3 Łączy się tutaj ironię z humorem, czy raczej z komizmem, który daje taki efekt wizerunkowy, co jest wynikiem przyjęcia stanowiska, że „tam, gdzie komizm językowy wiąże się z negatywną oceną prezentowanych treści i jest kpiną, mamy do czynienia z ironią" (Grochala 2006: 18). 
jak „oczytany”, „znawca tematu”, „wykształcony”, czy nawet „interesujący się". Bez łączników semantycznych z najczęściej zauważanymi pozostawałyby tylko atrybuty „szczery” i „realista”. Innymi słowy, jeśli spojrzeć w mniej reprezentowane cechy wizerunkowe autora, to okazuje się, że zdecydowana większość, chociaż wyraźnie przez respondentów zaznaczona jako elementy odmienne, koresponduje semantycznie z tymi na szczycie listy wszystkich wskazań.

Należy jednak podkreślić, iż relatywnie licznie, bo 67 razy (22,33\%) podano epitety, które nie dały się skategoryzować w żadną spójną cechę wizerunkową. Tego typu określenia podało $87 \%$ uczestników badania. Może to wskazywać na co najmniej dwa zjawiska. Po pierwsze, możliwe, że image pisarza jest spójny tylko w obrębie niewielu cech wizerunkowych, a reszta jest na tyle mało transparentna, że bardzo różnie interpretowana przez odbiorców. Po drugie, być może wizerunek werbalny (i nie tylko?) ma swoją ograniczoną „pojemność", tj. bez względu na to, co i jak zostałoby napisane, to i tak image będzie wyrazisty tylko w pewnym zakresie, a reszta pozostanie rozmyta, co należałoby wiązać $\mathrm{z}$ możliwościami percepcyjnymi odbiorców. Te dwie domeny komunikacji wizerunkowej mogą też ze sobą współgrać na zasadach wzajemnej zależności - image pozostaje spójny tylko w limitowanym zakresie, a inne cechy są spychane na bok, ponieważ interpretator ma ograniczone możliwości percepcyjne. Takiej interpretacji sprzyjałoby też zauważone korespondowanie semantyczne cech wizerunkowych. Ponieważ liczba tych cech ze względu na postrzeganiowy i poznawczy potencjał odbiorcy wypowiedzi nie może być zbyt duża, to wyłaniane są najbardziej wyraziste cechy, a inne je uzupełniają, tworząc spójny blok semantyczny. Analizy wyników tego samego i innych typów wizerunku pozostałych felietonistów pozwolą zweryfikować ten trop interpretacyjny.

Tabela 10. Kategorie komunikowanego werbalnie wizerunku anonimowego felietonisty - Krzysztofa Vargi

\begin{tabular}{|c|c|c|c|c|c|c|c|c|}
\hline lp. & wiedza & n & postawa & $\mathbf{n}$ & $\begin{array}{c}\text { cecha } \\
\text { charakteru }\end{array}$ & $\mathbf{n}$ & $\begin{array}{c}\text { sposób } \\
\text { komunikacji }\end{array}$ & n \\
\hline 1. & oczytany & 15 & ironiczny & 29 & inteligentny & 40 & $\begin{array}{l}\text { ciekawie } \\
\text { piszący }\end{array}$ & 24 \\
\hline 2. & $\begin{array}{l}\text { znawca } \\
\text { tematu }\end{array}$ & 11 & krytyczny & 15 & zabawny & 16 & & \\
\hline 3. & wykształcony & 7 & sceptyczny & 5 & szczery & 7 & & \\
\hline \multirow{2}{*}{4.} & \multirow{2}{*}{$\begin{array}{l}\text { interesujący } \\
\text { się }\end{array}$} & \multirow{2}{*}{11} & złośliwy & 6 & & & & \\
\hline & & & realista & 4 & & & & \\
\hline
\end{tabular}


Tabela 10 (cd.)

\begin{tabular}{|c|c|c|c|c|c|c|c|c|}
\hline lp. & wiedza & $\mathbf{n}$ & postawa & $\mathbf{n}$ & $\begin{array}{c}\text { cecha } \\
\text { charakteru }\end{array}$ & $\mathbf{n}$ & $\begin{array}{c}\text { sposób } \\
\text { komunikacji }\end{array}$ & $\mathbf{n}$ \\
\hline \multirow[t]{3}{*}{4.} & \multirow{3}{*}{$\begin{array}{l}\text { interesujący } \\
\text { się }\end{array}$} & \multirow[t]{3}{*}{11} & $\begin{array}{l}\text { dosadnie } \\
\text { przekazu- } \\
\text { jący swoje } \\
\text { odważne } \\
\text { sądy }\end{array}$ & 24 & & & & \\
\hline & & & $\begin{array}{l}\text { spostrze- } \\
\text { gawczy }\end{array}$ & 14 & & & & \\
\hline & & & młody & 5 & & & & \\
\hline & razem & 44 & & 102 & & 63 & & 24 \\
\hline
\end{tabular}

Źródło: opracowanie własne

Jeśli zestawić powyższe dane w kolejne grupy, to można wyłonić „obszary” komunikowania wizerunku werbalnego, kiedy autor pozostaje dla odbiorcy anonimowy. Zebrano je w tabeli 10. Komunikować więc poprzez tekst można takie aspekty image'u, jak: „wiedza”, „postawa”, „cechy charakteru” i „sposób komunikacji'. Jak wspomniano wyżej, same nazwy kategorii są arbitralne, motywowane tak danymi, jak i celem usystematyzowania ich. Czytelnicy tekstu najczęściej zauważają w jego autorze - przynajmniej w przypadku Krzysztofa Vargi - „postawę” (102 wskazań dotyczy cech wizerunkowych z tego zakresu) i cechy charakteru (63 wskazania). Zdecydowanie rzadziej dostrzegają „wiedzę" wypowiadającego się (33) i „sposób komunikacji” (24).

\subsubsection{Krzysztof Varga - wizerunek publiczny}

Na 126 osób, które zapytano: „Czy zna Pan/Pani nazwisko: Krzysztof Varga? Proszę zakreślić swoją odwiedź krzyżykiem”", 115 respondentów zaznaczyło „NIE. Jeśli nie, proszę schować kartkę do teczki”. 11 uczestników badania zakreśliło krzyżyk przy sformułowaniu „TAK. Jeśli tak, proszę przejść do pytania nr 2", a następnie odpowiedziało na pytanie nr 2: „Jakimi słowami scharakteryzował(a)by Pan/Pani osobę publiczną Krzysztofa Vargę?". Spośród tej grupy jedna osoba podała jedną cechę, jedna dwa określenia, trzy wypisały po trzy

4 Pytanie zadawano 63 osobom, które przeczytały opatrzony zdjęciem i nazwiskiem felieton Piotra Zaremby, i 63 respondentom będącym po lekturze tekstu Magdaleny Środy (w takich samych warunkach, także po wcześniejszej realizacji poleceń związanych z samym felietonem). Zob. tabela nr 4. 
epitety oraz sześciu respondentów podało po pięć przymiotów felietonisty, co dało łącznie 42 wskazania, a 43 określenia $^{5}$ skategoryzowane w 8 spójnych cech wizerunkowych.

Krzysztof Varga nie jest więc zbyt rozpoznawalny wśród uczestników badania, ale zdaje się, że nawet tak niewielkie liczbowo wyniki pozwalają zaobserwować pewne tendencje.

Tabela 11. Zestawienie odpowiedzi na pytanie „Jakimi słowami scharakteryzował(a)by Pan/Pani osobę publiczna_Krzysztofa Vargę?"

\begin{tabular}{|c|c|c|c|c|c|c|}
\hline \multirow{2}{*}{ lp. } & \multirow{2}{*}{$\begin{array}{c}\text { cecha } \\
\text { wizerunkowa }\end{array}$} & \multirow{2}{*}{ warianty leksykalne } & \multicolumn{2}{|c|}{ wskazania } & \multicolumn{2}{|c|}{ osoby } \\
\hline & & & $\mathbf{n}$ & $\%$ & $\mathbf{n}$ & $\%$ \\
\hline 1. & $\begin{array}{l}\text { pisarz/ } \\
\text { felietonista } \\
(4)\end{array}$ & $\begin{array}{l}\text { felietonista (2); autor; o lekkim } \\
\text { piórze; jest krytykiem literackim, } \\
\text { felietonistą, pisarzem }\end{array}$ & 9 & 20,93 & 6 & 54,55 \\
\hline 2. & $\begin{array}{l}\text { inteligentny } \\
\text { (5) }\end{array}$ & bystry; błyskotliwy & 7 & 16,28 & 5 & 45,45 \\
\hline 3. & stanowczy & wyrazisty; zasadniczy; dosadny & 4 & 9,30 & 2 & 18,18 \\
\hline 4. & ironiczny (2) & uszczypliwy; wredny & 4 & 9,30 & 4 & 36,36 \\
\hline 5. & erudyta (3) & & 3 & 6,98 & 3 & 27,27 \\
\hline 6. & $\begin{array}{l}\text { krytyk } \\
\text { literacki }\end{array}$ & $\begin{array}{l}\text { aktywny na scenie literackich (pu- } \\
\text { blikuje - zdaje się - w „Przekroju” } \\
\text { recenzje); jest krytykiem literac- } \\
\text { kim, felietonistą, pisarzem }\end{array}$ & 3 & 6,98 & 2 & 18,18 \\
\hline 7. & kreatywny & nowatorski & 2 & 4,65 & 2 & 18,18 \\
\hline 8. & inne & $\begin{array}{l}\text { dowcipny; zdystansowany; szcze- } \\
\text { ry; ma węgierskie pochodzenie; } \\
\text { krytyczny wobec innych; osobliwy; } \\
\text { niezbyt utalentowany; cieszy się } \\
\text { nieuzasadnioną sławą; smutny; } \\
\text { wrażliwy; zdolny }\end{array}$ & 11 & 25,58 & 6 & 45,45 \\
\hline & & razem & 43 & 100,00 & & \\
\hline
\end{tabular}

Źródło: opracowanie własne

W przypadku wizerunku publicznego (zob. tabela 11) wciąż dość silnie reprezentowana jest inteligencja felietonisty („inteligentny” - 7 wskazań - 16,28\%), zauważona przez 45,45\% uczestników (6), ale tym razem najwyraziściej eksponowaną cechą image’ową staje się „pisarz/felietonista” (9 wskazań,

5 Określenie „jest krytykiem literackim, felietonistą, pisarzem” potraktowano jako dwie cechy wizerunkowe i zakodowano jako „pisarz/felietonista” oraz jako „krytyk literacki”). 
$20,93 \%)$, istotny dla ponad połowy respondentów (54,55\% - 6 osób). Chociaż stanowczość („stanowczy”) i ironia („ironiczny”) mają po tyle samo wskazań (4; 9,3\%), to drugą z tych cech wizerunkowych zauważa dwa razy więcej osób (4 - 36,6\% w miejsce 2 - 18,8\%), musi więc być szerzej manifestowana w jego i o autorze wypowiedziach, podczas gdy stanowczość może być bardzo wyrazista, ale w mniejszej liczbie różnoznakowych wypowiedzi (stąd dla mniejszej liczby osób stała się istotna). Jest to również cecha o dużej złożoności i wariantywności leksykalnej, z czego może wynikać dublowanie jej na kartach odpowiedzi. Dla ponad 1/4 uczestników (3 - 27,27\%) znających nazwisko pisarza jawi się on jako „erudyta” ( $3-6,98 \%)$, równie często ( 3 wskazania - 6,98\%) jako „krytyk literacki”, choć zauważa to już tylko dwójka respondentów $(18,18 \%)$, czyli tyle samo osób $(2-18,8 \%)$, ile zwraca uwagę na kreatywność („kreatywny”) felietonisty (2 wskazania - 4,65\%). Ze względu na małą liczbę osób określających wizerunek publiczny twórcy, nie zwraca się tu uwagi na efekt wspomnianej wcześniej wyrazistości i rozmycia wizerunku.

Tak więc Krzysztof Varga to „inteligentny” „pisarz/felietonista”, który, stosując ironię („ironiczny”), przedstawia swoje poglądy. Te cechy wizerunkowe zarówno pod względem procentowego udziału wskazań, jak i liczby respondentów są dominujące. Słabiej manifestowana staje się stanowczość („,stanowczy”), erudycja („erudyta”) oraz kreatywność i dowcip („kreatywny”, „dowcipny”) „krytyka literackiego”. Podobnie jednak, jak w przypadku wizerunku werbalnego, zauważyć należy, iż „pisarz/felietonista” oraz „krytyk literacki” mogą stanowić swego rodzaju kompleks semantyczny - Krzysztof Varga najwyraźniej kojarzony jest z pisaniem w różnych formach (literatura piękna, dziennikarstwo).

Czym różni się wizerunek publiczny Krzysztofa Vargi od jego wizerunku werbalnego? Co ciekawe, jeśli przyjrzeć się poszczególnym cechom image’owym, to zbyt wiele różnic niekoniecznie uda się dostrzec. W jednym i drugim wizerunku inteligencja oraz ironia silnie charakteryzują pisarza. Zdaje się też, że „stanowczy” (z wizerunku publicznego) to tyle co „dosadnie przekazujący swoje odważne sądy” (wizerunek werbalny), zatem także w tym względzie widać podobieństwa. Najsilniej reprezentowane cechy „image’owe” pozostają bez zmian.

Istotne różnice zaczynają się dopiero, kiedy spojrzymy na wizerunek publiczny i pierwszą z jego cech: „pisarz/felietonista”. Wydaje się więc, że profesja danej osoby to coś, co niezbędne jest dla wizerunku publicznego. Staje się pierwszym wyraźnym filtrem budującym wyobrażenie o osobie, drogowskazem pozwalającym ją wstępnie określić. I najwyraźniej musi być zakomunikowana poza wypowiedzią samego autora słów, skoro nie pojawiła się żadna wzmianka o zawodzie wśród odpowiedzi respondentów czytających tekst. Po prostu autor felietonu pisze, nie zaznaczając swojego zawodu, a czytelnik 
natomiast zapewne musi więc być bardziej skupiony na przekazie niż na jego kontekście i dlatego po zaznajomieniu się z wypowiedzią nie bierze pod uwagę profesji autora. Ponieważ tekst był podany na białej kartce A4, możliwe, że zawód byłby wyłapywany przez odbiorców z drugiej grupy, tj. przez respondentów czytających kserokopię z tygodnika. W pewnym stopniu takie zachowanie może jednak hamować samo brzmienie polecenia dla czytelników („mając za podstawę tekst...”). Zweryfikują ten kierunek wyjaśnień wyniki ankiet przeprowadzonych wśród osób zapoznających się z felietonem autora o znanej tożsamości.

Druga istotna różnica to sama liczba cech wizerunkowych. W image’u publicznym udało się ich wyodrębnić siedem, podczas gdy na podstawie felietonu powstało 16 spójnych kategorii. Te rozbieżności mogą wynikać, z jednej strony, z innej liczby respondentów udzielających odpowiedzi (11 - 63 osoby) - więcej uczestników to więcej odpowiedzi i więcej podawanych określeń. Z drugiej strony, zasadna wydaje się interpretacja, że w przypadku wizerunku publicznego wywoływane są z pamięci najbardziej wyraziste cechy danej osoby i ich nie może być wiele ze względna na (ograniczoną) pojemność pamięci. Jeśli też mamy do czynienia $\mathrm{z}$ wieloma wypowiedziami (w różnych systemach znakowych), to utrwalają się nie te charakterystyczne dla jednej wypowiedzi, ale typowe dla wielu z nich cechy felietonisty. Pozostają w świadomości powtarzające się, najmocniej manifestowane cechy image’owe. To by wyjaśniało, dlaczego najsilniej reprezentowane cechy pojawiają się w obu typach wizerunku. Zaznaczyć także należy, że taka sytuacja może mieć miejsce wówczas, gdy oba typy wizerunku się ze sobą pokrywają, gdy komunikaty tworzone na podstawie tekstów - języka naturalnego - danej osoby (wizerunek werbalny) pokrywają się z komunikatami mającymi swoje źródło również $\mathrm{w}$ wypowiedziach $\mathrm{z}$ innych systemów znakowych - wypowiedziach samego autora oraz o nim (wizerunek publiczny). Powielanie tego samego komunikatu daje efekt $\mathrm{w}$ postaci $\mathrm{w}$ miarę spójnego wizerunku na poziomie najbardziej wyrazistych jego cech.

Widać przy tym, że skoro cechy wizerunkowe się pokrywają, to wizerunek werbalny musi współtworzyć wizerunek publiczny. Ten kierunek nie może być odwrotny, skoro słowo jest jednym z systemów znakowych odpowiedzialnych za wizerunek publiczny - wizerunek powstały na podstawie wszystkich systemów znakowych (dostępnych odbiorcy) nie może budować wizerunku skonstruowanego wyłącznie na bazie systemu języka naturalnego (w przypadku anonimowego autora wypowiedzi werbalnej). Sprawdźmy to jeszcze, budując kategorie o jeden poziom wyższe. 
Tabela 12. Kategorie wizerunku publicznego Krzysztofa Vargi

\begin{tabular}{|l|l|l|l|l|l|l|l|l|}
\hline lp. & zawód & $\mathbf{n}$ & wiedza & $\mathbf{n}$ & \multicolumn{1}{|c|}{ postawa } & $\mathbf{n}$ & cechy charakteru & $\mathbf{n}$ \\
\hline 1. & pisarz/felietonista & 9 & erudyta & 3 & stanowczy & 4 & inteligentny & 7 \\
\hline 2. & krytyk literacki & 3 & & & ironiczny & 4 & & \\
\hline 3. & & & & & kreatywny & 2 & & \\
\hline \multicolumn{2}{|c|}{ razem } & $\mathbf{1 2}$ & & $\mathbf{3}$ & & $\mathbf{1 0}$ & & $\mathbf{7}$ \\
\hline
\end{tabular}

Źródło: opracowanie własne

Stworzona z przytoczonych danych typologia kategorii możliwego do komunikowania za pomocą wszelkich systemów znakowych wizerunku publicznego różni się w pewnym zakresie od analogicznego zestawienia dotyczącego image’u werbalnego (gdy autor pozostaje anonimowy), co ilustruje tabela 12. Pojawia się nowy obszar image'u - „zawód” i jest on najwyżej reprezentowany, nie wykazuje żadnych podobieństw $\mathrm{z}$ imageem werbalnym. Nie ma natomiast miejsca w wizerunku publicznym na „sposób komunikacji”. Jest on słabo manifestowany w przypadku image'u (od)twarzanego $\mathrm{z}$ tekstu, nie dziwi więc, że tutaj nie mają swojej reprezentacji. Umacniałby się tym samym wniosek, że do wizerunku publicznego trafia $\mathrm{z}$ wizerunku werbalnego to, co jest wyraziste i często występujące $\mathrm{w}$ tym ostatnim, a pomijane są marginalne cechy. Dla publicznego wymiaru image’u „Zawód” staje się najbardziej wyeksponowanym obszarem, a zaraz po nim „postawa” i „cechy charakteru”. Dwie ostatnie z tych kategorii są wiodące w przypadku wizerunku werbalnego, więc również i tutaj potwierdzałoby się, że oba te typy image'u ze sobą korespondują w zakresie najmocniej wyeksponowanych aspektów wizerunku. Możliwe, że „sposób komunikowania” nie pojawia się w image’u werbalnym jako po prostu specyficzny wyłącznie dla tego typu wizerunku, jako że w innym typie wizerunku trudno jest zwrócić uwagę, że się interesująco pisze (kategorię „sposób komunikowania” tworzy wyłącznie jedna cecha wizerunkowa „ciekawie piszący”, niemożliwa do aplikacji w innych systemach znakowych, a być może, gdy odbiorca ma takich systemów wiele do dyspozycji, w ich gąszczu ginie „ciekawy sposób pisania”). Jako trzeci powtarza się także obszar „wiedzy”.

Dla wizerunku publicznego (Krzysztofa Vargi) kategoria „zawodu” staje się więc najbardziej istotna i w największym stopniu budująca wizerunek publiczny. Być może analiza kolejnych typów wizerunku pozwoli wyjaśnić jej obecność w tym rodzaju image'u. Z wizerunku werbalnego przenika tu przede wszystkim „postawa” i „cechy charakteru”, w mniejszym stopniu „wiedza”. Najprawdopodobniej ze względu na słabą reprezentację w wizerunku werbalnym „sposób komunikacji” nie wychodzi poza obszar słowa. Jest to zresztą - zdaje się - kategoria specyficzna dla tej sfery komunikacji. 


\subsubsection{Krzysztof Varga - wizerunek wizualny}

Zdjęcie Krzysztofa Vargi otrzymały 63 osoby (zob. zdjęcie w tabeli 6), do których kierowane było polecenie: „Mając za podstawę przedstawione zdjęcie, jakimi słowami opisałby Pan / opisałaby Pani przedstawioną na tej fotografii osobę?”, po wykonaniu zadania zostały także zapytane: „Czy wie Pan/ Pani, kogo przedstawia zdjęcie?” i pozostawiono im do wyboru odpowiedzi: „TAK, kogo?...”, „Nie jestem pewny/pewna, ale wydaje mi się, że może to być (kto?)...” oraz „NIE”. Wizerunek analizowano uwzględniwszy również znajomość felietonisty, mając na uwadze to, że znajomość danej osoby może wpływać na sposób (od)twarzania $\mathrm{z}$ fotografii jej wizerunku. Innymi słowy, osobno podliczono rezultaty dla tych, którzy znali nazwisko, odrębnie dla tych, którzy kojarzyli, ale nie byli pewni i wreszcie dla tych, którzy zdecydowanie zaprzeczyli wiedzy na temat postaci z fotografii.

Tylko jedna osoba znała tożsamość pisarza i nadała mu takie określenia, jak: „pewny siebie”, „zmęczony”, „stanowczy”, „zimny”, „surowy”. Nie analizuje się tutaj tych odpowiedzi ze względu na zbyt małą ich liczebność.

Trzech respondentów zaznaczyło brak pewności, co do imienia i nazwiska przedstawionej na fotografii osoby. Dwójka z nich wskazała: „Piotr Zaremba”, jeden z uczestników napisał: „Mariusz Szczygieł (ale chyba za gruby)”. Nazwisko Piotra Zaremby nieco dziwi, bowiem osoby, które otrzymywały fotografię i polecenie do niej, wcześniej czytały tekst opatrzony zdjęciem Piotra Zaremby (zob. tabela 3). Powinny więc zauważyć różnicę, zwłaszcza że mogły wracać do wcześniejszych kart i sprawdzić, czy postać na fotografii się różni. Zdaje się, że ci uczestnicy badania, chcąc udzielić odpowiedzi, szukali gdziekolwiek skojarzeń i to nazwisko przyszło im jako pierwsze do głowy, dlatego też je wypisali. Bez względu na motywację, takie wyniki potwierdzają tylko brak znajomości wyglądu i tożsamości Krzysztofa Vargi.

Tym samym, łatwiej wyizolować wizerunek wizualny, kiedy respondenci nie znają osoby ze zdjęcia. Takie warunki badania powinny ułatwić odpowiedź na pytanie, jaka jest różnica między wizerunkiem możliwym do komunikowania werbalnie a tym wyrażanym poprzez wiele systemów znakowych naraz i tylko poprzez warstwę wizualną.

Nie rozpoznało więc Krzysztofa Vargi i wyraźnie to zadeklarowało (odpowiedź „NIE”) 59 osób, spośród których jedna podała jedną cechę mężczyzny ze zdjęcia, cztery po dwa epitety, 11 respondentów po trzy określenia, 10 po cztery i 33 uczestników po pięć przymiotów, co dało łącznie 247 określeń, skategoryzowanych w 13 spójnych cech wizerunkowych. 
Tabela 13. Zestawienie odpowiedzi osób nieznających nazwiska Krzysztofa Vargi na pytanie: „Mając za podstawę przedstawione zdjęcie, jakimi słowami opisałby Pan / opisałaby Pani przedstawioną na tej fotografii osobę?"

\begin{tabular}{|c|c|c|c|c|c|c|}
\hline \multirow{2}{*}{ lp. } & \multirow{2}{*}{$\begin{array}{c}\text { cecha } \\
\text { wizerunkowa }\end{array}$} & \multirow{2}{*}{ warianty leksykalne } & \multicolumn{2}{|c|}{ wskazania } & \multicolumn{2}{|c|}{ osoby } \\
\hline & & & $\mathbf{n}$ & $\%$ & $\mathbf{n}$ & $\%$ \\
\hline 1. & $\begin{array}{l}\text { poważny } \\
(25)\end{array}$ & $\begin{array}{l}\text { poważna; osoba poważna; poważny czło- } \\
\text { wiek; skupiony (4); skupiona (2); zamy- } \\
\text { ślony (3); zamyślona (2); lekko zadumany }\end{array}$ & 40 & 16,19 & 33 & 55,93 \\
\hline 2. & $\begin{array}{l}\text { pewny } \\
\text { siebie (7) }\end{array}$ & $\begin{array}{l}\text { pewien siebie; pewna; pewna siebie; } \\
\text { pewna siebie, lecz bojąca się czegoś; } \\
\text { zdecydowany (2); zdecydowana; } \\
\text { stanowczy (2); stanowcza; człowiek } \\
\text { stanowczy; pewny własnego zdania; } \\
\text { człowiek z twardymi zasadami; mający } \\
\text { własne zdanie; mający swoje zdanie } \\
\text { (2); bezkompromisowy (2); raczej bez- } \\
\text { kompromisowa; silna; silny - o moc- } \\
\text { nym charakterze; agresywny; agresyw- } \\
\text { na; człowiek pragnący coś powiedzieć; } \\
\text { bezpośredni; zna swoją wartość - jest } \\
\text { pewien swojej wiedzy; nieugięty }\end{array}$ & 34 & 13,77 & 35 & 59,32 \\
\hline 3. & $\begin{array}{l}\text { zamknięty } \\
\text { w sobie (5) }\end{array}$ & $\begin{array}{l}\text { zamknięta w sobie (2); zamknięty; } \\
\text { smutny (9); smutna (2); ponury; ponu- } \\
\text { ra; ponury/przygnębiony; wycofany; } \\
\text { trochę wystraszony; apatyczna; } \\
\text { naburmuszona; tajemniczy (4); } \\
\text { tajemnicza; tajemniczość }\end{array}$ & 32 & 12,96 & 23 & 38,98 \\
\hline 4. & $\begin{array}{l}\text { inteligentny } \\
(14)\end{array}$ & $\begin{array}{l}\text { inteligentna; mądry ( } 3) \text {; myślący ( } 2 \text { ); } \\
\text { inteligentny wyraz twarzy (2); bystry/ } \\
\text { inteligentny }\end{array}$ & 23 & 9,31 & 22 & 37,29 \\
\hline 5. & spokojny (3) & $\begin{array}{l}\text { spokojna (2); spokojny/opanowany; } \\
\text { opanowana; cichy; ułożony; cierpliwy; } \\
\text { stateczny }\end{array}$ & 11 & 4,45 & 10 & 16,95 \\
\hline 6. & trudny $(0)$ & $\begin{array}{l}\text { trudna we współpracy; wymagający; } \\
\text { wymagająca od siebie i innych; gburo- } \\
\text { waty (2); nieprzyjemna; niemiły; przy- } \\
\text { wódczy; przemądrzały; władczy; apo- } \\
\text { dyktyczny; zarozumiały; małostkowy }\end{array}$ & 13 & 5,26 & 13 & 22,03 \\
\hline 7. & surowy (5) & surowa; oschły (3) & 9 & 3,64 & 9 & 15,25 \\
\hline 8. & $\begin{array}{l}\text { dorosły męż- } \\
\text { czyzna (1) }\end{array}$ & $\begin{array}{l}\text { dojrzały (3); w średnim wieku; po 40-stce; } \\
\text { osoba w średnim wieku; mężczyzna (2) }\end{array}$ & 9 & 3,64 & 8 & 13,56 \\
\hline 9. & $\begin{array}{l}\text { wykształcony } \\
\text { (2) }\end{array}$ & $\begin{array}{l}\text { wygląda na osobę wykształconą } \\
\text { i o szerokich horyzontach; oczytany } \\
\text { (2); inteligent }\end{array}$ & 6 & 2,43 & 5 & 8,47 \\
\hline 10. & realista (4) & twardo stąpający po ziemi; rozsądny & 6 & 2,43 & 5 & 8,47 \\
\hline
\end{tabular}




\begin{tabular}{|c|c|c|c|c|c|c|}
\hline \multirow{2}{*}{ lp. } & \multirow{2}{*}{$\begin{array}{c}\text { cecha } \\
\text { wizerunkowa }\end{array}$} & \multirow{2}{*}{ warianty leksykalne } & \multicolumn{2}{|c|}{ wskazania } & \multicolumn{2}{|c|}{ osoby } \\
\hline & & & $\mathbf{n}$ & $\%$ & $\mathbf{n}$ & $\%$ \\
\hline 11. & $\begin{array}{l}\text { z doświad- } \\
\text { czeniami (0) }\end{array}$ & $\begin{array}{l}\text { z bagażem życiowych doświadczeń; } \\
\text { z podłamaną wiarą w siebie; mający } \\
\text { za sobą jakieś dramatyczne przejścia; } \\
\text { zmęczony życiem/zestresowana; } \\
\text { doświadczony }\end{array}$ & 5 & 2,02 & 5 & 8,47 \\
\hline 12. & inne & $\begin{array}{l}\text { zdystansowany; zdystansowana; pod- } \\
\text { chodząca z dystansem do świata i ludzi; } \\
\text { krytyczny; krytyk; jest sceptykiem; } \\
\text { profesjonalny; profesjonalizm; rzeczo- } \\
\text { wa; przenikliwy; nieufny; podejrzliwy; } \\
\text { dążący do celu; wytrwałość; dążenie } \\
\text { co celu; groźny (2); ma władzę; na wy- } \\
\text { sokim stanowisku; bez emocji; minia } \\
\text { nieukazująca uczuć; myślący o innych; } \\
\text { współczujący; bez poczucia humoru; } \\
\text { pozbawiona poczucia humoru; ambitny } \\
\text { (2); manipulant; uczciwy; odpowie- } \\
\text { dzialny; kreatywny; osoba na fotografii } \\
\text { wygląda elegancko; łapiący kontakt } \\
\text { wzrokowy; historyczna; typ samotnika; } \\
\text { pracoholik; dumny; snobistyczny; znu- } \\
\text { dzony; obiektywny obserwator; schlud- } \\
\text { ny; biznesman; z celem gdzieś głęboko; } \\
\text { otyła; zły; dziennikarz; kulturalny; kon- } \\
\text { serwatywny; nieprzewidywalny; pokor- } \\
\text { ny; myśliciel; humanista; niespokojny; } \\
\text { obiektywny; konsekwentny; niezależny; } \\
\text { osoba publiczna; bogaty; szczery }\end{array}$ & 59 & 23,89 & 36 & 61,02 \\
\hline & & razem & 247 & 100,00 & & \\
\hline
\end{tabular}

Źródło: opracowanie własne

„Z wyglądu” Krzysztof Varga jawi się głównie jako osoba „poważna” $\mathrm{i}$ „pewna siebie”. Te cechy wizerunkowe należałoby przedstawiać w duecie ze względu na liczbę wskazań i osób je podających. O ile powagę wypisały 40 razy $(16,19 \%) 33$ osoby $(55,93 \%)$, o tyle pewność siebie reprezentuje mniejszą liczbę wskazań (34; 13,77\%), ale więcej respondentów ją zauważyło (35; 59,32\%). Te dwa elementy image’u wydają się więc porównywalnie istotne.

Ważne są także cechy wizerunkowe „zamknięty w sobie” oraz ,inteligentny". Mimo dużej rozbieżności między nimi w liczbie wskazań (odpowiednio: 32 - 12,96\% oraz $23-9,31 \%$ ), to mniej więcej tyle samo osób je dostrzegło (odpowiednio: 23 - 38,98\% oraz 22 - 37,29\%). Dla około 1/3 spośród tych, którzy mieli wrażenie izolacji felietonisty („zamknięty w sobie”), musiała to być cecha wizerunkowa szczególnie wyrazista, bowiem podawali ją więcej niż 
raz (stąd rozbieżność między liczbą wskazań i osób ich dokonujących). Ponieważ fotografia - w przeciwieństwie do tekstów - się nie zmieniała w badaniu, trudno mówić o bardziej wyrazistym eksponowaniu jakieś cechy na którymś ze zdjęć (jak mogło mieć to miejsce w przypadku różnych wypowiedzi werbalnych). Powtarzalność cechy image’owej „zamknięty w sobie” w odpowiedziach jednej osoby daje się chyba wyjaśnić jedynie (przynajmniej na tym etapie - bez porównań z wynikami dotyczącymi innych autorów) tym, że jest to cecha dość złożona, charakteryzująca się dużą synonimicznością leksykalną. Wówczas, gdy oglądającemu zdjęcie brakowało jednego odpowiedniego słowa, podawał dwa lub trzy bliskoznaczne. Stąd też w odpowiedziach poszczególnych respondentów pojawiły się określenia "zamknięty w sobie” obok epitetu „tajemniczy” albo „wycofany” obok „smutny”, czy „zamknięty w sobie” obok „ponury”. Brak możliwości znalezienia samodzielnego epitetu generował powstawanie wielu o podobnych znaczeniach. Ponieważ problem ten nie występuje w przypadku przymiotu „inteligentny”, który jest precyzyjnym określeniem o małej liczbie synonimów, to też tutaj liczba wskazań i osób je dokonujących właściwie się pokrywa (23 wskazania do 22 osób).

Powaga, pewność siebie, zamknięcie w sobie i inteligencja zdają się więc być najbardziej wyraziste i mieć kluczowe znaczenie dla wizerunku wizualnego pisarza, bowiem dotyczy ich duża liczba wskazań (od 9,13\% do 16,19\%), poczynionych przez równie dużą liczbę respondentów (od 37,29\% do 59,32\%), ale też należy zwrócić uwagę, iż każda kolejna cecha image’owa ma już prawie o połowę mniej wskazań niż najsłabiej reprezentowana spośród tych czterech wymienionych. Tak więc pojawia się cecha wizerunkowa „trudny”, wypisana 13 razy przez tyle samo, czyli przez 1/5 osób (5,23\% wskazań i 22,03\% osób) oglądających zdjęcie, natomiast siedem pozostałych cech wizerunkowych przedstawia już poziom wskazań poniżej $9(3,64 \%)$ i podawanych jest przez mniej niż 15,15\% respondentów (10). Zatem uczestnicy badania widzą w felietoniście „surowego" „dorosłego mężczyznę” (po 9 wskazań - 3,64\%; po odpowiednio 15,25\%, 13,56\% osób), który jest „wykształconym” „realistą" (po 6 - 2,43\% wskazań, po 6 - 8,47\% osób) „Z doświadczeniami” (5 wskazań $-2,02 \%$; tyle samo $-8,47 \%$ respondentów).

Podobnie jak w przypadku poprzednich typów wizerunku da się zauważyć połączenia semantyczne między poszczególnymi cechami wizerunkowymi. Wydaje się, że "poważny” koresponduje znaczeniowo z „zamknięty w sobie”, „spokojny” czy „z doświadczeniami”, natomiast „inteligentny” w pewnym stopniu z „wykształcony”, a także „pewny siebie” z „surowy” i „realista”. Jeśli tak, to w przypadku image'u wizualnego Krzysztofa Vargi mniej manifestowane cechy wizerunkowe $\mathrm{w}$ istocie wspierają tylko te najczęściej wymieniane: „poważny” / „zamknięty w sobie”, „inteligentny” „pewny siebie”, a zatem 
mimo pozornej różnorodności wizerunek ten zdaje się jednak dość spójny i wyrazisty.

Tabela 14. Kategorie wizerunku wizualnego Krzysztofa Vargi

\begin{tabular}{|l|l|l|l|l|l|l|l|l|l|l|}
\hline lp. & $\begin{array}{c}\text { stan } \\
\text { emocjonalno- } \\
\text {-poznawczy }\end{array}$ & $\mathbf{n}$ & postawa & $\mathbf{n}$ & $\begin{array}{c}\text { cecha } \\
\text { charakteru }\end{array}$ & $\mathbf{n}$ & wiek/płeć & $\mathbf{n}$ & wiedza & $\mathbf{n}$ \\
\hline 1. & poważny (25) & 40 & $\begin{array}{l}\text { pewny } \\
\text { siebie } \\
(7)\end{array}$ & 34 & $\begin{array}{l}\text { inteligentny } \\
(14)\end{array}$ & 23 & $\begin{array}{l}\text { dorosły } \\
\text { mężczyzna } \\
(1)\end{array}$ & 9 & $\begin{array}{l}\text { wykształ- } \\
\text { cony (2) }\end{array}$ & 6 \\
\hline 2. & $\begin{array}{l}\text { zamknięty } \\
\text { w sobie (5) }\end{array}$ & 32 & $\begin{array}{l}\text { realista } \\
(4)\end{array}$ & 6 & surowy (5) & 9 & & & & \\
\hline 3. & spokojny (3) & 11 & & & trudny (0) & 13 & & & & \\
\hline 4. & $\begin{array}{l}\text { z doświad- } \\
\text { czeniami (0) }\end{array}$ & 5 & & & & & & & & \\
\hline
\end{tabular}

Źródło: opracowanie własne

Jeśli stworzyć o poziom wyższe kategorie wizerunku wizualnego (tabela 14), to widać, że w obrębie tego typu image'u możliwe do komunikowania są: ,,tan emocjonalno-poznawczy”, „postawa”, „cechy charakteru”, „wiek/płeć” oraz „wiedza”. W przypadku wyglądu danej osoby najłatwiej odnotować stan emocjonalno-poznawczy - najwięcej wskazań dotyczy tej grupy cech wizerunkowych. Jest to jednocześnie nowość w stosunku do możliwości komunikacyjnych analizowanych do tej pory typów image'u. Tak samo więc, jak przy wizerunku publicznym, i tutaj nowa kategoria komunikowania stanowi także dominujący obszar. 88 wskazań dotyczy stanu emocjonalno-poznawczego, podczas gdy kolejne aspekty wizerunku wizualnego reprezentowane są przez prawie połowę mniej, czyli „cecha charakteru” - 45 oraz „postawa” - 40 wskazań; i są to już aspekty powtarzające się w każdym z branych pod uwagę do tej pory imageów. „Wiedza” również się powtarza i - podobnie jak w przypadku wizerunku publicznego - także tutaj jest wyjątkowo słabo reprezentowana (6 wskazań). „Wiek/płeć” okazuje się domeną wizerunku wizualnego.

Innymi słowy, w wizerunku wizualnym - i w żadnym innym do tej pory analizowanym - można komunikować „stan emocjonalno-poznawczy”, który jest kategorią reprezentowaną najwyżej i najwyraźniej specyficzną wyłącznie dla obrazu. Nie dotyczy tego typu image'u „sposób komunikacji” (obecny w wizerunku werbalnym) ani „zawód” (typowy dla wizerunku publicznego). Wspólnymi dla wszystkich kategoriami są „postawa” i „cechy charakteru”. Wiek - obszar komunikowany przez słowo i obraz - pozostaje aspektem dyskusyjnie 
wspólnym. Zaznaczyć na koniec należy, iż mowa cały czas o wizerunku wizualnym wyrażanym portretową fotografią. $Z$ pewnością wyniki znacznie by się różniły, gdyby na zdjęciu widniała cała sylwetka (tyle że wówczas ogromne znaczenie miałby ubiór, a tym można manipulować w dużo większym stopniu niż wyglądem twarzy).

\subsubsection{Krzysztof Varga - wizerunek na podstawie tekstu ze zdjęciem i informacją o tożsamości autora}

Wśród 63 respondentów, którzy po przeczytaniu tekstu Krzysztofa Vargi odpowiedzieli na pytanie: „Mając za podstawę tekst przeczytanego felietonu, jakimi słowami opisałby Pan / opisałaby Pani autora Krzysztofa Vargę?”, znalazła się jedna osoba, która podała tylko 2 epitety, 9 uczestników badania wskazujących po 3 określenia, 13 po 4 i 40 respondentów wypisujących po 5 przymiotów twórcy wypowiedzi werbalnej. Tym samym w sumie zebrano 281 określeń, przy czym 4 z nich należało kodować podwójnie oraz jedną potrójnie ${ }^{6}$, analizie więc poddano 287 atrybutów, skategoryzowanych w 16 spójnych cech wizerunkowych.

Tabela 15. Zestawienie odpowiedzi na pytanie: „Mając za podstawę tekst przeczytanego felietonu, jakimi słowami opisałby Pan/ opisałaby Pani autora Krzysztofa Vargę?"

\begin{tabular}{|c|c|c|c|c|c|c|}
\hline \multirow{2}{*}{ lp. } & \multirow{2}{*}{$\begin{array}{c}\text { cecha } \\
\text { wizerunkowa }\end{array}$} & \multirow{2}{*}{ warianty leksykalne } & \multicolumn{2}{|c|}{ wskazania } & \multicolumn{2}{|c|}{ osoby } \\
\hline & & & $\mathbf{n}$ & $\%$ & $\mathbf{n}$ & $\%$ \\
\hline 1. & $\begin{array}{l}\text { dosadnie } \\
\text { przekazujący } \\
\text { swoje } \\
\text { odważne } \\
\text { sądy(0) }\end{array}$ & $\begin{array}{l}\text { bezpośredni (6); odważny w osą- } \\
\text { dach; odważny; odważny dzienni- } \\
\text { karz; mocno trzymający się swojej } \\
\text { opinii; radykalne poglądy; posiada } \\
\text { swoje zdanie, które wypowiada } \\
\text { bez ogródek; ma swoje przekona- } \\
\text { nia; wyraża własne opinie; wydaje } \\
\text { mu się, że jego racja jest jedyna, } \\
\text { pewność siebie; pewny siebie (2); }\end{array}$ & 43 & 14,98 & 24 & 38,10 \\
\hline
\end{tabular}

6 Wypisane określenie „dowcipny/sarkastyczny” przyporządkowano do „zabawny” oraz „ironiczny”, „bezpośredni i zabawny, z dystansem” do "dosadnie wyrażający swoje odważne sądy” oraz „Zabawny”; z kolei: „ironiczny, dowcipny” uznano za wyraz cech wizerunkowych „ironiczny” oraz „zabawny”; natomiast „wykształcony i elokwentny” zakodowano jako „wykształcony” i „ciekawie piszący”, a określenie „wykształcony, zna się na rzeczy, oczytany” przypisano do „wykształcony”, „znawca tematu” oraz „oczytany”. 


\begin{tabular}{|c|c|c|c|c|c|c|}
\hline \multirow{2}{*}{ lp. } & \multirow{2}{*}{$\begin{array}{c}\text { cecha } \\
\text { wizerunkowa }\end{array}$} & \multirow{2}{*}{ warianty leksykalne } & \multicolumn{2}{|c|}{ wskazania } & \multicolumn{2}{|c|}{ osoby } \\
\hline & & & $\mathbf{n}$ & $\%$ & $\mathbf{n}$ & $\%$ \\
\hline 2. & $\begin{array}{l}\text { ironiczny } \\
(16)\end{array}$ & $\begin{array}{l}\text { ironizujący; ironista (2); ironiczny, } \\
\text { dowcipny; sarkastyczny (4); uży- } \\
\text { wający sarkazmu; kpiący; wyśmie- } \\
\text { wa się z twórczości Wolskiego } \\
\text { i Zychowicza; pamfleciarz; zaczep- } \\
\text { ny; dowcipny/sarkastyczny }\end{array}$ & 30 & 10,45 & 28 & 44,44 \\
\hline 3. & $\begin{array}{l}\text { inteligentny } \\
(15)\end{array}$ & $\begin{array}{l}\text { inteligentny/bezkompromisowy; } \\
\text { bystry (2); błyskotliwy; intelektu- } \\
\text { alista; człowiek myślący; osobo- } \\
\text { wość z głębią intelektualną }\end{array}$ & 22 & 7,67 & 21 & 33,33 \\
\hline 4. & $\begin{array}{l}\text { ciekawie } \\
\text { piszący }\end{array}$ & $\begin{array}{l}\text { elokwentny (3); wykształcony } \\
\text { i elokwentny; zręczny w słowach; } \\
\text { ma charakterystyczny język/styl } \\
\text { trochę wyniosły/przemądrzały; } \\
\text { charakterystyczny styl; poprawny } \\
\text { (styl.); słaby styl pisania, używa } \\
\text { czasowników na końcu zdania, } \\
\text { co czyta się bardzo słabo; stosuje } \\
\text { młodzieżowe, kolokwialne zwroty; } \\
\text { pisze zrozumiałym, potocznym } \\
\text { językiem, często używając pod- } \\
\text { tekstów; ciekawy; piszący tekst } \\
\text { w ciekawy sposób; potrafiący zain- } \\
\text { teresować czytelnika; posługuje się } \\
\text { wyszukanym słownictwem; „ar- } \\
\text { tysta”; prozo-poeta; lubi przeryso- } \\
\text { wania; zagorzały publicysta; publi- } \\
\text { cysta; dziennikarz; felietonista }\end{array}$ & 22 & 7,67 & 17 & 26,98 \\
\hline 5. & zabawny (4) & $\begin{array}{l}\text { dowcipny (5); dowcipny/sarka- } \\
\text { styczny; z poczuciem humoru (3); } \\
\text { zdystansowany (3); posiada } \\
\text { dystans do siebie; wesoły; bezpo- } \\
\text { średni i zabawny, z dystansem; } \\
\text { ironiczny, dowcipny }\end{array}$ & 20 & 6,97 & 18 & 28,57 \\
\hline 6. & $\begin{array}{l}\text { spostrzegaw- } \\
\text { czy }(8)\end{array}$ & $\begin{array}{l}\text { spostrzegawczy obserwator; ob- } \\
\text { serwator rzeczywistości; bystry } \\
\text { obserwator rzeczywistości; dobry } \\
\text { obserwator; baczny obserwator; } \\
\text { bystry obserwator; obserwator; } \\
\text { w swoich poglądach jak wnikliwy } \\
\text { obserwator rynku książkowego } \\
\text { i medialnego nie jest odosobnio- } \\
\text { ny; świadomy otaczającego go } \\
\text { świata }\end{array}$ & 17 & 5,92 & 17 & 26,98 \\
\hline 7. & znawca $(0)$ & $\begin{array}{l}\text { znający literaturę i jej historię; } \\
\text { znawca sztuki; zna się na historii; }\end{array}$ & 16 & 5,57 & 13 & 20,63 \\
\hline
\end{tabular}


Tabela 15 (cd.)

\begin{tabular}{|c|c|c|c|c|c|c|}
\hline \multirow{2}{*}{ lp. } & \multirow{2}{*}{$\begin{array}{c}\text { cecha } \\
\text { wizerunkowa }\end{array}$} & \multirow{2}{*}{ warianty leksykalne } & \multicolumn{2}{|c|}{ wskazania } & \multicolumn{2}{|c|}{ osoby } \\
\hline & & & $\mathbf{n}$ & $\%$ & $\mathbf{n}$ & $\%$ \\
\hline 8. & krytyczny (7) & $\begin{array}{l}\text { krytyk; jest bardzo krytyczny; } \\
\text { krytyczny w stosunku do Kościoła } \\
\text { i dewotyzmu; krytyczny w sto- } \\
\text { sunku do rzeczy, z którymi się nie } \\
\text { zgadza; sceptyk Kościoła katolic- } \\
\text { kiego/antyklerykalny }\end{array}$ & 12 & 4,18 & 11 & 17,46 \\
\hline 9. & $\begin{array}{l}\text { interesujący } \\
\text { się (0) }\end{array}$ & $\begin{array}{l}\text { żywo interesuje się literaturą, jej } \\
\text { położeniem („kondycją, brzydko } \\
\text { mówiąc”); miłośnik literatury; } \\
\text { miłośnik sportu; miłośnik historii; } \\
\text { fascynat; zafascynowany Sandau- } \\
\text { erem; z poczuciem dobrego smaku }\end{array}$ & 7 & 2,44 & 7 & 11,11 \\
\hline 10. & oczytany (4) & $\begin{array}{l}\text { człowiek oczytany; erudyta; } \\
\text { wykształcony, zna się na rzeczy, } \\
\text { oczytany }\end{array}$ & 7 & 2,44 & 7 & 11,11 \\
\hline 11. & cyniczny (4) & cynik (2) & 6 & 2,09 & 6 & 9,52 \\
\hline 12. & szczery (6) & & 6 & 2,09 & 6 & 9,52 \\
\hline 13. & $\begin{array}{l}\text { wykształcony } \\
(2)\end{array}$ & $\begin{array}{l}\text { wykształcona osoba; wykształcony } \\
\text { i elokwentny; wykształcony, zna } \\
\text { się na rzeczy, oczytany }\end{array}$ & 5 & 1,74 & 5 & 7,94 \\
\hline 14. & $\begin{array}{l}\text { dociekliwy } \\
(4)\end{array}$ & & 4 & 1,39 & 4 & 6,35 \\
\hline 15. & realista (2) & trzeźwo patrzący na świat (2) & 4 & 1,39 & 4 & 6,35 \\
\hline 16. & inne & & 66 & 23,00 & 40 & 63,49 \\
\hline & & razem & 287 & 100,00 & & \\
\hline
\end{tabular}

Źródło: opracowanie własne

Dominujące cechy wizerunkowe image'u werbalnego Krzysztofa Vargi, wśród osób czytających jego felieton i mających podaną tożsamość tego autora (nazwisko oraz zdjęcie), zawierają się w atrybutach: „dosadnie przekazujący swoje odważne sądy” oraz „ironiczny”. Wskazano je odpowiednio: 43 i 30 razy (14,98\% i 10,45\% wskazań), przy czym pierwszą z cech zauważyło $38,10 \%$ respondentów (24 osoby), a drugą więcej, bo $44,44 \%$ (28). W przypadku „dosadnie przekazujący swoje odważne sądy” różnica między liczbą wskazań a liczbą uczestników ich dokonujących wynikać może z różnego nasilenia manifestowania tej cechy, w zależności od konkretnego felietonu, ale główną przyczyną rozbieżności stał się zapewne złożony charakter semantyczny tej cechy wizerunkowej oraz wynikająca z tego duża wariantywność leksykalna. 
Czytający, mając trudności ze znalezieniem jednego słowa na określenie zauważanej cechy, powtarzał to, co dostrzegł (stąd np. wśród odpowiedzi jednej osoby zdarzały się „bezpośredni” obok „odważny w osądach” albo „mocno trzymający się swojej opinii” obok „ostre słowo”). Dla dość jednoznacznej i łatwej do zwerbalizowania cechy „,ironiczny” problem ten nie istniał.

Kolejne cechy wizerunkowe także wydają się mieć duże znaczenie. 1/3 uczestników badania (21 osób - 33,33\%) pisarz jawi się jako człowiek „inteligentny” (22 wskazania - 7,67\% wszystkich). Ponad $1 / 4$ widzi w nim osobę „ciekawie piszącą" (17 - 26,98\% osób), „zabawną" (18 - 28,57\%) i spostrzegawczą" (17 - 26,98\%) (odpowiednio: 22 wskazania - 7,67\%; 20 - 6,97\%; $17-5,92 \%)$. Nieco ponad 1/5(13-20,63\%) Krzysztofa Vargę uznaje za „znawcę” w dziedzinie, o której się wypowiada (16 wskazań - 5,57\%). 17,46\% (11 osób) uważa go za „krytycznego” (12 - 4,18\% wskazań). Wśród mniej reprezentowanych cech wizerunkowych, jakie występują poniżej 3\% wskazań, wypisanych przez mniej niż 15\% respondentów, znajdują się: „,interesujący się" i „oczytany" (wynotowane po 7 razy - 2,4\% wskazań przez taką samą liczbę respondentów - 11,11\%), „cyniczny” i „szczery”, zauważone sześciokrotnie (2,09\%) przez 6 osób (9,52\%), „wykształcony” (5 - 7,94\% wskazań; 5 - 7,94\% uczestników), „dociekliwy” i „realista” (odpowiednio po 4 - 13,39\% wskazań, $4-6,35 \%$ osób).

Krzysztof Varga w tym wariancie badania jawi się więc przede wszystkim jako osoba "dosadnie przekazująca swoje odważne sądy” oraz „ironiczna” i ,inteligentna”, a przy tym „ciekawie pisząca”. Tak jak w innych typach image'u, i tutaj da się zauważyć korespondencję semantyczną słabiej reprezentowanych cech wizerunkowych z tymi na szczycie listy. Tak więc z tą najczęściej wskazywaną („dosadnie przekazujący swoje odważne sądy”) łączy się zapewne „krytyczny”, wiele wspólnego z ,inteligencją” może mieć „spostrzegawczość”, a z "ironią" takie cechy wizerunkowe, jak „zabawny” czy ciekawie piszący”, w końcu swego rodzaju kompleks semantyczny mogą stanowić: „Znawca”, „interesujący się”, „oczytany”, „wykształcony”. Poza tymi grupami cech image’owych znalazłyby się tylko „szczery” oraz „realista”. W tym kontekście wizerunek werbalny w tej grupie uczestników badania wydaje się dość wyrazisty.

Czy istnieje i jaka jest różnica między tym wizerunkiem werbalnym Krzysztofa Vargi a tym samym typem jego wizerunku, gdy czytelnicy mają do dyspozycji anonimowy tekst? oraz czy i jaki wpływ na prezentowane powyżej wyniki ma wizerunek wizualny i publiczny?

Można dostrzec pewne rozbieżności między wizerunkiem werbalnym anonima a Krzysztofa Vargi, ale w istocie są one niewielkie. Wszystkich cech wizerunkowych $\mathrm{w}$ wariancie zakładającym jawność imienia i nazwiska felietonisty jest tylko o jedną mniej niż w wariancie $\mathrm{z}$ anonimowym tekstem. 
Jakościowo właściwie są to te same cechy wizerunkowe. Tylko trzy atrybuty z image'u znanego autora („złośliwy”, „septyczny”, „młody”) nie przechodzą do image’u twórcy o podanej tożsamości, dla którego z kolei wyłącznie specyficzne w tym porównaniu są „cyniczny” i „dociekliwy”. Kilka pierwszych cech na liście w wizerunku werbalnym znanego felietonisty łącznie daje więcej wskazań niż taka sama liczba pierwszych cech w wizerunku anonima. Są to jednocześnie właściwie te same cechy wizerunkowe. Wśród pierwszej ósemki tyko jedna z nich się nie dubluje. To by mogło wskazywać nieznacznie większą wyrazistość wizerunku werbalnego znanej osoby, ale jednak to niewielka różnica, bo proporcje wskazań w pierwszych ośmiu cechach wynoszą: 177 do 182, a więc relatywnie mało. Dwie cechy wizerunkowe z pierwszej trójki mają niemal identyczne wskaźniki liczbowe („inteligentny” - 29 wskazań w wizerunku anonima i 30 u znanego twórcy, „ciekawie piszący” - odpowiednio: 24 do 22). Co do mniej licznie wynotowywanych cech, różnice nie przekraczają 1,5\% w zakresie liczby wskazań i 4-5\% w obrębie liczby osób ich dokonujących. Co do różnic, jedyną rzeczywiście zwracającą na siebie uwagę jest przesunięcie „dosadnie przekazujący swoje odważne sądy” z czwartego miejsca listy wskazań tekstu anonima na pierwsze osoby znanej. Podsumowując: ze świecą szukać rozbieżności; nie ma istotnych różnic; wizerunek werbalny anonimowego twórcy i felietonisty o podanym nazwisku w przypadku Krzysztofa Vargi jest bardzo podobny.

Z czego te podobieństwa i jedna różnica (cecha „dosadnie...”) wynikają? Zauważyć należy, że na 126 osób zapytanych o wizerunek publiczny Krzysztofa Vargi jego znajomość potwierdziło jedynie 11, na 63 osoby zapytane o nazwisko osoby ze zdjęcia - tylko jedna osoba je podała (prawidłowo). Oznacza to bardzo słabą rozpoznawalność tego twórcy, a także wyjaśnia fakt niemal tożsamych wyników dotyczących wizerunku werbalnego anonima i felietonisty o podanej tożsamości - dla drugiej z tych grup respondentów autor i tak pozostawał anonimowy, po prostu go nie znali. Wizerunek publiczny nie miał więc nawet szans wpłynąć na wizerunek werbalny z tekstu felietonisty o podanym imieniu i nazwisku. Zdjęcie natomiast zmieniało nieco ten ostatni image, ale tylko w niewielkim stopniu. Wpływem bowiem wizerunku wizualnego da się wyjaśnić (pierwsze na liście) dominujące znaczenie cechy imageowej „dosadnie przekazujący swoje odważne sądy" (wskazania: 43 - 14,98\%; osoby: $24-38,10 \%)$, z którą wyraźnie koresponduje zauważona na fotografii przez największą liczbę respondentów (35 - 59,32\%) „pewność siebie” felietonisty (34 - 13,77\% wskazań). Atrybut „inteligencja”, który spadł w wizerunku werbalnym znanego twórcy - w porównaniu $\mathrm{z}$ wizerunkiem niewiadomego autora - $\mathrm{z}$ pierwszego na trzecie miejsce, $\mathrm{w}$ wizerunku wizualnym i werbalnym znanego felietonisty ma prawie po tyle samo wskazań (odpowiednio: 23 - 9,31\%; 
$22-7,67 \%$ ), dokonanych przez niemal identyczną liczbę osób (odpowiednio: 22 - 37,29\%; 21 - 33,33\%). Tak więc w zakresie tej cechy wizerunkowej odnaleźć da się pewne wpływy wizerunku wizualnego. Należy zwrócić uwagę, że - po pierwsze - oba typy wizerunku werbalnego w obrębie pozostałych cech wizerunkowych jakościowo i ilościowo nie wykazują istotnych różnic, a po drugie - inne cechy wizerunku wizualnego okazują się właściwe tylko jemu (np. „poważny”, „zamknięty w sobie”, „surowy” itd.) albo są podobne we wszystkich tych trzech typach wizerunku („wykształcony”, „realista” reprezentują porównywalną liczbę wskazań) lub nie mają znaczenia dla wizerunku werbalnego osoby o podanej tożsamości (cecha „krytyczny” jest cztery razy częściej przypisywana znanemu felietoniście niż osobie na zdjęciu, co nie miało wpływu na wizerunek konstruowany na podstawie tekstu). W takich warunkach trudno mówić o kolejnych zależnościach.

Tak więc w sytuacji, kiedy wizerunek werbalny autora o podanej tożsamości w dużej mierze pokrywa się $\mathrm{z}$ wizerunkiem werbalnym anonimowego twórcy i wyklucza się wpływy wizerunku publicznego, to wizerunek wizualny wpływa na ten pierwszy, ale w ograniczonym stopniu i tylko w zakresie tych cech, które da się komunikować zarówno na poziomie słowa, jak i obrazu (w przypadku Krzysztofa Vargi mowa o „inteligencji” oraz cesze wizerunkowej „dosadnie przekazujący swoje odważne zdanie”, na frekwencyjność której wpływ może mieć „pewność siebie” licznie manifestowana w wizerunku wizualnym). Warto przy tym zwrócić uwagę, że są to wyłącznie zmiany ilościowe, nie jakościowe. Innymi słowy, opatrzenie tekstu portretem autora nie spowodowało, aby przypisywano mu cechy wizerunkowe typowe dla wizerunku wizualnego. Jeśli jakieś się powtarzają, to wyłącznie te, które pokrywały się na etapie porównania wizerunku wizualnego $\mathrm{z}$ werbalnym anonimowego twórcy. Wizualizacja może uczynić bardziej wyrazistą jakąś cechę felietonisty, która i tak jest zauważalna „w tekście”, ale najwyraźniej nie jest w stanie tak przekierować uwagi, by odbiorca zauważył na poziomie wypowiedzi werbalnej to, co możliwe jest do stwierdzenia na poziomie obrazu. Chociaż teoretycznie z pewnością dałoby się przypisać „zamknięcie w sobie”, „spokój” bądź „surowość", mając za bazę słowa. Tyle przynajmniej pokazują wyniki dotyczące Krzysztofa Vargi. Tę interpretację zweryfikuje analiza rezultatów dotyczących pozostałych felietonistów. 
Tabela 16. Kategorie komunikowanego werbalnie wizerunku felietonisty o znanej tożsamości - Krzysztofa Vargi

\begin{tabular}{|l|l|l|l|l|l|l|l|l|}
\hline lp. & \multicolumn{1}{|c|}{ wiedza } & $\mathbf{n}$ & \multicolumn{1}{|c|}{ postawa } & $\mathbf{n}$ & $\begin{array}{c}\text { cecha } \\
\text { charakteru }\end{array}$ & $\mathbf{n}$ & $\begin{array}{c}\text { sposób } \\
\text { komunikacji }\end{array}$ & $\mathbf{n}$ \\
\hline 1. & znawca (0) & 16 & $\begin{array}{l}\text { dosadnie } \\
\text { przekazujący swoje } \\
\text { odważne sądy (0) }\end{array}$ & 43 & $\begin{array}{l}\text { inteligentny } \\
(15)\end{array}$ & $\begin{array}{l}22 \\
\text { ciekawie } \\
\text { piszący }\end{array}$ & $\mathbf{2 2}$ \\
\hline 2. & $\begin{array}{l}\text { interesują- } \\
\text { cy się (0) }\end{array}$ & 7 & ironiczny (16) & 30 & zabawny (4) & 20 & & \\
\hline 3. & $\begin{array}{l}\text { oczytany } \\
(4)\end{array}$ & 7 & spostrzegawczy (8) & 17 & szczery (6) & 6 & & \\
\hline 4. & $\begin{array}{l}\text { wykształ- } \\
\text { cony (2) }\end{array}$ & 5 & krytyczny (7) & 12 & & & & \\
\hline 5. & & & cyniczny (4) & 6 & & & & \\
\hline 6. & & dociekliwy (4) & 4 & & & & \\
\hline 7. & & $\mathbf{3 5}$ & & $\mathbf{1 1 6}$ & & $\mathbf{4 8}$ & \\
\hline
\end{tabular}

Źródło: opracowanie własne

Mając na uwadze powyższą analizę, łatwo można przewidzieć, iż obszary wizerunku komunikowanego werbalnie w sytuacji, kiedy znana jest tożsamość autora, będą zbieżne $\mathrm{z}$ tymi, które pojawiły się $\mathrm{w}$ przypadku autora anonimowego. Oczywiście dotyczy to wyłącznie osoby Krzysztofa Vargi. Jak ilustruje tabela 16 dwie wspomniane typologie w istocie są niemal identyczne. Kategorie komunikowanego wizerunku i ich hierarchia pozostają takie same. Niewielkiej zmianie ulegają jedynie proporcje poszczególnych aspektów. Najwyżej reprezentowana „postawa” dominuje jeszcze wyraziściej niż w przypadku wizerunku werbalnego anonima (116 wskazań w wynikach dotyczących znanego nazwiska autora do 97 przy nieznanym twórcy tekstu), a jej wzrost odbywa się kosztem pozostałych aspektów wizerunku: „cechy charakteru” z 63 wskazań zmniejszają się do 48, a „wiedza” z 44 do 35. „Sposób komunikowania" ma prawie stałą reprezentację, bo poprzednie 24 wskazania zastępują teraz 22. Tylko dwie cechy są nowe: „cyniczny” i „dociekliwy”. Głównie więc z powodu nieznajomości autora wśród respondentów kategorie komunikowanego werbalnie wizerunku anonimowego twórcy pokrywają się z kategoriami komunikowanego werbalnie wizerunku autora o podanej tożsamości - Krzysztofa Vargi. 


\subsubsection{Zależności między poszczególnymi typami wizerunków Krzysztofa Vargi}

W celu podsumowania powyższych rozważań, zauważyć należy, iż Krzysztof Varga dla czytelników (oba typy wizerunku werbalnego) to przede wszystkim osoba inteligentna, ironiczna, ciekawie pisząca i prezentująca dosadnie swoje odważne zdanie. W zakresie wizerunku publicznego rozpoznawalny jest jako pisarz/felietonista o pozostałych przymiotach takich samych, jak w wizerunku werbalnym. Filtr obrazu (wizerunek wizualny) pozwala dostrzec człowieka „poważanego”, „pewnego siebie” („dosadnie przekazującego swoje odważne zdanie”?), „zamkniętego w sobie” i „inteligentnego”.

W każdym z typów image’u te wymienione główne cechy wizerunkowe są wspierane prawie w pełni przez skupione wokół nich atrybuty rzadziej manifestowane, tj. mniej liczne razem z tymi najsilniej reprezentowanymi tworzą swego rodzaju bloki semantyczne (np. „wykształcony”, „znawca tematu” i „oczytany”, mimo że są zupełnie innymi cechami, zwracają uwagę na kompetencje autora tekstu). Tym widocznym w każdym typie image'u mechanizmem można próbować mierzyć wyrazistość wizerunku. Im więcej cech dających się grupować w ten sposób i im mniej pozostających poza spójnymi grupami, tym bardziej wizerunek jest wyrazisty. Krzysztof Varga cieszy się więc dość wyrazistym image'em.

Mniej więcej tyle samo spójnych cech wizerunkowych buduje każdy z rodzajów wizerunku werbalnego (15 i 16), mniej dotyczy image’u wizualnego (11), a zdecydowanie najmniej tworzy wizerunek publiczny (7). Ostatnie z tych zjawisk może wynikać albo z ograniczonych możliwości pamięci, której mechanizm jest uruchamiany przy (od)twarzaniu wizerunku publicznego danej osoby albo z niewielkiej liczby osób podających w tym zakresie swoje odpowiedzi (11). Analizy danych dotyczących kolejnych autorów pozwolą sprawdzić powtarzalność tych proporcji i zasadność interpretacji.

Zwracają także uwagę cechy zakodowane jako „inne”. Procent tych wskazań waha się od 22,33\% w wizerunku werbalnym anonima przez 23,00\% w image’u werbalnym autora o podanej tożsamości i $23,89 \%$ w wizerunku wizualnym, po $25,58 \%$ w publicznym. Do tej kategorii zaliczyły się odpowiedzi odpowiednio: 82,54\%, 63,49\%, 61,02\% i 54,55\% respondentów. Przy czym pamiętać trzeba, że image publiczny wskazywało tylko 11 osób, więc trzeba z dystansem traktować te dane. Zauważyć się da, że „inne” to każdorazowo więcej wskazań niż najwyżej reprezentowana cecha wizerunkowa. To samo dotyczy proporcji w zakresie osób (z wyjątkiem wizerunku publicznego - tu liczba respondentów wskazujących cechę niedającą się nigdzie zaklasyfikować jest równa liczbie osób podających tę najwyżej reprezentowaną). Są to więc 
duże dysproporcje. Jak już wcześniej zostało wspomniane, wyjaśniać to zjawisko może kwestia wyrazistości wizerunku wraz ze zjawiskiem wyłaniania grup semantycznych wokół niektórych cech wizerunkowych, a także ograniczona pojemność percepcyjna interpretatorów. Ta ostatnia powoduje, że tylko kilka najważniejszych i wyrazistych dla wizerunku cech (3-4) zwraca na siebie uwagę, a reszta albo je semantycznie wspiera, albo - jako mało reprezentatywna w skali odpowiedzi wielu respondentów - buduje kategorię „inne”. Porównanie z wynikami dotyczącymi pozostałych autorów pozwoli zweryfikować tę interpretację.

Poza niektórymi przypadkami, swoistymi dla konkretnego typu image'u, większość cech pisarza i kategorii możliwego do komunikowania wizerunku się powtarza. Kategoriami w różnym stopniu manifestowanymi, ale wspólnymi dla wszystkich rodzajów wizerunku stały się: „postawa”, „cechy charakteru” i „wiedza”. Dla obu rodzajów wizerunku werbalnego charakterystyczny jest „sposób komunikowania” (aspekt image’u, tworzony przez jedną cechę „ciekawie piszący”), który musi być bezpośrednio związany z systemem znaków (nie da się „,ciekawie pisać” poza „pisaniem”), dlatego nie wychodzi poza obszar komunikowania słowem.

$\mathrm{W}$ zakresie różnic, co ważne, w typach wizerunków pozawerbalnych, a więc $\mathrm{w}$ publicznym i wizualnym, pojawiają się obszary image'u niekomunikowane poza słowem, a co jeszcze ważniejsze - te obszary są najczęściej najliczniejszymi kategoriami danego rodzaju wizerunku. Mowa o „zawodzie” w przypadku image'u publicznego i o „stanie emocjonalno-poznawczym” wizerunku wizualnego, które są prymarne dla swoich typów image'u. Możliwe, że „zawód” pojawiłby się, gdyby czytelnicy felietonów autora o podanej tożsamości (lepiej) go kojarzyli, co pozwolą sprawdzić rezultaty dotyczące kolejnych autorów. Typową dla poziomu wizualnego kategorią pozostaje także „wiek/płeć".

Tak więc, kiedy interpretator ma do czynienia $\mathrm{z}$ wieloma systemami znaków, to zapamiętuje przede wszystkim „zawód”. Kiedy za podstawę konstrukcji otrzymuje obraz, zauważa głównie „stan emocjonalno-poznawczy”. Co w następnej kolejności? To, co wspólne dla wszystkich rodzajów wizerunku: najpierw (najliczniej reprezentowana w każdym typie wizerunku) „postawa”, potem „cechy charakteru” i w końcu „wiedza”.

Zdaje się tym samym, że postawiona na początku rozważań o wizerunku Krzysztofa Vargi teza, iż kierunek wpływu odbywa się od wizerunku werbalnego do wizerunku publicznego, nie daje się utrzymać po przeanalizowaniu większej liczby danych. Jeżeli te same kategorie wizerunkowe pojawiają się w każdym typie wizerunku, to najwyraźniej są możliwe do komunikowania na poziomie każdego (tu analizowanego) systemu znaków oddzielnie i jednocześnie. 
Respondenci wykazali się bardzo słabą znajomością Krzysztofa Vargi (11 osób na 126 zapytanych o znajomość nazwiska, 1 osoba na 63 poproszonych o identyfikacje mężczyzny ze zdjęcia), zatem image wizualny jest w istocie wizerunkiem anonimowej dla nich osoby, podobnie jak wizerunek werbalny, zatem wykluczyć należy wpływ wizerunku publicznego czy werbalnego na wizualny. Skoro wizualny i werbalny pozbawione są wpływów z zewnątrz, a wykazują podobne cechy (w zakresie wspomnianych trzech kategorii), które jednocześnie są zbieżne z cechami wizerunku publicznego, to image publiczny musi zależeć zarówno od wizerunku werbalnego, jak i wizualnego. Zatem image wizualny i werbalny wpływają na publiczny.

Ponieważ cechy się pokrywają albo są specyficzne dla pojedynczego rodzaju wizerunku, to trudno mówić o izolowanym wpływie słowa bądź obrazu na wizerunek publiczny. Musi to być determinacja złożona. W jakim stopniu, skoro w wizerunku publicznym najsilniej manifestowaną cechą jest „pisarz/ felietonista” (kategoria „zawód”) - cecha nieobecna w żadnym innym analizowanym tu wizerunku. Wyjaśnić się da ten wynik źródłem komunikatu. $\mathrm{O}$ ile podstawą każdego z wizerunków werbalnych były słowa autora, a bazą image'u wizualnego jego wygląd, to w przypadku wizerunku publicznego dochodzą również do głosu wypowiedzi „o” twórcy (np. hipotetycznie zasłyszane w mediach: „rozmawiamy dzisiaj z pisarzem, felietonistą «Gazety Wyborczej», Krzysztofem Vargą”) oraz komunikaty kontekstowe (hipotetycznie np. „widziałem jego książkę w księgarni, więc jest pisarzem”, „czytam jego felietony, więc jest dziennikarzem" itd.). I w jakim stopniu, skoro jednak da się zauważyć pewne niewielkie wpływy wizerunku wizualnego na werbalny felietonisty o podanej tożsamości? Mowa o wysokiej manifestacji „dosadnie przedstawiający swoje odważne sądy” i takiej samej reprezentatywności liczbowej w obu wizerunkach cechy ,inteligentny”. Ten stopień muszą regulować tu dwa czynniki: do wizerunku werbalnego "przechodzi” z wizualnego to, co w tym ostatnim licznie się pojawia, i to, co znajduje się w obrębie wspólnych dla obu typów image'u cech. Z tego powodu np. "poważny” nie znalazł się w wizerunku werbalnym, mimo najwyższej pozycji wśród cech budujących image wizualny. Stopień wpływu ogranicza się więc do regulacji ilościowych i dotyczy najwyżej reprezentowanych cech wspólnych dla obu wizerunków (to, co typowe dla wizerunku wizualnego, nie pojawiło się w werbalnym image'u Krzysztofa Vargi), a nie wiąże się z modyfikacjami jakościowymi.

Tak więc wizerunek wizualny może wpływać ilościowo na werbalny osoby o podanej tożsamości, a z kolei oba typy wizerunku werbalnego (anonima i osoby o znanym nazwisku i wyglądzie) oraz image wizualny mogą determinować wizerunek publiczny, poza kategorią specyficzną dla wizerunku wizualnego („stan emocjonalno-poznawczy") i poza charakterystycznym dla wizerunku publicznego 
komunikacyjnym obszarem „zawodu”. Temat wpływu wizerunku publicznego na image werbalny w sytuacji podanej tożsamości autora nie będzie tu rozpatrywany ze względu na słabą rozpoznawalność pisarza wśród respondentów - analizy kolejnych autorów mogą pomóc odnaleźć zależności w tym zakresie.

\subsection{Piotr Zaremba}

\subsubsection{Piotr Zaremba - wizerunek na podstawie anonimowego tekstu}

Spośród 63 uczestników badania, którzy po przeczytaniu tekstu anonimowego autora odpowiedzieli na pytanie: „Mając za podstawę tekst przeczytanego felietonu, jakimi słowami opisałby Pan / opisałaby Pani autora tego tekstu?", 9 osób wskazało po 3 określenia Piotra Zaremby, 14 respondentów wypisało po 4 epitety, a 40 po 5 przymiotów felietonisty. Razem dało to 283 wskazania, przy czym 2 zakodowano podwójnie ${ }^{7}$, więc w analizie znalazło się 285 cech skategoryzowanych w 22 spójne cechy wizerunkowe.

Po przeczytaniu i wykonaniu zadań związanych z określeniem wizerunku i wynotowaniem $\mathrm{z}$ tekstu fragmentów odpowiadających przypisanym felietoniście cechom, respondenci odpowiadali na pytanie: „Czy wiesz, kto jest autorem tekstu?" i mieli do wyboru trzy odpowiedzi: 1) TAK, wiem (kto?)..., 2) Nie jestem pewny/pewna - wydaje mi się, że autorem może być (kto?)...; oraz 3) NIE, nie wiem. Znajomość autora tekstu potwierdziły trzy osoby, ale błędnie zidentyfikowały tożsamość twórcy w „Sławomirze Mrożku”, którego dotyczył tekst, w „Mariuszu Cieślaku”, co zapewne stanowiło rodzaj żartu, lub w „Tomaszu Terlikowskim", do którego najwyraźniej respondenta zaprowadziła zbieżność wizerunkowa (przypisał Piotrowi Zarembie określenia „sprawiedliwy”, „wyważony”, „prawicowiec”, „antyliberał”, „patriota”, jakie można też łączyć z Tomaszem Terlikowskim). Brak pewności zaznaczyło sześć osób, z czego czwórka spodziewała się autorstwa „Krzysztofa Vargi”, a dwójka „Szymona Hołowni”. Takie sugestie musiały być wynikiem chęci odpowiedzi przy jednoczesnym braku jakiegokolwiek wyobrażenia o autorze, bowiem te dwa nazwiska należą do osób, których wizerunek publiczny wcześniej określali uczestnicy badania (każda z osób image zarówno Krzysztofa Vargi, jak i Szymona Hołowni (zob. tabela 3). 54 respondentów wprost zaprzeczyło faktowi posiadania wiedzy o autorze przeczytanego tekstu. Bez względu na brzmienie, wszystkie odpowiedzi wyraźnie zatem wskazują, iż czytający felietony nie znali tożsamości jego twórcy.

7 Określenie „oczytany/zorientowany” przypisano do cech wizerunkowych „oczytany” oraz „zna temat”, a epitet „inteligentny i obeznany - historyk” skategoryzowano jako cechy „inteligentny” oraz „znawca tematu”. 
Tabela 17. Zestawienie odpowiedzi respondentów czytających tekst anonimowego autora (Piotra Zaremby) na pytanie: „Mając za podstawę tekst przeczytanego felietonu, jakimi słowami opisałby Pan / opisałaby Pani autora tego tekstu?"

\begin{tabular}{|c|c|c|c|c|c|c|}
\hline \multirow{2}{*}{ lp. } & \multirow{2}{*}{$\begin{array}{c}\text { cecha } \\
\text { wizerunkowa }\end{array}$} & \multirow{2}{*}{ warianty leksykalne } & \multicolumn{2}{|c|}{ wskazania } & \multicolumn{2}{|c|}{ osoby } \\
\hline & & & $\mathbf{n}$ & $\%$ & $\mathbf{n}$ & $\%$ \\
\hline 1. & $\begin{array}{l}\text { dosadnie } \\
\text { przekazujący } \\
\text { swoje odważne } \\
\text { sądy }(0)\end{array}$ & $\begin{array}{l}\text { bezpośredni (4), pewny siebie (4); } \\
\text { osoba mająca swoje zdanie na temat } \\
\text { mediów i parlamentu; ma swoje } \\
\text { własne zdanie; wyraża własne zdanie; } \\
\text { konkretny (2); przekonany o swojej } \\
\text { nieomylności; odważny; indywidu- } \\
\text { alista; jego opinie są zdecydowane } \\
\text { i jasno określone; dosadny; dobitny; } \\
\text { przemądrzały; wyrazisty }\end{array}$ & 21 & 7,37 & 16 & 25,40 \\
\hline 2. & krytyczny (11) & $\begin{array}{l}\text { rozczarowany, rozgoryczony na } \\
\text { stan mediów komercyjnych; rozcza- } \\
\text { rowany programem; poirytowany } \\
\text { sytuacją, którą opisuje; poirytowany; } \\
\text { niezadowolony ze wszystkiego; zły; } \\
\text { oskarżający; krytyk }\end{array}$ & 20 & 7,02 & 18 & 28,57 \\
\hline 3. & $\begin{array}{l}\text { znawca tematu } \\
(0)\end{array}$ & $\begin{array}{l}\text { posiadający wiedzę o innych filmach; } \\
\text { znający realia kina; znawca kina; } \\
\text { obeznany w filmie/kinie; znający się } \\
\text { na filmie; znawca filmów; posiadający } \\
\text { dużą wiedzę historyczną; posiadający } \\
\text { wiedzę o innych filmach; obeznany } \\
\text { w historii; znawca historii Polski; ma } \\
\text { wiedzę z historii czy z historii filmu; } \\
\text { zna się na teatrze i literaturze; obezna- } \\
\text { ny w sztukach teatralnych; kompetent- } \\
\text { ny; ma dużą wiedzę na temat serialu; } \\
\text { posiadający dużą wiedzę; obeznany } \\
\text { w świecie mediów i polityki; recen- } \\
\text { zent; oczytany/zorientowany; inteli- } \\
\text { gentny i obeznany - historyk }\end{array}$ & 20 & 7,02 & 18 & 28,57 \\
\hline 4. & inteligentny (12) & $\begin{array}{l}\text { inteligentny i obeznany - historyk; } \\
\text { jest bystry; potrafi łączyć fakty i ko- } \\
\text { jarzyć je ze sobą; myślący }\end{array}$ & 16 & 5,61 & 15 & 23,81 \\
\hline 5. & ironiczny (13) & sarkastyczny (3) & 16 & 5,61 & 14 & 22,22 \\
\hline 6. & $\begin{array}{l}\text { interesujący się } \\
(0)\end{array}$ & $\begin{array}{l}\text { kinoman (2); kinomaniak; zaintere- } \\
\text { sowany kinem; lubi kino; zaintere- } \\
\text { sowany historią; doceniający sztukę; } \\
\text { entuzjasta twórczości A. Majewskiego; } \\
\text { pasjonat; pełen podziwu; zafascyno- } \\
\text { wany; miłośnik twórczości A. Fredry; } \\
\text { zainteresowany mediami i popkulturą; } \\
\text { piewca sztuki; wrażliwy na sztukę }\end{array}$ & 15 & 5,26 & 13 & 20,63 \\
\hline
\end{tabular}


Tabela 17 (cd.)

\begin{tabular}{|c|c|c|c|c|c|c|}
\hline \multirow{2}{*}{ lp. } & \multirow{2}{*}{$\begin{array}{c}\text { cecha } \\
\text { wizerunkowa }\end{array}$} & \multirow{2}{*}{ warianty leksykalne } & \multicolumn{2}{|c|}{ wskazania } & \multicolumn{2}{|c|}{ osoby } \\
\hline & & & $\mathbf{n}$ & $\%$ & $\mathbf{n}$ & $\%$ \\
\hline 7. & dociekliwy (5) & $\begin{array}{l}\text { wytrwałość w dążeniu do celu (po- } \\
\text { święcenie); filozof; ciekawość; cie- } \\
\text { kawy świata (3), żądny wiedzy }\end{array}$ & 12 & 4,21 & 11 & 17,46 \\
\hline 8. & $\begin{array}{l}\text { emocjonalny } \\
\text { (3) }\end{array}$ & $\begin{array}{l}\text { emocjonalny trochę; zbyt emocjo- } \\
\text { nalny; pełen emocji; emocjonalnie } \\
\text { podchodzący do sprawy; osoba } \\
\text { podchodząca do tematu emocjonal- } \\
\text { nie; porywczy (2); impulsywny }\end{array}$ & 11 & 3,86 & 9 & 14,29 \\
\hline 9. & obiektywny (6) & $\begin{array}{l}\text { wyważony; zrównoważony, spra- } \\
\text { wiedliwy; zdystansowany; zdystan- } \\
\text { sowany względem własnej osoby }\end{array}$ & 11 & 3,86 & 10 & 15,87 \\
\hline 10. & dokładny (5) & $\begin{array}{l}\text { dokładność; skupia się na konkre- } \\
\text { tach; skrupulatny; szczegółowy; } \\
\text { precyzyjny, zwracający uwagę na } \\
\text { szczegóły; rzetelny }\end{array}$ & 11 & 3,86 & 10 & 15,87 \\
\hline 11. & $\begin{array}{l}\text { ciekawie } \\
\text { piszący }(0)\end{array}$ & $\begin{array}{l}\text { elokwentny (2); bezczelność (uży- } \\
\text { wanie i nadużywanie kolokwia- } \\
\text { lizmów i wulgaryzmów); zwraca } \\
\text { się stylem nieformalnym; posiada } \\
\text { bogate słownictwo; w ciekawy spo- } \\
\text { sób opisujący problem; wulgarny; } \\
\text { przekonujący }\end{array}$ & 8 & 2,81 & 8 & 12,70 \\
\hline 12. & $\begin{array}{l}\text { sentymentalny } \\
\text { (7) }\end{array}$ & nostalgiczny & 8 & 2,81 & 8 & 12,70 \\
\hline 13. & $\begin{array}{l}\text { spostrzegawczy } \\
(5)\end{array}$ & $\begin{array}{l}\text { obserwator; obserwuje otaczający } \\
\text { go świat }\end{array}$ & 7 & 2,46 & 7 & 11,11 \\
\hline 14. & wrażliwy (6) & uczuciowy & 7 & 2,46 & 7 & 11,11 \\
\hline 15. & oczytany (4) & oczytany/zorientowany; erudyta & 6 & 2,11 & 5 & 7,94 \\
\hline 16. & patriota (6) & & 6 & 2,11 & 6 & 9,52 \\
\hline 17. & subiektywny (2) & $\begin{array}{l}\text { przedstawia subiektywną opinię; } \\
\text { wyrażający subiektywna opinię; } \\
\text { stronniczy; mało obiektywny }\end{array}$ & 6 & 2,11 & 5 & 7,94 \\
\hline 18. & tolerancyjny & $\begin{array}{l}\text { mało krytyczny; wyrozumiały (3); } \\
\text { życzliwy }\end{array}$ & 6 & 2,11 & 5 & 7,94 \\
\hline 19. & analizujący & $\begin{array}{l}\text { dokładanie analizuje i wyciąga } \\
\text { wnioski dla czytelnika; analityczny } \\
\text { umysł; posiada umiejętność analizy; } \\
\text { próbuje podejść do każdego zagad- } \\
\text { nienia z różnej perspektywy }\end{array}$ & 5 & 1,75 & 5 & 7,94 \\
\hline 20. & refleksyjny (3) & $\begin{array}{l}\text { snuje refleksje psychologiczne; } \\
\text { skłonny do refleksji }\end{array}$ & 5 & 1,75 & 5 & 7,94 \\
\hline
\end{tabular}




\begin{tabular}{|c|c|c|c|c|c|c|}
\hline \multirow{2}{*}{ lp. } & \multirow{2}{*}{$\begin{array}{c}\text { cecha } \\
\text { wizerunkowa }\end{array}$} & \multirow{2}{*}{ warianty leksykalne } & \multicolumn{2}{|c|}{ wskazania } & \multicolumn{2}{|c|}{ osoby } \\
\hline & & & $\mathbf{n}$ & $\%$ & $\mathbf{n}$ & $\%$ \\
\hline 21 & zabawny $(0)$ & $\begin{array}{l}\text { dowcipny; poczucie humoru; ma } \\
\text { poczucie humoru; próbuje być } \\
\text { zabawny za wszelką cenę; odnosi się } \\
\text { do Amerykanów z dystansem }\end{array}$ & 5 & 1,75 & 5 & 7,94 \\
\hline 22. & wymagający (3) & surowy & 4 & 1,40 & 4 & 6,35 \\
\hline 23. & inne & $\begin{array}{l}\text { wykształcony (2); jest ambitny; am- } \\
\text { bitny; szczery (2); trzeźwo myślący; } \\
\text { realista; racjonalista; stary; człowiek } \\
\text { w podeszłym wieku; tradycjonalista; } \\
\text { konserwatywny; marudny; malkon- } \\
\text { tent; niezdecydowany; prawicowiec; } \\
\text { antyliberał; głównonurtowy; zwolen- } \\
\text { nik polityki Kaczyńskiego; lubiący } \\
\text { różnorodność; mający szacunek dla } \\
\text { historii; pełen szacunku; lewicowy; li- } \\
\text { beralny; głoszący prawdę historyczną; } \\
\text { światły; dba o czystośc języka; zwięzły; } \\
\text { optymista; zniesmaczony; przewi- } \\
\text { dujący; relacjonujący; profesjonalny; } \\
\text { oceniający; marzyciel; uczulony na } \\
\text { problemy społeczne; samotny; spokoj- } \\
\text { ny; intuicyjny; poszukiwacz prawdy; } \\
\text { egocentryczny; niemiły; niepewny; } \\
\text { osoba zaangażowana w życie publicz- } \\
\text { ne; osoba domagająca się zachowana } \\
\text { powagi w sprawach istotnych; osoba } \\
\text { pogodzona z brakiem przejrzystości } \\
\text { mediów; ma nierealistyczne oczekiwa- } \\
\text { nia - zakłada, że każdy czytelnik do- } \\
\text { skonale zna tematykę jego tekstu; lubi } \\
\text { politykę; uszczypliwy; szybki w prze- } \\
\text { kazywaniu informacji; szybki w podej- } \\
\text { mowaniu decyzji; cyniczny; patrzy na } \\
\text { rzeczywistość z szerszej perspektywy; } \\
\text { religijny; zmęczony monotonią; czło- } \\
\text { wiek wierzący; otwarty, mówi o swo- } \\
\text { ich odczuciach; otwarty }\end{array}$ & 59 & 20,70 & 39 & 61,90 \\
\hline & & razem & 285 & 100,00 & & \\
\hline
\end{tabular}

Źródło: opracowanie własne

Czytelnicy tekstu anonimowego autora mają Piotra Zarembę za twórcę "dosadnie przekazującego swoje odważne zdanie” (21 - 7,31\% wskazań; 16 - 25,40\% osób) i „krytycznego" „znawcę tematu” (po 20 - 7,02\% wskazań; 18 - 28,57\% osób). Zważywszy znikome różnice liczbowe między tymi cechami wizerunkowymi, należałoby je rozpatrywać jako równie istotne. Niewiele 
mniejsze znaczenie ma dla odbiorców tekstów inteligencja („inteligentny”) ( 16 - 5,61\% wskazań; 15 - 23,81\% osób) oraz wynotowane tyle samo razy (16) przez jednego respondenta mniej $(14-22,22 \%)$ posługiwanie się ironią („ironiczny”) i zainteresowania („interesujący się"), zauważone piętnastokrotnie (5,26\%) przez 13 czytelników (20,63\%). Mniej istotne zdają się takie cechy wizerunkowe, jak: „dociekliwy” ( 12 - 4,21\% wskazań - 11 - 17,46\% osób), „emocjonalny” (11 - 2,86\%; 9 - 14,29\%), „obiektywny” i „dokładny” (po $11-3,86 \%$; 10 - 15,87\%), „ciekawie piszący” i „,sentymentalny” (po $8-2,81 \% ; 1-12,70 \%)$ oraz „spostrzegawczy” i „wrażliwy” (po 7 - 2,46\%, 1 - 11,11\%). Sześciokrotnie (2,11\% wskazań) uznano dziennikarza za „oczytanego”, „subiektywnego” i „tolerancyjnego" (po 5 - 7,94\% osób), „patriotę" (6 - 9,52\% respondentów). Tylko pięciokrotnie okazał się „analizujący”, „refleksyjny” i „zabawny” (każdorazowo dla 5 - 7,94\%). Wysokie oczekiwania („wymagający”) spostrzegły 4 osoby $(6,45 \% ; 4-1,40 \%$ wskazań).

Da się zauważyć podobieństwo semantyczne niektórych cech. Tak więc swego rodzaju blok korespondujących ze sobą cech wizerunkowych mogą tworzyć te dotyczące wyraziście zarysowanego stanowiska („dosadnie przekazujący swoje odważne sądy”, „krytyczny”, „ironiczny”, „subiektywny” „wymagający”), kompetencji („znawca tematu”, ,interesujący się”, „oczytany”), inteligencji („inteligentny”, „spostrzegawczy”), precyzji („dociekliwy”, „dokładny”, „analizujący”). Być może też należałoby łączyć „ciekawie piszący” z „zabawnym” lub „ironicznym”, a „wrażliwy” z „refleksyjnym” czy „sentymentalnym”. Piotr Zaremba to więc przede wszystkim zdecydowany w sądach i krytyczny, ale kompetentny znawca tematu, do tego inteligentny i dokładny oraz wrażliwy. Kilka cech wizerunkowych pozostaje poza zbiorami semantycznie bliskich sobie cech („emocjonalny”, „patriota”, „tolerancyjny”), będąc jednocześnie cechami rzadko wypisywanymi (maksymalnie 11 - 3,86\% wskazań).

Chociaż niewiele cech funkcjonuje samodzielnie, poza znaczeniowymi blokami, to o średnim poziomie wyrazistości wizerunkowej świadczyłaby niewielka liczba wskazań i respondentów ich dokonujących w zakresie najsilniej manifestowanych cech. W przypadku Krzysztofa Vargi najwyższa pozycja prezentowała wyniki na poziomie 40 wskazań (13,33\%), wynotowanych przez 33 - 52,38\% osób, podczas gdy analogiczne rezultaty Piotra Zaremby osiągnęły połowę tych wartości ( 21 - 7,31\% wskazań; 16 - 25,40\% osób). Wydaje się, że znaczenie mogła tu mieć długość tekstu. Krótszy felieton to mniej elementów wizerunkowych pojawiających się wielokrotnie w tym sensie, że o ile w dłuższej wypowiedzi niektóre cechy mają okazje się powtórzyć i tym samym zyskują na sile wyrazu, są mocniej manifestowane i łatwiej zauważone przez większą liczbę

8 Zob. przypis $4 \mathrm{w}$ rozdziale 2 o łączeniu ironii z dowcipem. 
respondentów, o tyle w krótszym tekście wszystkie cechy mogą być reprezentowane z podobnym natężeniem, a przynajmniej dysproporcja między cechami wyrazistymi a mniej zauważalnymi zdecydowanie się zmniejsza. I zdaje się to miało tutaj miejsce. Być może analiza kolejnych rodzajów imageów pozwoli zweryfikować relację między wyrazistością wizerunku a długością tekstu.

Zauważyć można jeszcze jedno ciekawe zjawisko, które należałoby obserwować w trakcie badania kolejnych typów wizerunków i wyników dotyczących pozostałych autorów. Mianowicie kilka najwyżej reprezentowanych cech imageowych powtarza się w przypadku obu analizowanych do tej pory felietonistów. „Dosadnie przekazujący swoje odważne sądy”, „krytyczny”, „inteligentny”, „ironiczny” to elementy image’u dublujące się w pierwszej szóstce wizerunku werbalnego anonima Krzysztofa Vargi i Piotra Zaremby. Rzadziej wynotowywane cechy także się powtarzają („ciekawie piszący”, „zabawny”, „oczytany”, „spostrzegawczy”, „interesujący się”, „znawca tematu”).

Pojawia się więc pytanie: na ile są to zbieżne wizerunki, a na ile wpływ ma sam gatunek felietonu? I kolejne: w takim razie charakterystycznych, typowych dla danej osoby cech wizerunku należałoby szukać w proporcjach między poszczególnymi cechami (zwracać jednak uwagę, które są najwyżej reprezentowane) czy raczej w tych cechach, które się nie powtarzają u poszczególnych felietonistów?

$\mathrm{Na}$ tym etapie trzeba jedynie zauważyć, że wstępne badania dotyczące możliwości i ograniczeń felietonu w zakresie komunikowania wizerunku (Krzysztofa Vargi i Szymona Hołowni) pozwoliły ustalić, że choć wiele cech się multiplikuje, to występują one w różnych proporcjach, do tego obok tych specyficznych dla jednego autora. Ponadto wszystkie cechy wizerunkowe nie wynikają bezpośrednio z cech gatunkowych, co by wskazywało, że felieton bardziej stwarza autorowi możliwości, które da się wykorzystać w dowolnym sposób, niż ogranicza czy narzuca cechy wizerunkowe (Barańska-Szmitko 2014c: 223-224).

Jeśli chodzi o cechy niewychodzące poza image każdego z felietonistów, to dla Krzysztofa Vargi byłyby to atrybuty: „,szczery”, „wykształcony”, „złośliwy”, „sceptyczny”, „młody”, „realista”, a dla Piotra Zaremby: „emocjonalny”, „obiektywny”, „patriota”, „subiektywny”, „tolerancyjny”, „refleksyjny”. Pomijając te elementy image'u, które są sprzeczne („obiektywny” i „subiektywny” u publicysty „W Sieci”), a skupiając się na zbiorze tych cech jako całości, to przynajmniej godna uwagi wydaje się propozycja szczególnego uwzględniania jedynie cech specyficznych dla pojedynczego autora przy określaniu jego image’u, zwłaszcza że te cechy dobrze charakteryzują każdego z nich. Jeśli jednak wziąć pod uwagę, że z kolei dublujące się cechy występują w bardzo różnych proporcjach (np. „ciekawie piszący” to dla Krzysztofa Vargi 8\% wskazań 
wynotowanych przez prawie $1 / 3$ respondentów - dokładnie $28,57 \%$, ale dla Piotra Zaremby to tylko 2,81\% wskazań, dokonanych przez $12,70 \%$ osób), to bardziej rzetelne wydaje się połączenie tych dwóch mechanizmów interpretacyjnych - zarówno cech wysoko reprezentowanych, powtarzających się u kilku felietonistów, jak i tych rzadko wskazywanych i specyficznych dla każdego z nich osobno. Tylko na jakich zasadach uwzględniać tę symbiozę?

Wsparciem dla odnalezienia pełnych odpowiedzi na postawione wyżej pytania powinny być jednak kolejne prowadzone tu analizy.

Tabela 18. Kategorie komunikowanego werbalnie wizerunku anonimowego felietonisty - Piotra Zaremby

\begin{tabular}{|c|c|c|c|c|c|c|c|c|c|c|}
\hline lp. & $\begin{array}{l}\text { poglądy/ } \\
\text { wartości }\end{array}$ & $\mathbf{n}$ & wiedza & $\mathbf{n}$ & postawa & $\mathbf{n}$ & $\begin{array}{c}\text { cecha } \\
\text { charakteru }\end{array}$ & $\mathbf{n}$ & $\begin{array}{l}\text { sposób } \\
\text { komuni- } \\
\text { kacji }\end{array}$ & $\mathbf{n}$ \\
\hline 1. & patriota & 6 & $\begin{array}{l}\text { znawca } \\
\text { tematu }\end{array}$ & 20 & $\begin{array}{l}\text { dosadnie } \\
\text { przekazujący } \\
\text { swoje } \\
\text { odważne sądy }\end{array}$ & 21 & inteligentny & 16 & $\begin{array}{l}\text { ciekawie } \\
\text { piszący }\end{array}$ & 8 \\
\hline 2. & $\begin{array}{l}\text { toleran- } \\
\text { cyjny }\end{array}$ & 6 & $\begin{array}{l}\text { interesu- } \\
\text { jący się }\end{array}$ & 15 & krytyczny & 20 & zabawny & 5 & & \\
\hline 3. & & & oczytany & 6 & ironiczny & 16 & emocjonalny & 11 & & \\
\hline 4. & & & & & $\begin{array}{l}\text { spostrzegaw- } \\
\text { czy }\end{array}$ & 7 & wrażliwy & 7 & & \\
\hline 5. & & & & & wymagający & 4 & & & & \\
\hline 6. & & & & & dociekliwy & 12 & & & & \\
\hline 7. & & & & & obiektywny & 11 & & & & \\
\hline 8. & & & & & subiektywny & 6 & & & & \\
\hline 9. & & & & & dokładny & 11 & & & & \\
\hline 10. & & & & & $\begin{array}{l}\text { sentymen- } \\
\text { talny }\end{array}$ & 8 & & & & \\
\hline 11. & & & & & analizujący & 5 & & & & \\
\hline 12. & & & & & refleksyjny & 5 & & & & \\
\hline & razem & 12 & & 41 & & 126 & & 39 & & 8 \\
\hline
\end{tabular}

Źródło: opracowanie własne

W zakresie aspektów, kategorii wizerunku możliwych do komunikowania werbalnie, gdy autor pozostaje anonimowy, nie ma zbyt wielu zmian w stosunku do Krzysztofa Vargi (tabela 18). Ponownie najliczniej reprezentowanymi 
kategoriami są „postawa”, „cechy charakteru” i „wiedza”, a pierwsza z nich wyraźnie dominuje nad resztą, choć tym razem dysproporcje są jeszcze większe, bo 126 wskazań „postawy” do 41 „wiedzy” $i$,39” ",cech charakteru” to zdecydowanie większy dystans niż analogiczny z zestawienia Krzysztofa Vargi (97 - 63 - 44). $\mathrm{O}$ ile dwa ostatnie aspekty pod względem zawierających w sobie cech się nie zmieniły, o tyle ten pierwszy wzbogacił się o osiem nowych atrybutów (zaznaczone w tabeli kursywą). Najmniej wskazań liczy znów „sposób komunikacji”. Nowością jest kategoria „poglądy/wartości”, w zakres której weszły takie cechy, jak „patriota” i „tolerancyjny” - jak się okazuje - również możliwe do komunikowania przez anonimowego autora tekstu.

\subsubsection{Piotr Zaremba - wizerunek publiczny}

126 osób udzieliło odpowiedzi na pytanie: „Czy zna Pan/Pani nazwisko: Piotr Zaremba? Proszę zakreślić swoją odwiedź krzyżykiem”, spośród których 107 respondentów zaznaczyło „NIE. Jeśli nie, proszę schować kartkę do teczki”, a 19 potwierdziło znajomość publicysty, zakreślając „TAK. Jeśli tak, proszę przejść do pytania nr 2" i następnie zrealizowało polecenie: „Jakimi słowami scharakteryzował(a)by Pan/Pani osobę publiczną Piotra Zarembę?". W tej grupie uczestników badania jedna osoba nie podała żadnej cechy felietonisty, cztery wypisały po jednym epitecie, trzech respondentów po dwa określenia, dwójka przywołała trzy cechy, cztery osoby po cztery przymioty autora oraz pięć po pięć epitetów. Rozpoznawalność Piotra Zaremby wśród uczestników badania jest więc wyższa niż w przypadku Krzysztofa Vargi, ale wciąż słaba. Ze względu na niską liczebność zebranych danych nie ma sensu poddawać ich głębokiej analizie, ale warto zwrócić uwagę na najważniejsze zmienne.

Tabela 19. Zestawienie odpowiedzi na pytanie: „Jakimi słowami scharakteryzował(a)by Pan/Pani osobę publiczną Piotra Zarembę?"

\begin{tabular}{|l|l|l|c|c|c|c|}
\hline \multirow{2}{*}{ lp. } & \multicolumn{1}{|c|}{$\begin{array}{c}\text { cecha } \\
\text { wizerunkowa }\end{array}$} & \multicolumn{1}{c|}{ warianty leksykalne } & \multicolumn{2}{|c|}{ wskazania } & \multicolumn{2}{|c|}{ osoby } \\
\cline { 3 - 7 } & $\begin{array}{l}\text { prawicowiec (3); prawicowy dzienni- } \\
\text { karz (2); pisze w prawicowych, za- } \\
\text { kłamanych i śmiesznych swoją walką } \\
\text { o polskość, czasopismach }\end{array}$ & 8 & 14,04 & 7 & $\mathbf{n}$ & $\%$ \\
\hline prawicowy (2) & $\begin{array}{l}\text { dziennikarz } \\
(2)\end{array}$ & $\begin{array}{l}\text { jest dziennikarzem; publicysta (3); } \\
\text { felietonista (2); komentator }\end{array}$ & 8 & 14,04 & 6 & 31,58 \\
\hline
\end{tabular}


Tabela 19 (cd.)

\begin{tabular}{|c|c|c|c|c|c|c|}
\hline \multirow{2}{*}{ lp. } & \multirow{2}{*}{$\begin{array}{c}\text { cecha } \\
\text { wizerunkowa }\end{array}$} & \multirow{2}{*}{ warianty leksykalne } & \multicolumn{2}{|c|}{ wskazania } & \multicolumn{2}{|c|}{ osoby } \\
\hline & & & $\mathbf{n}$ & $\%$ & $\mathbf{n}$ & $\%$ \\
\hline 3. & $\begin{array}{l}\text { dosadnie } \\
\text { przedstawia- } \\
\text { jący swoje } \\
\text { odważne sądy } \\
(0)\end{array}$ & $\begin{array}{l}\text { pewny siebie (2); poglądowy arogant; } \\
\text { uparcie i czasem bezpodstawnie broni } \\
\text { swoich przekonań; radykał; kontro- } \\
\text { wersyjny w przekonaniach; } \\
\text { kontrowersyjny }\end{array}$ & 7 & 12,28 & 5 & 26,32 \\
\hline 4. & $\begin{array}{l}\text { osoba me- } \\
\text { dialna }\end{array}$ & $\begin{array}{l}\text { ekspert, obecny w telewizji; medialny; } \\
\text { ekspert w programach TV; } \\
\text { komentator }\end{array}$ & 6 & 10,53 & 4 & 21,05 \\
\hline 5. & $\begin{array}{l}\text { inteligentny } \\
\text { (2) }\end{array}$ & mądry & 3 & 5,26 & 3 & 15,79 \\
\hline 6. & rzeczowy (2) & profesjonalny & 3 & 5,26 & 2 & 10,53 \\
\hline 7. & uprzejmy & miły, sympatyczny & 3 & 5,26 & 1 & 5,26 \\
\hline 8. & pisarz (0) & $\begin{array}{l}\text { napisał książki pt. Plama na suficie } \\
\text { i Czas na..., tworzył dzieła literackie, } \\
\text { np. Plama na suficie }\end{array}$ & 2 & 3,51 & 2 & 5,26 \\
\hline 9. & racjonalista & trzeźwo myślący & 2 & 3,51 & 1 & 5,26 \\
\hline 10. & inne & $\begin{array}{l}\text { prawnik, elokwentny, charakterystycz- } \\
\text { ny, katolik, malkontent, w okularach, } \\
\text { upolityczniony, nierzetelny jako dzien- } \\
\text { nikarz, małostkowy, zaczepny, znam } \\
\text { nazwisko, ale nie pamiętam, która to } \\
\text { osoba i jak wygląda, rezolutny, otwarty, } \\
\text { rzetelny, o wartościowych poglądach }\end{array}$ & 15 & 26,32 & 10 & 52,63 \\
\hline & & razem & 57 & 100,00 & & \\
\hline
\end{tabular}

Źródło: opracowanie własne

Przede wszystkim wizerunek publiczny wydaje się bardziej wyrazisty od wizerunku werbalnego anonima Piotra Zaremby. Pierwsza pozycja "prawicowy" została wynotowana 8 razy $(14,04 \%)$ przez ponad $1 / 3$ respondentów (7 - 36,84\%). Procent wskazań jest więc prawe dwukrotnie wyższy, a procent osób ich dokonujący większy o ponad $10 \%$ niż w przypadku autora anonimowego. To samo dotyczy drugiej cechy: „dziennikarz”, wypisywanej równie często przez jedną osobę mniej (6 - 31,58\%). Niemal tak samo istotne wydają się jeszcze cechy wizerunkowe: „dosadnie przedstawiający swoje odważne sądy" (7 - 12,28\% wskazań; 5 - 26,32\% osób) oraz „osoba medialna” (6 - 10,53\%; $4-21,05 \%)$. O połowę mniej wskazań odnotowują: „inteligentny”, „rzeczowy”, „uprzejmy” (3 - 5,26\%), wypisane przez odpowiednio: 3 - 15,79\%, 2 - 10,53\%, 5,26\% osób. Tylko dwukrotnie 
(3,52\%) zwrócono uwagę, że Piotr Zaremba to „pisarz” (2 - 5,26\% osób) i racjonalista $(1-5,26 \%)$.

Piotr Zaremba postrzegany jest więc przede wszystkim przez pryzmat swoich poglądów („prawicowy”), aktywności medialnej (bliskie sobie semantycznie: „dziennikarz”, „osoba medialna”, „pisarz”) oraz mocnego precyzowania stanowiska („dosadnie przedstawiający swoje odważne sądy”). Dużo mniejsze znaczenie dla wizerunku publicznego wydaje się mieć inteligencja, rzeczowość, uprzejmość i racjonalna postawa.

Image publiczny $\mathrm{w}$ porównaniu $\mathrm{z}$ werbalnym definiuje osobę przede wszystkim przez wykonywaną profesję. To element - tak samo jak u Vargi - nieobecny w image'u werbalnym, ale najwyraźniejszy w przypadku wizerunku publicznego. Na równi z nim ważne wydają się poglądy - najwięcej wskazań dotyczy cechy wizerunkowej „prawicowy”. W tym przypadku Piotra Zarembę kojarzy się z jego prawicowymi publikacjami lub takimiż wypowiedziami w mediach oraz z dziennikarstwem. Ale też - co ciekawe - nawet dziennikarz jednego z czołowych tygodników konserwatywnych, o wyraźnie zarysowanym profilu politycznym, może być znany „z tego, że jest znany", o czym świadczy - nowa w porównaniu z image’em werbalnym - cecha wizerunkowa „osoba medialna”, w której skategoryzowano takie określenia, jak np. „ekspert”, „obecny w telewizji”, „medialny”. Innymi słowy, respondenci wiedzą, że Piotr Zaremba pojawia się w telewizji, występuje w roli znawcy i uważają to za jego wyróżnik na równi z określonymi poglądami, sposobem artykułowania swoich sądów czy postawą wobec analizowanych problemów. Skojarzenie, że gdzieś widzieli tę osobę, że jest znana, to taki sam element image’u, jak bardziej precyzyjnie wyrażone cechy. Ponieważ obecność w mediach coraz częściej jest formą zawodu, uważa się tutaj, że „osoba medialna” wchodzi właśnie w tę kategorię. Spośród pozostałych cech powtarzają się w wizerunku werbalnym i publicznym jedynie „inteligentny” oraz "pewny siebie” (którą da się łączyć z „dosadnie przekazujący swoje odważne sądy”), pozostałe cechy nie dublują się.

Należałoby to zestawić z faktem, że tak samo, jak u Vargi, wizerunek publiczny buduje zdecydowanie mniej cech wizerunkowych (9) niż image werbalny anonimowego twórcy (22). Ponieważ kontekst tych danych w przypadku obu felietonistów jest podobny (mała liczba osób określa wizerunek publiczny: Varga - 11, Zaremba - 19), to pozostaje dotąd nierozstrzygnięte, czy te rezultaty to efekt niewielkiej liczby respondentów definiujących image, czy to kwestia pojemności pamięci, z której przywoływane są określenia go tworzące. W kolejnych analizach podjęto próbę rozwiązania tego problemu. 
Tabela 20. Kategorie wizerunku publicznego Piotra Zaremby

\begin{tabular}{|l|l|l|l|l|l|l|l|l|}
\hline lp. & \multicolumn{1}{|c|}{ zawód } & n & \multicolumn{1}{|c|}{$\begin{array}{c}\text { poglądy/ } \\
\text { wartości }\end{array}$} & $\mathbf{n}$ & \multicolumn{1}{|c|}{ postawa } & $\mathbf{n}$ & $\begin{array}{c}\text { cecha } \\
\text { charakteru }\end{array}$ & $\mathbf{n}$ \\
\hline 1. & dziennikarz & 8 & prawicowy & 8 & pewny siebie & 7 & inteligentny & 3 \\
\hline 2. & osoba medialna & 6 & & & rzeczowy & 3 & & \\
\hline 3. & pisarz & 2 & & & uprzejmy & 3 & & \\
\hline 4. & & & & & racjonalista & 2 & & \\
\hline & razem & $\mathbf{1 6}$ & & $\mathbf{8}$ & & $\mathbf{1 5}$ & & $\mathbf{3}$ \\
\hline
\end{tabular}

Źródło: opracowanie własne

Aby łatwiej zauważyć różnice między wizerunkiem publicznym a werbalnym publicysty „W Sieci”, warto też spojrzeć na stworzone na przykładzie jego cech wizerunkowych kategorie możliwego do komunikowania wizerunku publicznego (tabela 20). Pojawia się jeden obszar wizerunku, który nie był obecny w przypadku wizerunku werbalnego. "Zawód” jednak, bo o nim mowa, to aspekt znany już z wyników dotyczących Krzysztofa Vargi. Potwierdzałoby się więc, że to zakres image'u specyficzny wyłącznie dla jego publicznego wymiaru. Podobnie jak u felietonisty „Dużego Formatu”, także i tutaj jest to najliczniej reprezentowana kategoria (16 wskazań), na drugim miejscu również znajduje się „postawa” z niewiele mniejszą liczbą wskazań (15). Kontynuując zestawienie $\mathrm{z}$ wizerunkiem werbalnym, zauważyć należy, że powtarzają się kategorie „postawa”, „cechy charakteru”, brak natomiast „sposobu komunikacji” i „wiedzy”. Ten ostatni aspekt występował w przypadku Krzysztofa Vargi, więc zapewne po prostu nie wchodzi w zakres wizerunku Piotra Zaremby. Jak już wspomniano wyżej, jako nowe w wizerunku publicznym pojawiają się natomiast „zawód” oraz „poglądy/wartości”.

Potraktujmy jeszcze zbiorczo ustalenia dotyczące Krzysztofa Vargi i Piotra Zaremby w zakresie wizerunku publicznego w zestawieniu z werbalnym. Możliwe do komunikowania w obszarze wizerunku publicznego są następujące kategorie: „zawód”, „poglądy/wartości”, „postawa”, „cecha charakteru”, „wiedza”. Wspólne dla obu imageów mogą być wszystkie wymienione oprócz pierwszej, która jest typowa dla wizerunku publicznego, natomiast dla werbalnego specyficzne pozostają obszary: „sposób komunikacji”. Niewielką liczbę cech wizerunku publicznego $\mathrm{w}$ porównaniu $\mathrm{z}$ werbalnym należy zestawić z wynikami pozostałych felietonistów, by móc próbować wyciągać rzetelne wnioski. W świetle ustaleń dokonanych podczas analizy wszystkich typów wizerunku Krzysztofa Vargi (image werbalny i wizualny wpływają na publiczny), określenie wzajemnych wpływów powinno zostać przeprowadzone $\mathrm{z}$ uwzględnieniem danych o wizerunku wizualnym. 


\subsubsection{Piotr Zaremba - wizerunek wizualny}

W przypadku wyników dotyczących wizerunku wizualnego Piotra Zaremby zasadne jest podzielenie odpowiedzi respondentów na trzy grupy. Wszystkim co prawda zaprezentowano tę samą fotografię Piotra Zaremby (zob. zdjęcie w tabeli 6) i postawiono to samo pytanie („Mając za podstawę przedstawione zdjęcie, jakimi słowami opisałby Pan / opisałaby Pani przedstawioną na tej fotografii osobę?) (na zdjęciu Piotr Zaremba), ale następnie zapytano: „Czy wie Pan/Pani, kogo przedstawia zdjęcie?”, dając do wyboru „TAK, kogo?...”, „Nie jestem pewny/pewna, ale wydaje mi się, że może to być (kto?)...” oraz „NIE” i - w zależności od wybranej propozycji - dany uczestnik badania został zaliczony do jednej z trzech grup.

Najmniej liczna jest ta, w której potwierdzono znajomość Piotra Zaremby. Znalazły się w niej cztery osoby. Trzy z nich napisały, iż na zdjęciu znajduje się „Piotr Zaremba”, jedna „Paweł Zaremba”, uznano jednak wszystkie te odpowiedzi za tożsame. Ich liczebność nie pozwala na głębszą analizę, ale warto spojrzeć na wyniki (tabela 21), choćby po to, by zauważyć, że znajomość osoby widocznej na fotografii wpływa na przypisywane jej cechy. Pojawiają się np. określenia „prawicowy publicysta «W sieci» vel «Sieci» oraz w polityce.pl” (cecha wizerunkowa "prawicowiec”) albo „lubujący się w teoriach spiskowych” („inne”). Mimo więc wyraźnego zwrócenia uwagi w poleceniu na posłużenie się wyłącznie wizualnym aspektem („Mając za podstawę przedstawione zdjęcie...”), respondenci ulegali skonstruowanemu wcześniej przez siebie wizerunkowi publicznemu dziennikarza. Tym bardziej więc zasadne jest rozdzielenie odpowiedzi każdej z wyłonionych grup i osobna ich analiza.

Tabela 21. Zestawienie odpowiedzi osób rozpoznających na zdjęciu Piotra Zarembę na pytanie: „Mając za podstawę przedstawione zdjęcie, jakimi słowami opisałby Pan / opisałaby Pani przedstawioną na tej fotografii osobę?"

\begin{tabular}{|l|l|l|c|c|c|c|}
\hline \multirow{2}{*}{ lp. } & \multirow{2}{*}{$\begin{array}{c}\text { cecha } \\
\text { wizerunkowa }\end{array}$} & \multicolumn{1}{|c|}{ warianty leksykalne } & \multicolumn{2}{|c|}{ wskazania } & \multicolumn{2}{c|}{ osoby } \\
\cline { 4 - 7 } 1. & $\begin{array}{l}\text { pewny siebie } \\
(0)\end{array}$ & $\begin{array}{l}\text { ma uniesioną głowę - pewność } \\
\text { siebie; mający silne przekona- } \\
\text { nia; fanatyk; przemądrzały }\end{array}$ & 4 & 20,00 & 4 & 100,00 \\
\hline 2. & intelektualista & $\begin{array}{l}\text { okulary kojarzą się z intelek- } \\
\text { tualistą; wykształcony }\end{array}$ & 3 & 15,00 & 3 & 75,00 \\
\hline 3. & opanowany (0) & $\begin{array}{l}\text { powstrzymuje emocje; po- } \\
\text { ważna mina; kontroluje swo- } \\
\text { ją osobowość }\end{array}$ & 3 & 15,00 & 2 & 50,00 \\
\hline
\end{tabular}


Tabela 21 (cd.)

\begin{tabular}{|c|c|c|c|c|c|c|}
\hline \multirow{2}{*}{ lp. } & \multirow{2}{*}{$\begin{array}{c}\text { cecha } \\
\text { wizerunkowa }\end{array}$} & \multirow{2}{*}{ warianty leksykalne } & \multicolumn{2}{|c|}{ wskazania } & \multicolumn{2}{|c|}{ osoby } \\
\hline & & & $\mathbf{n}$ & $\%$ & $\mathbf{n}$ & $\%$ \\
\hline 4. & prawicowiec & $\begin{array}{l}\text { jest to Piotr Zaremba; prawi- } \\
\text { cowy publicysta „W sieci” vel } \\
\text { „Sieci” oraz w polityce.pl }\end{array}$ & 2 & 10 & 2 & 50,00 \\
\hline 5. & konsekwentny & konsekwentna & 2 & 10 & 2 & 50,00 \\
\hline 6. & inne & $\begin{array}{l}\text { surowy - doświadczony } \\
\text { życiowo; liczy się z opinią } \\
\text { innych; lubujący się w teo- } \\
\text { riach spiskowych; ponury; } \\
\text { cyniczny; niemiły }\end{array}$ & 6 & 30,00 & 6 & 100,00 \\
\hline & & razem & 20 & 100,00 & & \\
\hline
\end{tabular}

Źródło: opracowanie własne

Do drugiej natomiast grupy zaliczyć należy grono czterech osób, które nie były pewne tożsamości mężczyzny ze zdjęcia, z czego dwójka przypuszczała, że może to być: „Varga, Bauman” albo „Varga”, a kolejna dwójka zaznaczyła, ze rozpoznaje mężczyznę $\mathrm{z}$ fotografii, ale zamiast nazwiska pojawiła się adnotacja „TAK - podejrzewam, że to jakiś polityk” lub zasugerowano jednak niepewność znakiem zapytania, zapisując „TAK - Zaremba Piotr (?)”. Nazwisko Vargi pojawia się u respondentów, którzy otrzymali portret Piotra Zaremby po wykonaniu zadań związanych z tekstem Krzysztofa Vargi (to był felieton z widocznym zdjęciem pisarza i informacją o autorstwie Vargi - zob. tabela 3). Uczestnik wspominający o Baumanie czytał felieton, w którym autor odwoływał się do myśli Zygmunta Baumana. Takie odpowiedzi uwypuklają tylko brak znajomości osoby ze zdjęcia. Faktycznie tylko jeden uczestnik z tej grupy rozpoznał Piotra Zarembę poprawnie, choć też nie był pewny. Mając na uwadze różnorodność tych odpowiedzi (trzy zupełnie chybione, jedna poprawnie wskazująca publicystę) oraz ich znikomą liczebność (cztery osoby), należy zaniechać ich analizowania.

Zaprezentowanie danych (tabela 22) usprawiedliwia jedynie hipoteza analityczna, że zapewne zestawienie tych nielicznych odpowiedzi z licznymi danymi od osób, które zadeklarowały wprost brak znajomości osoby ze zdjęcia, ukazałby podobny wizerunek w obu grupach (skoro w każdej z nich twórca pozostawał nieznany). Takie tabelaryczne jedynie porównanie (zob. tabela 22 i tabela 23) potwierdza jedynie, że ze względu na zbyt małą liczbę odpowiedzi analizy w tym zakresie są nieuzasadnione. 
Tabela 22. Zestawienie odpowiedzi osób, które zadeklarowały brak pewności co do tożsamości mężczyzny ze zdjęcia (Piotra Zaremby), na pytanie: „Mając za podstawę przedstawione zdjęcie, jakimi słowami opisałby Pan / opisałaby Pani przedstawioną na tej fotografii osobę?"

\begin{tabular}{|c|c|c|c|c|c|c|}
\hline \multirow{2}{*}{ lp. } & \multirow{2}{*}{$\begin{array}{c}\text { cecha } \\
\text { wizerunkowa }\end{array}$} & \multirow{2}{*}{ warianty leksykalne } & \multicolumn{2}{|c|}{ wskazania } & \multicolumn{2}{|c|}{ osoby } \\
\hline & & & $\mathbf{n}$ & $\%$ & $\mathbf{n}$ & $\%$ \\
\hline 1. & inteligentny (3) & mądry & 4 & 23,53 & 4 & 100,00 \\
\hline 2. & wykształcony & kompetentny; oczytany & 3 & 17,65 & 2 & 50,00 \\
\hline 3. & poważny (2) & & 2 & 11,76 & 2 & 50,00 \\
\hline 4. & niemiły $(0)$ & gbur; chamski & 2 & 11,76 & 1 & 25,00 \\
\hline 5. & zachowawczy & zdystansowany & 2 & 11,76 & 1 & 25,00 \\
\hline 6. & inne & $\begin{array}{l}\text { sarkastyczny; surowy; } \\
\text { asertywny; finansista/biz- } \\
\text { nesmen/polityk }\end{array}$ & 4 & 23,53 & 4 & 100,00 \\
\hline \multicolumn{3}{|c|}{ razem } & 17 & 100,00 & & \\
\hline
\end{tabular}

Źródło: opracowanie własne

Największą więc grupę stworzyły osoby, które otwarcie zaprzeczyły znajomości osoby ze zdjęcia, choć - jak pokazują niektóre odpowiedzi - można przypuszczać, że nie zawsze były to szczere deklaracje (zob. tabela 23) - np. zob. określenie ,jeden z dziennikarzy «Uważam Rze»” - cecha „publicysta”). Ponieważ jednak nie sposób zweryfikować szczerości, należy deklaracje respondentów uznać za bardziej pewne niż przypuszczenia badacza dotyczące ich podstawy. Można było co prawda wyeliminować $\mathrm{z}$ analizy odpowiedzi tych osób, które podały cechy wizerunkowe wyraźnie inspirowane wizerunkiem publicznym (jak ta powyżej), tyle że to nie dawało pewności, że odpowiedzi innych nie mają tego samego źródła (tylko mniej widocznego). Ponieważ uznano, że nie ma miarodajnego narzędzia pomiaru szczerości odpowiedzi, który pozwoliłby stworzyć taki ich zbiór, co do którego byłaby pewność, że nie czerpią informacji spoza zdjęcia, zdecydowano się polegać wyłącznie na deklaracjach uczestników, tworząc przynajmniej pod tym względem koherentną grupę odpowiedzi.

Takich uczestników badania, którzy zadeklarowali brak znajomości osoby ze zdjęcia, było 55, z czego 3 osoby podały po 2 wskazania, 9 po 3,6 po 4 epitety, a 37 respondentów po 5 przymiotów mężczyzny ze zdjęcia, co dało łącznie 242 określenia, skodowane w 14 spójnych cech wizerunkowych. 
Tabela 23. Zestawienie odpowiedzi osób, które zadeklarowały całkowity brak znajomości mężczyzny ze zdjęcia (Piotra Zaremby), na pytanie: „Mając za podstawę przedstawione zdjęcie, jakimi słowami opisałby Pan / opisałaby Pani przedstawioną na tej fotografii osobę?"

\begin{tabular}{|c|c|c|c|c|c|c|}
\hline \multirow{2}{*}{ lp. } & \multirow{2}{*}{$\begin{array}{c}\text { cecha } \\
\text { wizerunkowa }\end{array}$} & \multirow{2}{*}{ warianty leksykalne } & \multicolumn{2}{|c|}{ wskazania } & \multicolumn{2}{|c|}{ osoby } \\
\hline & & & $\mathbf{n}$ & $\%$ & $\mathbf{n}$ & $\%$ \\
\hline 1. & $\begin{array}{l}\text { wywyższający } \\
\text { się (3) }\end{array}$ & $\begin{array}{l}\text { wywyższa siebie nad innych (1); } \\
\text { wyniosły (3); wyniosła (2); zarozu- } \\
\text { miały (2); zarozumiała (2); władczy, } \\
\text { władcza (2); arogancki; arogancka; } \\
\text { możliwe, że arogancki; przemądrza- } \\
\text { ły; przemądrzała; dumny (3); pod- } \\
\text { chodzi do ludzi z dystansem; pyszna; } \\
\text { despotyczny; mądrala; egocentrycz- } \\
\text { ny; zadufany w sobie; apodyktyczny; } \\
\text { uważający się za lepszego; narzuca- } \\
\text { jący swoje zdanie innym }\end{array}$ & 33 & 13,64 & 25 & 45,45 \\
\hline 2. & pewny siebie (10) & $\begin{array}{l}\text { pewna siebie (5); człowiek pewny } \\
\text { siebie, stanowczy (2); bezkompro- } \\
\text { misowa (2); zdecydowana; wydaje } \\
\text { się zdecydowany, a przynajmniej } \\
\text { na takiego pozuje; indywidualista; } \\
\text { charyzmatyczny; stanowcza; świa- } \\
\text { doma; silny; pewny swoich racji }\end{array}$ & 28 & 11,57 & 23 & 41,82 \\
\hline 3. & poważny (20) & poważna; zamyślony; skupiony (2) & 24 & 9,92 & 22 & 40,00 \\
\hline 4. & inteligentny (14) & $\begin{array}{l}\text { inteligentna (2); bystry, mądry (2); } \\
\text { mądra; myślący }\end{array}$ & 21 & 8,68 & 20 & 36,36 \\
\hline 5. & wykształcony (4) & $\begin{array}{l}\text { oczytany (2); prawdopodobnie } \\
\text { oczytany; inteligent; typ inteligenta; } \\
\text { naukowiec; polityk lub naukowiec; } \\
\text { uczony profesor; wykładowca; } \\
\text { kilka dyplomów posiada; inżynier; } \\
\text { z dużą wiedzą }\end{array}$ & 17 & 7,02 & 15 & 27,27 \\
\hline 6. & $\begin{array}{l}\text { niesympatyczny } \\
\text { (4) }\end{array}$ & $\begin{array}{l}\text { surowy (3); surowa; niemiły; niemi- } \\
\text { ła; nieuprzejmy; oschły; wredna }\end{array}$ & 13 & 5,37 & 12 & 21,82 \\
\hline 7. & $\begin{array}{l}\text { zamknięty } \\
\text { w sobie (2) }\end{array}$ & $\begin{array}{l}\text { zamknięty; wyobcowany; zdystanso- } \\
\text { wany (3); wycofany; wycofany (pod } \\
\text { względem kontaktu z otoczeniem) }\end{array}$ & 9 & 3,72 & 6 & 10,91 \\
\hline 8. & $\begin{array}{l}\text { mężczyzna } \\
\text { w średnim wieku }\end{array}$ & $\begin{array}{l}\text { w średnim wieku (3); osoba w śred- } \\
\text { nim wieku; dojrzały; mężczyzna; stary }\end{array}$ & 8 & 3,31 & 7 & 12,73 \\
\hline 9. & nudny (4) & $\begin{array}{l}\text { bez poczucie humoru (2); sztywny; } \\
\text { „sztywna” }\end{array}$ & 8 & 3,31 & 6 & 10,91 \\
\hline 10. & melancholik & $\begin{array}{l}\text { smutek na twarzy; smutas; zmęczony; } \\
\text { nieszczęśliwy; cierpiący; apatyczna }\end{array}$ & 7 & 2,89 & 7 & 12,73 \\
\hline
\end{tabular}




\begin{tabular}{|c|c|c|c|c|c|c|}
\hline \multirow{2}{*}{ lp. } & \multirow{2}{*}{$\begin{array}{c}\text { cecha } \\
\text { wizerunkowa }\end{array}$} & \multirow{2}{*}{ warianty leksykalne } & \multicolumn{2}{|c|}{ wskazania } & \multicolumn{2}{|c|}{ osoby } \\
\hline & & & $\mathbf{n}$ & $\%$ & $\mathbf{n}$ & $\%$ \\
\hline 11. & krytyczny (2) & $\begin{array}{l}\text { krytyczna; niezadowolona; } \\
\text { oceniający }\end{array}$ & 5 & 2,07 & 4 & 7,27 \\
\hline 12. & publicysta (2) & $\begin{array}{l}\text { jeden z dziennikarzy Uważam Rze; } \\
\text { Fronda }\end{array}$ & 4 & 1,65 & 4 & 7,27 \\
\hline 13. & spokojny (4) & & 4 & 1,65 & 4 & 7,27 \\
\hline 14. & $\begin{array}{l}\text { Z wadą wzroku } \\
(0)\end{array}$ & $\begin{array}{l}\text { ma problemy ze wzrokiem; krótko- } \\
\text { wzrokowiec; w okularach (2) }\end{array}$ & 4 & 1,65 & 4 & 7,27 \\
\hline 15. & inne & $\begin{array}{l}\text { ambitny (3); konserwatywny; kon- } \\
\text { serwatysta; wychowany w rodzinie } \\
\text { z tradycjami; zawzięty; zacięty } \\
\text { wyraz twarzy; uparty; o prawico- } \\
\text { wych poglądach; popiera prawicę; } \\
\text { doświadczony (2); cyniczny (2); } \\
\text { twardo stąpający po ziemi; rozważ- } \\
\text { ny; łysiejący (2); katolik; wierzący } \\
\text { w Boga; bezwzględny; bezlitonny; } \\
\text { konkretny; nerwowy; szowinista; } \\
\text { hipokryta; dostojny; spięty; chytry; } \\
\text { człowiek pruderyjny; snob; z wy- } \\
\text { sokim czołem; możliwe, że ma na } \\
\text { szyi koloratkę; przenikliwy; szczery; } \\
\text { postawny; ważna (w sensie pozycji } \\
\text { społecznej); radykalna; profesjonal- } \\
\text { ny; sceptycznie podchodzi do tego, } \\
\text { co mu obce; często zmyśla (patrzy } \\
\text { w prawą stronę, co uruchamia } \\
\text { prawą półkulę); nietolerancyjny; } \\
\text { nadgorliwy; może prawnik?; zain- } \\
\text { teresowany; z poczuciem humoru; } \\
\text { powściągliwy; przystojny; zły; od- } \\
\text { powiedzialny; ksiądz; pozer; anali- } \\
\text { tyczna; godna zaufania; filozof; brak } \\
\text { uśmiechu na twarzy }\end{array}$ & 59 & 23,55 & 34 & 61,82 \\
\hline & & razem & 242 & 100,00 & & \\
\hline
\end{tabular}

Źródło: opracowanie własne

Jak pokazuje Tabela 23. Zestawienie odpowiedzi osób, które zadeklarowały całkowity brak znajomości mężczyzny ze zdjęcia (Piotra Zaremby), na pytanie: „Mając za podstawę przedstawione zdjęcie, jakimi słowami opisałby Pan / opisałaby Pani przedstawioną na tej fotografii osobę?". Źródło: opracowanie własne, w wizerunku werbalnym Piotra Zaremby dominuje cecha 
„wywyższający się," wskazana 33 razy (13,64\% wszystkich wskazań) przez niemal połowę respondentów ( $25-45,45 \%)$. Nie ustępuje jej wiele pewność siebie publicysty („pewny siebie”: $28-11,57 \%$ wskazań), przypisana przez tylko dwie osoby mniej ( 23 - 41,82\% osób). W kręgu 40\% uczestników zauważających daną cechę mieści się jeszcze „poważny” (24 - 9,92\%; 22 - 40,00\%). Ponad $1 / 3$ osób $(20-36,36 \%)$ zwróciła uwagę na inteligencję („,inteligentny": $21-8,68 \%)$, ponad $1 / 4(15-27,27 \%)$ na wykształcenie („wykształcony”: $17-7,03 \%$ wskazań), a ponad $1 / 5(12-21,82 \%)$ na niesympatyczne usposobienie („niesympatyczny”: 13 - 5,37\%). Kolejne cechy wykazują liczbę wskazań poniżej 5\% i liczbę osób ich dokonujących poniżej 11\%. Tak więc stwierdzono, że mężczyzna ze zdjęcia to człowiek „zamknięty w sobie” ( 9 - 3,72\% wskazań; 6 - 10,91\% osób), „mężczyzna w średnim wieku” (8 - 3,31\%; 7 - 12,73\%), „nudny” (8 - 3,31\%; 6 - 10,91\%), „melancholik” (7 - 2,89\%; 7 - 12,73\%), do tego "krytyczny” (5 - 2,07\%; 4 - 7,27\%). Najrzadziej (po 4 - 1,65\% wskazań; po $4-7,27 \%$ osób) postrzegano dziennikarza jako „spokojnego” „publicystę" „Z wadą wzroku”.

Również i w tym przypadku zauważyć da się pewne połączenia semantyczne pomiędzy cechami. „Wywyższający się" koresponduje $\mathrm{z}$ "pewny siebie”, „krytyczny”, czy nawet „niesympatyczny”, również „poważny” pozostaje w związku znaczeniowym z "zamknięty w sobie”, „nudny”, „melancholik” i „spokojny”, a „inteligentny” może tworzyć jedną grupę $\mathrm{z}$ „wykształcony”. Wówczas poza takimi w miarę spójnymi zbiorami pozostają dość nisko reprezentowane (poniżej 3\% wskazań i 11\% respondentów ich dokonujących) jedynie „mężczyzna w średnim wieku”, „publicysta” i „z wadą wzroku”. Te wyniki świadczyłyby o dość spójnym i wyrazistym wizerunku. Zwłaszcza że o wyrazistości świadczy także fakt, iż pierwszych kilka cech jest wysoko reprezentowanych - szczególnie w porównaniu z innymi, analizowanymi do tej pory, typami image’u Piotra Zaremby (ok. 14-10\% wskazań i 40\% lub więcej osób w pierwszej trójce najwyżej manifestowanych cech w porównaniu np. z 7\% wynotowań niespełna $29 \%$ respondentów w przypadku najliczniejszych cech wizerunku werbalnego anonima). Piotr Zaremba na poziomie image'u wizualnego jawi się zatem przede wszystkim jako wywyższający się i inteligentny, pełen powagi melancholik. 
Tabela 24. Kategorie wizerunku wizualnego Piotra Zaremby

\begin{tabular}{|c|c|c|c|c|c|c|c|c|}
\hline lp. & $\begin{array}{c}\text { stan } \\
\text { emocjonalno- } \\
\text {-poznawczy }\end{array}$ & $\mathbf{n}$ & zawód & $\mathbf{n}$ & wiedza & $\mathbf{n}$ & postawa & $\mathbf{n}$ \\
\hline 1. & poważny & 24 & publicysta & 4 & wykształcony & 17 & wywyższający się & 33 \\
\hline 2. & $\begin{array}{l}\text { zamknięty } \\
\text { w sobie }\end{array}$ & 9 & & & & & pewny siebie & 28 \\
\hline 3. & spokojny & 4 & & & & & krytyczny & 5 \\
\hline 4. & melancholik & 7 & & & & & niesympatyczny & 13 \\
\hline \multirow[t]{2}{*}{5.} & nudny & 8 & & & & & & \\
\hline & razem & 52 & & 4 & & 17 & & 79 \\
\hline lp. & $\begin{array}{c}\text { cecha } \\
\text { charakteru }\end{array}$ & $\mathbf{n}$ & wiek/płeć & $\mathbf{n}$ & wygląd & $\mathbf{n}$ & & \\
\hline 1. & inteligentny & 21 & $\begin{array}{l}\text { w średnim } \\
\text { wieku }\end{array}$ & 8 & z wadą wzroku & 4 & & \\
\hline \multicolumn{2}{|r|}{ razem } & 21 & & 8 & & 4 & & \\
\hline
\end{tabular}

Źródło: opracowanie własne

O poziom wyższa kategoryzacja wizerunku wizualnego Piotra Zaremby (tabela 24) pozwala zauważyć, że możliwe do komunikowania na poziomie obrazu są takie obszary, jak najsilniej manifestowana „postawa” (79 wskazań dla tej kategorii), nieco oddalony od niej „stan emocjonalno-poznawczy” (52), a następnie już znacznie rzadziej wymieniane „cechy charakteru” (21) oraz „wiedza” (17), i w końcu marginalne: „wiek/płeć” (6), „zawód” (4) oraz „wygląd” (4). Pojawia się „stan emocjonalno-poznawczy”, który nie funkcjonuje w innych (analizowanych do tej pory) rodzajach image'u i jak u Vargi, tak i tutaj wydaje się specyficzny dla wymiaru wizualnego. Również „wiek/płeć” pozostaje tu swoistą kategorią. W zestawieniu z publicystą „Dużego Formatu” w przypadku Piotra Zaremby powtarzają się wszystkie kategorie, ale w nieco innych relacjach ilościowych między sobą, a ponadto wyłaniają się nowe obszary. Różnica w proporcjach wynika głównie z rozbieżności wizerunków. U publicysty „W Sieci” silniej zarysowana jest „postawa” (Varga: 46 wskazań; Zaremba: 79), na znaczeniu straciły też „cechy charakteru” (Varga: 45; Zaremba: 21). Nowe aspekty image’u to natomiast efekt wpływu wizerunku publicznego na wizualny („publicysta”) i atrybutów wyglądu (okulary - „Z wadą wzroku”). To ostatnie wskazywałoby na relatywnie duży potencjał komunikacyjny „dodatków” do naturalnej aparycji.

Innymi słowy, wyniki dotyczące Piotra Zaremby pozwalają potwierdzić dotychczasowe ustalenia, że „stan emocjonalno-poznawczy” jest domeną 
wyłącznie wizerunku wizualnego, oraz wzbogacić je o wniosek, że również „zawód” oraz „wygląd” mogą być udziałem obrazu. Przy czym przedostatni z tych aspektów image'u stanowi zapożyczenie z wizerunku „publicznego”, co świadczyłoby o braku możliwości rozdzielenia tych dwóch wizerunków i faktycznych wzajemnych interferencjach w sytuacji znajomości osoby ze zdjęcia ${ }^{9}$. Wspólne dla wszystkich trzech omawianych wizerunków publicysty (werbalnego anonimowego autora, publicznego i wizualnego) są „postawa” i „cechy charakteru”. „Sposób komunikacji” pozostaje typowy dla werbalnego anonima, „poglądy/wartości” dla obu werbalnych, a „zawód” dla publicznego i wizualnego. „Wiedza” to domena wizerunków werbalnego i wizualnego, choć - jak pokazują dane Krzysztofa Vargi - również publicznego. „Wiek/płeć” do tej pory okazuje się funkcjonować wyłącznie w obrębie image’u wizualnego.

\subsubsection{Piotr Zaremba - wizerunek na podstawie tekstu ze zdjęciem i informacją o tożsamości autora}

$\mathrm{Na} 63$ respondentów odpowiadających - po przeczytaniu kserokopii felietonu - na pytanie: „Mając za podstawę tekst przeczytanego felietonu, jakimi słowami opisałby Pan/opisałaby Pani autora Piotra Zarembę?”, jedna osoba wypisała jeden przymiot felietonisty, 13 wskazało po trzy określenia, 19 po cztery i 30 uczestników po pięć epitetów. W sumie uzyskano więc 267 cech, spośród których 3 skategoryzowano podwójnie ${ }^{10}$, uzyskując do analizy 270 określeń zakodowanych w 21 spójnych cech wizerunkowych.

Tabela 25. Zestawienie odpowiedzi na pytanie: „Mając za podstawę tekst przeczytanego felietonu, jakimi słowami opisałby Pan/ opisałaby Pani autora Piotra Zarembę?"

\begin{tabular}{|c|c|c|c|c|c|c|}
\hline \multirow{2}{*}{ lp. } & \multirow{2}{*}{$\begin{array}{c}\text { cecha } \\
\text { wizerunkowa }\end{array}$} & \multirow{2}{*}{ warianty leksykalne } & \multicolumn{2}{|c|}{ wskazania } & \multicolumn{2}{|c|}{ osoby } \\
\hline & & & $\mathbf{n}$ & $\%$ & $\mathbf{n}$ & $\%$ \\
\hline 1. & $\begin{array}{l}\text { dosadnie } \\
\text { przekazujący } \\
\text { swoje odważ- } \\
\text { ne sądy }(0)\end{array}$ & $\begin{array}{l}\text { bezpośredni (4); odważny (4); śmia- } \\
\text { ły; mający własną opinię; bezcere- } \\
\text { monialnie wyraża swoją opinię; }\end{array}$ & 33 & 12,22 & 26 & 41,27 \\
\hline
\end{tabular}

9 Przypomnieć należy, że w tej grupie respondenci - najwyraźniej nie zawsze zgodnie z prawdą - deklarowali brak znajomości osoby ze zdjęcia.

10 Wypisane jako pojedyncze przymioty ,inteligentny, obeznany” przyporządkowano do cechy wizerunkowej „inteligentny” oraz „zna temat”, „wymagający widz i baczny obserwator produkcji filmowych” do „inne” oraz „spostrzegawczy”, a „kreatywny, inteligentny” skategoryzowano jako „inne” cechy oraz ,inteligentny”. 


\begin{tabular}{|c|c|c|c|c|c|c|}
\hline \multirow{2}{*}{ lp. } & \multirow{2}{*}{$\begin{array}{c}\text { cecha } \\
\text { wizerunkowa }\end{array}$} & \multirow{2}{*}{ warianty leksykalne } & \multicolumn{2}{|c|}{ wskazania } & \multicolumn{2}{|c|}{ osoby } \\
\hline & & & $\mathbf{n}$ & $\%$ & $\mathbf{n}$ & $\%$ \\
\hline 2. & $\begin{array}{l}\text { krytyczny } \\
(15)\end{array}$ & $\begin{array}{l}\text { krytycznie opisuje świat reklam; } \\
\text { krytykuje, jednak potrafi zacho- } \\
\text { wać w tym umiar; umie krytycznie } \\
\text { spojrzeć na daną sprawę; krytyczny } \\
\text { wobec przeczytanych książek/obej- } \\
\text { rzanych filmów; buntownik przeciw } \\
\text { stereotypowemu myśleniu; krytyk; } \\
\text { po trosze krytyk }\end{array}$ & 22 & 8,15 & 15 & 23,81 \\
\hline 3. & $\begin{array}{l}\text { inteligentny } \\
(14)\end{array}$ & $\begin{array}{l}\text { inteligentny, obeznany; kreatywny, } \\
\text { inteligentny; myśliciel; błyskotliwy; } \\
\text { bystry }\end{array}$ & 19 & 7,04 & 18 & 28,57 \\
\hline 4. & $\begin{array}{l}\text { ciekawie } \\
\text { piszący }\end{array}$ & $\begin{array}{l}\text { nakłania (pytaniami) czytelnika do } \\
\text { przemyśleń; sprawia, że człowiek } \\
\text { musi się zastanowić nad tekstem, } \\
\text { od razu go nie rozumie; potrafiący } \\
\text { zainteresować; potrafi zaciekawić } \\
\text { czytelnika-odbiorcę artykułem; } \\
\text { osoba pisząca w interesujący, zajmu- } \\
\text { jący sposób; ciekawy (2); elokwentny } \\
\text { (3); wygadany; używa słownictwa } \\
\text { potocznego, pisze tak, by każdy } \\
\text { go zrozumiał; rozsądny; nie pisze } \\
\text { prostym językiem; posiada sztukę } \\
\text { dobrego pisania - potrafi zaciekawić } \\
\text { swoim tekstem; ma dobry warsztat } \\
\text { dziennikarski; sprawny językowo; } \\
\text { posiada dobry warsztat; artysta }\end{array}$ & 19 & 7,04 & 17 & 26,98 \\
\hline 5. & $\begin{array}{l}\text { znawca } \\
\text { tematu }\end{array}$ & $\begin{array}{l}\text { znający historię; znający fakty; znają- } \\
\text { cy politykę; znawca psychologii i so- } \\
\text { cjologii; znawca seriali i ich fabuły, } \\
\text { zna doskonale opisany przez siebie } \\
\text { przedmiot; znawca wielu tytułów } \\
\text { produkcji filmowych; wie, o czym pi- } \\
\text { sze; zna się na dobrym kinie; krytyk; } \\
\text { aktualny; posiada ogromną wiedzę; } \\
\text { mający wiedzę z zakresu kina; posia- } \\
\text { dający wiedzę w temacie; ma wiedzę } \\
\text { o mechanizmach rynku filmowego; } \\
\text { obeznany z aktualnymi reklamami, } \\
\text { filmami; obeznany; zorientowany } \\
\text { w telewizyjnych serialach, filmach } \\
\text { czy programach; inteligentny, } \\
\text { obeznany; jest specjalistą w swojej } \\
\text { dziedzinie }\end{array}$ & 19 & 7,04 & 17 & 26,98 \\
\hline 6. & $\begin{array}{l}\text { interesujący } \\
\text { się }(0)\end{array}$ & $\begin{array}{l}\text { interesujący się kinem; interesuje } \\
\text { się filmem; zainteresowany realiami } \\
\text { życia; }\end{array}$ & 12 & 4,44 & 11 & 17,46 \\
\hline
\end{tabular}


Tabela 25 (cd.)

\begin{tabular}{|c|c|c|c|c|c|c|}
\hline \multirow{2}{*}{ lp. } & \multirow{2}{*}{$\begin{array}{c}\text { cecha } \\
\text { wizerunkowa }\end{array}$} & \multirow{2}{*}{ warianty leksykalne } & \multicolumn{2}{|c|}{ wskazania } & \multicolumn{2}{|c|}{ osoby } \\
\hline & & & $\mathbf{n}$ & $\%$ & $\mathbf{n}$ & $\%$ \\
\hline 7. & dokładny (0) & $\begin{array}{l}\text { rzeczowy; konkretny; skrupulatny; } \\
\text { skrupulatny w szczegółach; drobia- } \\
\text { zgowy; przywiązuje wagę do nieści- } \\
\text { słości historycznych; dba o szczegó- } \\
\text { ły; rzetelny (3); nie wypowiada się } \\
\text { „na ślepo", śledził serial, zanim coś } \\
\text { o nim powiedział; dobrze przygoto- } \\
\text { wuje się do napisania artykułu }\end{array}$ & 12 & 4,44 & 10 & 15,87 \\
\hline 8. & $\begin{array}{l}\text { obiektywny } \\
\text { (9) }\end{array}$ & $\begin{array}{l}\text { patrzy na wydarzenia bardzo } \\
\text { obiektywnie }\end{array}$ & 10 & 3,70 & 10 & 15,87 \\
\hline 9. & zabawny (1) & $\begin{array}{l}\text { mający poczucie humoru; posiadają- } \\
\text { cy poczucie humoru; pełen poczucia } \\
\text { humoru; ma poczucie humoru; } \\
\text { dowcipny (3); autor jest żartobliwy }\end{array}$ & 9 & 3,33 & 8 & 12,70 \\
\hline 10. & szczery (7) & $\begin{array}{l}\text { szczery w swoich opiniach; } \\
\text { prawdomówny }\end{array}$ & 9 & 3,33 & 9 & 14,29 \\
\hline 11. & dociekliwy (5) & wnikliwy (4) & 9 & 3,33 & 9 & 14,29 \\
\hline 12. & ironiczny (4) & $\begin{array}{l}\text { ironiczny (momentami); nieco iro- } \\
\text { niczny; sarkastyczny }(2)\end{array}$ & 8 & 2,96 & 8 & 12,70 \\
\hline 13. & realista (3) & $\begin{array}{l}\text { jest realistą; rozsądny; pisze w spo- } \\
\text { sób realistyczny; racjonalny }\end{array}$ & 7 & 2,59 & 7 & 11,11 \\
\hline 14. & $\begin{array}{l}\text { konserwaty- } \\
\text { sta (2) }\end{array}$ & $\begin{array}{l}\text { tradycjonalista (3); konserwatywny; } \\
\text { nieprzychylny nowym trendom }\end{array}$ & 7 & 2,59 & 5 & 7,94 \\
\hline 15. & $\begin{array}{l}\text { spostrzegaw- } \\
\text { czy (3) }\end{array}$ & $\begin{array}{l}\text { dobry i czujny obserwator; wymaga- } \\
\text { jący widz i baczny obserwator pro- } \\
\text { dukcji filmowych; osoba wnikliwie } \\
\text { obserwująca otaczający ją świat }\end{array}$ & 6 & 2,22 & 6 & 9,52 \\
\hline 16. & oczytany (4) & erudyta & 5 & 1,85 & 5 & 7,94 \\
\hline 17. & $\begin{array}{l}\text { sentymental- } \\
\text { ny }(0)\end{array}$ & $\begin{array}{l}\text { sentymentalista; sentymentalny } \\
\text { - wspomina dzieciństwo; nawiązuje } \\
\text { do przeszłości; powracający myślami } \\
\text { do dzieciństwa; retrospekcyjny }\end{array}$ & 5 & 1,85 & 5 & 7,94 \\
\hline 18. & $\begin{array}{l}\text { analizujący } \\
(0)\end{array}$ & $\begin{array}{l}\text { dostrzega detale i lubi je analizować; } \\
\text { dokładnie analizuje każdą reklamę; } \\
\text { analityczny; zagłębia się w biogra- } \\
\text { fię, doszukuje się różnic; dogłębnie } \\
\text { analizujący filmy }\end{array}$ & 5 & 1,85 & 5 & 7,94 \\
\hline 19. & wrażliwy (3) & wrażliwy na otaczający świat; czuły & 5 & 1,85 & 4 & 6,35 \\
\hline 20. & $\begin{array}{l}\text { subiektywny } \\
\text { (2) }\end{array}$ & $\begin{array}{l}\text { nieobiektywny (chodzi mi o aspekt po- } \\
\text { lityczny słowa: prawicowy dziennikarz); } \\
\text { jest subiektywny w swoich ocenach }\end{array}$ & 4 & 1,48 & 4 & 6,35 \\
\hline
\end{tabular}




\begin{tabular}{|c|c|c|c|c|c|c|}
\hline \multirow{2}{*}{ lp. } & \multirow{2}{*}{$\begin{array}{c}\text { cecha } \\
\text { wizerunkowa }\end{array}$} & \multirow{2}{*}{ warianty leksykalne } & \multicolumn{2}{|c|}{ wskazania } & \multicolumn{2}{|c|}{ osoby } \\
\hline & & & $\mathbf{n}$ & $\%$ & $\mathbf{n}$ & $\%$ \\
\hline 21. & inne & $\begin{array}{l}\text { uszczypliwy (2); zadziorny; wy- } \\
\text { kształcony; kreatywny, inteligentny; } \\
\text { wymagający (2); wymagający widz } \\
\text { i baczny obserwator produkcji filmo- } \\
\text { wych; patriota (2); otwarty; opisuje } \\
\text { własne emocje; opiniotwórczy; two- } \\
\text { rzący teksty opiniotwórcze; czytelnik } \\
\text { prasy; dojrzały widz; ambitny; pro- } \\
\text { fesjonalista; przebiegły; kreatywny; } \\
\text { poszukujący niszowych produkcji } \\
\text { filmowych; ceni wartości rodzinne; } \\
\text { historyk; spokojny; nie wzbudza } \\
\text { sympatii; romantyk; tajemniczy; } \\
\text { chaotyczny; wartościujący; trochę } \\
\text { niejasny tekst dla kogoś kto nie zna; } \\
\text { człowiek uważający rozwój intelek- } \\
\text { tu za szansę dla funkcjonowania } \\
\text { faktycznej wolności słowa; pragnie, } \\
\text { aby dziennikarze w sposób porząd- } \\
\text { ny przekazali informacje widzowi; } \\
\text { powołuje się na innych; serdeczny; } \\
\text { intrygujący; dramatyczny; dobry; } \\
\text { katolik; religijny; antytelemaniak; } \\
\text { nieco zanudzający; cyniczny; zwo- } \\
\text { lennik awansów zawodowych kobiet; } \\
\text { zajmujący się tematami społeczno- } \\
\text {-kulturalnymi; dużo porównuje }\end{array}$ & 45 & 16,67 & 36 & 57,14 \\
\hline \multicolumn{3}{|r|}{ razem } & 270 & 100,00 & & \\
\hline
\end{tabular}

Źródło: opracowanie własne

Jak pokazuje tabela 25 wyraźnie dominującą cechą wizerunku werbalnego Piotra Zaremby w sytuacji opatrzenia tekstu zdjęciem oraz informacją o imieniu i nazwisku autora, jest „dosadnie przekazujący swoje odważne sądy” (33 wskazania - 12,22\%; 26 - 41,27\% osób). Słabiej reprezentowaną grupą, ale istotną dla image'u, są cechy wizerunkowe zajmujące ok. 7\% wszystkich wynotowań, a wymienione przez ok. 1/4 respondentów: „krytyczny” (22 - 8,15\%, 15 - 23,81\%), „inteligentny” (19 - 7,04\%; 18 - 28,57\%), „ciekawie piszący” i „znawca tematu” (po 19 - 7,04\%; 17 - 26,98\%). Koleje cechy wizerunkowe odnotowują już wartości o 1/3 mniejsze. „Interesujący się” i „dokładny” wynotowano dwunastokrotnie (4,44\%), a uczyniło to odpowiednio $11-17,46 \%$ i 10 - 15,87\% uczestników badania. Wciąż w limicie 10\% czytelników zauważających daną cechę wizerunkową i mniej więcej 3\% wskazań mieszczą się: „obiektywny” (10 - 3,70\%; 10 - 15,87\%), ,zabawny” (9 - 3,33\%; 9 - 12,70\%), 
„realista” (7 - 2,59\%; 7 - 11,11\%). Najmniejsze w perspektywie ilościowej znaczenie image’owe mają atrybuty: „konserwatysta” (7 - 2,59\%; 5 - 7,94\%), "spostrzegawczy” (6 - 2,22\%; 6 - 9,52\%), „oczytany” oraz „sentymentalny” i „analizujący” (po 5 - 1,85\%; 5 - 7,94\%), w końcu „wrażliwy” (5 - 1,85\%; $4-6,35 \%)$ i „subiektywny” (4-1,48\%; $4-6,35 \%)$.

Wygląda więc na to, że Piotr Zaremba to osoba dosadnie i krytycznie wypowiadająca się na tematy, jakich jest znawcą, a które potrafi wnikliwie i ciekawie przedstawić. Tak jak w innych typach wizerunku, także i tutaj dostrzec można korespondencję semantyczną między poszczególnym cechami. Wydaje się, że wyżej reprezentowane są uzupełniane przez mniej licznie wskazywane. „Dosadnie przedstawiający swoje odważne sądy” wspólnie z „krytyczny”, „ironiczny” i „subiektywny” tworzą swego rodzaju blok znaczeniowy, podobnie jak ,inteligentny” i „,spostrzegawczy” albo „znawca tematu”, „intersujący się" i „oczytany”. Możliwe, że atrybut „ciekawie piszący” wspierany jest semantycznie przez „zabawny” czy „ironiczny”. Nie zawsze z cechą wizerunkową ze szczytu listy łączy się jakaś rzadziej wskazywana. Zdarza się, że te mniej reprezentowane tworzą też samodzielne zbiory, jak np. „dokładny” z „dociekliwy” $\mathrm{i}$,analizujący” albo „sentymentalny” z „wrażliwy”. Możliwe, że pewne dalekie, ale jednak powinowactwo występuje między przymiotami „realista” i „obiektywny". Cechy niemające wspólnych relacji znaczeniowych z pozostałymi to „szczery” i „konserwatysta”, które dość rzadko wypisywano (maksymalnie 9 razy dla cechy, co stanowi 3,33\% wskazań). Jeśli zatem blokami semantycznymi mierzyć wyrazistość wizerunku, to image Piotra Zaremby wydaje się dość wyrazisty i spójny.

Porównanie wizerunku werbalnego Piotra Zaremby, gdy odbiorcom pokazano jego zdęcie i poinformowano o tożsamości (wariant $\mathrm{z}$ kserokopią strony $\mathrm{z}$ tygodnika), z image’em werbalnym anonimowego twórcy wykazuje wiele wspólnego między nimi, a ewentualne różnice da się najczęściej wyjaśnić wpływem image’u wizualnego.

W zakresie liczby przypisywanych cech wizerunek anonima ma ich tylko o dwie więcej (stosunek 20 do 22). W obszarze jakościowym aż 17 się dosłownie powtarza. Specyficzne dla image'u anonima pozostają cechy: „emocjonalny”, „patriota”, „tolerancyjny”, „refleksyjny”, „wymagający”, a dla wizerunku publicysty o jawnym nazwisku: „szczery”, „realista”, „konserwatysta”. Hierarchia w pierwszej szóstce cech w dużej mierze się powtarza (patrz: niżej). W zakresie reszty różnice między tymi dwoma wizerunkami w liczbie wskazań nie przekraczają natomiast $1 \%$, a w liczbie osób ich dokonujących - 3,5\%.

W pierwszej szóstce cech przypisanych „znanemu” felietoniście również odnotować można wiele podobieństw. Pięć atrybutów pokrywa się z imageem nieznanego autora, z czego cztery („krytyczny”, ,inteligentny”, „znawca tematu”, 
„interesujący się") mają zbieżne wyniki, bowiem maksymalnie różnią się trzema wskazaniami (np. dla „krytyczny”: 20 wskazań dla anonima i 22 dla autora o podanym nazwisku), przy czym trójka też jest największą różnicą w zakresie liczby respondentów (analogicznie: 18 - 15) wypisujących daną cechę wizerunkową.

Piąta z najczęściej wymienianych wspólnych cech image’owych to „dosadnie przekazujący swoje odważne sądy”, którą charakteryzuje znacznie więcej wynotowań ( 33 - 13,22\% wskazań; 26 - 41,27\% osób), gdy czytelnik zna autora, niż w przypadku wariantu z tekstem nieznanego felietonisty $(21-7,37 \%$; 16 - 25,40\%). Jeśli szukać wpływów takiego rezultatu w wizerunku publicznym, to trudno go zauważyć, skoro korespondująca cecha „pewny siebie” ma niższe wyniki ( 7 - 12,28\% wskazań; 5 - 26,32\% osób), a i tylko 19 na 126 zapytanych uczestników badania potwierdziło znajomość publicysty. Zatem podobnej rozpoznawalności można spodziewać się w grupie czytającej tekst z towarzyszącym mu nazwiskiem i zdjęciem felietonisty. Wizerunek werbalny autora $\mathrm{z}$ kserokopii strony $\mathrm{z}$ tygodnika w przypadku tej cechy wizerunkowej musiał być zdeterminowany przez image wizualny. „Dosadnie prezentujący swoje odważne poglądy" mógł być silnie inspirowany takimi cechami przypisanymi na podstawie obrazu, jak: „wywyższający się" i „pewny siebie”, które są pierwszymi dwiema najczęściej przypisywanymi (odpowiednio: 33 - 13,64\% oraz $11,57 \%$ wskazań) przez największą liczbę respondentów (odpowiednio: $25-45,45 \%$ i $23-41,82 \%)$.

W zakresie różnic zauważyć można, że w pierwszej szóstce wyników felietonisty o podanej tożsamości jedna (tylko) cecha się nie dubluje z odpowiedziami czytelników nieznanego autora. Zamiast „ironiczny” z image’u anonima, pojawia się „ciekawie piszący” w wizerunku werbalnym autora o jawnym nazwisku. "Ciekawie piszący” ma zresztą tym razem ponad dwa razy więcej wskazań ( $8-2,81 \%$ u anonima i $19-7,04 \%$ tutaj), dokonanych przez dwa razy więcej czytelników (analogicznie: 8 - 12,70\% i 17 - 26,98\%). Atrybut „,ironiczny" z kolei osiąga prawie dwa razy mniejsze rezultaty (we wcześniej analizowanym image'u: 16 - 5,61\% wskazań; 14 - 22,22\% osób; tutaj odpowiednio: $8-2,96 \% ; 8-12,70 \%)$. Skąd tak duża różnica, skoro ani image publiczny nie zwraca uwagi na ciekawy sposób pisania („dziennikarz” i „pisarz” raczej definiują felietonistę przez pryzmat zawodu niż interesującego przekazywania treści), ani tym bardziej wizualny? Być może, paradoksalnie, właśnie zdjęcie inspirowało do częstszego zauważania przejrzystego sposobu formułowania wypowiedzi, a ignorowania ironii - na zasadzie opozycji. Najliczniej reprezentowane cechy image'u wizualnego to kolejno: „wywyższający się," „pewny siebie”, „poważny”, „inteligentny”, „wykształcony”, „niesympatyczny”. Żadna nie sugeruje przystępnego sposobu pisania, a właśnie na to w dużej mierze zwrócili uwagę respondenci, przypisując cechę „ciekawie piszący” (w jej zakresie 
znajdują się np. takie określenia, jak: „używa słownictwa potocznego, pisze tak, by każdy go zrozumiał”, „wygadany”, „osoba pisząca w interesujący, zajmujący sposób"). Możliwe zatem, że kontrast między wizualną niedostępnością a werbalną łatwością przyswojenia treści podkreślił ostatni z tych przymiotów autora na poziomie słowa. Ta zaskakująca przystępność tekstu mogła przesunąć agresywną cechę „ironiczny” na dalszy plan. Być może spowodowała również przesunięcie cechy „zabawny” (wizerunek werbalny anonima: 5 - 1,75\% wskazań; 5 - 7,94\% osób; wizerunek autora o znanej tożsamości: 9 - 3,33\%, 8 - 12,70\%) z 21 na 9 miejsce pod względem częstości wynotowań. Zaskoczeni łatwością odbioru czytelnicy mogli stać się bardziej otwarci na pozytywne czy też odwołujące się do mniej formalnego stylu cechy autora tekstu, a bardziej zamknięci na budujące dystans. Zapewne porównania $\mathrm{z}$ wynikami dotyczącymi innych felietonistów pozwolą z większą pewnością potwierdzić lub zaprzeczyć tego typu odwróconemu wpływowi wizerunku wizualnego na werbalny.

Da się zaobserwować kolejne wpływy zdjęcia na wizerunek (od)twarzany na podstawie tekstu $\mathrm{z}$ fotografią, które świadczyłyby o złożoności tych relacji, ale zdaje się, że są to pozornie skomplikowane zależności. Możliwe, iż „wywyższający się”, „pewny siebie”, „poważny”, czy nawet „zamknięty w sobie”, „nudny” (elementy image’u wizualnego) mogły usunąć $\mathrm{z}$ wizerunku werbalnego autora o jawnej tożsamości cechę „emocjonalny”, obecną w image'u werbalnym anonima (na poziomie 11 - 3,86\% wskazań; 9 - 14,29\% osób), a tworzoną przez m.in. takie określenia, jak „impulsywny”, „pełen emocji”, „porywczy”. Innymi słowy, fotografia daleka $\mathrm{w}$ wyrazie od egzaltacji wyeliminowała $\mathrm{z}$ pola widzenia wizerunku werbalnego nadmierną pobudliwość. Na podobnych zasadach zniknąć $\mathrm{z}$ wizerunku werbalnego twórcy o podanym nazwisku mogła cecha wizerunkowa „refleksyjny”.

Pojawia się pytanie: dlaczego pozostały wspólne dla obu imageów cechy w jakimś stopniu pokrewne semantycznie: „sentymentalny”, „wrażliwy”, skoro zdjęcie ich nie sugeruje, a wręcz wyklucza? Zdaje się, że najbardziej rozsądna odpowiedź powinna mieć postać: nie przesadzajmy z wpływem zdjęcia na wizerunek werbalny. „Sentymentalny” i „wrażliwy” to jedne z cech rzadziej przypisywanych. Wcale nie muszą korespondować ze zdjęciem. Zbiór cech obu wizerunków werbalnych i wizualnego pokazuje, że wizerunki oparte na słowie rządzą się swoimi prawami, mają inną liczbę cech i większość z nich nie pokrywa się z tymi $\mathrm{z}$ wizerunku wizualnego. Zdjęcie może wpływać na to, co odczytywane jest $\mathrm{z}$ tekstu, ale w sposób pozornie tylko skomplikowany, w ograniczonym stopniu, opisanym powyżej.

Innymi słowy, w miejscach silnych kontrastów wizerunkowych (między image'em werbalnym jawnego autora a wizualnym) podkreślana jest cecha będąca zaskoczeniem („ciekawie piszący”, „zabawny”), a w miejscach zbieżnych 
między wizerunkiem werbalnym i wizualnym częściej przypisywana ta, która ma swoje odpowiedniki w cechach zauważanych na podstawie zdjęcia, a która dzięki temu zyskuje na wyrazistości i rozpoznawalności w tekście („dosadnie przekazujący swoje odważne sądy”). Silnie eksponowane cechy wizerunku wizualnego („wywyższający się”, „pewny siebie”, „poważny”) mogą wyeliminować z poziomu słowa atrybuty niepasujące do zdjęcia („emocjonalny”), ale nie dotyczą mniej licznie reprezentowanych w wypowiedzi słownej cech (np. „sentymentalny”, wrażliwy”).

Jak już wyżej zarysowano, więcej wspólnego z wizerunkiem werbalnym autora o podanej tożsamości ma wizerunek werbalny anonima - wręcz trudno znaleźć różnice. Może to być wynik słabej rozpoznawalności publicysty wśród respondentów (4 osoby na 63 rozpoznały poprawnie osobę ze zdjęcia, 19 osób na 126 zapytanych kojarzyło nazwisko Piotra Zaremby), ale może to też być siła słowa w budowaniu wizerunku. Warto bowiem zauważyć, że mało jest cech wizerunkowych image'u wizualnego, które dosłownie pokrywają się z wizerunkiem werbalnym - w przypadku publicysty „W Sieci” tylko „inteligentny” i „krytyczny”, przy czym ten ostatni ma zupełnie inną (mniejszą) liczbę wskazań w wizerunku wizualnym niż w obu werbalnych. Wygląda więc na to, że co do zasady poziomy obrazu i słowa rządzą się swoimi prawami, niekiedy tylko na siebie wpływając, a kiedy odbiorca dysponuje jednym i drugim, to słowo dominuje w konstrukcji wizerunku.

Potwierdza się więc konstatacja $\mathrm{z}$ analiz dotyczących wizerunków Krzysztofa Vargi, że wizualizacja może wzmocnić niektóre cechy wizerunkowe, które i tak są zauważalne na poziomie tekstu, ale nie jest w stanie tak zmienić optyki postrzegania, by umożliwić zobaczenie w tekście cech charakterystycznych dla zdjęcia, choć zapewne dałoby się zauważyć w tekście „nudny” albo „poważny”. Poziom werbalny jest prymarny. Do tego casus Zaremby unaocznia że w sytuacji silnego kontrastu między słowem i obrazem, w tekście zyskuje na wyrazistości cecha zaskakująca czytelników w porównaniu do tego, czego mogliby się spodziewać po osobie ze zdjęcia.

Nie bierze się tu pod uwagę wpływu wizerunku publicznego na werbalny autora o podanej tożsamości. Po pierwsze, nie widać żadnych zależności. Nawet jeśli w image'u publicznym pojawiają się cechy występujące lub korespondujące $\mathrm{z}$ wizerunkiem werbalnym (,inteligentny” w obu przypadkach, „pewny siebie” z publicznego, mogący łączyć się z "dosadnie przekazujący swoje odważne sądy”, "racjonalista” przypisywany na bazie wielu systemów znakowych z „realistą" odczytanym z tekstu), to w image'u publicznym te cechy mają znacznie niższe wartości. Jeśli więc określić kierunek wpływu, to raczej od wizerunku werbalnego do publicznego, a niższe wartości wskazań cech w drugim z nich da się wytłumaczyć tym, że na pierwszych miejscach image’u 
opartego na obrazie plasują się cechy komunikujące „poglądy/wartości” i „zawód” („prawicowy”, „dziennikarz”), więc siłą rzeczy pozostałe cechy muszą być usytuowane niżej (respondentom sugerowano podanie pięciu cech, więc większa reprezentacja jednej odbywa się zawsze kosztem innych). Po drugie, tylko 19 osób określiło wizerunek publiczny Piotra Zaremby, co pozwala na podjęcie prób zauważenia pewnych tendencji, ale wyklucza głębszą analizę.

W świetle tych wyników spodziewać się można, że kategorie wizerunku komunikowanego werbalnie w sytuacji podanej tożsamości autora wypowiedzi będą zbieżne $\mathrm{z}$ analogicznym zestawieniem dla wizerunku anonimowego felietonisty (zob. tabela 26).

Tabela 26. Kategorie komunikowanego werbalnie wizerunku felietonisty o jawnej tożsamości - Piotra Zaremby

\begin{tabular}{|c|c|c|c|c|c|c|c|c|c|c|}
\hline lp. & $\begin{array}{l}\text { poglądy/ } \\
\text { wartości }\end{array}$ & $\mathbf{n}$ & wiedza & $\mathbf{n}$ & postawa & n & $\begin{array}{c}\text { cecha } \\
\text { charakteru }\end{array}$ & $\mathbf{n}$ & $\begin{array}{l}\text { sposób } \\
\text { komuni- } \\
\text { kacji }\end{array}$ & $\mathbf{n}$ \\
\hline 1. & $\begin{array}{l}\text { konserwa- } \\
\text { tysta (3) }\end{array}$ & 7 & $\begin{array}{l}\text { znawca } \\
\text { tematu }\end{array}$ & 19 & $\begin{array}{l}\text { dosadnie } \\
\text { wyrażający } \\
\text { swoje zda- } \\
\text { nie }(0)\end{array}$ & 33 & $\begin{array}{l}\text { inteligentny } \\
\text { (14) }\end{array}$ & 19 & $\begin{array}{l}\text { ciekawie } \\
\text { piszący }\end{array}$ & 19 \\
\hline 2. & & & $\begin{array}{l}\text { intere- } \\
\text { sujący } \\
\text { się }(0)\end{array}$ & 12 & $\begin{array}{l}\text { krytyczny } \\
\text { (15) }\end{array}$ & 22 & zabawny (1) & 9 & & \\
\hline 3. & & & $\begin{array}{l}\text { oczyta- } \\
\text { ny (4) }\end{array}$ & 5 & $\begin{array}{l}\text { dokładny } \\
(0)\end{array}$ & 12 & szczery (7) & 9 & & \\
\hline 4. & & & & & $\begin{array}{l}\text { obiektywny } \\
\text { (9) }\end{array}$ & 10 & $\begin{array}{l}\text { wrażliwy } \\
\text { (3) }\end{array}$ & 5 & & \\
\hline 5. & & & & & $\begin{array}{l}\text { dociekliwy } \\
\text { (5) }\end{array}$ & 9 & & & & \\
\hline 6. & & & & & $\begin{array}{l}\text { ironiczny } \\
\text { (4) }\end{array}$ & 8 & & & & \\
\hline 7. & & & & & realista (3) & 7 & & & & \\
\hline 8. & & & & & $\begin{array}{l}\text { spostrze- } \\
\text { gawczy (3) }\end{array}$ & 6 & & & & \\
\hline 9. & & & & & $\begin{array}{l}\text { subiektyw- } \\
\text { ny (2) }\end{array}$ & 4 & & & & \\
\hline 10. & & & & & $\begin{array}{l}\text { analizujący } \\
\text { (0) }\end{array}$ & 5 & & & & \\
\hline 11. & & & & & $\begin{array}{l}\text { sentymen- } \\
\text { talny }(0)\end{array}$ & 5 & & & & \\
\hline \multicolumn{2}{|r|}{ razem } & 7 & & 36 & & 121 & & 42 & & 19 \\
\hline
\end{tabular}

Źródło: opracowanie własne 
Wyłonione kategorie pozostają takie same. Ich proporcje również niewiele się zmieniają. W obu typach wizerunku werbalnego dominuje "postawa" (w przypadku anonima: 126 wskazań, tutaj: 121), a za nią porównywalne wyniki mają „wiedza” (analogicznie: 41; 36) i „cechy charakteru” (39; 42). „Poglądy/ wartości" reprezentują o 5 wskazań mniej (7). Sposób komunikacji obejmuje tylko cechę „ciekawie piszący”, która ma dwukrotnie więcej wynotowań (19 w miejsce 18), co - jak wyżej zauważono - może mieć związek z nietypowym wpływem wizerunku wizualnego.

\subsubsection{Zależności między poszczególnymi typami wizerunków Piotra Zaremby}

Uzyskane dane wskazują, iż Piotr Zaremba w zakresie obu typów wizerunku werbalnego jest uznawany za osobę dosadnie przekazującą swoje odważne i krytyczne sądy, inteligentnym i precyzyjnym znawcą tematu. $\mathrm{W}$ obrębie image’u publicznego daje się poznać jako osoba medialna, dziennikarz o prawicowych poglądach, również inteligentny i rzeczowy. W wizerunku wizualnym bardziej widoczny staje się dystans, wsparty przez kompetencje, stąd przypisywano publicyście wywyższanie się, pewność siebie, powagę czy zamknięcie w sobie, ale także inteligencję i wykształcenie. Nie są więc to wizerunki tak zbieżne, jak w przypadku Krzysztofa Vargi, bo też komunikaty się różnią, a te odmienności są jeszcze uwypuklane przez specyfikę poszczególnych typów image'u.

Podobnie jak u publicysty „Dużego Formatu”, także i u Piotra Zaremby da się zauważyć grupy cech skupione wokół jednego bloku semantycznego, przy czym nie tylko najbardziej manifestowane cechy są wspierane przez te mniej licznie wynotowywane, ale także te rzadziej wskazywane samodzielnie potrafią tworzyć niewielkie skupiska znaczeniowe.

Na uwage ponownie zasługuje kategoria „inne”. Tylko w image'u werbalnym autora o jawnej tożsamości liczba wskazań wynosiła mniej niż 20\% (45-16,67\%), w pozostałych natomiast plasowała się powyżej dwudziestoprocentowego progu (wizerunek werbalny nieznanego felietonisty: $59-20,70 \%$; image oparty na obrazie: 57 - 23,55\%; publiczny: 15 - 26,32\%). Liczba osób dokonujących tych wskazań wszędzie przekraczała 50\% (36 - 61,82\% dla wizerunku werbalnego felietonisty o podanym nazwisku; 36 - 57,14\% dla image'u werbalnego anonima; 10 - 52,63\% dla publicznego i $34-61,82 \%$ dla wizualnego). Ponownie zatem kategoria „inne” liczy wszędzie więcej wskazań, dokonanych przez większą liczbę osób, niż ma to miejsce w przypadku najwyżej reprezentowanej cechy każdego z imageów. Powtarzają się więc 
wyniki z badań dotyczących Krzysztofa Vargi. Tłumaczyć je można ograniczonymi możliwościami poznawczymi i pamięciowymi, które w połączniu ze zjawiskiem wyrazistości wizerunkowej, wspieranej przez powstanie grup semantycznych, powodują, że poszczególne cechy albo łączą się właśnie w bloki znaczeniowe, albo skategoryzować je można jako „inne”.

Kategorie wizerunkowe, które powtarzają się w każdym typie image'u Piotra Zaremby, to „postawa” i „cechy charakteru”. „Sposób komunikacji” pozostaje typowy dla obu wizerunków werbalnych, „wiedza” jest specyficzna dla werbalnych i wizualnego, „wiek/płeć” określano wyłącznie w zakresie image’u komunikowanego obrazem. Nowością stał się obszar „poglądy/wartości", pojawiający się w obu wizerunkach werbalnych, co musiało zapewne być inspiracją dla wizerunku publicznego, w obrębie którego „poglądy/wartości” także funkcjonują. Ponownie „zawód” stał się charakterystyczną i dominującą kategorią wizerunku publicznego, ale tym razem zasilił także szeregi kategorii wizerunku wizualnego, co musiało być wpływem tego pierwszego (a czemu zaprzeczyli respondenci, deklarując brak znajomości osoby ze zdjęcia) lub rezultatem działania stereotypu wyglądu dziennikarza. Również w przypadku publicysty „W Sieci” „stan emocjonalno-poznawczy” nie wychodzi poza ramy image'u wizualnego.

Jakie wnioski uzyskamy, sumując wyniki dotyczące Krzysztofa Vargi i Piotra Zaremby?

W zakresie kategorii możliwego do komunikowania wizerunku uniwersalnymi obszarami image'u są „postawa”, „cechy charakteru” i „wiedza”, przy czym pierwszy i ostatni z nich zdecydowanie dominują pod względem łącznej liczby wskazań w obszarze obu imageów werbalnych, a mają mniejsze znaczenie w wymiarze wizualnym i publicznym. Inne wyłonione obszary najczęściej nie wychodzą z ram jednego typu wizerunku. „Sposób komunikacji” wciąż stanowi element wyłącznie wizerunków werbalnych. „Wiek/płeć” pozostają charakterystyczne dla image wizualnego. „Zawód” jest typowy dla wizerunku publicznego, a jego pojawienie się w wynikach wizerunku wizualnego - jak wyżej wspomniano - stanowi rezultat niespójnych informacji od respondentów bądź działania stereotypu. "Stan emocjonalno-poznawczy” i „wygląd” nie wychodzą poza obręb image'u wizualnego. „Poglądy/wartości” to domena wymiaru werbalnego w obu odsłonach (anonim i jawny autor wypowiedzi) oraz publicznego.

Potwierdza się kilka ustaleń, powstałych w trakcie analizy danych Krzysztofa Vargi. Kategorie wizerunkowe wspólne wszystkim wizerunkom obu publicystów wydają się mieć charakter uniwersalny, czyli możliwe są do komunikowania w obrębie każdego typu image'u. Ponieważ pokrywają się cechy wizerunku opartego na obrazie i słowie $\mathrm{z}$ tymi $\mathrm{z}$ image'u publicznego, to spodziewać się można, że na publiczny dwa wspomniane wpływają jednocześnie, 
nie w izolacji (przynajmniej w przypadku faktycznej znajomości tożsamości autora i kojarzenia jego wyglądu z nazwiskiem).

„Zawód” pozostaje typowy dla wizerunku publicznego ze względu na determinację tego image’u również informacjami „o" autorze, a nie tylko jego wypowiedziami. Nie dziwi przynależność aspektu „wyglądu” do kategorii wizerunku wizualnego, chociaż zauważyć należy, że w przypadku innych osób publicznych (np. niektórych gwiazd estrady), dla których niekiedy ubiór jest istotnym wyróżnikiem, te wyniki mogłyby nieco inaczej wyglądać ( $\mathrm{tj}$. „wygląd” mógłby także znaleźć się w zakresie image’u publicznego). „Stan emocjonalno-poznawczy" również pozostaje w wizerunku wizualnym i tutaj chyba już na stałe. Najwyraźniej łatwiej jest go zakomunikować dzięki fizjonomii niż za pomocą wypowiedzi werbalnej.

Co nowego w dotychczasową analizę wprowadzają dane dotyczące Piotra Zaremby?

Zauważyć należy, że tylko w zakresie powtarzających się w każdym typie wizerunku kategorii („postawa”, „cechy charakteru”, „wiedza”) możliwy jest wpływ jednego typu wizerunku na drugi, wyrażający się migracją cech między image’ami. Kategorie image’u specyficzne dla poszczególnych typów wizerunku nie mają mocy dublowania się w innych rodzajach image’u (np. stan emocjonalno-poznawczy), mimo zdolności zwiększenia reprezentacji niektórych cech z trzech wymienionych wspólnych kategorii.

Ciekawe, że najczęściej reprezentowane cechy wizerunków werbalnych, jak „dosadnie przekazujący swoje odważne sądy”, „inteligentny”, „krytyczny”, "spostrzegawczy”, powtarzają się - choć w różnych proporcjach - jako najliczniejsze zarówno u Krzysztofa Vargi, jak i Piotra Zaremby. Wyjaśnienia można szukać albo w unifikacji wynikającej ze wspólnego autorom gatunku felietonu, albo w zbieżności wizerunkowej, albo w konieczności wyróżnienia się na rynku medialnym wypowiedziami dosadnymi, krytycznymi i inteligentnymi, co wiązałoby się ze specyfiką dyskursu publicystycznego. W tym kontekście pojawia się także pytanie: gdzie właściwie szukać faktycznych wyróżników wizerunku: w tych cechach najmniej reprezentowanych czy proporcjach tych najliczniejszych, czy może ze względu na zjawisko grupowania się semantycznego niektórych cech - i tu, i tu. Chociaż w przyjętej analizie dokłada się starań, by stosować ostanie z tych rozwiązań, to kwestię zarówno źródeł zbieżności, jak i interpretacji wizerunku, pozostawia się do analizy z uwzględnieniem wyników dwóch pozostałych felietonistów.

Na uwagę zwraca także cecha wizerunkowa „osoba medialna”, funkcjonująca zresztą obok cechy „dziennikarz” jako zjawisko celebrytyzacji dziennikarskiego środowiska. Z pewnością zasługuje to na uwagę, zwłaszcza w kontekście wyników dotyczących Szymona Hołowni, który znany jest ze swoich 
wypowiedzi typowo dziennikarskich, jak i z roli prezentera w jednym z programów rozrywkowych.

Chociaż już wcześniej widoczna była inspiracja wizerunku werbalnego z podaną tożsamością autora wizerunkiem wizualnym, to wyniki dotyczące Piotra Zaremby rzucają nowe światło na to zjawisko, bowiem okazuje się, że kiedy komunikat ze zdjęcia kontrastuje z tym z poziomu słowa, to $\mathrm{w}$ wizerunku werbalnym wyraźniejsze i zyskujące w wymiarze ilościowym są właśnie cechy kontrastowe $\mathrm{z}$ tekstu. Przynajmniej w zakresie tych najliczniej manifestowanych.

Ciekawym zjawiskiem jest również względna powtarzalność u obu autorów liczby spójnych cech wizerunkowych w obrębie poszczególnych typów image'u, co udaje się zaobserwować w przypadku obydwu analizowanych do tej pory felietonistów. Najwięcej cech pojawia się w kontekście wizerunku werbalnego anonimowego autora (Varga: 16 cech wizerunkowych, Zaremba: 22), następnie w sytuacji, gdy czytający ma podaną tożsamość twórcy (Varga: 15, Zaremba: 20), potem w image'u wizualnym (Varga: 11, Zaremba: 14) i na końcu w publicznym (Varga: 7, Zaremba 9). Co prawda rezultaty dotyczące wizerunku wizualnego, a zwłaszcza publicznego, należy wziąć w nawias ze względu na mniejszą liczbę udzielających odpowiedzi i być może selektywny mechanizm pamięci $\mathrm{w}$ przypadku ostatniego $\mathrm{z}$ tych imageów, ale jeśli proporcje te powtórzą się w wynikach dotyczących innych felietonistów, będzie można mówić o pewnej stałej tendencji co do liczby cech wizerunkowych, właściwej poszczególnym typom wizerunku.

\subsection{Magdalena Środa}

\subsubsection{Magdalena Środa - wizerunek na podstawie anonimowego tekstu}

Na pytanie: „Mając za podstawę tekst przeczytanego felietonu, jakimi słowami opisałby Pan / opisałaby Pani autorkę tego tekstu?" odpowiedziały 63 osoby, spośród których 6 wskazało po 3 cechy, 11 po 4 przymioty i 46 respondentów po 5 określeń, czyli łącznie zebrano 292 wskazania, wśród których znalazły się 3 kodowane podwójnie ${ }^{11}$, zatem analizie poddano 296 epitetów, skategoryzowanych w 21 spójnych cech wizerunkowych.

11 Pojedyncze określenia „pewna siebie oraz wiarygodna” skategoryzowano jako „dosadnie wyrażająca swoje odważne sądy” oraz „inne”, przymiot „erudytka, ironiczna” został potraktowany jako „oczytana” oraz „ironiczna”, natomiast „rzetelny dziennikarz, wykształcony” zakodowano jako „dokładna” oraz „wykształcona”. 
Po wykonaniu poleceń dotyczących przeczytania, określenia cech wizerunkowych oraz wypisania z tekstu fragmentów stanowiących wyraz wyłonionych cech, respondenci odpowiadali również na pytanie: „Czy wiesz, kto jest autorem tekstu?”, mając do wyboru trzy możliwości: 1) TAK, wiem (kto?)...", którą zaznaczyło czterech uczestników badania, poprawnie przypisując autorstwo Magdalenie Środzie, 2) „Nie jestem pewny/pewna - wydaje mi się, że autorką może być (kto?)...” oraz 3) „NIE, nie wiem”, zakreśloną przez 53 osoby. Brak pewności wybrało sześciu respondentów, a spodziewali się, że twórcą felietonu jest: „Karolina Korwin-Piotrowska”, „Korwin”, „Monika Olejnik”, ,jakaś dziennikarka GW?”, „Magdalena Środa” i „wykładowca”. Do grona zagadkowych należy zaliczyć odpowiedź „Korwin”. Trudno bowiem rozstrzygnąć, czy mowa o Karolinie Korwin Piotrowskiej, czy o Januszu Korwin-Mikkem. Podanie tych nazwisk da się jednak wyjaśnić zbieżnością wizerunkową na poziomie dosadności wypowiedzi (zarówno dziennikarka, jak i polityk słyną ze zdecydowanego sposobu wyrażania swoich poglądów). Podobna motywacja oraz przekonania feministyczne mogły odpowiadać za przywołanie Moniki Olejnik i skojarzenia z "Gazetą Wyborczą" (patrz zwłaszcza „Wysokie Obcasy”). „Wykładowca”, czyli zapewne osoba prowadząca, to raczej wyraz chęci udzielenia odpowiedzi przy braku skojarzenia z którąś z osób publicznych.

Poprawne odpowiedzi respondentów dotyczące znajomości tożsamości felietonistki zostały włączone do poniższej analizy, ponieważ warunek anonimowości tekstu na poziomie podanej uczestnikom badania informacji został zachowany, natomiast cechy przypisane przez tę czwórkę osób nie wykazują wpływu wizerunku publicznego (który wizerunkiem werbalnym jest skądinąd między innymi determinowany), a przy tym podane cytaty odpowiadające wskazanym określeniom szczególnie wyraźnie je egzemplifikują ${ }^{12}$.

12 Jedna z osób podała takie określenia: „bezpruderyjna”, „cięty język”, „subiektywna”, „elokwentna”, „inteligentna”; druga: „stara się być osobą skonkretyzowaną”, „używa wielu kolokwializmów”, „jasno określa cele”, „jej styl podobny jest do nowomowy”, „jest miła”; trzecia: „lewaczka”, „aktywistka”, „pani wojownik/wojowniczka”, „feministka”, „wodzówna/pani wódz”; czwarty z respondentów: „,ironiczna”, „inteligentna”, „lewicowa”, „ekspresywna” (ten uczestnik podał tylko cztery epitety). 
Tabela 27. Zestawienie odpowiedzi respondentów czytających tekst anonimowego autora (Magdaleny Środy) na pytanie: „Mając za podstawę tekst przeczytanego felietonu, jakimi słowami opisałby Pan / opisałaby Pani autorkę tego tekstu?"

\begin{tabular}{|c|c|c|c|c|c|c|}
\hline \multirow{2}{*}{ lp. } & \multirow{2}{*}{$\begin{array}{c}\text { cecha } \\
\text { wizerunkowa }\end{array}$} & \multirow{2}{*}{ warianty leksykalne } & \multicolumn{2}{|c|}{ wskazania } & \multicolumn{2}{|c|}{ osoby } \\
\hline & & & $\mathbf{n}$ & $\%$ & $\mathbf{n}$ & $\%$ \\
\hline 1. & $\begin{array}{l}\text { dosadnie } \\
\text { przedstawia- } \\
\text { jąca swoje } \\
\text { odważne } \\
\text { sądy }\end{array}$ & $\begin{array}{l}\text { mająca swoje zdanie; ma własne zda- } \\
\text { nie i nie boi się go ukazywać; mająca } \\
\text { własne zdanie; odważna (9); śmiało } \\
\text { wyrażająca swoją opinię; osoba o sil- } \\
\text { nym własnym zdaniu na temat; bezpo- } \\
\text { średnia (4); pewna swoich racji; pewna } \\
\text { siebie oraz wiarygodna; jest pewna } \\
\text { swoich racji; pewna swoich poglądów; } \\
\text { pewna słuszności swoich poglądów; } \\
\text { stanowcza; ma stanowcze zdanie na } \\
\text { ten temat; bezkompromisowa (3); jest } \\
\text { bezkompromisowa; konkretna (2); } \\
\text { buntowniczka; buntowniczka, nie zga- } \\
\text { dza się z zastaną rzeczywistością, non- } \\
\text { konformistka; posiada silny charakter, } \\
\text { ale i chce przestrzec rodziców itp.; } \\
\text { kontrowersyjna; dosadna; bezprude- } \\
\text { ryjna; posiada siłę przebicia; wyrazista; } \\
\text { niezależna; asertywna (tzn. ma własne } \\
\text { poglądy, których broni); nie chce pod- } \\
\text { porządkowywać się ani polityce PO, } \\
\text { ani PiS-u, nie jest konformistką }\end{array}$ & 42 & 14,24 & 29 & 46,03 \\
\hline 2. & $\begin{array}{l}\text { inteligentna } \\
(18)\end{array}$ & błyskotliwa (2); mądra & 21 & 7,12 & 21 & 33,33 \\
\hline 3. & krytyczna (7) & $\begin{array}{l}\text { krytyczna w stosunku do polityki, } \\
\text { która nie chce równości, postępuje ze } \\
\text { szkodą dla ludzi; krytyczna w tym, co } \\
\text { pisze; sprzeciwia się zabobonom; prze- } \\
\text { ciwna hipokryzji polityków; rozcza- } \\
\text { rowana; nie jest zadowolona z sytuacji } \\
\text { obecnej, tj. rządów tych dwóch partii, } \\
\text { biorąc pod uwagę Kościół, szkolnictwo } \\
\text { czy relacje pomiędzy politykami; uwa- } \\
\text { ża rząd za „bandę ignorantów”; zbun- } \\
\text { towana przeciw ustawie aborcyjnej; } \\
\text { posiadająca zdolność do krytycznej } \\
\text { analizy sytuacji; konstruktywnie kryty- } \\
\text { kuje; indywidualistka - mocna krytyka }\end{array}$ & 18 & 6,10 & 18 & 28,57 \\
\hline 4. & $\begin{array}{l}\text { ironiczna } \\
(10)\end{array}$ & $\begin{array}{l}\text { ironizująca; cięty jezyk; Wypowiada } \\
\text { się ironicznie o polityce obu partii.; } \\
\text { ironia; sarkastyczna (3); sarkastyczna / } \\
\text { ironiczna; erudytka, ironiczna }\end{array}$ & 20 & 6,78 & 19 & 30,16 \\
\hline
\end{tabular}




\begin{tabular}{|c|c|c|c|c|c|c|}
\hline \multirow{2}{*}{ lp. } & \multirow{2}{*}{$\begin{array}{c}\text { cecha } \\
\text { wizerunkowa }\end{array}$} & \multirow{2}{*}{ warianty leksykalne } & \multicolumn{2}{|c|}{ wskazania } & \multicolumn{2}{|c|}{ osoby } \\
\hline & & & $\mathbf{n}$ & $\%$ & $\mathbf{n}$ & $\%$ \\
\hline 5. & $\begin{array}{l}\text { zaangażowa- } \\
\text { na }(2)\end{array}$ & $\begin{array}{l}\text { wydawać by się mogło, że dotyka ją } \\
\text { to osobiście; walcząca o sprawiedli- } \\
\text { wość; wrażliwy na zło świata; mająca } \\
\text { na celu dobro instytucji publicznych; } \\
\text { chcąca zmian; zdeterminowana; akty- } \\
\text { wistka; pani wojownik/wojowniczka; } \\
\text { próbująca coś innym uświadomić; } \\
\text { wojownicza; „próbująca przebić mur”; } \\
\text { pragnąca prawdziwej wolności }\end{array}$ & 14 & 4,75 & 13 & 20,63 \\
\hline 6. & zabawna (0) & $\begin{array}{l}\text { dowcipna (5); poczucie humoru (2); } \\
\text { z poczuciem humoru; żartobliwa (2); } \\
\text { humorystyczna }\end{array}$ & 11 & 3,73 & 10 & 15,87 \\
\hline 7. & $\begin{array}{l}\text { dociekliwa } \\
\text { (6) }\end{array}$ & $\begin{array}{l}\text { ciekawska; ciekawy świata; wnikliwie } \\
\text { zajmująca się sprawą, którą chce udo- } \\
\text { wodnić/o której chce pisać; wnikliwa }\end{array}$ & 10 & 3,39 & 10 & 15,87 \\
\hline 8. & zna temat $(0)$ & $\begin{array}{l}\text { nie narzuca religii, jest zbyt ogarnięta } \\
\text { w temacie; zorientowana; poinformo- } \\
\text { wana w zmianie sytuacji politycznej; } \\
\text { obeznana z polityką; doświadczona } \\
\text { (wiedzą); obeznana w temacie; świa- } \\
\text { doma sytuacji politycznej w Polsce; } \\
\text { obeznana w świecie (2) }\end{array}$ & 9 & 3,05 & 9 & 14,29 \\
\hline 9. & $\begin{array}{l}\text { antyklerykal- } \\
\text { na (1) }\end{array}$ & $\begin{array}{l}\text { jest antyklerykalna; antyklerykał; } \\
\text { napada na kościół, a to księża są win- } \\
\text { ni; krytyczny/a wobec postępowania } \\
\text { Kościoła; przeciwniczka Kościoła; } \\
\text { stojąca w opozycji do decyzji Kościo- } \\
\text { ła; nie jest zwolenniczką Kościoła; } \\
\text { krytycznie podchodzi do kościoła }\end{array}$ & 9 & 3,05 & 8 & 12,70 \\
\hline 10. & $\begin{array}{l}\text { obiektywna } \\
\text { (4) }\end{array}$ & $\begin{array}{l}\text { obiektywny; wypowiadająca się } \\
\text { obiektywnie; obiektywna (momen- } \\
\text { tami); autorka stara się obiektywnie } \\
\text { zaprezentować swoje koncepcje co do } \\
\text { polityki PO i PiS }\end{array}$ & 8 & 2,71 & 8 & 12,70 \\
\hline 11. & $\begin{array}{l}\text { wykształco- } \\
\text { na (5) }\end{array}$ & $\begin{array}{l}\text { badaczka (naukowiec?); rzetelny } \\
\text { dziennikarz, wykształcony }\end{array}$ & 7 & 2,37 & 7 & 11,11 \\
\hline 12. & dokładna (0) & $\begin{array}{l}\text { szczegółowa/precyzyjna; precyzyjna; } \\
\text { rzetelna; rzetelny dziennikarz, wy- } \\
\text { kształcony; stara się być osobą skon- } \\
\text { kretyzowaną; mądra (opiera się na } \\
\text { faktach); jasno określa cele }\end{array}$ & 7 & 2,37 & 7 & 11,11 \\
\hline 13. & $\begin{array}{l}\text { ciekawie } \\
\text { pisząca }(0)\end{array}$ & $\begin{array}{l}\text { elokwentna (4); wypowiada się w elo- } \\
\text { kwentny sposób; używa wielu kolo- } \\
\text { kwializmów; jej styl podobny jest do } \\
\text { nowomowy }\end{array}$ & 7 & 2,37 & 6 & 9,52 \\
\hline
\end{tabular}


Tabela 27 (cd.)

\begin{tabular}{|c|c|c|c|c|c|c|}
\hline \multirow{2}{*}{ lp. } & \multirow{2}{*}{$\begin{array}{l}\text { cecha } \\
\text { wizerunkowa }\end{array}$} & \multirow{2}{*}{ warianty leksykalne } & \multicolumn{2}{|c|}{ wskazania } & \multicolumn{2}{|c|}{ osoby } \\
\hline & & & $\mathbf{n}$ & $\%$ & $\mathbf{n}$ & $\%$ \\
\hline 14. & realistka $(0)$ & $\begin{array}{l}\text { racjonalna (5); racjonalista; racjonal- } \\
\text { nie patrząca na in vitro }\end{array}$ & 7 & 2,37 & 7 & 11,11 \\
\hline 15. & $\begin{array}{l}\text { subiektywna } \\
(6)\end{array}$ & subiektywna (momentami) & 7 & 2,37 & 7 & 11,11 \\
\hline 16. & feministka (6) & & 6 & 2,03 & 6 & 9,52 \\
\hline 17. & szczera (6) & & 6 & 2,03 & 6 & 9,52 \\
\hline 18. & $\begin{array}{l}\text { spostrzegaw- } \\
\text { cza }(2)\end{array}$ & $\begin{array}{l}\text { obserwuje to, co się wokół niego dzieje; } \\
\text { obserwatorka życia społecznego; trafnie } \\
\text { analizuje zjawiska sceny politycznej }\end{array}$ & 5 & 1,69 & 4 & 6,35 \\
\hline 19. & $\begin{array}{l}\text { przeciwnicz- } \\
\text { ka PiS }(0)\end{array}$ & $\begin{array}{l}\text { przeciwniczka partii PiS; antypra- } \\
\text { wicowa; nie jest za prawicą; anty PiS } \\
\text { - w sensie; podchodzi krytycznie do } \\
\text { skrajnego konserwatyzmu PiS-u }\end{array}$ & 5 & 1,69 & 5 & 7,94 \\
\hline 20. & empatyczna & $\begin{array}{l}\text { jest osobą z dużą empatią, lecz nie- } \\
\text { wierzącą; ludzka; wrażliwa }\end{array}$ & 4 & 1,36 & 4 & 6,35 \\
\hline 21. & oczytana (3) & erudytka & 4 & 1,36 & 4 & 6,35 \\
\hline 22. & inne & $\begin{array}{l}\text { cyniczna (3); dumna (analiz sytuacji); } \\
\text { dumna; dumna z tego, że jest Polką; } \\
\text { z pomysłem; kreatywna; wyobraźnia; } \\
\text { nowoczesna; postępowa; wyemancypo- } \\
\text { wana; wyzwolona; kochana; jest miła; } \\
\text { sympatyczna; lekkoduch; niefrasobliwa; } \\
\text { emocjonalna; ekspresywna; idealistka; } \\
\text { trochę oderwana od rzeczywistości; } \\
\text { marzycielka; nieszczęśliwa; sfrustrowa- } \\
\text { na; katoliczka; nie trzyma słowa; popie- } \\
\text { rająca równość w społeczeństwie; lubi } \\
\text { zamieszanie; jest za studiami gender; } \\
\text { wredna; zwolenniczka zasady „złotego } \\
\text { środka”; ceniąca prawdę; piętnująca } \\
\text { cynizm; ograniczona; antypatriotka; } \\
\text { hipokrytka; zniechęcona/zawiedziona; } \\
\text { zdystansowana; posiada dobrą pamięć; } \\
\text { zestawiający/a teraźniejszość z przeszło- } \\
\text { ścią; wodzówna/pani wódz; uporząd- } \\
\text { kowana; sceptyczna; moralizująca; ma } \\
\text { rację; bezradna; samotna; żyje w stra- } \\
\text { chu; ma odwrócony obraz świata; upar- } \\
\text { ta; myśląca o przyszłości; wiarygodna; } \\
\text { wywyższająca się ponad innych; młoda; } \\
\text { heteroseksualna; zmęczona mrzonkami } \\
\text { politycznymi; trwała w wyznawanych } \\
\text { zasadach; liberalna; upolityczniona }\end{array}$ & 68 & 23,05 & 37 & 58,73 \\
\hline
\end{tabular}




\begin{tabular}{|c|c|c|c|c|c|c|}
\hline \multirow{2}{*}{ lp. } & \multirow{2}{*}{$\begin{array}{c}\text { cecha } \\
\text { wizerunkowa }\end{array}$} & \multirow{2}{*}{ warianty leksykalne } & \multicolumn{2}{|c|}{ wskazania } & \multicolumn{2}{|c|}{ osoby } \\
\hline & & & $\mathbf{n}$ & $\%$ & $\mathbf{n}$ & $\%$ \\
\hline 22. & inne & $\begin{array}{l}\text { niepopierająca zapatrzenia w politykę; } \\
\text { widzi skrajne oblicza państwa; zwo- } \\
\text { lenniczka lewicy; lewaczka; lewicowa; } \\
\text { interesująca się sprawami społeczeń- } \\
\text { stwa polskiego; interesuje się polityką; } \\
\text { pewna siebie oraz wiarygodna }\end{array}$ & & & & \\
\hline & & razem & 295 & 100,00 & & \\
\hline
\end{tabular}

Źródło: opracowanie własne

Osobom nieznającym autorki tekstu Magdalena Środa jawi się przede wszystkim (zob. tabela 27) jako kobieta „dosadnie prezentująca swoje odważne sądy" - to zdecydowanie dominująca cecha, wskazana 42 razy $(14,24 \%)$ przez niespełna połowę respondentów (29 osób - 46,03\%). Kolejne wysoko manifestowane cechy, lecz wynotowywane już tylko przez ok. 1/3 czytelników, to „inteligentna” (21 - 7,12\% wskazań; 21 - 33,33\% osób), „krytyczna” (18 - 6,10\%; 18 - 28,57\%), ,ironiczna” (20 - 6,78\%, 19 - 30,16\%). Atrybut „zaangażowana" występuje na piątym miejscu, ale z liczbą wskazań już o $1 / 3$ mniejszą (14 - 4,75\%), dokonaną przez $1 / 5$ respondentów (13 - 20,63\%). Czytelnicy uważają też felietonistkę za "zabawną" (11 - 3,73\%; 10 - 15,87\%) i „dociekliwą" (10 - 3,39\%; 10 - 15,87\%), „znawczynię tematu” ( 9 - 3,05\%; 8 - 12,70\%). Ciekawe, że świadczący o subiektywizmie antyklerykalizm filozofki („antyklerykalna”) ma prawie takie same wyniki, jak „obiektywna” postawa (odpowiednio wskazania: 9 - 3,05\% i 8 - 2,71\%; osoby: po 8 - 12,70\%). Po 7 wskazań (2,37\%) odnotowały cechy: „wykształcona”, „dokładana”, „ciekawie pisząca”, „realistka”, "subiektywna” (wynotowane przez 7 uczestników badania - 11,11\%, z wyjątkiem „ciekawie pisząca”: 6 - 9,52\% osób). Marginalne pod względem ilościowym znaczenie mają takie cechy, jak: „feministka” i „szczera” (po 6 - 2,03\% wskazań; 6 - 9,52\% osób), „spostrzegawcza” i „przeciwniczka PiS” (po 5 - 1,36\% i odpowiednio: $4-6,35 \%$ oraz $5-7,94 \%$ osób), a na końcu „empatyczna” i „oczytana” (po $4-1,36 \% ; 4-6,35 \%$ ).

Bliższe przyjrzenie się tym danym pozwala zauważyć korespondencje semantycznie między niektórymi cechami. Tak np. „dosadnie przedstawiająca swoje odważne sądy” może łączyć się znaczeniowo z „krytyczna”, „ironiczna” czy nawet „subiektywna”, a ,inteligentna” ze „spostrzegawcza”. Pewne podobieństwa można też dostrzec między cechami wyrażającymi kompetencje, takimi jak: „znawca tematu”, „wykształcona” i „oczytana” albo między tymi dotyczącymi sposobu analizy, czyli: „dociekliwa” i „dokładna”. Możliwe, że przypisywane zaangażowanie („zaangażowana”) należałoby łączyć z konkretnymi 
jego realizacjami w postaci takich cech wizerunkowych, jak „, antyklerykalna”, „feministka” czy „przeciwniczka PiS”, a „ciekawie pisząca” jest cechą wspieraną przez „zabawna” i „ironiczna”. Chociaż daleko skojarzone, to jednak połączone semantycznie wydają się atrybuty „obiektywna” i „realistka”. W takim układzie poza grupami semantycznymi pozostałyby tylko „szczera” i „empatyczna", co też wskazywałoby na wyrazistość wizerunku, jeśli mierzyć ją liczbą cech wizerunkowych poza zbiorami bliskich sobie znaczeniowo atrybutów.

Gdyby więc syntetycznie określić wizerunek werbalny anonimowej Magdaleny Środy, to jest osobą o bardzo jasno zaznaczonej, często krytycznej postawie, inteligentną i dowcipną, przy tym zaangażowaną społecznie/politycznie oraz wykształconą.

Łatwo zauważyć, że najliczniej reprezentowane cechy - jak: „dosadnie przedstawiająca swoje odważne sądy”, „inteligentna”, „krytyczna”, „ironiczna” "zabawna”, „znawca tematu” - powielają się z takimi samymi przymiotami, znanymi już z czołówki wskazań dotyczących Krzysztofa Vargi i Piotra Zaremby. Mając na uwadze wizerunek Magdaleny Środy, zauważyć należy, że występują one w różnych proporcjach i towarzyszą im nieco inne, rzadziej wskazywane cechy. O ile „inteligentny”, „,ironiczny” i „ciekawie piszący" to pierwsze trzy przypisane Krzysztofowi Vardze, o tyle u Piotra Zaremby to "dosadnie przekazujący swoje odważne sądy”, „krytyczny”, „znawca tematu”, a u Magdaleny Środy „dosadnie przekazująca swoje odważne sądy”, „krytyczna”, „inteligentna”. Relacje ilościowe między cechami też są różne. Bywa, że trzy (Varga) lub jedna (Środa) wyraźnie dominują nad innymi, ale bywa też, że relatywnie mało wskazań dotyczy kilku pierwszych (Zaremba). Zagadnienie to zostawiamy do obserwacji analitycznej, próbując sformułować rozstrzygające ustalenia na koniec analiz, tj. w trakcie omawiania rezultatów dotyczących Szymona Hołowni.

„Dosadnie przekazujący swoje odważne sądy” wskazało 29 osób 42 razy, więc cecha ta dublowała się w odpowiedziach respondentów, tj. jeden czytelnik wskazywał ją więcej niż raz. Powtarza się zatem schemat, gdzie złożona i trudna do wyrażenia cecha charakteryzuje się dużą wariantywnością leksykalną, będącą rezultatem poszukiwań przez czytelnika odpowiedniego słowa na daną cechę wizerunkową felietonisty/-tki. Zaznaczyć przy tym należy, że bez względu na to, czy weźmiemy pod uwagę liczbę wskazań czy (mniejszą) liczbę osób ich dokonujących, to omawiana cecha wizerunkowa pozostaje w przypadku Magdaleny Środy wyraźnie dominująca i kolejną na liście („inteligentny") dwukrotnie rzadziej wynotowywało (21 razy - 7,12\%) znacznie mniej osób (21 - 33,33\%). 
Tabela 28. Kategorie komunikowanego werbalnie wizerunku anonimowego felietonisty - Magdaleny Środy

\begin{tabular}{|c|c|c|c|c|c|c|c|c|c|c|}
\hline lp. & $\begin{array}{l}\text { poglądy } \\
\text { /wartości }\end{array}$ & $\mathbf{n}$ & wiedza & $\mathbf{n}$ & postawa & $\mathbf{n}$ & $\begin{array}{c}\text { cecha } \\
\text { charakteru }\end{array}$ & $\mathbf{n}$ & $\begin{array}{l}\text { sposób } \\
\text { komu- } \\
\text { nikacji }\end{array}$ & $\mathbf{n}$ \\
\hline 1. & $\begin{array}{l}\text { antykle- } \\
\text { rykalna }\end{array}$ & 9 & $\begin{array}{l}\text { znawca } \\
\text { tematu }\end{array}$ & 9 & $\begin{array}{l}\text { dosadnie } \\
\text { przedsta- } \\
\text { wiająca } \\
\text { swoje od- } \\
\text { ważne sądy }\end{array}$ & 42 & inteligentna & 21 & $\begin{array}{l}\text { ciekawie } \\
\text { pisząca }\end{array}$ & 7 \\
\hline 2. & $\begin{array}{l}\text { feminist- } \\
\text { ka }\end{array}$ & 6 & $\begin{array}{l}\text { wykształ- } \\
\text { cona }\end{array}$ & 7 & krytyczna & 18 & zabawna & 11 & & \\
\hline 3. & $\begin{array}{l}\text { przeciw- } \\
\text { niczka } \\
\text { PiS }\end{array}$ & 5 & oczytana & 4 & ironiczna & 20 & szczera & 6 & & \\
\hline 4. & & & & & $\begin{array}{l}\text { zaangażo- } \\
\text { wana }\end{array}$ & 14 & $\begin{array}{l}\text { empatycz- } \\
\text { na }\end{array}$ & 4 & & \\
\hline 5. & & & & & dociekliwa & 10 & & & & \\
\hline 6. & & & & & obiektywna & 8 & & & & \\
\hline 7. & & & & & dokładna & 7 & & & & \\
\hline 8. & & & & & realistka & 7 & & & & \\
\hline 9. & & & & & $\begin{array}{l}\text { subiektyw- } \\
\text { na }\end{array}$ & 7 & & & & \\
\hline 10. & & & & & $\begin{array}{l}\text { spostrze- } \\
\text { gawcza }\end{array}$ & 5 & & & & \\
\hline & razem & 20 & & 20 & & 138 & & 42 & & 7 \\
\hline
\end{tabular}

Źródło: opracowanie własne

Kategorie wizerunku komunikowanego werbalnie (tabela 28), wyznaczone na podstawie odpowiedzi respondentów czytających anonimowy tekst Magdaleny Środy, nie wprowadzają wiele nowego do dotychczasowych ustaleń. Tak samo jak u Piotra Zaremby, także i tutaj pojawia się obszar image’u „poglądy/wartości”, który tym razem wykazuje się wyższą reprezentacją (u publicysty „W Sieci” - 12 wskazań, u felietonistki - 20), co może wynikać ze sprofilowania tematycznego tekstu. Filozofka zajmuje się problemami społeczno-politycznymi, które generują ekspresję poglądów i wartości wypowiadającego dużo bardziej niż ocena filmów, spektakli czy programów telewizyjnych. Cechą wspólną dla wszystkich autorów jest także wyraźna dominacja „postawy”, znacznie wyprzedzającej „cechy charakteru”. Na trzecim miejscu pod względem łącznej liczby wynotowań dotyczących danej kategorii podobnie jak 
w omawianych wcześniej przypadkach, znajduje się „wiedza”, choć w przypadku Magdaleny Środy ex aequo z „poglądami/wartościami” i z nieco większą liczbą wskazań niż u poprzednika.. Niezmiennie najmniej licznie wskazywano na „sposób komunikacji”.

\subsubsection{Magdalena Środa - wizerunek publiczny}

Na 126 osób, odpowiadających na pytanie: „Czy zna Pan/Pani nazwisko: Magdalena Środa? Proszę zakreślić swoją odwiedź krzyżykiem”, 77 zaznaczyło „NIE. Jeśli nie, proszę schować kartkę do teczki”, zaprzeczając tym samym faktowi znajomości Magdaleny Środy, 49 wskazało „TAK. Jeśli tak, proszę przejść do pytania nr 2" i następnie otrzymało zadanie w postaci pytania: „Jakimi słowami scharakteryzował(a)by Pan/Pani osobę publiczną Magdalenę Środę?”. Jeden z uczestników badania nie wypisał żadnej cechy felietonistki, 4 osoby wskazały jedno określenie, 6 po dwa, 5 respondentów po trzy przymioty, 8 po cztery, a pozostali, czyli 25 osób, po pięć epitetów, co dało łącznie 188 wskazań, skategoryzowanych w 11 spójnych kategorii.

Tabela 29. Zestawienie odpowiedzi osób potwierdzających znajomość osoby publicznej Magdaleny Środy na pytanie „Jakimi słowami scharakteryzował(a)by Pan/Pani osobę publiczną Magdalenę Środę?"

\begin{tabular}{|c|c|c|c|c|c|c|}
\hline \multirow{2}{*}{ lp. } & \multirow{2}{*}{$\begin{array}{c}\text { cecha } \\
\text { wizerunkowa }\end{array}$} & \multirow{2}{*}{ warianty leksykalne } & \multicolumn{2}{|c|}{ wskazania } & \multicolumn{2}{|c|}{ osoby } \\
\hline & & & $\mathbf{n}$ & $\%$ & $\mathbf{n}$ & $\%$ \\
\hline 1. & $\begin{array}{l}\text { dosadnie } \\
\text { przekazująca } \\
\text { swoje } \\
\text { odważne } \\
\text { sądy }(0)\end{array}$ & $\begin{array}{l}\text { odważna (4); zadufana, wierząca } \\
\text { w swoją nieomylność; mająca swoje } \\
\text { zdanie na każdy temat; pewna swoich } \\
\text { przekonań (2); pewna siebie; posiadają- } \\
\text { ca własny punkt widzenia; ma określo- } \\
\text { ne poglądy; jednoznaczne poglądy; nie } \\
\text { boi się mówić, co myśli; wypowiadająca } \\
\text { swoje zdanie bez obaw; mówi wprost } \\
\text { na tematy trudne medialnie; radykalna; } \\
\text { mająca radyklane poglądy w niektórych } \\
\text { sprawach; radykalna w swoich opi- } \\
\text { niach; kontrowersyjna (8); wzbudzają- } \\
\text { ca kontrowersje; kontrowersyjna w nie- } \\
\text { których środowiskach; bezpośrednia; } \\
\text { jest bezpośrednia; zdecydowana (2), } \\
\text { walcząca; walcząca o swoje; nietoleru- } \\
\text { jąca modeli życia innych niż jej własne; } \\
\text { despotyczna; stanowcza; stała w swoich } \\
\text { przekonaniach }\end{array}$ & 51 & 27,13 & 37 & 75,51 \\
\hline
\end{tabular}




\begin{tabular}{|c|c|c|c|c|c|c|}
\hline \multirow{2}{*}{ lp. } & \multirow{2}{*}{$\begin{array}{c}\text { cecha } \\
\text { wizerunkowa }\end{array}$} & \multirow{2}{*}{ warianty leksykalne } & \multicolumn{2}{|c|}{ wskazania } & \multicolumn{2}{|c|}{ osoby } \\
\hline & & & $\mathbf{n}$ & $\%$ & $\mathbf{n}$ & $\%$ \\
\hline 2. & $\begin{array}{l}\text { feministka } \\
\text { (15) }\end{array}$ & $\begin{array}{l}\text { feministka wojująca; przedstawicielka } \\
\text { nurtu feministycznego; walczy o prawa } \\
\text { kobiet, aktywistka (2); aktywna (2); } \\
\text { kobieta czynu (2); zaangażowana (2); } \\
\text { oddana swojej sprawie, zaangażowana } \\
\text { społecznie, niezależna, działaczka }\end{array}$ & 30 & 15,96 & 19 & 38,78 \\
\hline 3. & $\begin{array}{l}\text { inteligentna } \\
(14)\end{array}$ & intelektualistka (2), mądra & 17 & 9,04 & 17 & 34,69 \\
\hline 4. & naukowiec & $\begin{array}{l}\text { profesor (2), wykładowczyni UW; } \\
\text { humanistka (2); badaczka polskiego } \\
\text { społeczeństwa; socjolog; }\end{array}$ & 8 & 4,26 & 5 & 10,20 \\
\hline 5. & filozof (2) & $\begin{array}{l}\text { filozof (dla p. Środy - filozofka); } \\
\text { filozofka; znana polska filozof }\end{array}$ & 5 & 2,66 & 5 & 10,20 \\
\hline 6. & $\begin{array}{l}\text { związana } \\
\text { z polityką }\end{array}$ & $\begin{array}{l}\text { polityk?; polityk; niekompetentna na } \\
\text { stanowisko polityka; zaangażowana } \\
\text { politycznie }\end{array}$ & 5 & 2,66 & 5 & 10,20 \\
\hline 7. & lewicowa (2) & $\begin{array}{l}\text { wojowniczka lewicy; poglądy lewicowe, } \\
\text { laickie; lewa strona medalu }\end{array}$ & 5 & 2,66 & 5 & 10,20 \\
\hline 8. & medialna (2) & $\begin{array}{l}\text { medialna (lubi udzielać wywiadów); } \\
\text { znana (2) }\end{array}$ & 5 & 2,66 & 5 & 10,20 \\
\hline 9. & otwarta (4) & & 4 & 2,13 & 4 & 8,16 \\
\hline 10. & wyważona & rozsądna; opanowana; spokojna/prawa & 4 & 2,13 & 4 & 8,16 \\
\hline 11. & $\begin{array}{l}\text { znawca te- } \\
\text { matu }(0)\end{array}$ & $\begin{array}{l}\text { rzetelnie przekazuje informacje na dany } \\
\text { temat; wie, o czym mówi; wykształcona; } \\
\text { potrafi dowodzić swoich racji }\end{array}$ & 4 & 2,13 & 4 & 8,16 \\
\hline 12. & inne & $\begin{array}{l}\text { konserwatywna; niepostępowa; } \\
\text { uprzejma; miła; uparta; elokwentna; } \\
\text { częściowo oderwana od realiów życia; } \\
\text { osoba o trudnym charakterze; chłodna; } \\
\text { charakterystyczne nazwisko; szczera; } \\
\text { zakompleksiona; manie; okno; kom- } \\
\text { bajn; wypowiada się na tematy etyczne; } \\
\text { ką́liwa; oczytana; poważna; ceniona; } \\
\text { kobieta sukcesu; prawdziwa; kobieta; } \\
\text { lubiąca dyskusje; przebojowa; preten- } \\
\text { sjonalna; przeciętnej urody; pogodna; } \\
\text { osoba prymitywna; konformistka; dow- } \\
\text { cipna; utalentowana; chroni swoja pry- } \\
\text { watność; chytra; nie do końca znająca } \\
\text { temat, którym się zajmuje }\end{array}$ & 50 & 26,60 & 34 & 69,39 \\
\hline
\end{tabular}


Tabela 29 (cd.)

\begin{tabular}{|l|l|l|c|c|c|c|}
\hline \multirow{2}{*}{ lp. } & \multirow{2}{*}{$\begin{array}{c}\text { cecha } \\
\text { wizerunkowa }\end{array}$} & \multicolumn{2}{|c|}{ warianty leksykalne } & \multicolumn{2}{|c|}{ wskazania } & \multicolumn{2}{c|}{ osoby } \\
\cline { 3 - 6 } 12. & inne & $\begin{array}{l}\text { chrześcijanka; wiecznie niezadowo- } \\
\text { lona; konserwatywna; niepostępowa; } \\
\text { uprzejma; miła; znam to nazwisko, ale } \\
\text { nie jestem pewna, czy dobrze kojarzę tę } \\
\text { osobę; niestety, kojarzę jej osobę, ale nie } \\
\text { na tyle, by ją opisać. Jest mi obojętna }\end{array}$ & $\mathbf{n}$ & $\mathbf{n}$ & $\%$ \\
\hline & razem & $\mathbf{1 8 8}$ & $\mathbf{1 0 0 , 0 0}$ & & \\
\hline
\end{tabular}

Źródło: opracowanie własne

Chociaż w wizerunku publicznym Magdaleny Środy trzy cechy - mimo zróżnicowania ilościowego między sobą - wyraźnie dominują, oddzielone od reszty zdecydowanie wyższą liczbą wskazań i osób ich dokonujących, to „dosadnie przekazująca swoje odważne sądy” znajduje się na szczycie listy z rekordowym wynikiem 51 wynotowań $(27,13 \%) 37$ respondentów (to aż $75,51 \%$ wszystkich udzielających odpowiedzi). Na drugim miejscu znajduje się „feministka” również z wysoką liczbą wskazań (30 - 12,96\%) i liczbą respondentów ich dokonujących $(19-38,78 \%)$. W końcu w trójce najczęściej podawanych cech mieści się także „inteligentna” (17 - 9,04\%), wynotowana 17 razy $(9,04 \%)$ przez taką samą liczbę uczestników (17 - 34,69\%). Kolejną grupę cech stanowią atrybuty przypisane przez nieco ponad $10 \%$ respondentów (5 - 10,20\%), a wśród nich cecha wskazana 8 razy $(4,26 \%)$ - „naukowiec” oraz pozostałe, wynotowane po 5 razy (2,66\%): „filozof”, „związana z polityką", „lewicowa”, „medialna”. Zatem w pierwszej ósemce cech znajdują się głównie te związane z określaniem profesji bądź poglądów/wartości, nieco mniejsze znaczenie mają wypisane 4 razy $(2,13 \%)$ przez 4 osoby $(8,16 \%)$ przymioty: „otwarta”, „wyważona”, „znawca tematu”.

W wizerunku publicznym Magdaleny Środy zdecydowanie największe znaczenie ma więc wyraźnie polemiczna postawa felietonistki, ale także jej poglądy feministyczne i inteligencja. Być może właśnie feministyczne poglądy spowodowały wyjątkowo częste przypisywanie cechy „dosadnie wyrażająca swoje odważne sądy", ale lepiej, by dane z kolejnych wizerunków pomogły potwierdzić lub obalić tę interpretację. Jeśli zwrócić uwagę na kolejne przypisywane jej atrybuty, to mimo rozproszenia, da się zaważyć silną manifestację cech komunikujących profesję („naukowiec”, „filozof”), kojarzoną tu również zapewne $\mathrm{z}$ orientacją w poruszanych tematach („znawca tematu), a także postawę ideową, wyrażaną ogólną cechą „związana z polityką”, ale też 
wykazującą się większą konkretyzacją: „lewicowa”, która w pewnym sensie uzupełnia częściej wskazywaną „feministkę”. Tak więc wizerunek publiczny Magdaleny Środy należałoby zdefiniować jako mieszankę dosadnego formułowania swoich odważnych i inteligentnych sądów z lewicową, feministyczną postawą ideową i wykonywanym zawodem.

Oprócz wspomnianych wyżej bloków semantycznych da się także wyróżnić inne, choć tutaj bardziej niż w przypadku pozostałych felietonistów zazębiają się one ze sobą. „Naukowiec" i „filozof” mogą bowiem wskazywać na zawód i pewną medialną etykietę, i wówczas należałoby je łączyć $\mathrm{z}$ „medialna” (naukowiec i filozof pojawiający się w mediach). $\mathrm{Z}$ drugiej, te dwie pierwsze etykiety mogą wskazywać na wykształcenie i kompetencje, wówczas tworzyłyby blok semantyczny wspólnie ze „znawca tematu”. Możliwe, że „wyważona” to duet z „obiektywna”. Być może „inteligentna” i „otwarta” także mają wiele wspólnego, chociaż „otwarta” może się wiązać również w poglądami („feministka”, „lewicowa”). Jeśli blokami semantycznymi mierzyć wyrazistość i spójność wizerunku, to można je jak najbardziej przypisać image’owi Magdaleny Środy.

Zauważyć jednak należy, że casus tej felietonistki uwypukla słabe strony definiowania bloków semantycznych jako sposobu analizy wizerunku. Po pierwsze, wtedy gdy dane cechy wizerunkowe nie są jednoznaczne, mogą wchodzić w zakres kilku grup semantycznych, co utrudnia jasne określenie image’u, gdyby np. chcieć oszacować ilościowo wskazania w każdej z grup semantycznych. Po drugie, trudne jest określenie klarownego kryterium przynależności do danego zespołu cech. Czasami skojarzenia są dość odległe, a granica tej odległości bardzo elastyczna, co naraża na zarzut o swobodność prowadzonych kategoryzacji i budzi wątpliwości co do rzetelności. Nie da się jednak zaprzeczyć, że takie bloki semantyczne są widoczne i istotne dla wizerunku oraz pozwalają lepiej zauważyć najważniejsze cechy felietonistów. Wynikają przy tym zapewne z daleko idącej wariantywności leksykalnej, charakteryzującej respondentów, a także $\mathrm{z}$ tego, że każdy z nich ma prawo przesunąć punkt ciężkości zauważonej cechy wizerunkowej na inny jej aspekt, co ma konsekwencje w odmiennych wyborach słownikowych. Analizy kolejnych wizerunków być może ułatwią określenie zasadności i sposób funkcjonowania zespołów cech o podobnej semantyce.

Porównując wyniki wizerunku publicznego Magdaleny Środy z analogicznymi Krzysztofa Vargi i Piotra Zaremby, zauważyć należy, że w każdym z tych przypadków pierwsze 2-3 cechy wyraźnie dominują nad innymi. Mimo większej liczby osób określających wizerunek publicystki (49, Varga - 11, Zaremba - 19 respondentów), wskazano porównywalną liczbę cech wizerunkowych: u felietonistki 11, u poprzedników 8 (publicysta „Dużego Formatu”) i 9 (dziennikarz „W Sieci”). Możliwe, że w konstrukcji tego wizerunku biorą 
udział najlepiej zapamiętane cechy publicystów, a ich ze względu na pojemność pamięci nie może być zbyt wiele i zachowują się te najbardziej wyraziste.

Podobnie jak u Piotra Zaremby, także i tutaj pojawia się cecha wizerunkowa „osoba medialna” niemal na równi z „naukowiec” czy „filozof”. Sama obecność w mediach może więc wyróżniać nawet osobę o rozpoznawalnych poglądach i zawodzie.

Tabela 30. Kategorie wizerunku publicznego Magdaleny Środy

\begin{tabular}{|l|l|l|l|l|l|l|l|l|l|l|}
\hline lp. & zawód & $\mathbf{n}$ & $\begin{array}{l}\text { poglądy/ } \\
\text { wartości }\end{array}$ & $\mathbf{n}$ & wiedza & $\mathbf{n}$ & postawa & $\mathbf{n}$ & $\begin{array}{c}\text { cecha } \\
\text { charakteru }\end{array}$ & $\mathbf{n}$ \\
\hline 1. & naukowiec & 8 & $\begin{array}{l}\text { feministka } \\
(15)\end{array}$ & 30 & $\begin{array}{l}\text { znawca } \\
\text { tematu } \\
(0)\end{array}$ & 4 & $\begin{array}{l}\text { dosadnie } \\
\text { przekazu- } \\
\text { jąca swoje } \\
\text { odważne } \\
\text { sądy (0) }\end{array}$ & 51 & $\begin{array}{l}\text { inteligentna } \\
(14)\end{array}$ & 17 \\
\hline 2. & filozof (2) & 5 & $\begin{array}{l}\text { związana } \\
\text { z polityką }\end{array}$ & 5 & & & $\begin{array}{l}\text { otwarta } \\
(4)\end{array}$ & 4 & & \\
\hline 3. & $\begin{array}{l}\text { medialna } \\
(2)\end{array}$ & 5 & $\begin{array}{l}\text { lewicowa } \\
(2)\end{array}$ & 5 & & & wyważona & 4 & & \\
\hline \multicolumn{2}{|l|}{ razem } & $\mathbf{1 8}$ & & $\mathbf{4 0}$ & & $\mathbf{4}$ & & $\mathbf{5 9}$ & \\
\hline
\end{tabular}

Źródło: opracowanie własne

Jeśli przyjrzeć się kategoriom wizerunku publicznego (tabela 30), to głównie za sprawą cechy „dosadnie przekazująca swoje odważne sądy” najwyżej reprezentowany jest obszar „postawa”, na drugim miejscu „poglądy/wartości”, a na trzecim i czwartym odpowiednio „zawód” i „cechy charakteru”, choć różnią się ilościowo tylko jednym wskazaniem (odpowiednio: 18 i 17). Na końcu uplasowała się ,wiedza”.

Wszystkie kategorie są tożsame z tymi znanymi już z badań wizerunku publicysty „W Sieci”, chociaż w innych proporcjach. Po raz pierwszy do tej pory (tj. na tle wyników Krzysztofa Vargi i Piotra Zaremby) „zawód” został zepchnięty z pierwszej na daleką trzecią pozycję, a zdecydowaną przewagę nad innymi obszarami image'u publicznego ma „postawa”. Po raz pierwszy też "poglądy/wartości” są tak wysoko reprezentowane i zajmują nie trzecią, ale silną drugą pozycję na liście wskazań (celowo nie porównuje się tutaj konkretnych liczb ze względu na różną liczbę respondentów udzielających odpowiedzi: 19 - Piotra Zaremba, 49 - Magdalena Środa). Tak wysokie rezultaty obu ostatnich z tych kategorii można tłumaczyć tematyką społeczno-polityczną podejmowaną w wypowiedziach medialnych Magdaleny Środy, która generuje prezentowanie swoich przekonań i sposobu podejścia do omawianych kwestii. 
To by też wskazywało na wpływ image’u werbalnego na publiczny. Wspierają tę interpretację też inne wyniki. Wiele cech bowiem występuje zarówno w wizerunku werbalnym anonimowej felietonistki, jak i w jej image'u publicznym (dosłownie powtarzają się: „dosadnie przekazująca swoje odważne sądy”, „inteligentna”, „feministka”, „znawca tematu”, do analogicznych można zaliczyć: „wykształcona” i „naukowiec”, „filozof”), choć oczywiście tradycyjnie nie dublują się (dosłownie) cechy z kategorii specyficznych dla poszczególnych wizerunków - czyli dla wizerunku publicznego „zawód” oraz dla werbalnego „sposób komunikacji”. Wykazano już wpływ wizerunku werbalnego na publiczny, a raczej werbalnego i wizualnego jednocześnie, dlatego dalsze rozważana na temat determinant image'u publicznego zamieszczono w stosownych rozdziałach (podsumowanie - rozdz. 2.4.5. Zależności między poszczególnymi typami wizerunków Magdaleny Środy).

\subsubsection{Magdalena Środa - wizerunek wizualny}

Pytanie: „Mając za podstawę przedstawione zdjęcie, jakimi słowami opisałby Pan / opisałaby Pani przedstawioną na tej fotografii osobę? (na zdjęciu Magdalena Środa) zadano 63 osobom, które podały różne określenia felietonistki w reakcji na to samo jej zdjęcie (zob. zdjęcie z tabeli 6). Po wykonaniu tego zadania zapytano także: „Czy wie Pan/Pani, kogo przedstawia zdjęcie?”, dając do wyboru trzy odpowiedzi: 1) „TAK, kogo?...”, 2) Nie jestem pewny/pewna, ale wydaje mi się, że może to być (kto?)..., 3) „NIE”. Nikt nie zaznaczył niepewności, co do osoby na zdęciu, za to pozostałe odpowiedzi można podzielić na dwie kategorie: tych, którzy rozpoznali Magdalenę Środę, i tych, którzy nie wiedzieli, czyj to portret (zob. zdjęcie przedstawione respondentom w tabeli 6).

By zweryfikować, czy istnieje różnica w konstrukcji wizerunku wizualnego w zakresie tych dwóch grup uczestników badania, odrębnie dla każdej z nich skodowano zebrane dane. Ponieważ 17 osób zadeklarowało, iż wie, kogo przedstawia zdjęcie, i poprawnie wskazało jej tożsamość, a 46 zaprzeczyło takiej wiedzy, to należy wyniki pierwszej z tych grup, ze względu na małą liczebność odpowiedzi, wziąć w nawis - warto na nie spojrzeć, by próbować znaleźć pewne tendencje, ale ani te dane same w sobie, ani zestawienie ich $\mathrm{z}$ rezultatami $\mathrm{z}$ drugiej $\mathrm{z}$ omawianych tu grup nie będą przedmiotem głębokich analiz.

Poprawnie określiło tożsamość Magdaleny Środy 17 osób, z czego 12 wypisało po 5 epitetów, 2 po cztery cechy i 3 respondentów po trzy określenia, co dało łącznie 77 wskazania, skodowane w 12 spójnych cech wizerunkowych. 
Tabela 31. Zestawienie odpowiedzi osób rozpoznających na zdjęciu Magdalenę Środę na pytanie: „Mając za podstawę przedstawione zdjęcie, jakimi słowami opisałby Pan / opisałby Pani przedstawioną na tej fotografii osobę?"

\begin{tabular}{|c|c|c|c|c|c|c|}
\hline \multirow{2}{*}{ lp. } & \multirow{2}{*}{$\begin{array}{c}\text { cecha } \\
\text { wizerunkowa }\end{array}$} & \multirow{2}{*}{ warianty leksykalne } & \multicolumn{2}{|c|}{ wskazania } & \multicolumn{2}{|c|}{ osoby } \\
\hline & & & $\mathbf{n}$ & $\%$ & n & $\%$ \\
\hline 1. & surowa (2) & $\begin{array}{l}\text { sroga (palec podniesiony do góry) } \\
\text { (2); dosyć sroga; władcza (2); budząca } \\
\text { strach; silna; walcząca; rozkazująca; } \\
\text { z mentorskim tonem - wychowująca } \\
\text { innych; mająca autorytet; groźna; kar- } \\
\text { cąca; wiedząca lepiej; rygorystyczna; } \\
\text { wymagająca }\end{array}$ & 18 & 23,38 & 12 & 70,59 \\
\hline 2. & $\begin{array}{l}\text { pewna siebie } \\
\text { (2) }\end{array}$ & $\begin{array}{l}\text { pewna swoich przekonań; stanowcza (2); } \\
\text { zdeterminowana; wyrazista; broniąca } \\
\text { własnego zdania; wierna swoim racjom }\end{array}$ & 9 & 11,69 & 8 & 47,06 \\
\hline 3. & miła (3) & $\begin{array}{l}\text { sympatyczna; na pierwszy rzut oka } \\
\text { nawet sympatyczna; pogodna; optymi- } \\
\text { styczna; uśmiechnięta (2) }\end{array}$ & 9 & 11,69 & 8 & 47,06 \\
\hline 4. & $\begin{array}{l}\text { konkretna } \\
\text { (5) }\end{array}$ & & 5 & 6,49 & 5 & 29,41 \\
\hline 5. & poważna (3) & zamyślona & 4 & 5,19 & 4 & 23,53 \\
\hline 6. & $\begin{array}{l}\text { niesympa- } \\
\text { tyczna (2) }\end{array}$ & niecierpliwa & 3 & 3,90 & 3 & 17,65 \\
\hline 7. & $\begin{array}{l}\text { inteligentna } \\
\text { (2) }\end{array}$ & inteligentny & 3 & 3,90 & 3 & 17,65 \\
\hline 8. & starsza & poczciwa staruszka; w średnim wieku & 3 & 3,90 & 3 & 17,65 \\
\hline 9. & otwarta (2) & & 2 & 2,60 & 2 & 11,76 \\
\hline 10. & $\begin{array}{l}\text { wykształcona } \\
\text { (2) }\end{array}$ & & 2 & 2,60 & 2 & 11,76 \\
\hline 11. & ironiczna & sarkastyczna & 2 & 2,60 & 2 & 11,76 \\
\hline 12. & opanowana & spokojna & 2 & 2,60 & 2 & 11,76 \\
\hline 13. & inne & $\begin{array}{l}\text { z duży dystansem; osoba publiczna/ } \\
\text { filozof; działająca w ruchu feministycz- } \\
\text { nym; chcąca dyskusji na tematy proble- } \\
\text { mowe; chętna do dzielenia się wiedzą } \\
\text { i doświadczeniem; wie, co mówić na } \\
\text { dany temat; świadoma tego, co robi; } \\
\text { goniąca; dba o wygląd; naturalna; } \\
\text { kiepsko ubrana; romantyczna; } \\
\text { irytująca; rodzinna; aktywna }\end{array}$ & 15 & 19,48 & 10 & 58,82 \\
\hline & & razem & 77 & 100,00 & & \\
\hline
\end{tabular}

Źródło: opracowanie własne 
Osoby rozpoznające Magdalenę Środę na zdjęciu, mając za podstawę fotografię, widzą w niej przede wszystkim osobę „surową" - to aż 23,38\% wszystkich wskazań (czyli 18 wynotowań), dokonanych przez 70,59\% osób (12). Ta złożona cecha charakteryzuje się dużą wariantywnością słownikową. $\mathrm{Na}$ drugim miejscu znajduje się cecha korespondująca z pierwszą: „pewna siebie" ( 9 - 11,69\%; 8 - 47,06\%), ale - co ciekawe - na trzecim, z identycznymi wartościami (9 - 11,69\%; 8 - 47,06\%), pojawia się oddalona semantycznie "miła”. Niespełna $1 / 3$ respondentów uznaje felietonistkę za „konkretną" (5 - 6,49\%; 5 - 29,41\%), a niemal 1/4 za "poważną" (4 - 5,19\%, 4 - 23,53\%). Poniżej 4\% wskazań mają „niesympatyczna”, „inteligentna”, „starsza” (po 4 - 5,19\% wynotowań, 3 - 17,65\% respondentów). Tylko po dwie osoby $(11,76 \%)$ określiły kobietę jako „otwartą", „wykształconą”, „ironiczną” i „opanowaną" ( 2 - 2,60\% wskazań). 15 epitetów (19,48\%) nadanych przez 10 osób $(58,82 \%)$ tworzy kategorię „inne”.

Da się zauważyć korespondencje semantyczne między cechami. Tak więc „surowa” łączyć się może z „pewna siebie” i „konkretna”, „poważna” z „opanowana”, natomiast ,inteligentna” $\mathrm{z}$,wykształcona” $\mathrm{i}$ „otwarta”, a „niesympatyczna" $\mathrm{z}$,ironiczna”. Poza tymi zespołami bliskości znaczeniowej pozostawałyby „miła” oraz „starsza”. Jeśli wziąć pod uwagę tak powstałe grupy i ich ilościową reprezentację, to Magdalena Środa jest przede wszystkim kobietą zdecydowaną i surową, ale także miłą i o otwartym umyśle, do tego opanowaną i w mniejszym stopniu niesympatyczną. Zauważyć też się da jej dojrzały wiek.

Tabela 32. Kategorie wizerunku wizualnego Magdaleny Środy w sytuacji rozpoznania przez respondentów osoby ze zdjęcia

\begin{tabular}{|l|l|l|l|l|l|l|l|l|l|l|}
\hline lp. & $\begin{array}{c}\text { stan emo- } \\
\text { cjonalno- } \\
\text {-poznawczy }\end{array}$ & $\mathbf{n}$ & wiedza & $\mathbf{n}$ & postawa & $\mathbf{n}$ & $\begin{array}{c}\text { cecha } \\
\text { charakteru }\end{array}$ & $\mathbf{n}$ & $\begin{array}{c}\text { wiek/ } \\
\text { płeć }\end{array}$ & $\mathbf{n}$ \\
\hline 1. & poważna & 4 & $\begin{array}{l}\text { wykształ- } \\
\text { cona }\end{array}$ & 2 & $\begin{array}{l}\text { pewna } \\
\text { siebie }\end{array}$ & 9 & inteligentna & 3 & starsza & 3 \\
\hline 2. & opanowana & 2 & & & miła & 9 & surowa & 18 & & \\
\hline 3. & & & & & konkretna & 5 & & & & \\
\hline 4. & & & & & $\begin{array}{l}\text { niesympa- } \\
\text { tyczna }\end{array}$ & 3 & & & & \\
\hline 5. & & & & & otwarta & 2 & & & & \\
\hline 6. & & & & & ironiczna & 2 & & & & \\
\hline
\end{tabular}

Źródło: opracowanie własne 
W zakresie kategorii wizerunku możliwego do komunikowania wizualnie w sytuacji rozpoznania osoby ze zdjęcia w przypadku Magdaleny Środy najwyżej manifestowanym aspektem image’u jest „postawa” (30 wskazań), po niej „cechy charakteru” (21), a marginalne znaczenie ilościowe mają „stan emocjonalno-poznawczy” oraz „wiedza” i „wiek/płeć”. Zaskakuje w tym zestawieniu odległa pozycja „stanu emocjonalno-poznawczego", który do tej pory albo znajdował się na pierwszym miejscu (Varga), albo w czołówce na drugim (Zaremba). Możliwe, że zaważyła interferencja wizerunku publicznego i/lub werbalnego („postawa” i „cechy charakteru” też najczęściej zauważane). Pomocą $\mathrm{w}$ interpretacji tych wyników będzie z pewnością uwzględnienie danych z grupy osób nierozpoznających na fotografii Magdaleny Środy.

Na brak znajomości tożsamości osoby ze zdjęcia wskazało 46 respondentów, z czego jedna osoba wypisała 2 cechy, 8 po 3 epitety, kolejnych 8 po 4 określenia, 29 respondentów po 5 przymiotów. Dało to łącznie 203 epitety. Po uwzględnieniu podwójnego kodowania jednego $\mathrm{z}$ nich ${ }^{13}$ analizie poddano 204 wskazania, tworzące 11 spójnych cech wizerunkowych.

Tabela 33. Zestawienie odpowiedzi osób, które zadeklarowały całkowity brak znajomości kobiety ze zdjęcia (Magdalena Środa), na pytanie: „Mając za podstawę przedstawione zdjęcie, jakimi słowami opisałby Pan / opisałby Pani przedstawioną na tej fotografii osobę?"

\begin{tabular}{|l|l|l|l|l|l|l|}
\hline \multirow{2}{*}{ lp. } & \multirow{2}{*}{$\begin{array}{c}\text { cecha } \\
\text { wizerunkowa }\end{array}$} & \multicolumn{1}{|c|}{ warianty leksykalne } & wskazania & \multicolumn{2}{|c|}{ osoby } \\
\cline { 3 - 6 } 1. & $\begin{array}{l}\text { pewny siebie; pewna siebie (wzrok } \\
\text { od razu do kamery); zdecydowana } \\
\text { (8); stanowcza (10); mająca swoje } \\
\text { zdanie (2); mająca swoje bardzo } \\
\text { pewna siebie } \\
\text { mocno określone stanowisko; ma- } \\
\text { jąca własne zdanie; pewna swych } \\
\text { poglądów; mająca określone stano- } \\
\text { wisko w danej kwestii; ma własne } \\
\text { zdanie; posiadająca własne zdanie; } \\
\text { trzymająca się swoich zasad; prze- } \\
\text { konana o swojej wiedzy; wiedząca, } \\
\text { czego chce; zasadami; mocna } \\
\text { kobieta; charakterna; silna osobo- } \\
\text { wość; silna kobieta; silny charak- } \\
\text { ter - osobowość; osoba o mocnej } \\
\text { osobowości; charyzmatyczna }\end{array}$ & 60 & n & 29,41 & \% & 76,09 \\
\hline
\end{tabular}

13 „Ostra, ale sympatyczna” przyporządkowano do dwóch cech wizerunkowych „surowa” i „sympatyczna”. 


\begin{tabular}{|c|c|c|c|c|c|c|}
\hline \multirow{2}{*}{ lp. } & \multirow{2}{*}{$\begin{array}{c}\text { cecha } \\
\text { wizerunkowa }\end{array}$} & \multirow{2}{*}{ warianty leksykalne } & \multicolumn{2}{|c|}{ wskazania } & \multicolumn{2}{|c|}{ osoby } \\
\hline & & & $\mathbf{n}$ & $\%$ & $\mathbf{n}$ & $\%$ \\
\hline 2. & surowa $(10)$ & $\begin{array}{l}\text { asertywna (2); ma coś do po- } \\
\text { wiedzenia (palec); władcza (3); } \\
\text { dominująca; groźna (2); budząca } \\
\text { niepokój; zasadnicza (2); prze- } \\
\text { strzegająca zasad; ostra; ostra, } \\
\text { ale sympatyczna; pouczająca (2); } \\
\text { utrzymująca dyscyplinę; osoba na } \\
\text { zdjęciu chce być postrzegana jako } \\
\text { osoba wzbudzająca autorytet; bu- } \\
\text { dząca respekt; jej gest kojarzy mi } \\
\text { się ze słowami „pamiętaj”, „zwróć } \\
\text { na to uwagę”; sroga; wywyższająca } \\
\text { się; nie znosząca sprzeciwu }\end{array}$ & 31 & 15,20 & 22 & 47,83 \\
\hline 3. & $\begin{array}{l}\text { sympatyczna } \\
(10)\end{array}$ & $\begin{array}{l}\text { ostra, ale sympatyczna; ale również } \\
\text { sympatyczna; ale także sympatycz- } \\
\text { na; miła (6); miła (uśmiechnięta); } \\
\text { uśmiechnięta (3); pogodna (2); } \\
\text { ciepła; życzliwa }\end{array}$ & 27 & 13,24 & 25 & 54,35 \\
\hline 4. & inteligentna (6) & mądry; mądra & 8 & 3,92 & 8 & 17,39 \\
\hline 5. & $\begin{array}{l}\text { doświadczo- } \\
\text { na (7) }\end{array}$ & & 7 & 3,43 & 7 & 15,22 \\
\hline 6. & $\begin{array}{l}\text { niesympa- } \\
\text { tyczna }(2)\end{array}$ & $\begin{array}{l}\text { niemiła; niemiły; niecierpliwa; } \\
\text { nieprzyjemna }\end{array}$ & 6 & 2,94 & 5 & 10,87 \\
\hline 7. & $\begin{array}{l}\text { z poczuciem } \\
\text { humoru }(2)\end{array}$ & dowcipna (2) & 4 & 1,96 & 4 & 8,70 \\
\hline 8. & pomocna (3) & udzielająca dobrej rady (1) & 4 & 1,96 & 4 & 8,70 \\
\hline 9. & konkretna (4) & & 4 & 1,96 & 4 & 8,70 \\
\hline 10. & rozważna (2) & $\begin{array}{l}\text { stąpająca twardo po ziemi; } \\
\text { rozsądna }\end{array}$ & 4 & 1,96 & 4 & 8,70 \\
\hline 11. & $\begin{array}{l}\text { starsza kobie- } \\
\operatorname{ta}(2)\end{array}$ & $\begin{array}{l}\text { kobieta w średnim wieku; } \\
\text { osoba dojrzała }\end{array}$ & 4 & 1,96 & 4 & 8,70 \\
\hline 12. & inne & $\begin{array}{l}\text { krytyczna; niezadowolona; pra- } \\
\text { cowita; sumienna; złośliwa; iro- } \\
\text { niczna; opanowana (2); spokojna; } \\
\text { obiektywna (2); sprawiedliwa; } \\
\text { otwarta (2); zadbana (2); ambitna } \\
\text { (2); mogłabym jej zaufać; wzbudza } \\
\text { zaufanie; energiczna; pełna wigo- } \\
\text { ru; wykształcona; typ pracownika } \\
\text { akademickiego bądź polityka; } \\
\text { zmartwiona (oczy); fałszywa; za- } \\
\text { rozumiała; głupia; konfliktowa; } \\
\text { wyrozumiała; szczera; zamknięta na } \\
\text { dyskusję; elegancka; nieelokwentna }\end{array}$ & 45 & 22,06 & 28 & 60,87 \\
\hline
\end{tabular}


Tabela 33 (cd.)

\begin{tabular}{|c|c|c|c|c|c|c|}
\hline \multirow{2}{*}{ lp. } & \multirow{2}{*}{$\begin{array}{c}\text { cecha } \\
\text { wizerunkowa }\end{array}$} & \multirow{2}{*}{ warianty leksykalne } & \multicolumn{2}{|c|}{ wskazania } & \multicolumn{2}{|c|}{ osoby } \\
\hline & & & $\mathbf{n}$ & $\%$ & $\mathbf{n}$ & $\%$ \\
\hline 12. & inne & $\begin{array}{l}\text { rzadko uśmiecha się; dobry mówca; } \\
\text { elokwentna; trzyma rękę na pulsie; } \\
\text { poważny; pogardliwy; wyluzowana; } \\
\text { zła; elegancka; odpowiedzialna }\end{array}$ & & & & \\
\hline & & razem & 204 & 100,00 & & \\
\hline
\end{tabular}

Źródło: opracowanie własne

Dla tych, którzy nie rozpoznali felietonistki, kobieta ze zdjęcia to osoba głównie „pewna siebie”, na co wskazuje najwięcej - 60 (29,41\%) - wynotowań tej cechy wizerunkowej, dokonanych przez ponad 3/4 respondentów tej grupy (36 - 76,09\%). Niemal połowę mniej wskazań ma „surowa” (31 - 15,20\%; 22 - 47,83\% osób). Obie cechy charakteryzują się dużą wariantywnością leksykalną, co zapewne - jak w innych tego typu przypadkach - wynika z trudności w znalezieniu odpowiedniego słowa na określenie złożonej cechy wizerunkowej. Do trzeciej z najczęściej wypisywanych cech zalicza się - odbiegający od dwóch pierwszych semantycznie - atrybut „sympatyczna” (27 - 13,24\% wskazań; 25 - 54,35\% osób). Pozostałe cechy wizerunkowe od tych trzech dzieli bardzo duży dystans ilościowy. „Inteligentna” to tylko 8 - 3,92\% wskazań (8 - 17,39\% osób), „doświadczona” 7 - 3,43\% wynotowań i 7 - 15,22\% respondentów, „niesympatyczna” - $6-2,94 \%$ wypisanych cech i 5 - 10,87\% uczestników badania w tej grupie. Kolejne cechy wizerunkowe nie przekraczają dwuprocentowego progu wskazań: „z poczuciem humoru”, „pomocna”, „konkretna”, „rozważna”, „starsza kobieta” (po $4-1,96 \% ; 4-8,70 \%$ ).

Tabela 34. Kategorie wizerunku wizualnego Magdaleny Środy w sytuacji braku rozpoznania przez respondentów tożsamości osoby ze zdjęcia

\begin{tabular}{|l|l|l|l|c|l|c|l|l|}
\hline lp. & \multicolumn{1}{|c|}{ wiedza } & $\mathbf{n}$ & \multicolumn{1}{|c|}{ postawa } & $\mathbf{n}$ & $\begin{array}{c}\text { cecha } \\
\text { charakteru }\end{array}$ & $\mathbf{n}$ & \multicolumn{1}{|c|}{ wiek } & $\mathbf{n}$ \\
\hline 1. & doświadczona & 7 & pewna siebie & 60 & surowa & 31 & $\begin{array}{l}\text { starsza } \\
\text { kobieta }\end{array}$ & 4 \\
\hline 2. & & & sympatyczna & 27 & inteligentna & 8 & & \\
\hline 3. & & & niesympatyczna & 6 & $\begin{array}{l}\text { z poczuciem } \\
\text { humoru }\end{array}$ & 4 & & \\
\hline 4. & & & pomocna & 4 & & & & \\
\hline 5. & & & konkretna & 4 & & & & \\
\hline
\end{tabular}




\begin{tabular}{|l|c|c|l|c|c|c|c|c|}
\hline lp. & wiedza & $\mathbf{n}$ & postawa & $\mathbf{n}$ & $\begin{array}{c}\text { cecha } \\
\text { charakteru }\end{array}$ & n & wiek & n \\
\hline 6. & & & rozważna & 4 & & & & \\
\hline \multicolumn{2}{|c|}{ razem } & 7 & & $\mathbf{1 0 5}$ & & $\mathbf{4 3}$ & & 4 \\
\hline
\end{tabular}

Źródło: opracowanie własne

Kategorie wizerunku możliwego do komunikowania na poziomie wizualnym w przypadku Magdaleny Środy i w sytuacji, gdy kobieta na zdjęciu pozostaje dla osoby patrzącej na fotografię anonimowa, wprowadzają pewną istotną zmianę w stosunku do dotychczasowych obserwacji. Otóż, o ile do tej pory obszar „stan emocjonalno-poznawczy” był albo najwyżej reprezentowany, albo przynajmniej obecny i specyficzny dla wizerunku wizualnego, o tyle tym razem w ogóle uczestnicy badania nie wskazali cech, które można by zaliczyć do tego aspektu image’u. Najwyraźniej inne cechy wizerunkowe felietonistki zyskały taką przewagę, że pominięto ten obszar wizerunku. Możliwe, że wykorzystanie gestu podniesionego palca wskazującego skupiło uwagę odbiorców wypowiedzi i wyeliminowało z pola widzenia elementy emocjonalno-poznawcze w procesie konstruowania wizerunku, a przynajmniej zepchnęło je na na tyle daleki plan, że nieuchwytny w przypadku konieczności wybrania pięciu określeń przypisywanych osobie $\mathrm{z}$ fotografii. Bez zmian za to, bowiem podobnie jak w image'u Piotra Zaremby i w wizerunku rozpoznawalnej felietonistki, „postawa” jest kategorią najczęściej zauważaną przez respondentów (tutaj 105 wskazań). Drugi pod względem liczby wynotowań jest aspekt „,cecha charakteru”, ale reprezentuje już o połowę mniejsze wartości (45 wskazań). Pozostałe obszary mają marginalne znacznie ilościowe (wiedza - 7 wskazań, wiek - 4).

Jeśli uwzględnić brane do tej pory dane, to w zakresie wizerunku wizualnego najłatwiej komunikowanymi za pomocą znaków systemu wizualnego, a tym samym najwyżej reprezentowanymi kategoriami są „stan emocjonalno-poznawczy” oraz „postawa”, przy czym pierwsza z nich pojawia się wyłącznie w image'u komunikowanym na poziomie obrazu, a druga ma uniwersalny komunikacyjny charakter i występuje w każdym z omawianych typów image’u.

Także i tutaj da się wyłonić grupy bliskich sobie semantycznie cech wizerunkowych, chociaż wzajemne konfiguracje poszczególnych cech wskazują na inne łączenia. Identycznie, jak w przypadku wizualnego wizerunku rozpoznawalnej Magdaleny Środy, również i tym razem łączą się ze sobą „pewna siebie”, „surowa” i „konkretna” (tabela 35). Jednak już „sympatyczna” (w image’u o nieznanej tożsamości „miła”) nie pozostaje w izolacji, ale tworzy blok znaczeniowy z „pomocna” i „z poczuciem humoru”, ocieplając nieco ten wizerunek. W stronę ocieplenia i mądrości życiowej idzie też „inteligentna”, wcześniej 
łączona $\mathrm{z}$ „wykształcona” i „otwarta”, a teraz z „rozważna” i „doświadczona”. „Niesympatyczna” nie tworzy duetu jak wcześniej ( $\mathrm{z}$ „ironiczna”) i podobnie jak „starsza kobieta” (ta ostatnia bez zmian) pozostaje cechą samodzielną.

Tabela 35. Bloki semantyczne wizerunków wizualnych Magdaleny Środy wśród osób poprawnie identyfikujących ją na zdjęciu i respondentów jej nierozpoznających

\begin{tabular}{|c|c|c|c|c|c|c|c|c|c|}
\hline \multicolumn{5}{|c|}{$\begin{array}{l}\text { bloki semantyczne wizerunku wizualnego } \\
\text { Magdaleny Środy - respondenci poprawnie } \\
\text { identyfikują osobę ze zdjęcia }\end{array}$} & \multicolumn{5}{|c|}{ 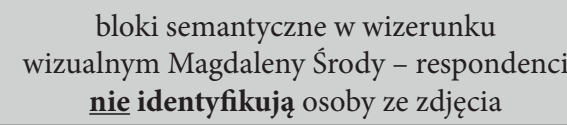 } \\
\hline \multirow{2}{*}{ cecha } & \multicolumn{2}{|c|}{ wskazania } & \multicolumn{2}{|c|}{ osoby } & \multirow{2}{*}{ cecha } & \multicolumn{2}{|c|}{ wskazania } & \multicolumn{2}{|c|}{ osoby } \\
\hline & $\mathbf{n}$ & $\%$ & $\mathbf{n}$ & $\%$ & & $\mathbf{n}$ & $\%$ & $\mathbf{n}$ & $\%$ \\
\hline surowa & 18 & 23,38 & 12 & 70,59 & pewna siebie & 60 & 29,41 & 35 & 76,09 \\
\hline pewna siebie & 9 & 11,69 & 8 & 47,06 & surowa & 31 & 15,20 & 22 & 47,83 \\
\hline \multirow[t]{2}{*}{ konkretna } & 5 & 6,49 & 5 & 29,41 & konkretna & 4 & 1,96 & 4 & 8,70 \\
\hline & 32 & 41,56 & & & & 95 & 46,57 & & \\
\hline \multirow[t]{2}{*}{ miła } & 9 & 11,69 & 8 & 47,06 & sympatyczna & 27 & 13,24 & 25 & 54,35 \\
\hline & 9 & 11,69 & & & pomocna & 4 & 1,96 & 4 & 8,70 \\
\hline inteligentna & 3 & 3,90 & 3 & 17,65 & $\begin{array}{l}\text { z poczuciem } \\
\text { humoru }\end{array}$ & 4 & 1,96 & 4 & 8,70 \\
\hline wykształcona & 2 & 2,60 & 2 & 11,76 & & 35 & 17,16 & & \\
\hline \multirow[t]{2}{*}{ otwarta } & 2 & 2,60 & 2 & 11,76 & inteligentna & 8 & 3,92 & 8 & 17,39 \\
\hline & 7 & 9,09 & & & rozważna & 4 & 1,96 & 4 & 8,70 \\
\hline opanowana & 2 & 2,60 & 2 & 11,76 & doświadczona & 7 & 3,43 & 7 & 15,22 \\
\hline \multirow[t]{2}{*}{ poważna } & 4 & 5,19 & 4 & 23,53 & & 19 & 9,31 & & \\
\hline & 6 & 7,79 & & & $\begin{array}{l}\text { niesympa- } \\
\text { tyczna }\end{array}$ & 6 & 2,94 & 5 & 10,87 \\
\hline $\begin{array}{l}\text { niesympa- } \\
\text { tyczna }\end{array}$ & 3 & 3,90 & 3 & 17,65 & & 6 & 2,94 & & \\
\hline \multirow[t]{2}{*}{ ironiczna } & 2 & 2,60 & 2 & 11,76 & $\begin{array}{l}\text { starsza kobieta } \\
\text { (2) }\end{array}$ & 4 & 1,96 & 4 & 8,70 \\
\hline & 5 & 6,49 & & & & 4 & 1,96 & & \\
\hline \multirow[t]{2}{*}{ starsza } & 3 & 3,90 & 3 & 17,65 & & & & & \\
\hline & 3 & 3,90 & & & & & & & \\
\hline
\end{tabular}

Źródło: opracowanie własne

Jeśli zestawić dwa image’e wizualne Magdaleny Środy (gdy była rozpoznawana na fotografii i gdy pozostawała dla respondenta anonimowa), to widać pewne różnice, zwłaszcza biorąc pod uwagę bloki semantyczne cech 
wizerunkowych (tabela 35). O ile „pewna siebie”, „surowa”, „konkretna” stanowią porównywalny pod względem wskazań obszar znaczeniowy (łącznie 41,56\% wynotowań w grupie znającej felietonistkę i 46,57\% wśród osób jej nierozpoznających), to w zakresie pozostałych bloków widać istotne różnice, wskazujące na nieprzystępność rozpoznawalnej Magdaleny Środy oraz większą bliskość i ciepło anonimowej kobiety. Kiedy uczestnicy badania nie znali felietonistki, nie zauważali jej opanowania i powagi (brak cech z tego bloku), a także dwukrotnie rzadziej dostrzegali dystans i nieuprzejmość („niesympatyczna”, „ironiczna” - łącznie 6,49\% wskazań, przy poprawnej identyfikacji osoby ze zdjęcia i $2,94 \%$, gdy respondent nie potrafił określić tożsamości). Częściej też uznawano autorkę za sympatyczną (17,16\% wskazań, gdy pozostawała anonimowa, i 11,69\%, gdy ją znano - „miła”). W przypadku braku rozpoznawalności ponad dwukrotnie rzadziej przypisywano jej „niesympatyczność" (relacja: 2,94\% do 6,49\%). W zakresie inteligencji wizerunek rozpoznawalnej Magdaleny Środy należałoby łączyć z kompetencjami („wykształcona”) i otwartą postawą („otwarta”), a gdy pozostaje anonimowa zyskuje na bliskości, bo inteligencja („inteligentna”) raczej łączy się z „rozważna” oraz „doświadczona”. O ile więc rozpoznawalna felietonistka na poziomie obrazu kojarzona jest bardziej z dystansem, powagą, kompetencjami i brakiem sympatii, o tyle jej anonimowość powoduje przesunięcia w wizerunku wizualnym w stronę większej bliskości, ciepła i wzbudzania sympatii.

Skąd ten dystans w przypadku wizualnego wizerunku Magdaleny Środy, gdy jej tożsamość jest poprawnie identyfikowana?

Próżno szukać wpływu w (samym) wizerunku werbalnym anonimowego autora. Chociaż z pewnością „dosadnie przekazująca swoje odważne sądy” (image werbalny nieznanej felietonistki) jest odpowiednikiem „pewna siebie”, a także pozostaje w bliskim związku z „surowa” (pierwsze dwie pozycje wizerunku wizualnego rozpoznawanej Magdaleny Środy), to pierwsza $\mathrm{z}$ wymienionych tu cech ma znacznie niższą reprezentację $(14,24 \%$ wskazań, 46,03\% respondentów) niż cechy przypisywane na podstawie zdjęcia („surowa”: 23,38\% wskazań i 70,59\% osób, „pewna siebie”: 11,69\%; 47,06\%). Nawet jeśli uwzględnić dysproporcje w liczbie osób udzielających w każdej grupie odpowiedzi (63 uczestników mających do dyspozycji tekst nieznanego autora do 17 respondentów rozpoznających na zdjęciu felietonistkę), to jednak ponaddwukrotna przewaga przypisywania zdecydowanej postawy Magdalenie Środzie widocznej na zdjęciu (łącznie pierwsze dwie cechy to $35,07 \%$ wskazań) nad dosadnym wyrażaniem swoich sądów w przypadku wizerunku werbalnego (14,24\% wskazań) jest wyraźnym sygnałem, że słowa nie miały większego wpływu na image wizualny Magdaleny Środy, a przynajmniej nie bezpośrednio. 
A czy miały pośredni wpływ? Wydaje się, że tak. Wyjaśnia go zestawienie wizualnego wizerunku rozpoznawanej Magdaleny Środy z jej image’em publicznym (tabela 29). Tu też należy szukać odpowiedzi na pytanie, skąd chłodniejszy wizerunek wizualny autorki o znanej tożsamości w porównaniu $\mathrm{z}$ rezultatami grupy określającej na podstawie zdjęcia image anonimowej osoby.

Kluczem wydaje się analiza dwóch pierwszych cech każdego $\mathrm{z}$ dwóch omawianych imageów i wynikające $z$ tego implikacje. Dla wizerunku publicznego to „dosadnie przekazująca swoje odważne sądy” oraz „feministka” (razem 42,82\% wskazań), dla wizualnego „surowa” i „pewna siebie” (razem 35,07\% wskazań). Możliwe, że stereotyp feministki mógł wpłynąć na wizerunek wizualny Magdaleny Środy, kiedy ją rozpoznawano na fotografii. Jeśli zestawić stereotyp z wizerunkiem publicznym felietonistki i każdym z wizerunków wizualnych, to da się zauważyć zależności.

„Feminizm, zgodnie z potocznym rozumieniem tego słowa, stanowi ideologię kobiet samotnych, agresywnych, radyklanych pod każdym względem" (Środa 2009: 14), ale takie wyobrażenie o feministkach potwierdzają również badania naukowe. Analiza historyczna (Mandal, Banot 2007: 61-65) wykazuje, że syntetycznie rzecz ujmując:

Wśród określeń feministki można wyodrębnić grupę wyrazów odwołujących się do poetyki walki czy wojny, np. „wojowniczka”, „palaczka”, a nawet „Zwolenniczka aborcji". Wiele wyrazów to nazwy ekspresywne, które przekazują pejoratywne ustosunkowanie emocjonalne, np.: „baba”, „siekiera”, „wiedźma”, „wariatka”, „lesba”, „brzydula”. Konotują takie uczucia, jak: niechęć, lęk, wstręt, pogarda, lęk. Pojawiają się także nazwy kobiecych części garderoby: „spódnica”, „pończocha”, „biustonosz” (Mandal, Banot 2007: 65).

Historycznie w wyobrażeniu feministki dominują więc cechy negatywne, dla których motywem przewodnim jest agresja.

Wydaje się, że współcześnie niewiele się zmieniło. Badania psychologów społecznych wskazują, iż można wyodrębnić trzy podkategorie (podtypy) stereotypu feministki ${ }^{14}$ : kobieta walcząca o równouprawnienie, kobieta walcząca z mężczyznami, współczesna kobieta sukcesu. Pierwsze dwa podtypy dotyczyły odpowiedzi 63\% respondentów (odpowiednio: $34,24 \%$ i $28,76 \%$ ), ostatni 17,80\%. Z pozostałych wypowiedzi (19,20\%) nie dało się wyłonić żadnej z wymienionych podkategorii (Mandal, Banot 2007: 69). Także i tutaj pojawia się wyraziste utożsamianie feministki z kobietą walczącą. 
W tym samym badaniu (zob. Mandal, Banot 2007) starano się odtworzyć cechy, nazwane „specyficznymi dla feministki”"15, a które definiowano jako "charakterystyczne tylko dla niej” (Mandal, Banot 2007: 75). Zdecydowanie najczęściej przypisywaną cechą była „wojująca”. Wskazało na nią aż $37,77 \%$ kobiet i 20,43\% mężczyzn, podczas gdy kolejne najliczniej się pojawiające w odpowiedziach to: "podejmująca radyklane działania” (5,55\% kobiet, 0,00\% mężczyzn) i "mająca skłonność do wyolbrzymiania problemów” (3,33\% kobiet, 2,15\% mężczyzn). Należy podkreślić dużą różnicę liczbową między określaniem feministki „wojującą" a pozostałymi cechami, co wskazuje na zdecydowaną dominację kojarzenia zwolenniczek równouprawnienia z walką. Pozostałe przymioty to: „lubiąca przesadę”, „fanatyczna”, „popadająca w skrajności”, „mająca skłonność do zniekształcania rzeczywistości”, „zwariowana”, „groźna” (Mandal, Banot 2007: 73-75). Potwierdzają się wcześniej zacytowane wyniki z innej części badania - feministka walczy i opisuje się ją raczej negatywnymi epitetami.

Zaznaczyć przy tym należy, że „kobiety i mężczyźni w podobnie wysokim stopniu postrzegają feministkę jako osobę posiadającą specyficzne cechy" (Mandal, Banot 2007: 68), tzn. głębsza analiza wyników wykazała, że nie ma istotnych różnić między kobietami i mężczyznami w zakresie wyobrażenia o feministce.

Z wysoką frekwencją cechy „wojująca” korespondują wyniki badań, w których starano się wyjaśnić, co wpływa na pejoratywną ocenę feministek (Mandal, Kofta 2009). Uczestnicy badania oceniali CV i listy motywacyjne osób, które deklarowały się jako feministki lub tego nie robiły. Kiedy składano taką deklarację, istotnie obniżała się chęć zatrudnienia kandydatki, chęć inwestowania w jej szkolenia i chęć awansowania. Analizy wykazały, iż „prototypowa feministka jest (...) postrzegana jako osoba silnie agresywna interpersonalnie”, a w kontekście procedury badawczej ,jedynym czynnikiem odpowiedzialnym za negatywny wpływ etykiety «feministka» na oceny kandydatki jest przypisywanie feministkom wysokiego stopnia agresywności interpersonalnej" (Mandal, Kofta 2009: 167).

Być może te ustalenia mogą pomóc $w$ interpretacji jednej z różnic między wizualnym wizerunkiem identyfikowanej Magdaleny Środy oraz image’em anonimowej felietonistki, którego podstawą było także zdjęcie. Zapewne „sroga” i „pewna siebie” są łatwo widoczne na fotografii, skoro stanowią cechy najczęściej wskazywane w obu wizerunkach wizualnych. „Pewna/-y siebie” to

$15 \mathrm{~W}$ tej części badania „osoby badane otrzymały jednostronicową ankietę, składającą się z metryki, czterech pytań wyboru i jednego pytania otwartego «Co myślisz o feminizmie?». Z uzyskanych w ten sposób swobodnych wypowiedzi wyodrębniono zbiór 10 cech określonych jako «specyficzne dla feministki»" (Mandal, Banot 2007: 66). 
także cecha, która pojawia się w pierwszej dwójce wskazań w każdym z analizowanych do tej pory wizerunków wizualnych (felietonistów o nierozpoznanej na podstawie fotografii tożsamości), a możliwe, że odpowiada za jej zauważenie wzrok skierowany do obiektywu ${ }^{16}$. Samo więc pojawienie się tych cech musi być wynikiem wypowiedzi wizualnej bez wpływów z zewnątrz. Ale zaskakują odwrócone niemal wyniki tych dwóch cech wizerunkowych, jeśli zestawić omawiane imagee. W grupie nierozpoznającej felietonistki rzadziej wypisywana cecha „surowa” to $15,20 \%$ wynotowan $47,83 \%$ respondentów, a „pewna siebie” to $29,41 \%$ wskazań dokonanych przez $76,09 \%$ osób. W przypadku wizerunku znanej Magdaleny Środy proporcje są niemal symetrycznie odwrotne, bo najczęściej pojawiająca się „surowa” to 23,38\% wskazań i 70,59\% respondentów, a "pewna siebie” to $11,69 \%$ wskazań i 47,06\% osób. Możliwe, że na wysoką manifestację cechy „surowa” w grupie rozpoznającej felietonistkę miał wpływ właśnie stereotyp feministki (licznie manifestowana w wizerunku publicznym cecha „feministka”) i mieszcząca się w nim agresja, wojowniczość czy radykalizm. O ile „pewna siebie” może oznaczać osobę, która ma swoje przekonania i nie boi się ich artykułować, o tyle „sroga” może sugerować, że taka osoba ma także prawo oceniać i ustalać, co jest lepsze, a co gorsze, narzucać określony sposób myślenia. W tym sensie wysoka frekwencja cechy „sroga” może w image’u wizualnym rozpoznawanej na zdjęciu Magdaleny Środy być wynikiem „przefiltrowania” wypowiedzi wizualnej przez stereotyp agresywnej feministki, który to stał się komponentem wizerunku publicznego felietonistki, a ponieważ dotyczy poglądów i jego podstawą musiały być wypowiedzi werbalne autorki tekstów i/lub słowa o niej, to też poziom języka naturalnego ma tutaj pośrednie znaczenie.

Stereotyp może też wyjaśniać, skąd mniej sympatii, a więcej chłodu i dystansu $\mathrm{w}$ przypadku pozostałych cech $\mathrm{w}$ wizerunku wizualnym identyfikowanej przez respondentów felietonistki w porównaniu z określaniem image’u anonimowej kobiety ze zdjęcia. Po pierwsze, etykieta feministki aktywizuje wyobrażenia mieszczące się w jej stereotypie i tym samym wywołuje „irracjonalne uprzedzenia” (Mandal, Koftta 2009: 164). Po drugie, nawet jeśli dana osoba identyfikuje się z poszczególnymi ideami feminizmu, to pejoratywnie wartościuje samo określenie „feministka” i nie chce być tak nazywana. Badania socjologiczne pokazują, że „Polki w selektywny sposób przyjmują postulaty feministyczne, równocześnie dystansując się wobec określenia «feministka», które ma w świadomości wielu kobiet charakter negatywnej etykiety" (Frąckowiak-Sochańska 2011: 150; zob. taż 2009: 203-207). Tym bardziej więc

16 Zwraca wprost na to zresztą uwagę jeden z respondentów nieidentyfikujących Magdaleny Środy na fotografii, pisząc: „pewna siebie (wzrok od razu do kamery)”. 
ci, którzy publicznie deklarują i komunikują przynależność do tego nurtu ideowego, traktowani są z dystansem. Ta silna stygmatyzacja „feministki” mogła wpływać na wyniki w przypadku wizerunku wizualnego rozpoznawanej na zdjęciu Magdaleny Środy. Uprzedzenia i niechęć być może stały się przyczyną wyższej frekwencji cech skupionych wokół „niesympatyczna”, a niższej tych związanych z „sympatyczna”, w końcu mogły wywoływać częstsze wskazywanie na opanowanie, powagę i wykształcenie, a nie na doświadczenie i rozwagę.

Jak zatem widać, rezultaty dotyczące obu wizerunków wizualnych Magdaleny Środy wskazują, że w konstrukcji wizerunku na podstawie obrazu ma duży udział image publiczny, jeśli dana osoba jest rozpoznawalna i jeśli kontakt $\mathrm{z}$ wieloma systemami znaków spowodował przypisywanie jej cech stereotypowych. Wówczas stereotyp może wpływać znacząco na komunikat powstały na bazie obrazu. W przypadku tej felietonistki po raz pierwszy nie pojawił się obszar „stan emocjonalno-poznawczy” w zakresie image'u anonimowej na zdjęciu osoby. Kategoria ta w przypadku wcześniej analizowanych felietonistów zawsze dotyczyła image'u wizualnego i tylko w nim występowała. Jej brak w wynikach dotyczących Magdaleny Środy obniża nieco specyfikę tej kategorii w zakresie wizerunku wizualnego. ( Na poziomie metodologicznych rozwiązań przydatne okazało się porównanie bloków semantycznych obu wizerunków konstruowanych na podstawie zdjęcia. Pozwoliło to bowiem zauważyć istotne między nimi różnice i zasugerowało trop interpretacyjny (stereotyp).

\subsubsection{Magdalena Środa - wizerunek na podstawie tekstu ze zdjęciem i informacją o tożsamości autora}

Na 63 osoby, które odpowiedziały na pytanie: „Mając za podstawę tekst przeczytanego felietonu, jakimi słowami opisałby Pan / opisałaby Pani autorkę Magdalenę Środę?", 9 wypisało po 3 przymioty felietonistki, 13 po 4 i 47 respondentów wskazało po 5 epitetów, co pozwoliło zgromadzić 296 wskazań, przy czym dwa z określeń skategoryzowano podwójnie, więc ostatecznie zebrano $298 \mathrm{cech}^{17}$, zakodowanych w 20 spójnych cech wizerunkowych.

17 Wypisany jako pojedyncza cecha epitet „krytyczna, ironiczna” przyporządkowano do „krytyczna” oraz „ironiczna”, natomiast „krytyczna wobec polityków i księży” skategoryzowano w cechy wizerunkowe „antyklerykalna” oraz „krytyczna”. 
Tabela 36. Zestawienie odpowiedzi na pytanie: „Mając za podstawę tekst przeczytanego felietonu, jakimi słowami opisałby Pan / opisałaby Pani autorkę Magdalenę Środę?"

\begin{tabular}{|c|c|c|c|c|c|c|}
\hline \multirow{2}{*}{ lp. } & \multirow{2}{*}{$\begin{array}{c}\text { cecha } \\
\text { wizerunkowa }\end{array}$} & \multirow{2}{*}{ warianty leksykalne } & \multicolumn{2}{|c|}{ wskazania } & \multicolumn{2}{|c|}{ osoby } \\
\hline & & & $\mathrm{n}$ & $\%$ & $\mathrm{n}$ & $\%$ \\
\hline 1. & $\begin{array}{l}\text { dosadnie } \\
\text { wyrażająca } \\
\text { swoje } \\
\text { odważne sądy } \\
(0)\end{array}$ & $\begin{array}{l}\text { odważna, gdyż sprzeciwia się słowom arcy- } \\
\text { biskupa Michalika; odważna (10), odważna } \\
\text { w słowach (w pozytywnym znaczeniu); } \\
\text { pełna odwagi; bezpośrednia (6); mająca } \\
\text { własne zdanie; posiadająca własne zdanie; } \\
\text { wyraźnych poglądach; ma swoje poglądy; } \\
\text { budząca własne opinie; ma własną opinię } \\
\text { na każdy temat; odważnie wypowiada } \\
\text { swoje zdanie; mająca swój światopogląd; } \\
\text { pokazuje swój punkt widzenia; niebojąca } \\
\text { się wyrażania własnej opinii; nie boi się ich } \\
\text { wygłaszać; nie boi się nazywać rzeczy po } \\
\text { imieniu; zdecydowana (4); dosadna; potrafi } \\
\text { coś podkreślić w dosadny sposób, ale aż za } \\
\text { bardzo nie w niegrzeczny sposób; stanowcza } \\
\text { (2); pewna swoich poglądów politycznych } \\
\text { i kulturowych; pewna siebie (2); agresywna } \\
\text { (2); kontrowersyjna (4); z maniami szowi- } \\
\text { nistycznymi; przekonana o swoich racjach; } \\
\text { buntownicza; przemądrzała; prostolinijna; } \\
\text { opozycyjna; dążąca do celu/zuchwała; śmia- } \\
\text { ła do realizacji swoich celów; asertywna; ... } \\
\text { co czyni ją indywidualistką, bo „nie idzie za } \\
\text { tylko wysłyszanym głosem ludu”; niezależ- } \\
\text { na; zaczepna; nonkonformistka; konkretna; } \\
\text { porusza odważne tematy; silna }\end{array}$ & 64 & 21,48 & 39 & 61,90 \\
\hline 2. & ironiczna (13) & $\begin{array}{l}\text { sarkastyczna (3); nieco sarkastyczna; } \\
\text { podchodzi do tematu z dystansem; kry- } \\
\text { tyczna, ironiczna }\end{array}$ & 19 & 6,38 & 17 & 26,98 \\
\hline 3. & $\begin{array}{l}\text { inteligentna } \\
(13)\end{array}$ & $\begin{array}{l}\text { błyskotliwa (2); mądra; mądra kobieta; } \\
\text { wolny umysł }\end{array}$ & 18 & 6,04 & 17 & 26,98 \\
\hline 4. & feministka (9) & $\begin{array}{l}\text { zwolenniczka równouprawnienia; kobieta } \\
\text { wyzwolona od świata męskiego, niezależ- } \\
\text { na; walcząca o prawa kobiet; wyzwolona; } \\
\text { radykalna; dbająca o dobro kobiet }\end{array}$ & 15 & 5,03 & 15 & 23,81 \\
\hline 5. & $\begin{array}{l}\text { obiektywna } \\
\text { (9) }\end{array}$ & $\begin{array}{l}\text { bezstronna (2); nie jest stronnicza, jeśli cho- } \\
\text { dzi o konkretne partie polityczne w Polsce; } \\
\text { stojąca na neutralnym gruncie politycznym }\end{array}$ & 13 & 4,36 & 11 & 17,46 \\
\hline 6. & krytyczna (2) & $\begin{array}{l}\text { krytyczna, ironiczna; używająca krytyki; } \\
\text { krytyk; krytyczna wobec polityków i księży; } \\
\text { nastawiona krytycznie do systemu naucza- } \\
\text { nia; krytycznie spogląda na układ polityczny } \\
\text { w Polsce; wyśmiewająca zmienność poglą- } \\
\text { dów; przeciwna wyglądowi naszego Pań- } \\
\text { stwa; odkrywająca absurdy }\end{array}$ & 11 & 3,69 & 11 & 17,46 \\
\hline
\end{tabular}




\begin{tabular}{|c|c|c|c|c|c|c|}
\hline \multirow{2}{*}{ lp. } & \multirow{2}{*}{$\begin{array}{c}\text { cecha } \\
\text { wizerunkowa }\end{array}$} & \multirow{2}{*}{ warianty leksykalne } & \multicolumn{2}{|c|}{ wskazania } & \multicolumn{2}{|c|}{ osoby } \\
\hline & & & $\mathbf{n}$ & $\%$ & $\mathbf{n}$ & $\%$ \\
\hline 7. & $\begin{array}{l}\text { zaangażo- } \\
\text { wana }\end{array}$ & $\begin{array}{l}\text { zaangażowana społecznie; zaangażowa- } \\
\text { na politycznie; pragnie zmian; chcąca } \\
\text { zmian; poruszająca tematy ważne dla } \\
\text { społeczeństwa; zauważa problemy ko- } \\
\text { ścioła, wiernych i duchownych; zagrze- } \\
\text { wająca do działania; przywódcza; liderka; } \\
\text { działaczka dążąca do zmiany świadomo- } \\
\text { ści społeczeństwa w kwestii uczestnicze- } \\
\text { nia kobiet w życiu publicznym i politycz- } \\
\text { nym; zwolenniczka wspólnego działania } \\
\text { ponad wszelkimi podziałami }\end{array}$ & 11 & 3,69 & 9 & 14,29 \\
\hline 8. & zna temat $(0)$ & $\begin{array}{l}\text { mająca wiedzę, czym jest pedofili, femi- } \\
\text { nizm; ma dużą wiedzę na temat femini- } \\
\text { zmu; pokazująca swoją wiedzę; mająca } \\
\text { dużą wiedzę; dobrze zna sprawy poli- } \\
\text { tyki i współczesności; osoba obeznana } \\
\text { w polskiej polityce; zorientowana po- } \\
\text { litycznie; zorientowana w poruszanym } \\
\text { przez nią temacie; świadoma; świadoma } \\
\text { sytuacji, jaka panuje w Polsce }\end{array}$ & 10 & 3,36 & 10 & 15,87 \\
\hline 9. & $\begin{array}{l}\text { dociekliwa } \\
(6)\end{array}$ & $\begin{array}{l}\text { ciekawa; otwarta; wyemancypowana; } \\
\text { wnikliwa }\end{array}$ & 10 & 3,36 & 10 & 15,87 \\
\hline 10. & $\begin{array}{l}\text { antyklerykal- } \\
\text { na (4) }\end{array}$ & $\begin{array}{l}\text { uprzedzona do Kościoła; nieutożsamia- } \\
\text { jąca się z Kościołem; mająca dystans } \\
\text { do Kościoła; może nawet antyreligijna; } \\
\text { krytyczna wobec polityków i księży }\end{array}$ & 9 & 3,02 & 8 & 12,70 \\
\hline 11. & realistka (2) & $\begin{array}{l}\text { racjonalna (2); racjonalista; rozważna; } \\
\text { trzeźwo spogląda na sprawę; trzeźwo } \\
\text { i realistycznie patrząca na świat; twardo } \\
\text { stąpająca po ziemi; rozumna; patrzy na } \\
\text { świat i politykę rozsądnie, nie poddaje } \\
\text { się zabiegom psychologicznym }\end{array}$ & 9 & 3,02 & 7 & 11,11 \\
\hline 12. & zabawna & $\begin{array}{l}\text { z poczuciem humoru (3); ma poczucie } \\
\text { humoru; dowcipna; osoba dowcipna; } \\
\text { żartobliwa; z dystansem }\end{array}$ & 9 & 3,02 & 8 & 12,70 \\
\hline 13. & $\begin{array}{l}\text { spostrzegaw- } \\
\text { cza (3) }\end{array}$ & $\begin{array}{l}\text { dobra obserwatorka; świetny obserwator; } \\
\text { mająca trafne spostrzeżenia; przenikliwa (2) }\end{array}$ & 8 & 2,68 & 8 & 12,70 \\
\hline 14. & $\begin{array}{l}\text { ciekawie } \\
\text { pisząca }(0)\end{array}$ & $\begin{array}{l}\text { elokwentna; potrafiąca przekazać swój } \\
\text { punkt widzenia; dobra pisarka/dzien- } \\
\text { nikarka, dobrze operuje słowem; ma } \\
\text { talent do trafnego wyrażania poglądów; } \\
\text { dobra dziennikarka }\end{array}$ & 5 & 1,68 & 5 & 7,94 \\
\hline 15. & lewicowa (2) & $\begin{array}{l}\text { zwolenniczka lewicy; o „lewicowych” } \\
\text { poglądach; o poglądach lewicowych }\end{array}$ & 5 & 1,68 & 5 & 7,94 \\
\hline 16. & $\begin{array}{l}\text { przeciwnicz- } \\
\text { ka PiS }\end{array}$ & $\begin{array}{l}\text { przeciwniczka PiS-u (prawicy); przeciwna } \\
\text { PiSowi; przeciwnik PiS-u; anty-prawicowa }\end{array}$ & 5 & 1,68 & 5 & 7,94 \\
\hline
\end{tabular}


Tabela 36 (cd.)

\begin{tabular}{|c|c|c|c|c|c|c|}
\hline \multirow{2}{*}{ lp. } & \multirow{2}{*}{$\begin{array}{c}\text { cecha } \\
\text { wizerunkowa }\end{array}$} & \multirow{2}{*}{ warianty leksykalne } & \multicolumn{2}{|c|}{ wskazania } & \multicolumn{2}{|c|}{ osoby } \\
\hline & & & $\mathrm{n}$ & $\%$ & $\mathbf{n}$ & $\%$ \\
\hline 17. & liberalna (3) & progresywistka & 4 & 1,34 & 4 & 6,35 \\
\hline 18. & $\begin{array}{l}\text { wykształcona } \\
(4)\end{array}$ & & 4 & 1,34 & 4 & 6,35 \\
\hline 19. & szczera (4) & & 4 & 1,34 & 4 & 6,35 \\
\hline 20. & inne & & 65 & 21,81 & 37 & 58,73 \\
\hline & & razem & 298 & 100,00 & & \\
\hline
\end{tabular}

Źródło: opracowanie własne

Omawiając wyniki dotyczące wizerunku werbalnego Magdaleny Środy, której tożsamość została podana poprzez towarzyszącą tekstowi informację o nazwisku oraz fotografię, warto zwrócić uwagę na różnice i podobieństwa z image'em anonimowej felietonistki. W obu przypadkach „dosadnie wyrażająca swoje odważne sądy" to cecha najwyżej reprezentowana, którą dzieli duży dystans między kolejnymi na liście wskazań. Dla wizerunku znanej autorki było to do $21,48 \%$ (64) wynotowań dokonanych przez 61,90\% (39) respondentów i są to wartości o połowę większe niż w przypadku image’u nieokreślonej felietonistki ( 42 - 14,24\% wskazań 29 - 46,03\% osób). Dla czytelników posiadających dane o twórcy kolejne cechy najczęściej wskazywane to: „ironiczna" (19-6,38\% wskazań, 17 - 26,98\% respondentów) oraz wynotowana przez taką samą liczbę osób „inteligentna” (18 - 6,04\% wskazań), na czwartym miejscu „feministka” (15 - 5,03\%; 15 - 23,82\%). W tej pierwszej czwórce obu wizerunków werbalnych podobne dane prezentują „,ironiczna” (w wizerunku anonimowej autorki 20 - 6,78\% wskazań 19 - 30,16\% respondentów) i „inteligentna” (analogicznie u nieznanej twórczyni: 21 - 7,12\% wynotowań $21-33,33 \%$ osób). W image'u werbalnym felietonistki o podanej tożsamości wśród pierwszych czterech cech pojawia się „feministka” (jej miejsce w wynikach anonima zajmowała cecha „krytyczna”), zdaniem czytelników manifestowana tym razem ponad dwukrotnie mocniej niż w przypadku image'u nieznanej autorki (6 - 2,03\% wskazań, 6 - 9,52\% respondentów). „Feministka” zatem $\mathrm{z}$ końcówki wskazań $\mathrm{w}$ wizerunku werbalnym anonimowej felietonistki przechodzi do czołówki w image’u werbalnym Magdaleny Środy, na co zapewne ma wpływ zarówno wizerunek publiczny, jak i płeć osoby z fotografii towarzyszącej tekstowi.

W obu wizerunkach werbalnych od piątej w kolejności w dół cechy wizerunkowej pojawiają się takie, które reprezentują poziom wskazań poniżej 5\% 
oraz poziom mniejszy lub równy $20 \%$ osób ich dokonujących. W przypadku opartego na słowie wizerunku twórcy wypowiedzi o jawnym imieniu i nazwisku będą to: „obiektywna” ( 13 - 4,36\% wskazań 11 - 17,46\% osób), „krytyczna” (11 - 3,69\%; 11 - 17,46\%), ,zaangażowana” (11 - 3,69\%; 9 - 14,29\%), „znawca tematu” i „dociekliwa” (po 10 - 3,36\% wskazań, dokonanych przez $10-15,87 \%$ respondentów), wynotowane dziewięciokrotnie (3,02\% wskazań) „antyklerykalna”, „realistka”, „zabawna” przez odpowiednio 8 - 12,70\%, 7 - 11,11\% i 8 - 12,70\% czytelników. Mniej niż 3\% wskazań reprezentują cechy: „spostrzegawcza” ( $8-2,68 \% ; 8-12,70 \%)$, „ciekawie pisząca”, ,lewicowa”, „przeciwniczka PiS”18 (po 5 - 1,68\%; 5 - 7,94\%), najrzadziej wypisywano: „liberalna”, „wykształcona”, „szczera” (po 4 - 1,34\%; 4 - 6,35\%).

Nieco więcej cech wizerunkowych wykazuje wyższy niż 3\% poziom wskazań w wizerunku znanej autorki (12 cech) niż w przypadku braku podania jej tożsamości (9). Ta dysproporcja się zwiększa, jeśli wziąć pod uwagę, że $\mathrm{w}$ warunkach pozostawienia informacji o imieniu i nazwisku generalnie dało się wyłonić mniej spójnych cech ( 19 w porównaniu z $21 \mathrm{w}$ przypadku image’u nieznanego twórcy tekstu). Może to świadczyć o zmniejszeniu rozproszenia cech wizerunkowych i większej ich spójności, kiedy wiadomo, kto napisał felieton. Możliwe, że wpływ wizerunku publicznego oraz wizualnego w pewien sposób ukierunkował wybory respondentów.

Tabela 37. Kategorie komunikowanego werbalnie wizerunku felietonisty o znanej tożsamości - Magdaleny Środy

\begin{tabular}{|l|l|l|l|l|l|l|l|l|l|l|}
\hline lp. & $\begin{array}{l}\text { poglądy/ } \\
\text { wartości }\end{array}$ & $\mathbf{n}$ & wiedza & $\mathbf{n}$ & postawa & $\mathbf{n}$ & $\begin{array}{c}\text { cecha } \\
\text { charakteru }\end{array}$ & $\mathbf{n}$ & $\begin{array}{c}\text { sposób } \\
\text { komuni- } \\
\text { kacji }\end{array}$ & $\mathbf{n}$ \\
\hline 1. & feministka & 15 & $\begin{array}{l}\text { zna } \\
\text { temat }\end{array}$ & 10 & $\begin{array}{l}\text { dosadnie wy- } \\
\text { rażająca swoje } \\
\text { odważne sądy }\end{array}$ & 64 & $\begin{array}{l}\text { inteligent- } \\
\text { na }\end{array}$ & 18 & $\begin{array}{l}\text { ciekawie } \\
\text { pisząca }\end{array}$ & 5 \\
\hline 2. & $\begin{array}{l}\text { antyklery- } \\
\text { kalna }\end{array}$ & 9 & $\begin{array}{l}\text { wy- } \\
\text { kształ- } \\
\text { cona }\end{array}$ & 4 & ironiczna & 19 & zabawna & 9 & & \\
\hline 3. & lewicowa & 5 & & & obiektywna & 13 & szczera & 4 & \\
\hline
\end{tabular}

18 „Lewicowa” i „przeciwniczka PiS” skodowano jako oddzielne cechy wizerunkowe, ponieważ nie są to określenia tożsame semantycznie, a też nie zawsze bliskoznaczne, więc scalenie ich byłoby nadużyciem, a ponadto wymagałoby wyboru jednego z nich jako reprezentującego cechę wizerunkową. To z kolei wprowadzałoby w błąd obiorcę wyników tych badań i czyniło wizerunek Magdaleny Środy nierzetelnym. Trudno też było znaleźć leksem, który byłby arbitralnie nadany, a wiązałby te dwa znaczenia bez szkody jakościowej. Stąd też decyzja o pozostaniu przy wyborach słownikowych respondentów. 
Tabela 37 (cd.)

\begin{tabular}{|l|l|l|l|l|l|r|r|r|r|r|}
\hline lp. & $\begin{array}{l}\text { poglądy/ } \\
\text { wartości }\end{array}$ & $\mathbf{n}$ & wiedza & $\mathbf{n}$ & \multicolumn{1}{|c|}{ postawa } & $\mathbf{n}$ & $\begin{array}{c}\text { cecha } \\
\text { charakteru }\end{array}$ & $\begin{array}{c}\text { sposób } \\
\text { komuni- } \\
\text { kacji }\end{array}$ & $\mathbf{n}$ \\
\hline 4. & $\begin{array}{l}\text { przeciw- } \\
\text { niczka PiS }\end{array}$ & 5 & & & krytyczna & 11 & & & & \\
\hline 5. & liberalna & 4 & & & zaangażowana & 11 & & & & \\
\hline 6. & & & & & dociekliwa & 10 & & & & \\
\hline 7. & & & & & realistka & 9 & & & & \\
\hline 8. & & & & & spostrzegawcza & 8 & & & & $\mathbf{5}$ \\
\hline
\end{tabular}

Źródło: opracowanie własne

Kategorie komunikowanego werbalnie wizerunku felietonistki o znanej tożsamości - Magdaleny Środy (tabela 37) ukazują wyraźną dominację (jak we wszystkich image'ach werbalnych analizowanych do tej pory) „postawy” (liczba wskazań dla wszystkich cech w tym aspekcie image'u: 145). Drugi w kolejności obszar - „poglądy/wartości” - obejmuje już trzykrotnie mniej wskazań (38), trzeci - „cechy charakteru” - nieco tylko mniej (31). Najmniejsze znacznie ma „wiedza” (14) i „sposób komunikacji” (5).

W porównaniu $\mathrm{z}$ kategoriami dla opartego na słowie wizerunku anonima nie ma zmian jakościowych - nie pojawiają się nowe kategorie. Widać za to modyfikacje ilościowe. Zdecydowanie zyskały na znaczeniu „poglądy/ wartości” (wcześniej 20, teraz 38 wskazań), a straciła „wiedza” (wcześniej 20, teraz 14 wynotowań), co można tłumaczyć wpływem wizerunku publicznego (utożsamianie Magdaleny Środy z określoną postawą ideową).

W zakresie grup semantycznych tworzonych przez poszczególne cechy zauważyć się da, że skupiają się one wokół najliczniej reprezentowanych cech znanej felietonistki (zob. tabela 38) oraz jest ich mniej niż w przypadku wizerunku wyłanianego na podstawie tekstu nieznanej twórczyni. Najwyrazistsza dla image’u werbalnego autorki o jawnej tożsamości pozostaje postawa bezkompromisowego przedstawiania swojego stanowiska („dosadnie przedstawiająca swoje odważne sądy”, „ironiczna”, „krytyczna” - razem 94 wskazania - 21,49\%, wcześniej dla wizerunku anonima: 87 - 29,49\%) i chociaż niemal o połowę mniej wynotowań liczą cechy wizerunkowe wyrażające jej zaangażowanie społeczno-polityczne („zaangażowana”, „feministka”, „antyklerykalna”, „lewicowa”, „przeciwniczka PiS”, „liberalna”), to ta ostatnia grupa znaczeniowa liczy o 1/3 wskazań więcej niż analogiczna w przypadku image’u nieznanej 
twórczyni wypowiedzi (stosunek 49 - 16,44\% do 34 - 11,53\% wynotowań). Wyrazista postawa dominuje więc w obu image'ach werbalnych, podczas gdy zaangażowanie ideowe jest lepiej widoczne u znanej Magdaleny Środy.

Tabela 38. Bloki semantyczne obu wizerunków werbalnych Magdaleny Środy

\begin{tabular}{|c|c|c|c|c|c|c|c|c|c|}
\hline \multicolumn{5}{|c|}{$\begin{array}{l}\text { bloki semantyczne wizerunku werbalnego } \\
\text { anonimowej Magdaleny Środy } \\
\text { (wariant: sam tekst) }\end{array}$} & \multicolumn{5}{|c|}{$\begin{array}{l}\text { bloki semantyczne w wizerunku werbalnym } \\
\text { z podaną tożsamością Magdaleny Środy } \\
\text { (wariant: tekst + foto + nazwisko) }\end{array}$} \\
\hline \multirow{2}{*}{$\begin{array}{c}\text { cecha } \\
\text { wizerunkowa }\end{array}$} & \multicolumn{2}{|c|}{ wskazania } & \multicolumn{2}{|c|}{ osoby } & \multirow{2}{*}{$\begin{array}{c}\text { cecha } \\
\text { wizerunkowa }\end{array}$} & \multicolumn{2}{|c|}{ wskazania } & \multicolumn{2}{|c|}{ osoby } \\
\hline & $\mathbf{n}$ & $\%$ & $\mathbf{n}$ & $\%$ & & $\mathbf{n}$ & $\%$ & $\mathbf{n}$ & $\%$ \\
\hline $\begin{array}{l}\text { dosadnie } \\
\text { przedstawiają- } \\
\text { ca swoje od- } \\
\text { ważne sądy }\end{array}$ & 42 & 14,24 & 29 & 46,03 & $\begin{array}{l}\text { dosadnie } \\
\text { przedstawiająca } \\
\text { swoje odważne } \\
\text { sądy }\end{array}$ & 64 & 21,48 & 39 & 61,90 \\
\hline krytyczna & 18 & 6,10 & 18 & 28,57 & ironiczna & 19 & 6,38 & 17 & 26,98 \\
\hline ironiczna & 20 & 6,78 & 19 & 30,16 & krytyczna & 11 & 3,69 & 11 & 17,46 \\
\hline \multirow[t]{2}{*}{ subiektywna } & 7 & 2,37 & 7 & 11,11 & & 94 & 31,54 & & \\
\hline & 87 & 29,49 & & & feministka & 15 & 5,03 & 15 & 23,81 \\
\hline zaangażowana & 14 & 4,75 & 13 & 20,63 & zaangażowana & 11 & 3,69 & 9 & 14,29 \\
\hline antyklerykalna & 9 & 3,05 & 8 & 12,70 & antyklerykalna & 9 & 3,02 & 8 & 12,70 \\
\hline feministka & 6 & 2,03 & 6 & 9,52 & lewicowa & 5 & 1,68 & 5 & 7,94 \\
\hline \multirow[t]{2}{*}{$\begin{array}{l}\text { przeciwniczka } \\
\text { PiS }\end{array}$} & 5 & 1,69 & 5 & 7,94 & $\begin{array}{l}\text { przeciwniczka } \\
\text { PiS }\end{array}$ & 5 & 1,68 & 5 & 7,94 \\
\hline & 34 & 11,53 & & & liberalna & 4 & 1,34 & 4 & 6,35 \\
\hline inteligentna & 21 & 7,12 & 21 & 33,33 & & 49 & 16,44 & & \\
\hline \multirow[t]{2}{*}{ spostrzegawcza } & 5 & 1,69 & 4 & 6,35 & inteligentna & 18 & 6,04 & 17 & 26,98 \\
\hline & 26 & 8,81 & & & spostrzegawcza & 8 & 2,68 & 8 & 12,70 \\
\hline znawca tematu & 9 & 3,05 & 9 & 14,29 & & 26 & 8,72 & & \\
\hline wykształcona & 7 & 2,37 & 7 & 11,11 & obiektywna & 13 & 4,36 & 11 & 17,46 \\
\hline \multirow[t]{2}{*}{ oczytana } & 4 & 1,36 & 4 & 6,35 & realistka & 9 & 3,02 & 7 & 11,11 \\
\hline & 20 & 6,78 & & & & 22 & 7,38 & & \\
\hline zabawna & 11 & 3,73 & 10 & 15,87 & znawca tematu & 10 & 3,36 & 10 & 15,87 \\
\hline \multirow[t]{2}{*}{$\begin{array}{l}\text { ciekawie } \\
\text { pisząca }\end{array}$} & 7 & 2,37 & 6 & 9,52 & wykształcona & 4 & 1,34 & 4 & 6,35 \\
\hline & 18 & 6,10 & & & & 14 & 4,70 & & \\
\hline dociekliwa & 10 & 3,39 & 10 & 15,87 & zabawna & 9 & 3,02 & 8 & 12,70 \\
\hline \multirow[t]{2}{*}{ dokładna } & 7 & 2,37 & 7 & 11,11 & $\begin{array}{l}\text { ciekawie } \\
\text { pisząca }\end{array}$ & 5 & 1,68 & 5 & 7,94 \\
\hline & 17 & 5,76 & & & & 14 & 4,70 & & \\
\hline
\end{tabular}


Tabela 38 (cd.)

\begin{tabular}{|c|c|c|c|c|c|c|c|c|c|}
\hline \multirow{2}{*}{$\begin{array}{c}\text { cecha } \\
\text { wizerunkowa }\end{array}$} & \multicolumn{2}{|c|}{ wskazania } & \multicolumn{2}{|c|}{ osoby } & \multirow{2}{*}{$\begin{array}{c}\text { cecha } \\
\text { wizerunkowa }\end{array}$} & \multicolumn{2}{|c|}{ wskazania } & \multicolumn{2}{|c|}{ osoby } \\
\hline & $\mathbf{n}$ & $\%$ & $\mathbf{n}$ & $\%$ & & $\mathbf{n}$ & $\%$ & $\mathbf{n}$ & $\%$ \\
\hline obiektywna & 8 & 2,71 & 8 & 12,70 & dociekliwa (6) & 10 & 3,36 & 10 & 15,87 \\
\hline realistka & 7 & 2,37 & 7 & 11,11 & szczera (4) & 4 & 1,34 & 4 & 6,35 \\
\hline & 15 & 5,08 & & & & & & & \\
\hline szczera & 6 & 2,03 & 6 & 9,52 & & & & & \\
\hline empatyczna & 4 & 1,36 & 4 & 6,35 & & & & & \\
\hline
\end{tabular}

Źródło: opracowanie własne

Inteligencja („,inteligentna” $\mathrm{i}$,spostrzegawcza”) to trzeci z najwyżej manifestowanych bloków o porównywalnych wynikach z wizerunkiem werbalnym anonima (po 26 wskazań), lecz na czwartym miejscu nie są już usytuowane kompetencje, ale obiektywizm („obiektywna”, „realistka”) wypowiadającej się (razem 22 - 7,38\% wskazań), który zyskuje na znaczeniu, jeśli wziąć pod uwagę, że w image'u werbalnym nieznanej osoby plasował się na ostatniej pozycji wśród spójnych obszarów semantycznych $(15$ - 5,08\%). Kompetencje („znawca tematu”, „wykształcona”) to dopiero piąty (i ostatni) pod względem ilościowym blok znaczeniowy, reprezentowany na równi z poczuciem humoru („zabawna”, „ciekawie pisząca”) (po 14 - 4,70\% wskazań dla każdego z tych dwóch obszarów semantycznych). Poza obrębem spójnych stref znaczeniowych pozostały: „dociekliwa” i „szczera”.

W image’u, powstałym na podstawie słów anonimowej autorki „dociekliwa” tworzyła blok z „dokładna”, dla utworzenia którego tym razem nie było podstaw. Wcześniej (wariant: sam tekst) wysoko sytuowane kompetencje („znawca tematu”, „wykształcona”, „oczytana” - razem 20 - 6,78\% wskazań) i poczucie humoru („zabawna”, „ciekawie pisząca” - łącznie 18 - 6,10 wynotowań) spadły tym razem (wariant: tekst + fotografia + nazwisko) na ostatnie pozycje (z łącznymi wynikami po $14-4,70 \%)$. Siedem bloków semantycznych tworzyło wizerunek werbalny anonima, podczas gdy w przypadku jawnego nazwiska jest ich mniej - pięć.

W obu wizerunkach werbalnych felietonistki zdecydowanie więc dominuje jej bezkompromisowa postawa. W przypadku image’u autorki o znanej tożsamości ta dominacja staje się jeszcze bardziej wyraźna. Na równym poziomie uwidacznia się także inteligencja, ale już w image’u jawnej felietonistki zaangażowanie społeczno-polityczne jest znacząco częściej wskazywane i, co ciekawe, mimo to zyskuje na znaczeniu obiektywizm, a traci znajomość poruszanych tematów oraz poczucie humoru. W ogóle nie pojawia się blok cech skupionych wokół dociekliwości. 
Skąd w wizerunku werbalnym felietonistki o jawnym nazwisku więcej zaangażowania ideowego i obiektywizmu, a mniej dociekliwości, znajomości omawianych treści i dowcipu? Częściowo te wyniki mogą być wytłumaczone przez wpływ wizerunku publicznego, w którym dosadność wypowiedzi i feminizm Magdaleny Środy stanowią czołówkę wskazań. Interferencja musi jednak pozostać ograniczona, skoro wysoko eksponowane kompetencje nie znalazły w wizerunku werbalnym symetrycznie dużego odzwierciedlenia. Jeśli uwzględnić to, że na pytanie o image publiczny, znajomość publicystki potwierdziło niespełna $40 \%$ zapytanych, to skala (niedużego) wpływu okaże się bardziej zrozumiała. Wysoka reprezentacja bezkompromisowości poglądów mogła być wsparta także najczęściej wskazywanymi cechami wizerunku wizualnego („pewna siebie”, „surowa”). Być może zdecydowana postawa i - przypisywane także - sympatyczne usposobienie pozwoliły czytelnikom dostrzec obiektywizm autorki. Ponieważ pierwszych kilka cech skupiło na sobie dużą uwagę, a w badaniu sugerowano podanie stałej liczby określeń, to automatycznie te wyrażające dociekliwość, znajomość tematu czy poczucie humoru straciły dla czytelników na skali reprezentacji. Ciekawe, że stereotyp feministki nie miał tutaj tak dużego znaczenia, tj. trudno dostrzec jego działanie na wizerunek werbalny autorki o jawnym nazwisku i wyglądzie, co by oznaczało, że siła stereotypu zmniejsza się, jeśli da się konkretnej osobie „dojść do głosu”.

Tak więc, zarówno image publiczny, jak i wizualny, miały pewien ograniczony wpływ na wizerunek werbalny znanej felietonistki, przy czym niewielka jej rozpoznawalność sprawiła, że wymiar wizualny miał nieco większe znaczenie niż aspekt publiczny dla determinacji image’u opartego na słownie. Ta przewaga obrazu nad imageem publicznym stanowi też jeden $\mathrm{z}$ mechanizmów zahamowania stygmatyzacji stereotypem feministki. Skoro wpływ kojarzenia nazwiska z określoną ideologią został ograniczony, to także i determinacja stereotypu. Ten proces musiał być ograniczony także przez konieczność przeczytania przez respondenta całości wypowiedzi felietonistki, przez co nie tyle wcześniejsze (również wynikające ze zdjęcia) wyobrażenia przeważały w konstrukcji komunikatu, co głównie słowa autorki.

Potwierdzają się zatem ustalenia towarzyszące wcześniejszym analizom (Varga, Zaremba), że wizerunek wizualny ma wpływ na werbalny, ale ograniczony w tym sensie, że może wzmocnić niektóre cechy czy bloki semantyczne i tak już funkcjonujące na poziomie słowa, jednak nie może doprowadzić do konstrukcji cech charakterystycznych dla obrazu („stan emocjonalno-poznawczy”). Przypadek Magdaleny Środy dodaje do tego konstatację, że także wizerunek publiczny ma swój ograniczony wpływ - na tych samych zasadach, czyli zwiększa eksponowanie cech funkcjonujących w wypowiedzi 
języka naturalnego, ale nie powoduje zauważenia typowych dla siebie („zawód"). W przypadku tekstu felietonisty o jawnej tożsamości, mimo wpływów z zewnątrz, wciąż dominujące pozostaje słowo.

\subsubsection{Zależności między poszczególnymi typami wizerunków Magdaleny Środy}

Magdalena Środa czytelnikom anonimowego tekstu jawi się jako osoba dosadnie przedstawiająca swoje bezkompromisowe stanowisko, zaangażowana ideowo, a także inteligentna i kompetentna, jak również zabawna, dociekliwa i obiektywna. Zdecydowaną postawę i oddanie sprawom społeczno-politycznym jeszcze wyraźnej widzą czytelnicy tekstów felietonistki o znanej tożsamości, uważając ją równocześnie ze inteligentną, wyważoną w ocenach, kompetentną oraz zabawną. W wizerunku publicznym eksponowane jest zdecydowanie, zaangażowanie - zwłaszcza w realizację idei feministycznych - i wykształcenie oraz obiektywizm. W zakresie wizerunku wizualnego dla tych, którzy kojarzyli nazwisko Magdaleny Środy, była ona zdecydowana i surowa, ale też miła i o otwartym umyśle, do tego opanowana i nieco niesympatyczna, podczas gdy osoby nierozpoznające felietonistki na fotografii widziały ją jako nieco cieplejszą osobę, niebudującą dystansu - choć zgadzali się co do pewności siebie i surowości, a także sympatyczności osoby z portretu, to rzadziej uznawali za niesympatyczną, a inteligencję bardziej postrzegali w kategoriach mądrości życiowej. Wydaje się, że drobne różnice są wynikiem specyfiki każdego z typów wizerunku lub ewentualnych wzajemnych wpływów mających wyraz ilościowy (nie jakościowy - nie pojawiają się istotne rozbieżności), dlatego całościowo image felietonistki można uznać za spójny.

Zauważana do tej pory prawidłowość dotycząca kategorii „inne” częściowo potwierdza się również $\mathrm{u}$ analizowanej felietonistki. W przypadku Krzysztofa Vargi i Piotra Zaremby „inne” to najczęściej (z jednym tylko wyjątkiem) wskazania na poziomie procentowym powyżej $20 \%$ i liczba osób ich dokonujących powyżej 50\%, co oznaczało, że w każdym typie image’u najwyżej wskazywana cecha wizerunkowa prezentuje wyniki procentowe niższe niż „inne”. W zakresie progu $20 \%$ wskazań i $50 \%$ osób ich dokonujących trudno szukać odstępstw od przywołanej reguły. Poziom $20 \%$ przekroczony zostaje $\mathrm{w}$ przypadkach image'u werbalnego anonima $(23,05 \%)$ i znanej felietonistki $(21,81 \%)$, wizualnego kobiety o niejawnym nazwisku $(22,06 \%)$ i publicznego (26,60\%). Mniejszy wskaźnik pojawia się tylko w wizerunku wizualnym autorki rozpoznawalnej, ale odstępstwo od $20 \%$ pozostaje niewielkie (19,48\%). Wskazań skodowanych jako „inne” dokonuje też 
ponad połowa respondentów (niejawny autor tekstu: 58,73\%, podane nazwisko: $58,73 \%$, image wizualny rozpoznawalnej autorki: $58,82 \%$, wizerunek wizualny nieznanej osoby: 60,87\%, image publiczny: 69,39\%). Większe różnice widać, jeśli spojrzeć na wartości względne. W dwóch tylko bowiem przypadkach (na pięć omawianych) wartość procentowa wskazań z „inne” jest wyższa niż dla najwyżej reprezentowanej cechy wizerunkowej (image werbalny nieznanej felietonistki: $23,05 \%$ wskazań w stosunku do najliczniej manifestowanej cechy $14,24 \%$; oraz wizerunek werbalny autorki o podanym nazwisku: $21,81 \%$ w relacji do najczęściej wypisywanej cechy 21,48\%), przy czym w ostatnim z tych przypadków różnice są minimalne. W pozostałych wizerunkach „inne” prezentują mniejsze wartości od najliczniej wynotowywanej cechy (image publiczny: „inne” to $26,60 \%$, a cecha pierwsza na liście: $27,13 \%$; wizerunek wizualny rozpoznawanej felietonistki: $19,48 \%$ w relacji do $23,38 \%$; image wizualny anonimowej osoby: „inne” to $22,06 \%$, a najczęściej wypisywana cecha $-29,41 \%$ ).

Jak zinterpretować to zmniejszenie wielkości kategorii „inne”? Wydaje się, że - wbrew pozorom - mechanizm wyłaniania się spójnych cech wizerunkowych i tych tworzących grupę „inne” pozostaje bez zmian, tj. jeśli uwzględnić bloki semantyczne, które da się zauważyć, to wizerunek (którykolwiek jego typ) pozostaje wyrazisty w obrębie kilku tylko cech (wokół których widać synonimiczne określenia), co zapewne regulują ograniczone możliwości percepcyjne interpretatorów. Te 3-4 cechy dla każdego odbiorcy wypowiedzi w skali zebrania danych od wielu interpretatorów oznaczają 5-7 bloków semantycznych. Te przymioty danej osoby, które dla interpretatorów są silnie eksponowane, tworzą spójne cechy wizerunkowe, a pozostałe tworzą grupę „inne”. „Objętość” wizerunku pozostaje zawsze taka sama, zmieniają się tylko proporcje udziału poszczególnych cech. I tak też jest w przypadku Magdaleny Środy: generowana przez różne procesy silna manifestacja jednej cechy zmniejsza znaczenie kategorii „inne”. A w przypadku felietonistki najliczniej wskazywana cecha jest wynikiem funkcjonowania stereotypu feministki (wizerunek publiczny, wizerunek werbalny osoby o podanym nazwisku) oraz wyrazistego gestu (podniesiony palec - wizerunek wizualny anonimowej kobiety na zdjęciu). Zwiększenie znaczenia kategorii „inne” nie dotyczy wizerunków werbalnych, gdzie te wpływy są ograniczone (zdjęcie i informacja o nazwisku autora obok tekstu) albo ich funkcjonowanie jest niezauważalne (felieton osoby o nieznanej tożsamości). Jeśli więc pojawia się coś w wizerunku, co pozwala zwiększyć jego wyrazistość (zmniejszyć liczbę przypisywanych cech bądź bloków semantycznych czy zwiększyć reprezentatywność poszczególnych cech wizerunkowych) - jak stereotyp czy gest - to kategoria „inne” traci nieco na znaczeniu, choć jej obszerność nieustająco pozostaje duża. 
Kategorie wizerunkowe pojawiające się we wszystkich typach image'u Magdaleny Środy to „postawa”, „cechy charakteru” i „wiedza”. „Poglądy/wartości” pojawiają się w każdym wymiarze image’u oprócz wizualnego. „Sposób komunikacji” pozostaje specyficzny dla poziomu słowa, „zawód” dla wizerunku publicznego, „stan emocjonalno-poznawczy” dla komunikacji obrazem, ale tym razem tylko wówczas, gdy osoba ze zdjęcia była rozpoznawana przez respondentów. W przypadku typu publicznego pojawiła się kategoria „inne”, która obejmowała takie cechy, jak „kojarzę, ale słabo” oraz „irytująca”.

Jakie wnioski uzyskamy, łącząc wyniki analiz wizerunków Magdaleny Środy z ustaleniami dotyczącymi Krzysztofa Vargi i Piotra Zaremby?

Kategoriami pojawiającymi się we wszystkich typach wizerunków są: „postawa”, „cechy charakteru” $i$,wiedza”. Do tej pory pierwsze dwa z tych aspektów image'u dominowały ilościowo $\mathrm{w}$ wizerunkach werbalnych i publicznym, teraz ten trend został rozszerzony o imagee wizualne, a ograniczony w opartym na słowie wizerunku autorki o jawnym nazwisku i wyglądzie, gdzie kategoriami z największą liczbą wskazań zostały „postawa” oraz „poglądy/wartości”. Podobnie jak u Piotra Zaremby, także i w przypadku Magdaleny Środy występują "poglądy/wartości” w image’u werbalnym i publicznym (u Krzysztofa Vargi w ogóle ta kategoria się nie pojawia). Wydaje się, że udział reprezentacji "poglądów/wartości” wzrasta wraz z przesunięciem optyki wywodu w stronę tematyki społeczno-politycznej. „Sposób komunikacji” niezmiennie jest domeną słowa, „zawód” wymiaru publicznego, a „wiek/płeć” obrazu. „Wygląd” do tej pory pojawił się incydentalnie u Piotra Zaremby jako element jego wizerunku wizualnego. „Stan emocjonalno-poznawczy” przestaje być domeną tylko wizerunku wizualnego - u Magdaleny Środy nie pojawił się w image’u opartym na obrazie, kiedy osoba ze zdjęcia była dla respondentów anonimowa. W przypadku wizerunku publicznego wyodrębnić należało grupę „inne”.

Potwierdza się, że powtarzające się kategorie wizerunkowe mają charakter uniwersalny - zarówno ze względu na typ image’u, jak i osobę, której dotyczą. Cechy wszystkich typów wizerunków powielają się w dosłownej lub synonimicznej formie, więc w mocy pozostaje ustalenie, że image wizualny i werbalny wpływają na publiczny jednocześnie, choć odwrotny kierunek wpływu również da się zauważyć - wtedy, gdy interpretatorzy oglądają zdjęcie znanej im osoby i zwłaszcza wtedy, gdy silnym komponentem wizerunku publicznego staje się stereotyp (tutaj: feministki). „Zawód” pozostaje typowy dla wizerunku publicznego, ze względu na determinację tego image’u także przez wiadomości „o” felietoniście, a nie tylko jego słowa. Ciekawe, że „stan emocjonalno-poznawczy" nie pojawił się w wizerunku anonimowej osoby na zdjęciu. Możliwe, że gest podniesionego palca wskazującego tak zdominował percepcję interpretatorów, że wyeliminowali ten aspekt image’u z jego konstrukcji. 
To by oznaczało istotny wpływ „dodatkowych” atrybutów wyglądu. U Piotra Zaremby nie bez znaczenia okazały się okulary, u felietonistki gest wykonany ręką. Zwrócić też należy uwagę na „poglądy/wartości”, których udział w wizerunku rośnie wraz z ilością poruszanych społeczno-politycznych tematów i - zdaje się - wraz z siłą ich wyrazu (wzmacnianą przez działanie stereotypu).

Podobnie jak w przypadku felietonisty „Dużego Formatu” i „W Sieci”, także i u Magdaleny Środy widać, że migracje cech nie są możliwe ze specyficznych dla danego typu wizerunku kategorii, tj. np. nie pojawi się cecha reprezentująca „stan emocjonalno-poznawczy” w wizerunku werbalnym, choć przynajmniej teoretycznie byłoby możliwe, by na podstawie tekstu uznać kogoś za np. „opanowanego”.

Piotrowi Zarembie i Magdalenie Środzie respondenci przypisywali cechę świadczącą o celebrytyzacji publicystyki - „osoba medialna”. Z pewnością wyniki dotyczące Szymona Hołowni dodadzą ciekawe wątki.

Analiza wizerunku werbalnego, gdy imię i nazwisko oraz wygląd autorki pozostawały jawne, wykazała determinację image’em publicznym i wizualnym, ale pamiętać należy, że wpływy ograniczają się do eksponowania tych cech wizerunkowych, które już są w tekście i stały się jedynie dla odbiorcy bardziej widoczne.

Co nowego do dotychczasowych ustaleń pozwalają dodać wyniki analiz wizerunków Magdaleny Środy?

Wpływy wizerunku werbalnego i wizualnego na image publiczny są oczywiste, ale tym razem stereotyp feministki (którego źródłem musiały być słowa) stał się katalizatorem podnoszącym wartości liczbowe najwyżej reprezentowanych cech wizerunku publicznego („dosadnie wyrażająca swoje odważne sądy” i „feministka”). Bezkompromisowa postawa oraz poglądy felietonistki zyskały tak wysoką reprezentację, że kategoria wizerunkowa „zawód” z pierwszej pozycji u poprzednich autorów została zepchnięta u Magdaleny Środy na trzecie miejsce. Dało się wyłonić 17 cech wizerunkowych image’u publicznego w miejsce ośmiu (Varga) i dziewięciu (Zaremba), ale możliwe, że relatywnie duża liczba odpowiadających zdeterminowała kształt tych wyników.

Stereotyp miał także wpływ na rezultaty w zakresie wizerunku wizualnego rozpoznawanej Magdaleny Środy. Przypisywane feministkom waleczność i agresja znalazły odzwierciedlenie w image'u o większym dystansie i chłodzie, a mniejszym wrażeniu sympatyczności w porównaniu $\mathrm{z}$ wizerunkiem anonimowej kobiety $\mathrm{z}$ fotografii.

U wszystkich trzech analizowanych do tej pory felietonistów najliczniej manifestowane cechy, takie jak „dosadnie przedstawiający/-a swoje odważne sądy”, „inteligentny/-a”, „krytyczny/-a”, „spostrzegawczy/-a” powtarzają się w czołówce wskazań. Tak jak już wspomniano wcześniej (rozdział 2.3.5. Zależności między 
poszczególnymi typami wizerunków Piotra Zaremby), możliwe, że wynika to ze zbieżności wizerunkowej, a ponadto determinować taki stan rzeczy może gatunek felietonu lub konieczność wyróżnienia się na rynku medialnym (wyraz dyskursu publicystycznego). Pamiętać jednak należy, że proporcje wspomnianych cech są znacząco różne, co dobitnie ukazuje casus Magdaleny Środy i wykluczyć należy zbieżność wizerunkową.

Powyższy problem wygenerował pytanie, gdzie szukać $\mathrm{w}$ takim razie faktycznych wyróżników wizerunku: w proporcjach między najliczniej reprezentowanymi cechami, w blokach semantycznych, jakie niewątpliwie cechy wizerunkowe tworzą, czy w obu tych miejscach. Udało się nieco zbliżyć do odpowiedzi. Ciekawe wyniki przyniosła wnikliwsza analiza grup semantycznych, która w przypadku obu wizerunków wizualnych pozwoliła zlokalizować źródło różnic w stereotypie. Wydaje się, że w analizie wizerunku danej osoby grupy semantyczne są bardzo pomocnym narzędziem, choć należy też pamiętać o różnicach $\mathrm{w}$ wartościach poszczególnych cech między wizerunkami, jeśli takie się pojawiają (mogą stanowić istotną wskazówkę interpretacyjną).

Posługiwanie się narzędziem bloków semantycznych ma niewątpliwy walor wsparcia w określeniu najważniejszych wyróżników wizerunku i dobrze spaja w grupy cechy o zbliżonej semantyce. Wciąż jednak na uwagę zasługuje problem zjawiska przynależności cech niejednoznacznych do zakresów znaczeniowych różnych bloków i trudność w ustaleniu granic przynależności do danej kategorii. Być może analiza wizerunków Szymona Hołowni pozwoli sprecyzować ustalenia.

W każdym razie, o ile wskazanie kategorii wizerunkowych pozwala określić obszary, w jakich można komunikować dany typ wizerunku, o tyle wyodrębnienie bloków semantycznych wraz z uwzględnieniem najliczniej wskazywanych cech ułatwia określenie najważniejszych komponentów wizerunku danej osoby publicznej.

W zakresie liczby spójnych cech wizerunkowych budujących każdy z wizerunków także zaszły pewne zmiany. O ile u Krzysztofa Vargi i Piotra Zaremby najwięcej cech liczył image werbalny anonima, nieco mniej werbalny felietonisty o podanej tożsamości, następnie wizualny (nieznanej osoby) i na końcu publiczny, to przypadek Magdaleny Środy zaburza te proporcje i miejscami zamieniają się dwa ostatnie. Image na podstawie samego tekstu to $21 \mathrm{cech}$; wizerunek, którego bazą jest tekst $\mathrm{z}$ informacją o autorze, to 19 cech; następnie wizerunek publiczny buduje 17 cech; i na końcu wizualne: 12 (rozpoznawalna felietonistka) i 11 (nieznana). Być może na takie wyniki miała wpływ liczba respondentów, większa tym razem w przypadku wizerunku publicznego, a mniejsza dla obu wizualnych. 


\subsection{Szymon Hołownia ${ }^{19}$}

\subsubsection{Szymon Hołownia - wizerunek na podstawie anonimowego tekstu}

Na 63 uczestników badania, którzy odpowiedzieli na pytanie: „Mając za podstawę tekst przeczytanego felietonu, jakimi słowami opisałby Pan / opisałaby Pani autora tego tekstu?", 7 osób podało po 3 epitety, 13 po 4 określenia i 43 po 5, co pozwoliło zebrać łącznie 288 wskazań, przy czym dwa z nich poddano podwójnemu kodowaniu ${ }^{20}$. Wyodrębniono 24 spójne cechy wizerunkowe.

Tabela 39. Zestawienie odpowiedzi respondentów czytających tekst anonimowego autora (Szymona Hołowni) na pytanie: „Mając za podstawę tekst przeczytanego felietonu, jakimi słowami opisałby Pan / opisałaby Pani autora tego tekstu?"

\begin{tabular}{|c|c|c|c|c|c|c|}
\hline \multirow{2}{*}{ lp. } & \multirow{2}{*}{$\begin{array}{c}\text { cecha } \\
\text { wizerunkowa }\end{array}$} & \multirow{2}{*}{ warianty leksykalne } & \multicolumn{2}{|c|}{ wskazania } & \multicolumn{2}{|c|}{ osoby } \\
\hline & & & $\mathbf{n}$ & $\%$ & $\mathbf{n}$ & $\%$ \\
\hline 1. & $\begin{array}{l}\text { inteligentny } \\
\text { (10) }\end{array}$ & $\begin{array}{l}\text { inteligentny (również w stylu } \\
\text { pisania); intelektualista (2); my- } \\
\text { ślący (2); bystry (2); błyskotliwy; } \\
\text { błyskotliwa; mądry (2); rozsądny; } \\
\text { bystry, spostrzegawczy; opisuje } \\
\text { problemy oraz potrzeby Kościoła, } \\
\text { co świadczy o tym, że jest człowie- } \\
\text { kiem obeznanym i inteligentnym }\end{array}$ & 24 & 8,28 & 22 & 34,92 \\
\hline 2. & wierzący (5) & $\begin{array}{l}\text { głęboko wierzący; katolik (4); ka- } \\
\text { tolik, religijny; religijny (3); osoba } \\
\text { wierząca; osoba wierząca, którą } \\
\text { denerwuje Kościól jako instytucja; } \\
\text { chrześcijanin; chrześcijanin - opo- } \\
\text { wiada się po stronie Kościoła; } \\
\text { teolog; uduchowiony }\end{array}$ & 20 & 6,90 & 18 & 28,57 \\
\hline 3. & $\begin{array}{l}\text { dosadnie } \\
\text { przedstawia- } \\
\text { jący swoje } \\
\text { odważne sądy } \\
\text { (0) }\end{array}$ & $\begin{array}{l}\text { odważny (2); odważny, bo nie } \\
\text { boi się powiedzieć, co myśli; bez- } \\
\text { pośredni; pewny siebie, swoich } \\
\text { poglądów; pewny siebie i swoich } \\
\text { racji; elokwentny (3); pomysłowy } \\
\text { - przekazujące ciekawe treści }\end{array}$ & 19 & 6,55 & 19 & 30,16 \\
\hline
\end{tabular}

19 Cząstkowe wyniki dotyczące wizerunków Szymona Hołowni zob. Barańska-Szmitko 2014d.

20 Określenie „bystry, spostrzegawczy” skategoryzowano jako „inteligentny” oraz „obserwator”, a „opisuje problemy oraz potrzeby kościoła, co świadczy o tym, że jest człowiekiem obeznanym i inteligentnym” zakodowano jako „zna temat” i ,inteligentny”. 
Tabela 39 (cd.)

\begin{tabular}{|c|c|c|c|c|c|c|}
\hline \multirow{2}{*}{ lp. } & \multirow{2}{*}{$\begin{array}{c}\text { cecha } \\
\text { wizerunkowa }\end{array}$} & \multirow{2}{*}{ warianty leksykalne } & \multicolumn{2}{|c|}{ wskazania } & \multicolumn{2}{|c|}{ osoby } \\
\hline & & & $\mathbf{n}$ & $\%$ & $\mathbf{n}$ & $\%$ \\
\hline 4. & $\begin{array}{l}\text { ciekawie } \\
\text { piszący }(0)\end{array}$ & $\begin{array}{l}\text { interesująca; potrafiący dotrzeć } \\
\text { w myśli każdego; umiejętnie gra sło- } \\
\text { wem; jego tekst dociera do odbiorcy } \\
\text { w jasny sposób, gdyż autor posługuje } \\
\text { się prostym, ale współczesnym ję- } \\
\text { zykiem; ważna jest dla niego komu- } \\
\text { nikacja z odbiorcą, chce być dobrze } \\
\text { zrozumiany; komunikatywny - po- } \\
\text { toczne słownictwo; lubiący patos; } \\
\text { operuje retoryką; literat; dziennikarz; } \\
\text { dobrze argumentuje swoje zdanie; } \\
\text { ekscentryczny }\end{array}$ & 16 & 5,52 & 15 & 23,81 \\
\hline 5. & krytyczny (3) & $\begin{array}{l}\text { krytykujący; krytykuje to, w jaki } \\
\text { sposób oraz czym kierują się kar- } \\
\text { dynałowie przy wyborze papieża; } \\
\text { przedstawia sytuację, oceniając; } \\
\text { oburzony; wściekły; wartościujący; } \\
\text { zażenowany; kontestujący; krytyczny } \\
\text { wobec siebie; samokrytyczny; rozgo- } \\
\text { ryczony (2) }\end{array}$ & 15 & 5,17 & 14 & 22,22 \\
\hline 6. & obiektywny (7) & $\begin{array}{l}\text { obiektywna; obiektywizm; obiektyw- } \\
\text { nie wypowiadający się i oceniający } \\
\text { obecną sytuację w Kościele; nie } \\
\text { jest stronniczy; sprawiedliwy; stara } \\
\text { się podejść do opisywanej sprawy } \\
\text { w dwojaki sposób, nie przyjmuje jed- } \\
\text { noznacznego stanowiska w sprawie; } \\
\text { rozstrzyga różne opcje }\end{array}$ & 14 & 4,83 & 13 & 20,63 \\
\hline 7. & zna temat & $\begin{array}{l}\text { znający się na poruszanym temacie; } \\
\text { znający się w temacie religii i Ko- } \\
\text { ścioła; posiada wiedzę na tematy } \\
\text { religijne, biblijne; dobrze zoriento- } \\
\text { wana; jest zorientowany w sytuacji } \\
\text { panującej w kraju, nie tylko wśród } \\
\text { bogatszych, ale też biedniejszych } \\
\text { sfer; jest na bieżąco w temacie, do- } \\
\text { brze przygotowany; zorientowana; } \\
\text { znawca religii katolickiej; świadomy; } \\
\text { obyty; dużo wie o świecie i mechani- } \\
\text { zmach w nich działających; opisuje } \\
\text { problemy oraz potrzeby Kościoła, co } \\
\text { świadczy o tym, że jest człowiekiem } \\
\text { obeznanym i inteligentnym; wie, } \\
\text { o czym pisze }\end{array}$ & 14 & 4,83 & 14 & 22,22 \\
\hline 8. & ironiczny (6) & $\begin{array}{l}\text { ironiczny/kpiący; posługiwanie się } \\
\text { ironią; ironiczność; sarkastyczny (3) }\end{array}$ & 12 & 4,14 & 11 & 17,46 \\
\hline
\end{tabular}




\begin{tabular}{|c|c|c|c|c|c|c|}
\hline \multirow{2}{*}{ lp. } & \multirow{2}{*}{$\begin{array}{c}\text { cecha } \\
\text { wizerunkowa }\end{array}$} & \multirow{2}{*}{ warianty leksykalne } & \multicolumn{2}{|c|}{ wskazania } & \multicolumn{2}{|c|}{ osoby } \\
\hline & & & n & $\%$ & $\mathbf{n}$ & $\%$ \\
\hline 9. & obserwator (5) & $\begin{array}{l}\text { obserwuje społeczeństwo, zacho- } \\
\text { wanie ludzi; zdolny obserwator; } \\
\text { wnikliwy obserwator; spostrze- } \\
\text { gawczy; bystry, spostrzegawczy; } \\
\text { opisuje faktyczną rzeczywistość }\end{array}$ & 11 & 3,79 & 9 & 14,29 \\
\hline 10. & dociekliwy (5) & $\begin{array}{l}\text { dociekliwość, by dobrze przed- } \\
\text { stawić temat z każdej strony; } \\
\text { przenikliwy (tezę oparł na kilku } \\
\text { argumentach, z kilku stron pod- } \\
\text { chodząc do tematu); wnikliwy (3) }\end{array}$ & 10 & 3,45 & 9 & 14,29 \\
\hline 11. & dokładny (0) & $\begin{array}{l}\text { rzeczowy (3); rzetelnie opisuje } \\
\text { sytuację panującą przed wyborem } \\
\text { nowego papieża; skrupulatny; skru- } \\
\text { pulatna; wiarygodny; rzetelny (2) }\end{array}$ & 9 & 3,10 & 8 & 12,70 \\
\hline 12. & zabawny & $\begin{array}{l}\text { zdystansowany (3); dowcipny; } \\
\text { z poczuciem humoru; posiada } \\
\text { humor; podchodzi do życia } \\
\text { z dystansem; dystans }\end{array}$ & 9 & 3,10 & 9 & 14,29 \\
\hline 13. & oczytany (7) & wydaje się oczytany - zna Orwella & 8 & 2,76 & 8 & 12,70 \\
\hline 14. & $\begin{array}{l}\text { zaangażowany } \\
(0)\end{array}$ & $\begin{array}{l}\text { zaangażowany w temat; zaangażowa- } \\
\text { ny w swoją religię, czuć, że uważa ją } \\
\text { za słuszną; przejęty sprawami świata; } \\
\text { zaangażowany społecznie; niepokój } \\
\text { związany z podziałem chrześcijań- } \\
\text { stwa; zachwycony nowym papieżem; } \\
\text { stawia ważne pytania }\end{array}$ & 7 & 2,41 & 6 & 9,52 \\
\hline 15. & ciekawy (3) & $\begin{array}{l}\text { ciekawa świata; ciekawość; otwar- } \\
\text { tość umysłu; nie boi się nowych } \\
\text { i ciekawych wyzwań }\end{array}$ & 7 & 2,41 & 6 & 9,52 \\
\hline 16. & $\begin{array}{l}\text { empatyczny } \\
(3)\end{array}$ & $\begin{array}{l}\text { wyrozumiały; dostrzega innych } \\
\text { ludzi, współczujący; współczujący }\end{array}$ & 6 & 2,07 & 6 & 9,52 \\
\hline 17. & realista (3) & $\begin{array}{l}\text { racjonalnie patrzący na świat; ra- } \\
\text { cjonalnie argumentujący; posiada } \\
\text { zdrowe spojrzenie na otaczającą } \\
\text { go rzeczywistość }\end{array}$ & 6 & 2,07 & 5 & 7,94 \\
\hline 18. & $\begin{array}{l}\text { interesujący } \\
\text { się (5) }\end{array}$ & $\begin{array}{l}\text { zainteresowany; zainteresowana; } \\
\text { zainteresowany współczesnymi pro- } \\
\text { blemami; zainteresowany sprawami } \\
\text { Kościoła; fascynat starymi budowla- } \\
\text { mi i nowoczesną architekturą }\end{array}$ & 5 & 1,72 & 5 & 7,94 \\
\hline 19. & $\begin{array}{l}\text { konserwatyw- } \\
\text { ny }(2)\end{array}$ & $\begin{array}{l}\text { tradycyjny; tradycjonalista ale z nutą } \\
\text { nowoczesności; tradycjonalista }\end{array}$ & 5 & 1,72 & 5 & 7,94 \\
\hline 20. & otwarty (2) & $\begin{array}{l}\text { otwarty umysł; szeroki światopo- } \\
\text { gląd; otwartość }\end{array}$ & 5 & 1,72 & 4 & 6,35 \\
\hline
\end{tabular}


Tabela 39 (cd.)

\begin{tabular}{|c|c|c|c|c|c|c|}
\hline \multirow{2}{*}{ lp. } & \multirow{2}{*}{$\begin{array}{c}\text { cecha } \\
\text { wizerunkowa }\end{array}$} & \multirow{2}{*}{ warianty leksykalne } & \multicolumn{2}{|c|}{ wskazania } & \multicolumn{2}{|c|}{ osoby } \\
\hline & & & $\mathbf{n}$ & $\%$ & $\mathbf{n}$ & $\%$ \\
\hline 21. & $\begin{array}{l}\text { subiektywny } \\
\text { (3) }\end{array}$ & tendencyjny; stronniczy & 5 & 1,72 & 4 & 6,35 \\
\hline 22. & wykształcony & $\begin{array}{l}\text { wykształcona; człowiek wykształ- } \\
\text { cony; naukowiec }\end{array}$ & 4 & 1,38 & 4 & 6,35 \\
\hline 23. & młody & $\begin{array}{l}\text { młody (nie nosi znamion konser- } \\
\text { watyzmu); nowoczesny (2) }\end{array}$ & 4 & 1,38 & 4 & 6,35 \\
\hline 24. & szczery (2) & szczera; szczerość & 4 & 1,38 & 4 & 6,35 \\
\hline 25. & inne & $\begin{array}{l}\text { doświadczony (2); cyniczny; cy- } \\
\text { nik; moralizator; moralista; tole- } \\
\text { rancyjny; szanujący ludzi i ich po- } \\
\text { glądy; tolerancyjny, przynajmniej } \\
\text { deklaratywnie; chaotyczny (2); } \\
\text { uszczypliwy (2); odważny (3); no- } \\
\text { watorski; oryginalny; pomysłowy; } \\
\text { podróżnik (2); dużo podróżuje po } \\
\text { świecie; w pełni poświęcony swo- } \\
\text { jej pracy; zaradny; ambitny; czło- } \\
\text { wiek myślący „prawidłowo” (nie } \\
\text { kategoriami); akceptujący ustalone } \\
\text { zasady; sprawiedliwy; usatysfak- } \\
\text { cjonowana; niezaangażowany; } \\
\text { wiara w ludzi; filozof; dążący do } \\
\text { zwrócenia uwagi na problem; } \\
\text { spontaniczny; prawicowy - kpią- } \\
\text { cy ton w 1. akapicie; obrażalski; } \\
\text { marzyciel; gbur; despota; człowiek } \\
\text { nietolerancyjny, odwracający kota } \\
\text { ogonem; szanuje instytucję, jaką } \\
\text { jest Kościół, odnosi się z wielkim } \\
\text { szacunkiem do osoby, którą opisu- } \\
\text { je; kulturalny; przychylny; Euro- } \\
\text { pejczyk; dygresyjny; głupiomądry; } \\
\text { przestraszony; sceptyczny; tajem- } \\
\text { niczy; hipokryta; cierpliwa }\end{array}$ & 51 & 17,59 & 30 & 47,62 \\
\hline & & razem & 290 & 100,00 & & \\
\hline
\end{tabular}

Źródło: opracowanie własne

Wizerunek Szymona Hołowni jako anonimowego autora felietonu nie ma wyraźnie dominującej jednej cechy, jak imagee Krzysztofa Vargi albo Magdaleny Środy, ale podobnie jak w przypadku Piotra Zaremby pojawia się kilka atrybutów mających porównywalnie wysoką reprezentację. Na poziomie ok. 8-7\% wskazań i 30\% osób ich dokonujących utrzymuje się pierwsza trójka 
cech wizerunkowych: „inteligentny” (24 - 8,28\% wynotowań; 22 - 34,92\% czytelników), „wierzący” (20 - 6,90\%; $18-28,57 \%)$, „dosadnie przedstawiający swoje odważne sądy" (19-6,55\%; 19 - 30,16\%).

Ciekawe, że wyjątkowo na tle innych felietonistów ostatnia z tych cech nie ma większej, ale równą liczbę wskazań w stosunku do ilości osób, które tych wynotowań dokonały (19). Do tej pory przewagę liczby wskazań tłumaczono złożonością „dosadnie prezentujący...” i trudnością w wyborze odpowiedniego słownego określenia. Taka interpretacja wydaje się do utrzymania. Możliwe, że dysproporcje między tymi dwiema wartościami zmniejszają się, kiedy tematyka jest ujednolicona, a związana z nią postawa niepopularna. Szymon Hołownia niemal zawsze pisze o kwestiach związanych z religijnością lub Kościołem (stąd zapewne tak wysoka manifestacja cechy „wierzący”) z punktu widzenia katolika, a pamiętać należy, że sfera wiary pozostaje w Polsce wciąż w zakresie tabu ${ }^{21}$. Wyrazistość prezentowanej postawy zwiększa posługiwanie się prostym, komunikatywnym językiem, nierzadko potocznym (por. Kowal 2011, 2011), dalekim od typowego dla dyskursu religijnego (zob. Makuchowska 2013: 489). Ten otwarty i w powszechnym odczuciu niewygodny przekaz powtarzany w każdym felietonie może powodować, że „dosadnie przekazujący swoje odważne sądy” dotyczy tylko postawy wyraziście artykułującego swoje poglądy katolika. Jasny i prosty konstrukt nie wymaga doprecyzowania, stąd też czytelnicy nie stosowali synonimów i nie dublowali swoich odpowiedzi w obrębie jednej cechy wizerunkowej.

Wracając do całościowego oglądu wizerunku, wymienić można cechy prezentujące ok. 5\% wskazań wypisanych przez mniej więcej 1/5 uczestników: „ciekawie piszący” (16 - 5,52\%; 15 - 23,81\%) i dwie cechy o nieco odmiennych znaczeniach, a podobnych wartościach: „krytyczny” (15 - 5,17\%; $14-22,22 \%)$ oraz „obiektywny” (14 - 4,83\%; 13 - 20,26\%). Ok. 4\% wskazań lub mniej liczą: „ironiczny” (12 - 4,14\%; $11-17,46 \%)$, „obserwator” (11 - 3,79\%; 9 - 14,29\%), „dociekliwy” (10 - 3,45\%; 9 - 14,29\%), „dokładny” ( 9 - 3,10\%; 8 - 12,70\%), „zabawny” (9-3,10\%; 9 - 14,29\%). Wśród cech wizerunkowych funkcjonujących na poziomie mniej niż $3 \%$ wynotowań znajdują się: „oczytany” (8 - 2,76\%; 8 - 12,79\%); „Zaangażowany” i „ciekawy” (po 7 - 2,41\%; 6 - 9,52\%), „empatyczny” (6 - 2,07\%; 6 - 9,52\%) oraz „realista” (6 - 2,07\%; 5 - 7,94\%). Poniżej $2 \%$ wynotowań mają cechy: „interesujący się" i „konserwatywny” (5 - 1,72\%; 5 - 7,94\%), „otwarty” i „subiektywny” (po 5 - 1,72\%; 4 - 6,36\%), ,wykształcony”, „młody” i „szczery” (po 4 - 1,38\%; 4 - 6,35\%).

21 Z raportu „Tematy tabu w Polsce”, przygotowanego na zlecenie National Geographic Channel i Telewizji TTV, wynika, że 24\% Polaków uważa Kościół/religię za temat tabu i jest to trzeci z najczęściej wskazywanych zakazanych obszarów tematycznych. Zob. http://www.tabupolska. $\mathrm{pl} /$ survey/summary/ (data dostępu: 02.12.2015). 
Wizerunki felietonistów

Tabela 40. Bloki semantyczne wizerunku werbalnego anonimowego dla czytelników Szymona Hołowni

\begin{tabular}{|c|c|c|c|c|c|}
\hline \multirow{2}{*}{ lp. } & \multirow{2}{*}{ cecha wizerunkowa } & \multicolumn{2}{|c|}{ wskazania } & \multicolumn{2}{|c|}{ osoby } \\
\hline & & $\mathbf{n}$ & $\%$ & $\mathbf{n}$ & $\%$ \\
\hline 1. & $\begin{array}{l}\text { dosadnie przedstawiający swoje } \\
\text { odważne sądy }(0)\end{array}$ & 19 & 6,55 & 19 & 30,16 \\
\hline 2. & krytyczny (3) & 15 & 5,17 & 14 & 22,22 \\
\hline 3. & ironiczny (6) & 12 & 4,14 & 11 & 17,46 \\
\hline 4. & subiektywny (3) & 5 & 1,72 & 4 & 6,35 \\
\hline & & 51 & 17,59 & & \\
\hline 5. & ciekawie piszący $(0)$ & 16 & 5,52 & 15 & 23,81 \\
\hline 6. & zabawny & 9 & 3,10 & 9 & 14,29 \\
\hline 7. & ironiczny (6) & 12 & 4,14 & 11 & 17,46 \\
\hline & & 37 & 12,76 & & \\
\hline 8. & inteligentny (10) & 24 & 8,28 & 22 & 34,92 \\
\hline 9. & obserwator (11) & 11 & 3,79 & 9 & 14,29 \\
\hline & & 35 & 12,07 & & \\
\hline 10. & wierzący (5) & 20 & 6,90 & 18 & 28,57 \\
\hline 11. & zaangażowany $(0)$ & 7 & 2,41 & 6 & 9,52 \\
\hline 12. & konserwatywny (2) & 5 & 1,72 & 5 & 7,94 \\
\hline & & 32 & 11,03 & & \\
\hline 13. & interesujący się (5) & 5 & 1,72 & 5 & 7,94 \\
\hline 14. & zna temat & 14 & 4,83 & 14 & 22,22 \\
\hline 15. & wykształcony & 4 & 1,38 & 4 & 6,35 \\
\hline 16. & oczytany (7) & 8 & 2,76 & 8 & 12,70 \\
\hline & & 31 & 10,69 & & \\
\hline 17. & obiektywny (7) & 14 & 4,83 & 13 & 20,63 \\
\hline 18. & realista (3) & 6 & 2,07 & 5 & 7,94 \\
\hline & & 20 & 6,90 & & \\
\hline 19. & dociekliwy (5) & 10 & 3,45 & 9 & 14,29 \\
\hline 20. & dokładny (0) & 9 & 3,10 & 8 & 12,70 \\
\hline & & 19 & 6,55 & & \\
\hline 21. & ciekawy (3) & 7 & 2,41 & 6 & 9,52 \\
\hline 22. & otwarty (2) & 5 & 1,72 & 4 & 6,35 \\
\hline 23. & młody & 4 & 1,38 & 4 & 6,35 \\
\hline & & 16 & 5,52 & & \\
\hline
\end{tabular}




\begin{tabular}{|c|l|c|c|c|c|}
\hline \multirow{2}{*}{ lp. } & \multirow{2}{*}{ cecha wizerunkowa } & \multicolumn{2}{c|}{ wskazania } & \multicolumn{2}{c|}{ osoby } \\
\cline { 3 - 6 } & & $\mathbf{n}$ & $\mathbf{\%}$ & $\mathbf{n}$ & \% \\
\hline 24. & szczery (2) & 4 & 1,38 & 4 & 6,35 \\
\hline 25. & empatyczny (3) & 6 & 2,07 & 6 & 9,52 \\
\hline
\end{tabular}

Źródło: opracowanie własne

Jeśli zwrócić uwagę na najliczniej manifestowane w odbiorze respondentów cechy, to Szymon Hołownia jest przede wszystkim „inteligentny”, „wierzący” i „dosadnie przedstawiający swoje odważne sądy”, a do tego „ciekawie piszący” i mimo krytycyzmu („krytyczny”) zachowuje obiektywizm („obiektywny"). Jeśli zanalizować ten wizerunek pod kątem bloków semantycznych (tabela 40), w jakie łączą się cechy wizerunkowe, to nie ma zbyt dużych różnic między wynikami tych dwóch podejść analitycznych. Grupy pojedynczych atrybutów wspierają te najwyżej reprezentowane cechy i choć zauważyć się da rozbieżności ilościowe, to są one na znikomym poziomie. Pierwszy na liście blok semantyczny koncentruje się wokół dosadnego formułowania swoich poglądów (17,59\% wszystkich wskazań), a kolejny - oddalony jedynie niespełna pięcioma punktami procentowymi - dotyczy interesującego sposobu przekazywania treści $(12,76 \%)$. Następne obszary znaczeniowe nie schodzą poniżej 10\% wskazań, czyli reprezentują podobny poziom, a dotyczą inteligencji $(12,07 \%)$, wiary i zaangażowania w nią $(11,03 \%)$, znajomości poruszanych tematów (10,69\%). Innymi słowy, tak jak na liście frekwencyjnej pojedynczych cech, tak w przypadku grup semantycznych nie ma żadnego wyróżnika wizerunku, który zdecydowanie dominowałby nad innymi, ale występuje kilka charakterystycznych atrybutów, które mniej więcej w równym stopniu łączone są z Szymonem Hołownią.

Tabela 41. Kategorie komunikowanego werbalnie wizerunku felietonisty o anonimowej tożsamości - Szymona Hołowni

\begin{tabular}{|l|l|l|l|l|l|l|l|l|l|l|}
\hline lp. & $\begin{array}{l}\text { poglądy/ } \\
\text { wartości }\end{array}$ & $\mathbf{n}$ & wiedza & $\mathbf{n}$ & postawa & $\mathbf{n}$ & $\begin{array}{c}\text { cecha } \\
\text { charak- } \\
\text { teru }\end{array}$ & $\mathbf{n}$ & $\begin{array}{l}\text { sposób } \\
\text { komu- } \\
\text { nikacji }\end{array}$ & $\mathbf{n}$ \\
\hline 1. & $\begin{array}{l}\text { wierzący } \\
(5)\end{array}$ & 20 & zna temat & 14 & $\begin{array}{l}\text { dosadnie } \\
\text { przedstawia- } \\
\text { jący swoje } \\
\text { odważne } \\
\text { sądy (0) }\end{array}$ & 19 & $\begin{array}{l}\text { inteli- } \\
\text { gentny } \\
(10)\end{array}$ & 24 & $\begin{array}{l}\text { ciekawie } \\
\text { piszący } \\
(0)\end{array}$ & 16 \\
\hline 2. & $\begin{array}{l}\text { konserwa- } \\
\text { tywny (2) }\end{array}$ & 5 & oczytany (7) & 8 & $\begin{array}{l}\text { krytyczny } \\
(3)\end{array}$ & 15 & zabawny & 9 & \\
\hline
\end{tabular}


Tabela 41 (cd.)

\begin{tabular}{|c|c|c|c|c|c|c|c|c|c|c|}
\hline lp. & $\begin{array}{l}\text { poglądy/ } \\
\text { wartości }\end{array}$ & $\mathbf{n}$ & wiedza & $\mathbf{n}$ & postawa & $\mathbf{n}$ & $\begin{array}{c}\text { cecha } \\
\text { charak- } \\
\text { teru }\end{array}$ & $\mathbf{n}$ & $\begin{array}{l}\text { sposób } \\
\text { komu- } \\
\text { nikacji }\end{array}$ & $\mathbf{n}$ \\
\hline 3. & & & $\begin{array}{l}\text { interesujący } \\
\text { się (5) }\end{array}$ & 5 & $\begin{array}{l}\text { obiektywny } \\
\text { (7) }\end{array}$ & 14 & $\begin{array}{l}\text { empa- } \\
\text { tyczny } \\
(3)\end{array}$ & 6 & & \\
\hline 4. & & & wykształcony & 4 & $\begin{array}{l}\text { obserwator } \\
\text { (11) }\end{array}$ & 11 & $\begin{array}{l}\text { szczery } \\
(2)\end{array}$ & 4 & & \\
\hline 5. & & & & & $\begin{array}{l}\text { dociekliwy } \\
\text { (5) }\end{array}$ & 10 & & & & \\
\hline 6. & & & & & dokładny (0) & 9 & & & & \\
\hline 7. & & & & & $\begin{array}{l}\text { zaangażo- } \\
\text { wany }(0)\end{array}$ & 7 & & & & \\
\hline 8. & & & & & ciekawy (3) & 7 & & & & \\
\hline 9. & & & & & realista (3) & 6 & & & & \\
\hline 10. & & & & & otwarty (2) & 5 & & & & \\
\hline 11. & & & & & $\begin{array}{l}\text { subiektyw- } \\
\text { ny (3) }\end{array}$ & 5 & & & & \\
\hline 12. & & & & & młody & 4 & & & & \\
\hline 13. & & & & & ironiczny (6) & 12 & & & & \\
\hline & razem & 25 & & 31 & & 124 & & 43 & & 16 \\
\hline
\end{tabular}

Źródło: opracowanie własne

Kategorie możliwego do komunikowania wizerunku werbalnego Szymona Hołowni, gdy autor pozostaje anonimowy, potwierdzają dotychczasowe ustalenia. Komunikować za pomocą tekstu nieznanego autora można przede wszystkim „postawę" (124 wskazań), a następnie znacznie rzadziej wskazywane „cechy charakteru” (43) i kategorie, które nie wykazują już między sobą dużych dysproporcji wartości liczbowych: „wiedzę” (31), „poglądy/wartości” (25) oraz „sposób komunikacji” (16). „Poglądy/wartości” u Magdaleny Środy i Szymona Hołowni manifestowane są częściej niż u pozostałych analizowanych felietonistów, co potwierdzałoby wcześniejszą interpretację, że taki stan rzeczy wynika z poruszanej tematyki społeczno-politycznej, która sprzyja komunikowaniu zakresu tej kategorii bardziej niż treści dotyczące szeroko rozumianej kultury. Także podobnie jak u publicystki, mniejsze znaczenie okazuje się mieć „wiedza” (Varga: 44 wskazania w tym obszarze, Zaremba: 41, Środa: 20, Hołownia: 31), co znów może oznaczać determinację tematyką. Tym razem jednak problematyka kulturalna okazałaby się bardziej podatna na komunikowanie tego aspektu wizerunku. 


\subsubsection{Szymon Hołownia - wizerunek publiczny}

Respondenci określający wizerunek publiczny Szymona Hołowni zostali zapytani: „Czy zna Pan/Pani nazwisko: Szymon Hołownia? Proszę zakreślić swoją odwiedź krzyżykiem”. Mieli do wyboru: „TAK. Jeśli tak, proszę przejść do pytania nr 2” oraz „NIE. Jeśli nie, proszę schować kartkę do teczki”. Ci, którzy na zadane pytanie odpowiedzieli twierdząco, otrzymali zadanie do wykonania o treści: „Jakimi słowami scharakteryzował(a)by Pan/Pani osobę publiczną Szymona Hołownię?".

Spośród 126 zapytanych osób 14 zaprzeczyło znajomości nazwiska Szymona Hołowni. 112 respondentów potwierdziło, przy czym jedną cechę wskazała jedna osoba, 6 uczestników badania po 2 epitety, 16 osób po 3, 32 po 4 oraz 57 respondentów wypisało po 5 określeń, co dało łącznie 474 wskazania, spośród których 2 zostały zakodowane podwójnie jako wykładniki łącznie 4 cech $^{22}$, więc analizowanych epitetów ostatecznie zostało 476 i utworzyły 18 spójnych cech wizerunkowych.

Tabela 42. Zestawienie odpowiedzi osób potwierdzających znajomość osoby publicznej Szymona Hołowni na pytanie: „Jakimi słowami scharakteryzował(a)by Pan/Pani osobę publiczną Szymona Hołownię?”

\begin{tabular}{|c|c|c|c|c|c|c|}
\hline \multirow{2}{*}{ lp. } & \multirow{2}{*}{$\begin{array}{c}\text { cecha } \\
\text { wizerunkowa }\end{array}$} & \multirow{2}{*}{ warianty leksykalne } & \multicolumn{2}{|c|}{ wskazania } & \multicolumn{2}{|c|}{ osoby } \\
\hline & & & $\mathbf{n}$ & $\%$ & $\mathbf{n}$ & $\%$ \\
\hline 1. & religijny (34) & $\begin{array}{l}\text { religijna; religia; katolik (10); } \\
\text { wybitny krzewiciel katolicyzmu; } \\
\text { czynny w mediach reprezentant } \\
\text { katolików; prokatolik; wierzący } \\
\text { katolik; dobrze, że katolik cho- } \\
\text { ciaż; odpowiadający za katolickie } \\
\text { media; wierzący (9); bardzo wie- } \\
\text { rzący; wierzący i broniący wła- } \\
\text { snych przekonań; osoba wierząca; } \\
\text { pobożny (2); uduchowiony; } \\
\text { duchowny; zbytnio eksponowana } \\
\text { religijność }\end{array}$ & 69 & 14,50 & 66 & 58,93 \\
\hline 2. & zabawny (29) & $\begin{array}{l}\text { zabawny/ironiczny; z poczuciem } \\
\text { humoru (12); poczucie humoru } \\
\text { (2); charakterystyczny głos i po- } \\
\text { czucie humoru; posiada poczucie } \\
\text { humoru; humor; specyficzne } \\
\text { poczucie humoru; dowcipny (8) }\end{array}$ & 67 & 14,08 & 62 & 55,36 \\
\hline
\end{tabular}

22 „Niski, ale przystojny” skategoryzowano jako „niski” oraz „inne”, natomiast „otwarty elokwentny” przyporządkowano do „otwarty” i ,elokwentny”. 
Tabela 42 (cd.)

\begin{tabular}{|c|c|c|c|c|c|c|}
\hline \multirow{2}{*}{ lp. } & \multirow{2}{*}{$\begin{array}{c}\text { cecha } \\
\text { wizerunkowa }\end{array}$} & \multirow{2}{*}{ warianty leksykalne } & \multicolumn{2}{|c|}{ wskazania } & \multicolumn{2}{|c|}{ osoby } \\
\hline & & & $\mathbf{n}$ & $\%$ & $\mathbf{n}$ & $\%$ \\
\hline 3. & inteligentny (38) & $\begin{array}{l}\text { inteligencja; mądry (3), mądry } \\
\text { sympatyczny; mądra; bystry; } \\
\text { błyskotliwy }\end{array}$ & 46 & 9,66 & 44 & 39,29 \\
\hline 4. & sympatyczny (13) & $\begin{array}{l}\text { miły (5); uprzejmy (4); kulturalny } \\
\text { (4), ułożony (2); dobrze wychowa- } \\
\text { ny (2); szarmancki; dobry; przyja- } \\
\text { cielski; przyjazny/miły; przyjazny; } \\
\text { taktowny; ciepły człowiek; uroczy }\end{array}$ & 38 & 7,98 & 29 & 25,89 \\
\hline 5. & pewny siebie (3) & $\begin{array}{l}\text { odważny (3); bezkompromisowy } \\
\text { (2); kontrowersyjny?; kontrowersyj- } \\
\text { ny (2); stanowczy (3); zbyt pewny } \\
\text { siebie; uparty (2); zarozumiały } \\
\text { (4); broniący swoich przekonań; } \\
\text { nie kryje się z własnymi opiniami; } \\
\text { wierny swoim przekonaniom; po- } \\
\text { siadający system wartości; wytrwały; } \\
\text { silna osobowość; zadufany w sobie; } \\
\text { zadziorny; zagorzały; zaciętość; } \\
\text { pewność; zacietrzewienie; apodyk- } \\
\text { tyczny; z zasadami; dogmatyczny }\end{array}$ & 36 & 7,56 & 26 & 23,21 \\
\hline 6. & medialny (5) & $\begin{array}{l}\text { popularny (3); showman (2); } \\
\text { sławny (2); celebryta (2); prowa- } \\
\text { dzący Mam talent (2); prowa- } \\
\text { dzący Mam talent z Prokopem; } \\
\text { prowadzi Mam talent; żartobliwy } \\
\text { juror Mam talent; juror w The } \\
\text { Voice of Poland; rozpoznawalny; } \\
\text { prezenter telewizyjny; dobrze } \\
\text { odnajdujący się przed kamerą } \\
\text { „na żywo”; prowadzący }\end{array}$ & 24 & 5,04 & 21 & 18,75 \\
\hline 7. & elokwentny (9) & $\begin{array}{l}\text { wygadany (5); komunikatywny } \\
\text { (3); rozmowny; rozmowny, wyga- } \\
\text { dany; ma dużo do powiedzenia; } \\
\text { umiejętność pięknego mówienia; } \\
\text { otwarty elokwentny }\end{array}$ & 22 & 4,62 & 19 & 16,96 \\
\hline 8. & oczytany (5) & $\begin{array}{l}\text { bardzo oczytany; wykształcony } \\
\text { (4); kompetentny (2); kompe- } \\
\text { tencja; posiadający dużą wiedzę; } \\
\text { wszechstronna wiedza }\end{array}$ & 15 & 3,15 & 13 & 11,61 \\
\hline 9. & spokojny (7) & $\begin{array}{l}\text { opanowany (3); stonowany; sto- } \\
\text { nowany, zrównoważony; mało } \\
\text { ekstrawagancki }\end{array}$ & 13 & 2,73 & 10 & 8,93 \\
\hline 10. & $\begin{array}{l}\text { konserwatywny } \\
\text { (6) }\end{array}$ & $\begin{array}{l}\text { konserwatysta (2), konserwa- } \\
\text { tyzm, tradycjonalista ( } 3 \text { ) }\end{array}$ & 12 & 2,52 & 11 & 9,82 \\
\hline
\end{tabular}




\begin{tabular}{|c|c|c|c|c|c|c|}
\hline \multirow{2}{*}{ lp. } & \multirow{2}{*}{$\begin{array}{c}\text { cecha } \\
\text { wizerunkowa }\end{array}$} & \multirow{2}{*}{ warianty leksykalne } & \multicolumn{2}{|c|}{ wskazania } & \multicolumn{2}{|c|}{ osoby } \\
\hline & & & $\mathbf{n}$ & $\%$ & $\mathbf{n}$ & $\%$ \\
\hline 11. & rzetelny (5) & $\begin{array}{l}\text { rzetelnie podchodzi do pracy } \\
\text { dziennikarza; rzeczowy (3); } \\
\text { profesjonalny }\end{array}$ & 10 & 2,10 & 10 & 8,93 \\
\hline 12. & otwarty (4) & $\begin{array}{l}\text { otwarty elokwentny; otwartość; } \\
\text { osoba otwarta }\end{array}$ & 7 & 1,47 & 7 & 6,25 \\
\hline 13. & dziennikarz (3) & $\begin{array}{l}\text { dobry dziennikarz (2); felietoni- } \\
\text { sta; dziennikarz religijny }\end{array}$ & 7 & 1,47 & 7 & 6,25 \\
\hline 14. & dobroduszny & $\begin{array}{l}\text { charytatywny; współczujący; } \\
\text { wrażliwy na ludzką krzywdę; czu- } \\
\text { ły; uczuciowy; bezinteresowny }\end{array}$ & 7 & 1,47 & 7 & 6,25 \\
\hline 15. & niski (6) & niski, ale przystojny & 7 & 1,47 & 7 & 6,25 \\
\hline 16. & wysoki (6) & & 6 & 1,26 & 6 & 5,36 \\
\hline 17. & $\begin{array}{l}\text { charyzmatyczny } \\
\text { (6) }\end{array}$ & & 6 & 1,26 & 6 & 5,36 \\
\hline 18. & szczery (6) & & 6 & 1,26 & 6 & 5,36 \\
\hline 19. & interesujący (2) & ciekawy (2) & 4 & 0,84 & 4 & 3,57 \\
\hline 20. & inne & $\begin{array}{l}\text { poważny (3); utalentowany (2); } \\
\text { zdolny; racjonalny; ze zdrowym } \\
\text { podejściem do rzeczywistości; } \\
\text { rozważny; tolerancyjny (2); } \\
\text { uczciwy; etyczny; nowoczesny } \\
\text { (2); budzący zaufanie; wiary- } \\
\text { godny; przebojowa; przebojowy; } \\
\text { charakterystyczny (2); wyróż- } \\
\text { niający się; przystojny; ładny; } \\
\text { konsekwentny (2); nieszczery; } \\
\text { zakłamany; pomysłowy; kre- } \\
\text { atywny; ambitny (2); ma ideały; } \\
\text { idealista; sprawiedliwy; zaanga- } \\
\text { żowany politycznie; prawicowy; } \\
\text { spięty; stronniczy; młoda; często } \\
\text { się śmieje; obiektywny; wymaga } \\
\text { od siebie i innych; przekonu- } \\
\text { jący w swych sądach; odszedł } \\
\text { z „Newsweeka”; sumienny; nie- } \\
\text { chętny ludziom inaczej postrze- } \\
\text { gającym świat; idiota; gałgan; } \\
\text { pozer; frajer; dewota; sztuczny; } \\
\text { sztywny; niejednoznaczny; } \\
\text { sarkastyczny; uporządkowa- } \\
\text { ny; dociekliwy; polemiczny; } \\
\text { uśmiechnięty; sprecyzowane, } \\
\text { ograniczone poglądy; lewak; ka- } \\
\text { rierowicz; mało zabawny; szybki; } \\
\text { niekonsekwentny; nudny }\end{array}$ & 74 & 15,55 & 50 & 44,64 \\
\hline
\end{tabular}


Tabela 42 (cd.)

\begin{tabular}{|c|c|c|c|c|c|c|}
\hline \multirow{2}{*}{ lp. } & \multirow{2}{*}{$\begin{array}{c}\text { cecha } \\
\text { wizerunkowa }\end{array}$} & \multirow{2}{*}{ warianty leksykalne } & \multicolumn{2}{|c|}{ wskazania } & \multicolumn{2}{|c|}{ osoby } \\
\hline & & & $\mathbf{n}$ & $\%$ & $\mathbf{n}$ & $\%$ \\
\hline 20. & inne & $\begin{array}{l}\text { demagog; skrajnie podchodzą- } \\
\text { cy do Pisma Świętego pomimo } \\
\text { małego zasobu wiedzy; niski, ale } \\
\text { przystojny; ekspresyjny; energicz- } \\
\text { ny; gwałtowny; wybuchowy }\end{array}$ & & & & \\
\hline & & razem & 476 & 100,00 & & \\
\hline
\end{tabular}

Źródło: opracowanie własne

Dla większości odpowiadających Szymon Hołownia to osoba „religijna” (69 - 14,50\% wskazań; 66 - 58,93\% respondentów) oraz „zabawna” (67 - 14,08\%; 62 - 55,36\%). Te dwie cechy wizerunkowe mają niemal identyczne (bardzo wysokie) wartości. Kolejnym z istotnych wyróżników publicysty jest jego inteligencja („inteligentny”: 46 - 9,66\%; 44 - 39,29\%). Nieco powyżej 7\% wskazań, dokonanych przez około 1/4 uczestników tej części badania, mają atrybuty: „sympatyczny” (38 - 7,98\%; 29 - 25,89\%) oraz „pewny siebie" (36 - 7,56\%; 26 - 23,21\%). Około 5\% wskazań dotyczy cech „medialny” (24 - 5,04\%; 21 - 18,75\%) i „elokwentny” (22 - 4,62\%; 19 - 16,96\%). Pozostałych 13 cech to trzyprocentowy lub mniejszy poziom wynotowań oraz niższy niż $12 \%$ pułap osób je wypisujących. W tej grupie znalazły się takie cechy, jak: „oczytany” (15 - 3,15\%; 13 - 11,61\%), „spokojny” (13 - 2,73\%; 10 - 8,93\%), „konserwatywny" (12 - 2,52\%; $11-9,82 \%)$, „rzetelny” (10 - 2,10\%, $10-8,93 \%)$. Jeszcze rzadziej wynotowywano: „otwarty”, „dziennikarz”, „dobroduszny”, „niski” (po 7 - 1,47\% wskazań i 7 - 6,25 osób), a także: „wysoki”, „charyzmatyczny”, „szczery” (po 6 - 1,26\%; 6 - 5,36\%) oraz „interesujący” (4-0,84\%, $4-3,57 \%)$.

W przypadku Szymona Hołowni występuje więcej spójnych cech wizerunkowych (18) w zakresie image'u publicznego niż u Krzysztofa Vargi (7) i Piotra Zaremby (9), a nieco tylko więcej niż u Magdaleny Środy (17). Tłumaczyć to należy liczbą osób udzielających odpowiedzi (Hołownia: 112, Varga: 11, Zaremba: 19, Środa: 49). Wydaje się, że im więcej osób określających wizerunek, tym więcej cech, choć granica liczby cech najwyraźniej sięga ok. 20 (u Szymona Hołowni najwięcej osób udzielało odpowiedzi i skodowano 18 spójnych cech wizerunkowych, tylko o jedną więcej niż u Magdaleny Środy, której wizerunek wynotowywała o połowę mniejsza liczba osób). 
Tabela 43. Bloki semantyczne wizerunku publicznego Szymona Hołowni

\begin{tabular}{|c|c|c|c|c|c|}
\hline \multirow{2}{*}{ lp. } & \multirow{2}{*}{ cecha wizerunkowa } & \multicolumn{2}{|c|}{ wskazania } & \multicolumn{2}{|c|}{ osoby } \\
\hline & & $\mathbf{n}$ & $\%$ & $\mathbf{n}$ & $\%$ \\
\hline 1. & zabawny (29) & 67 & 14,08 & 62 & 55,36 \\
\hline 2. & sympatyczny (13) & 38 & 7,98 & 29 & 25,89 \\
\hline 3. & otwarty (4) & 7 & 1,47 & 7 & 6,25 \\
\hline & & 112 & 23,53 & & \\
\hline 4. & religijny (34) & 69 & 14,50 & 66 & 58,93 \\
\hline 5. & konserwatywny (6) & 12 & 2,52 & 11 & 9,82 \\
\hline & & 81 & 17,02 & & \\
\hline 6. & inteligentny (38) & 46 & 9,66 & 44 & 39,29 \\
\hline 7. & oczytany (5) & 15 & 3,15 & 13 & 11,61 \\
\hline 8. & rzetelny (5) & 10 & 2,10 & 10 & 8,93 \\
\hline & & 71 & 14,92 & & \\
\hline 9. & pewny siebie (3) & 36 & 7,56 & 26 & 23,21 \\
\hline 10. & szczery (6) & 6 & 1,26 & 6 & 5,36 \\
\hline 11. & charyzmatyczny (6) & 6 & 1,26 & 6 & 5,36 \\
\hline 12. & interesujący (2) & 4 & 0,84 & 4 & 3,57 \\
\hline & & 52 & 10,92 & & \\
\hline 13. & medialny (5) & 24 & 5,04 & 21 & 18,75 \\
\hline 14. & dziennikarz (3) & 7 & 1,47 & 7 & 6,25 \\
\hline & & 31 & 6,51 & & \\
\hline 15. & elokwentny (9) & 22 & 4,62 & 19 & 16,96 \\
\hline 16. & dobroduszny & 7 & 1,47 & 7 & 6,25 \\
\hline 17. & niski (6) & 7 & 1,47 & 7 & 6,25 \\
\hline 18. & wysoki (6) & 6 & 1,26 & 6 & 5,36 \\
\hline
\end{tabular}

Źródło: opracowanie własne

Podobnie jak w przypadku wizerunku werbalnego anonima, także i w image’u publicznym dziennikarza bloki semantyczne skupiają się wokół najliczniej reprezentowanych cech wizerunkowych (tabela 43). Tym razem kolejność wyznaczona łączną liczbą wskazań w obrębie każdego obszaru znaczeniowego pokrywa się idealnie z kolejnością pojedynczych cech, uporządkowanych od najliczniej reprezentowanych do najmniej. Zauważyć jednak należy, że o ile w wyliczeniu pojedynczych cech „zabawny” i „religijny” niemal ex aequo stanowią czołówkę, o tyle aspekt sympatyczności i poczucia humoru w przypadku bloków semantycznych przeważa nad kojarzeniem dziennikarza 
z kwestiami duchowymi (relacja 112 cech do 81 wskazań). Dlaczego wyniki nie pokrywają się z wynikami listy skodowanych cech? I czy muszą?

Należy uwzględnić specyfikę poszczególnych cech wchodzących w skład danej grupy znaczeniowej. „Religijny” ma dość jednoznaczny charakter i dlatego nie będzie $w$ tym bloku semantycznym wielu innych cech i nie zwiększą one $\mathrm{w}$ zestawieniu liczbowego znaczenia tego bloku, natomiast cechy korespondujące ze wzbudzaniem sympatii mają większy potencjał synonimiczny, co mogło wpłynąć na ich multiplikowanie i łączną wyższą wartość liczbową w obrębie bloku. Po drugie, ponieważ trudno wypracować ścisłe kryteria przyporządkowywania do poszczególnych obszarów znaczeniowych, wyniki liczbowe należy uwzględniać, ale jednocześnie brać w pewien nawias. Czasami bowiem przestrzeń znaczeniowa danej grupy semantycznej jest tak duża, że właściwie usunięcie jednej cechy $\mathrm{z}$ danej grupy semantycznej i przeniesienie jej do innej może nie wzbudzać sprzeciwu merytorycznego, a zmienić pozycje danego bloku $\mathrm{z}$ ważnego drugiego miejsca na np. dalsze czwarte. To wada stosowania narzędzia bloków semantycznych w analizie wizerunku, wspominana już wcześniej.

Ale czy muszą się wyniki pokrywać pod względem ilościowym w obu podejściach analitycznych (lista cech i obszary znaczeniowe)? Wydaje się, że nie. Zwłaszcza że należałoby postawić każdemu $\mathrm{z}$ tych narzędzi inne cele. W pierwszym przypadku - w analizie występowania poszczególnych cech - wiemy, jakie określenia przypisuje się autorowi wypowiedzi. Istotna może być wyraźna dominacja jakiejś cechy nad innymi lub jej brak, liczba osób przypisująca konkretną cechę wizerunkową, w końcu hierarchia cech i odległości ilościowe między nimi (liczba wskazań i osób ich dokonujących). Bloki semantyczne natomiast pokazują nam semantyczne ukierunkowanie wskazywanych atrybutów. Jeśli cecha „inteligentny” funkcjonuje na tle i w powiązaniu z takimi, jak „oczytany” czy „rzetelny” (image publiczny Szymona Hołowni), to bardziej będzie wiązała się z wiedzą i w tym kontekście sytuowała wizerunek, ale - jeśli sąsiedztwem jest dla niej „obserwator” (wizerunek werbalny anonimowego Szymona Hołowni), to inteligencja raczej łączona tu jest $\mathrm{z}$ umiejętnością analizy i wyciągania wniosków. Otoczenie, w jakim funkcjonuje dana cecha, może zmieniać ostateczny kształt bloku semantycznego i samego wizerunku. Obszary znaczeniowe ograniczą nam też liczbę komponentów wizerunkowych do mniejszej liczby (5-8), porządkując image i dając o nim lepsze wyobrażenie, co ma swoje znaczenie zwłaszcza w kontekście częstego powtarzania się kilku pierwszych cech wizerunkowych u każdego z felietonistów, szczególnie w zakresie wizerunków werbalnych - zblokowanie cech pozwala zauważyć optykę konstruowania wizerunku (np. kompetencje i agresja u Magdaleny Środy rozpoznawanej na zdjęciu i bardziej mądrość życiowa oraz sympatyczność, gdy respondenci nie wiedzieli, kto jest na fotografii). 
Wydaje się, że kluczowe dla image’u Szymona Hołowni są jego otwartość łączona $\mathrm{z}$ poczuciem humoru i wzbudzaniem sympatii oraz religijność i wiedza, potem kolejne bloki semantyczne: pewność siebie (52), rozpoznawalność (31). Poza grupami synonimów pozostały cechy: „elokwentny” „dobroduszny”, „niski”, „wysoki”.

Bez względu na to, czy weźmiemy pod uwagę kolejność pojedynczych cech czy bloków semantycznych, to poczucie humoru i religia są dwoma najsilniej kojarzonymi z dziennikarzem elementami wizerunku. Z całą pewnością drugi $\mathrm{z}$ tych atrybutów może mieć swoje źródło w słowach publicysty (wizerunek werbalny), w przejawach jego działalności (np. Religia.tv, Stacja7.pl - np. zobaczenie postaci na ekranie, nazwiska przy tekście artykułu) lub też w informacjach o nim. Dowcip natomiast jest szczególnie eksponowany w roli prowadzącego, jaką Szymon Hołownia odgrywa z Marcinem Prokopem w programie Mam talent.

Porównanie wizerunku publicznego w imageem werbalnym anonimowego twórcy pozwala zauważyć wpływ słowa na wymiar publiczny, ale ograniczany przez udział kontekstu medialnego w tworzeniu image’u publicznego. Na poziomie słowa komunikowane są cechy skupione wokół obiektywnej i realistycznej postawy oraz dociekliwości, które nie mają swoich odpowiedników na poziomie image’u publicznego, są więc dość specyficzne dla języka naturalnego. Inne jednak komponenty image’u werbalnego mają już swoje odpowiedniki, choć często pozbawione są prymarnego znaczenia. Ciekawy sposób pisania wiąże się z poczuciem humoru autora tekstu i ten blok semantyczny jest dość wysoko reprezentowany, podczas gdy wymiar publiczny ogranicza go do elokwencji i ekspresyjności dużo mniej wyeksponowanej. Kiedy interpretator ma do dyspozycji wyłącznie słowo, częściej zauważa bezkompromisową postawę, co wynika - jak się zdaje - ze specyfiki tekstu publicystycznego, a w szczególności felietonu, w którym powinna pojawić się opinia autora wypowiedzi. Nie ma takiej szansy prowadzący talent show, nie jest jego rolą wygłaszanie własnych poglądów, stąd też mniej eksponowane takie cechy w image’u publicznym, jak „pewny siebie” czy „ekspresyjny”, które zresztą - zważywszy na otoczenie w postaci innych cech - dotyczą raczej otwartości i komunikatywności w wyrażaniu poglądów niż bezkompromisowości. Natomiast wyższa manifestacja poczucia humoru, religijności i intelektu w wizerunku publicznym mogą wynikać zarówno ze słów publicysty (skoro współtworzą image werbalny anonima), jak i ról medialnych, z jakich znany jest Szymon Hołownia, co świadczyłoby o spójności jego wizerunku oraz wzmacnianiu niektórych cech wyrażanych werbalnie przez funkcje, jakie pełni w określonej sytuacji komunikacyjnej, oraz przez tło komunikacyjne (rozrywkowa formuła programu, tematyka kanału Religia.tv). W wymiarze publicznym funkcjonują również cechy podkreślające obecność medialną publicysty („medialny”, „dziennikarz”), które nie mają żadnej podstawy w samych wypowiedziach Szymona Hołowni. Słowa są 
więc marginalizowane lub wzmacniane przez kontekst pozawerbalny - kontekst ukierunkowuje interpretacje poziomu werbalnego i wpływa na określoną konstrukcję wizerunku publicznego. Język naturalny w pewnym sensie stanowi tutaj podstawę image’u, ale dosyć elastycznie można operować obszarami semantycznymi wizerunku, jakie język tworzy, powiększając je, zmniejszając lub zmieniając optykę postrzegania.

Tabela 44. Kategorie wizerunku publicznego Szymona Hołowni

\begin{tabular}{|c|c|c|c|c|c|c|c|c|}
\hline lp. & zawód & n & $\begin{array}{l}\text { poglądy/ } \\
\text { wartości }\end{array}$ & $\mathbf{n}$ & wiedza & $\mathbf{n}$ & postawa & $\mathbf{n}$ \\
\hline 1. & medialny (5) & 24 & $\begin{array}{l}\text { religijny } \\
(34)\end{array}$ & 69 & oczytany (5) & 15 & sympatyczny (13) & 38 \\
\hline 2. & dziennikarz (3) & 7 & $\begin{array}{l}\text { konserwa- } \\
\text { tywny (6) }\end{array}$ & 12 & & & pewny siebie (3) & 36 \\
\hline 3. & & & & & & & rzetelny (5) & 10 \\
\hline 4. & & & & & & & otwarty (4) & 7 \\
\hline 5. & & & & & & & spokojny (7) & 13 \\
\hline \multicolumn{2}{|r|}{ razem } & 31 & & 81 & & 15 & & 104 \\
\hline lp. & $\begin{array}{c}\text { cecha } \\
\text { charakteru }\end{array}$ & n & wygląd & n & $\begin{array}{c}\text { sposób } \\
\text { komunikacji }\end{array}$ & n & inne & $\mathbf{n}$ \\
\hline 1. & zabawny (29) & 67 & niski (6) & 7 & elokwentny (9) & 22 & $\begin{array}{l}\text { charyzmatyczny } \\
\text { (6) }\end{array}$ & 6 \\
\hline 2. & inteligentny (38) & 46 & wysoki (6) & 6 & & & interesujący (2) & 4 \\
\hline 3. & dobroduszny & 7 & & & & & & \\
\hline 4. & szczery (6) & 6 & & & & & & \\
\hline \multicolumn{2}{|r|}{ razem } & 126 & & 13 & & 22 & & 10 \\
\hline
\end{tabular}

Źródło: opracowanie własne

Kategorie możliwego do komunikowania wizerunku publicznego są chyba najbardziej rozbudowanym podziałem w przypadku Szymona Hołowni, jeśli uwzględnić tę typologię u innych analizowanych felietonistów. Do tej pory najliczniejszym obszarem była „postawa” lub „zawód”, tym razem „cechy charakteru", co może mieć ponownie swoje źródło w roli odgrywanej w innych mediach, zwłaszcza jeśli zauważyć, że $\mathrm{w}$ telewizji publicysta występuje $\mathrm{w}$ interakcji, co sprzyja komunikowaniu „cech charakteru”. Druga w kolejności jest „postawa”, a trzecie "poglądy/wartości”, które wysoką pozycją odznaczały się także u Magdaleny Środy (drugą). Im więcej zakotwiczenia w tematyce społeczno-politycznej (w przypadku Szymona Hołowni - religijnej), tym bardziej wyeksponowane 
osadzenie wizerunku publicznego w „poglądach/wartościach (Krzysztofa Vargi nie dotyczyły w ogóle, a i u Piotra Zaremby tylko 8 wskazań łączono z tym aspektem image'u publicznego). Pojawia się w przypadku omawianego publicysty także kategoria „zawód”. W tym kontekście znów zwraca uwagę celebrytyzacja zawodu dziennikarza (cecha „medialny”). „Wiedza” tradycyjnie już w image'u publicznym jest w słabej reprezentacji, ale niezmiennie funkcjonuje. Nowość to „wygląd”, który do tej pory pojawił się tylko u Piotra Zaremby jako kategoria wizerunku wizualnego, oraz „sposób komunikacji”, dotychczas typowy wyłącznie dla image’u werbalnego w jego obydwu wymiarach (tekst anonimowego autora i znanego). „Wygląd” wydaje się inspirowany znów obrazami telewizyjnymi. Zwłaszcza na tle wyjątkowo wysokiego Marcina Prokopa (tworzą duet prowadzących Mam talent) Szymon Hołownia wydaje się niski (stąd przypisanie cechy „niski”), choć w innym kontekście wizualnym widać, że do takich nie należy (cecha „wysoki”), co tym bardziej może być odnotowywane, zważywszy na kontrast z pierwszą z tych sytuacji przestrzennych. Najwyraźniej bez względu na okoliczności wzrost felietonisty zostaje zauważony. Szymon Hołownia rzeczywiście wyróżnia się sposobem wypowiedzi bez względu na to, w jakiej komunikacyjnie przestrzeni się znajduje (zob. Kowal 2011, 2012). Zapewne dlatego „sposób komunikacji” stał się częścią wizerunku publicznego (a nie tylko werbalnych). Cechy „charyzmatyczny” i „intersujący” przyporządkowano do obszaru „inne”.

Widać zatem, że duża rozpoznawalność danej osoby i sposób jej medialnego funkcjonowania mogą regulować cechy znane już z wizerunku werbalnego, a także determinować pojawienie się innych (realizowanych tu w kategoriach „zawód”, „wygląd”, „sposób komunikacji”).

\subsubsection{Szymon Hołownia - wizerunek wizualny}

Kartkę ze zdjęciem Szymona Hołowni otrzymały 63 osoby (zob. zdjęcie w tabeli 6) oraz kolejną z pytaniem: „Mając za podstawę przedstawione zdjęcie, jakimi słowami opisałby Pan / opisałaby Pani przedstawioną na tej fotografii osobę?”. Odpowiedzi należy podzielić na dwie grupy. Tę, w której respondenci po realizacji zadania zaprzeczyli, że rozpoznali osobę z fotografii, i na pytanie: „Czy wie Pan/Pani, kogo przedstawia zdjęcie?”, zakreślili odpowiedź „NIE”; oraz na tę, w której uczestnicy badania wybrali „TAK, kogo?...”, i poprawnie podali nazwisko Szymona Hołowni. Nikt nie zaznaczył „Nie jestem pewny/ pewna, ale wydaje mi się, że może to być (kto?)...”.

Cztery osoby nie wiedziały, czyj portret przedstawia zdjęcie, z czego w tę grupę zaliczono trzy odpowiedzi, w jakich wprost zaznaczono brak rozpoznania felietonisty oraz jedną błędnie przyporządkowującą tożsamość osobie 
ze zdęcia dziennikarzowi Kamilowi Durczokowi (odpowiedź: „TAK, kogo? Kamil Durczok"). Zbyt mała liczba wskazań nie pozwala zauważyć w tej grupie odpowiedzi stałych wizerunkowych ${ }^{23}$.

Pewność, co do znajomości osoby ze zdjęcia zaznaczyło 59 osób, z czego 54 podały imię i nazwisko "Szymon Hołownia”, a pięć popełniło różne błędy, w tym 2 osoby pomyliły imię („Piotr Hołownia”, „Krzysztof Hołownia”), dwie podały źródło znajomości nazwiska („Pana prowadzącego Mam Talent, „ten z religia tv :)”), jedna zaznaczyła: „nie pamiętam, jak się nazywa”. Odpowiedzi tych pięciu respondentów włączono do grupy respondentów znających nazwisko felietonisty. $Z$ całej tej grupy 38 osób podało po 5 cech, 14 po 4,3 respondentów po 6 określeń i jedna osoba tylko jeden epitet, co dało łącznie 265 wskazań, a - po uwzględnieniu kodowanych podwójnie dwóch wskazań - $267^{24}$, które stały się podstawą do wyłonienia 16 spójnych cech wizerunkowych.

Tabela 45. Zestawienie odpowiedzi osób rozpoznających na zdjęciu Szymona Hołownię na pytanie: „Mając za podstawę przedstawione zdjęcie, jakimi słowami opisałby Pan / opisałaby Pani przedstawioną na tej fotografii osobę?"

\begin{tabular}{|c|c|c|c|c|c|c|}
\hline \multirow{2}{*}{ lp. } & \multirow{2}{*}{$\begin{array}{c}\text { cecha } \\
\text { wizerunkowa }\end{array}$} & \multirow{2}{*}{ warianty leksykalne } & \multicolumn{2}{|c|}{ wskazania } & \multicolumn{2}{|c|}{ osoby } \\
\hline & & & $\mathbf{n}$ & $\%$ & $\mathbf{n}$ & $\%$ \\
\hline 1. & $\begin{array}{l}\text { inteligentny } \\
(23)\end{array}$ & $\begin{array}{l}\text { inteligentny katolik, inteligentna } \\
\text { (2), inteligentne spojrzenie ( } 2) \text {, } \\
\text { wybitnie inteligentny, błyskotli- } \\
\text { wy (4), bystry (2), bystry (bystre } \\
\text { spojrzenie), bystre spojrzenie }\end{array}$ & 37 & 13,86 & 29 & 49,15 \\
\hline 2. & zabawny (6) & $\begin{array}{l}\text { zabawny, gdy to potrzebne, ma } \\
\text { poczucie humoru (2), poczucie } \\
\text { humoru, dobre poczucie humoru, } \\
\text { ze specyficznym poczuciem hu- } \\
\text { moru, humorystyczny, dowcipny } \\
\text { (3), dowcipna, dystans, zabaw- } \\
\text { ny/z dystansem do siebie, zdystan- } \\
\text { sowany, żartobliwość, żartowniś }\end{array}$ & 22 & 8,24 & 20 & 33,90 \\
\hline
\end{tabular}

23 Odpowiedzi trzech respondentów znalazły się w tej grupie, z czego dwóch uczestników badania podało po 5 cech mężczyzny ze zdjęcia, jeden 4 , łącznie 14 cech. Jedna z osób podała następujące określenia: „chytry; ma coś do powiedzenia; mężczyzna; wysoki; przyjazny”, druga: „raczej spokojny - nie ekstrawagancki; ma swoje ideologie; lubi rozmyślać; pokorny; wnikliwa”; trzecia: „intrygująca; zabawna; nieustępliwa; w średnim wieku”.

24 Określenie „inteligentny katolik” skategoryzowano w cechach wizerunkowych jako „inteligentny” oraz „katolik”, natomiast „aktor/dziennikarz” przyporządkowano do „człowiek mediów” („dziennikarz”) oraz do kategorii ,inne” („aktor”). 


\begin{tabular}{|c|c|c|c|c|c|c|}
\hline \multirow{2}{*}{ lp. } & \multirow{2}{*}{$\begin{array}{c}\text { cecha } \\
\text { wizerunkowa }\end{array}$} & \multirow{2}{*}{ warianty leksykalne } & \multicolumn{2}{|c|}{ wskazania } & \multicolumn{2}{|c|}{ osoby } \\
\hline & & & $\mathbf{n}$ & $\%$ & $\mathbf{n}$ & $\%$ \\
\hline 3. & $\begin{array}{l}\text { pewny siebie } \\
(7)\end{array}$ & $\begin{array}{l}\text { mający własne zdanie (2), mający } \\
\text { swoje przekonania, których po- } \\
\text { trafi bronić, pewny swoich poglą- } \\
\text { dów, o konkretnych poglądach, } \\
\text { nienarzucający nikomu swoich } \\
\text { poglądów, których jednak mocno } \\
\text { się trzyma, }\end{array}$ & 22 & 8,24 & 15 & 25,42 \\
\hline 4. & $\begin{array}{l}\text { kontaktowy } \\
\text { (1) }\end{array}$ & $\begin{array}{l}\text { otwarty (4), otwarta, miły (3), } \\
\text { przyjaźnie nastawiony, przyjazny, } \\
\text { sympatyczny (3), uprzejmy (2), } \\
\text { pomocny, śmiały }\end{array}$ & 18 & 6,74 & 12 & 20,34 \\
\hline 5. & $\begin{array}{l}\text { człowiek } \\
\text { mediów (1) }\end{array}$ & $\begin{array}{l}\text { prezenter telewizyjny (2), prezen- } \\
\text { ter, świetny prezenter, dzienni- } \\
\text { karz (2), aktor/dziennikarz, czę- } \\
\text { sto prowadzi autorskie przeglądy } \\
\text { prasy w telewizji, publicysta, } \\
\text { osoba publiczna (2), prowadzący } \\
\text { Mam talent, prowadzący wiele } \\
\text { programów TV, showman, popu- } \\
\text { larny (2), znany }\end{array}$ & 18 & 6,74 & 11 & 18,64 \\
\hline 6. & wierzący $(0)$ & $\begin{array}{l}\text { religijny (7), oczywiście religijny, } \\
\text { jest wierzący, fanatyk religijny, } \\
\text { zabobonny, katolik (2), kojarzony } \\
\text { z kwestiami religijnymi, w „zdro- } \\
\text { wy sposób” podchodzi do pojęcia } \\
\text { wiary i przystępnie dzieli się nią } \\
\text { z innymi, inteligentny katolik }\end{array}$ & 16 & 5,99 & 15 & 25,42 \\
\hline 7. & ułożony (2) & $\begin{array}{l}\text { dobrze ułożony, wychowanie, } \\
\text { poukładany, opanowany, spo- } \\
\text { kojny(4), spokojna, spokojny/ } \\
\text { łagodny }\end{array}$ & 12 & 4,49 & 11 & 18,64 \\
\hline 8. & $\begin{array}{l}\text { wykształcony } \\
(4)\end{array}$ & $\begin{array}{l}\text { oczytany (4), kompetentny, } \\
\text { mający dużą wiedzę o świecie }\end{array}$ & 10 & 3,75 & 9 & 15,25 \\
\hline 9. & zadbany (3) & $\begin{array}{l}\text { zadbany/elegancki, elegancki, } \\
\text { stara się być „na czasie” - fryzura }\end{array}$ & 6 & 2,25 & 5 & 8,47 \\
\hline 10. & poważny (4) & poważna, skupiony, & 6 & 2,25 & 6 & 10,17 \\
\hline 11. & $\begin{array}{l}\text { elokwentny } \\
(4)\end{array}$ & wygadany & 5 & 1,87 & 5 & 8,47 \\
\hline 12. & ciekawy (2) & $\begin{array}{l}\text { ciekawe poglądy, intrygujący, } \\
\text { interesujący }\end{array}$ & 5 & 1,87 & 5 & 8,47 \\
\hline 13. & młody (4) & młody lub pozorujący młodego & 5 & 1,87 & 5 & 8,47 \\
\hline 14. & przystojny (3) & piękny & 4 & 1,50 & 5 & 8,47 \\
\hline 15. & $\begin{array}{l}\text { przenikliwy } \\
\text { (2) }\end{array}$ & dociekliwy, wnikliwy & 4 & 1,50 & 4 & 6,78 \\
\hline
\end{tabular}


Tabela 45 (cd.)

\begin{tabular}{|c|c|c|c|c|c|c|}
\hline \multirow{2}{*}{ lp. } & \multirow{2}{*}{$\begin{array}{c}\text { cecha } \\
\text { wizerunkowa }\end{array}$} & \multirow{2}{*}{ warianty leksykalne } & \multicolumn{2}{|c|}{ wskazania } & \multicolumn{2}{|c|}{ osoby } \\
\hline & & & $\mathbf{n}$ & $\%$ & $\mathbf{n}$ & $\%$ \\
\hline 16. & inne & $\begin{array}{l}\text { konserwatywny (2), konserwatyw- } \\
\text { ny/tradycyjny, sarkastyczny, sarka- } \\
\text { styczna, lekko złośliwy, sceptyczny, } \\
\text { sceptyczna, podejrzliwy, pytająca, } \\
\text { wątpiąca, skromny (2), profesjona- } \\
\text { lista, fachowy, skryty (2), wycofany, } \\
\text { zarozumiały, wysoce myślący } \\
\text { o sobie, wywyższający się, zdziwio- } \\
\text { ny, wygląda na zdziwionego, zasko- } \\
\text { czony, mężczyzna (3), w średnim } \\
\text { wieku, ok. 40, mężczyzna w śred- } \\
\text { nim wieku (2), ciekawy świata, } \\
\text { ciekawski, interesuje się polityką, } \\
\text { rzeczowy, dążący do ukazania } \\
\text { prawdy, bogaty, hiena, lubi kawę, } \\
\text { prawicowy, pisarz, kontrowersyjny, } \\
\text { propagujący idee, smak, (na szczę- } \\
\text { ście) nieradykalny, z pomysłami, } \\
\text { tolerancyjny, nie narzuca swojej } \\
\text { opinii innym, uczciwy, dobry, } \\
\text { pogubiony, niespokojny, ambitny, } \\
\text { z zasadami, ortodoksyjny, umiejący } \\
\text { dostosować swoje zachowanie do } \\
\text { charakteru programu, obiektywna, } \\
\text { wrażliwy, spostrzegawczy, ciekawy, } \\
\text { krytyczny, godny zaufania, zain- } \\
\text { teresowany czymś, cwany, górno- } \\
\text { lotna, niedoświadczony, smutny, } \\
\text { ma ciekawe spojrzenie, jest lekko } \\
\text { uśmiechnięty, jest zadowolona, } \\
\text { na pierwszy rzut oka przypomina } \\
\text { pakistańskiego przeżuwacza fu- } \\
\text { sów, sprytny, aktor/dziennikarz, } \\
\text { dyplomata; rozsądny; wyważona, } \\
\text { rozważny, trzeźwo myślący }\end{array}$ & 77 & 28,84 & 49 & 83,05 \\
\hline \multicolumn{3}{|r|}{ razem } & 267 & 100,00 & & \\
\hline
\end{tabular}

Źródło: opracowanie własne

Wizerunek wizualny rozpoznawalnego na fotografii Szymona Hołowni jest swego rodzaju hybrydą w istocie skonstruowaną nie tylko na podstawie obrazu, ale i innych systemów znaków. Pojawiają się cechy, które już w przypadku innych felietonistów były wymieniane przez respondentów. Jak choćby pierwsza na liście: „inteligentny” (37 - 13,86\% wskazań) - zauważona przez 
niemal połowę uczestników badania tej grupy (29 - 49,15\%). Wydaje się, że kolejne trzy też mogą mieć swoją podstawę w warstwie wizualnej: „zabawny” (22 - 8,24\% wskazań; 20 - 33,90\% osób ich dokonujących), "pewny siebie” (22 - 8,24\%; 15 - 25,42\%), ,kontaktowy (18 - 6,74\%; 12 - 20,34\%), ale następne dwie muszą swoje źródło sytuować już poza wypowiedzią wizualną: „człowiek mediów” (18 - 6,74\%; 12 - 20,34\%) oraz „wierzący” (16 - 5,99\%; 15 - 25,42\%).

Co prawda w przypadku Piotra Zaremby pojawiła się analogiczna do „człowieka mediów” cecha wizerunkowa (wizerunek wizualny) - „publicysta”, ale pamiętać należy, że osoby, które tym mianem nazwały dziennikarza „W Sieci”, łączyły też jego nazwisko z konkretnymi tytułami z polskiego rynku prasowego, co wskazywało na wyraźną inspirację wypowiedziami spoza poziomu fotografii. Wydaje się, że tutaj występuje analogiczna sytuacja, tj. respondenci, rozpoznając z różnych przekazów medialnych Szymona Hołownię, przypisują mu medialność, nawet jeśli proszeni są o podanie cech, „mając za podstawę przedstawione zdęcie”. Zdaje się, że świadczy to, po pierwsze, o popularności publicysty, a po drugie - o bardzo dużym wpływie wizerunku publicznego na wizualny w warunkach tejże niemałej rozpoznawalności. Taki sam wniosek wyciągnąć można, analizując pojawienie się wśród cech image’u wizualnego „wierzący”. W wizerunku na podstawie obrazu, nawet kiedy uczestnicy badania dobrze kojarzyli Magdalenę Środę, nie pojawiały się cechy dotyczące jej feministycznych poglądów, choć wyraźnie jest $\mathrm{z}$ nimi łączona. To, że wpływ publicznego wymiaru image’u ma znaczenie dla wizerunku Szymona Hołowni, można tłumaczyć właśnie jego dużą popularnością, a także wpływem kontekstu wypowiedzi. O ile trudno przywołać programy telewizyjne, w których występowałaby Magdalena Środa i które już w nazwie miałyby sugestię co do jej poglądów, to można założyć, że silną moc profilowania wizerunku ma pojawienie się Szymona Hołowni w programie kanału Religia.tv.

Kolejne $\mathrm{z}$ wymienionych przez uczestników badania cech to: „ułożony” (12 - 4,49\%; 11 - 18,64\%), „wykształcony” (10 - 3,75\%; 9 - 15,25\%), po $2,25 \%$ wskazań mają „zadbany” i „poważny” (odpowiednio $5-8,47 \%$ i 6 - 10,17\% osób). Poniżej 2\% wynotowań reprezentują „elokwentny”, „ciekawy”, „młody” (po 5 - 1,87\% i po 5 - 8,47\%), a także "przystojny”, ,rozsądny” i "przenikliwy" (po 4 - 1,5\% wskazań i odpowiednio: 5 - 8,47\%; 3 - 5,08\%; $4-6,78 \%$ respondentów je dokonujących).

Inteligencja (,inteligentny”) dominuje w zestawie pojedynczych cech wizerunkowych, bowiem następna w kolejności „zabawny” ma o ponad 1/3 mniej wskazań $(13,86 \%$ do $8,24 \%)$ i taka sama relacja ilościowa dotyczy liczby osób $(49,15 \%$ do $33,90 \%)$, choć zaznaczyć należy, że w do tej pory analizowanych wizerunkach zdarzały się większe dysproporcje. Kolejne cechy, takie jak „pewny siebie”, „kontaktowy”, „człowiek mediów”, utrzymują się na poziomie ok. 7-8\% wynotowań i $20-25 \%$ respondentów je zauważających. Mamy więc 
jeden element wizerunku („inteligentny”) i skupionych wokół niego, ale w pewnym oddaleniu, kilka pomniejszych.

Tabela 46. Bloki semantyczne wizerunku wizualnego rozpoznawanego przez respondentów Szymona Hołowni

\begin{tabular}{|c|c|c|c|c|c|}
\hline \multirow{2}{*}{ lp. } & \multirow{2}{*}{ cecha wizerunkowa } & \multicolumn{2}{|c|}{ wskazania } & \multicolumn{2}{|c|}{ osoby } \\
\hline & & $\mathbf{n}$ & $\%$ & $\mathbf{n}$ & $\%$ \\
\hline 1. & inteligentny (23) & 37 & 13,86 & 29 & 49,15 \\
\hline 2. & wykształcony (4) & 10 & 3,75 & 9 & 15,25 \\
\hline & & 47 & 17,60 & & \\
\hline 3. & zabawny (6) & 22 & 8,24 & 20 & 33,90 \\
\hline 4. & kontaktowy (1) & 18 & 6,74 & 12 & 20,34 \\
\hline & & 40 & 14,98 & & \\
\hline 5. & pewny siebie (7) & 22 & 8,24 & 15 & 25,42 \\
\hline 6. & ciekawy (2) & 5 & 1,87 & 5 & 8,47 \\
\hline & & 27 & 10,11 & & \\
\hline 7. & człowiek mediów (1) & 18 & 6,74 & 11 & 18,64 \\
\hline 8. & elokwentny (4) & 5 & 1,87 & 5 & 8,47 \\
\hline & & 23 & 8,61 & & \\
\hline 9. & ułożony (2) & 12 & 4,49 & 11 & 18,64 \\
\hline 10. & zadbany (3) & 6 & 2,25 & 5 & 8,47 \\
\hline & & 18 & 6,74 & & \\
\hline 11. & poważny (4) & 6 & 2,25 & 6 & 10,17 \\
\hline 12. & przenikliwy (2) & 4 & 1,50 & 4 & 6,78 \\
\hline & & 10 & 3,75 & & \\
\hline 13. & wierzący $(0)$ & 16 & 5,99 & 15 & 25,42 \\
\hline 14. & młody (4) & 5 & 1,87 & 5 & 8,47 \\
\hline 15. & przystojny (3) & 4 & 1,50 & 5 & 8,47 \\
\hline
\end{tabular}

Źródło: opracowanie własne

Analiza bloków semantycznych (tabela 46) nie wprowadza istotnych zmian do powyższych obserwacji. Zaznaczyć należy, że grupy synonimicznych cech koncentrują się nie tylko wokół tych ze szczytu listy frekwencyjnej, ale także wokół mniej licznie reprezentowanych, przy czym kolejność pierwszych czterech obszarów znaczeniowych odpowiada kolejności cech, z którymi są związane. Potwierdza się duże znaczenie inteligencji (razem 47 wskazań), której jednak tym razem poczucie humoru i kontaktowość (łącznie 40) nie ustępują zbyt wiele 
miejsca. W tym drugim bloku należałoby też szukać inspiracji wizerunkiem publicznym. Następnie jest „pewność siebie” (27) i medialność (23) - blok, który musiał mieć podstawy w wymiarze publicznym. Zwrócono też uwagę na nienaganność kontaktu („ułożony” i „zadbany” - razem 18 wynotowań) oraz wyważoną postawę („poważny”, „przenikliwy” - wypisane w sumie 10 razy). Wydaje się, że te dwie ostatnie grupy cech stanowią najbardziej wyrazistą swego rodzaju mieszankę tego, co respondenci skonstruowali na podstawie zdjęcia, i co zaczerpnęli z wizerunku publicznego. Poza spójnymi grupami znaczeniowymi znalazły się: „wierzący”, „młody”, „przystojny”. Widać większy niż do tej pory wpływ wizerunku publicznego na wizualny. Respondenci nie potrafili od siebie oddzielić tych dwóch wymiarów wizerunku. Analizę powinny jednak uzupełnić dane dotyczące kategorii image'u komunikowanych na poziomie wizualnym.

Tabela 47. Kategorie wizerunku wizualnego Szymona Hołowni w sytuacji rozpoznania przez respondentów osoby ze zdjęcia

\begin{tabular}{|c|c|c|c|c|c|c|c|c|c|c|}
\hline lp. & $\begin{array}{l}\text { poglądy } \\
\text { /wartości }\end{array}$ & $\mathbf{n}$ & zawód & $\mathbf{n}$ & $\begin{array}{c}\text { stan } \\
\text { emocjonalno- } \\
\text {-poznawczy }\end{array}$ & $\mathbf{n}$ & wiedza & $\mathbf{n}$ & postawa & $\mathbf{n}$ \\
\hline 1. & $\begin{array}{l}\text { wierzący } \\
(0)\end{array}$ & 16 & $\begin{array}{l}\text { człowiek } \\
\text { mediów } \\
(1)\end{array}$ & 18 & poważny (4) & 6 & $\begin{array}{l}\text { wykształ- } \\
\text { cony (4) }\end{array}$ & 10 & $\begin{array}{l}\text { pewny } \\
\text { siebie } \\
(7)\end{array}$ & 22 \\
\hline 2. & & & & & & & & & $\begin{array}{l}\text { ułożony } \\
\text { (2) }\end{array}$ & 12 \\
\hline 3. & & & & & & & & & $\begin{array}{l}\text { przeni- } \\
\text { kliwy } \\
(2)\end{array}$ & 4 \\
\hline 4. & & & & & & & & & $\begin{array}{l}\text { kontak- } \\
\text { towy (1) }\end{array}$ & 18 \\
\hline \multicolumn{2}{|r|}{ razem } & 16 & & 18 & & 6 & & 10 & & 56 \\
\hline lp. & $\begin{array}{c}\text { cecha } \\
\text { charakteru }\end{array}$ & $\mathbf{n}$ & wiek & $\mathbf{n}$ & $\begin{array}{c}\text { sposób } \\
\text { komunikacji }\end{array}$ & $\mathbf{n}$ & wygląd & $\mathbf{n}$ & inne & $\mathbf{n}$ \\
\hline 1. & $\begin{array}{l}\text { inteligent- } \\
\text { ny }(23)\end{array}$ & 37 & $\begin{array}{l}\text { młody } \\
(4)\end{array}$ & 5 & $\begin{array}{l}\text { elokwentny } \\
\text { (4) }\end{array}$ & 5 & $\begin{array}{l}\text { zadbany } \\
\text { (3) }\end{array}$ & 6 & $\begin{array}{l}\text { ciekawy } \\
\text { (2) }\end{array}$ & 5 \\
\hline 2. & $\begin{array}{l}\text { zabawny } \\
(6)\end{array}$ & 22 & & & & & $\begin{array}{l}\text { przystoj- } \\
\text { ny (3) }\end{array}$ & 4 & & \\
\hline \multicolumn{2}{|r|}{ razem } & 59 & & 5 & & 5 & & 10 & & 5 \\
\hline
\end{tabular}

Źródło: opracowanie własne

Jeśli spojrzeć na kategorie wizerunku możliwego do komunikowania na poziomie wizualnym (tabela 54), to casus Szymona Hołowni cechuje się 
największą różnorodnością i bogactwem wśród wszystkich do tej pory analizowanych, a tym samym największą hybrydowością, o której wspomniano na początku tego rozdziału. Tradycyjnie już w przypadku image'u opartego na obrazie pojawiają się wysoko reprezentowane obszary „postawy” i „cech charakteru” oraz w niewielkim stopniu, ale niezmiennie obecna jest „wiedza”. Widoczny pozostaje też u wszystkich zauważalny „stan emocjonalno-poznawczy” ${ }^{25}$ oraz „wiek/płeć”. Spośród aspektów image’u, które występują u tego publicysty, a u innych pojawiły się incydentalnie, wymienić należy „zawód” oraz „wygląd” (oba dotyczyły tylko Piotra Zaremby). Na poziomie wizerunku wizualnego jeszcze nie wyodrębniono kategorii „inne”, a w tym przypadku ma to miejsce. Nowością są też „poglądy/wartości” oraz „sposób komunikacji”, które u innych felietonistów dotyczyły albo obu wizerunków werbalnych i publicznego („poglądy/wartości”), albo wyłącznie poziomu słowa („sposób komunikacji”), ale nigdy obrazu.

Warto przy tym zaznaczyć, że nie pojawia się żadna zupełnie nowa kategoria, która nie byłaby znana $\mathrm{z}$ analizy któregoś $\mathrm{z}$ dotychczas branych pod uwagę typów wizerunków, ale za to po raz pierwszy mamy do czynienia $\mathrm{z}$ (dużą) migracją cech pomiędzy typami imageów. Innymi słowy, wizerunek wizualny Szymona Hołowni „zabiera” kategorie z innych typów imageów, a to oznacza wpływ tych innych (werbalnych i publicznego) na wizualny. Obecność w mediach (cecha „człowiek mediów”, kategoria „zawód”), a także kontekst (nazwa kanału, format programu) i treść tej obecności („wierzący” $\rightarrow$ „poglądy/wartości”) oraz konsekwentnie realizowana, charakterystyczna forma przekazu („elokwentny” $\rightarrow$ „sposób komunikacji”) sprawiają, że elementy image’u publicznego i werbalnego przechodzą do typu opartego na obrazie. Wysoka rozpoznawalność i popularność publicysty, duży udział kontekstu komunikacyjnego w konstrukcji wizerunku, oraz - zdaje się - też spójność wizerunku, a przynajmniej brak komunikowania wyraźnie sprzecznych cech na poziomie wypowiedzi w różnych systemach znaków, sprawiają, że poszczególne typy image’u wzajemnie się u tego dziennikarza przenikają.

Dlaczego takiej zależności nie widać u innych publicystów, których wizerunku są tu analizowane? Po pierwsze, nie są tak rozpoznawalni, co pokazały wyniki w zakresie wizerunków publicznych i wizualnych (tylko Magdalena Środa i Szymon Hołownia cechowali się wystarczającą rozpoznawalnością ze zdjęcia, by móc poddać jakiejkolwiek analizie wyniki ich imageów opartych na obrazie w grupie osób poprawnie ich identyfikujących). Po drugie, tylko Szymona Hołownię cechowała w czasie poprzedzającym badania i w ich trakcie wyjątkowa (w porównaniu $\mathrm{z}$ resztą publicystów) ekspozycja $\mathrm{w}$ mediach oraz kontekst komunikacyjny wzmacniający niektóre cechy wizerunkowe (programy

$25 \mathrm{~W}$ image’u wizualnym „stan emocjonalno-poznawczy” nie występował jedynie w przypadku Magdaleny Środy, kiedy pozostawała anonimowa dla odbiorcy fotografii. 
związane z tematyką religijną - „religijny”, talent show - „zabawny”). Programy telewizyjne (i ich obecność w sieci), teksty w prasie i Internecie oraz publikacje książkowe i ich promocja były źródłami wypowiedzi, z jakimi mogli zetknąć się respondenci. Możliwe przy tym, że nawet ci uczestnicy badania, którzy rozpoznawali i podwali cechy wizerunku publicznego każdego z trzech pozostałych felietonistów, po prostu ze względu na mniejszą medialną ekspozycję tych twórców mieli ich wizerunek mniej „utrwalony”.

Rozpoznawalność i ekspozycja medialna oraz sytuacja komunikacyjna miałyby tutaj kluczowe znaczenie, tłumaczące migracje $\mathrm{z}$ innych typów image’u zarówno cech, jak i kategorii wizerunkowych do wizerunku wizualnego rozpoznawanego ze zdjęcia Szymona Hołowni.

\subsubsection{Szymon Hołownia - wizerunek na podstawie tekstu ze zdjęciem i informacją o tożsamości autora}

Na pytanie: „Mając za podstawę tekst przeczytanego felietonu, jakimi słowami opisałby Pan / opisałaby Pani autora Szymona Hołownię?” odpowiedziały 63 osoby. Spośród nich 9 wskazało po 3 przymioty dziennikarza, 14 respondentów podało po 4 określenia oraz 40 uczestników po 5 . W sumie zebrano więc 283 cechy, wśród których znalazły się 2 kodowane podwójnie ${ }^{26}$. Łącznie zatem analiza uwzględnia 285 wskazań skategoryzowanych w 21 spójnych cech wizerunkowych.

Tabela 48. Zestawienie odpowiedzi na pytanie: „Mając za podstawę tekst przeczytanego felietonu, jakimi słowami opisałby Pan / opisałaby Pani autora Szymona Hołownię?"

\begin{tabular}{|c|c|c|c|c|c|c|}
\hline \multirow{2}{*}{ lp. } & \multirow{2}{*}{$\begin{array}{c}\text { cecha } \\
\text { wizerunkowa }\end{array}$} & \multirow{2}{*}{ warianty leksykalne } & \multicolumn{2}{|c|}{ wskazania } & \multicolumn{2}{|c|}{ osoby } \\
\hline & & & $\mathbf{n}$ & $\%$ & $\mathbf{n}$ & $\%$ \\
\hline 1. & $\begin{array}{l}\text { dosadnie } \\
\text { wyrażający swoje } \\
\text { odważne sądy }(0)\end{array}$ & $\begin{array}{l}\text { odważny (2); odważny w sło- } \\
\text { wach - potrafi głośno mówić } \\
\text { także o tematach tabu; bezpo- } \\
\text { średni (3); prostolinijny; ma } \\
\text { swoje zdanie; własne zdanie; } \\
\text { konsekwentny w przedstawia- } \\
\text { niu swojego punktu widzenia }\end{array}$ & 35 & 12,24 & 28 & 44,44 \\
\hline
\end{tabular}

26 Wskazane przez respondenta jako pojedyncze określenie „zabawny, ironiczny” przyporządkowano do cech wizerunkowych „zabawny” oraz „ironiczny”, epitet „myślący, analizujący” skategoryzowano jako ,inteligentny” oraz „inne”, natomiast „pewny siebie, próżny” jako „dosadnie przedstawiający swoje odważne sądy” oraz „inne”. 
Tabela 48 (cd.)

\begin{tabular}{|c|c|c|c|c|c|c|}
\hline \multirow{2}{*}{ lp. } & \multirow{2}{*}{$\begin{array}{c}\text { cecha } \\
\text { wizerunkowa }\end{array}$} & \multirow{2}{*}{ warianty leksykalne } & \multicolumn{2}{|c|}{ wskazania } & \multicolumn{2}{|c|}{ osoby } \\
\hline & & & $\mathbf{n}$ & $\%$ & $\mathbf{n}$ & $\%$ \\
\hline 1. & $\begin{array}{l}\text { dosadnie } \\
\text { wyrażający swoje } \\
\text { odważne sądy }(0)\end{array}$ & $\begin{array}{l}\text { trzymająca się swoich zasad, } \\
\text { przekonań; jest wierny swoim } \\
\text { ideałom i przekonaniom; jest } \\
\text { nieugięty w swoich sądach; } \\
\text { o sprecyzowanych poglądach; } \\
\text { wyraża swobodnie swoje po- } \\
\text { glądy; pewny siebie; pewny } \\
\text { siebie, próżny; pewny swoich } \\
\text { racji; zdeterminowany; zde- } \\
\text { cydowany (4); stanowczy (3); } \\
\text { kontrowersyjny (2); kontro- } \\
\text { wersyjny (ale w jakimś celu, } \\
\text { a nie dla samego szokowania); } \\
\text { opiniotwórczy (2); nieboją- } \\
\text { cy się wypowiadać swojego } \\
\text { zdania i bronić go; niebojący } \\
\text { się wyrazić własnego zdania; } \\
\text { konkretny (2) }\end{array}$ & & & & \\
\hline 2. & inteligentny (19) & $\begin{array}{l}\text { inteligentny człowiek; inteli- } \\
\text { gencja; błyskotliwy (4); bystry; } \\
\text { myślący; myślący, analizujący }\end{array}$ & 28 & 9,79 & 25 & 39,68 \\
\hline 3. & wierzący (6) & $\begin{array}{l}\text { mocno wierzący; osoba wie- } \\
\text { rząca; wierzący, chrześcijanin; } \\
\text { mocno wierzący, pokładający } \\
\text { nadzieję w wierze i Bogu; } \\
\text { religijny (6); głęboko religijny; } \\
\text { człowiek niezwykle religijny; } \\
\text { bardzo religijny; katolik (3); } \\
\text { zadeklarowany katolik; bogo- } \\
\text { bojny; nawrócony; ufny Bogu }\end{array}$ & 26 & 9,09 & 23 & 36,51 \\
\hline 4. & krytyczny (7) & $\begin{array}{l}\text { krytyczny wobec postaw nie- } \\
\text { których duchownych; kryty- } \\
\text { kant; krytyk; polemizujący ze } \\
\text { sprawami w Kościele; niechęt- } \\
\text { ny kapitalizmowi; przeciwny } \\
\text { gwałtownemu rozwojowi } \\
\text { technologii; potrafi skrytyko- } \\
\text { wać rodaków }\end{array}$ & 14 & 4,90 & 13 & 20,63 \\
\hline 5. & ironiczny (9) & $\begin{array}{l}\text { ironia (2); sarkastyczny; } \\
\text { zabawny/ironiczny }\end{array}$ & 13 & 4,55 & 12 & 19,05 \\
\hline 6. & $\begin{array}{l}\text { ciekawie piszący } \\
(0)\end{array}$ & $\begin{array}{l}\text { elokwentny (5); felietonista } \\
\text { (2); pisze o tematach trudnych } \\
\text { w zrozumiały sposób; }\end{array}$ & 12 & 4,20 & 11 & 17,46 \\
\hline
\end{tabular}




\begin{tabular}{|c|c|c|c|c|c|c|}
\hline \multirow{2}{*}{ lp. } & \multirow{2}{*}{$\begin{array}{c}\text { cecha } \\
\text { wizerunkowa }\end{array}$} & \multirow{2}{*}{ warianty leksykalne } & \multicolumn{2}{|c|}{ wskazania } & \multicolumn{2}{|c|}{ osoby } \\
\hline & & & $\mathbf{n}$ & $\%$ & $\mathbf{n}$ & $\%$ \\
\hline 6. & $\begin{array}{l}\text { ciekawie piszący } \\
(0)\end{array}$ & $\begin{array}{l}\text { potrafi trafić do odbiorcy; ko- } \\
\text { munikatywny; przekonujący; } \\
\text { stawiający na obrazowość }\end{array}$ & 12 & 4,20 & 11 & 17,46 \\
\hline 7. & zabawny & $\begin{array}{l}\text { dowcipny (3); zdystansowany } \\
\text { (3); zabawny/ironiczny; } \\
\text { z poczuciem humoru; } \\
\text { podchodzący z dystansem } \\
\text { do rzeczywistości }\end{array}$ & 10 & 3,50 & 10 & 15,87 \\
\hline 8. & zna temat & $\begin{array}{l}\text { posiadający dużą wiedzę doty- } \\
\text { czącą wiary; wykazuje się dużą } \\
\text { wiedzą; mający wiedzę o religii; } \\
\text { zorientowany w problemach } \\
\text { współczesnego świata; zorien- } \\
\text { towany w sprawach tego, co się } \\
\text { dzieje na świecie; zorientowany } \\
\text { w temacie; obeznany; obeznany } \\
\text { w sytuacji Kościoła katolickiego; } \\
\text { świadomy tego, o czym pisze; } \\
\text { obyty w świecie }\end{array}$ & 10 & 3,50 & 10 & 15,87 \\
\hline 9. & dokładny & $\begin{array}{l}\text { rzeczowy (3); merytoryczny; } \\
\text { logiczny; skrupulatny (2); } \\
\text { dokładny i skrupulatny w ana- } \\
\text { lizie problemu; wyważony }\end{array}$ & 10 & 3,50 & 6 & 9,52 \\
\hline 10. & zaangażowany & $\begin{array}{l}\text { zaangażowany w sprawy } \\
\text { religijne; angażujący się; za- } \\
\text { angażowany społecznie; czuje } \\
\text { się częścią społeczeństwa, } \\
\text { asymiluje; oddany sprawie; } \\
\text { „obrońca wiary”; obrońca } \\
\text { katolicyzmu; obrońca kleru }\end{array}$ & 9 & 3,15 & 8 & 12,70 \\
\hline 11. & konserwatywny (6) & tradycyjny; wierny tradycji & 8 & 2,80 & 7 & 11,11 \\
\hline 12. & dociekliwy (3) & $\begin{array}{l}\text { wnikliwy; ciekawy (2); } \\
\text { ciekawy świata }\end{array}$ & 7 & 2,45 & 6 & 9,52 \\
\hline 13. & oczytany (4) & $\begin{array}{l}\text { oczytany - duża wiedza } \\
\text { (np. historyczna); erudyta }\end{array}$ & 6 & 2,10 & 6 & 9,52 \\
\hline 14. & $\begin{array}{l}\text { spostrzegawczy } \\
\text { (3) }\end{array}$ & $\begin{array}{l}\text { dobry obserwator; uważny } \\
\text { obserwator otaczającego } \\
\text { świata; baczny obserwator }\end{array}$ & 6 & 2,10 & 6 & 9,52 \\
\hline 15. & obiektywny (4) & $\begin{array}{l}\text { obiektywnie patrzy na świat; } \\
\text { sprawiedliwy }\end{array}$ & 6 & 2,10 & 5 & 7,94 \\
\hline 16. & realista & $\begin{array}{l}\text { realistycznie patrzący na życie; } \\
\text { trzeźwo parzy na rzeczywi- } \\
\text { stość; wyważony/racjonalista; } \\
\text { rozsądny; racjonalnie myślący }\end{array}$ & 6 & 2,10 & 5 & 7,94 \\
\hline
\end{tabular}


Tabela 48 (cd.)

\begin{tabular}{|c|c|c|c|c|c|c|}
\hline \multirow{2}{*}{ lp. } & \multirow{2}{*}{$\begin{array}{c}\text { cecha } \\
\text { wizerunkowa }\end{array}$} & \multirow{2}{*}{ warianty leksykalne } & \multicolumn{2}{|c|}{ wskazania } & \multicolumn{2}{|c|}{ osoby } \\
\hline & & & $\mathbf{n}$ & $\%$ & $\mathbf{n}$ & $\%$ \\
\hline 17. & tolerancyjny & $\begin{array}{l}\text { szacunek dla innych ludzi; } \\
\text { szanujący innych; kulturalny } \\
\text { - szanuje przeciwnika, } \\
\text { nie obraża go, ale walczy na } \\
\text { argumenty; wyrozumiały }\end{array}$ & 5 & 1,75 & 5 & 7,94 \\
\hline 18. & empatyczny & $\begin{array}{l}\text { ludzki; umiejący słuchać } \\
\text { (innego/drugiego) człowieka; } \\
\text { współczujący }\end{array}$ & 4 & 1,40 & 4 & 6,35 \\
\hline 19. & $\begin{array}{l}\text { interesujący się } \\
(0)\end{array}$ & $\begin{array}{l}\text { interesuje się (światem), Ko- } \\
\text { ściołem; interesuje się polity- } \\
\text { ką; posiada pasję; pasjonat }\end{array}$ & 4 & 1,40 & 4 & 6,35 \\
\hline 20. & szczery (4) & & 4 & 1,40 & 4 & 6,35 \\
\hline 21. & złośliwy & $\begin{array}{l}\text { zgryźliwy; ma cięty język; } \\
\text { językowo zgryźliwy }\end{array}$ & 4 & 1,40 & 4 & 6,35 \\
\hline 22. & inne & $\begin{array}{l}\text { ambitny (2); otwarty (2); } \\
\text { moralny; usiłuje moralizo- } \\
\text { wać; kompetentny; bardzo } \\
\text { wykształcony; osoba wykształ- } \\
\text { cona o światowych poglądach; } \\
\text { gwałtowny; impulsywny; } \\
\text { analityk; analizuje występujące } \\
\text { zjawiska; myślący, analizujący; } \\
\text { odważny; próbuje porównać } \\
\text { Kościoły z wielu państw; z dy- } \\
\text { stansem; cierpliwy; doświad- } \\
\text { czony; uporządkowany; wy- } \\
\text { straszony; sceptyczny wobec } \\
\text { polskiego antyklerykalizmu; } \\
\text { niepopulistyczny (nie idzie za } \\
\text { opinią publiczną); wrażliwy; } \\
\text { dotkliwy; niewyróżniający się } \\
\text { z tłumu; refleksyjny; poważny; } \\
\text { dobroduszny; zaradny; stron- } \\
\text { niczy; zrównoważony; wyma- } \\
\text { gający; konsekwentny; pełen } \\
\text { wątpliwości; prawdomówny; } \\
\text { światowy; zastanawia się nad } \\
\text { sensem religii; broniący men- } \\
\text { talności; medialny; budzący } \\
\text { autorytet; nieagresywna; spo- } \\
\text { kojna; potrafi przyznać się do } \\
\text { błędu; zawsze stara się znaleźć } \\
\text { dobre strony; zdolny } \\
\text { do kompromisu; }\end{array}$ & 59 & 20,63 & 34 & 53,97 \\
\hline
\end{tabular}




\begin{tabular}{|l|l|l|l|l|l|l|}
\hline \multirow{2}{*}{ lp. } & \multirow{2}{*}{$\begin{array}{c}\text { cecha } \\
\text { wizerunkowa }\end{array}$} & warianty leksykalne & \multicolumn{2}{|c|}{ wskazania } & \multicolumn{2}{|c|}{ osoby } \\
\cline { 3 - 6 } 2. & $\begin{array}{l}\text { postępowe poglądy; przebie- } \\
\text { gły; pozer; zwraca uwagę na } \\
\text { zmianę podejścia do pewnych } \\
\text { grup (dyskryminacja uczuć re- } \\
\text { ligijnych chrześcijan); surowy; } \\
\text { przyjazny; czuje się częścią } \\
\text { społeczeństwa; klerykalny; } \\
\text { altruista; idealista; pewny sie- } \\
\text { bie, próżny; poruszył istotny } \\
\text { temat, o którym wie, według } \\
\text { mnie, mało osób }\end{array}$ & n & & & \% \\
\hline
\end{tabular}

Źródło: opracowanie własne

W wizerunku werbalnym Szymona Hołowni, którego wygląd i nazwisko są znane czytelnikom, najsilniej eksponowaną cechą jest „dosadnie przedstawiający swoje odważne sądy" (35 - 12,28\% wskazań; 28 - 44,44\% respondentów ich dokonujących). Nieco mniej, ale wciąż istotne ilościowo, są „inteligentny” (28 - 9,82\%; 25 - 39,68\%) oraz „wierzący” (26 - 9,12\%; 23 - 36,51\%). Za nimi sytuują się cechy o wartościach poniżej 5\% wskazań: „krytyczny” (14 - 4,91\%; 13 - 20,63\%), ,ironiczny” (13 - 4,56\%; 12 - 19,05\%), „,ciekawie piszący” (12 - 4,21\%, 11 - 17,46\%). Mniej niż 4\% wynotowań dotyczy: „zabawny” i „zna temat" (po $10-3,51 \% ; 10$ - 15,87\%), ,dokładny” (10 - 3,51\%; 6 - 9,52\%), „zaangażowany” ( $9-3,16 \% ; 8-12,70 \%)$. Ponad połowa cech (11 na 21) nie przekracza $3 \%$ progu wskazań, a wśród nich są: „konserwatywny” ( $8-2,81 \%$; 7 - 11,11\%), „dociekliwy” (7 - 2,46\%; 6 - 9,52\%), „oczytany” i „spostrzegawczy” (po 6 - 2,11\% i 6 - 9,52\%) czy „obiektywny” i „realista” (po 6 - 2,11\% i $5-7,94 \%)$. Najmniejsze pod względem ilościowym znaczenie mają cechy: „tolerancyjny” (5 - 1,75\%, 5 - 7,95\%), „empatyczny”, „interesujący się”, „szczery”, „złośliwy” (po 4 - 1,40\% wskazań i po 4 - 6,35\% osób, które je wypisały).

Dla czytelników wiedzących, kto jest autorem tekstu, felietonista jawi się przede wszystkim jako osoba o bezkompromisowej postawie („dosadnie przedstawiający swoje odważne sądy”), ,inteligentna”, „wierząca”, „krytyczna” i „ironiczna”. Oparty na słowie image Szymona Hołowni wydaje się nieco bardziej wyrazisty od jego wizerunku jako anonimowego twórcy, jeśli wyrazistość określać jako (mniejszą) liczbę przypisywanych cech oraz frekwencję cech najwyżej usytuowanych na liście. W przypadku jawnego autora tekstu występuje 21 spójnych cech wizerunkowych, podczas gdy o 3 więcej pojawiły się, gdy twórca tekstu pozostawał nieznany. Obszerniejsza liczba 
cech w image'u werbalnym anonima jest zresztą stałą tendencją zauważalną u każdego z felietonistów. Swoiste natomiast pozostaje to, że pierwsze trzy cechy wyraźniej dominują nad resztą niż miało to miejsce w image'u niejawnego felietonisty. „Inteligentny”, „wierzący” i „dosadnie przedstawiający swoje odważne sądy" liczą łącznie 63 wskazania (21,72\%) w przypadku, gdy respondenci nie wiedzieli, kto jest autorem tekstu i 89 (31,23\%), kiedy mieli świadomość tożsamości twórcy wypowiedzi. Tę częstszą zauważalność da się wytłumaczyć wpływem wizerunku publicznego. Cechy tożsame lub analogiczne, „religijny”, „inteligentny” i „pewny siebie”, to odpowiednio pierwsza, trzecia i szósta cecha image'u, którego podstawą są wszystkie dostępne do momentu badania systemy znaków i wypowiedzi dotyczące publicysty.

Po raz kolejny też widać granicę tego wpływu. Podobnie bowiem jak $\mathrm{w}$ przypadkach innych felietonistów, wizerunek publiczny uwypuklił w werbalnym (znany autor) to, co i tak na poziomie słowa się znajdowało (anonimowy twórca) i było często odnotowywane, a nie widać tej zależności w przypadku rzadziej podawanych cech wizerunkowych. Kiedy np. cecha „zabawny” była manifestowana w tekście nieznanego autora na poziomie 3,10\% wskazań i 14,29\% respondentów, którzy przypisali tę cechę wypowiadającemu się, to i tak bardzo wysoka reprezentacja w wizerunku publicznym („zabawny” - druga pozycja na liście z wartością 14,08\% wskazań dokonanych przez $58,93 \%$ respondentów) nie podwyższyła istotnie wartości w image’u werbalnym autora o jawnym nazwisku (3,51\% wskazań 15,87\% czytelników).

W obu wizerunkach werbalnych powtórzyło się dosłownie 18 cech wizerunkowych. Tam, gdzie twórca tekstu pozostawał anonimowy, image „bogatszy” był o: „obserwator”, „ciekawy”, „otwarty”, „subiektywny”, „wykształcony”, „młody”. Natomiast swoiste dla opartego na słowie wizerunku felietonisty o podanej tożsamości stały się: „spostrzegawczy”, „tolerancyjny”, „złośliwy”. $\mathrm{W}$ obu przypadkach to cechy $\mathrm{z}$ drugiej połowy listy wskazań (z wyjątkiem „obserwatora” - 9 pozycja na 24 wszystkie w image'u anonima), a więc mniej znaczące ilościowo. Zestawienie z blokami semantycznymi powinno uwypuklić konsekwencje wizerunkowe tych różnic. 
Tabela 49. Bloki semantyczne w obu wizerunkach werbalnych Szymona Hołowni

\begin{tabular}{|c|c|c|c|c|c|c|c|c|c|}
\hline \multicolumn{5}{|c|}{$\begin{array}{l}\text { bloki semantyczne wizerunku werbalnego } \\
\text { anonimowego Szymona Hołowni } \\
\text { (wariant: sam tekst) }\end{array}$} & \multicolumn{5}{|c|}{$\begin{array}{l}\text { bloki semantyczne w wizerunku werbalnym } \\
\text { z podaną tożsamością Szymona Hołowni } \\
\text { (wariant: tekst + fotografia + nazwisko) }\end{array}$} \\
\hline \multirow{2}{*}{$\begin{array}{c}\text { cecha } \\
\text { wizerunkowa }\end{array}$} & \multicolumn{2}{|c|}{ wskazania } & \multicolumn{2}{|c|}{ osoby } & \multirow{2}{*}{$\begin{array}{c}\text { cecha } \\
\text { wizerunkowa }\end{array}$} & \multicolumn{2}{|c|}{ wskazania } & \multicolumn{2}{|c|}{ osoby } \\
\hline & $\mathbf{n}$ & $\%$ & $\mathbf{n}$ & $\%$ & & $\mathbf{n}$ & $\%$ & $\mathbf{n}$ & $\%$ \\
\hline $\begin{array}{l}\text { dosadnie przed- } \\
\text { stawiający swoje } \\
\text { odważne sądy }\end{array}$ & 19 & 6,55 & 19 & 30,16 & $\begin{array}{l}\text { dosadnie przed- } \\
\text { stawiający swoje } \\
\text { odważne sądy }\end{array}$ & 35 & 12,28 & 28 & 44,44 \\
\hline krytyczny (3) & 15 & 5,17 & 14 & 22,22 & krytyczny (7) & 14 & 4,91 & 13 & 20,63 \\
\hline ironiczny (6) & 12 & 4,14 & 11 & 17,46 & ironiczny (9) & 13 & 4,56 & 12 & 19,05 \\
\hline \multirow[t]{2}{*}{ subiektywny (3) } & 5 & 1,72 & 4 & 6,35 & złośliwy & 4 & 1,40 & 4 & 6,35 \\
\hline & 51 & 17,59 & & & & 66 & 23,16 & & \\
\hline ciekawie piszący $(0)$ & 16 & 5,52 & 15 & 23,81 & wierzący $(6)$ & 26 & 9,12 & 23 & 36,51 \\
\hline zabawny & 9 & 3,10 & 9 & 14,29 & zaangażowany & 9 & 3,16 & 8 & 12,70 \\
\hline \multirow[t]{2}{*}{ ironiczny (6) } & 12 & 4,14 & 11 & 17,46 & $\begin{array}{l}\text { konserwatywny } \\
\text { (6) }\end{array}$ & 8 & 2,81 & 7 & 11,11 \\
\hline & 37 & 12,76 & & & & 43 & 15,09 & & \\
\hline inteligentny (10) & 24 & 8,28 & 22 & 34,92 & $\begin{array}{l}\text { ciekawie piszący } \\
(0)\end{array}$ & 12 & 4,21 & 11 & 17,46 \\
\hline \multirow[t]{2}{*}{ obserwator (11) } & 11 & 3,79 & 9 & 14,29 & ironiczny $(9)$ & 13 & 4,56 & 12 & 19,05 \\
\hline & 35 & 12,07 & & & zabawny & 10 & 3,51 & 10 & 15,87 \\
\hline wierzący (5) & 20 & 6,90 & 18 & 28,57 & & 35 & 12,28 & & \\
\hline zaangażowany $(0)$ & 7 & 2,41 & 6 & 9,52 & inteligentny (19) & 28 & 9,82 & 25 & 39,68 \\
\hline \multirow[t]{2}{*}{ konserwatywny (2) } & 5 & 1,72 & 5 & 7,94 & spostrzegawczy (3) & 6 & 2,11 & 6 & 9,52 \\
\hline & 32 & 11,03 & & & & 34 & 11,93 & & \\
\hline interesujący się (5) & 5 & 1,72 & 5 & 7,94 & znawca tematu & 10 & 3,51 & 10 & 15,87 \\
\hline znawca tematu & 14 & 4,83 & 14 & 22,22 & oczytany (4) & 6 & 2,11 & 6 & 9,52 \\
\hline wykształcony & 4 & 1,38 & 4 & 6,35 & interesujący się (0) & 4 & 1,40 & 4 & 6,35 \\
\hline \multirow[t]{2}{*}{ oczytany (7) } & 8 & 2,76 & 8 & 12,70 & & 20 & 7,02 & & \\
\hline & 31 & 10,69 & & & dokładny & 10 & 3,51 & 6 & 9,52 \\
\hline obiektywny (7) & 14 & 4,83 & 13 & 20,63 & dociekliwy (3) & 7 & 2,46 & 6 & 9,52 \\
\hline \multirow[t]{2}{*}{ realista (3) } & 6 & 2,07 & 5 & 7,94 & & 17 & 5,96 & & \\
\hline & 20 & 6,90 & & & obiektywny (4) & 6 & 2,11 & 5 & 7,94 \\
\hline dociekliwy (5) & 10 & 3,45 & 9 & 14,29 & realista & 6 & 2,11 & 5 & 7,94 \\
\hline \multirow[t]{2}{*}{ dokładny (0) } & 9 & 3,10 & 8 & 12,70 & & 12 & 4,21 & & \\
\hline & 19 & 6,55 & & & tolerancyjny & 5 & 1,75 & 5 & 7,94 \\
\hline ciekawy (3) & 7 & 2,41 & 6 & 9,52 & empatyczny & 4 & 1,40 & 4 & 6,35 \\
\hline otwarty (2) & 5 & 1,72 & 4 & 6,35 & & 9 & 3,16 & & \\
\hline \multirow[t]{2}{*}{ młody } & 4 & 1,38 & 4 & 6,35 & szczery (4) & 4 & 1,40 & 4 & 6,35 \\
\hline & 16 & 5,52 & & & & & & & \\
\hline szczery (2) & 4 & 1,38 & 4 & 6,35 & & & & & \\
\hline empatyczny (3) & 6 & 2,07 & 6 & 9,52 & & & & & \\
\hline
\end{tabular}

Źródło: opracowanie własne 
W obu image’ach werbalnych da się wyróżnić po 8 spójnych grup semantycznych, $\mathrm{z}$ czego 7 budują te same lub podobne znaczeniowo cechy, a ósma różni 2 porównywane image'e. Ten ostatni obszar, utworzony z "ciekawy”, „otwarty”, „młody”, w przypadku czytania tekstu anonima oraz „tolerancyjny” i „empatyczny”, gdy znano imię i nazwisko autora, jednocześnie odzwierciedla pewną zmianę optyki w konstruowaniu wizerunku Szymona Hołowni, widzianą na poziomie wszystkich bloków semantycznych. Kiedy nie wiadomo było, kto napisał felieton, bardziej dostrzegano kompetencje (patrz: bloki skupione wokół „zna temat”, „dociekliwy”) i otwartość intelektualno-poznawczą (cechy podobne do „ciekawy”), a mniej przekonania (obszar cech przy „wierzący”) i stosunek nie tyle do tematu, co do innych ludzi („empatyczny”, „tolerancyjny"). Chociaż pierwsze 4 bloki są skonstruowane przez niemal identyczne cechy, a bezkompromisowość postawy w obu przypadkach ma największe ilościowe znaczenie, to ciekawa forma przekazu i inteligencja plasują się na drugiej i trzeciej pozycji w wizerunku nieznanego felietonisty, kwestię wiary spychając na czwarte miejsce, podczas gdy w przypadku image’u jawnego twórcy wiara znajduje się wysoko - jako druga wśród grup znaczeniowych. Przyczyny takiego układu należałoby szukać we wpływie wizerunku publicznego, podnoszącego ekspozycję wiary w wizerunku werbalnym autora o podanej tożsamości. W obu przypadkach cechy skoncentrowane przy „znawcy tematu" plasują się na piątej pozycji wśród bloków, ale reprezentują łącznie więcej wskazań, kiedy nie wiedziano, kto napisał tekst (relacja 31 wskazań), niż gdy dane były jawne (20 wskazań), co znów wynikać może z wpływów wymiaru publicznego image'u.

Ponieważ analiza wizerunku wizualnego wykazała duży wpływ image’u publicznego, to $\mathrm{w}$ wizerunku werbalnym felietonisty o podanym nazwisku trudno wykazać determinację zdjęciem autora. Wyraźnie jednak da się zauważać wpływ wizerunku publicznego na werbalny, zarówno uwzględniając analizę pojedynczych cech, jak i bloków semantycznych. Wizerunek anonimowego Szymona Hołowni nieco bardziej podkreśla jego kompetencje (patrz: więcej cech skupionych wokół „znawca tematu”) oraz otwartość poznawczą (blok: „ciekawy”, „otwarty”, „młody”), podczas gdy image jawnego autora tekstu uwypukla wiarę publicysty (wysoka reprezentacja „wierzący”), co jest wynikiem wpływu innych źródeł wypowiedzi i tym samym wizerunku publicznego. Wśród bloków semantycznych ostatniego z wymienionych typów image'u na pierwszym miejscu znalazła się grupa takich cech, jak „zabawny”, „sympatyczny”, „otwarty”, co być może znalazło swoje odzwierciedlenie w pojawieniu się cechy „tolerancyjny” wśród tych przypisanych znanemu autorowi tekstu (brak tej cechy w wizerunku anonimowego felietonisty). 
Tabela 50. Kategorie komunikowanego werbalnie wizerunku felietonisty o znanej tożsamości - Szymona Hołowni

\begin{tabular}{|c|c|c|c|c|c|c|c|c|c|c|}
\hline lp. & $\begin{array}{l}\text { poglądy/ } \\
\text { wartości }\end{array}$ & $\mathbf{n}$ & wiedza & $\mathbf{n}$ & postawa & n & $\begin{array}{c}\text { cecha } \\
\text { charakteru }\end{array}$ & $\mathbf{n}$ & $\begin{array}{l}\text { sposób } \\
\text { komu- } \\
\text { nikacji }\end{array}$ & $\mathbf{n}$ \\
\hline 1. & $\begin{array}{l}\text { wierzący } \\
\text { (6) }\end{array}$ & 26 & zna temat & 10 & $\begin{array}{l}\text { dosadnie } \\
\text { przedstawia- } \\
\text { jący swoje } \\
\text { odważne } \\
\text { sądy }\end{array}$ & 35 & $\begin{array}{l}\text { inteligentny } \\
\text { (19) }\end{array}$ & 28 & $\begin{array}{l}\text { ciekawie } \\
\text { piszący } \\
(0)\end{array}$ & 12 \\
\hline 2. & $\begin{array}{l}\text { konser- } \\
\text { watywny } \\
\text { (6) }\end{array}$ & 8 & $\begin{array}{l}\text { oczytany } \\
\text { (4) }\end{array}$ & 6 & krytyczny (7) & 14 & zabawny & 10 & & \\
\hline 3. & $\begin{array}{l}\text { toleran- } \\
\text { cyjny }\end{array}$ & 5 & $\begin{array}{l}\text { interesują- } \\
\text { cy się (0) }\end{array}$ & 4 & ironiczny (9) & 13 & $\begin{array}{l}\text { empatycz- } \\
\text { ny }\end{array}$ & 4 & & \\
\hline 4. & & & & & dokładny & 10 & szczery (4) & 4 & & \\
\hline 5. & & & & & $\begin{array}{l}\text { zaangażo- } \\
\text { wany }\end{array}$ & 9 & & & & \\
\hline 6. & & & & & $\begin{array}{l}\text { dociekliwy } \\
\text { (3) }\end{array}$ & 7 & & & & \\
\hline 7. & & & & & $\begin{array}{l}\text { obiektywny } \\
\text { (4) }\end{array}$ & 6 & & & & \\
\hline 8. & & & & & realista & 6 & & & & \\
\hline 9. & & & & & $\begin{array}{l}\text { spostrzegaw- } \\
\text { czy (3) }\end{array}$ & 6 & & & & \\
\hline 10. & & & & & złośliwy & 4 & & & & \\
\hline & razem & 39 & & 20 & & 110 & & 46 & & 12 \\
\hline
\end{tabular}

Źródło: opracowanie własne

Jeśli podsumować zestawienie danych dotyczących wizerunku jawnego autora tekstu z jego image'em publicznym, to widać wpływ wizerunku publicznego na jego wymiar werbalny, ale ogranicza się on do uwypuklenia tych atrybutów, które i tak znajdują się w tekście - może dojść do zmiany proporcji najliczniej reprezentowanych cech (nie tych z końca listy) lub wygenerowania nowej, choć nisko reprezentowanej (pojedynczy taki przypadek).

W zakresie kategorii możliwego do komunikowania werbalnie wizerunku Szymona Hołowni w sytuacji, kiedy autor wypowiedzi jest znany, nie da się wprowadzić zbyt wielu zmian do dotychczasowych ustaleń. Podobnie jak u Krzysztofa Vargi i Piotra Zaremby, najwięcej cech wizerunkowych mieści się w obszarze „postawy” oraz „cechy charakteru”. W pierwszej trójce znajdują się jeszcze „poglądy/wartości”, które zajmowały drugą pozycję 
u Magdaleny Środy, ostatnią u Piotra Zaremby, a w ogóle nie występowały u Krzysztofa Vargi). Takie zależności potwierdzają wcześniejszą interpretację, że „poglądy/wartości” są bardziej eksponowane tam, gdzie porusza się tematykę społeczno-polityczną. Najrzadziej czytelnicy biorą pod uwagę w konstrukcji image’u jawnego felietonisty „wiedzę” oraz „sposób komunikacji”, co stanowi układ typowy dla wszystkich felietonistów.

\subsubsection{Zależności między poszczególnymi typami wizerunków Szymona Hołowni}

Szymon Hołownia jako twórca anonimowego tekstu jawił się czytelnikom głównie jako osoba inteligentna, wierząca, dosadnie przedstawiająca swoje odważne sądy i ciekawie pisząca. Kiedy wiadomo było, kto napisał felieton, przypisywano mu niemal te same cechy, choć tym razem zmieniły się nieco proporcje i najczęściej wskazywano dosadne przedstawianie swoich poglądów, a następnie inteligencję, wiarę i krytyczną postawę. Image publiczny podkreślał religijność, inteligencję, poczucie humoru i sympatyczność. Warstwa wizualna zaznaczała głównie takie cechy, jak: inteligentny, zabawny, pewny siebie, kontaktowy. W wymiarze werbalnym częściej zauważana jest krytyczna postawa, na poziomie publicznym i wizualnym (na który publiczny bardzo wpływa) zyskują na znaczeniu cechy generowane przez medialny kontekst komunikacyjny.

Analiza bloków semantycznych wykazuje, że powstają one, skupiając się wokół najliczniej reprezentowanych cech, lub te rzadziej wskazywane gromadzą się w samodzielnie powstałych grupach. Mogą więc występować cechy, które pozornie (ilościowo) mają małe znaczenie, jednak zyskują wagę dla wizerunku, kiedy uwzględnić kształt wyłonionych obszarów semantycznych. Zaznaczyć przy tym należy, że analiza bloków semantycznych jest dobrym narzędziem, zwłaszcza jeśli podlegają jej dane jakościowe (jakie bloki powstają, jakie cechy łączą, jaki filtr semantyczny dominuje) w dużo większym stopniu niż dane ilościowe (ile bloków powstało, jaką mają kolejność), a towarzyszy temu próba interpretacji różnic między obszarami znaczeniowymi a listą frekwencji wskazań cech wizerunkowych.

Ponownie zwraca uwagę zakres obejmujący cechy image'owe wchodzące w kategorię „inne”. Najwyżej reprezentowana cecha ma zawsze w przypadku Szymona Hołowni (podobnie jak u innych omawianych tu felietonistów) ${ }^{27}$ wartość niższą niż te zgrupowane w „inne”, czyli niezmiennie dużo. Wydaje

27 Wyjątek stanowi wizerunek publiczny i wizualny Magdaleny Środy, gdzie kategoria „inne” przyjmowała wartości mniejsze niż najwyżej manifestowana cecha danego image’u. 
się, że w mocy pozostaje wcześniejsza interpretacja takiego stanu rzeczy. Wizerunek dla interpretatorów wypowiedzi (w jakimkolwiek systemie znaków) może być wyrazisty tylko w ograniczonym stopniu. Dodać należy, że w ograniczonym do 5-8 bloków semantycznych, do wysoko reprezentowanych cech („wierzący” w wizerunku wizualnym rozpoznawanego Hołowni był pojedynczą cechą, ale miał poziom wskazań wyższy od najmniejszego bloku semantycznego) i do określonych kategorii, właściwych dla każdego typu wizerunku.

Najczęściej cechy zgrupowane w „inne” reprezentują poziom ok. 20\% wskazań i większy od $50 \%$ pułap osób dokonujących wynotowań. Wydaje się, że odejście od tej reguły ma miejsce wówczas, gdy pojawia się swego rodzaju katalizator wizerunku, jak np. w przypadku Magdaleny Środy stereotyp feministki w image'u publicznym czy podniesiony palec w wizerunku wizualnym, gdy rozpoznawano kobietę ze zdjęcia. Podwyższa on wartości niektórych cech i automatycznie zmniejsza udział procentowy cech trudnych do klasyfikacji. Dla Szymona Hołowni byłby to kontekst medialny (pozafelietonowy), który ograniczył liczbę wskazań w „inne” do 15,55\%, dokonanych przez 44,64\% respondentów. Z drugiej strony, niepopularna tematyka (religijna) i popularny (upraszający) sposób jej ujęcia - w image’u werbalnym anonima zaważyły zapewne na niskim poziomie wskazań równym 17,59\% i osób ich dokonujących - 47,62\%. Jednoczenie warto zaznaczyć, iż takie ułatwienie profilowania wizerunku w jednym przypadku może innym razem stanowić utrudnienie powstania spójnego obrazu danej osoby. Tak też w imagu wizualnym rozpoznawanego publicysty mieszał się kontekst medialny i wynikający z niego image z warstwą wizualną zdjęcia, co miało swoje odzwierciedlenie w wynikach - aż 28,84\% wskazań trafiło do „inne”, a dokonało ich 83,05\% osób. Respondentom trudno było wyizolować konstrukcję wizerunku na podstawie wypowiedzi wizualnej z konstrukcji wizerunku już utrwalonej na podstawie wszystkich dostępnych systemów znaków oraz wypowiedzi również „o” publicyście.

Z pojedynczych cech na uwagę zasługuje także „dosadnie przedstawiający swoje odważne sądy" - cecha, która w wizerunku werbalnym anonima miała liczbę wskazań nie większą, ale równą z liczbą osób dokonujących jej wynotowań. Zapewne wiązano ją z wyrażaniem swoich poglądów na temat religii i ponieważ nie dotyczyła niczego innego, to respondenci jej nie dublowali. Potwierdza się więc, że w sytuacji cechy wieloznacznej określenia ją wyrażające powielą się, a w przypadku względnej niewieloznaczności danej cechy wizerunkowej liczba jej wskazań i liczba osób ją wynotowujących będą sobie bliskie.

Po raz kolejny respondenci przypisywali cechę „medialny” (wizerunek publiczny Szymona Hołowni) czy też „człowiek mediów” (image wizualny rozpoznawanego publicysty), co świadczy o celebrytyzacji zawodu dziennikarza, a większa niż u Magdaleny Środy liczba wskazań dotycząca tych cech 
potwierdza wysoką ekspozycję medialną Szymona Hołowni (odpowiednio 24 i 18 wskazań u felietonisty oraz tylko 5 u autorki tekstów).

Najwięcej cech przypisano nieznanemu felietoniście (24), potem jawne$\mathrm{mu}(21)$, nieco mniej dotyczy wizerunku publicznego (18) i najmniej wizualnego w przypadku rozpoznawania osoby ze zdjęcia (15). Powiela to proporcje występujące u Magdaleny Środy, ale nie zgadza się z rezultatami dotyczącymi Krzysztofa Vargi i Piotra Zaremby, gdzie przedostatni pod względem liczby cech wizerunkowych był image wizualny, a ostatni publiczny. Pamiętać jednak należy, że image publiczny piszących o kulturze publicystów określało bardzo mało osób (odpowiednio: 11 i 19), co zapewne determinowało wyniki.

Kategoriami wizerunkowymi występującymi u Szymona Hołowni w każdym wizerunku są „postawa”, „cechy charakteru”, ,wiedza”, a także - i tylko u tego publicysty - „poglądy/wartości” (wcześniej nie pojawiały się w wymiarze wizualnym) i „sposób komunikacji” ( $u$ innych autorów funkcjonujący wyłącznie na poziomie obu imageów werbalnych). Większa manifestacja „poglądów/wartości” u Magdaleny Środy i Szymona Hołowni świadczy o podatności komunikowania tej kategorii przez tematykę społeczno-polityczną. Typowy do tej pory dla obrazu „wygląd” teraz występuje także w typie publicznym. Odwrotna migracja, a raczej ekspansja (z wizerunku publicznego do wizualnego) dotyczy „zawodu”. Spośród kategorii specyficznych dla jednego typu wizerunku można wymienić jedynie „stan emocjonalno-poznawczy” i ,wiek/płeć”, właściwe wyłącznie dla wymiaru obrazu.

Wydaje się, że - bardzo upraszczając - swego rodzaju bazą jest tu wizerunek werbalny ${ }^{28}$, on bowiem przenika do publicznego („sposób komunikacji”), a z kolei publiczny wywiera wpływ na wizualny („zawód”, „sposób komunikacji” w tym ostatnim), który cechuje się wysokim stopniem absorbcji cech z innych typów imageów i jednocześnie małymi możliwościami izolacji od nich w przypadku rozpoznawania osoby z fotografii (patrz: akapit wyżej).

Przeciwieństwem image’u wizualnego staje się wizerunek werbalny, który okazuje się u Szymona Hołowni najbardziej stabilny. Mimo widocznego wpływu wymiaru publicznego na słowo, determinacja ogranicza się do najwyżej reprezentowanych cech, których źródłem i tak jest wypowiedź werbalna. Nie występują cechy nowe, typowe dla innego rodzaju wizerunku (jak ma to miejsce w image'u wizualnym).

Szerzej o możliwościach komunikacyjnych każdego z typów wizerunku oraz o różnicach i wzajemnych wpływach w kolejnych rozdziałach, sumujących wyniki i ustalenia dotyczące wszystkich analizowanych felietonistów.

28 „Bardzo upraszczając”, bo obecność kilku kategorii we wszystkich typach wizerunku niekoniecznie świadczy o podstawie w postaci słowa, ale raczej o uniwersalności komponentów wizerunku - bez względu na system znaków interpretator uznaje cechy z tych powtarzających się kategorii za elementy wizerunku. 
ROZDZIAŁ III 



\section{Wnioski}

3.1. Możliwy do komunikowania wizerunek na podstawie wyników dotyczących wszystkich autorów

Przedstawiona niżej tabela (tabela 51), lokująca w jednym miejscu wszystkie cechy każdego analizowanego wizerunku każdego z felietonistów i uwzględniająca wyłonione kategorie komunikowanego image'u, niech będzie podstawą niniejszego podsumowania. 


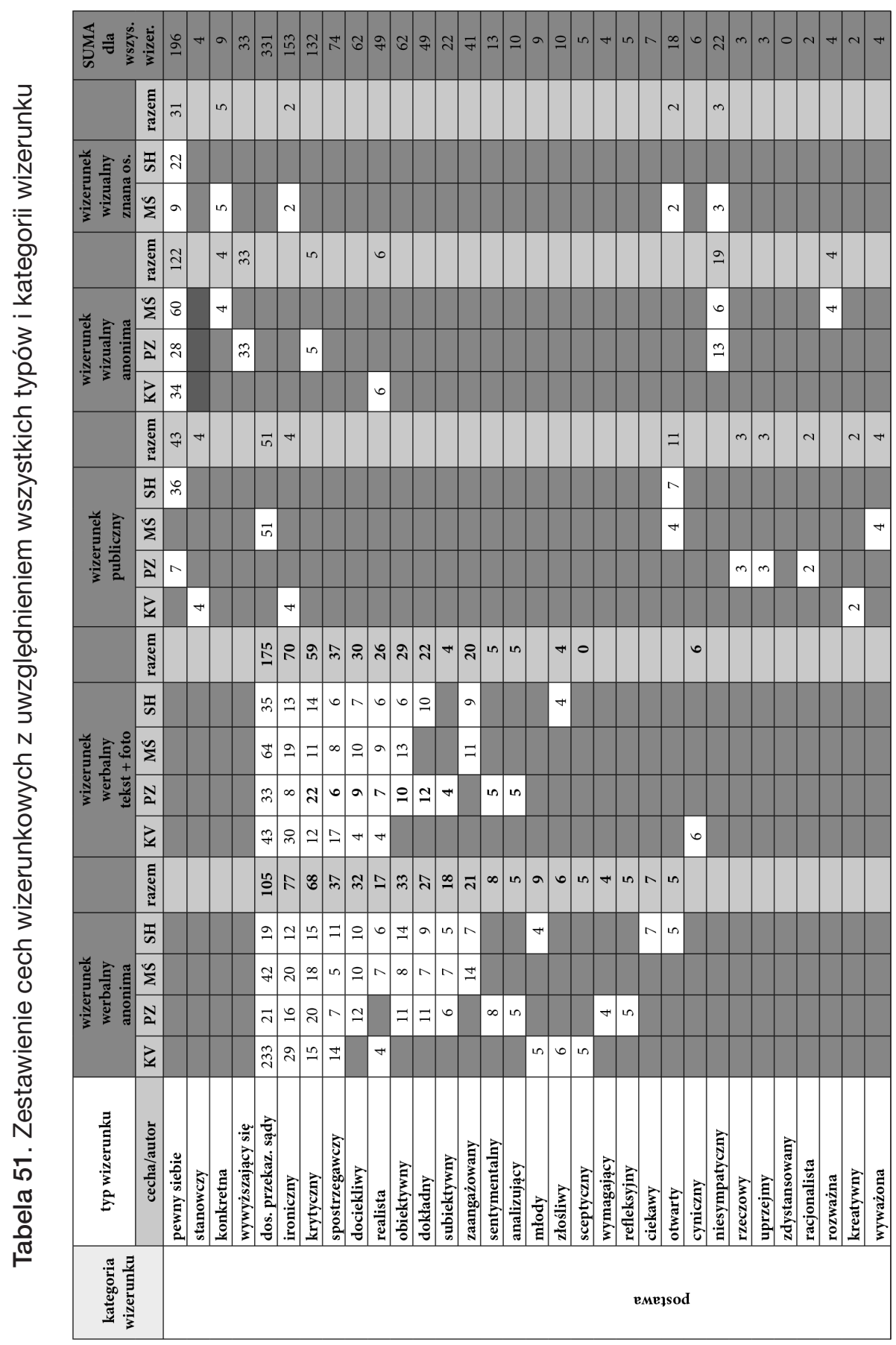




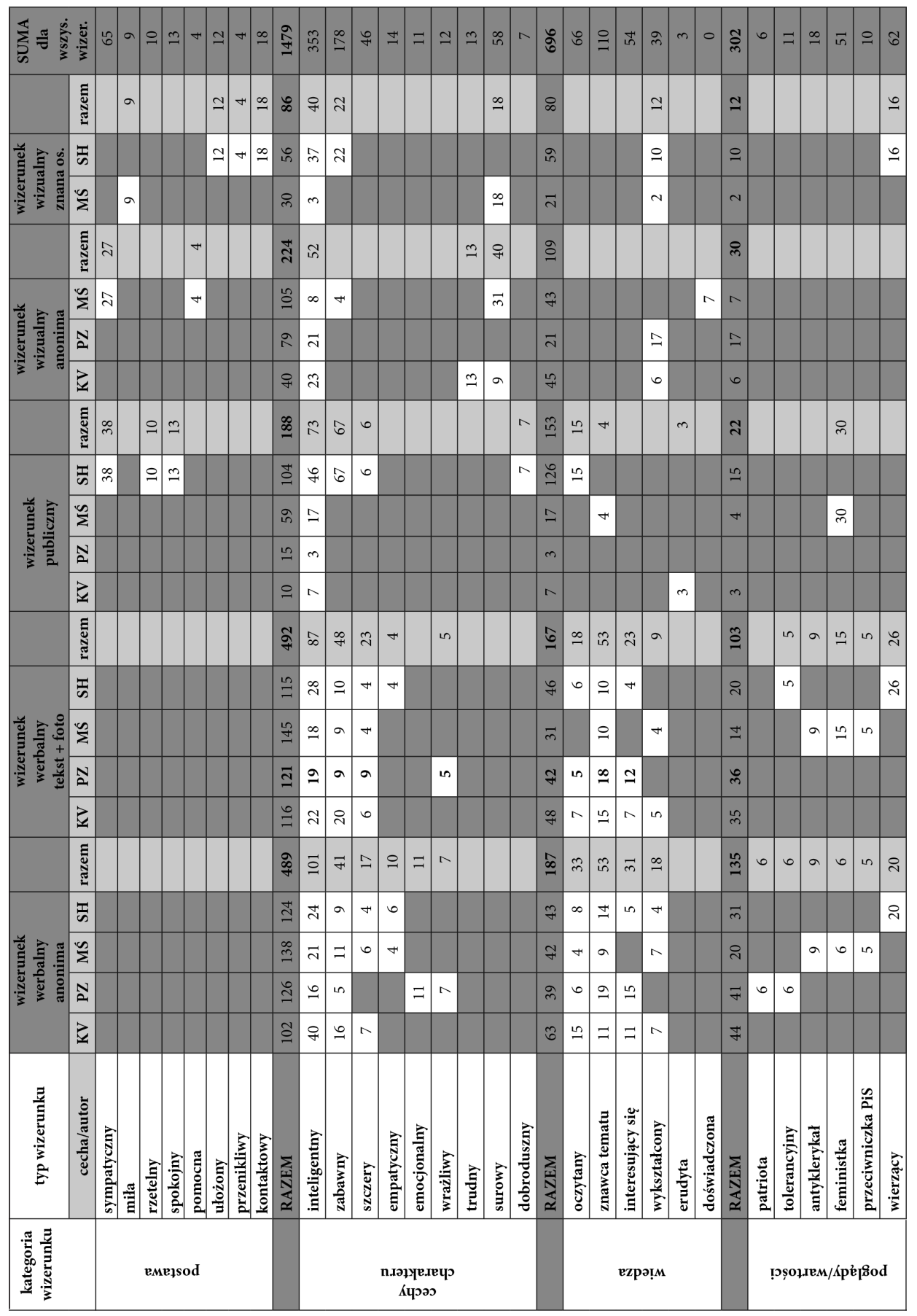




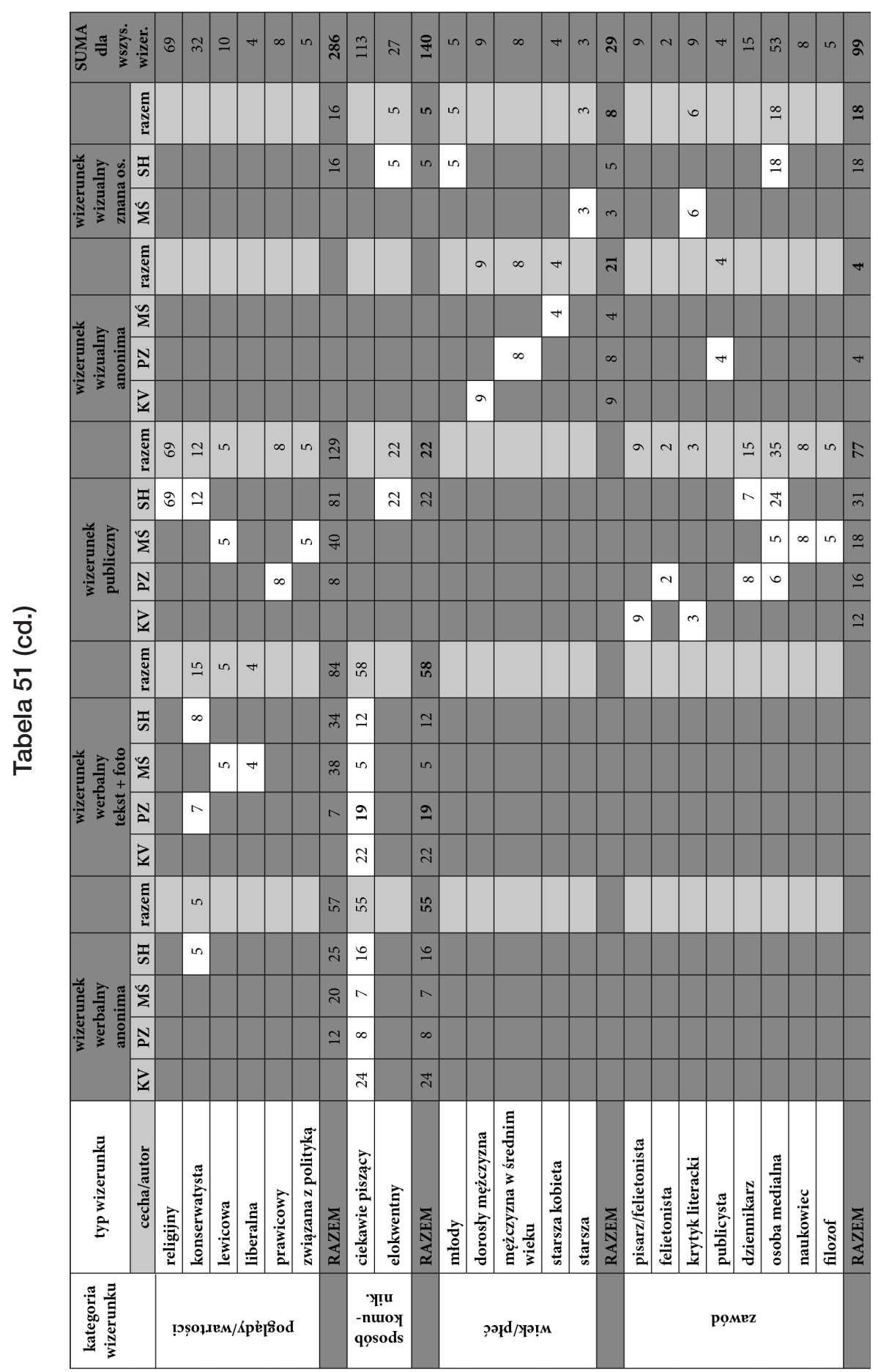




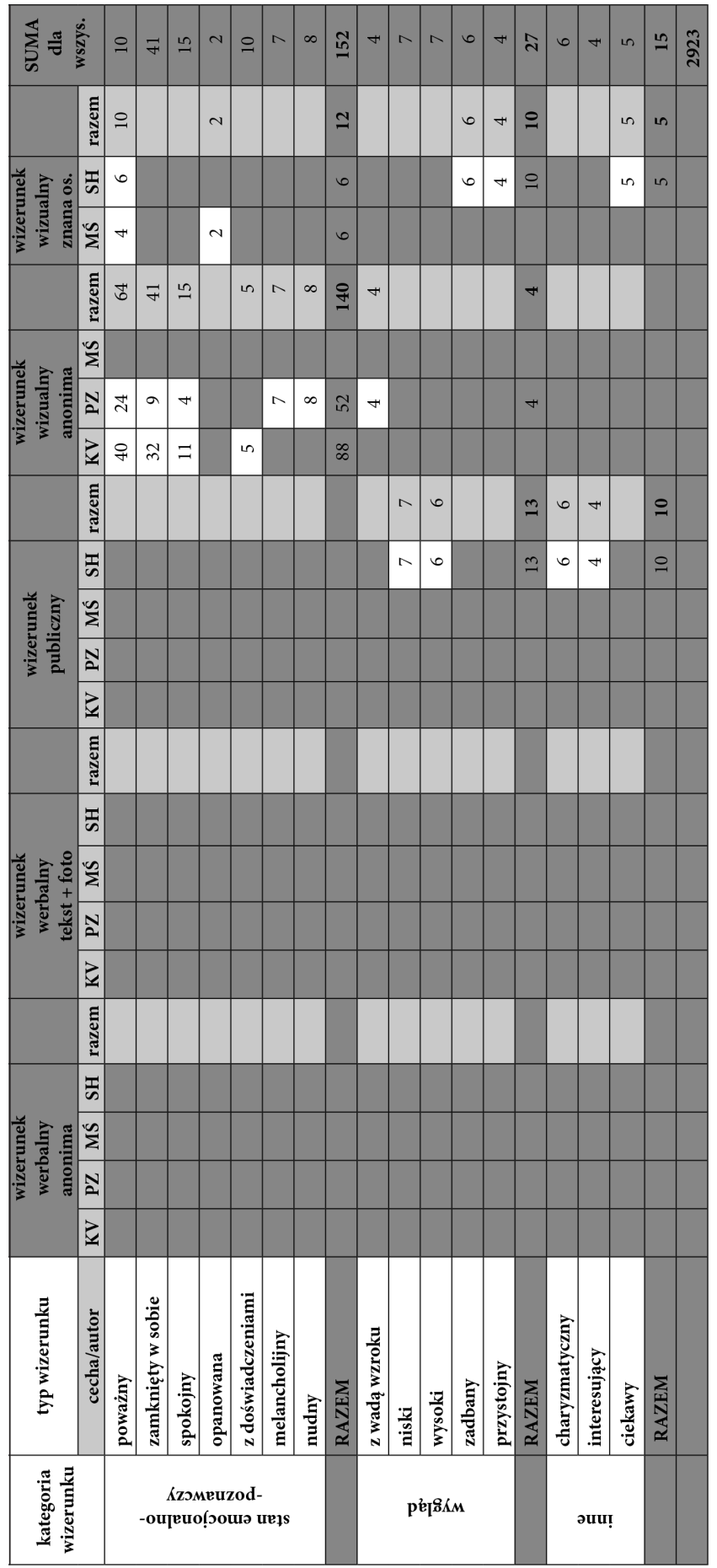

0
$\frac{1}{10}$
$\frac{\pi}{3}$
$\frac{0}{0}$
$\frac{0}{1}$
$\frac{\pi}{3}$
0
0
$\frac{\pi}{0}$
0
0
0
0
.0
$N$ 


\subsubsection{Wizerunek werbalny anonimowego autora tekstu i felietonisty o znanej tożsamości}

Pierwsze kolumny (tabela 51) pozwalają podjąć próbę odpowiedzi na pytanie badawcze nr 1 (patrz rozdział 1.3.1): „Jaki wizerunek autora tekstu może być przez niego komunikowany, gdy pisze na temat inny niż własna osoba i w sytuacji, gdy taki autor słów pozostaje anonimowy dla odbiorcy wypowiedzi?" oraz nr 2: Jaki wizerunek autora tekstu może być przez niego komunikowany, gdy mówi na temat inny niż własna osoba i w sytuacji, gdy tożsamość takiego autora słów jest znana odbiorcy wypowiedzi? Liczby w tabeli to ilości wskazań dotyczące poszczególnych cech, ciemny kolor komórki oznacza 0 (zero) wskazań.

W tym miejscu także należy przypomnieć hipotezę badawczą: Wizerunek werbalny anonimowego i jawnego twórcy są podobne, a mogą komunikować cechy charakteru (np. „zabawny”, „inteligentny”, „indywidualista”, „szczery”, „empatyczny”), postawę (np. „racjonalista”, „otwarty”, „obserwator”, „doradzający”) i poglądy/wartości (np. „patriota”), wiedzę (np. filozof) (Barańska 2011, 2012). Zweryfikowano ją pozytywnie.

Średnio wizerunek werbalny anonima to 20,75 cech przypisanych felietoniście, a w przypadku image’u jawnego twórcy to 18,75 cech. Wpływy z zewnątrz zatem wydają się nieco precyzować wizerunek i ograniczają liczbę konstruowanych cech ${ }^{1}$. Ale wciąż są to prawie te same cechy.

Potencjał komunikacyjny w zakresie wizerunku nieznanego i jawnego twórcy tekstu rozpatrywać należy łącznie, ponieważ w obszarze możliwych do komunikowania kategorii nie wykazują różnic. W obu przypadkach, u wszystkich felietonistów, wyraźnie nad innymi aspektami image’u dominuje możliwość komunikowania „postawy”. Zaliczono tutaj 22 cechy wizerunkowe, sumujące 490 wskazań w przypadku wizerunku anonima i 497 wynotowań dla image’u felietonisty o znanej tożsamości. Drugą z najliczniejszych kategorii są „cechy charakteru”, choć prezentują wartości o ponad połowę mniejsze, bowiem znalazło się tu już tylko 6 cech image’owych z łączną liczbą wskazań na poziomie odpowiednio 187 i 167. System języka naturalnego staje się też dogodnym miejscem ekspresji „wiedzy: (4 cechy, wskazania odpowiednio: 136 i 105) oraz „poglądów/wartości” (7 cech, wskazania: 57 i 79) i „sposobu komunikacji” (1 cecha, odpowiednio 55 i 58 wynotowań).

1 Co potwierdza wcześniejsze obserwacje w zakresie wizerunków werbalnych Aloszy Awdiejewa (Barańska 2011) i prowadzone na mniejszej (i innej) próbie badanie dotyczące Szymona Hołowni (Barańska-Szmitko 2014). Wyjątkiem od tej generalnej zasady jest Krzysztof Varga, u którego wyniki dotyczące obu wizerunków werbalnych są dużo bardziej zbieżne ze sobą na tle imageów innych autorów zarówno w opisywanym tu badaniu, jak i w mniejszych, wcześniejszych (Barańska-Szmitko 2013), co tłumaczy się tutaj niską jego rozpoznawalnością. 
„Poglądy/wartości” różnicują się na poszczególnych felietonistów, tj. ponieważ wybrani autorzy reprezentują odmienne postawy ideowe, to nie powtarzają się żadne cechy między nimi. Nie zawsze też te cechy są przypisywane, czyli nie wtedy, gdy tematyka jest ściśle związana z kulturą i nie występują w niej odniesienia polityczne i społeczne. Stąd też Krzysztofowi Vardze, piszącemu o kulturze i estetyce, nie było dane być określonym w obrębie tego obszaru wizerunku.

Zaznaczyć przy tym należy, że wizerunki werbalne są jedynym wśród analizowanych typów, który nie ma ani jednej swoistej kategorii, tj. wszystkie pięć wyłonionych obszarów pojawia się też w innych rodzajach wizerunków (publiczny, wizualny), co świadczy o bardzo dużych możliwościach ekspansji (nawet na wizerunek wizualny) kategorii dotyczących słowa.

Te możliwości ekspansji nie oznaczają jednak braku wpływów. Chociaż ich wyraźnie nie widać w zbiorczym zestawieniu, stawały się lepiej eksponowane w analizie kolejnych typów wizerunków poszczególnych felietonistów. Kiedy wiadomo było, kto jest autorem słów i tego autora charakteryzowała wysoka lub przynajmniej średnia rozpoznawalność (Środa, Hołownia), to w porównaniu $\mathrm{z}$ wizerunkiem anonimowego twórcy wypowiedzi u znanego wyżej reprezentowane okazywały się cechy o wysokich wartościach w wizerunku publicznym (np. Magdalenie Środzie częściej w image’u werbalnym jawnego felietonisty przypisywano cechę „feministka”, z której to jest znana w wymiarze publicznym). W analizie wizerunków powtarzała się obserwacja, że image publiczny wpływa na werbalny (gdy wiadomo, czyjego autorstwa jest tekst) w zakresie cech najwyżej reprezentowanych w wizerunku werbalnym. Czyli znajomość felietonisty ułatwia konstrukcję cech, które i tak w tekście funkcjonowały, ale dzięki wizerunkowi publicznemu stały się lepiej i częściej „widoczne” dla czytelnika. Natomiast w przypadku mniej popularnych/rozpoznawalnych twórców (Krzysztof Varga, Piotr Zaremba) pewne znaczenie miało zdjęcie towarzyszące słownej wypowiedzi. Zmieniało na większą wartość wskazań tych cech, które były wysoko manifestowane w wizerunku wizualnym (Varga, Zaremba) i/lub podwyższało frekwencję tych cech wizerunku werbalnego, które były wysoce niezgodne z komunikatem opartym na obrazie (ponieważ zdjęcie sugerowało coś zupełnie innego niż tekst, to te niepasujące do fotografii cechy stawały się bardziej wyraźne). Wpływy na wizerunek werbalny występują i choć nie wnoszą nowych jakości, to wprowadzają zmiany ilościowe.

Typowe dla imageów werbalnych jest to, że w porównaniu z innymi rodzajami wizerunków cechy przypisane na podstawie słów w dużej mierze się pokrywają i niektóre z nich są takie same dla każdego z autorów (zob. tabela 51), choć oczywiście i ukształtowanie wypowiedzi i wpływ wizerunku publicznego determinują ilościową reprezentację tych cech. Wszyscy z twórców 
zostali w obu wizerunkach werbalnych opisani np. jako „dosadnie przedstawiający swoje odważne sądy”, „ironiczni”, „krytyczni”, „zabawni”, „znający temat". Podobne cechy można spotkać w innych typach image’u, ale nie dotyczą już wtedy każdego z felietonistów i nie są tak licznie wskazywane.

Tabela 52. Cechy wspólne felietonistom lub specyficzne dla jednego $z$ nich w wizerunkach werbalnych

\begin{tabular}{|c|c|c|c|c|c|}
\hline \multirow[b]{2}{*}{ lp. } & \multirow{2}{*}{$\begin{array}{l}\text { wizerunki } \\
\text { werbalne }\end{array}$} & \multicolumn{4}{|c|}{ cechy } \\
\hline & & $\begin{array}{l}\text { czterech } \\
\text { autorów }\end{array}$ & $\begin{array}{l}\text { trzech } \\
\text { autorów }\end{array}$ & $\begin{array}{l}\text { dwóch } \\
\text { autorów }\end{array}$ & jeden autor \\
\hline 1. & postawa & $\begin{array}{l}\text { dosadnie przed- } \\
\text { stawiający swoje } \\
\text { odważne sądy; iro- } \\
\text { niczny; krytyczny; } \\
\text { spostrzegawczy; } \\
\text { dociekliwy; realista }\end{array}$ & $\begin{array}{l}\text { obiektywny; } \\
\text { dokładny; } \\
\text { subiektywny }\end{array}$ & $\begin{array}{l}\text { zaangażowa- } \\
\text { ny; młody; } \\
\text { złośliwy }\end{array}$ & $\begin{array}{l}\text { sentymentalny; } \\
\text { analizujący; scep- } \\
\text { tyczny; wymaga- } \\
\text { jący; refleksyjny; } \\
\text { obserwator; cie- } \\
\text { kawy; otwarty; } \\
\text { cyniczny }\end{array}$ \\
\hline 2. & $\begin{array}{l}\text { cechy } \\
\text { charakteru }\end{array}$ & $\begin{array}{l}\text { inteligentny; za- } \\
\text { bawny; szczery }\end{array}$ & & empatyczny & $\begin{array}{l}\text { emocjonalny; } \\
\text { wrażliwy }\end{array}$ \\
\hline 3. & wiedza & $\begin{array}{l}\text { oczytany; znawca } \\
\text { tematu }\end{array}$ & $\begin{array}{l}\text { interesujący } \\
\text { się; wykształ- } \\
\text { cony }\end{array}$ & & \\
\hline 4. & $\begin{array}{l}\text { poglądy/ } \\
\text { wartości }\end{array}$ & & & & $\begin{array}{l}\text { patriota; toleran- } \\
\text { cyjny; antyklery- } \\
\text { kał; feministka; } \\
\text { przeciwniczka PiS } \\
\text { wierzący; konser- } \\
\text { watysta; lewicowa; } \\
\text { liberalna }\end{array}$ \\
\hline 5. & $\begin{array}{l}\text { sposób } \\
\text { komuni- } \\
\text { kacji }\end{array}$ & ciekawie piszący & & & \\
\hline
\end{tabular}

Źródło: opracowanie własne

Jak interpretować taką „Wszechobecność” niektórych cech? Wydaje się, że przypisywanie ich wszystkim felietonistom świadczy o ich predyspozycji do bycia zauważanymi i konstruowanymi jako elementy wizerunku werbalnego przez interpretatorów. Innymi słowy, wymienione w tabeli powyżej cechy charakteryzujące każdego z czterech autorów odznaczają się swego rodzaju łatwością komunikowania za pomocą słowa. Bez względu na tematykę, poglądy wypowiadającego się, styl pisania i płeć, czytelnicy widzą w autorze takie właśnie przymioty, jak przedstawiono w tabeli powyżej, w kolumnie „czterech autorów”. 
Możliwe, że na uniwersalność tych cech mają pewien wpływ reguły gatunkowe felietonu (patrz rozdział 1.3.2.5. Dlaczego felieton?) i właściwości dyskursu publicznego. $Z$ całą pewnością nieco rozjaśniłoby tę kwestię przeprowadzenie podobnych badań $\mathrm{z}$ tekstem innego niż felieton gatunku, a przede wszystkim gatunku spoza prasy i dyskursu publicystycznego (jakiego?). Problem ten pozostawia się tutaj jako otwarty i czekający na zbadanie.

Nieco mniejszą moc łatwości komunikacji werbalnej zdają się mieć cechy łączone z trójką autorów, ale wciąż za zasadne uważa się im przypisanie pewnego stopnia uniwersalności komunikacyjnej. Inaczej jest, jeśli spojrzeć na cechy zauważane u jednego lub dwóch twórców. Mają one bowiem bardziej charakter jednostkowy, typowy wyłącznie dla danego felietonisty.

Respondenci określali więc autora wypowiedzi werbalnej w kategoriach „postawy”, „cech charakteru”, „wiedzy”, „poglądów/wartości” i „sposobu komunikacji”, z czego ostatni można uznać za swoisty dla słowa. Nie dostrzegali natomiast w twórcy tekstu cech wchodzących w zakres kategorii: „wiek/płeć” „zawód”, „stan emocjonalno-poznawczy”, „wygląd”. Ograniczone wpływy ma na wizerunek werbalny wymiar publiczny image'u, kiedy dana osoba charakteryzuje się dużą rozpoznawalnością, a poziom obrazu, kiedy autor jest słabo lub nie jest wcale kojarzony przez czytelnika. Niektóre cechy odznaczają się uniwersalnością, co świadczyć może o łatwości ich komunikowania i/lub dużym wpływie właściwości dyskursu publicystycznego na wizerunek werbalny.

\subsubsection{Wizerunek publiczny}

Dane dotyczące wizerunku publicznego pozwalają odpowiedzieć na pytanie badawcze nr 4: „Jaki wizerunek osoby jest możliwy do komunikowania przez całość działań komunikacyjnych (jakie cechy przypisuje się danej osobie, gdy przywoła się jej tożsamość - imię i nazwisko)?”.

Pytanie zadane respondentom było jedynym pytaniem dotyczącym wizerunku, gdzie nie proszono o trzymanie się określonej podstawy jego konstrukcji. Nie przypisywano cech, mając za bazę tekst czy zdjęcie, ale uczestnik badania miał pełną dowolność w odpowiedzi, motywowaną możliwościami poznawczymi, pojemnością pamięci i w końcu skonstruowanym wizerunkiem, który pozostawał po kontakcie $\mathrm{z}$ wypowiedziami w różnych systemach znaków.

Przewidywano (hipoteza badawcza), że ze względu na wielość możliwych źródeł wypowiedzi i podstaw konstrukcji wizerunku image publiczny powinien wykazywać się największą absorbcją cech i kategorii z innych typów wizerunków. Nie potwierdza się to w warunkach uwzględnionych w tym 
badaniu. Najwięcej wymiar publiczny zapożycza ze słowa. Zarówno na poziomie werbalnym, jak i publicznym pojawiają się kategorie "postawy” (tutaj łącznie 13 cech i 188 wskazań), „cech charakteru” (cztery cechy wizerunkowe, 153 wskazania) i w obu przypadkach są to obszary o najwyższych wartościach liczbowych. W wymiarze publicznym kolejne to: (nie „wiedza” jak w wizerunkach werbalnych) „poglądy/wartości” (też funkcjonują w obrębie słowa, 6 cech, 129 wynotowań) oraz nieobecny już na poziomie werbalnym „zawód” (7 cech, 77 wskazań), w końcu wspólna wymiarowi publicznemu i językowemu „wiedza” (3 cechy, 22 wynotowania) oraz „sposób komunikacji” (1 cecha, też 77 wskazań). Najmniej wskazań (13 i 2 cechy) liczy „wygląd”.

„Zawód” i „wygląd” zasługują na odrębną uwagę. Pierwsza z tych kategorii ma swoje cechy również w wizerunku wizualnym. Ponieważ jednak mało prawdopodobne wydaje się, że „publicysta” i „osoba medialna” to konstrukcja na podstawie portretowego zdjęcia, uznać należy, że „zawód” jest swoistą dla wizerunku publicznego kategorią, wykazującą ekspansję na poziom wizualny.

W przypadku „wyglądu” kierunek wpływu wydaje się nieco inny. W image'u opartym na fotografii pojawiły się w tym obszarze takie cechy wizerunkowe, jak „zadbany” i „przystojny”, których związek z cechami przynależnymi do tej samej kategorii w image'u publicznym - czyli z „wysoki” i „niski” - jest trudny do wykazania. Innymi słowy, nie występuje tutaj migracja $\mathrm{z}$ wizerunku wizualnego do publicznego, mimo obecności kategorii „wyglądu” w każdym z tych typów image'u. „Wygląd” w wizerunku publicznym wydaje się mieć swoją podstawę co prawda w warstwie wizualnej, ale dotyczy całej sylwetki i jej usytuowania w jakimś kontekście przestrzennym (wydaje się on niezbędny do określenia kogoś jako „niskiego” lub „wysokiego”). Zmienne uwzględnione w procedurze badawczej każą więc „wygląd” wizerunku publicznego i wizualnego rozpatrywać jako osobne, niezależne kategorie.

Skupić się jeszcze należy na wpływach wizerunku werbalnego na publiczny. Taka determinacja wyraźnie jest widoczna w powtarzalności w każdym z tych typów image'u pięciu tych samych kategorii: „postawy”, „cech charakteru”, „wiedzy”, „poglądów/wartości” i w przypadku jednego felietonisty „sposobu komunikacji”. Na ile w tych obszarach znajdują się cechy rzeczywiście migrujące bezpośrednio z image'u werbalnego, na ile są nim inspirowane, a na ile to elementy wizerunku $\mathrm{w}$ istocie właściwe wyłącznie wizerunkowi publicznemu i motywowane innym źródłem niż wypowiedzi samych felietonistów?

Wydaje się, że najbardziej bezpośrednio z imageem opartym na słowie związane są cechy wizerunku publicznego zgromadzone w obszarze „cechy charakteru". W wymiarze publicznym 3 na 4 występują dokładnie w takiej 
samej formie leksykalnej jak w wizerunku werbalnym. Mowa o: „,inteligentny”, „zabawny”, , ,szczery”. Pojawia się także „dobroduszny”, ale nie ma swojego dosłownego odpowiednika - być może inspirowany jest cechą „empatyczny”, przypisywaną autorowi tekstu. W zakresie „wiedzy” jedna cecha jest identyczna („znawca tematu”), a druga występuje w dokładnie tej samej formie w obu imageach („oczytany”) lub w synonimicznej wersji w wizerunku publicznym („erudyta”). Połowa z sześciu cech z kategorii „poglądy/wartości” przeszła do poziomu publicznego w niezmienionej postaci („feministka”, „konserwatysta”, „lewicowa”), a druga połowa albo pojawiła się w wymiarze publicznym jako synonim („wierzący” $\rightarrow$ „religijny”), albo wpływ języka naturalnego pozostaje pośredni („przeciwniczka PiS”, „lewicowa” $\rightarrow$ „związana z polityką”), albo kwestia kierunku wpływu jest niejednoznaczna (werbalny „konserwatysta” mógł zaowocować przypisaniem cechy „prawicowy” publicznemu wymiarowi wizerunku Piotra Zaremby, ale wydaje się, że możliwy jest też odwrotny kierunek inspiracji - kojarzenie dziennikarza jako „prawicowego" mogło wpłynąć na przypisanie mu na podstawie tekstu cechy „konserwatysta”). W przypadku „sposobu komunikacji” „elokwentny” wydaje się określeniem bliskoznacznym do łączonej z autorem felietonu cechy „ciekawie piszący”. W zdecydowanej większości przypadków z zakresu „cech charakteru”, „poglądów/wartości” i „sposobu komunikacji” widać inspirację wizerunkiem werbalnym w publicznym wymiarze image'u.

Najobszerniejszą grupę stanowią cechy zgromadzone $\mathrm{w}$ kategorii „postawa”. W wizerunku publicznym jest ich 13. Tylko $3 \mathrm{z}$ nich przechodzą z image'u werbalnego do publicznego w identycznej formie leksykalnej („dosadnie przekazujący swoje odważne sądy”, „ironiczny”, „otwarty”). Wśród pozostałych da się wyłonić 7 inspirowanych warstwą językową, jak np. "pewny siebie” i „konkretny” (być może mają swoje źródło w „dosadnie przekazujący swoje odważne sądy”) czy „rzeczowy” i „rzetelny” (możliwe, że obie cechy motywowane są np. takimi atrybutami z poziomu werbalnego, jak: „dokładny”, „analizujący”, „dociekliwy”) albo „kreatywny” (wynikający z „ciekawie piszący” - to cechy przypisane Krzysztofowi Vardze), „wyważona” (synonim „obiektywna”, „realistka”), tudzież „racjonalista” (bliskoznaczne określenie dla „realista”). Trzy pozostałe cechy wizerunku publicznego są dość odległe od którychkolwiek z image’u werbalnego - mowa o "uprzejmy”, „sympatyczny”, „spokojny”. Z tego „sympatyczny” pojawia się także na poziomie wizualnym, ale ma tam mniej wskazań niż w wymiarze publicznym (relacja 38 do 27), co sugeruje raczej kierunek wpływu: wizerunek publiczny $\rightarrow$ wizerunek wizualny lub wynika z obserwacji publicysty w warunkach interakcji. Ta ostania grupa cech wydaje się więc nie tyle inspirowana słowami felietonisty czy jego wyglądem, a ma raczej wymiar interakcyjny i mogła 
być zauważona i przypisana np. na podstawie zachowania w którymś z programów, w jakich występuje Szymon Hołownia (bo to cechy z nim właśnie łączone). Chociaż w przypadku „postawy” wpływ wizerunku werbalnego na publiczny w 3 cechach pozostaje niewidoczny, to w 3 jest bezpośredni, a w 7 zauważalne są inspiracje poziomem słowa.

Determinację image'em werbalnym zauważa się więc nie tylko w powtarzalności kategorii, ale również w powtarzalności cech.

Jeśli zebrać te ustalenia w jedną całość, to swoistą dla wizerunku publicznego kategorią wizerunkową staje się „zawód”, wykazujący migracje do image’u wizualnego w przypadku wysokiej rozpoznawalności publicysty. „Wygląd” także wydaje się typowy dla wymiaru publicznego, ponieważ uwzględnia inne aspekty aparycji niż ma to miejsce $\mathrm{w}$ wizerunku wizualnym (sylwetka, a nie twarz). Pozostałe kategorie są najczęściej bezpośrednio lub pośrednio inspirowane image’em werbalnym („postawa”, „poglądy/wartości”, „cechy charakteru”, „wiedza”, „sposób komunikacji”).

Wizerunek publiczny charakteryzuje się najmniejszą średnią liczbą przypisanych cech $(11,25)$, ale ze względu na relatywnie małą liczbę osób udzielających odpowiedzi (deklarujących znajomość nazwiska) dane te nie powinny podlegać dalszej analizie.

Image publiczny w dużej mierze zależy zatem od słowa, chociaż pamiętać należy, że swego rodzaju katalizatorem staje się kontekst komunikacyjny dla wypowiedzi werbalnej (np. rozpoznawalność Szymona Hołowni i zapewne kojarzenie go z programem rozrywkowym zaważyły na częstszym niż w wymiarze języka naturalnego przypisywaniu mu cechy „zabawny”).

Tabela 53. Cechy wspólne felietonistom lub specyficzne dla jednego z nich w wizerunku publicznym

\begin{tabular}{|l|l|l|c|c|l|}
\hline \multirow{2}{*}{ lp. } & \multirow{2}{*}{$\begin{array}{c}\text { wizerunek } \\
\text { publiczny }\end{array}$} & \multicolumn{1}{|c|}{$\begin{array}{c}\text { czterech } \\
\text { autorów }\end{array}$} & $\begin{array}{c}\text { trzech } \\
\text { autorów }\end{array}$ & $\begin{array}{c}\text { dwóch } \\
\text { autorów }\end{array}$ & jeden autor \\
\cline { 3 - 6 } 1. & postawa & $\begin{array}{l}\text { synonimiczne: pew- } \\
\text { ny siebie (dwóch } \\
\text { felietonistów); sta- } \\
\text { nowczy; dosadnie } \\
\text { przekazujący swoje } \\
\text { odważne sądy }\end{array}$ & & otwarty & $\begin{array}{l}\text { czowy; uprzejmy; } \\
\text { racjonalista; kre- } \\
\text { atywny; wyważo- } \\
\text { na; sympatyczny; } \\
\text { rzetelny; spokojny }\end{array}$ \\
\hline 2. & $\begin{array}{l}\text { cechy } \\
\text { charakteru }\end{array}$ & inteligentny & & $\begin{array}{l}\text { zabawny; szczery; } \\
\text { dobroduszny }\end{array}$ \\
\hline 3. & wiedza & & $\begin{array}{l}\text { synonimicz- } \\
\text { ne: oczytany; } \\
\text { erudyta }\end{array}$ & znawca tematu \\
\hline
\end{tabular}




\begin{tabular}{|c|c|c|c|c|c|}
\hline \multirow[b]{2}{*}{ lp. } & \multirow{2}{*}{$\begin{array}{l}\text { wizerunek } \\
\text { publiczny }\end{array}$} & \multicolumn{4}{|c|}{ cechy } \\
\hline & & czterech autorów & $\begin{array}{l}\text { trzech } \\
\text { autorów }\end{array}$ & $\begin{array}{l}\text { dwóch } \\
\text { autorów }\end{array}$ & jeden autor \\
\hline 4. & $\begin{array}{l}\text { poglądy/ } \\
\text { wartości }\end{array}$ & & & & $\begin{array}{l}\text { feministka; } \\
\text { konserwatysta; } \\
\text { lewicowa; prawi- } \\
\text { cowy; związana } \\
\text { z polityką }\end{array}$ \\
\hline 5. & $\begin{array}{l}\text { sposób } \\
\text { komunikacji }\end{array}$ & & & & elokwentny \\
\hline 6. & zawód & & $\begin{array}{l}\text { osoba } \\
\text { medialna }\end{array}$ & dziennikarz & $\begin{array}{l}\text { felietonista; pi- } \\
\text { sarz; krytyk lite- } \\
\text { racki; naukowiec; } \\
\text { filozof }\end{array}$ \\
\hline 7. & wygląd & & & & niski; wysoki \\
\hline 8. & inne & & & & $\begin{array}{l}\text { charyzmatyczny; } \\
\text { intersujący }\end{array}$ \\
\hline
\end{tabular}

Źródło: opracowanie własne

Chociaż różna liczba osób określała wizerunek publiczny, to wydaje się zasadny sąd, że jest on w dużo większym stopniu zróżnicowany dla każdego z felietonistów niż ich image'e werbalne (zob. tabela 53). Tylko jedna bowiem cecha („inteligentny”) w dosłownym brzmieniu dotyczy wszystkich czterech publicystów i jedna wydaje się operować tym samym zakresem semantycznym mimo kilku wariantów leksykalnych („pewny siebie”, „stanowczy”, „dosadnie przedstawiający swoje odważne sądy”). Również tylko jedna cecha dotyczy trzech autorów („osoba medialna”), tylko dwie obejmują dwójkę twórców, a wszystkie pozostałe dotyczą pojedynczych felietonistów. Mimo że wizerunek publiczny zależy w dużej mierze od image'u werbalnego, to wydaje się, iż w wymiarze publicznym zostają cechy najbardziej wyraziste, najłatwiejsze do zapamiętania i kojarzenia $\mathrm{z}$ daną osobą, najbardziej ją wyróżniające. Powtarzające się cechy image’u opartego na słowie mogą stanowić swego rodzaju tło, na tle którego wyłaniają się cechy będące faktycznymi wyróżnikami wizerunku publicznego. Tym samym potwierdza się (ale nie umacnia ostatecznie) wcześniej już wspomniana interpretacja, że na powtarzalność cech felietonistów w ich image’u werbalnym wpływać mogą właściwości dyskursu publicystycznego. Cechy wyrażające ten dyskurs nie są więc w istocie cechami poszczególnych autorów i dlatego ulegają marginalizacji w procesie konstrukcji wizerunku publicznego.

Wizerunek publiczny w dużej mierze zależy więc od werbalnego (stąd kategorie: „postawa”, „cechy charakteru”, „poglądy/wartości”, „wiedza”, „sposób 
komunikacji”) ${ }^{2}$, a swoiste są dla niego obszary „zawodu” i „wyglądu”, z czego pierwszy może migrować do image’u wizualnego. Na publiczny wymiar wpływa kontekst komunikacyjny - sytuacyjny, werbalny i wizualny. Przypisywane cechy mają najczęściej charakter specyficzny dla twórcy, tj. dotyczą jednego autora, można zatem się spodziewać, że na tym poziomie zostaje w image’u to, co każdego z felietonistów wyróżnia.

\subsubsection{Wizerunek wizualny}

Wyniki dotyczące wizerunku wizualnego pozwalają odpowiedzieć na pytanie badawcze nr 3: „Jaki wizerunek osoby jest możliwy do komunikowania przez fotografię z jej podobizną?". Zaznaczyć przy tym należy, że podobizna dotyczyła wyłącznie twarzy, nie sylwetki, i w dwóch przypadkach nie pojawiały się żadne dodatkowe elementy mogące służyć komunikacji (Varga, Hołownia), a w pozostałych dwóch występowały okulary (Zaremba) i podniesiona dłoń z palcem wskazującym uniesionym do góry (Środa).

Hipoteza brzmiała: wygląd i cechy charakteru będą elementami najbardziej podkreślanymi w image'u wizualnym, zauważony powinien też być wiek.

Zweryfikowano ją negatywnie. Występują pewne różnice, ale wizerunek wizualny w dużej mierze pokrywa się z werbalnymi i publicznym.

Ponieważ między wizerunkiem wizualnym anonimowej dla interpretatora osoby a wizualnym rozpoznawanej osoby nie ma zbyt wielu różnic, poniżej nie będą rozpatrywane osobno, ale dane z obu tych typów wizerunku zostaną potraktowane zbiorczo i omawiane, jako „wizerunek wizualny”.

W zakres wizerunku wizualnego wchodzą kategorie znane już z image'u werbalnego i publicznego: „postawa” (14 cech wizerunkowych, 224 wskazania dla image'u anonima i 86 dla znanej osoby), „cechy charakteru” (4 cechy, wskazania odpowiednio: 109 i 80), „wiedza” (2, wskazania: 30 i 12), „sposób komunikacji” ( 1,5 wskazań tylko w przypadku rozpoznawalności osoby z fotografii), „poglądy/wartości” (1, 16, również tylko wtedy, gdy kojarzono poprawnie nazwisko postaci ze zdjęcia). Inspirowana wizerunkiem publicznym wydaje się kategoria „zawód” (2 cechy, 4 i 18 wskazań). Swoiste dla poziomu obrazu są "stan emocjonalno-poznawczy” (7 cech, 140 i 12 wskazań), „wiek/płeć” (5 cech, 21 i 8 wynotowań), a także „wygląd” (2 cechy, 10 wskazań"), którego zbieżność $\mathrm{z}$ wizerunkiem publicznym jest pozorna (patrz: poprzedni rozdział).

2 Taki trop interpretacyjny pojawił się w wynikach obejmujących mniejszą liczbę respondentów, a dotyczących Szymona Hołowni (Barańska-Szmitko 2014). 
Czy i jakich wpływów należałoby szukać w zakresie wizerunku wizualnego oraz od czego zależą? Wydaje się, że zależne wyłącznie od wypowiedzi wizualnej są kategorie „stan emocjonalno-poznawczy”, „wiek/płeć” i w pewnym zakresie „wygląd”. Te obszary nie występują w innych image’ach. „Sposób komunikacji" musi być wynikiem inspiracji słowem i poziomem publicznym. Podobnie „poglądy/wartości”, które są ściśle tematyczne i trudno je wyrazić poza słowem. Oba te obszary pojawiły się zresztą wyłącznie u publicysty, którego tożsamość poprawnie na zdjęciu rozpoznawano. „Zawód” częściowo może wykazywać kierunek wpływu od image’u publicznego do wizualnego (Hołownia), a częściowo może wynikać z możliwości samego obrazu (wydaje się prawdopodobne, że fotografia Piotra Zaremby realizuje na poziomie wizualnym stereotyp publicysty).

„Wiedza”, „cechy charakteru” i „postawa” są bardziej złożonymi kategoriami. Chociaż „wiedza” funkcjonuje na poziomie każdego $\mathrm{z}$ analizowanych imageów, to możliwe, że „wykształcony” nie tyle (lepiej: nie tylko) jest efektem dosłownego przeniesienia cech z wymiaru słowa, co również cechą chętnie zauważaną przez interpretatorów w obrazie (pojawia się także w wizerunku wizualnym nierozpoznawanych felietonistów). Jeszcze wyraźniej widać łączenie absorbcji cech z samodzielnym ich komunikowaniem w przypadku „cech charakteru”. „Inteligentny” jest najbardziej uniwersalną cechą - charakteryzuje każdego z felietonistów na poziomie każdego z omawianych typów wizerunków. Trudno zatem wykazywać tutaj kierunek wpływu. Ta uniwersalność dotyczy raczej preferencji samych interpretatorów niż możliwości komunikacyjnych imageów. To najchętniej przez nich dostrzegana i konstruowana cecha bez względu na system(-y) znaków, jakim dysponują. Poczucie humoru („zabawny”) natomiast jest już bardziej zależne od samej osoby publicznej. Występuje w każdym typie wizerunku, co świadczyłoby o dużym potencjale komunikacyjnym tej cechy (wiele systemów znaków może ją komunikować), ale też o złożonym procesie wpływu. Dużo zależy także od eksponowania tej cechy - przypisano ją tylko jednemu felietoniście w wymiarze każdego image’u. Inne cechy (2) wykazują autonomię - są typowe tylko dla image'u wizualnego („trudny”, „surowy”). Analogiczna złożoność problemu wpływu na wizerunek wizualny wykazuje kategoria „postawa”. „Pewny siebie” - podobnie jak ,inteligentny” - funkcjonuje we wszystkich typach image'u (przybierając synonimiczne określenia: „stanowczy”, „dosadnie przekazujący swoje odważne sądy”), więc ta cecha, obok możliwości komunikowania jej na wielu poziomach, wskazuje również na preferencje konstrukcji wśród interpretatorów (i zapewne preferencje komunikowania samych felietonistów). Tylko w wizerunkach wizualnych występuje 9 (na 14) cech: „wywyższający się” „rozważana”, „pomocna” (anonim), „miła”, „ułożony”, „przenikliwy”, „kontaktowy” 
(znana osoba na zdjęciu), „konkretna”, „niesympatyczny” (oba typy). Da się zauważyć inspirację niektórymi synonimicznymi cechami wizerunku publicznego. Te z grup, gdzie poprawnie określano tożsamość publicysty, częściowo mogą być inspirowane sytuacjami komunikacyjnymi, w jakich w programach telewizyjnych widziany był Szymon Hołownia (jego głównie dotyczą te cechy). Jeśli zwrócić uwagę na wartości wskazań poszczególnych cech, to tam, gdzie są zbieżne lub synonimiczne, zwłaszcza z poziomem publicznym, da się zauważyć jego wpływ na wizerunek $\mathrm{z}$ obrazu.

Jak zatem widzimy, wizerunek wizualny - z jednej strony - posiada takie kategorie i cechy, które są tylko dla niego specyficzne („wygląd”, „wiek/płeć”, „stan emocjonalno-poznawczy"), takie, które są efektem pełnego wpływu innych imageów („sposób komunikacji”, poglądy wartości”), i takie, które częściowo zależą od pozostałych wymiarów wizerunku („zawód”, „wiedza”, „cechy charakteru”, „postawa”), ale też uwzględnienie liczby wskazań poszczególnych cech (zob. wyżej rozdział dotyczący wizerunku wizualnego Szymona Hołowni) sugeruje wpływ zwłaszcza image’u publicznego. W każdym razie ten wizerunek w pewnej części zachowuje własną autonomię, lecz wykazuje też największą na tle innych absorbcję cech $\mathrm{z}$ innych typów wizerunków. Trudno natomiast wykazać wpływ wizerunku wizualnego na inne. Pamiętać też należy, że analiza poszczególnych wizerunków wykazała, że stereotyp funkcjonujący w wymiarze publicznym może profilować image wizualny rozpoznawanej osoby (casus Magdaleny Środy).

Średnia liczba cech przypisywanych $\mathrm{w}$ wizerunkach wizualnych to 15,33 dla anonimowej na zdjęciu osoby i 13,5, gdy jest rozpoznawana.

Tabela 54. Cechy wspólne felietonistom lub specyficzne dla jednego $z$ nich w wizerunkach wizualnych

\begin{tabular}{|l|l|l|l|l|l|}
\hline \multirow{2}{*}{ lp. } & \multirow{2}{*}{$\begin{array}{c}\text { wizerunki } \\
\text { wizualne }\end{array}$} & $\begin{array}{c}\text { czterech } \\
\text { autorów }\end{array}$ & $\begin{array}{c}\text { trzech } \\
\text { autorów }\end{array}$ & $\begin{array}{c}\text { dwóch } \\
\text { autorów }\end{array}$ & \multicolumn{1}{|c|}{ jeden autor } \\
\cline { 3 - 6 } & postawa & pewny siebie & & niesympatyczny & $\begin{array}{l}\text { konkretna; wywyż- } \\
\text { szający się; ironiczny; } \\
\text { krytyczny; realista; } \\
\text { otwarty; rozważna; } \\
\text { sympatyczny; miła; } \\
\text { pomocna; ułożony; } \\
\text { przenikliwy; } \\
\text { kontaktowy }\end{array}$ \\
\hline 2. & $\begin{array}{l}\text { cechy } \\
\text { charakteru }\end{array}$ & inteligentny & & surowy & zabawny; trudny \\
\hline 3. & wiedza & & $\begin{array}{l}\text { wykształ- } \\
\text { cony }\end{array}$ & & doświadczona \\
\hline
\end{tabular}




\begin{tabular}{|c|c|c|c|c|c|}
\hline \multirow[b]{2}{*}{ lp. } & \multirow{2}{*}{$\begin{array}{l}\text { wizerunki } \\
\text { wizualne }\end{array}$} & \multicolumn{4}{|c|}{ cechy } \\
\hline & & $\begin{array}{l}\text { czterech } \\
\text { autorów }\end{array}$ & $\begin{array}{l}\text { trzech } \\
\text { autorów }\end{array}$ & $\begin{array}{c}\text { dwóch } \\
\text { autorów }\end{array}$ & jeden autor \\
\hline 4. & $\begin{array}{l}\text { poglądy/ } \\
\text { wartości }\end{array}$ & & & & wierzący \\
\hline 5. & $\begin{array}{l}\text { sposób } \\
\text { komunikacji }\end{array}$ & & & & elokwentny \\
\hline 6. & wiek/płeć & & & & $\begin{array}{l}\text { dorosły mężczyzn; } \\
\text { mężczyzna w średnim } \\
\text { wieku; starsza kobieta }\end{array}$ \\
\hline 7. & zawód & & & & $\begin{array}{l}\text { publicysta; osoba } \\
\text { medialna }\end{array}$ \\
\hline 8. & $\begin{array}{l}\text { stan } \\
\text { emocjonalno- } \\
\text {-poznawczy }\end{array}$ & poważny & & $\begin{array}{l}\text { zamknięty } \\
\text { w sobie; spo- } \\
\text { kojny }\end{array}$ & $\begin{array}{l}\text { opanowana; } \\
\text { z doświadczeniami; } \\
\text { melancholijny; nudny }\end{array}$ \\
\hline 9. & wygląd & & & & $\begin{array}{l}\text { z wadą wzroku; } \\
\text { zadbany; przystojny }\end{array}$ \\
\hline 10. & inne & & & & ciekawy \\
\hline
\end{tabular}

Źródło: opracowanie własne

Przypisywane cechy wizerunku wizualnego w dużym stopniu różnicują się na poszczególnych felietonistów (zob. tabela 54), czyli wiele jest takich, które dotyczą wyłącznie jednego z autorów. Te występujące u wszystkich - jak wyżej wspomniano - mogą być wynikiem preferencji interpretatorów, skłonnych do konstruowania tych właśnie cech, a z drugiej strony, preferencji twórców, chętnie je komunikujących. Ponieważ wiele jest charakteryzujących pojedyncze osoby, wnioskować można, iż nawet zapożyczone z innych imageów cechy są dość swoiste dla danego publicysty. Wydaje się przy tym, że część z nich nie stanowi kluczowych dla omawianych tu osób wyróżników wizerunku (np. „wiek/płeć” czy „wygląd”).

\subsection{Wizerunek werbalny, wizualny, publiczny - wzajemne wpływy}

Konieczność opisu wzajemnych wpływów między wizerunkami pojawiła się już przy charakterystyce możliwości komunikacyjnych każdego z wizerunków. Analiza więc znajduje się w trzech poprzednich rozdziałach. Niżej, dla porządku, przedstawiono najważniejsze wnioski, stosując formułę odpowiedzi na kolejne szczegółowe pytania badawcze, a następnie sumując ustalenia, które uznano za istotne, a wymykające się prostej relacji: pytanie-odpowiedź. 
Pytanie badawcze 5: Czy/jaki wpływ na kreowany przez interpretatora wizerunek autora wypowiedzi werbalnej ma informacja o tożsamości mówiącego oraz jego zdjęcie, które towarzyszą wypowiedzi werbalnej? = jaka jest różnica między wizerunkiem anonimowego autora tekstu a wizerunkiem autora tekstu o znanej tożsamości i wyglądzie?

Analizowane wyniki weryfikują hipotezę badawczą: Wizerunki będą podobne, przy czym image anonimowego felietonisty będzie bardziej rozproszony (mając więcej cech) (Barańska 2011). Zweryfikowano ją pozytywnie.

Informacja o tożsamości autora wypowiedzi wpływa na wizerunek konstruowany na podstawie jego słów tylko wtedy, gdy autor charakteryzuje się dużą rozpoznawalnością, a odnotowany wpływ ma charakter wyłącznie ilościowy, realizowany w obrębie najwyżej reprezentowanych cech wizerunku werbalnego felietonisty o jawnym nazwisku i wyglądzie. Podstawą tych wniosków są wyniki dotyczące Magdaleny Środy i Szymona Hołowni. Wiedza o autorze wpłynęła na wizerunek werbalny w ten sposób, że najwyżej manifestowane cechy były częściej przypisywane twórcy tekstu, gdy był on znany, niż wtedy, gdy pozostawał anonimowy. Średnio nieco mniej cech ma image konstruowany ze słów jawnego felietonisty (relacja 20,75 do 18,75), co wskazywałoby na ograniczanie możliwości konstrukcji wizerunku werbalnego przez image publiczny. Nie pojawiły się jednak zmiany jakościowe, w tym sensie, że wiedza o autorze nie wygenerowała pojawienia się nowych cech, które byłyby wyraźnie motywowane wizerunkiem publicznym. Trudno tym samym wskazać inne niż ilościowe (więcej wskazań cech wspólnych dla wizerunku werbalnego i publicznego) różnice między wizerunkami werbalnymi. Słowo generuje stabilny wizerunek, na konstrukcję którego trudno wpłynąć.

Pytanie badawcze 6: Czy/jaki jest wpływ wizerunku komunikowanego w systemie wizualnym na wizerunek komunikowany werbalnie? = jaka jest różnica między komunikowanym wizerunkiem za pomocą warstwy wizualnej i werbalnej?

Wysunięto hipotezę, iż wizerunek wizualny będzie aktualizował wizerunek publiczny i ten ostatni wpłynie na image werbalny. Potwierdzono ją częściowo.

Zdjęcie aktualizuje wizerunek publiczny, ale tylko wtedy, gdy dana osoba jest znana (Magdalena Środa, Szymon Hołownia), zwiększając w image’u werbalnym reprezentację tych cech, które są charakterystyczne (Szymon Hołownia) lub które wynikają ze skojarzeń (stereotyp feministki - Magdalena Środa), nie dodając jednak nowych.

Kiedy tekst opatrzony jest zdjęciem i informacją o imieniu i nazwisku autora, a czytelnicy nie rozpoznają osoby z fotografii i nie kojarzą nazwiska, to wówczas czerpią wskazówki do konstrukcji wizerunku werbalnego również z wypowiedzi wizualnej. Wpływ ten najlepiej widać u Krzysztofa Vargi 
i Piotra Zaremby. Realizuje się w zakresie analogicznych cech, najwyżej reprezentowanych, możliwych do komunikowania jednocześnie na poziomie obrazu i słowa. Jest to więc identyczny mechanizm, jak ten dotyczący zależności między image’em publicznym i werbalnym. Dodać do tego należy, że jeśli komunikat skonstruowany na podstawie fotografii wyraźnie kontrastuje z niektórymi cechami autora tekstu, w wizerunku werbalnym zwiększy się liczba wskazań tych cech, które potwierdzają komunikat wizualny, i tych, które mu przeczą (widać ten mechanizm wyraźnie u Piotra Zaremby).

Wizerunek komunikowany za pomocą słowa jest najbardziej stabilnym wizerunkiem, zależącym w największym stopniu tylko od siebie. Wizerunek wizualny okazuje się przy tym najmniej stabilny, w tym sensie, że najbardziej absorbuje wpływy z zewnątrz - kategorie z innych image’ów przenikają do wizualnego, ale nie odwrotnie.

Pytanie badawcze 7: Na ile wizerunek autora wypowiedzi determinowany jest przez samą jego wypowiedź, a na ile przez wygląd (towarzyszący tekstowi obraz z podobizną autora) i przypisywany mu przez odbiorcę wizerunek, powstały jeszcze przed przeczytaniem tekstu? Innymi słowy: który z wpływających na konstrukcję wizerunku systemów znakowych jest dominujący?

Hipoteza brzmiała: Fotografia aktualizuje wizerunek publiczny, dlatego jej wpływ jest niewielki. W konstrukcji wizerunku werbalnego dominuje wizerunek publiczny, który wpływa na to, co tworzy czytelnik na podstawie danej wypowiedzi werbalnej i jakie cechy przypisuje osobie $\mathrm{z}$ fotografii.

Zweryfikowano negatywnie wpływ wizerunku publicznego na werbalny, pozytywnie zaś wpływ image'u publicznego na wizualny.

Jeśli już dana osoba się wypowiada werbalnie i jej przekaz stanowi podstawę konstrukcji jej wizerunku (wypowiedź jest czytana), to system języka naturalnego dominuje $\mathrm{w}$ procesie kreowania image'u przez interpretatora. Jak już wyżej wspomniano, wizerunek publiczny wpływa na ten oparty na słowie, ale wówczas, gdy czytelnicy rozpoznają twórcę, a obraz ma znaczenie, gdy autor słów pozostaje nieznany. Nawet w warunkach tych zależności poziom werbalny staje się dominujący, bowiem determinacja obrazu ogranicza się do powodowania wyższej frekwencji cech ze szczytu listy wskazań image’u werbalnego, które pokrywają się z tymi zauważanymi na poziomie wizerunku wizualnego, a które i tak wskazywano, kiedy autor tekstu pozostawał anonimowy.

Warto też zwrócić uwagę na fakt, że „postawa”, „cechy charakteru” i „wiedza” pojawiają się we wszystkich typach wizerunku, a ponieważ są najwyżej reprezentowane właśnie na poziomie słowa, to może to świadczyć o usytuowaniu podstawy wizerunku w warstwie werbalnej. Te kategorie są przez interpretatorów najbardziej preferowane do konstrukcji wizerunku (któregokolwiek typu), a najlepiej wyrażane na poziomie systemu języka 
naturalnego. Wizerunek werbalny stanowiłby więc podstawę, ale nie $\mathrm{w}$ tym sensie, że cechy z wizerunku werbalnego przenikają do innych wizerunków, lecz w tym znaczeniu, że kategorie "postawy”, „cech charakteru” i „wiedzy” są elementami, których zawsze interpretatorzy szukają, konstruując wizerunek danej osoby.

Pytanie badawcze nr 8: Czy/jaki jest wpływ tematu wypowiedzi na wizerunek jej autora?

Tym samym można przynajmniej częściowo zweryfikować hipotezę badawczą nr 8: wizerunek kreowany przez odbiorców zależy od poruszanej przez wypowiadających się tematyki (Barańska-Szmitko 2011, 2012).

Temat wypowiedzi ma duże znacznie dla konstrukcji wypowiedzi. Problematyka społeczno-polityczna staje się szczególnie istotna, ponieważ generuje przypisywanie cech z kategorii „poglądy/wartości”, a te są najbardziej specyficzne dla poszczególnych autorów, zatem ułatwiają znalezienie wyróżnika image’u (Magdalena Środa - feministka, Szymon Hołownia - wierzący). Dużo trudniej znaleźć taki dla autorów zajmujących się kulturą (Krzysztof Varga, Piotr Zaremba). Zachowania dyskursywne lepiej będą widoczne na poziomie analizy wykładników językowych poszczególnych cech, ale już teraz należy potwierdzić stawianą wyżej hipotezę, bowiem zdaje się, że oprócz tematyki tylko one mogą wpływać na wizerunek, przynajmniej na poziomie wypowiedzi werbalnej anonimowego autora.

Pytanie badawcze 9: Czy/jaki jest wpływ postawy ideowej/światopoglądu na wizerunek jego przedstawiciela?

Hipoteza: Reprezentowany światopogląd ma wpływ na wizerunek. Tematyka społeczno-polityczna służyć będzie bardziej komunikowaniu cech wyrażających poglądy ideowe.

Hipotezę zweryfikowano pozytywnie. Postawa ideowa realizuje się na poziomie tematyki wypowiedzi i powoduje konstrukcje cech $\mathrm{z}$ zakresu "poglądów/wartości”, wysoko manifestowanych na liście wskazań (image'u werbalnego i publicznego). Problematyka społeczno-polityczna jest tu uprzywilejowana. Chociaż niewątpliwe możliwe jest odtworzenie z tekstów Krzysztofa Vargi jego światopoglądu, to tematyka kulturalna okazała się w tym względzie barierą utrudniającą jego określenie. Być może analiza wykładników komunikacyjnych poszczególnych cech pozwoli znaleźć głębsze zależności.

Ponadto zaznaczyć należy, że w zakresie badania pojedynczych imageów poszczególnych publicystów dobre efekty daje wsparcie analizy częstości wskazań poszczególnych cech wizerunkowych analizą bloków semantycznych. Ich wyodrębnienie nie cechuje się sztywnymi regułami i w braniu pod uwagę hierarchii bloków oraz liczebności wskazań w ich obrębie należy uwzględnić też 
specyfikę niektórych pojedynczych cech, ale grupy znaczeniowe pozwalają uporządkować image i zauważyć sprofilowanie semantyczne wizerunku.

Szczególnie przydaje się to narzędzie w przypadku wizerunku werbalnego, gdzie pierwszych pięć cech jest zbieżnych u wszystkich felietonistów („dosadnie wyrażający swoje odważne sądy”, „inteligentny”, „ironiczny” „krytyczny”, „ciekawie piszący”). Pozwala lepiej zauważyć wówczas różnice.

W tym miejscu należy pełniej odpowiedzieć na pytanie, gdzie szukać wyróżników wizerunku werbalnego, skoro pierwszych kilka cech dotyczy wszystkich publicystów (w proporcjach między tymi cechami? w cechach mniej licznie reprezentowanych? w blokach semantycznych?). Taki stan rzeczy będzie chyba miał zawsze miejsce $\mathrm{w}$ tekstach prasowych, bo wynika $\mathrm{z}$ właściwości dyskursu publicystycznego, cech gatunkowych felietonu, narzuconych przez rynek medialny reguł funkcjonowania (dosadność wypowiadania sądów i ironia, odwołania do źródeł inf., inteligencja, konieczność ciekawego dla odbiorcy ujęcia tematu jako sine qua non istnienia w mediach), a także preferencji samych interpretatorów do oparcia konstrukcji image’u w dużej mierze właśnie na wspomnianej piątce cech. Wydaje się, że wyróżnika wizerunku nie należy szukać w pierwszej na liście cesze felietonisty, ale w różnicach między autorami, tj. w takiej cesze, która pojawia się wśród pierwszych kilku, a która albo jest nowością w porównaniu z innymi (Środa - feministka; Hołownia - religijny), albo jest w porównaniu $\mathrm{z}$ innymi szczególnie wysoko reprezentowana (Varga - ciekawie piszący, Zaremba - dociekliwość, sentyment) i ma swój wyraz w blokach semantycznych (widać optykę przyjętą do konstrukcji wizerunku w ukształtowaniu semantycznym wyłonionych obszarów znaczeniowych). Zwraca przy tym uwagę już wcześniej zasygnalizowany fakt, że łatwiej taki wyróżnik określić w przypadku autorów tekstów społeczno-politycznych. Ich wizerunek dużo bardziej oparty jest na treści wypowiedzi niż na jej formie - stąd obecność kategorii „poglądów/wartości” w ich imageach werbalnych, a także w imageach publicznych. Krzysztof Varga nie jest kojarzony $\mathrm{z}$ konkretnymi ideami, w wizerunku publicznym na pierwszy plan wysuwa się „zawód”. Natomiast obecny w mediach w roli komentatora zjawisk politycznych Piotr Zaremba jest już w wymiarze publicznym przede wszystkim „prawicowy”, a dopiero później „dziennikarzem”. Na poziomie imageów werbalnych wyróżniki dotyczą raczej treści przekazu niż formy. Najwyraźniej trudniej interpretatorowi jednym określeniem podsumować poglądy estetyczne niż nastawienie ideowe.

Zaznaczyć na koniec należy, że nazwy utworzonych w niniejszym opracowaniu kategorii są dość umowne. Wyłonione obszary można było nazwać inaczej. Nawet niektóre cechy mogły zostać inaczej usytuowane. Z całą pewnością zaproponowane kategorie porządkują dane, ułatwiają (umożliwiają?) 
analizę w kontekście stawianych w badaniu celów i pomagają odpowiedzieć na formułowane na wstępie pytania. Można oczywiście nie zgadzać się ani $\mathrm{z}$ zastosowanym podziałem kategorii (tym, jakie zostały wyłonione), ani z ich zawartością (przyporządkowaniem poszczególnych cech do konkretnych obszarów wizerunku). Autorka niniejszego opracowania uważa jednak, że żadne modyfikacje nie zmienią w sposób istotny generalnych ustaleń tu poczynionych ani odpowiedzi na postawione pytania badawcze. 


\section{Zakończenie}

Szczegółowe ustalenia i wnioski z analizy wizerunków i analizy wykładników znajdują się w poprzednich rozdziałach, w tym szczególnie w rozdziale trzecim. W niniejszym zakończeniu przedstawiono skrótowo wcześniej omówione zagadnienia w kontekście stawianego celu badawczego.

Zakładano zbadanie w sposób intersubiektywny możliwości komunikowania i konstruowania wizerunku werbalnego (konstruowanego na podstawie wypowiedzi werbalnej), wizualnego (na podstawie wypowiedzi wizualnej) i publicznego (konstruowanego w wyniku zetknięcia interpretatora $\mathrm{z}$ wypowiedziami, powstałymi w różnych systemach znakowych). Wypowiedzi werbalne miały być przy tym autorstwa osoby publicznej, której wizerunek się sprawdza, a traktować miały na tematy inne niż własna osoba. Dodatkowo sprawdzano wpływ tematyki i wyrażanej postawy ideologicznej na konstruowany przez interpretatorów wizerunek Za bazę teoretyczno-metodologiczną posłużył racjonalny konstruktywizm Michaela Fleischera, zgodnie z którym rzeczywistość, w której funkcjonujemy, a w tym także wizerunek osób publicznych, tworzymy za pomocą i na podstawie komunikacji. Wykorzystano eksperyment w kilku grupach badawczych i wariantach, by zrealizować stawiane cele.

Przeprowadzone badania pokazują, iż wizerunek werbalny może być komunikowany w następujących kategoriach wizerunkowych: „postawa”, „cechy charakteru”, „poglądy/wartości”, „sposób komunikowania”. Wizerunek publiczny te same zakresy image'u wzbogaca o „zawód”, „wygląd” i „inne”. Wizerunek wizualny dzieli wszystkie te kategorie z poprzednimi typami imageów oraz dodaje specyficzne dla siebie: „wiek/płeć”, „stan emocjonalno-poznawczy”.

Wizerunki werbalne (image anonima i jawnego autora) są do siebie bardzo podobne. Ten na postawie tekstu znanego twórcy ma nieco mniej cech, jednak image bardziej różnią się ilościowo niż jakościowo, tj. te same cechy 
są częściej wskazywane, gdy autor jest znany, ale przywołanie nazwiska i fotografii nie generuje przypisywania nowych cech wizerunkowych. Tym samym najwyraźniej wizerunek publiczny wpływa na werbalny, jednak w ograniczonym stopniu.

Znajomość autora (wizerunek publiczny) w relatywnie niewielkim stopniu wpływa na wizerunek werbalny, nawet jeśli twórca wypowiedzi jest dość znany. Wysoka rozpoznawalność publicysty - jak w przypadku Szymona Hołowni - powodowała częstsze przypisywanie mu niektórych cech, gdy czytano jego felieton, ale wciąż były to cechy wskazywane również wtedy, gdy respondenci czytali jego tekst, nie wiedząc, kto jest autorem (mowa o cechach: „religijny”, „zabawny”). Wpływ może mieć też udział stereotypu z wizerunku publicznego. Łączenie na poziomie image’u publicznego Magdaleny Środy z feminizmem, który kojarzony jest ze stanowczością i agresją, spowodowało rekordowo wysokie przypisywanie jej cech wizerunkowych właśnie z feminizmem wiązanych („dosadnie wyrażająca swoje odważne sądy” $i$ „feministka”).

Kiedy natomiast przywołanie nazwiska i opatrzenie tekstu zdjęciem nie wywołuje skojarzeń z konkretnym wizerunkiem publicznym (felietonista nieznany czytelnikowi), to wówczas niewielki wpływ na wizerunek konstruowany na podstawie tekstu jawnego autora ma jego fotografia. Wpływ ten polega jedynie na wzmocnieniu reprezentatywności w wizerunku werbalnym cech funkcjonujących „w tekście”, a pokrywających się z synonimicznymi z wizerunku wizualnego (w przypadku Krzysztofa Vargi to "inteligencja” i „dosadne wypowiadanie odważnych sądów”). Przykład Piotra Zaremby potwierdzał taki mechanizm, choć okazało się także, że w przypadku silnego kontrastu między słowem a obrazem, po przeczytaniu tekstu, zyskuje na wyrazie ta cecha, która zaskakuje czytelników w porównaniu z oczekiwaniami co do osoby ze zdjęcia - tak też „poważny” czy „wywyższający się” publicysta widoczny na zdjęciu, po zapoznaniu się odbiorcy z felietonem częściej (w porównaniu $\mathrm{z}$ tekstem anonima) okazywał się w jego oczach „ciekawie piszący” czy nawet „zabawny”.

Charakterystyczna jest więc dla wizerunków werbalnych duża stabilność, którą trudno naruszyć. Wydaje się zasadna interpretacja, że jeżeli zapoznamy się z czyimiś słowami, to właśnie poziom werbalny będzie dominujący w konstrukcji wizerunku.

Wizerunek publiczny wykazuje duże podobieństwo do werbalnego (dzieli z werbalnym wszystkie kategorie wizerunku: „postawa”, „cechy charakteru”, „poglądy/wartości” „sposób komunikowania”), ale na jego konstrukcję - poza wypowiedziami publicysty i wypowiedziami „o" nim - wpływa też kontekst wypowiedzi. Właśnie kontekst zdaje się generować kategorię wizerunkową „zawód”, specyficzną dla tego wymiaru image’u, a następnie zapożyczaną 
przez wizerunek wizualny (zawód publicysty bardziej sugerowany jest przez kontekst wypowiedzi niż portret autora słów). Image publiczny wykazuje się przy tym największą ekspansją - ten typ potrafi wpływać zarówno na wizerunkowy wymiar werbalny, jak i wizualny. Jak już wspomniano wyżej, wzmacnia obecne w tekście cechy image’u werbalnego. Wizerunek publiczny jest też przywoływany przez image wizualny, tj. skojarzenia $\mathrm{z}$ felietonistą wpływają na cechy przypisywane w oparciu o zdjęcie. Stąd też na podstawie obrazu bywają ze sfotografowanym łączone cechy mieszące się np. w kategorii „zawód”.

Sam wizerunek wizualny wykazuje się największą absorbcją cech z innych typów wizerunku - obraz bowiem aktualizuje zarówno wizerunek publiczny, jak i werbalny. Widząc zdjęcie, respondenci wiązali sportretowaną osobę z cechami funkcjonującymi w dwóch pozostałych typach wizerunków. Poziom obrazu aktualizuje przy tym cechy $\mathrm{z}$ wszystkich kategorii, znanych $\mathrm{z}$ wizerunku werbalnego i publicznego: „postawa”, „cechy charakteru”, „poglądy/wartości”, „sposób komunikowania”, „zawód”, „wygląd”. Ciekawe, że związek z image'em werbalnym i publicznym jest na tyle duży, że nawet „poglądy/wartości” i „sposób komunikowania” są udziałem wizerunku wizualnego. Zauważono też możliwość przenikania stereotypu na cechy konstruowane po kontakcie z fotografią (patrz: Magdalena Środa). Swoiste dla image'u opartego na obrazie są jedynie obszary „wiek/płeć” i „stan emocjonalno-poznawczy”, choć trudno wykazać ich wpływ na inne wymiary image’u. Pewne zależności (opisane wyżej) widać jedynie w przypadku relacji: wizerunek wizualny $\rightarrow$ werbalny, gdy autor tekstu nie jest rozpoznawany przez czytelników.

Warto też zauważyć, że postawa ideowa wpływa na wizerunek - jej reprezentowanie generuje przypisywanie cech z kategorii „poglądy/wartości”. Poruszany temat wiąże się z postawą ideową i tym samym z cechą wizerunkową. Interesujące wydaje się to, że poruszana tematyka może blokować konstruowanie cech z zakresu „poglądów/wartości”. Operowanie problematyką społeczno-polityczną powoduje częstsze przypisywanie cech z omawianej kategorii wizerunkowej (Hołownia, Środa) niż wypowiadanie się w kwestiach wydarzeń kulturalnych, choć zarówno poglądy Krzysztofa Vargi, jak i Piotra Zaremby można (zre)konstruować na podstawie felietonów wykorzystanych w badaniu.

Należy jeszcze zauważyć powtarzalność najwyżej reprezentowanych cech u wszystkich felietonistów w podobnym wymiarze (cechy np. „inteligentny”, „krytyczny”, „znawca tematu”, „dosadnie prezentujący swoje odważne sądy” to najczęściej wymieniane atrybuty każdego $\mathrm{z}$ autorów). Warto przyjrzeć się tej kwestii z dwóch perspektyw: metodologicznej i merytorycznej.

W zakresie metody, obok liczbowego ujęcia każdej z wymienionych cech, warto zwrócić uwagę na tzw. bloki semantyczne, w które można łączyć synonimiczne cechy wizerunkowe. Pozwalają uporządkować wielość cech i zauważyć 
semantyczne ukierunkowanie danego wizerunku. Jeśli wykorzystać ten sposób badania image'u, to nie wysoka reprezentatywność poszczególnych cech ma kluczowe znaczenie dla wizerunku, ale zyskuje na randze układ i zawartość bloków semantycznych, gdzie należałoby szukać wyróżników wizerunku danego publicysty (oczywiście jednocześnie uwzględniając też cechy unikatowe dla felietonisty lub szczególnie często wynotowywane).

Ujęcie merytoryczne pozwala powtarzalność kilku najwyżej reprezentowanych cech wizerunkowych łączyć $\mathrm{z}$ odejściem $\mathrm{w}$ prasie (i szerzej: mediach) od podziału na gatunki informacyjne i publicystyczne, na rzecz tych drugich, dla których wyróżnikiem jest komentarz i ocena zjawisk (np. Bogołębska 2016: 245; Wojtak 2015c: 65; Kita 2013: 215; Kudra 2001: 5-6; Szczepaniak 2007). Opinia i krytyka (konstruktywna lub nie) powoli stają się cechą na stałe wpisaną nawet w gatunki informacyjne, a w publicystycznych zyskują na wyrazistości i sile. Drugą z tendencji stanowi inforozrywka (Fras 2013; Worsowicz 2002; Wojtak 2015h: 64) czy po prostu rozrywka (Wojtak 2007), czyli włączanie elementów humorystycznych, komicznych czy satyrycznych $\mathrm{w}$ treści informacyjne. To tłumaczy, dlaczego w pierwszej siódemce pojawiły się takie cechy, jak „dosadnie”, „krytyczny”, ,ironiczny” (ocena) oraz „ciekawie piszący” czy „zabawna”, a także „ironiczny” (rozrywka), czyli cechy najczęściej wskazywane i to najczęściej u każdego z felietonistów. Najwyraźniej tendencje medialne (ocena i rozrywka), a także cechy gatunkowe felietonu (jak np. subiektywizm, silne wartościowanie czy swoboda stylistyczna) wpływają na wizerunek publicystów, którzy im podlegają i którzy je kreują. Ocena i humor charakterystyczne dla dyskursu medialnego odbijają się również w ich wizerunku. Ponieważ jednak bloki semantyczne pokazują różnice między autorami, to dodać należy, że raczej najczęściej wymieniane cechy są nie tyle wyróżnikiem wizerunkowym osoby publicznej, co raczej warunkiem funkcjonowania w mediach, najwyraźniej pożądanym i zauważanym przez odbiorców.

Drugą z najczęściej wynotowywanych cech wizerunkowych stanowi atrybut „inteligentny”. Przypisywany jest każdemu twórcy w każdym typie wizerunku (również publicznym i wizualnym!), co by znaczyło, że stanowi dla interpretatorów niezbędny element wizerunku, którego mają potrzebę w wypowiedzi (werbalnej, wizualnej, akustycznej) „szukać”. Tutaj więc potrzeba odbiorcy wypowiedzi ma decydujące znaczenie w konstrukcji image'u. Możliwe, że ten mechanizm także występuje w przypadku „dosadnie” i „krytyczny”, bowiem analogicznymi cechami z imageów publicznego i wizualnego byłyby „pewny siebie”, „konkretna”, „stanowczy”, „wywyższający się”, a więc są to cechy przypisywane łącznie każdemu autorowi w każdym typie image'u. Może zatem i te cechy wizerunkowe oparte na wartościowaniu wynikają z potrzeb interpretatorów w zakresie konstrukcji image’u? Zwłaszcza że w Polsce 
po 1989 roku mówi się o „rynku odbiorcy mediów”, o dostosowaniu się mediów do czytelników, widzów, słuchaczy poprzez zaspokojenie ich potrzeb (np. Fras 2013: 9; Wolny-Zmorzyński, Kaliszewski, Furman 2006: 3; Kita 2013: 199-200; Wojtak 2007: 39; 2015g: 204; Bralczyk, Majkowska 2000: 45-46; Wojtak 2015g: 204), a także o zsubiektywizowaniu wypowiedzi i silnym, wartościującym sposobie komunikacji, w tym ironicznym (Wojtak 2015g: 208; 2015i: 187, Kamińska-Szmaj 2001: 59; Fras 1999: 38; Szczepaniak 2007).

Pytanie o to, co było pierwsze: image jako wynik określonego ukształtowania wypowiedzi, czy też ukształtowanie wypowiedzi powstałe na potrzeby odbiorcy, jest pytaniem o to, co było pierwsze: jajko czy kura. Uprawniony wydaje się sąd, że te dwa mechanizmy funkcjonują na zasadzie sprzężenia zwrotnego, wzajemnie się konstytuując i wpływając na siebie. Pytanie: który kierunek wpływu jest dominujący i na jakich dokładnie zasadach? Zweryfikowanie stopnia determinacji wizerunku przez cechy dyskursu i preferencje interpretatora może tym samym stanowić dobry punkt wyjścia dla dalszych badań nad kreowaniem image’u autora słów przez odbiorcę tekstu. 



\section{Literatura}

Adamczyk K. (2016), Opinie o prezydencie Rafale Dudkiewiczu wśród wrocławian i internautów w kwietniu 2015 r., [w:] Siemes A., Grech M., Wszołek M. (red.), Badanie i projektowanie komunikacji 5, Wrocław, s. 119-145. Altkorn J. (2004), Wizerunek firmy, Dąbrowa Górnicza.

Awdiejew A. (2011), Ogólna teoria komunikacji a analiza dyskursu, „Communication Design Magazine”, nr 2 [online], http://www.cd-magazine.uni. wroc.pl/artykul/teoria_komunikacji_analiza_dyskursu/ (data dostępu: 30.09.2015).

Awdiejew A. (2012), Świadomość i nieświadomość w komunikacji, [w:] Steciąg M., Bugajski M. (red.), Świadomość językowa w komunikowaniu, Zielona Góra, s. 41-48.

Awdiejew A. (2011), Trzy poziomy schematyzacji w procesie komunikacji międzyludzkiej, [w:] Habrajska G. (red.), Kategorialne aspekty komunikacji, „Rozmowy o Komunikacji”, nr 5, Łódź, s. 46-56.

Awdiejew A., Habrajska G. (2010), Komponowanie sensu w procesie odbioru komunikatów, Łódź.

Awdiejew A., Habrajska G. (2011), Obrazy ideacyjne w interpretacji tekstu, [w:] Habrajska G. (red.), Kategorialne aspekty komunikacji, „Rozmowy o Komunikacji”, nr 5, Łódź, s. 57-66.

Babbie E. (2004), Badania społeczne w praktyce, Warszawa.

Bachórz J., Kowalczykowa A. (red.) (1991), Felieton, [w:] Słownik literatury polskiej XIX wieku, Wrocław-Warszawa-Kraków, s. 260-264.

Balcerzak A., Gackowski T. (2009), Analiza zawartości, [w:] Gackowski T., Łączyński M. (red.), Metody badania wizerunku w mediach, Warszawa, s. 17-32.

Baranowska K. (2012), Analiza treści komunikatów zamieszczonych na stronach internetowych firm public relations $w$ województwie dolnośląkim 
i małopolskim, [w:] Grech M. (red.), Badanie wizerunku: ludzie, marki, branże, Łódź, s. 332-358.

Barańska-Szmitko A. (2011), Wpływ znajomości tożsamości autora na konstrukcje jego wizerunku. Badanie wizerunku Aloszy Awdiejewa jako autora felietonów „Szkice z filozofii potocznej”, [w:] Habrajska G. (red.), Poznawać. Tworzyć. Komunikować. Komunikatywizm w Polsce. Wybrane zagadnienia $z$ teorii i praktyki, Łódź, s. 174-185.

Barańska-Szmitko A. (2012), Wpływ zmiany zdjęcia autora felietonu na jego wizerunek, [w:] Grech M., Siemes A. (red.), Communication design. Projektowanie komunikacji 1, Wrocław, s. 157-170.

Barańska-Szmitko A. (2013), Wizerunek Krzysztofa Vargi komunikowany słowem. Reprezentacja językowa cech przypisywanych autorowi tekstu, [w:] Grech M., Siemes A. (red.), Badanie i projektowanie komunikacji 2, Wrocław, s. 155-177.

Barańska-Szmitko A. (2014a), Image from Words. What do Authors of Columns Communicate about Themselves to their Readers?, „Humanities \& Social Sciences Review", t. 3, nr 4, s. 67-74.

Barańska-Szmitko A. (2014b), Komunikowanie (nie)obiektywności na poziomie werbalnym, [w:] Graszewicz M. (red.), Teorie komunikacji i mediów 7, Wrocław, s. 197-213.

Barańska-Szmitko A. (2014c), Możliwości i ograniczenia felietonu jako narzędzia kreowania wizerunku jego autora, „Acta Universitatis Lodziensis. Folia Litteraria Polonica", nr 1 (23), s. 211-227.

Barańska-Szmitko A. (2014d), Wizerunek Szymona Hołowni komunikowany w jego felietonach, [w:] Wszołek M. (red.), Badanie i projektowanie komunikacji 3, Wrocław, s. 173-197.

Barańska-Szmitko A. (2016a), Cechy wypowiedzi ironisty. Werbalne sposoby komunikowania „ironiczności”, [w:] Siemes A., Grech M., Wszołek M. (red.), Badanie i projektowanie komunikacji 5, Wrocław, s. 147-163.

Barańska-Szmitko A. (2016b), Co oprócz tematu wypowiedzi wplywa na wizerunek nadawcy komunikatu?, [w:] Odelski M., Knapik A., Chruszczewski P., Chłopicki W. (red.), Niedosłowność w języku, „Język a Komunikacja”, t. 37, Kraków, s. 269-278.

Barańska-Szmitko A. (2016c), Jak komunikować poczucie humoru? Badanie empiryczne na materiale felietonów, [w:] Habrajska G. (red.), Komunikatywizm - przyszłość nauki XXI wieku, Łódź, s. 260-278.

Barańska-Szmitko A. (2016d), Kreowanie wizerunku osoby kompetentnej w zakresie „znajomości tematu”. Empiryczne badanie wizerunku na materiale felietonów, [w:] Graszewicz M., Wszołek M. (red.), Teorie komunikacji i mediów 9. Konstrukcje komunikacji i mediów, Wrocław, s. 119-134. 
Barańska-Szmitko A. (2016e), Means of Communicating an Image of Being "Engaged" and "A Realist" in Newspaper Columns: Results of Empirical Research, „Humanities and Social Sciences Review”, t. 6, nr 1, s. 127-136.

Barańska-Szmitko A. (2016f), The Capacities and Limitations of the Newspaper Column as a Tool for Creating the Image of Its Author, „Acta Universitatis Lodziensis. Folia Litteraria Polonica", nr 5 (35), s. 115-129.

Barańska-Szmitko A. (2016g), Wplyw użytej w wypowiedzi leksyki potocznej na wizerunek felietonisty, „Acta Universitatis Lodziensis. Folia Litteraria Polonica", nr 2 (32), s. 107-117.

Barańska-Szmitko A. (2017a), Proste treści w komunikacji ze współczesnym interpretatorem - nawiązania do tekstów kultury oraz ich efekt dla wizerunku autora wypowiedzi, „Media i Społeczeństwo”, nr 7, s. 99-109.

Barańska-Szmitko A. (2017b), Różnorodność stylistyczna i jej możliwości komunikacyjne w wypowiedzi felietonowej, [w:] Knapik A., Misior-Mroczkowska A., Chruszczewski P., Chłopicki W. (red.), Style komunikacyjne, „Język a Komunikacja”, t. 39, Kraków, s. 85-96.

Barańska-Szmitko A. (2017c), Wolność ekspresji siebie a granice wizerunku na przykładzie image’u Magdaleny Środy, [w:] Kozioł K. (red.), Wolność człowieka i jej granice, Lublin, s. 56-69.

Barańska-Szmitko A. (2017d), Werbalne sposoby komunikowania „dociekliwości” przez felietonistów (Piotra Zarembę, Magdalenę Środę i Szymona Hołownię). Wyniki badań empirycznych, „Acta Universitatis Lodziensis. Folia Litteraria Polonica", nr 4 (41), s. 221-234.

Barańska-Szmitko A. (2017e), The application of generalising judgements and their influence on the images of selected Polish columnists (a constructivism-focussed quantitative and qualitative approach, „Acta Universitatis Lodziensis. Folia Litteraria Polonica", nr 5 (43), s. 185-198.

Barańska-Szmitko A. (2018), Wizerunek felietonisty i sposoby jego werbalnego komunikowania, Łódź.

Bartmiński J. (1990), Kolekcja w strukturze tematycznej tekstu ustnego, [w:] Dobrzyńska T. (red.), Tekst w kontekście. Zbiór studiów, WrocławWarszawa-Kraków, s. 155-174.

Bartmiński J. (1998), Tekst jako przedmiot tekstologii lingwistycznej, [w:] Bartmiński J., Boniecka B. (red.), Tekst. Problemy teoretyczne, Lublin, s. 9-25.

Bartmiński J. (red.) (2006), Język. Wartości. Polityka. Zmiany rozumienia nazw wartości w okresie transformacji ustrojowej w Polsce. Raport z badań empirycznych, Lublin.

Bartmiński J., Niebrzegowska-Bartmińska (2009), Tekstologia, Warszawa.

Białopiotrowicz G. (2009), Kreowanie wizerunku w biznesie i polityce, Warszawa. 
Bobrowska A., Garska M. (2012), Elementy kreacji wizerunku podmiotu politycznego w rzeczywistości wyborczej, „Colloquium Wydziału Nauk Humanistycznych i Społecznych", nr 2 (6), s. 147-164.

Bogołebska B. (2016), Przenikanie się dyskursów dziennikarskich i medialnych, [w:] Witosz B., Sujkowska-Sobisz K., Ficek E. (red.), Dyskurs i jego odmiany, Katowice, s. 244-253.

Bogołębska B., Worsowicz M. (red.) (2010), Styl - dyskurs - media, Łódź.

Bojakowski W. (2014), Kobieta i mężczyzna w reklamie. Analiza komunikacji koncernów samochodowych, [w:] Wszołek M. (red.), Badanie i projektowanie komunikacji 3, Wrocław, s. 289-298.

Bolanowski J. (2013), Wizerunek Szymona Hołowni w ramach działalności medialnej, [w:] Waszkiewicz A. (red.), Obszary badań wizerunku, Warszawa.

Borkowski I. (2011), Rzecznictwo prasowe a kształtowanie wizerunku polskich zgromadzeń zakonnych. Teoria - praktyka - case study, [w:] Borkowski I., Stasiuk-Krajewska K. (red.), Ksztattowanie wizerunku jako narzędzie Public Relations, Wrocław, s. 57-80.

Borkowski I., Stasiuk-Krajewska K. (red.) (2011), Kształtowanie wizerunku jako narzędzie Public Relations, Wrocław.

Borkowski I., Stasiuk-Krajewska K. (2011), Wstęp - Wizerunek, opis świata, konstrukcja komunikacji, [w:] tychże (red.), Kształtowanie wizerunku jako narzędzie Public Relations, Wrocław, s. 11-15.

Bralczyk J., Majkowska G. (2000), Język mediów - perspektywa aksjologiczna, [w:] Bralczyk J., Mosiołek-Kłosińska K. (red.), Język w mediach masowych, Warszawa, s. 43-50.

Bralczyk J., Wasilewski J. (2008), Język w mediach. Medialność w języku, [w:] Bauer Z., Chudziński E. (red.), Dziennikarstwo $i$ świat mediów, wyd. IV, Kraków, s. 379-401.

Budzyński W. (2002), Wizerunek firmy. Kreowanie, zarzadzanie, efekty, Warszawa. Budzyński W. (2008), Wizerunek równoległy. Nowa szansa promocji firmy i marki, Warszawa.

Burska J. (2013), Kognitywny wizerunek ,inteligentnego domu”, t. 5-6 [online], http://www.cd-magazine.uni.wroc.pl/artykul/kognitywny_wizerunek_ inteligentnego_domu/ (data dostępu: 21.03.2016).

Burska J. (2013), Kognitywny wizerunek „inteligentnego domu”, [w:] Wszołek M. (red.), Komunikacje w rozmowie 2, Wrocław, s. 181-223.

Cesielska M. (brw), Komunikacja wizualna $w$ działaniu, [w:] Wszołek M. (red.), Komunikacje w rozmowie 2, Wrocław, s. 103-121.

Chachołek S. (2011), Efektywność a efektowność wizerunku jednostek samorzadu terytorialnego, [w:] Stasiuk-Krajewska K., Tworzydło D., 
Chmielewski Z. (red.), Public Relations - doświadczenia, badania, wątpliwości, Rzeszów, s. 125-144.

Charmaz K. (2009), Teoria ugruntowana. Praktyczny przewodnik po analizie jakościowej, Warszawa.

Chmielewski Z. (2010), Aspekty realizacji procesu badawczego, [w:] Tworzydło D., Chmielewski Z. (red.), Badania i pomiar efektów w Public Relations, Rzeszów, s. 95-106.

Choma K. (2012), Obraz własnej osoby w oczach różnych obserwatorów, [w:] Grech M. (red.), Badanie wizerunku: ludzie, marki, branże, Łódź, s. 29-59.

Chudziński E. (2008), Felieton. Geneza i ewolucja gatunku, [w:] Bauer Z., Chudziński E. (red.), Dziennikarstwo i świat mediów, Kraków, s. 345-360.

Chycki J. (2013), Konstruktywny wizerunek buddyzmu, „Communication Design Magazine”, t. 5-6 [online], http://www.cd-magazine.uni.wroc.pl/artykul/konstruktywny_wizerunek_buddyzmu/(data dostępu: 21.03.2016).

Creswell J.W. (2013), Projektowanie badań naukowych. Metody jakościowe, ilościowe i mieszane, Kraków.

Cross-Müller C. (2006), Jak wypaść przekonująco. Mowa ciała i autoprezentacja dla kobiet, przeł. P. Gawlik, Białystok.

Cychański J. (2013), Badanie wizerunku policji - metodologia i cele badań, [w:] Graszewicz M. (red.), Teorie komunikacji i mediów 6. Poprawność i stosowność w komunikacji, Wrocław, s. 425-434.

Cychański J. (2014), Wizerunek zewnętrzny i wewnętrzny policjanta. Jaki jest typowy policjant - wyniki i analiza badań empirycznych, [w:] Stasiuk-Krajewska K., Graszewicz M. (red.), Teorie komunikacji i mediów 7. Od teorii do empirii, Wrocław, s. 311-327.

Daszkiewicz M., Waniowski P. (2007), Symbole i wyróżniki w procesie kreowania wizerunku kraju, [w:] Soliński T., Tworzydło D. (red.), Public Relations - narzędzia przyszłości, Rzeszów, s. 25-37.

Dawidziak-Kładoczna M. (2002), Autokreacja w wywiadach prasowych udzielanych przez Józefa Piłsudskiego, [w:] Michalewski K. (red.), Tekst w mediach, Łódź, s. 198-209.

Dąbrowska A. (2008), Zmiany obszarów podlegających tabu we współczesnej kulturze, [w:] tejże (red.), Tom jubileuszowy, „Język a Kultura”, t. 20, Wrocław, s. 173-196.

Dąbrowska-Cendrowska O. (2011), Krystyna Kofta jako reprezentantka felietonistów „Twojego Stylu” w latach 1990-2009, [w:] Wolny-Zmorzyński K., Furman W., Snopek J. (red.), Mistrzowie literatury czy dziennikarstwa?, Warszawa, s. 61-73.

Dąbrowski T.J. (2010), Reputacja przedsiębiorstwa. Tworzenie kapitału zaufania, Kraków. 
Dembowska-Wosik I. (2014), Pojęcie wizerunku i jego związki z glottodydaktyką. Na przykładzie wizerunku Łodzi w chicagowskim „Dzienniku Związkowym”, „Acta Univesitas Lodzensis. Kształcenie Polonistyczne Cudzoziemców", nr 21, s. 289-298.

Dembowska-Wosik I. (2017), Obraz Polski i Polaków w chicagowskim „Dzienniku Zwiazkowym”, Łódź.

Dobrzyńska T. (2003), Tekst - styl - poetyka. Zbiór studiów, Kraków.

Dunning T. (2012), Natural Experiments in the Social Sciences. A Design-Based Approach, Cambridge.

Duszak A. (1998), Tekst, dyskurs, komunikacja międzykulturowa, Warszawa.

Figiel A. (2013), Reputacja w zarządzaniu przedsiębiorstwem. Ujęcie marketingowe, Kraków.

Fleischer M. (2000), Obraz świata. Ujęcie z punktu widzenia teorii systemów i konstruktywizmu, [w:] Dąbrowska A., Anusiewicz J. (red.), Językowy obraz świata i kultura, „Język a Kultura”, t. 13, Wrocław, s. 45-71.

Fleischer M. (2003), Stabilność polskiej symboliki kolektywnej, [w:] Bartmiński J. (red.), Język w kręgu wartości. Studia semantyczne, Lublin, s. 107-143.

Fleischer M. (2003a), Corporate identity i public relations, Wrocław.

Fleischer M. (2003b), Wplyw rodzaju pisma na konstrukcje wizerunku firmy, „2K - Komunikacja i Kultura”, nr 1, s. 28-36.

Fleischer M. (2004), Konstruktywny charakter image’u osobowości, „2K - Komunikacja i Kultura", nr 2/04, s. 143-152.

Fleischer M. (2006), Obszar tabu w systemie polskiej kultury, [w:] Graszewicz M., Stasiuk K. (red.), Literatura, kultura, komunikacja. Ksiega Pamiątkowa ku czci Profesora Jerzego Jastrzębskiego w 60. rocznicę urodzin, Wrocław, s. 283-300.

Fleischer M. (2007), Ogólna teoria komunikacji, Wrocław.

Fleischer M. (2008a), Konstrukcja rzeczywistości 2, Wrocław.

Fleischer M. (2008b), Koncepty - elementy sterujace komunikacji, Wrocław.

Fleischer M. (2011), Wypowiedź a komunikacja, [w:] Habrajska G. (red.), Kategorialne aspekty komunikacji, „Rozmowy o Komunikacji”, nr 5, Łódź, s. 13-25.

Fleischer M. (2012), Typologia komunikacji, Łódź.

Fleischer M. (brw), Komunikacja - jak to jest. Konstruktywistyczne ujęcie komunikacji, [w:] Wszołek M. (red.), Komunikacje w rozmowie 1, Wrocław, s. 9-15.

Flick U. (2010), Projektowanie badania jakościowego, Warszawa.

Flick U. (2011), Jakość w badaniach jakościowych, Warszawa.

Fras J. (1999 [2005]), Dziennikarski warsztat językowy, Wrocław.

Fras J. (2013), O pojmowaniu infotainmentu i nadmiernej rozrywkowości mediów masowych we współczesnym medioznawstwie, „Środkowoeuropejskie Studia Polityczne", nr 1, s. 7-31. 
Frąckowiak-Sochańska M. (2009), Pozainstytucjonalny wymiar życia politycznego - postawy kobiet wobec ruchu feministycznego, [w:] tejże, Preferencje ładów normatywnych $w$ postawach kobiet wobec wartości w Polsce na przełomie XX i XXI wieku, Poznań, s. 203-207.

Frąckowiak-Sochańska M. (2011), Postawy polskich kobiet wobec feminizmu. O samoograniczającej się świadomości feministycznej kobiet, „Acta Universitatis Lodziensis. Folia Sociologica", nr 39, s. 149-170.

Gackowski T., Łączyński M. (red.) (2009), Metody badania wizerunku w mediach, Warszawa.

Gackowski T., Łączyński M. (2009a), Analiza wizerunku - od teorii do praktyki, [w:] Gackowski T., Łączyński M. (red.), Metody badania wizerunku w mediach, Warszawa, s. 105-115.

Gackowski T., Łączyński M. (2009b), Badanie wizerunku Ryszarda Krauzego - raport, [w:] Gackowski T., Łączyński M. (red.), Metody badania wizerunku w mediach, Warszawa, s. 139-272.

Gackowski T., Gackowska A., Dziedzic J. (red.) (2010), PR w RP, czyli dwadzieścia lat polskiej branży Public Relations, Warszawa.

Gałązka W. (2010), Czego Jaś się nie nauczy, tego Jan nie będzie umiał. O szkoleniach wizerunkowych polskich polityków, [w:] Tworzydło D., Chmielewski Z. (red.), Public relations $w$ procesie kształtowania relacji z otoczeniem, Kraków-Rzeszów-Zamość, s. 441-452.

Garncarek E. (2009), Kobieta bez dziecka vs. mężczyzna bez dziecka w świetle wypowiedzi autorów postów internetowych, „Acta Universitas Lodzensis. Folia Sociologica", nr 34, s. 127-141.

Gibbs G. (2011), Analizowanie danych jakościowych, Warszawa.

Gliniecka M. (2017), Wizerunek produktu na podstawie opakowania - badanie pilotażowe wizerunku opakowania perfum Odeur 53 marki Comme des Garçons, [w:] Badanie i projektowanie komunikacji 6. Tom dedykowany, Wrocław, s. 323-338.

Glińska E. (2011), Sposoby badania wizerunku miejsca, „Samorząd Terytorialny", nr 11, s. 33-44.

Goban-Klas T. (1997), Public Relations czyli promocja reputacji. Pojęcia, definicje, uwarunkowania, Warszawa.

Goffman E. (1981), Człowiek $w$ teatrze życia codziennego, Warszawa.

Grala M. (2011), Wizerunek zakładów pogrzebowych w Polsce, [w:] Borkowski I., Stasiuk-Krajewska K. (red.), Kształtowanie wizerunku jako narzedzie Public Relations, Wrocław, s. 99-105.

Graszewicz M., Ulidis M. (2011), Style życia. Zarys systemowej teorii i koncepcji badawczej, [w:] Borkowski I., Stasiuk-Krajewska K. (red.), Kształtowanie wizerunku jako narzędzie Public Relations, Wrocław, s. 19-30. 
Grech M. (2010), Komunikacja i wizerunek uczelni niepublicznych. Metodologia i wyniki badań empirycznych, Łódź.

Grech M. (2011), Wyniki badania wizerunku Uniwersytetu Wrocławskiego wśród jego studentów, t. 1 [online], http://www.cd-magazine.uni.wroc. pl/artykul/wyniki_badania_wizerunku_uniwersytetu_wroclawskiego_ wsrod_jego_studentow/ (data dostępu: 21.03.2016).

Grech M. (2012), Badanie wizerunku - metody ankietowe. Metodologia badań, [w:] Grech M. (red.), Badanie wizerunku: ludzie, marki, branże, Łódź, s. 11-26. Grech M. (2013), Obraz „uniwersytetu” w opinii mieszkańców Polski, Wrocław. Grech M. (2014), Obraz pracowników uniwersytetów w opinii mieszkańców Polski, [w:] Wszołek M. (red.), Badanie i projektowanie komunikacji 3, Wrocław.

Grobelna A. (2012), Wpływ obuwia na całościowy wizerunek człowieka. Wyniki badań empirycznych wśród studentów, [w:] Grech M. (red.), Badanie wizerunku: ludzie, marki, branże, Łódź, s. 79-110.

Grobelna A. (2013) Wpływ oprawek okularów na całościowy wizerunek człowieka, „Communication Design Magazine”, t. 5-6 [online], http://www. cd-magazine.uni.wroc.pl/artykul/wplyw_oprawek_okularow_na_wizerunek_czlowieka/ (data dostępu: 21.03.2016).

Habrajska G. (2000), Metody ankietowe i analiza tekstów w badaniach językowego obrazu świata, [w:] Dąbrowska A., Anusiewicza J. (red.), Językowy obraz świata i kultura, „Język a Kultura”, t. 13, Wrocław, s. 73-84.

Habrajska G. (2002), Semantyka i pragmatyka informacji prasowej (sens, interpretacja i rozumienie informacji prasowej, [w:] Michalewski K. (red.), Tekst w mediach, Łódź, s. 239-250.

Habrajska G. (2006), Poprawność polityczna, [w:] Habrajska G. (red.), Poprawność polityczna, „Rozmowy o Komunikacji”, nr 1, Łask, s. 17-27.

Habrajska G. (2012), Wybrane zagadnienia wprowadzajace do nauki o komunikowaniu, Łódź.

Habrajska G. (2013), Co może komunikacja werbalna, a co wizualna (badania pilotażowe), [w:] Wszołek M. (red.), Badanie i projektowanie komunikacji 3, Wrocław, s. 17-28.

Hajduk G. (2004), Kreowanie wizerunku w działaniach promocyjnych przedsiębiorstwa, [w:] Tworzydło D., Soliński T. (red.), Public Relations - wyzwania współczesności, Rzeszów, s. 319-329.

Hałafin A. (2016), Wplyw imienia i nazwiska na kognitywny wizerunek tekstu publicystycznego i autora, [w:] Graszewicz M., Wszołek M. (red.), Teorie komunikacji i mediów 9. Konstrukcje komunikacji i mediów, Wrocław, s. 201-227.

Hawryszczuk K. (2012), Pisarz o muzyce - kompozytor o literaturze. Zwiazki muzyki i literatury w felietonach Stefana Kisielewskiego, „Acta Universitatis Lodziensis. Folia Litteraria Polonica”, nr 2 (16), s. 173-181. 
Imiołek A., Suchecka A., Szostak J. (2013), Rola biblioteki $w$ kreowaniu wizerunku uczelni na przykładzie Wyższej Szkoły Humanistycznej w Sosnowcu, [w:] Kaczmarczyk M., Widera Z. (red.), Public Relations $i$ marketing $w$ nowoczesnym społeczeństwie, Sosnowiec-Warszawa, s. $159-170$.

Iwańczyk P. (2014), Felietonowe gry z konwencjami gatunkowymi w „Rzucie $z$ autu” Waldemara Lodzińskiego, „Językoznawstwo", nr 1 (8), s. 30-38.

Janicka A. (2012), Wplyw zmiany opakowania produktu na wizerunek jego marki, [w:] Grech M. (red.), Badanie wizerunku: ludzie, marki, branże, Łódź, s. $171-206$.

Jedliński R. (1984), Gatunki publicystyczne w szkole średniej, Warszawa.

Jeżewska M. (2013), Wizerunki wybranych samochodów: Mini Cooper, Fiat 500, Volkswagen Beetle, „Communication Design Magazine”, t. 5-6 [online], http://www.cd-magazine.uni.wroc.pl/artykul/wizerunki_mini_fiat_beetle/ (data dostępu: 21.03.2016).

Kaczmarczyk M. (2013), Modele public relations - od publicity do współdziałania, [w:] Kaczmarczyk M., Widera Z. (red.), Public Relations i marketing w nowoczesnym społeczeństwie, Sosnowiec-Warszawa, s. 9-29.

Kaczmarczyk M., Widera Z. (red.) (2013), Public Relations i marketing w nowoczesnym społeczeństwie, Sosnowiec-Warszawa.

Kadragic A., Czarnowski P. (1997), Public Relations czyli promocja reputacji. Praktyka działania, Warszawa.

Kamińska-Szmaj I. (2001), Słowa na wolności. Język polityki po 1989 roku, Wrocław.

Kaye E.A. (2007), Jak się wypromować w każdej sytuacji?, przeł. P. Głuchowska, Warszawa.

Kil A. (2011), Teoria ugruntowana w skrzynce z narzędziami badacza/badaczki wizerunku dziennikarstwa obywatelskiego, [w:] Borkowski I., Stasiuk-Krajewska K. (red.), Kształtowanie wizerunku jako narzędzie Public Relations, Wrocław, s. 31-40.

Kita M. (2013), Dyskurs prasowy, [w:] Malinowska E., Nocoń J., Żydek-Bednarczuk U. (red.), Style współczesnej polszczyzny. Przewodnik po stylistyce polskiej, Kraków, s. 199-288.

Klein T. (1983), Felieton - niektóre historyczne i teoretyczne aspekty gatunku, „Polonistyka”, nr 4.

Kochanek P. (2018), Wizerunek kobiet w reklamach sportowych, [w:] Wszołek M., Grech M., Siemes A. (red.), Badanie komunikacji 1, Wrocław, s. 313-330.

Kocoń P., Lubieniecka-Kocoń K. (2007), Wizerunek mafii w literaturze Mario Puzo, [w:] Soliński T., Tworzydło D. (red.), Public Relations - narzędzia przyszłości, Rzeszów, s. 109-115. 
Kolarska-Bobińska L. (red.) (2003), Obraz Polski i Polaków w Europie, Warszawa.

Kolbus B. (2011), Marka: miasto. Kreowanie wizerunku miasta, [w:] Stasiuk-Krajewska K., Tworzydło D., Chmielewski Z. (red.), Public Relations - doświadczenia, badania, wattpliwości, Rzeszów, s. 145-161.

Kotliński A., Urban A. (2010), Gromadzenie i obróbka danych, [w:] Tworzydło D., Chmielewski Z. (red.), Badania i pomiar efektów w Public Relations, Rzeszów, s. 107-116.

Kowal A. (2011), Język pop-teologiczny Szymona Hołowni, [w:] Majkowski G. (red.), Język w komunikacji, t. 1, Częstochowa, s. 75-83.

Kowal A. (2012), Czy niebo to wieczny orgazm? Prowokacja jako swoistość języka religijnego Szymona Hołowni, „Kwartalnik Językoznawczy”, nr 4, s. 18-32.

Krawiec F. (2009), Kreowanie i zarzadzanie reputacja firmy, Warszawa.

Królik G. (2012), Autoprezentacja, czyli jak się sprzedać pracodawcy, Katowice.

Kupisz P. (2001), Strategia promocji wizerunku miasta na przykładzie Radomia, [w:] Ślusarczyk S., Świda J., Tworzydło D. (red.), Public Relations w kształtowaniu pozycji konkurencyjnej organizacji, Rzeszów, s. 263-273.

Kurek O. (2010), Wizerunek niepublicznych szkół wyższych $w$ Rzeszowie w opinii maturzystów - raport $z$ badań, [w:] Tworzydło D., Chmielewski Z. (red.), Public relations $w$ procesie ksztattowania relacji z otoczeniem, Kraków-Rzeszów-Zamość, s. 121-133.

Kwiecień A. (2010), Zarzadzanie reputacją przedsiębiorstwa, Katowice.

Kysztymowa I. (2013), Kreacja wizerunku osobowego. Podstawy psychosemiotyki image'u, Poznań-Gniezno.

Labocha J. (2008), Tekst, wypowiedź, dyskurs w procesie komunikacji językowej, Kraków.

Laermer R., Prichinello M. (red.) (2004), Public Relations, przeł. E. Jusiewicz-Kalter, Gdańsk.

Leszczuk-Fiedziukiewicz A. (2011), Internet jako narzędzie kreowania wizerunku polityka, „Nowe Media. Studia i Rozprawy”, nr 2, s. 31-54.

Leszczyńska A., Mikołajczyk K., Miszczak N. (2011), Rekonstrukcja wizerunku studentów dziennikarstwa i komunikacji społecznej wśród studentów informatyki, t. 2 [online], http://www.cd-magazine.uni.wroc.pl/artykul/ wizerunek_studentow_dziennikarstwa_wsrod_studentow_informatyki/ (data dostępu: 21.03.2016).

Lipski A. (2012), Metody badań społecznych, Katowice.

Lisowska-Magdziarz M. (2006), Analiza tekstu w dyskursie medialnym, Kraków. Luhmann N. (1990), Das Erkenntnisprogramm des Konstruktivismus und die unbekannt bleibende Realität, [w:] tegoż, Soziologische Aufklärung, t. V: Konstruktivistische Perspektiven, Oladen, s. 31-58. 
Luhmann N. (1994 [1981]), Teoria polityczna państwa bezpieczeństwa socjalnego, przeł. G. Skąpska, Warszawa.

Luhmann N. (2007 [1984]), Systemy społeczne. Zarys ogólnej teorii, przeł. M. Kaczmarczyk, wyd. 2, Kraków.

Łączyński M. (2010), Komputerowe badanie tekstów w ewaluacji działań PR - prezentacja narzędzia badawczego, [w:] Gackowski T., Gackowska A., Dziedzic J. (red.), $P R w R P$, czyli dwadzieścia lat polskiej branży Public Relations, Warszawa, s. 145-153.

Łopuch M. (2012), Wplyw wybranych marek samochodowych na wizerunek człowieka, [w:] Grech M. (red.), Badanie wizerunku: ludzie, marki, bran$\dot{z} e$, Łódź, s. 60-78.

Łysoń J. (2012), Wplyw ceny na wizerunek marki produktów FMCG oraz produktów dlugotrwałego użytku w momencie ich prezentacji, [w:] Grech M. (red.), Badanie wizerunku: ludzie, marki, branże, Łódź, s. 207-236.

Maison D., Noga-Bogomilski A. (red.) (2007), Badania marketingowe. Od teorii do praktyki, Gdańsk.

Makowska M. (2013), Jakim językiem mówią tekst i obraz? O relacji tekst-obraz na przykładzie demotywatorów, „Tekst i Dyskurs”, nr 6, s. 169-184.

Makuchowska M. (2013), Styl religijny, [w:] Malinowska E., Nocoń J., Żydek-Bednarczuk U. (red.), Style współczesnej polszczyzny. Przewodnik po stylistyce polskiej, Kraków, s. 487-528.

Mandal E., Banot A. E. (2007), Kobiecość i męskość a stereotyp feministki, [w:] Mandal E. (red.), W kręgu gender, Katowice, s. 58-78.

Mandal E., Kofta M. (2009), Wykluczanie społeczne feministek jako przejaw usprawiedliwiania patriarchalnego systemu społecznego, [w:] Cisłak A., Henne K., Skarżyńska K. (red.), Przekonania w życiu jednostek, grup, społeczności, Warszawa, s. 153-170.

Maziarski J. (1976), Felieton, [w:] Maślanka J. (red.), Encyklopedia wiedzy o prasie, Wrocław.

Mazur J. (2002), Metody badania rozumienia przekazów w komunikacji marketingowej, [w:] Kędzior Z. (red.), Marketing - metody i techniki badawcze, Dąbrowa Górnicza, s. 99-111.

Mazurkiewicz B.M. (2008), Wizerunek Leonida Kuczmy na łamach tygodnika „Wprost”, w latach 1994-2004, „Studia Medioznawcze”, nr 3 (34), s. 11-44.

Miotk A. (2010), Badania w procesie oceny działań komunikacyjnych, [w:] Tworzydło D., Chmielewski Z. (red.), Badania i pomiar efektów w Public Relations, Rzeszów, s. 25-67.

Młynarczuk R. (2010), Wizerunek miasta - od pomystu do realizacji, [w:] Tworzydło D., Chmielewski Z. (red.), Public relations w procesie kształtowania relacji z otoczeniem, Kraków-Rzeszów-Zamość, s. 467-472. 
Navarro Maillo F. (2011), Historia opowiedziana za pomoca słów i obrazów - od Kapuścińskiego do fotoreportażu, [w:] Borkowski I., Stasiuk-Krajewska K. (red.), Kształtowanie wizerunku jako narzędzie Public Relations, Wrocław, s. 205-215.

Niczyperowicz A. (1996), Przepis na felieton, [w:] tegoż (red.), Abecadło dziennikarza, Poznań, s. 45-57.

Niczyperowicz A. (2001), Felieton. Piękny pasożyt, [w:] tegoż (red.), Dziennikarstwo od kuchni, Poznań, s. 81-94.

Nieremberg B. (2009), Felieton, [w:] Chudziński E. (red.), Słownik wiedzy o mediach, Bielsko-Biała, s. 291-295.

Nikodemska-Wołowik A.M. (1999), Jakościowe badania marketingowe, Warszawa.

Nikodemska-Wołowik A.M. (2008), Komunikowanie tożsamości rynkowej w otoczeniu międzynarodowym, Gdańsk.

Nykiel T. (2010), Macierz celów wizerunkowych jako metoda pomiaru sytuacji wizerunkowej podmiotu, [w:] Tworzydło D., Chmielewski Z. (red.), Public relations w procesie kształtowania relacji z otoczeniem, Kraków-RzeszówZamość, s. 195-212.

Olender K. (2017), Obraz uchodźców w dyskursie wybranych polskich partii politycznych, [w:] Badanie i projektowanie komunikacji 6. Tom dedykowany, Wrocław, s. 265-277.

Olędzki J., Tworzydło D. (red.) (2009), Leksykon Public Relations, Rzeszów, s. 16-22, 24-25, 27, 43, 72, 149-150, 174-176 (hasła: analiza jakościowa i ilościowa przekazów medialnych, analiza połowa, analiza rezonansu medialnego (s. 17-18), analiza sieci komunikacyjnych (s. 18), analiza zawartości (s. 19), ankieta CATI (s. 19-20), audyt komunikacyjny (s. 21), audyt medialny (s. 21-22), audyt społeczny, autoprezentacja (s. 22), badania ad hoc, badania ilościowe, badania jakościowe (s. 24), badania marketingowe (s. 24-25), badania mediów, badania rynku, nadania trackingowe (s. 25), bilans wizerunkowy (s. 27), corporate identity, corporate image (s. 43), reputacja (s. 149-150), wizerunek (174), wizerunek branży (174-175), wizerunek firmy (s. 175), wizerunek kraju (s. 175-176), image, image branży, image kraju (s. 74)).

Öttl Ch., Hälter G. (2009), Autopromocja, czyli jak wykorzystać swoje atuty, Warszawa.

Ożóg K. (2007 [2001]), Ekspansywna potoczność, [w:] tegoż, Polszczyzna przełomu XX i XXI wieku, wyd. III, Rzeszów, s. 52-76.

Ożóg K. (2007 [2001]), Wartościowanie w polskich kampaniach wyborczych, [w:] tegoż, Polszczyzna przełomu XX i XXI wieku, wyd. III, Rzeszów, s. $158-179$. 
Pawlak J. (2009), Autokreacja. Psychologiczna analiza zjawiska i jego znaczenie dla rozwoju człowieka, Kraków.

Piasny K. (2013), Wizerunek marek herbat. Profile osobowe marek herbat, „Communication Design Magazine”, t. 5-6 [online], http://www. cd-magazine.uni.wroc.pl/artykul/profile_osobowe_marek_herbat/ (data dostępu: 21.03.2016).

Piątek P. (2011), Publicysta w sporach dzienników opinii w Polsce. Analiza felietonów Rafała Ziemkiewicza w „Rzeczpospolitej”, „Refleksje”, nr 3, s. 83-97.

Pielużek M. (2018), Wizerunek imigrantów w komunikacji brytyjskiej skrajnej prawicy na przykładzie publikacji Britain First i Brytyjskiej Partii Narodowej, [w:] Wszołek M., Grech M., Siemes A. (red.), Badanie komunikacji, t. 1, Wrocław, s. 95-120.

Pietrzak A. (2012), Wizerunek studiów prawniczych na Uniwersytecie Opolskim. Wyniki badań wśród władz wydziału, pracowników naukowych oraz studentów, [w:] Grech M. (red.), Badanie wizerunku: ludzie, marki, branże, Łódź, s. 259-286.

Pietrzak M. (2013), Obraz nadawcy w recenzjach Henryka Sienkiewicza, „Acta Universitatis Lodziensis. Folia Linguistica", nr 47, s. 46-58.

Pilch J. (2010), Felieton, [w:] Skworz A., Niziołek A. (red.), Biblia dziennikarstwa, Kraków, s. 632-639.

Pisarek W. (1983), Analiza treści przekazów. Procedura badawcza, [w:] Malikowski M., Niezgoda M. (red.), Badania empiryczne w socjologii, t. II, Tyczyn, s. 321-362.

Pisarek W. (1983), Analiza zawartości prasy, Kraków.

Pisarek W. (red.) (2006), Felieton, [w:] Słownik terminologii medialnej, Kraków, s. 57.

Pisarek W. (2007), Jak zmierzyć zrozumiałość tekstu, [w:] tegoż, O mediach i ję$z y k u$, Kraków, s. 245-262.

Pisarek W. (2011), Nowa retoryka dziennikarska, Kraków.

Polacy o tematach tabu [online] http://www.tabupolska.pl/survey/summary/ (data dostępu: 02.12.2015).

Rabenda-Derman M. (2017), Kolor marka, kultura. Tworzenie wizerunku instytucji na podstawie palety kolorów - badanie empiryczne, [w:] Badanie i projektowanie komunikacji 6. Tom dedykowany, Wrocław, s. 193-222.

Radion E. (2004), Kreowanie wizerunku poety w mediach, [w:] Tworzydło D., Soliński T. (red.), Public Relations - wyzwania współczesności, Rzeszów, s. 211-222.

Retter H. (2005), Komunikacja codzienna w pedagogice, przeł. M. Wojdak-Piątkowska, Gdańsk. 
Romańczukiewicz K. (2012), Kognitywny wizerunek designu i wzornictwa w Polsce, [w:] Wszołek M. (red.), Komunikacje w rozmowie 1, Wrocław, s. 129-141.

Ropa A. (1976), W poszukiwaniu istoty felietonu, „Zeszyty Prasoznawcze”, nr 2 (68), r. XVII, s. 85-89.

Rozmus A. (2010), Problem kształtowania wizerunku - ujęcie interdyscyplinarne, [w:] Tworzydło D., Chmielewski Z. (red.), Public relations w procesie ksztattowania relacji z otoczeniem, Kraków-Rzeszów-Zamość, s. 299-312.

Rozwadowska B. (2002), Public Relations. Teoria. Praktyka. Perspektywy, Warszawa.

Rudy-Muża M. (2011), Internetowe lustro autoprezentacji, Toruń.

Rzemieniak M. (2011), Wizerunkowy aspekt shockvertisingu, [w:] Stasiuk-Krajewska K., Tworzydło D., Chmielewski Z. (red.), Public Relations - doświadczenia, badania, wattpliwości, Rzeszów, s. 71-87.

Sajewicz M. (2010), Badania w public relations, [w:] Tworzydło D., Chmielewski Z. (red.), Badania i pomiar efektów w Public Relations, Rzeszów, s. 13-24. Sampson E. (2004), Zbuduj własna markę, Gliwice.

Secler B. (2013), Ksiądz Józef Tischner jako osobowość medialna, „Studia Medioznawcze", nr 4 (55), s. 113-130.

Siemes A. (2011), Jak badać komunikację?, „Communication Design Magazine" t. 2 [online], http://www.cd-magazine.uni.wroc.pl/artykul/jak_badac_komunikacje/ (data dostępu: 06.01.2014).

Siemes A. (2011), Semantyka globalnych marek i firm, „Communication Design Magazine” t. 1 [online], http://www.cd-magazine.uni.wroc.pl/artykul/semantyka_globalnych_marek_i_firm/(data dostępu: 30.09.2015).

Sierakowska J. (2012), Porównanie wizerunków portali Facebook i Nasza-Klasa wśród ich użytkowników, [w:] Grech M. (red.), Badanie wizerunku: ludzie, marki, branże, Łódź, s. 237-258.

Silverman D. (2009a), Interpretacja danych jakościowych. Metody analizy rozmo$w y$, tekstu i interakcji, przeł. M. Głowacka-Grajper, J. Ostrowska, Warszawa.

Silverman D. (2009b), Prowadzenie badań jakościowych, przeł. J. Ostrowska, Warszawa.

Skawińska M. (2007), Zmiana wizerunku służby zdrowia w Polsce - konieczność i potrzeba społeczna, [w:] Soliński T., Tworzydło D. (red.), Public Relations - narzędzia przyszłości, Rzeszów, s. 271-281.

Skąpska G. (2007), Niklas Luhmann i teoria systemów społecznych. Wstęp do wydania polskiego, [w:] Luhmann N., Systemy społeczne. Zarys ogólnej teorii, przeł. M. Kaczmarczyk, Kraków, s. VII-XVIII.

Skrzypczak A. (2009), Łączenie źródet i triangulacja jako strategie poprawy jakości badań empirycznych, [w:] Bąk A., Kubisz-Muła Ł. (red.), Metody, techniki i praktyka badań społecznych, Bielsko-Biała, s. 93-101. 
Sławkowa E. (2000), Style współczesnego felietonu (Z zagadnień stylistyki gatunku), [w:] Ostaszewska D. (red.), Gatunki mowy i ich ewolucja, t. I: Mowy piękno wielorakie, Katowice, s. 305-315.

Słobodianiuk E. (2005), Wizerunek osobisty. Tworzenie wizerunku narzędziami PR [online], www.proto.pl/PR/Pdf/Wizerunek_osobisty.pdf (data dostępu: 05.111.2015).

Smółka-Dolecka A. (2012), Wpływ marki na wizerunek użytkownika na przykładzie portali społecznościowych, [w:] Grech M. (red.), Badanie wizerunku: ludzie, marki, branże, Łódź, s. 136-167.

Smyczyńska A. (2007), Niedyskretny urok grupy. Grupy studenckie a kształtowanie wizerunku uczelni wyższej na przykładzie Wyższej szkoły Zarzadzania i Bankowości w Krakowie, [w:] Soliński T., Tworzydło D. (red.), Public Relations - narzędzia przyszłości, Rzeszów, s. 283-293.

Socha J., Kotula Z. (2004), Znaczenie wizerunku Polski w kontekście członkostwa w Unii Europejskiej, [w:] Tworzydło D., Soliński T. (red.), Public Relations - wyzwania współczesności, Rzeszów, s. 343-354.

Soliński T., Tworzydło D. (red.) (2007), Public Relations - narzędzia przyszłości, Rzeszów.

Stasiński P. (1982), Poetyka i pragmatyka felietonu, Warszawa.

Stasiołek I. (2012), Językowy obraz zmagań pisarskich Teodora Parnickiego na podstawie „Dzienników z lat osiemdziesiątych”, „Język w Komunikacji”, nr 2, s. 111-117.

Stasiuk-Krajewska K. (2011), Budowanie wizerunku wyższych uczelni w kontekście media relations (na przykładzie Wyższej Szkoły Kultury Społecznej i Medialnej w Toruniu), [w:] Stasiuk-Krajewska K., Tworzydło D., Chmielewski Z. (red.), Public Relations - doświadczenia, badania, wątpliwości, Rzeszów, s. 259-282.

Stasiuk-Krajewska K. (2011), Funkcje i struktura dziennikarskiego samoopisu - przypadek „Naszego Dziennika”, [w:] Borkowski I., Stasiuk-Krajewska K. (red.), Kształtowanie wizerunku jako narzędzie Public Relations, Wrocław, s. 41-55.

Stasiuk-Krajewska K., Tworzydło D., Chmielewski Z. (red.) (2011), Public Relations - doświadczenia, badania, wątpliwości, Rzeszów.

Steciąg M. (2006), Informacja, wywiad, felieton. Sposób istnienia tradycyjnych gatunków w radiu komercyjnym, Zielona Góra.

Stojanowska E. (1998), Opisywanie siebie $w$ warunkach autoprezentacji oraz prywatnie. Style autoprezentacji, Warszawa.

Stojanowska E. (red.) (2010), Autoprezentacja dzieci i dorosłych. Temperamentalne, tożsamościowe oraz środowiskowe uwarunkowania, Warszawa.

Stomma L. (2010), Swego rodzaju szlachectwo, [w:] Skworz A., Niziołek A. (red.), Biblia dziennikarstwa, Kraków, s. 640-645.

Szacki J. (2012), Historia myśli socjologicznej, Warszawa. 
Szafraniec J. (2007), Duży sukces małej Ani, czyli reklamowa kampania wizerunkowa na usługach PR, [w:] Soliński T., Tworzydło D. (red.), Public Relations - narzędzia przyszłości, Rzeszów, s. 295-309.

Szczepaniak J. (2007), Wartościowanie w tekście prasowym na przykładzie niemieckiej gazety „Bild-Zeitung”, [w:] Oskiera A. (red.), Antynomie wartości. Problematyka aksjologiczna w językoznawstwie, Łódź, s. 29-38.

Szczepańska K. (2002), Ogłoszenia prasowe "dam pracę" jako identyfikator popytu na rynku pracy ( $w$ świetle analizy zawartości ogłoszeń $w$ „Gazecie Wyborczej"), [w:] Kędzior Z. (red.), Marketing - metody i techniki badawcze, Dąbrowa Górnicza, s. 137-145.

Szmajke A. (1996), Samoutrudnianie jako sposób autoprezentacji: czy rzucanie kłód pod własne nogi jest skuteczna metoda wywierania korzystnego wrażenia na innych?, Warszawa.

Szmajke A. (1999), Maski, pozy, miny, Olsztyn.

Szwichtenberg Z. (2003), Możliwości wykorzystania Public Relations w kreowaniu wizerunku Koszalina przez administrację samorządowa, [w:] Świda J., Tworzydło D. (red.), Public Relations, Rzeszów, s. 279-289.

Szydłowska J. (2004), Besserwisser za katedra, czyli o funkcjach prowokacji w poetyce felietonu, [w:] Napis, seria X, Warszawa, s. 271-279.

Szymanek K. (2005), Sztuka argumentacji. Słownik terminologiczny, Warszawa.

Szymańska A. (2003), Planowanie strategiczne w kreowaniu wizerunku szkoły wyższej, [w:] Świda J., Tworzydło D. (red.), Public Relations, Rzeszów, s. 379-396. Szymański A. (2013), Wizerunek Steve’a Jobsa, „Communication Design Magazine", t. 5-6 [online], http://www.cd-magazine.uni.wroc.pl/artykul/ wizerunek_steve_jobs/(data dostępu: 21.03.2016).

Szymczak R. (2006), Mierzenie efektywności w PR, [w:] Sztuka Public Relations.

$Z$ doświadczeń polskich praktyków, publikacja zbiorowa, Warszawa, s. 265-282.

Ślusarczyk S., Świda J., Tworzydło D. (red.) (2001), Public Relations w ksztattowaniu pozycji konkurencyjnej organizacji, Rzeszów.

Śmigiel Ł. (2011), Strona www - elektroniczna wizytówka pisarza, [w:] Borkowski I., Stasiuk-Krajewska K. (red.), Kształtowanie wizerunku jako narzędzie Public Relations, Wrocław, s. 81-97.

Środa M. (2009), Kobiety i władza, Warszawa.

Świda J., Tworzydło D. (red.) (2003), Public Relations, Rzeszów.

Tarczydło B. (2007), Marketingowa koncepcja kształtowania wizerunku przedsiębiorstwa, [w:] Soliński T., Tworzydło D. (red.), Public Relations - narzędzia przyszłości, Rzeszów, s. 325-336.

Tarczydło B. (2011), Metody pomiaru rezultatów działań Public Relations, [w:] Stasiuk-Krajewska K., Tworzydło D., Chmielewski Z. (red.), Public Relations - doświadczenia, badania, wątpliwości, Rzeszów, s. 89-108. 
Tracy B., Arden R. (2013), Potęga uroku osobistego. Jak zjednywać sobie ludzi, przeł. K. Dumińska, Warszawa.

Trzciałkowska M. (2016), Społeczne konstruowanie wizerunku wegetarianizmu na podstawie triangulacji metodologicznej, [w:] Graszewicz M., Wszołek M. (red.), Teorie komunikacji i mediów 9. Konstrukcje komunikacji i mediów, Wrocław, s. 243-277.

Trzmielak D. (2001), Badanie wizerunku firm na podstawie badań wybranych marek samochodów, [w:] Ślusarczyk S., Świda J., Tworzydło D. (red.), Public Relations w kształtowaniu pozycji konkurencyjnej organizacji, Rzeszów, s. 65-74. Turek P. (2013), Wizerunek Państwowego Muzeum Auschwitz-Birkenau wśród Polaków, którzy rozpoczęli naukę szkolna po 1989 roku, „Communication Design Magazine”, t. 5-6 [online], http://www.cd-magazine.uni.wroc. pl/artykul/wizerunek_muzeum_auschwitz_birkenau_wsrod_polakow/ (data dostępu: 21.03.2016).

Tworzydło D. (2007), Wykorzystanie macierzy celów wizerunkowych w analizie i ocenie sytuacji wyjściowej firmy, [w:] Soliński T., Tworzydło D. (red.), Public Relations - narzędzia przyszłości, Rzeszów, s. 337-344.

Tworzydło D. (2008), Macierz celów wizerunkowych w procesie oceny efektów public relations, Rzeszów.

Tworzydło D. (2010), Tworzenie narzędzi badawczych, [w:] Tworzydło D., Chmielewski Z. (red.), Badania i pomiar efektów w Public Relations, Rzeszów, s. 87-94.

Tworzydło D., Chmielewski Z. (red.) (2010), Badania i pomiar efektów w Public Relations, Rzeszów.

Tworzydło D., Chmielewski Z. (red.) (2010), Public relations w procesie kształtowania relacji z otoczeniem, Kraków-Rzeszów-Zamość.

Tworzydło D., Rymarz W., Górska D. (2004), Wpływ systemu zarządzania jakościa na wizerunek firmy Zeto-Rzeszów Sp. z o.o., [w:] Tworzydło D., Soliński T. (red.), Public Relations - wyzwania współczesności, Rzeszów, s. $223-231$.

Tworzydło D., Soliński T. (red.) (2004), Public Relations - wyzwania współczesności, Rzeszów.

Waszkiewicz A. (2010), Diagnoza wizerunku uczelni wyższej w Polsce a wizerunkowe Public Relations instytucji pożytku publicznego, [w:] Gackowski T., Gackowska A., Dziedzic J. (red.), $P R$ w RP, czyli dwadzieścia lat polskiej branży Public Relations, Warszawa, s. 133-144.

Waszkiewicz A. (2011), Wielowymiarowy wizerunek uczelni wyższej w Polsce - refleksje badawcze, [w:] Stasiuk-Krajewska K., Tworzydło D., Chmielewski Z. (red.), Public Relations - doświadczenia, badania, watpliwości, Rzeszów, s. 239-257. 
Waszkiewicz A. (2013), Metodologie badania wizerunku organizacji pożytku publicznego na przykładzie szkoły wyższej, [w:] Kaczmarczyk M., Widera Z. (red.), Public Relations i marketing $w$ nowoczesnym społeczeństwie, Sosnowiec-Warszawa, s. 123-140.

Wieczorek K. (2007), Kultura w felietonach Daniela Passenta, „Acta Universitatis Lodziensis. Folia Litteraria Polonica”, nr 9, s. 428-445.

Wielgus A., Żukowska M. (2012), Wizerunek palenia i osób palących w wybranych grupach naprzykładzie maturzystów istudentów, [w:] Grech M.(red.), Badanie wizerunku: ludzie, marki, branże, Łódź, s. 111-135.

Wojcik K. (2009), Public Relations. Wiarygodny dialog z otoczeniem. Podręcznik dla teoretyków. Poradnik dla praktyków, Warszawa.

Wojtak M. (2002b), O doskonałości wypowiedzi publicystycznej na przykładzie felietonów J. Szczepkowskiej, [w:] Maliszewska A. (red.), O doskonałości, cz. 1, Łódź, s. 377-392.

Wojtak M. (2004), Felieton - informacja zakamuflowana, [w:] tejże, Gatunki prasowe, Lublin, s. 202-237.

Wojtak M. (2007), Rozrywka w prasie codziennej - wybrane aspekty, [w:] Mazur J., Rumińska M. (red.), Humor i karnawalizacja we współczesnej komunikacji językowej, Lublin, s. 39-49.

Wojtak M. (2010a), Pisać felietonowo to koniecznie pisać felietony?, [w:] tejże, Analiza gatunków prasowych, Lublin, s. 109-121.

Wojtak M. (2010b), Głosy indywidualistów, [w:] Głosy z teraźniejszości. O języku współczesnej polskiej prasy, Lublin, s.143-158.

Wojtak M. (2010c), Styl dziennikarstwa prasowego w perspektywie dyskursywnej, [w:] Bogołębska B., Worsowicz M. (red.), Styl - dyskurs - media, Łódź, s. 81-91.

Wojtak M. (2011), O relacjach dyskursu, stylu, gatunku i tekstu, „Tekst i Dyskurs", nr 4, s. 69-78.

Wojtak M. (2015a), Językoznawca na medialnym polu badawczym, [w:] tejże, Rozłożone gazety. Studia z zakresu prasowego dyskursu, języka i stylu, Lublin, s. 15-29.

Wojtak M. (2015b), Stylistyczne ukształtowanie gatunków prasowych, [w:] tejże, Rozłożone gazety. Studia z zakresu prasowego dyskursu, języka i stylu, Lublin, s. 45-61.

Wojtak M. (2015e), Komizm we współczesnej polskiej prasie, [w:] tejże, Rozłożone gazety. Studia z zakresu prasowego dyskursu, języka i stylu, Lublin, s. 151-170.

Wojtak M. (2015g), Współczesnej publicystki prasowej oblicza różne, [w:] tejże, Rozłożone gazety. Studia z zakresu prasowego dyskursu, języka i stylu, Lublin, s. 203-217.

Wojtak M. (2015h), Przejawy mody w sposobie kształtowania informacyjnych gatunków prasowych, [w:] tejże, Rozłożone gazety. Studia z zakresu prasowego dyskursu, języka i stylu, Lublin, s. 63-80. 
Wojtak M. (2015i), Kolaże tekstowe jako forma komunikacji publicystycznej, [w:] tejże, Rozłożone gazety. Studia z zakresu prasowego dyskursu, języka i stylu, Lublin, s. 171-187.

Wolny-Zmorzyński K., Kaliszewski A., Furman W. (2006), Gatunki dziennikarskie. Teoria, praktyka, język, Warszawa.

Worsowicz M. (2002), Faits divers - inforozrywka w prasie, „Acta Universitatis Lodzensis. Folia Litteraria Polonica", nr 5, s. 253-259.

Wójcik P. (2007), Eksperyment w badaniach marketingowych, [w:] Maison D., Noga-Bogomilski A. (red.), Badania marketingowe. Od teorii do praktyki, Gdańsk, s. 135-152.

Wójtowicz-Dawid A. (2011), Wizerunek - wybrane zagadnienia, [w:] Stasiuk-Krajewska K., Tworzydło D., Chmielewski Z. (red.), Public Relations - doświadczenia, badania, wątpliwości, Rzeszów, s. 47-70.

Wszołek M. (2010), Mity i kity komunikacji, mediów i reklamy, [w:] Gackowski T., Gackowska A., Dziedzic J. (red.), PR w RP, czyli dwadzieścia lat polskiej branży Public Relations, Warszawa, s. 154-162.

Wszołek M. (2013), Kognitywny wizerunek wrocławskiej Galerii Wnętrz, „Communication Design Magazine”, t. 5-6 [online], http://www.cd-magazine.uni.wroc.pl/artykul/kognitywny_wizerunek_galerii_wnetrz/ (data dostępu: 21.03.2016).

Wszołek M. (2013), Scenariusze autoprezentacyjne $w$ kulturze polskiej, [w:] Grech M., Siemes A. (red.), Badanie i projektowanie komunikacji 2, Wrocław, s. 143-154.

Wszołek M. (2015), Reklama. Operacjonalizacja pojęcia, Kraków.

Wszołek M., Moszczyński K., Mackiewicz P. (2017), Wpływ barwy i etykiety opakowań na postrzeganie produktu - wyniki badań empirycznych, [w:] Badanie i projektowanie komunikacji 6. Tom dedykowany, Wrocław, s. $77-122$.

Wydrzyńska M. (2010), Procedura realizacji badań, [w:] Tworzydło D., Chmielewski Z. (red.), Badania i pomiar efektów w Public Relations, Rzeszów, s. 69-85.

Zemanek E. (2017), Badanie wizerunku uczelni w zakresie tzw. komunikacji wizualnej (case study), [w:] Badanie i projektowanie komunikacji 6. Tom dedykowany, Wrocław, s. 355-394.

http://natemat.pl/58399,szymon-holownia-bedzie-pisal-w-rzeczpospolitej (data dostępu: 12.04.2016).

http://polska.newsweek.pl/---newsweek-odpowiada--polemika-z-szymonem-holownia,94588,1,1.html (data dostępu: 12.04.2016).

http://wiadomosci.onet.pl/kraj/szymon-holownia-odchodzi-z-wprost/gje9g (data dostępu: 12.04.2016). 
http://www.gazetaprawna.pl/galerie/694136,duze-zdjecie,1, holownia-odchodzi-z-wprost-z-powodu-in-vitro-mainstream-relegowal-mnie-ze-swych-szeregow.html (data dostępu: 12.04.2016).

http://www.internetpr.pl/pr_wiedza/z_mediow/art3006,szymon-holownia-bedzie-pisal-do-rzeczpospolitej.html (data dostępu: 12.04.2016).

http://www.rmf24.pl/news-holownia-odchodzi-z-wprost,nId,950766 (data dostępu: 12.04 .2016$)$.

http://www.wiadomosci24.pl/artykul/holownia_odchodzi_z_wprost_poszlo_o_poglady_265669.html (data dostępu: 12.04.2016).

http://www.wirtualnemedia.pl/artykul/ikonowicz-zarzeczny-kot-i-urbanski-w-uwazam-rze (data dostępu: 21.03.2016).

http://www.wirtualnemedia.pl/artykul/szymon-holownia-odchodzi-z-newsweeka\# (data dostępu: 12.04.2016).

http://www.wirtualnemedia.pl/artykul/szymon-holownia-odchodzi-z-newsweeka\# (data dostępu: 12.04.2016).

http://wyborcza.pl/1,76842,12950426,_Uwazam_Rze_i__w_Sieci__czyli_ konflikty_medialnej.html (data dostępu: 21.03.2016). http://wyborcza.pl/1,76842,14388168,Wraca__W_Sieci__Bracia_Karnowscy_wygrali_w_sadzie.html (data dostępu: 12.04.2016). 


\section{Spis tabel}

Tabela 1. Triadyczne szeregi w koncepcji trzech rzeczywistości

Tabela 2. Realizacja pytań badawczych w poszczególnych wariantach lub częściach badania

Tabela 3. Układ i kolejność felietonistów, których dotyczyły pytania w poszczególnych grupach i wariantach badania

Tabela 4. Układ wariantów i brzmienie pytań w każdej grupie na przykładzie badania wizerunku werbalnego Krzysztofa Vargi, wizualnego Piotra Zaremby oraz publicznego Piotra Zaremby i Magdaleny Środy

Tabela 5. Analogiczne brzmienie pytań dotyczących wizerunku oraz wykładników cech przypisanych felietonistom

Tabela 6. Zdjęcia dołączane przez redakcje do felietonów w tekstach, które pojawity się w badaniu

Tabela 7. Miejsce realizacji badania w każdej z trzech tur czasowych oraz ilościowy udział studentów poszczególnych kierunków

Tabela 8. Liczba i płeć respondentów z uwzględnieniem miejsca i czasu badania oraz kierunku i roku studiów

Tabela 9. Zestawienie odpowiedzi respondentów czytających tekst anonimowego autora (Krzysztofa Vargi) na pytanie: „Mając za podstawę tekst przeczytanego felietonu, jakimi słowami opisałby Pan / opisałaby Pani autora tego tekstu?"

Tabela 10. Kategorie komunikowanego werbalnie wizerunku anonimowego felietonisty - Krzysztofa Vargi

Tabela 11. Zestawienie odpowiedzi na pytanie „Jakimi słowami scharakteryzował(a)by Pan/Pani osobę publiczną Krzysztofa Vargę?"

Tabela 12. Kategorie wizerunku publicznego Krzysztofa Vargi

Tabela 13. Zestawienie odpowiedzi osób nieznających nazwiska Krzysztofa Vargi na pytanie: „Mając za podstawę przedstawione zdjęcie, jakimi słowami opisałby Pan / opisałaby Pani przedstawioną na tej fotografii osobę?" 
Tabela 15. Zestawienie odpowiedzi na pytanie: „Mając za podstawę tekst przeczytanego felietonu, jakimi słowami opisałby Pan / opisałaby Pani autora Krzysztofa Vargę?"

Tabela 16. Kategorie komunikowanego werbalnie wizerunku felietonisty o znanej tożsamości - Krzysztofa Vargi

Tabela 17. Zestawienie odpowiedzi respondentów czytających tekst anonimowego autora (Piotra Zaremby) na pytanie: „Mając za podstawę tekst przeczytanego felietonu, jakimi słowami opisałby Pan / opisałaby Pani autora tego tekstu?"

Tabela 18. Kategorie komunikowanego werbalnie wizerunku anonimowego felietonisty - Piotra Zaremby

Tabela 19. Zestawienie odpowiedzi na pytanie: „Jakimi słowami scharakteryzował(a)by Pan/Pani osobę publiczną Piotra Zarembę?"

Tabela 20. Kategorie wizerunku publicznego Piotra Zaremby

Tabela 21. Zestawienie odpowiedzi osób rozpoznających na zdjęciu Piotra Zarembę na pytanie: „Mając za podstawę przedstawione zdjęcie, jakimi słowami opisałby Pan / opisałaby Pani przedstawioną na tej fotografii osobę?"

Tabela 22. Zestawienie odpowiedzi osób, które zadeklarowały brak pewności co do tożsamości mężczyzny ze zdjęcia (Piotra Zaremby), na pytanie: „Mając za podstawę przedstawione zdjęcie, jakimi słowami opisałby Pan / opisałaby Pani przedstawioną na tej fotografii osobę?"

Tabela 23. Zestawienie odpowiedzi osób, które zadeklarowały całkowity brak znajomości mężczyzny ze zdjęcia (Piotra Zaremby), na pytanie: „Mając za podstawę przedstawione zdjęcie, jakimi słowami opisałby Pan / opisałaby Pani przedstawioną na tej fotografii osobę?"

Tabela 24. Kategorie wizerunku wizualnego Piotra Zaremby

Tabela 25. Zestawienie odpowiedzi na pytanie: „Mając za podstawę tekst prze-

czytanego felietonu, jakimi słowami opisałby Pan/ opisałaby Pani autora Piotra Zarembę?"

Tabela 26. Kategorie komunikowanego werbalnie wizerunku felietonisty o jawnej tożsamości - Piotra Zaremby

Tabela 27. Zestawienie odpowiedzi respondentów czytających tekst anonimo-

wego autora (Magdaleny Środy) na pytanie: „Mając za podstawę tekst przeczytanego felietonu, jakimi słowami opisałby Pan / opisałaby Pani autorkę tego tekstu?"

Tabela 28. Kategorie komunikowanego werbalnie wizerunku anonimowego felietonisty - Magdaleny Środy

Tabela 29. Zestawienie odpowiedzi osób potwierdzających znajomość osoby

publicznej Magdaleny Środy na pytanie „Jakimi słowami

scharakteryzował(a)by Pan/Pani osobę publiczną Magdalenę Środę?"

Tabela 30. Kategorie wizerunku publicznego Magdaleny Środy 
Tabela 31. Zestawienie odpowiedzi osób rozpoznających na zdjęciu Magdalenę Środę na pytanie: „Mając za podstawę przedstawione zdjęcie, jakimi słowami opisałby Pan / opisałby Pani przedstawioną na tej fotografii osobę?" 134

Tabela 32. Kategorie wizerunku wizualnego Magdaleny Środy w sytuacji rozpoznania przez respondentów osoby ze zdjęcia

Tabela 33. Zestawienie odpowiedzi osób, które zadeklarowały całkowity brak znajomości kobiety ze zdjęcia (Magdalena Środa), na pytanie: „Mając za podstawę przedstawione zdjęcie, jakimi słowami opisałby Pan / opisałby Pani przedstawioną na tej fotografii osobę?"

Tabela 34. Kategorie wizerunku wizualnego Magdaleny Środy w sytuacji braku rozpoznania przez respondentów tożsamości osoby ze zdjęcia

Tabela 35. Bloki semantyczne wizerunków wizualnych Magdaleny Środy wśród osób poprawnie identyfikujących ją na zdjęciu i respondentów jej nierozpoznających

Tabela 36. Zestawienie odpowiedzi na pytanie: „Mając za podstawę tekst przeczytanego felietonu, jakimi słowami opisałby Pan / opisałaby Pani autorkę Magdalenę Środę?"

Tabela 37. Kategorie komunikowanego werbalnie wizerunku felietonisty o znanej tożsamości - Magdaleny Środy

Tabela 38. Bloki semantyczne obu wizerunków werbalnych Magdaleny Środy 151

Tabela 39. Zestawienie odpowiedzi respondentów czytających tekst anonimowego autora (Szymona Hołowni) na pytanie: „Mając za podstawę tekst przeczytanego felietonu, jakimi słowami opisałby Pan / opisałaby Pani autora tego tekstu?"

Tabela 40. Bloki semantyczne wizerunku werbalnego anonimowego dla czytelników Szymona Hołowni

Tabela 41. Kategorie komunikowanego werbalnie wizerunku felietonisty o anonimowej tożsamości - Szymona Hołowni

Tabela 42. Zestawienie odpowiedzi osób potwierdzających znajomość osoby publicznej Szymona Hołowni na pytanie: „Jakimi słowami scharakteryzował(a)by Pan/Pani osobę publiczną Szymona Hołownię?"

Tabela 43. Bloki semantyczne wizerunku publicznego Szymona Hołowni

Tabela 44. Kategorie wizerunku publicznego Szymona Hołowni

Tabela 45. Zestawienie odpowiedzi osób rozpoznających na zdjęciu Szymona Hołownię na pytanie: „Mając za podstawę przedstawione zdjęcie, jakimi słowami opisatby Pan / opisałaby Pani przedstawioną na tej fotografii osobę?"

Tabela 46. Bloki semantyczne wizerunku wizualnego rozpoznawanego przez respondentów Szymona Hołowni

Tabela 47. Kategorie wizerunku wizualnego Szymona Hołowni w sytuacji rozpoznania przez respondentów osoby ze zdjęcia 
Spis tabel

Tabela 48. Zestawienie odpowiedzi na pytanie: „Mając za podstawę tekst przeczytanego felietonu, jakimi słowami opisałby Pan / opisałaby Pani autora Szymona Hołownię?"

Tabela 49. Bloki semantyczne w obu wizerunkach werbalnych Szymona Hołowni

Tabela 50. Kategorie komunikowanego werbalnie wizerunku felietonisty o znanej tożsamości - Szymona Hołowni

Tabela 51. Zestawienie cech wizerunkowych z uwzględnieniem wszystkich typów i kategorii wizerunku

Tabela 52. Cechy wspólne felietonistom lub specyficzne dla jednego z nich w wizerunkach werbalnych

Tabela 53. Cechy wspólne felietonistom lub specyficzne dla jednego z nich w wizerunku publicznym

Tabela 54. Cechy wspólne felietonistom lub specyficzne dla jednego z nich w wizerunkach wizualnych 


\section{Aneks 1}

\section{Spis wykorzystanych w badaniu felietonów}

\begin{tabular}{|c|c|c|c|}
\hline \multicolumn{4}{|c|}{ KRZYSZTOF VARGA } \\
\hline \multicolumn{4}{|c|}{ jesień 2013} \\
\hline lp. & tytuł felietonu & $\begin{array}{l}\text { data wydania } \\
\text { / nr wydania / strona }\end{array}$ & tygodnik \\
\hline 1. & Rozmowy kontrolowane, czyli śledź się sam & 03.10 .2013$, nr 231 , s. 3 & \multirow{7}{*}{ „Duży Format” } \\
\hline 2. & Ciotka ideologia, czyli pisarze prawi i lewi & 26.09.2013, nr 225, s. 3 & \\
\hline 3. & Ocieranie się, czyli sztuka stuszna i niska & 19.09.2013, nr 219, s. 3 & \\
\hline 4. & $\begin{array}{l}\text { Kibolskie braterstwo, czyli polsko-wegierska przy- } \\
\text { jaźń kwitnie }\end{array}$ & $12.09 .2013, \mathrm{nr} 213, \mathrm{s.} 3$ & \\
\hline 5. & Bolszewika goń, czyli zabawa łosiami & 05.09.2013, nr 207, s. 3 & \\
\hline 6. & Piękno Gomułki, czyli reglamentować zdjęcia & 29.08 .2013$, nr 209, s. 3 & \\
\hline 7. & Szatan wymiata, czyli iluminaci grają rocka & 22.08.2013, nr 195, s. 3 & \\
\hline \multicolumn{4}{|c|}{ wiosna 2013} \\
\hline 1. & Trzech kumpli czyli upiorna Mitteleuropa & $29.05 .2013, \mathrm{nr} 124$, s. 24 & \multirow{7}{*}{ „Duży Format” } \\
\hline 2. & Sztuka blasfemii czyli Bogu dzięki za bluźnierców & 23.05.2013, nr 119, s. 16 & \\
\hline 3. & Brzechwa dzieciofob czyli kompleks bajkopisarza & 16.05.2013, nr 113, s. 16 & \\
\hline 4. & Fikcja to real czyli politycy do warzywniaków & 09.05.2013, nr 107, s. 16 & \\
\hline 5. & Papieżz poliestru czyli pogański biznes & 02.05 .2013$, nr 102, s. 16 & \\
\hline 6. & Wielka Łopata czyli sztuka w stużbie idei & 25.04.2013, nr 97, s. 16 & \\
\hline 7. & Premier pisze do Dody czyli taniec na minach & 18.04.2013, nr 91, s. 16 & \\
\hline \multicolumn{4}{|c|}{ wiosna 2012} \\
\hline 1. & Szela był cool, czyli rżnać neoliberałów & 17.05 .2012 , nr 114 , s. 23 & \multirow{2}{*}{ „Duży Format” } \\
\hline 2. & Rafalski, odwagi! czyli Ziemkiewicz heroiczny & 10.05 .2012$, nr 108, s. 23 & \\
\hline
\end{tabular}




\begin{tabular}{|c|c|c|c|}
\hline lp. & tytuł felietonu & $\begin{array}{c}\text { data wydania } \\
\text { / nr wydania / strona }\end{array}$ & tygodnik \\
\hline 3. & Romantyzm polski, czyli wszystko to literatura & 26.04.2012, nr 98, s. 23 & \multirow{5}{*}{ „Duży Format” } \\
\hline 4. & Pod mocnym Pilchem, czyli „Dziennik” wstrząsa & 19.04.2012, nr 92, s. 23 & \\
\hline 5. & Czytanie nakazane, czyli format nadciaga & 12.04.2012, nr 86, s. 23 & \\
\hline 6. & Klątwa Klossa, czyli ofiary adoracji & 29.03.2012, nr 75, s. 23 & \\
\hline 7. & Chcę przykrości, czyli Miron i Sandauer & $22.03 .2012, \mathrm{nr} 69$, s. 23 & \\
\hline
\end{tabular}

\begin{tabular}{|c|c|c|c|}
\hline \multicolumn{4}{|c|}{ PIOTR ZAREMBA } \\
\hline \multicolumn{4}{|c|}{ jesień 2013} \\
\hline lp. & tytul felietonu & $\begin{array}{c}\text { data wydania } \\
\text { / nr wydania / strona }\end{array}$ & tygodnik \\
\hline 1. & Historyczne jaja Sekielskiego & 39/2013, s. 58 & \multirow{7}{*}{ „W Sieci” } \\
\hline 2. & Dwie aktorki: studium zagubienia & 38/2013, s. 58 & \\
\hline 3. & Jak John Adams został Amerykaninem & $37 / 2013$, s. 58 & \\
\hline 4. & Kiedyś to byly seriale... I sa! & $36 / 2013$, s. 62 & \\
\hline 5. & Jogurt musi splywać, pani aktorko & 35/2013, s. 69 & \\
\hline 6. & „Tango" Mrożka dzieje się dziś & $34 / 2013$, s. 73 & \\
\hline 7. & „Bonanza” - utracone dzieciństwo & $33 / 2013$, s. 71 & \\
\hline \multicolumn{4}{|c|}{ wiosna 2013} \\
\hline 1. & Prawda tamtego pokolenia & $22 / 2013$, s. 47 & \multirow{7}{*}{ „Sieci” } \\
\hline 2. & $\begin{array}{l}\text { Angielskie pogwarki czyli świetny „Downton } \\
\text { Abbey” }\end{array}$ & $21 / 2013$, s. 51 & \\
\hline 3. & Gdy Wajda był młody... & 20/2013, s. 49 & \\
\hline 4. & Anna German w paru nutach & 19/2013, s. 45 & \\
\hline 5. & Hrabia Fredro krzepi & $18 / 2013$, s. 51 & \\
\hline 6. & Serialowy powrót kanibala & 16-17/2013, s. 77 & \\
\hline 7. & Debata przegrywa $z$ karaluchem & $15 / 2013$, s. 51 & \\
\hline \multicolumn{4}{|c|}{ wiosna 2012} \\
\hline 1. & Ostatnie zwycięstwo mediów nad złem & 19/2012, s. 45. & \multirow{7}{*}{ „Uważam Rze” } \\
\hline 2. & Zabójstwo tuż przy rodzinnym obiedzie & $17-18 / 2012$, s. 51 & \\
\hline 3. & Niech będzie i Rzymianin $z$ broda & 16/2012, s. 52 & \\
\hline 4. & $\begin{array}{l}\text { Kim była siostra Henryka VIII, czyli o wier- } \\
\text { ności faktom }\end{array}$ & 15/2012, s. 55 & \\
\hline 5. & Elektrownie w kisielu & 13/2012, s. 45 & \\
\hline 6. & Okładanie po głowie & $12 / 2012$, s. 45 & \\
\hline 7. & Kaczyński widział świat $z$ „Domu złego” & 11/2012, s. 44 & \\
\hline
\end{tabular}




\begin{tabular}{|c|c|c|c|}
\hline \multicolumn{4}{|c|}{ MAGDALENA ŚRODA } \\
\hline \multicolumn{4}{|c|}{ jesień 2013} \\
\hline lp. & tytuł felietonu & $\begin{array}{c}\text { data wydania } \\
\text { / nr wydania / strona }\end{array}$ & tygodnik \\
\hline 1. & Arcybiskup Michalik Macierewiczem Kościoła & 43/2013, s. 4 & \multirow{7}{*}{ „Wprost” } \\
\hline 2. & Zseksualizowane dzieci & $42 / 2013$, s. 4 & \\
\hline 3. & Widmo krąży po Europie (i Białymstoku) & $41 / 2013$, s. 38 & \\
\hline 4. & Straszna wolność & 40/2013, s. 6 & \\
\hline 5. & Magowie, eksperci i etyka & 39/2013, s. 4 & \\
\hline 6. & Poset i jego (duże) dobra osobiste & $38 / 2013$, s. 4 & \\
\hline 7. & Polska prawica stoi & 37/2013, s. 12 & \\
\hline \multicolumn{4}{|c|}{ wiosna 2013} \\
\hline 1. & Ofensywa rynsztoka pod skrzydłami PiS & $22 / 2013$, s. 42 & \multirow{7}{*}{ „Wprost” } \\
\hline 2. & Świat na opak wywrócony! & 20/2013, s.19 & \\
\hline 3. & Kościół błądzi & $16 / 2013$, s. 45 & \\
\hline 4. & Co $z$ tym Kongresem & $15 / 2013$, s. 33 & \\
\hline 5. & Kukiz zbliża się & $13 / 2013$, s. 52 & \\
\hline 6. & Zespół 39 & $12 / 2013$, s. 41 & \\
\hline 7. & O Polkę niepodległą! & 11/2013, s. 53 & \\
\hline \multicolumn{4}{|c|}{ wiosna 2012} \\
\hline 1. & Gdy się baby nie bije... & 21/2012, s. 44 & \multirow{7}{*}{ „Wprost” } \\
\hline 2. & Co można zrobić za 2,6 mln zł? & 20/2012, s. 48 & \\
\hline 3. & Rzecz o myśleniu & 19/2012, s. 44 & \\
\hline 4. & Polityk inteligentny inaczej? & 18/2012, s. 40 & \\
\hline 5. & Z kim na pochód 1 maja? & 17/2012, s. 38 & \\
\hline 6. & PO-PiS wiecznie żywy! & $16 / 2012$, s. 32 & \\
\hline 7. & Polski seks typu A & 15/2012, s. 44 & \\
\hline
\end{tabular}

\begin{tabular}{|c|c|c|c|}
\hline \multicolumn{4}{|c|}{ SZYMON HOŁOWNIA } \\
\hline \multicolumn{4}{|c|}{ jesień 2013} \\
\hline lp. & tytuł felietonu & $\begin{array}{c}\text { data wydania } \\
\text { / nr wydania / strona }\end{array}$ & $\begin{array}{l}\text { tygodnik/ } \\
\text { dziennik }\end{array}$ \\
\hline 1. & Kardynat na froncie & $12-13.10 .2013$, nr 239 , s. 2 & \multirow{7}{*}{ „Rzeczpospolita” } \\
\hline 2. & Nie zarazić się złem & 5-6.10.2013, nr 233, s. 2 & \\
\hline 3. & Terror na własne życzenie & 28-29.09.2013, nr 227, s. 2 & \\
\hline 4. & Ksiądz powietrzem się nie wyżywi & 21-22.09.2013, nr 220, s. 2 & \\
\hline 5. & Jest jeszcze Opatrzność & 14-15.09.2013, nr 215, s. 2 & \\
\hline 6. & Być działaczem & 7-8.09.2013, nr 209, s. 2 & \\
\hline 7. & Zamienić mieszkania w kościoły & 24-25.08.2013, nr 197, s. 2 & \\
\hline
\end{tabular}




\begin{tabular}{|c|c|c|c|}
\hline lp. & tytuł felietonu & $\begin{array}{c}\text { data wydania } \\
\text { / nr wydania / strona }\end{array}$ & $\begin{array}{l}\text { tygodnik/ } \\
\text { dziennik }\end{array}$ \\
\hline \multicolumn{4}{|c|}{ wiosna 2013} \\
\hline 1. & Grillowanie papieża & $12 / 2013$, s. 74 & \multirow{7}{*}{ „Wprost” } \\
\hline 2. & To nie piekarnia & 11/2013, s. 69 & \\
\hline 3. & Przed Konklawe & 10/2013, s. 57 & \\
\hline 4. & Hotelowa Biblia & 9/2013, s. 39 & \\
\hline 5. & Gdy rozum się martwi & 8/2013, s. 59 & \\
\hline 6. & Krzyż a sprawa polska & 4/2013, s. 53 & \\
\hline 7. & Prymas pokorny & 5/2013, s. 23 & \\
\hline \multicolumn{4}{|c|}{ wiosna 2012} \\
\hline 1. & O. Rydzyk jest naszym lustrem & 20/2012, s. 31 & \multirow{7}{*}{ „Newsweek” } \\
\hline 2. & Wartość tradycji & $19 / 2012$, s. 38 & \\
\hline 3. & Zrozumieć dom & 18/2012, s. 74 & \\
\hline 4. & Sumienie na recepte & $17 / 2012$, s. 40 & \\
\hline 5. & Katociotość & $16 / 2012$, s. 36 & \\
\hline 6. & Miejscówka w raju & 15/2012, s. 18 & \\
\hline 7. & Burczenie w brzuchu & $13 / 2012$, s. 75 & \\
\hline
\end{tabular}




\section{Aneks 2}

Przykłady kart odpowiedzi dla każdego z wariantów badania

\section{Wariant 1 (sam tekst)}

\section{Oryginalnie kartka A5 w orientacji poziomej}

Mając za podstawę tekst przeczytanego felietonu, jakimi słowami opisałby Pan / opisałaby Pani autora tego tekstu?

1)

2)

3)

4)

5)

tytuł felietonu: 
Aneks 2

Oryginalnie kartka A5 w orientacji poziomej

Mając za podstawę tekst przeczytanego felietonu, jakimi słowami opisałby Pan / opisałaby Pani autorkę tego tekstu?

1)

2)

3)

4)

5)

tytuł felietonu: 


\section{Oryginalnie kartka A5 w orientacji pionowej}

Proszę do każdej wskazanej przez Pana/Panią cechy autora felietonu wypisać z tekstu słowa/zdania/fragmenty, które stały się podstawą do wyłonienia danej cechy.

1)

2)

3)

4)

5) 
Aneks 2

\section{Oryginalnie kartka A5 w orientacji poziomej}

Czy wiesz, kto jest autorem tekstu?

Proszę zakreślić swoją odpowiedź krzyżykiem (

$\square$ TAK, wiem (kto?)

$\square$ Nie jestem pewny/pewna - wydaje mi się, że autorem może być (kto?)

$\square$ NIE, nie wiem.

Wariant 2 (tekst + zdjęcie + nazwisko)

\section{Oryginalnie kartka A5 w orientacji poziomej}

Mając za podstawę tekst przeczytanego felietonu, jakimi słowami opisałby Pan / opisałaby Pani autora Krzysztofa Vargę?

1)

2)

3)

4)

5)

tytuł felietonu: 
Aneks 2

Oryginalnie kartka A5 w orientacji poziomej

Mając za podstawę tekst przeczytanego felietonu, jakimi słowami opisałby Pan / opisałaby Pani autora Piotra Zarembę?

1)

2)

3)

4)

5)

tytuł felietonu: 
Aneks 2

\section{Oryginalnie kartka A5 w orientacji pionowej}

Proszę do każdej wskazanej przez Pana/Panią cechy Krzysztofa Vargi wypisać z tekstu słowa/zdania/fragmenty, które stały się podstawą do wyłonienia danej cechy.

1)

2)

3)

4)

5) 
Aneks 2

Wariant 3 (zdjęcie)

Oryginalnie kartka A4 w orientacji pionowej

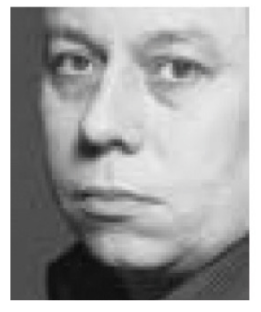


Aneks 2

Oryginalnie kartka A4 w orientacji pionowej

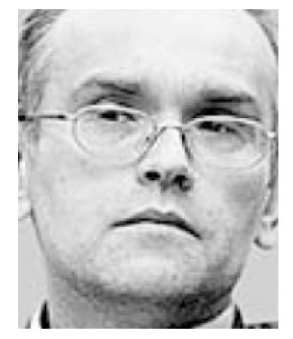


Aneks 2

Oryginalnie kartka A4 w orientacji pionowej

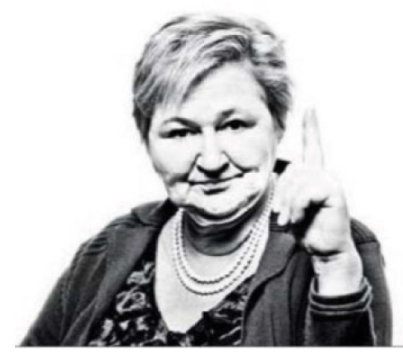


Aneks 2

Oryginalnie kartka A4 w orientacji pionowej

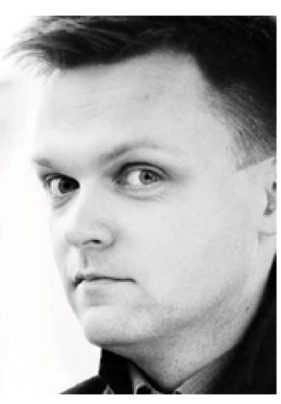


Aneks 2

\section{Oryginalnie kartka A5 w orientacji poziomej}

Mając za podstawę przedstawione zdjęcie, jakimi słowami opisałby Pan / opisałaby Pani przedstawioną na tej fotografii osobę?

1)

2)

3)

4)

5)

Czy wie Pan/Pani, kogo przedstawia zdjęcie?

- TAK $\square$ kogo?.

- Nie jestem pewny/pewna, ale wydaje mi się, że może to być (kto?).

- NIE 
Aneks 2

Wariant 4 (nazwisko)

\section{Oryginalnie kartka A5 w orientacji poziomej}

1. Czy zna Pan/Pani nazwisko: Piotr Zaremba? Proszę zakreślić swoją odwiedź krzyżykiem (凶).

$\square$ TAK. Jeśli tak, proszę przejść do pytania nr 2.

$\square$ NIE. Jeśli nie, proszę schować kartkę do teczki.

2. Jakimi słowami scharakteryzował(a)by Pan/Pani osobę publiczną Piotra Zarembę?

1)

2)

3)

4)

5) 


\section{Aneks 3}

Przykładowe karty z felietonami z wariantu 1 (sam tekst) 


\section{Rozmowy kontrolowane, czyli śledź się sam}

Tak bardzo chcemy, aby nas śledzono, że wciąż informujemy, gdzie się znajdujemy i co właśnie zjedliśmy, właściwie to nie możemy wytrzymać w sytuacji, gdy chwilowo nikt nas nie śledzi

Podobno wielce modne jest obecnie wypisywanie się z Facebooka, no ale przecież żeby się modnie wypisać z Facebooka, wcześniej trzeba się do niego było modnie zapisać. Tak czy owak - szansa na bycie modnym znów mnie ominęła, bo nawet chętnie bym się wypisał z Facebooka, gdyby nie to, że nigdy się do niego nie zapisałem. Naturalnie mógłbym się szybko zapisać po to, żeby się równie szybko wypisać, ale obawiam się, że akurat jak się będę wypisywał, to wszyscy na powrót znów się będą zapisywać, bo się trend odwróci, w dzisiejszych czasach trendy, jak wiadomo, odwracają się opętańczo szybko.

Rozumiem jednak tę emocję bycia na Facebooku, ja nawet stoczyłem sam ze sobą burzliwą walkę, gdyż czułem wyraźne pokuszenie, aby relacje z ludźmi przenieść na poziom wirtualny, a - spowiedzi ciąg dalszy - zdarza się, że będąc w towarzystwie kogoś, kto właśnie swoje konto na fejsie przegląda, podczytuję skrycie, a nawet czasam żądam, aby mi wszelakie wpisy pokazać, bo ciekawi mnie, co ludzie mają tam do powiedzenia, jakie zdjęcia wrzucają, jakie historie snują, jakie sensacje ujawniają. Rozumiem dobrze, że każdy chętnie pozbędzie się części swojej prywatności, byle tam być, wśród wirtualnych przyjaciół, którzy coraz bardziej są atrakcyjni od tych realnych.

Dziwna rzecz - o ile zazwyczaj z podglądacką przyjemnością czytam dzienniki pisarzy, zarówno te publikowane dopiero $w$ dekady po śmierci, jak i te z premedytacją pisane, by wydać je za życia, tomy korespondencji nijak mnie nie pociągają, fundamentalnie nie ciekawi mnie epistolografia choćby i największych umysłów, prawidłowości tej nie umiem rozpracować i wytłumaczyć, jakoś mi się zdaje, że list jest z zasady tylko dla oczu adresata przeznaczony, że wszelakie ujawnianie korespondencji, osobliwie tej intymnej, trąci o obleśność, a wręcz o rodzaj inwigilacji tłumaczonej szlachetnym zamiarem przybliżenia spuścizny wielkich ludzi. Często jednak przecież idzie o to, aby pokazać też owych wielkich ludzi małość, nic nie robi nam takiej przyjemności jak to, gdy możemy sobie z ulgą powiedzieć, że nawet najporządniejszy człowiek to po prawdzie tylko świnia, gdyż wtedy nasza własna świńskość jakoś jest usprawiedliwiona. Czytanie cudzych listów obmierzłe mi się wydaje, być może dlatego że pamiętam, iż kiedyś specjalni byli urzędnicy przeznaczeni do czytania cudzej korespondencji.

Podaję tu tę garść mało odkrywczych refleksji, gdyż temat inwigilacji staje się jednym z tematów dziś wiodących, wciąż dowiadujemy się, że nasze wpisy na Facebooku, listy elektroniczne i rozmowy telefoniczne śledzone są przez tajne agencje, ale i przez korporacje, które odpowiednio nas profilują, że nawet jeśli nam się wydaje, że jesteśmy schowani za gardą swej prywatności, to i tak znaczy to tylko tyle, że ci, co mają o nas coś wiedzieć, to i tak wszystko wiedzą, to także dzięki Facebookowi i Google'owi się dzieje, które śledzą nas w pewnym sensie na naszą prośbę. Nie jest to najnowsze odkrycie, ale jeśli temat podejmuje Zygmunt Bauman, to ja się zaczynam tym od razu mocniej interesować. "Płynna inwigilacja" to rozmowy z Baumanem, które przeprowadził socjolog David Lyon, jak zawsze wszystko, co mówi Bauman, jest ciekawe, w przeciwieństwie do wszystkiego, co ostatnio mówili o Baumanie ci, którzy go nigdy nie czytali, ale mieli wyrobione zdanie. Osobliwie wśród kibiców piłkarskich i innych niepokornych oraz wyklętych Bauman był żywo komentowany, choć niepodparte te komentarze były jego lekturą, jak wiadomo, najlepiej wyrabia się sobie zdanie nie przez czytanie, ale przez osmozę cudzych poglądów.

Przyznaję, że wolę, jak Bauman sam pisze, niż jak daje wywiady, wszystkie jego samodzielnie napisane książki ocierają się mocno o słowo objawione, w wywiadach czy też nawet bardziej w rozmowach rzekach rzecz się często zbyt przechyla w naukową hermetyczność. Tak jest też nieco w przypadku "Płynnej inwigilacji", ale jednak przecież Bauman wciąż mówi nam tu rzeczy zasadnicze, mocno trzyma rękę na pulsie nowoczesności, a jak wiadomo, ten puls jest coraz bardziej nierówny.

"Nasze prawo do prywatności wydajemy na rzeź z własnej woli" - powiada Bauman, komentując życie na Facebooku. Dziwna to jest potrzeba, aby samemu się zgłosić na rzeź, ale tak właśnie jest, myślę, że to jest kwestia kłopotów naszych z wolnością. Bo nie będzie pewnie odkryciem, że mamy problem z wolnością, z wolnością nie do końca sobie radzimy, zapewne jest to zasiedziałość jakaś ewolucyjna, zaskorupiały atawizm po przodkach, z których przecież większość nawet o wolności nie myślała, bo sytuację zniewolenia uznawała za naturalną. Tak więc sami lubimy się trochę zniewolić, choćby i podświadomie, chętnie uprawiamy ucieczkę od wolności, ponieważ wolność to jest niestety odpowiedzialność, a odpowiedzialność to jest - przyznajmy - przykrość. Wolność zresztą to jest bardzo przereklamowane słowo, każdy, kto planuje kogoś zniewolić, w przebraniu wolności to reklamuje, szczególnie uważać trzeba na tych, którzy dużo i głośno mówią o wolności; jak ktoś ciągle mówi o wolności - strzeż się!

A więc ciekawy paradoks nam się narodził: im więcej mamy wolności, tym mniej mamy wolności. Dziwniejsze jeszcze: wszyscy pragniemy chronić swoją prywatność, a jednocześnie kupczymy nią na całego - taki jest wniosek z lektury Baumana. Tak bardzo chcemy aby nas śledzono, że wciąż informujemy, gdzie się znajdujemy i co właśnie zjedliśmy, właściwie to sami się już śledzimy, bo nie możemy wytrzymać w sytuacji, gdy chwilowo nikt nas nie śledzi. Nie jest wykluczone, że za jakiś czas psychoanalitycy będą przyjmowali pacjentów cierpiących na zaniżoną samoocenę z powodu bycia nieśledzonymi, może się to okazać schorzeniem cywilizacyjnym przyszłości. Bo jeśli akurat nikt mnie nie śledzi, a przynajmniej nie śledzi moich wpisów na Facebooku, to znaczy, że jestem rozpaczliwie samotny. A samotność to jest dziś coś gorszego od raka, zdaje się, że człowiek samotny to jest współczesny zadżumiony - a kto chciałby się kolegować z zadżumionym?

Każdy więc dziś mówi: ujawniam swoje tajemnice! I czeka z nadzieją, że owe wstrząsające tajemnice poczynią jakieś poruszenie, najstraszliwszym rozczarowaniem jawi się sytuacja, w której twoje ujawnione właśnie, głęboko skrywane tajemnice nikogo nie zainteresują. Nie masz ciekawych tajemnic do ujawnienia w sieci? Znaczy, że cię nie ma, w pewnym sensie nie istniejesz, nie jesteś atrakcyjnym towarem do sprzedania. Bo Bauman powiada, że obecnie "każdy jest jednocześnie akwizytorem zachwalającym towar i towarem, który zachwala". I powtarza: "członkowie społeczeństwa konsumentów sami są towarami konsumpcyjnymi".

Zatęsknimy jeszcze, powiadam, za głosem w słuchawce mówiącym w złotych czasach telefonii stacjonarnej "rozmowa kontrolowana", wzruszymy się, przypominając sobie poczciwego cenzora, który nasze niewyraźnym pismem kreślone listy odczytywał, psując sobie wzrok, zdaje się, że tamta pamiętna inwigilacja to była czysta niewinność w porównaniu z nową płynną i globalną inwigilacją. 


\section{„Bonanza” - utracone dzieciństwo}

Komu przyszło do głowy, aby powtarzać serial „Bonanza” w TVP1 około drugiej w nocy? Kiedy my zasiadaliśmy, by go oglądać w czarno-białych telewizorkach, uchodził za produkt dla trochę starszych dzieci, choć nie tylko dla nich.

Ale dzięki tej nocnej przygodzie, przypomniałem sobie sporo odcinków. Bo tamte fabułki nie przetrwały na ogół próby pamięci. Przetrwało wrażenie emocji, gdy na początku płonie mapa okolic rancza Ponderosa i wyłania się Ben Cartwright z synami: Adamem, Joe’em i Hossem na koniach (dacie wiarę, żaden już nie żyje, nawet mały Joe). Emocje były obowiązkowe: sam miałem wtedy kowbojski kapelusz i kolta.

Ale zarazem pamiętam, jak moja mama emocjonowała się, że to także serial „psychologiczny”, więc dyskutowaliśmy przy stole po każdym odcinku, dlaczego Cartwrightowie postąpili tak a nie inaczej. Dyskusje były ożywione, choć dylematy nie bardzo dramatyczne. Mieliśmy do czynienia z ludźmi sprawiedliwymi, którzy podejmują dobre decyzje. Jednak w tamtych czasach szukało się w telewizji nauk, również etycznych.

Obśmiać ten serial można na wszelkie sposoby. Ma 430 odcinków, więc jedna rodzina z Nevady doznaje przygód, którymi można by obdzielić kilkadziesiąt. Ale to prawo takich produkcji.

Można też wysnuć zarzuty poważniejsze. Niewątpliwie autorzy scenariusza idealizują Dziki Zachód, w duchu poprawności z lat 60. Owszem, mogli się tam wyjątkowo trafić np. ludzie tak życzliwi wobec Indian jak Cartwrightowie, lecz mielibyśmy z tą swoją postawą większe kłopoty, nie mówiąc o tym, że wyrażaliby ją innym językiem. Takie przykłady można mnożyć. To Dziki Zachód z pokrzepiającej czytanki.

Czy to źle? Z pewnością dobrze dla bardzo młodych ludzi, którzy to oglądali. Przy wszystkich naiwnościach nasiąkali dobrymi wzorcami. Zwłaszcza że „Bonanza”, liberalna w stosunku do kwestii rasowych, była jeszcze zaskakująco tradycyjna $w$ innych sferach. Wręcz idealizowała rodzinę. Skądinąd rodzinę nietypową, bo bez kobiet. Nie pamiętam, czy któryś z braci w końcu się z kimś związał.

Choć kobiety nie raz i nie dwa pojawiały się w tle. Serial uczył traktować je podmiotowo (co akurat dla zachodnich kresów Ameryki, było obserwacją prawdziwą, sama natura tamtejszego życia do tego zmuszała). Ale też zalecał wierność, lojalność i wzajemne poświęcenie. Czego chcieć więcej?

Można się tylko zastanowić nad szokiem, kiedy wychowani na „Bonanzie” trafiliśmy potem na „Dziką bandę" Sama Peckinpaha. Jednak tak to już jest, że traci się dzieciństwo. I że co więcej, w jakimś sensie straciła je cała ludzkość. Czasem dzieciństwa szkoda. 


\section{Polska prawicą stoi}

Mamy jej w bród! Od lewa - by tak rzec - do prawa. Są w niej nacjonaliści, którzy wielbią Wielką Czystą Polskę wolną od gejów, liberałów, demokratów, Murzynów, feministek, lewaków i wszystkiego, czego nie lubią narodowi przywódcy (po sensacjach z WikiLeaks nie lubią również siebie wzajem). Są kibole -bardzo radykalni i bardzo bogoojczyźniani, którzy patriotyzm traktują jako formę dominacji panów nad chamami, a politykę jako umiejętność obrażania i stosowania przemocy; są ksenofobiczni słuchacze Radia Maryja, którzy zrobią wszystko, by ich guru, ojciec Rydzyk, wzbogacił się i zwiększył zasięg prania mózgów swoich słuchaczy; są pielgrzymi, dla których Jasna Góra stała się miejscem kultywowania nienawiści do rządu i wszystkiego, co wódz, czyli Jarosław Kaczyński, zdefiniuje jako wrogie mitowi potęgi własnego brata i „winy smoleńskiej”; są cyniczni wojownicy partii PiS (mistrz Hofman może służyć jako wzorzec z Sèvres), jak również zdeterminowani miłośnicy wielkiego szeryfa Zbigniewa Ziobry, który obiecuje, że jak wróci, to zrobi porządek (znając jego poprzednie dokonania, jest się czego bać).

Na prawicy znajduje się również szef kanapowej partii Polska Jest Najważniejsza Paweł Kowal, który uważa, że cuda stanowią element dziejów i Matka Boska była i jest zawsze z Polakami (nie wiem, na ile tezy te przyjmują się w Europie, ale też nie słyszałam, by odwaga posła Kowala wich głoszeniu przekraczała granice polskiego zaścianka). To z prawej strony świeci też gwiazda posła Godsona, który polityczną energię czerpie z niechęci do gejów. To na prawicy rozpościera swój pawi ogon największy narcyz polskiej polityki poseł Gowin, który swój marsz do wielkiej polityki zainicjował obwieszczeniem o słyszanym przez niego „krzyku zarodków” i który dziś przybiera różne maski obrońcy „tradycyjnych wartości”.

Na tak zwane tradycyjne wartości czy tradycję tout court powołują się zresztą wszyscy konserwatyści, choć konia z rzędem temu, kto wyłuska wśród owych wartości coś więcej niż stereotypy, zwykłą ignorancję i prywatne ambicje. W sumie bardzo łatwo być prawicowcem. Nie trzeba przygotowania, programu, wykształcenia, wielkiego namysłu, wystarczy chwytliwy pomysł medialny. Czy ktoś na przykład słyszał o senatorze Marku Martynowskim? Skąd! I oto nagle jest! Wystarczyło, że powiedział, że koncert Marii Peszek jest „hańbiący i bluźnierczy”, by jego nazwisko (zapewne nie bez pomocy kilku usłużnych i polujących na sensację dziennikarzy) obiegło media. Metoda, która zastosował senator Martynowski, można nazwać metodą „na Tomczaka”. Tomczak był eurodeputowanym, który uszkodził w Zachęcie rzeźbę papieża przygniecionego meteorem. I zrobił na tym karierę. Niejeden już „obrońca wartości” wzrósł na ignorancji estetycznej (liczni krytycy Nieznalskiej czy Kozyry). Metoda ta znacznie jednak wykracza poza sprawy estetyczne.

Ignorancja dotyczy również nauki, ekonomii, wiedzy o świecie współczesnym czy znajomości etyki. Można powiedzieć, że „na Tomczaka” to jedna z najpowszechniejszych metod wśród prawicowych gwiazd. Wykorzystuje ją zarówno prof. Longchamps de Bérier, jak i poseł Żalek (o hierarchach kościelnych nie wspominając). Przypadek Żalka jest wzorcowy. Przez lata pan poseł nie przejawiał żadnej aktywności politycznej, spokojnie działając jako wiceprzewodniczący parlamentarnego zespołu na rzecz ochrony życia oraz parlamentarnej grupy polsko-singapurskiej. I nagle jego gwiazda rozbłysła! Wystarczyła determinacja, traf i odrobina szaleństwa. Poseł Żalek objawił się światu jako radykalny przeciwnik in vitro, związków partnerskich, handlu w niedzielę, sprzedaży środków antykoncepcyjnych przez farmaceutów oraz jako wielki zwolennik posła Gowina. Bardzo to prosty program polityczny, ale przede wszystkim nośny medialnie. Metodą "na Żalka" wzrośnie zapewne jeszcze wielu prawicowych polityków. I tak Polska prawicą stoi i stać zapewne będzie. Światła w tunelu jakoś nie widać. Mimo że Europa tak blisko. 


\section{Nie zarazić się złem}

Ostatnie zmagania z pedofilami niszczącymi życie innym, Kościołowi i sobie obserwowałem z Nigerii.

Dokładnie w tym samym czasie pseudoreligijni wynaturzeńcy z bojówki Boko Haram do listy zamordowanych przez siebie setek ludzi dodali tu kilkudziesięciu śpiących studentów, a kilka dni później na drodze z Damaturu do Maiduguri obcięli głowy jeszcze dziesięciu osobom.

Tu i ówdzie z miejsca pojawiły się znów komentarze z gatunku: „tak wygląda religia pokoju", „muzułmanie to niebezpieczni wariaci". Śledzę tutejsze media i widzę, że islamskie środowiska są równie przerażone i zdruzgotane atakami co reszta kraju. Wśród zabitych studentów byli wyznawcy Allaha. Boko Haram morduje jak leci, rozstrzeliwuje wioski, podpala samochody z żywnością, nie pytając o wyznanie, morduje podróżnych, którzy czasem muszą przejechać pięćdziesiąt kilometrów, żeby złapać zasięg i wykonać ważny telefon.

Nie porównuję pedofilii z terrorystami. Koincydencja czasowa tych dwu historii przypomina mi jednak po raz kolejny, że gdy trzeba wprowadzić ład w świat, w którym ktoś narobił bałaganu, generalizacje nie mają żadnego sensu, a rozkręcając palnik z emocjami, samemu można się dotkliwie poparzyć.

Po pierwsze więc (choć w uniesieniu kusi), trzeba sobie do znudzenia powtarzać rzecz oczywistą, że tak jak dalece nie wszyscy muzułmanie to potencjalni zabójcy, tak nie wszyscy księża to potencjalni pedofile. Bezmyślność reakcji, o których czytam: „zabiorę teraz dziecko z religii, bo nie wiadomo, co ci księża z nim zrobią", jest porażająca. Wszystkimi znanymi mi księżmi cała ta sytuacja wstrząsnęła dokładnie tak samo jak każdym normalnym człowiekiem. Pisali mi w SMS-ach: „Przez tych dwóch naprawdę można wiarę stracić". Problemem nie jest Kościół, a kilku ślepych urzędasów. Z którymi (czy są kościelni, czy świeccy) jest zwykle ten kłopot, że z podążania wzdłuż utartych kolein może ich czasem wyrwać tylko eksplozja z ofiarami w ludziach. Da Bóg, że może tym razem wyciągną z niej wnioski.

Po drugie - w emocjonalnej pogoni za złem warto uważać, żeby samemu nie dać się nim zarazić. Od organizowania pościgu za podejrzanym księdzem nie jest pospolite ruszenie sąsiadów i dziennikarzy, lecz policja, którą należy ze skuteczności rozliczać. Ustalenie, co zaszło, osądzenie winy i karanie to nie zadanie moje, a sądu, który będzie miał do dyspozycji wszystkie dane, a oskarżony będzie mógł się przed nim bronić. Andersa Breivika (znów - z zachowaniem wszelkich proporcji) też można było zlinczować, zwyciężyło jednak przekonanie, że nawet jeśli ktoś zachowuje się nieludzko, ja nadal muszę pozostać człowiekiem. I jeśli np. sąd uzna, że któryś z oskarżonych księży wymaga leczenia, przyjąć to do wiadomości, a nie domagać się jego anihilacji.

To najtrudniejsze - pilnować właściwej proporcji między piętnowaniem zła a czynieniem dobra. Ten świat nie posunie się ani odrobinę do przodu, ba - cofnie się w rozwoju - jeśli obok dyszenia oburzeniem na wieść o złu, na które nie mamy wpływu, nie zrobimy natychmiast czegoś dobrego w otoczeniu, na które wpływ mamy. 



\section{Aneks 4}

Przykładowe kopie stron felietonów wykorzystanych w badaniu dla wariantu 2 (tekst + zdjęcie + nazwisko) 


\section{Varga}

\section{Rozmowy kontrolowane, czyli śledź się sam}

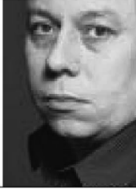

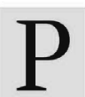

odobno wielce modne jest
obernie wypisywaniesiez Fa-
cebooka, no ale przecież zeby się modnie wypisaćc $z$ Facedo niego bylo modnie zapiycie modnym znów mnie omineta, bo nawe ize niply nie mógłtym się szyłko zapisać po to, Żeby się, rónmie szy̧oko wypisać, ale obawiam sie, że akurat jak się bede wypisywar, to wszyscy na po
wrót znów sie beda zapisywać bo sie trend wróci, w drisiejszych czasach trendy jak wiadomo, odwracają się opętańczo szybko. Rozumiem jectnak te emocję bycia na Facewą walke, gdyż czutem wrożne polą bure. aby relacie z ludámi przeniesć na poziom wis tualny, a - spowiedzi ciag dalszy - zdarza sie, krycie, a nawet czasami zadam, aby mi wszelakie wpisy pokazać, bo ciekawi mnie, co ltdzie mają tam do powiedzenia, jakie zljęcia
wrzucaja, jakie historie snuja, jakie sensacje

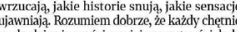
pozbeddzie się cześci swojej prywatności, byle
tam być, wsiod wirtualnych przyjaciołł ktorzy coraz bardziej są atrakcyini od tych realnych. Diwna rzecz- - ile zazsyczai z podgladac
ka przyjemnoscią czytam dzienniki pisarzy, zarówno te publikowane dopiero w w dekady yo Śmierci, iaki te zpremedytacia pisane, by wy-
dać je za życia, tomy korespondencji nijak cac je za zycia, tomy korespondencli nila umysłów, prawidłowości tej nie umiem rozpracować 1 wytumaczyć, jakoś mi się zdaje, 2 the encii, osobliwie tej intymnej, traci o oble-

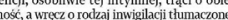

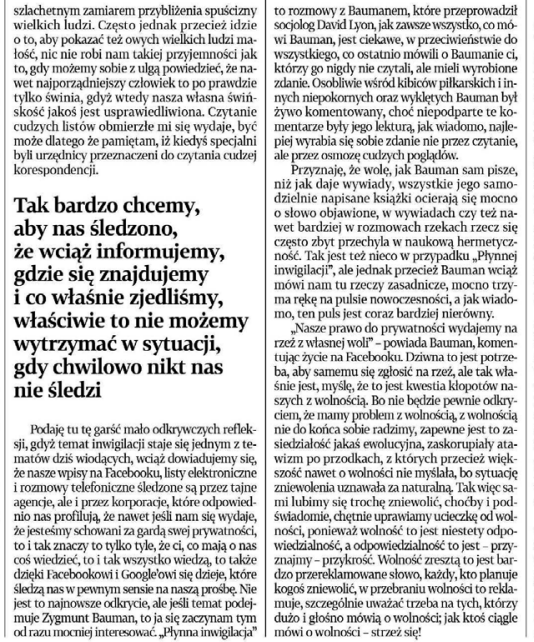
więcej manyy wolności, tym mniej man my chronić swoja prywatność, a jednocześni upczymy nią na całego - taki jest wniose lektury Baumana. Tak bardzo chcemy, aby na sledzono, ze wciazz informujemy, gdzie się zna mi sie już sledtimy, bo nie możemy wy wrzy má
w sytuacii, gdy chwilowo nikt nas nie sledzi. Nie jest wyklucrone, ie za jakiś cras psychoanalitycy beda przyimowali pacientónw cierpiacych na
zanižną samoocenę $z$ powodu bycia niessedzanimi, moźz się to ok kazás schorzeniem cywiliza cyinym przyszzośći. Bo jesli akurat nikt mnie nie sledzi, a przynajmniej nie sledzi moich wpisíw

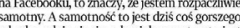
draka, zdaje sie, że czlowiek samotny to jest wspótczesny zadżumiony Kazdy więc dzis mówi: ujawniam swoje ta

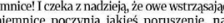
w której twoje ujawnione włáśnie, glęboko skrywane tajennice nikogo nie zainteresuja. N. d? Znaczy, że cię nie ma, w pewnym sensie ni istniejesz, nie jestes atrakcyinym towarem do przedania. Bo Bauman powiada, ze obecni . wtarza: ,czlonkowie spoteczeństwa konsume tow sami są towarami konsumpcyinymin. zank onii stacionarnej ,rozmowa kontrolo wzruszymy sie, przypominając sobie poczciwego cenzora, ktory nasze niewyraznym pismen

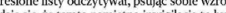
czysta niewinność w porównaniu z nową płyn-
nąi globalną inwigilacąą. Krzyszot Vare

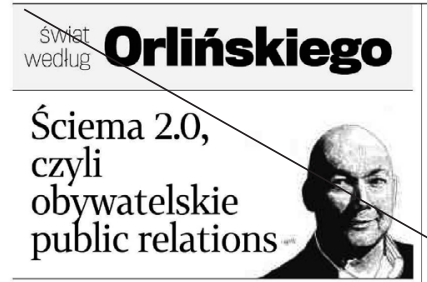

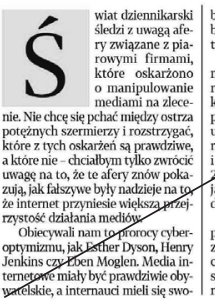

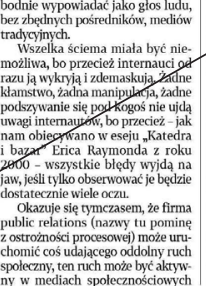

Byty to nie tylko materiaty zwiaza- nikt tego nie zdemaskuje, dopóki a sprawa nie zacznie węszyc rasowy zuje sie, ze tysiace occu intemautów czu poiedynczego zawodowca. Stado się tak nie dlatego, że wspo-
mniana firma trzymata się $z$ dalek mniana firma trzymata się z daleka
od internetu. Przeciwnie, waznnym elementem medialnej obsługi ich
klienta, pewnej firmy z branży akumulatorowej, było prowadzenie tzw.
fanpejdża, cyyli strony na Facebooku. "nejdża, cyli strony na facebooku,
trona ma nawę "Nie róbcie kwasu" udaje oddolną akcie zatroskany

cyklingu, a nawet ukradziony skąds

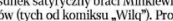
zenie takiej strony nie kosztuj wiele wysitku, wystarczy codzienn wack materiat wyprodukowany Jak ktoś chce w internecie udawać ze jest fajny, tokażde zdanie musi kończyć uśmieszkiem

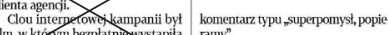
ilm, w krinym bezplatme wystapiita oklasycznymini internetowymi madami - pojawit
Vimeo i Wykopie.

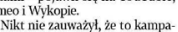
na zlecenie, a nie oddolny ruch spoleczny. Fanpédż̀ dziatal na Facebooku do czerwca 2013, gdy kampania wygasta. Przez ten czas działal
jak normalna strona tego typu projak normal na strona tego typu pro-
wadzona przzz zapalencóv danego tematu - codziennie pojawiało sie cos nowego.

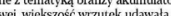
tentyczna troskę o srodowisko, dlate-
go pojawialy się tam takže linki o re-

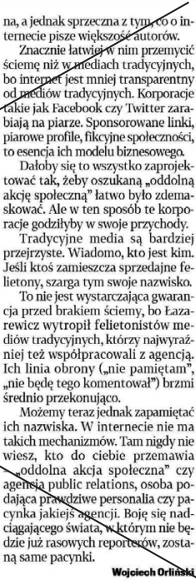




\section{Białym helikopterem do Opery Lesnej}

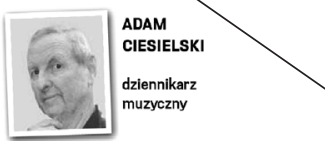

Zastanawiająca jest trwałošč zjawisk ulotnych. Zmieniaja się epoki, style, organizatorzy, niemal na co dzień gošcimy światowe gwiazdy, a można być pewnym, że pod koniec sierpnia w Operze Lešnej i tak po staremu odbędzie się międzynarodowy festiwal piosenki. Przeczytatem, że w tym roku w charterze największych atrakcji świecić maja m.in. Matt Dusk, Rick Astley, Belinda Carlisle, grupa Opus, a ponadto Budka Suflera I - uwaga - sama Edyta Górrilak!

Nogi się pode mną ugięły pod w/ażeniem tych tem, że muszę - po wieloletniej przerwie-niezwłocznie akredytować się na Sopocki festiwal. Ale gdy otrzeźn hałem, zdecydowałem się jednak nie ryz y kować. Bo jako festiwalowy bywalec nie a aik rzeczy już widziałem i słyszałem.
Festiwalom piosenki w Sopocie, zainaugurowanym w $1961 \mathrm{r}$., przyświecała idea lansowan rodzimej rozrywki. Chwalebny zamiar wzbudził entuzjazm, ale nie mógł się sprawdzić, bo gzeszył naiwnością. Karier i szlagierów nigdzi na Swiecie nie kreują festiwalowe konkursy, lecz shou-biznes z prawdziwego zarzenia którego u nasprzez kilkadziesiarpowojennych ktorego unasprzez kilkadziesiar powojennych nie wyfrunęa dalekożzdna piosenk

Nie bywałem nafestiwalu w okresie, kied Nie bywałem nacestiwalu w okresie, kiedy
triumfowaty Inena Santor, Biva Demarczyk, triumfowaty Ir na Santor, Bua Demarczyk, Anna German i Violetta Villas, a pierwsza sprawozdawca muzyczny „Życia Warszany W Operze Leśnej zacząłem się pojawiá́ pod ko niec lat 70. i byłem tam kilkanaście razy, zaliczając" m. in. recitale Charlesa Aznavoura, Jose Feliciano Johny'ego Casha, Whitney Houston, niemówią jużo Alle Pugaczowej, Helenie Vonnie mowiąc już o Alle Pugaczow

Akurat ci goście śpiewali naprawdę, ale byl i inni. Przeżywający w erze disco apogeum popularności zespół Boney M. występował do muzyki z playbacku, lecz umiał zręcznie ma kować "spiew”. Natomiast Demis Rousso stukilogramowy Grek, paradujący w złocistych szarawarach, nie wysilał się, by ruchami ust trafiać J dźwięki. Gdy jednak domagano się bisów artysta wrócił zza kulis i ogłosił przez mikrofon: „OK, wait a moment, my manager must change the tape!". Nieznajacca angielskiego publicznośc zapowiedźzmiany taśmy powirała burzabraw. Gwiazdy bywy kac Gwazdy bywaty kapryse. Wspomniany Roussos zażądał klimatyzowanego apartamentu a ze w Crand Hotelu takich wygod nie było obsługa wstawiała mu do pokoju... kubły z lodem. Grupie Boney M. zachciało się białego helikoptera. I dostała go - przemalowano wypożyczoną od wojska zieloną maszyn Spragniona zachodnich atrakcji widownia klaskała, nawet jeśli w roli gwiazdora wystęeewał włoski hydraulik Drupi (pojawia sie u nas do dziś) lub jego rodaczka Sabrina. Ta śpiewac supełnie nie umiała ale miała krótpie postrze ściagała podkosżlek. ciaggała podkoszulek.

Mieszanka przezýa artystycznych z blichtrem celebrytów i maxeniami o wielkim świecie znaczy półwieczną historię festiwalu w Operze Leśnej. To piosenka wciżz nieskończona. Co rok przybywa nowa zwrotk

ZAREMBA PRZED TELEWIZOREM

\section{"Bonanza" - utracone dzieciństwo}

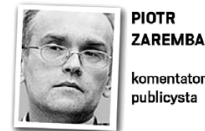

Komu przyszto do glowy, aby powtarzać serial „Bonanza" w TVP1 okolo drugiej $w$ nocy? Kiedy my zasiadališmy, by go ogląda w czarno-białych telewizorkach. uchodzit za produkt dla troch starszych dzieci, choć nie tylk dla nich.

Ale dzięki tej nocnej przygodzie przypomniałem sobie sporo odcinków. Bo tamte fabułki nie przetrwały na ogół próby pamięci. Przetrwało wrazenie emocji, gdy na poczatku płonie mapa okolic rancza Ponderosa i wyłania się Ben Cartwright z synami: Adamem, Joe'em i Hossem na koniach (dacie wiarę, żaden już ni żyje, nawet mały Joe). Emocje były obowiązkowe: sam miałem wted kowbojski kapelusz i kolta.

A zarazem pamiętam, jak moja mama emocjonowała się, że to także serial "psychologiczny" więc dyskutowaliśmy przy stolep każdym odcinku, dlaczego Cartwrightowie postąpili tak a nie inaczej. Dyskusje były ożywione, cho dylematy nie bardzo dramatyczne. Mieliśmy do czynienia $\mathrm{z}$ ludźm sprawiedliwymi, którzy podejmuja dobre decyzje. Jednak w tamtych czasach szukato się w telewiz nauk, również etycznych.

Obśmiać ten serial można na wszelkie sposoby. Ma 430 odcinków, więc jedna rodzina z Nevady doznaje przygód, którymi można by obdzielić kilkadziesiąt. Ale to prawo takich produkcii.

Można też wysnuć zarzuty poważniejsze. Niewątpliwie autorzy scenariusza idealizują Dzik Zachód, w duchu poprawnośc $\mathrm{z}$ lat 60. Owszem, mogli się tam wyjątkowo trafić np. ludzie tak życzliwi wobec Indian jak Cartwrightowie, lecz mieliby z tą swoja postawą większe kłopoty, nie mówiąc o tym, że wyrażaliby ją innym językiem. Takie przykłady możn mnożyć. To Dziki Zachód z pokrzepiającej czytanki.

Czy to źle? Z pewnością dobrze dla bardzo młodych ludzi, którzy to oglądali. Przy wszystkich naiwnościach nasiąkali dobrymi wzorcami. Zwłaszcza że "Bonanza”, liberalna w stosunku do kwest rasowych, była jeszcze zaskaku- jąco tradycyjna w innych sferach. Wręcz idealizowała rodzinę. Skądinąd rodzinę nietypową, bo bez kobiet. Nie pamiętam, czy któryś z braci w końcu się z kimś zwiazzał. Choć kobiety nie raz i nie dwa pojawiały się w tle. Serial uczy? traktować je podmiotowo (co polowo (co A resow Ameryki było obserwacją prawdziwą, sama natura tamtejszego zycia do tego zmuszała). Ale te zalecał wierność, lojalność i wzajemne poświęcenie. Czego chcieć więcej?

Można się tylko zastanawiac nad szokiem, kiedy wychowani n "Bonanzie" trafialiśmy potem na "Dziką bandę" Sama Peckinpaha. Jednak tak to juz jest, ze traci się dzieciństwo. I że co wieccej w jakim sensie straciła je cała ludzkość Czasem dzieciństwa szkoda. 


\section{Polska prawicą stoi}

MAGDALENA ŚRODA

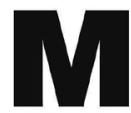

amy jej w bród! Od lewa - by tak rzec - do prawa. Są w niej nacjonaliści, którzy wielbią Wielką Czyst Polskę wolną od gejów, liberałów, demokratów, Murzynów, feministek, lewaków i wszystkiego, czego nie lubią narodowi przywódcy (po sensacjach $\mathrm{z}$ WikiLeaks nie lubią również siebie wzajem). Są kibole - bardzo radykalni i bardzo bogoojczyźniani, którzy patriotyzm traktuja jako formę dominacji panów nad chamami, a politykę jako umiejętność obrażania i stosowania przemocy; s ksenofobiczni słuchacze Radia Maryja, którzy zrobią wszystko, by ich guru, ojciec Rydzyk, wzbogacił sie i zwiększył zasięg prania mózgów swoich słuchaczy; są pielgrzymi, dla których Jasna Góra stała się miej scem kultywowania nienawišci do rządu i wszystkiego cowódz, czyli Jarosław Kaczyński, zdefiniuje jako wrogie mitowi potęgi własnego brata $i$, winy smoleńskiej"; są cyniczni wojownicy partii PiS (mistrz Hofman moż służyć jako wzorzec z Sèvres), jak również zdeterminowani miłośnicy wielkiego szeryfa Zbigniewa Ziobry, który obiecuje, że jak wróci, to zrobi porządek (znają jego poprzednie dokonania, jest się czego bać).

Naprawicy znajduje się również szef kanapowej partii Polska Jest Najważniejsza Paweł Kowal, który uważa że cuda stanowią element dziejów i Matka Boska był ijest zawsze z Polakami (nie wiem, na ile tezy te przyjmują się w Europie, ale też nie słyszałam, by odwaga posła Kowala w ich głoszeniu przekraczała granice polskiego zaścianka). To z prawej strony świeci też gwiazda posł Godsona, który polityczną energię czerpie z niechęc dogejów. To na prawicy rozpościera swój pawiogon największy narcyz polskiej polityki poseł Gowin, który swój marsz do wielkiej polityki zainicjował obwieszczeniem o słyszanym przez niego krzyku zarodków" i który dzi prybiera rón maskiobricy

Na tak zwane tradycyjne wartości czy tradycję tou court powołują się zresztą wszyscy konserwatyści, choć konia z rzędem temu, kto wyłuska wśród owych wartości coś więcej niż stereotypy, zwykłą ignorancję i prywatne ambicje.

W sumie bardzo łatwo być prawicowcem. Nie trzeb przygotowania, programu, wykształcenia, wielkiego namysłu, wystarczy chwytliwy pomysł medialny. Czy ktoś na przykład słyszał o senatorze Mark Martynowskim? Skąd! I oto nagle jest! Wystarczyło, że powiedział, że koncert Marii Peszek jest „hańbiący i bluźnierczy”, by jego nazwisko (zapewne ni bez pomocy kilku usłuźnych i polujących na sensację dziennikarzy) obiegło media. Metoda, która zastosował senator Martynowski, można nazwać metodą "na Tomczaka". Tomczak był eurodeputowanym, który uszkodził w Zachęcie rzeźbę papieża przygniecionego meteorem. I zrobił na tym karierę. Niejeden już "obrońca wartości" wzrósł na ignorancji estetyczne (liczni krytycy Nieznalskiej czy Kozyry). Metoda t znacznie jednak wykracza poza sprawy estetyczne.

\section{Bardzo łatwo być prawicowcem. Nie trzeba przygotowania, programu, wykształcenia, namysłu, wystarczy chwytliwy pomysł medialny}

Ignorancja dotyczy również nauki, ekonomii, wiedzy o ŝwiecie współczesnym czy znajomości etyki.

Można powiedzieć, że „na Tomczaka” to jedna z najpowszechniejszych metod wśród prawicowych gwiazd. Wykorzystuje ja zarówno prof. Longchamps de Bérier, jak i poseł Żalek (o hierarchach kościelnych nie wspominając). Przypadek Żalka jest wzorcowy. Prze lata pan poset nie przejawiat żadnej aktywności politycznej, spokojnie działając jako wiceprzewodniczący parlamentarnego zespołu na rzecz ochrony życia oraz parlamentarnej grupy polsko-singapurskiej. I nagle tarczyła determinacja, traf $i$ odrobina szaleństwa. Poset Żalek objawił się światu jako radykalny przeciwnik in vitro, związków partnerskich, handlu w niedzielę, sprzedaży środków antykoncepcyjnych przez farmaceutów orazjako wielk zwolennik posła Gowina. Bardzo to prosty program polityczny, ale przede wszystkim nośny medialnie. Metoda „na Żalka” wzrośnie zapewne jeszcze wielu prawicowych polityków. I tak Polska prawicą stoi i stać zapewne będzie. Światła w tunelu jakoś nie widać. Mimo że Europa tak blisko. 


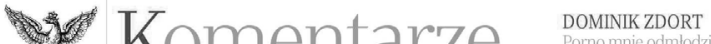

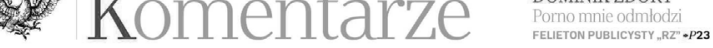

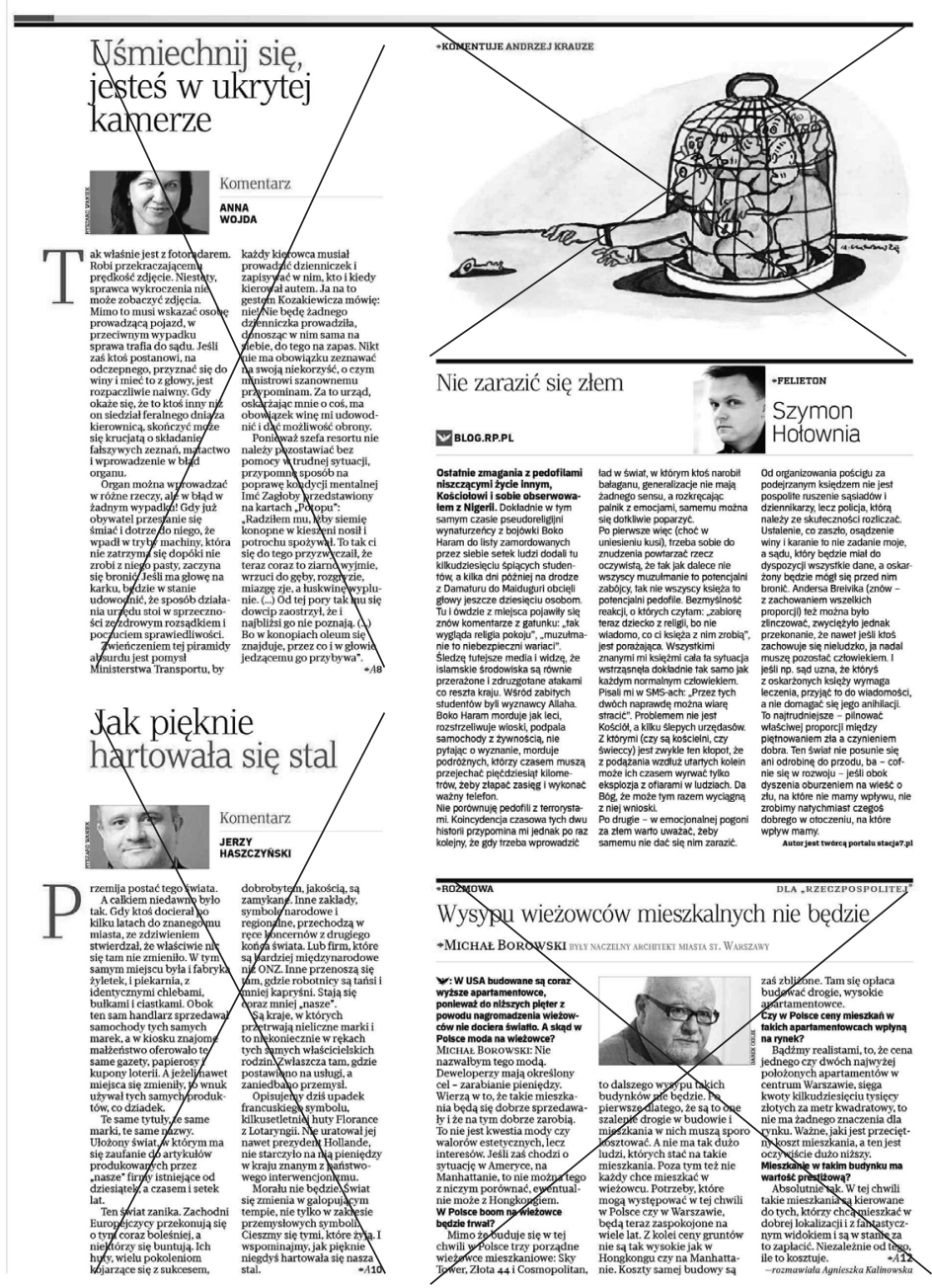


